\title{
₹USGS
}

\section{Geology of the Chesapeake and Ohio Canal National Historical Park and Potomac River Corridor, District of Columbia, Maryland, West Virginia, and Virginia}

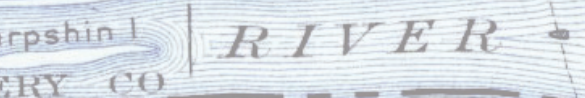

$\mathrm{CRY}_{\mathrm{CO}}-\mathrm{IO}_{\text {Lowes Island }}$

Professional Paper $₫ 691$

U.S. Department of the Interior U.S. Geological Survey 
On the cover: In the background, 1:62,500-scale topographic map of the Seneca quadrangle, Md., (surveyed in 1907 by the U.S. Geological Survey and produced in cooperation with the State of Maryland). In the foreground, clockwise from top left, photograph of canal boat along the towpath (courtesy of National Park Service); view of the north portal of the Paw Paw Tunnel, looking south (around 1900) (photograph courtesy of National Park Service); photograph of Devil's Eyebrow, an anticline of shale, sandstone, and limestone of the Silurian Bloomsburg Formation at the site of the Round Top Cement Mill, west of Hancock, Md. (photograph taken in 1897 by C.D. Walcott, Director of the U.S. Geological Survey); and photograph (around 1876) of a barge at Lock 33, across the Potomac River at Harpers Ferry, W. Va. (courtesy of National Park Service). 


\section{Geology of the Chesapeake and Ohio Canal National Historical Park and Potomac River Corridor, District of Columbia, Maryland, West Virginia, and Virginia}

By Scott Southworth, David K. Brezinski, Randall C. Orndorff, John E. Repetski, and Danielle M. Denenny

Professional Paper 1691 


\title{
U.S. Department of the Interior DIRK KEMPTHORNE, Secretary
}

\author{
U.S. Geological Survey \\ Mark D. Myers, Director
}

U.S. Geological Survey, Reston, Virginia: 2008

For product and ordering information:

World Wide Web: http://www.usgs.gov/pubprod

Telephone: 1-888-ASK-USGS

For more information on the USGS-The Federal source for science about the Earth, its natural and living resources, natural hazards, and the environment:

World Wide Web: http://www.usgs.gov

Telephone: 1-888-ASK-USGS

Any use of trade, product, or firm names is for descriptive purposes only and does not imply endorsement by the U.S. Government.

Although this report is in the public domain, permission must be secured from the individual copyright owners to reproduce any copyrighted materials contained within this report.

Suggested citation:

Southworth, Scott, Brezinski, D.K., Orndorff, R.C., Repetski, J.E., Denenny, D.M., 2008, Geology of the Chesapeake and Ohio Canal National Historical Park and Potomac River Corridor, District of Columbia, Maryland, West Virginia, and Virginia: U.S. Geological Survey Professional Paper 1691, 144 p., 1 pl. 


\section{Contents}

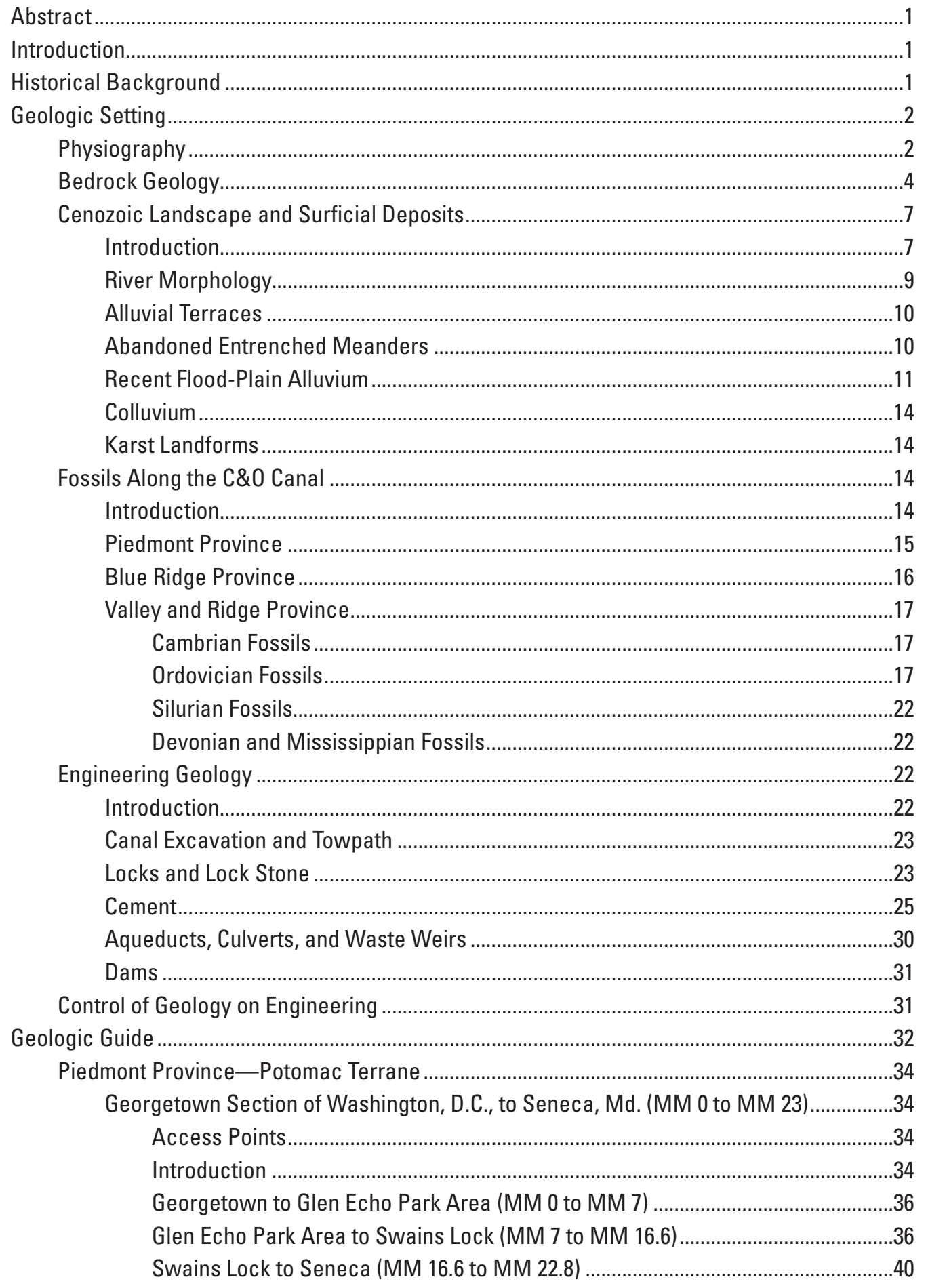


Piedmont Province - Culpeper Basin, Westminster Terrane, and Frederick Valley ................45

Seneca, Md., to Point of Rocks, Md. (MM 22.8 to MM 48.2) ........................................45

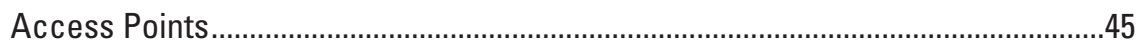

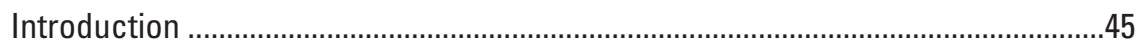

Seneca to Edwards Ferry (MM 22.8 to MM 30.8) ...............................................47

Edwards Ferry to Monocacy Aqueduct (MM 30.8 to MM 42.2) ...............................48

Monocacy Aqueduct to Point of Rocks (MM 42.2 to MM 48.2) ..............................48

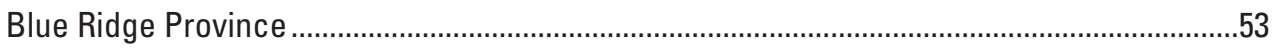

Point of Rocks, Md., to Fort Duncan (MM 48.2 to MM 63) .............................................53

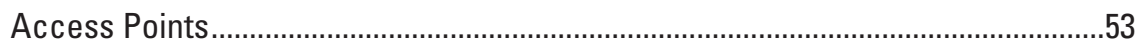

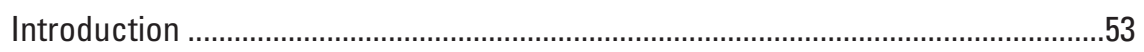

Point of Rocks to Brunswick (MM 48.2 to MM 55) .................................................55

Brunswick to Fort Duncan (MM 55 to MM 62.5) ...................................................55

Valley and Ridge Province—Great Valley Section.............................................................65

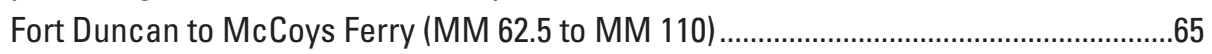

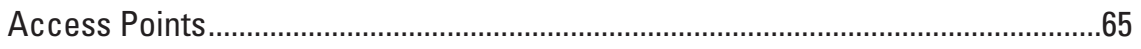

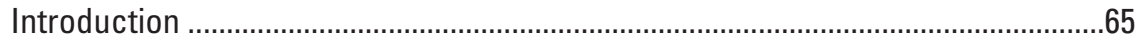

Fort Duncan to Antietam Creek (MM 62.5 to MM 69) ............................................65

Antietam Creek to Big Slackwater (MM 69 to MM 85.5)........................................68

Big Slackwater to Williamsport (MM 85.5 to MM 99.5) ......................................70

Williamsport to McCoys Ferry (MM 99.5 to MM 110) ............................................72

Valley and Ridge Province —West of North Mountain Thrust Fault .........................................76

McCoys Ferry to Cumberland, Md. (MM 110 to MM 184.5) ...........................................76

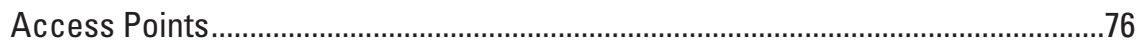

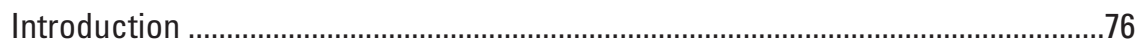

McCoys Ferry to Licking Creek Aqueduct (MM 110 to MM 116) ...........................78

Licking Creek Aqueduct to Round Top Cement Mill (MM 116 to MM 127.5)...........78

Round Top Cement Mill to Sideling Hill Aqueduct (MM 127.5 to about MM 137)...80

Sideling Hill Aqueduct to Paw Paw Tunnel (MM 137 to MM 156) ..........................88

Paw Paw Tunnel to Oldtown (MM 156 to MM 167) .............................................90

Oldtown to Spring Gap (MM 167 to MM 173.5) .................................................91

Spring Gap to Cumberland (MM 173.5 to MM 184.5) ..............................................91

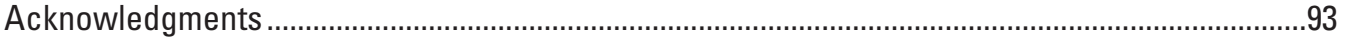

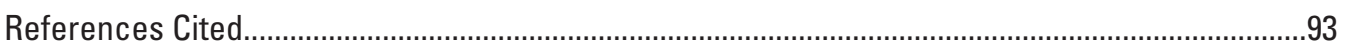

Appendix 1-Sources of Data-Geologic Maps of 7.5-Minute Quadrangles ................................99

\section{Plates}

1. Geology of the Chesapeake and Ohio Canal National Historical Park and Potomac River Corridor, District of Columbia, Maryland, West Virginia, and Virginia. 
2-20. Geologic maps of the Chesapeake and Ohio Canal National Historical Park and Potomac River Corridor from:

2. Georgetown (MM 0) to near Glen Echo Park (about MM 7).................................107

3. Near Glen Echo Park (about MM 7) to Swains Lock (MM 17) .............................109

4. Swains Lock (MM 17) to Seneca (MM 22.8) ................................................111

5. Seneca (MM 22.8) to Edwards Ferry (MM 30) .................................................113

6. Edwards Ferry (MM 30) to Monocacy River Aqueduct (MM 42.2) ......................115

7. Monocacy River Aqueduct (MM 42.2) to Point of Rocks (MM 48.2) ....................117

8. Point of Rocks (MM 48.2) to Brunswick (MM 55) ...............................................119

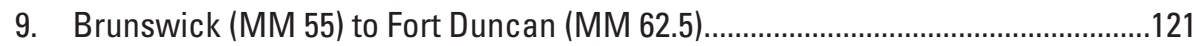

10. Fort Duncan (MM 62.5) to Antietam Creek (MM 69) ............................................123

11. Antietam Creek (MM 69) to Big Slackwater (MM 85.5)......................................125

12. Big Slackwater (MM 85.5) to Williamsport (MM 99.5)..........................................127

13. Williamsport (MM 99.5) to McCoys Ferry (MM 110) ..........................................129

14. McCoys Ferry (MM 110) to Licking Creek Aqueduct (MM 116) ............................131

15. Licking Creek Aqueduct (MM 116) to Round Top Cement Company mill

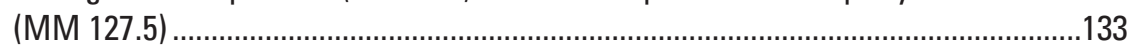

16. Round Top Cement Company mill (MM 127.5) to Little Orleans (MM 141) ...........135

17. Little Orleans (MM 141) to Paw Paw Tunnel (MM 156) ........................................137

18. Paw Paw Tunnel (MM 156) to Oldtown (MM 167) ................................................139

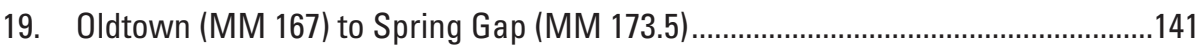

20. Spring Gap (MM 173.5) to Cumberland (MM 184.5) .............................................143

\section{Figures}

1. Sketch map showing the geologic provinces in the mid-Atlantic region and the locations of the Chesapeake and Ohio (C\&O) Canal, the Potomac River, and the

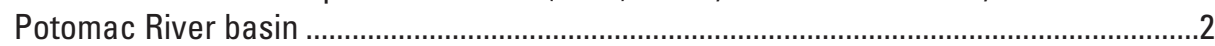

2. Maps showing the earliest beginnings of canal transport..................................................

3. Tectonic map of the study area .................................................................................

4. Diagrammatic sketches showing the geologic history of the Potomac River valley over the past 1 billion years ..............................................................................................

5. Maps of alluvium and alluvial terraces of the Potomac River ............................................8

6. Schematic cross sections of the Potomac River valley at Cumberland, Md. (A-A'), and the Georgetown section of Washington, D.C. (B-B') ...............................................

7. Sketch map showing large water-filled potholes and channels on the eastern half of Bear Island near MM 13 and Widewater ...........................................................10

8. Potholes in migmatite of the Neoproterozoic and (or) Lower Cambrian Mather Gorge Formation along the bluff of Mather Gorge in Virginia .........................................11

9. Aerial photograph showing fish weirs constructed by Native Americans.......................11

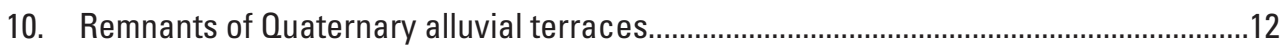

11. Sketch maps illustrating the evolution of the abandoned incised meanders of the Potomac and Little Cacapon Rivers near Paw Paw, W. Va.

12. Schematic maps of the Great Falls of the Potomac River showing the evolution of the abandoned channel of Widewater and of Glade Hill ..... 
13. Rounded boulder of diabase ( $5 \mathrm{ft}$ in diameter) deposited by the Potomac River on terrace at south end of Glade Hill...............................................................................13

14. Recent alluvium along the Monocacy River ..............................................................13

15. Schematic map showing the distribution of carbonate rocks and noncarbonate rocks along the C\&O Canal and Potomac River corridor................................................14

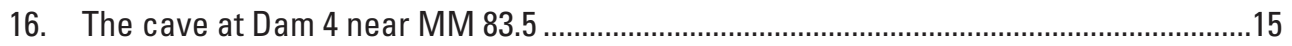

17. Fossils from rocks of the Frederick Valley section, western Piedmont province ............16

18. Dinosaur tracks in the Upper Triassic Balls Bluff Siltstone exposed in the Culpeper Stone Co. quarry near Culpeper, Va. 17

19. Brachiopods in Silurian and Devonian rocks.............................................................17

20. Key index fossils present in the rocks found along the C\&O Canal in the Valley

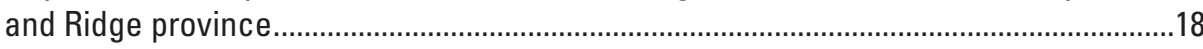

21. Key guide conodonts to the strata of the Valley and Ridge province ..............................20

22. Map showing locks, aqueducts, dams, and known quarries near the canal..................24

23. Stone berms constructed to prevent erosion between the towpath and the

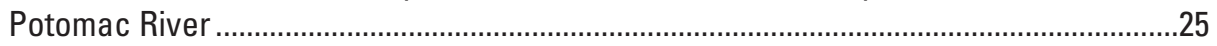

24. An example of modern erosion in the canal near Lock 34 (west of MM 62) ..................25

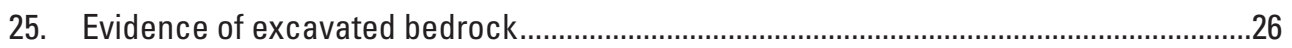

26. Historical photographs of Paw Paw Tunnel, near MM 155 ............................................26

27. Examples of Lower Cretaceous Potomac Formation ........................................................2

28. Upper Triassic Poolesville Member of the Manassas Sandstone ...................................27

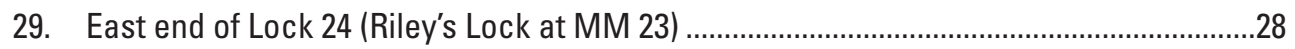

30. Nonfoliated Ordovician Ellicott City Granodiorite …….................................................28

31. Quartzite of the Lower Cambrian Weverton Formation..................................................28

32. Limestone of the Lower Cambrian Bolivar Heights Member of the Tomstown

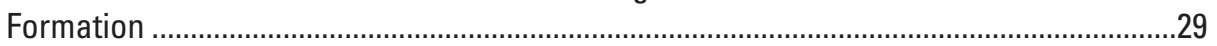

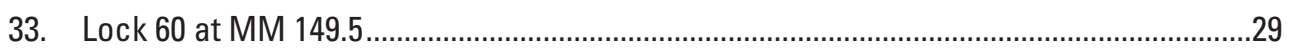

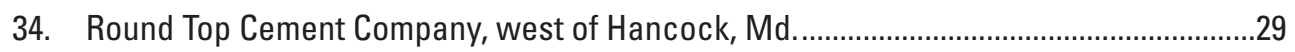

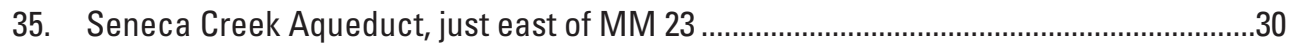

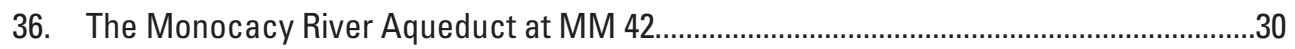

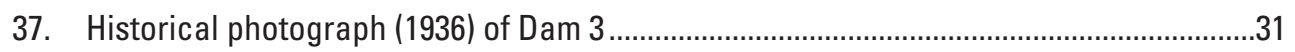

38. Dam 6, which was located north of Great Cacapon, W. Va., near MM 134 ....................32

39. Historical photograph (1940) showing reconstruction of the towpath and canal

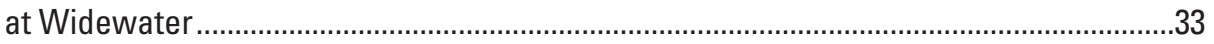

40. Excavation of the canal through bedrock.......................................................................

41. Generalized structure map and cross section of a portion of the C\&O Canal National Historical Park and Potomac River corridor as it crosses the Piedmont province and easternmost part of the Blue Ridge province............................................35

42. Part of a National Historical Marker where the C\&O Canal enters Rock Creek .............36

43. Igneous rocks of the Early to Middle Ordovician Georgetown Intrusive Suite

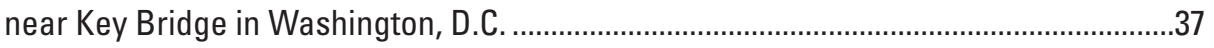

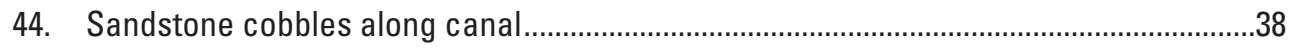

45. Undeformed sedimentary mélange of the Lower Cambrian Sykesville Formation at MM 9.8

46. Sheared mélange of the Lower Cambrian Sykesville Formation near MM 11.5 _.............38

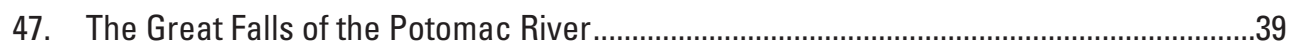


48. Phyllonite of the Neoproterozoic and (or) Lower Cambrian Mather Gorge Formation near MM 12.5 ......

49. Migmatite of the Neoproterozoic and (or) Lower Cambrian Mather Gorge Formation

50. Migmatite of the Neoproterozoic and (or) Lower Cambrian Mather Gorge Formation

51. Dark amphibolite within the Neoproterozoic and (or) Lower Cambrian Mather Gorge Formation intruded by white pegmatite of the Ordovician(?) Bear Island Granodiorite

52. Milky white, fractured vein quartz intruding metagraywacke of the Neoproterozoic and Lower Cambrian Mather Gorge Formation near Widewater near MM 13.5............42

53. Underground gold mine north of Great Falls Tavern......................................................43

54. Late Devonian lamprophyre dikes intruding metagraywacke of the Neoproterozoic and (or) Lower Cambrian Mather Gorge Formation.....

55. Folding in metagraywacke and schist of the Neoproterozoic and (or) Lower Cambrian Mather Gorge Formation.

56. Folded metagraywacke of the Neoproterozoic and (or) Lower Cambrian Mather Gorge Formation

57. Sheared phyllite and folded white vein quartz of the Neoproterozoic(?) and Lower Cambrian(?) ljamsville Phyllite that lies above the Martic thrust fault along the Monocacy River

58. Tightly folded, thin-bedded limestone within the ljamsville Phyllite along the Monocacy River

59. Metasiltstone of the Lower and Middle Cambrian Araby Formation showing foliation with near-vertical cleavage along the CSXT railroad north of MM 43

60. Examples of the varieties of limestone in the Upper Cambrian Frederick Formation

61. Conical hill north of Nolands Ferry and Maryland Route 28 representing topographic inversion

62. Stereoscopic pair of aerial photographs showing the change in the morphology of the Potomac River valley in the Piedmont province across the boundary between the Culpeper basin and Potomac terrane.

63. Conglomerate of the Upper Triassic Reston Member of the Manassas Sandstone that forms the base of the Culpeper basin

64. Limestone conglomerate interbedded with red siltstone of the Upper Triassic Leesburg Member of the Balls Bluff Siltstone.

65. Limestone conglomerate of the Upper Triassic Leesburg Member of the Bull Run Formation

66. Lower Cambrian Tomstown Formation ..........................................................................52

67. Lower Cambrian rocks of the Blue Ridge province ........................................................52

68. Generalized structure map and cross section of a portion of the C\&O Canal National Historical Park and Potomac River corridor as it crosses the westernmost part of the Piedmont province, the Blue Ridge province, and the easternmost part of the Great Valley Section.

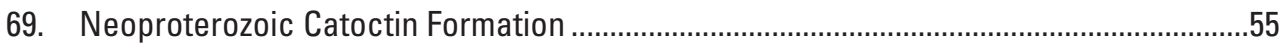

70. Stereoscopic pair of aerial photographs and sketch centered on Point of Rocks, $\mathrm{Md}$.

71. Pods of marble in the Neoproterozoic Swift Run Formation 
72. Basement rocks of the Blue Ridge province.

73. Weverton Cliffs at the southern end of South Mountain in Maryland ..............................57

74. Polymictic conglomerate of the Lower Cambrian Loudoun Formation north of the Potomac River on the east flank of South Mountain ......................................................58

75. Mesoproterozoic rocks between Weverton, Md., and Harpers Ferry, W. Va. .................58

76. Stereoscopic pair of aerial photographs and sketch centered on Harpers Ferry, W. Va., showing the Potomac River gorge and water gap ...............................................59

77. Sketch of the bluffs of Elk Ridge north of the C\&O Canal ................................................60

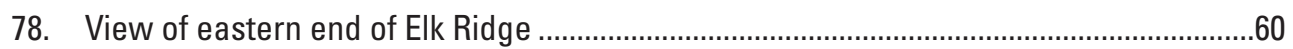

79. Historical photograph of the westernmost overturned anticline of quartzite in the Lower Cambrian Buzzard Knob Member of the Weverton Formation ........................61

81. View of the westernmost overturned anticline shown in figure 80...............................61

80. Historical photograph showing the easternmost overturned anticline in quartzite of the Lower Cambrian Buzzard Knob Member of the Weverton Formation....................61

82. Crossbedding in quartzite of the Lower Cambrian Weverton Formation at Maryland Heights

83. Geologic sketch of the bluffs from about MM 61 to the Great Valley west of Lock 36 (MM 62.5)

84. Folded and cleaved metasiltstone of the Lower Cambrian Harpers Formation.

85. Cleavage in metasiltstone of the Lower Cambrian Harpers Formation folded as the result of motion along a thrust fault.........................................................................64

86. Outcrops of Lower Cambrian Harpers and Antietam Formations ..................................64

87. Generalized structure map and cross section of a portion of the C\&O Canal National Historical Park and Potomac River corridor as it crosses the western part of the Blue Ridge province and the Great Valley section of the Valley and Ridge province

88. Geologic sketch from about MM 65.2 westward.

89. Limestone of the Lower Cambrian Bolivar Heights Member of the Tomstown Formation near MM 68.

90. Examples of karst features in the Fort Duncan Member of the Tomstown Formation near MM 68.

91. Outcrops of Lower and Middle Cambrian Waynesboro Formation in the vicinity of the C\&O Canal.

92. Historical photograph (around 1895) showing Botelers and Reynolds Cement Mill's quarries in near-vertical limestone (in West Virginia opposite MM 71.6) and Botelers and Reynolds Dam for mill race for the cement mill.

93. Historical sketch (around 1867) of soldiers and citizens in and around Killiansburg cave near MM 75.7

94. Historical photograph (date unknown) showing location north of Dam 4 ... .70

95. Geologic sketch from McMahons Mill near MM 88 westward to Lock 41 depicting Ordovician rocks of the older Stoufferstown Member of the Stonehenge Limestone thrust above limestone of the younger Rockdale Run Formation.

96. Mylonitic limestone within the Lower Ordovician Stoufferstown Member of the Stonehenge Limestone

97. Depositional features in the Lower and Middle Ordovician Rockdale Run Formation

98. Historical photograph (around 1920) of Cushwa basin at Williamsport (MM 100) ..........73 
99. Upper part of Middle Ordovician Martinsburg Formation along the railroad north

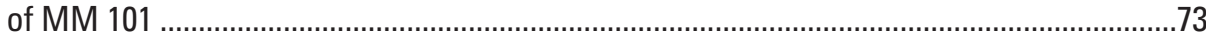

100. Geologic sketches showing structures in Cambrian and Ordovician rocks of the Great Valley section of the Valley and Ridge province

101. Mudcracks on Upper Cambrian and Lower Ordovician Conococheague Limestone at MM 107.8.

102. Stromatolites in the Middle and Upper Cambrian Elbrook Limestone east of McCoys Ferry 75

103. Upper Ordovician and Lower Silurian Tuscarora Quartzite................................................76

104. Side-looking airborne radar (SLAR) image, generalized structure map, and cross section of a portion of the C\&O Canal National Historical Park and Potomac River corridor as it crosses the Valley and Ridge province, including the westernmost

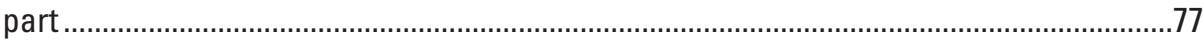

105. Fort Frederick and Big Pool at MM 112.........................................................................79

106. Historical photograph of workers and mules scraping the floor of Big Pool after it was drained to remove silt................................................................................................79

107. Upper Silurian and Lower Devonian Helderberg Limestone and Lower Devonian Shriver Chert................................................................................................................ 80

108. Thin-bedded sandstone and shale of the Upper Devonian Brallier Shale .....................80

109. Upper Devonian Foreknobs Formation........................................................................81

110. Middle Devonian Marcellus Shale southeast of MM 125 in West Virginia ....................82

111. Historical photograph of the Devil's Eyebrow.................................................................82

112. Sketch of the Devil's Eyebrow and ruins of Round Top Cement Company mill west of Hancock, Md.................................................................................................................83

113. Folds in Upper Silurian Bloomsburg and Wills Creek Formations..................................83

114. Historical photograph (1897) looking down the axis of an anticline ...............................83

115. Shale of the Middle Silurian Rose Hill Formation..............................................................84

116. Historical photograph from the overlook on Cacapon Mountain in West Virginia..........84

117. Geologic sketch of the bedrock along the section of the C\&O Canal from east of MM 133 west to Dam 6 and Tonoloway Ridge ................................................................85

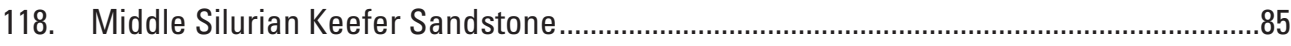

119. Geologic sketch of folded and faulted rocks of the Upper Silurian Wills Creek

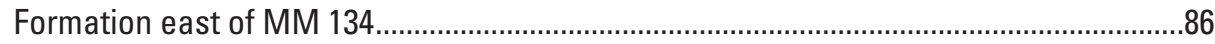

120. Folded and faulted strata at Fluted Rocks .......................................................................86

121. Upper Silurian and Lower Devonian Helderberg Limestone.............................................87

122. Brachiopods in Lower Devonian Oriskany Sandstone underlying Tonoloway Ridge

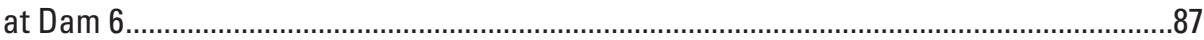

123. Outcrop of Lower and Middle Devonian Needmore Shale ..............................................87

124. Historical photograph (undated) showing folded and faulted shale and sandstone

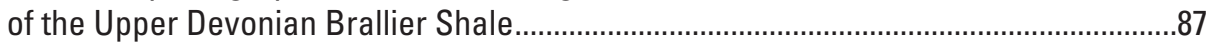

125. Mississippian rocks of the Sideling Hill syncline .................................................................8

126. Sandstone in the Upper Devonian and Lower Mississippian Rockwell Formation exposed along the Sideling Hill Creek Aqueduct at MM 136.5 .........................................88

127. Structures in the Upper Devonian Brallier Shale ...........................................................89

128. Upper Devonian Brallier Shale near MM 155 .................................................................90

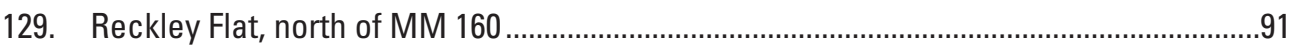


130. Devonian Hampshire Formation, exposed east of Town Creek on the limb of the Town Creek syncline

131. Lower Devonian Oriskany Sandstone on the west limb of the Broadtop anticline .........91

132. Upper Devonian Brallier Shale near MM 172 _..........................................................92

133. Historical photograph showing the C\&O Canal and wharf area at Cumberland

\section{Table}

1. Dimension stone used for the $C \& O$ Canal locks and aqueducts and the source geologic unit

\section{Conversion Factors}

\begin{tabular}{lcl}
\hline Multiply & By & \multicolumn{1}{c}{ To obtain } \\
\hline & Length & \\
\hline inch (in.) & 2.54 & centimeter (cm) \\
foot (ft) & 0.3048 & meter (m) \\
mile (mi) & 1.609 & kilometer (km) \\
\hline
\end{tabular}




\title{
Geology of the Chesapeake and Ohio Canal National Historical Park and Potomac River Corridor, District of Columbia, Maryland, West Virginia, and Virginia
}

\author{
By Scott Southworth, ${ }^{1}$ David K. Brezinski, ${ }^{2}$ Randall C. Orndorff, John E. Repetski, and Danielle M. Denenny
}

\section{Abstract}

The Chesapeake and Ohio Canal National Historical Park is $184.5 \mathrm{mi}$ long and extends from Washington, D.C., to Cumberland, Md. The canal passes through three physiographic provinces including the Piedmont, Valley and Ridge, and the Blue Ridge; the map area also includes rocks of the Coastal Plain and Appalachian Plateaus provinces. Each province contains unique packages of rocks that influenced the character of the canal and towpath. The ages of the bedrock encountered along the length of the park range from Mesoproterozoic to Jurassic and represent a variety of tectonic and depositional environments. The different rock types and surficial deposits dictated the various construction methods for the canal, which was excavated in Quaternary flood-plain deposits as well as through bedrock. The ancient course of the Potomac River and the deposits it left behind also influenced the location of the canal and towpath. The engineers made good use of the many rock types to construct the locks, dams, aqueducts, and culverts that guided water from the Potomac River into the canal and maintained the water level as canal boats traveled between higher elevations in western Maryland to sea level in Washington, D.C. The canal and towpath provide a unique transect across the central Appalachian region for examining the rich geologic diversity and history.

\section{Introduction}

The Chesapeake and Ohio Canal National Historical Park (herein referred to as the $\mathrm{C} \& \mathrm{O}$ Canal) is unique in that it is the only land within the National Park Service (NPS) system that crosses 5 physiographic provinces along a major river. From the Georgetown section of Washington, D.C., to Cumberland, Md., the C\&O Canal provides an opportunity to examine the geologic history of the central Appalachian region and how the canal contributed to the development of this area. This report and map

${ }^{1}$ U.S. Geological Survey, Reston, VA 20192.

${ }^{2}$ Maryland Geological Survey, Baltimore, MD 21218 cover the entire park within an area that is $184.5 \mathrm{mi}$ long and $2 \mathrm{mi}$ wide (see plate 1). The geologic guide is presented as if traveling the canal from east to west, from Georgetown to Cumberland, by provinces and sections, such as the Piedmont (fig. 1). Geologic features are keyed to the NPS mile markers (MM) that are found along the left-hand side of the towpath as one travels westward from Georgetown (MM 0) to Cumberland (MM 184.5). Distances shown are approximate and taken from Clague (1977). Included in the guide are references to detailed geologic information. Additional historical information is found in other guidebooks of the C\&O Canal (Boy Scouts of America, 1983; National Park Service, 1991; Hahn, 1995; High, 1997; Davies, 1999).

\section{Historical Background}

The C\&O Canal is located alongside the Potomac River, one of many tributary rivers that empty into the Chesapeake Bay. During colonial times, large ships could travel far up these rivers until they encountered the Fall Line (or Fall Zone), which is the boundary between the sandy, gravelly Coastal Plain and the rocky Piedmont province. It was at this boundary that ships encountered rapids, waterfalls, or shallow and narrow channels and could go no further upstream, and so it was there that settlements and centers of commerce were established. Cities such as Baltimore, Georgetown (later to become part of Washington, D.C.) in Maryland, and Fredericksburg and Richmond in Virginia are typical examples of communities that developed along the Fall Line. As the population in the Tidewater region grew and expanded westward, the Potomac River became one of the most viable means to cross the Appalachian Mountains to the fertile Ohio River valley and beyond. In 1785, the Patowmack Company, under the leadership of George Washington, began a series of "skirting" canals and riverbed improvements from Georgetown to Harpers Ferry (Brown, 1963; Garrett and Garrett, 1987). These skirting canals and sluices connected iron-ore prospects, furnaces, and foundaries with the armory at Harpers Ferry (fig. 2). The Patowmack Company's failure to construct a passage around the Great Falls of the Potomac in Virginia, and the success of the Erie Canal in New York (built between 1817 


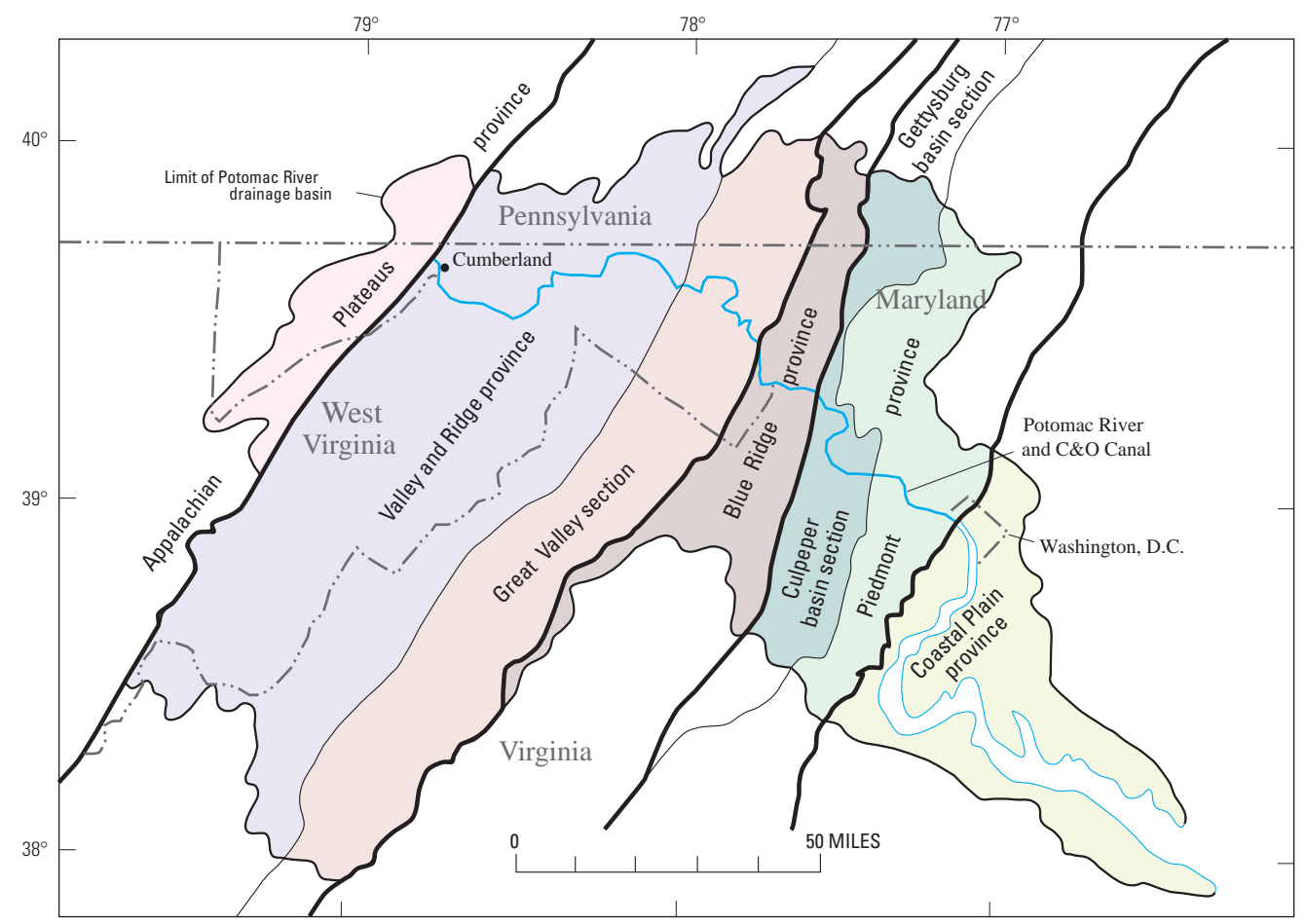

Figure 1. Sketch map showing the geologic provinces in the mid-Atlantic region and the locations of the Chesapeake and Ohio (C\&O) Canal, the Potomac River, and the Potomac River basin.

and 1825) provided momentum for the "Great National Project," which was to build a canal along the Potomac River that would eventually reach the Ohio River at Pittsburgh, Pa.

Construction of the canal, towpath, and associated structures began on July 4, 1828. The canal was open to Seneca, Md., by 1831 ; to Harpers Ferry, W. Va., by 1834; to near Woodmont, Md., by 1839; and was completed only to Cumberland, Md., in 1850. Although work on both the C\&O Canal and the Baltimore and Ohio (B\&O) Railroad began on the same day, the B\&O Railroad had been operating for eight years along essentially the same route when the canal finally reached Cumberland, Md. The C\&O Canal was used mainly to transport coal from the Appalachian Plateaus province, where it was mined, to eastern parts of Maryland, Virginia, and Washington, D.C., where it was used to heat homes and buildings.

A typical canal trip took 4.5 days one way or 9 days round trip. Mules towed a $92-\mathrm{ft}-$ long boat that, when fully loaded, weighed more than 120 tons. At peak activity, the canal saw 540 boat trips per year. Beginning with the Johnstown, Pa., flood in 1889 , a series of devastating floods ruined the canal and there was insufficient money to rebuild it. The B\&O Railroad purchased, rebuilt, and operated the canal until 1924 when it was again flooded and then drained. The B\&O Railroad gave the canal property to the U.S. Government in 1938 in lieu of a $\$ 2$ million debt. Justice William Douglas successfully campaigned in the 1950s to prevent filling in the canal for the construction of a scenic highway. The C\&O Canal was designated a National Monument by President Dwight D. Eisenhower in 1961, and a National Historical Park by President Richard M. Nixon in 1971. George Washington's vision of an industrial corridor along the Potomac River did not happen. Manufacturing plants powered by the Potomac River were obsolete when electricity was devel- oped, and local iron production was replaced by steel mills near Pittsburgh, $\mathrm{Pa}$. The result is a river valley nearly restored to its natural state in the backyard of the Nation's capital.

\section{Geologic Setting}

\section{Physiography}

The C\&O Canal extends from Rock Creek in the Georgetown section of Washington, D.C. (MM 0), to the confluence of the North Fork of the Potomac River with Wills Creek at Cumberland, Md. (MM 184.5). It is located along the northern bank of the Potomac River in Maryland. The easternmost $5 \mathrm{mi}$ of the canal lies within the city limits of Washington, D.C. The Potomac River drainage basin (fig. 1) encompasses 14,670 $\mathrm{mi}^{2}$ of Virginia, Maryland, West Virginia, Pennsylvania, and the District of Columbia. The river valley transects five major physiographic provinces and at least five subprovinces, called "sections." From east to west, they are as follows: (1) the Coastal Plain province, (2) the Piedmont province, which includes the Potomac terrane (eastern Piedmont), the Westminster terrane (central Piedmont), Culpeper basin, and Frederick Valley (western Piedmont); (3) the Blue Ridge province; (4) the Valley and Ridge province, which includes the Great Valley section; and (5) the Appalachian Plateaus province (fig. 1). The provinces and sections are unique because of the underlying bedrock, surficial deposits, and resultant landscape. Because the Appalachian Plateaus begin just west of Cumberland, Md., and the Coastal Plain begins east of Theodore Roosevelt Memorial Bridge in Washington, D.C., the C\&O Canal traverses only three of the five provinces. 

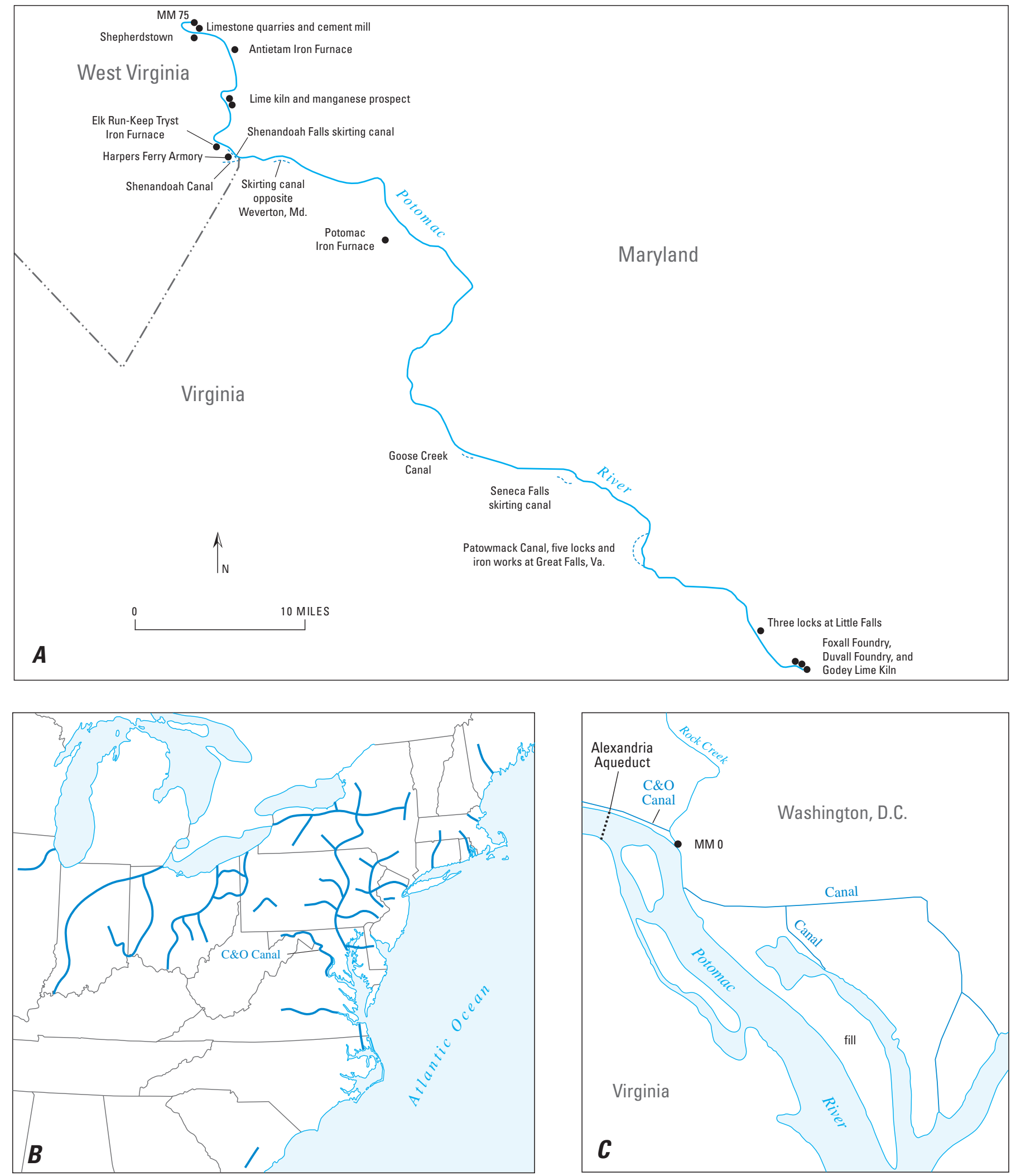

Figure 2. Sketch maps showing the earliest beginnings of canal transport. $A$, The historic Patowmack Company's skirting canals and locks, iron and manganese prospects and furnaces, limestone quarries, mills, kilns, foundries, and armory associated with early commerce along the Potomac River. B, U.S. canal system in 1850 (National Park Service, 1991). C, Canals and Potomac River near Washington, D.C., in 1771 as shown on a map by Pierre L'Enfant (Hall, 1991). The C\&O Canal in the Georgetown section of Washington, D.C. (where MM 0 is the mile marker for the beginning of the canal), the Alexandria Aqueduct, and the Alexandria Canal were built by 1843. 
Geology of the Chesapeake and Ohio Canal National Historical Park and Potomac River Corridor

Coastal Plain deposits are scattered in this region due to erosion. The Fall Line (or Fall Zone) is the boundary between the Piedmont and Coastal Plain. The boundary is not sharp, but is more of a broad area characterized by waterfalls in the Potomac River from Washington, D.C. (Little Falls) west to Seneca, Md. (Seneca Falls), which is a distance of about $17 \mathrm{mi}$. The Piedmont province is the relatively low-relief area east of the Blue Ridge that extends from Washington, D.C., to Point of Rocks, Md. In general, the Culpeper basin and Frederick valley sections form a lowland and the Westminster and Potomac terranes form dissected uplands. The boundary between the Piedmont and Blue Ridge provinces is at the foot of Catoctin and Furnace Mountains. The Blue Ridge province extends from Catoctin and Furnace Mountains west to Blue Ridge and Elk Ridge. The Valley and Ridge province extends from Blue Ridge and Elk Ridge to Cumberland, Md.; however, the Great Valley section is contained between Blue Ridge and Elk Ridge on the east and North Mountain on the west. The Great Valley section contains the Shenandoah Valley in Virginia and the Hagerstown Valley in Maryland. The Appalachian Plateaus extend westward from Cumberland into western Maryland.

The Potomac River eroded the rocks of these distinct provinces and sections and therefore had a direct bearing on the landscape evolution of the river valley, and thus also upon the engineering of the $\mathrm{C} \& \mathrm{O}$ Canal. The majority of the canal was excavated in Quaternary alluvium adjacent to the Potomac River, so good exposures of bedrock are not always evident. Elsewhere, alluvium was thin or absent, and manual drilling and blasting using black powder was necessary to excavate the canal and its towpath through bluffs of bedrock.

\section{Bedrock Geology}

For over 100 years, the bedrock exposures along the Potomac River valley have been studied in order to help unravel the geological history of the central Appalachian region. There are more than 100 bedrock formations identified along the Potomac River. Of these, there are 27 type localities of rock formations along the river, 21 type localities near the river, and 24 type localities elsewhere within the drainage basin. The type localities are areas where the rocks were named and described because of good exposure. These rocks record a complex developmental history of ocean-basin creation and destruction in response to plate-tectonic processes.

The geology of the C\&O Canal originally was mapped at 1:24,000 scale by many workers (see Appendix 1). The geologic units, faults, folds, and structural point data for this report were assembled from those larger scale maps in order to prepare a continuous geologic map for this report. On the detailed maps in this report (plates 2 through 20), fold axes and structural symbols for strike and dip of bedding, schistosity, and cleavage are not shown in order to clearly portray the geology; however, in order to understand the regional structure of the various provinces through which the canal passes, a summary map that shows just faults and folds is provided (fig. 3 ). Note that the density of fault and fold symbols varies from province to province and is based only on what has been mapped at the surface. Larger scale representations of structures are shown in some of the illustrations that accompany the Geologic Guide section of the report. Tectonic events of this part of the central Appalachian region are illustrated in figure 4 and are described from oldest to youngest in the following paragraphs.

The Blue Ridge province exposes some of the oldest rocks known from this region. These granitic gneisses were formed more than 1 billion years ago during the Mesoproterozoic Grenville orogeny (fig. 4A). These plutonic rocks were intruded in several stages over a period of 100 million years (m.y.) (Aleinikoff and others, 2000) to form a basement upon which all other rocks of the Appalachian region were deposited. Metadiabase and metarhyolite dikes that intrude these basement rocks and the extrusive flows that overlie them are the result of Neoproterozoic (700-545 Ma) continental rifting that produced the Iapetus Ocean. These volcanic rocks were intruded through cracks in the granitic gneisses and extruded onto the land surface during the breakup of the continental land mass (fig. 4B).

Fluvial and shallow-marine sediments were deposited on the newly formed margin of the continent (fig. 4C). Today, these sedimentary rocks are exposed on (from east to west) Catoctin Mountain, Short Hill, South Mountain, Blue Ridge, and Elk Ridge. They also occur in the western Piedmont (in the Sugarloaf Mountain anticlinorium and Frederick Valley synclinorium) and Great Valley section of the Valley and Ridge province. The Cambrian and Ordovician (545-480 Ma) carbonate rocks that make up much of the Great Valley section represent a grand platform in a shallow sea that deepened to the east (fig. 4D). These shelly carbonate rocks are overlain by Ordovician (450 Ma) shale. The shale was deposited by the erosion of a rising highland to the east and marks the beginning of the Taconian orogeny (fig. 4E). This highland became one boundary of the Appalachian basin, which was centered in what is now West Virginia. During the Late Ordovician, oceanic sedimentary rocks of the Iapetus Ocean (found in the Potomac terrane of the eastern Piedmont) were thrust westward onto other deepwater sedimentary rocks of the western Piedmont (found in the Westminster terrane) along the Pleasant Grove thrust fault. Moreover, rocks of the Westminster terrane were thrust concurrently onto the continental-margin rocks of the Sugarloaf Mountain anticlinorium and Frederick Valley synclinorium along the Martic thrust fault. Sandstone, shale, siltstone, quartzite, and limestone were then deposited in the shallow-marine to deltaic environment of the Appalachian basin. These rocks currently underlie the Valley and Ridge province. Such shallow-marine to fluvial sedimentation continued for a period of about 200 m.y. during the Ordovician, Silurian, Devonian, Mississippian, Pennsylvanian, and Permian Periods (fig. 4F). Many of these rocks consist of sediments shed from highlands that were rising to the east as the result of tectonic events in the Ordovician (Taconian orogeny) and Devonian (Acadian orogeny).

The Iapetus Ocean narrowed and closed up during the late Paleozoic mountain-building event known as the Alleghanian orogeny, during which the North American continental plate 


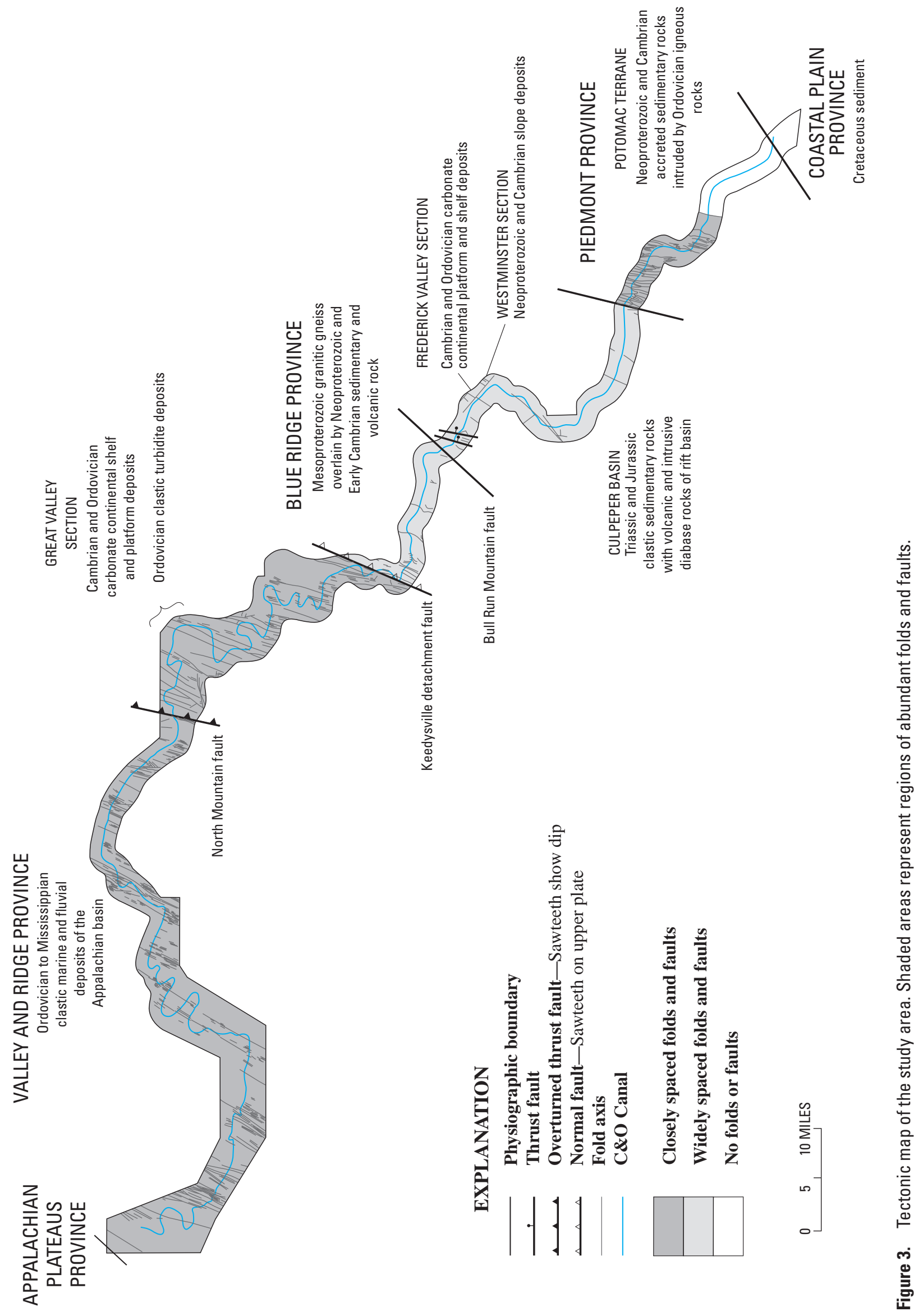


WEST

Mesoproterozoic

A $1.1 \mathrm{Ga}$ to $950 \mathrm{Ma}$

B Neoproterozoic

770 to $575 \mathrm{Ma}$

Cambrian and

Ordovician

545 to $480 \mathrm{Ma}$

C $545 \mathrm{Ma}$

Fossils appear
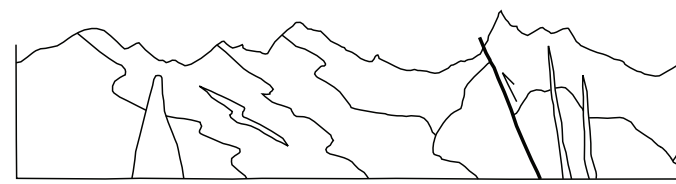

EAST

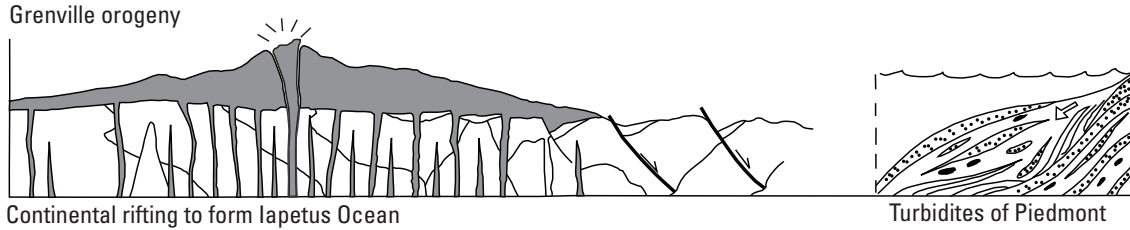

province deposited

(volcanic rocks)
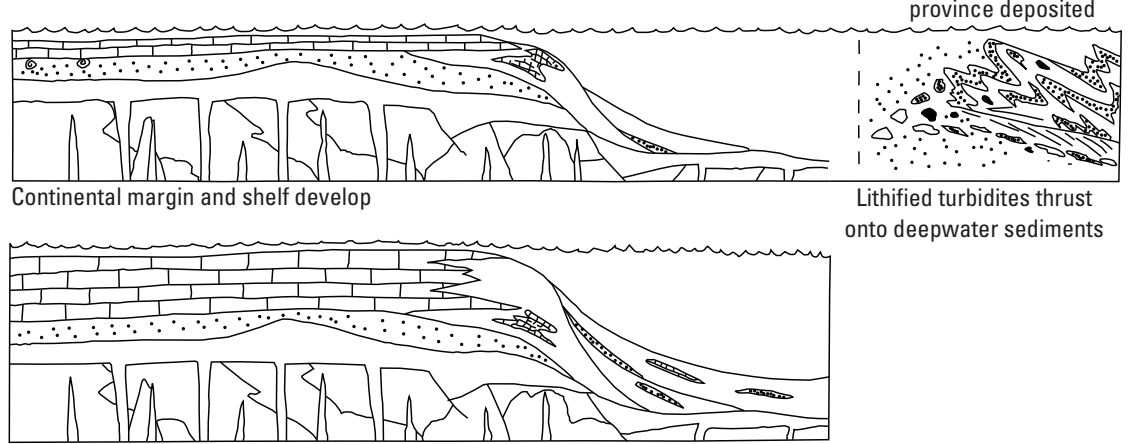

Carbonate shelf platform, platform edge, and oceanic basin develop on passive margin of continent

Plummers Island thrust fault onto deepwater sediments

Martic thrust fault

Ordovician

E 480 to

$450 \mathrm{Ma}$

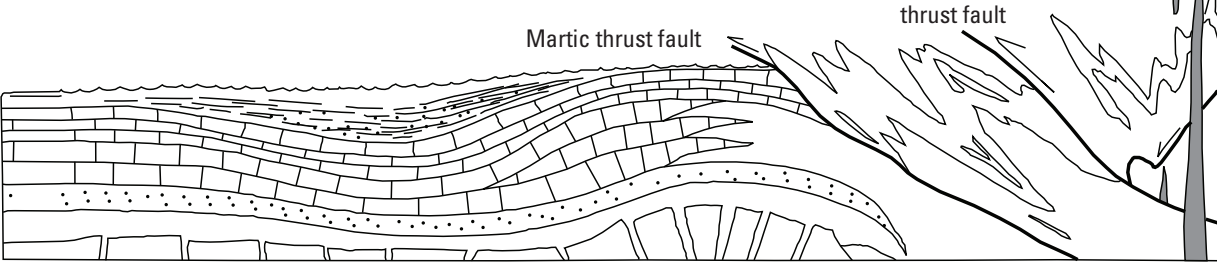

Carbonate shelf founders, flysch of Martinsburg Formation deposited. Piedmont rocks transported onto continental margin rocks, plutonic rocks intrude eastern Piedmont.
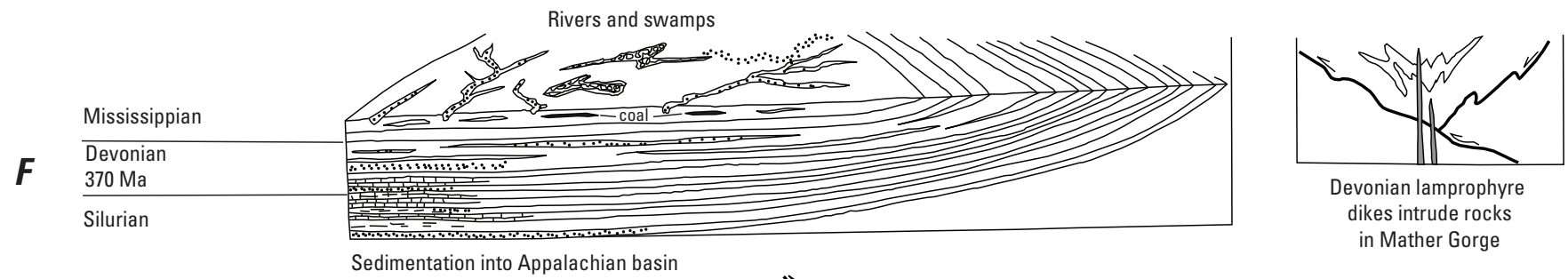

Sedimentation into Appalachian basin

in Mather Gorge

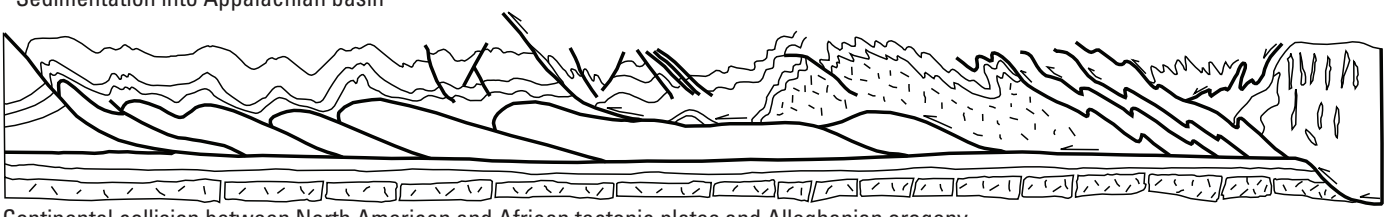

Continental collision between North American and African tectonic plates and Alleghanian orogeny

Diabase dikes and flows

Triassic and

H Jurassic

220 to $200 \mathrm{Ma}$

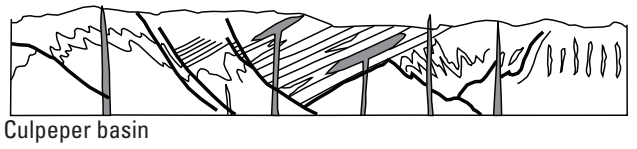

Cretaceous

and

I Tertiary

220 to $200 \mathrm{Ma}$

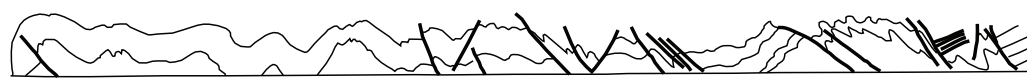

Continental rifting creates basins and results in opening of Atlantic Ocean. Erosion from highlands

provides sediment for deposition on Coastal Plain.

PIEDMONT

VALLEY AND RIDGE

J Present

$\triangle$

Present erosion level

Great
Valley


collided with the African continental plate to form the Appalachian Mountain belt (fig. 4G). The rocks were deformed by folds and faults to produce the Sugarloaf Mountain anticlinorium and the Frederick Valley synclinorium in the western Piedmont, the Blue Ridge-South Mountain anticlinorium, the Massanutten synclinorium in the Great Valley section, and the numerous anticlinoria and synclinoria of the rest of the Valley and Ridge province. During this orogeny, rocks of the Great Valley section, Blue Ridge, and Piedmont provinces were transported westward onto younger rocks of the Valley and Ridge province along the North Mountain fault (fig. 4G). Rocks that were already deformed in the eastern Piedmont also were folded and faulted and existing thrust faults were reactivated as both strike-slip and thrust faults.

After the Alleghanian orogeny, the deformed rocks of the joined continents began to break apart, a process that took place between 220 and $200 \mathrm{Ma}$ in the Mesozoic (fig. 4H). This episode of rifting or crustal fracturing initiated the formation of the current Atlantic Ocean (fig. 4l). Large alluvial fans and streams carried debris shed from the earlier uplifted Blue Ridge and Piedmont provinces and deposited it in fault-created troughs, such as the Culpeper basin in the western Piedmont. The large faults that formed the western boundary of the Culpeper basin provided an escarpment that quickly became covered with such eroded debris. Igneous rocks were intruded into these strata as subhorizontal sheets (sills) and near-vertical dikes that extend beyond the basin into adjacent rocks. After these molten igneous rocks were emplaced at $200 \mathrm{Ma}$, the region underwent a period of slow uplift and erosion. Thick deposits of unconsolidated gravel, sand, and silt shed from the eroded mountains were deposited as part of the Atlantic Coastal Plain (fig. 4l). The process continues today: the mountains are eroded, sediment is deposited on the Coastal Plain, and the landscape is dissected by rivers bordered by alluvial terraces, thereby creating the landscape of the present valley (fig. 4J ). For additional technical information and abundant references, see the summaries in Hatcher and others (1989).

\section{Cenozoic Landscape and Surficial Deposits}

\section{Introduction}

The landscape and geomorphology of the Potomac River valley are the result of erosion and deposition from about the middle part of the Cenozoic Era to the present (about the past 5 m.y.). The distribution of flood-plain alluvium and ancient fluvial terraces of the Potomac River and adjacent tributaries record the historical development of the drainage system (fig. 5). There

Figure 4 (facing page). Diagrammatic sketches showing the geologic history of the Potomac River valley over the past 1 billion years.

A, Granitic gneiss intrusions, metamorphism, and deformation related to the Grenvillian orogeny lasted 60 m.y., from $1.1 \mathrm{Ga}$ to $950 \mathrm{Ma}$. These rocks are found in the Blue Ridge province.

$B$, Continental rifting and volcanic activity in the Grenville terrane (the current Blue Ridge province) and turbidite deposition in a deepwater basin to the east (the current Piedmont province) lasted about 200 m.y., from about 770 to $575 \mathrm{Ma}$.

$C$, The margin of the continent became stable with carbonate rocks deposited in quiet water (rocks of the current Great Valley and Frederick Valley sections). To the east (the current Piedmont province), thrust sheets of the turbidite deposits created a sedimentary mélange. Shelly fossils appeared at about $545 \mathrm{Ma}$.

$D$, Deepwater rocks were deposited into a basin east of the shelf margin for about 65 m.y. (the current western part of the Piedmont province).

E, The stable shelf foundered as the Taconian orogeny ( 480 to $450 \mathrm{Ma}$ ) elevated the rocks to the east and provided a source for the clastic material that makes up the shale of the Middle and Upper Ordovician Martinsburg Formation (the current center of the Great Valley section). Rocks in the Piedmont province were intruded by plutonic rocks (near the Georgetown section of Washington, D.C.) and were transported westward along the Pleasant Grove and Martic thrust faults.

$F$, A thick sequence of sedimentary rocks was deposited in a deepening Appalachian basin for 120 m.y. Most of these rocks are now found in the Valley and Ridge province. At about $370 \mathrm{Ma}$, igneous rocks were intruded in older rocks near Great Falls.

G, At about $280 \mathrm{Ma}$, the continental tectonic plates of North America and Africa collided, resulting in the Alleghanian orogeny. Many of the folds and faults in rocks west of the Piedmont province are related to this event.

$H$, About 60 m.y. later, continental rifting began and lasted for about 20 m.y. (220 to $200 \mathrm{Ma}$ ). Thick sequences of sedimentary rock were deposited in fault-bounded basins, and there was volcanic activity. The end result was the creation of the Atlantic 0cean. The Culpeper and Gettysburg basins in the western Piedmont province also are the result of this event.

I, For the last 200 m.y., the landscape has eroded and rivers have carried the sediment eastward to deposit the thick strata of the Atlantic Coastal Plain.

$J$, Further erosion has removed much of these extensive Coastal Plain deposits and sculpted the bedrock to create the modern landscape. Some patches of Coastal Plain deposits remain near the Fall Line of the Potomac River. 


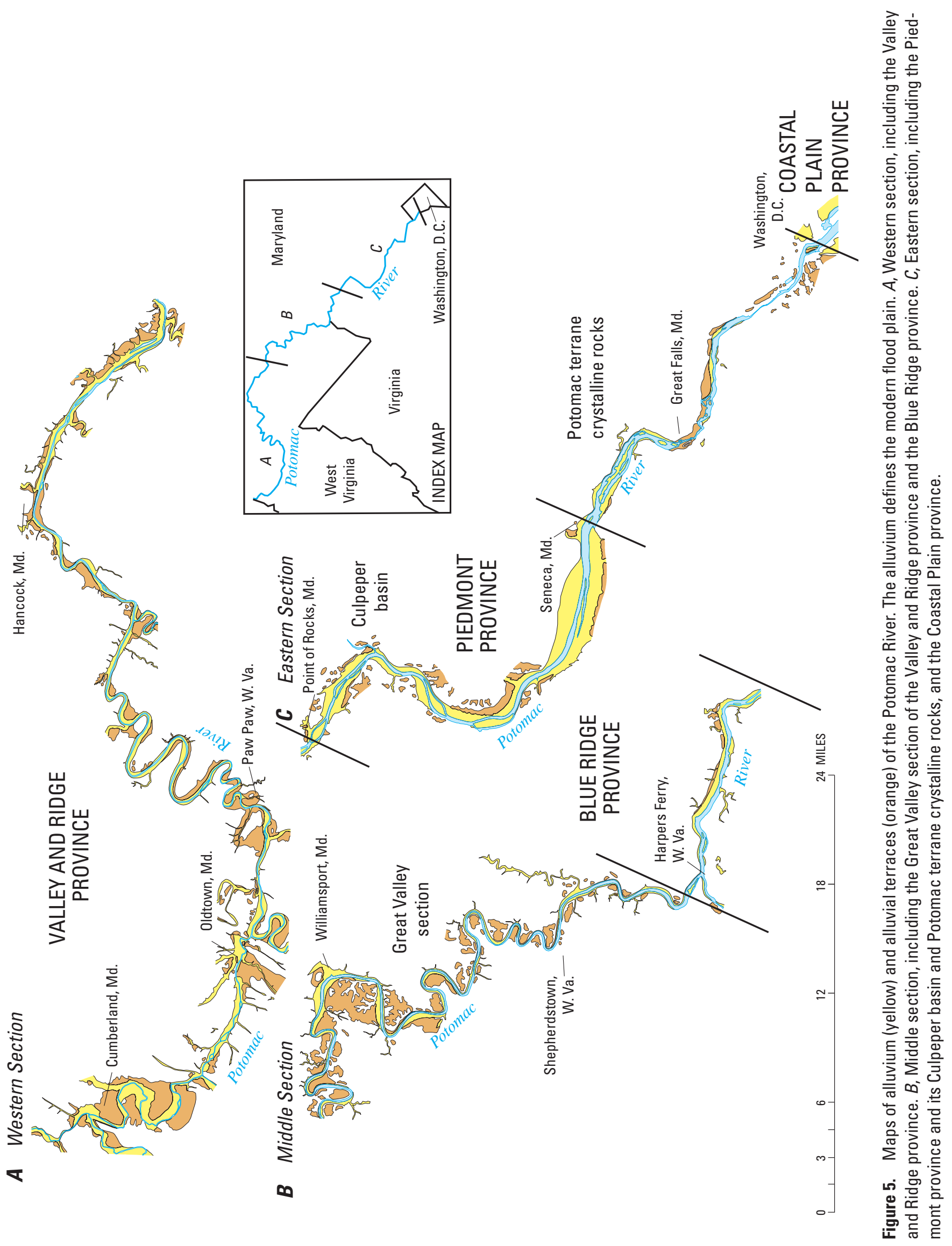




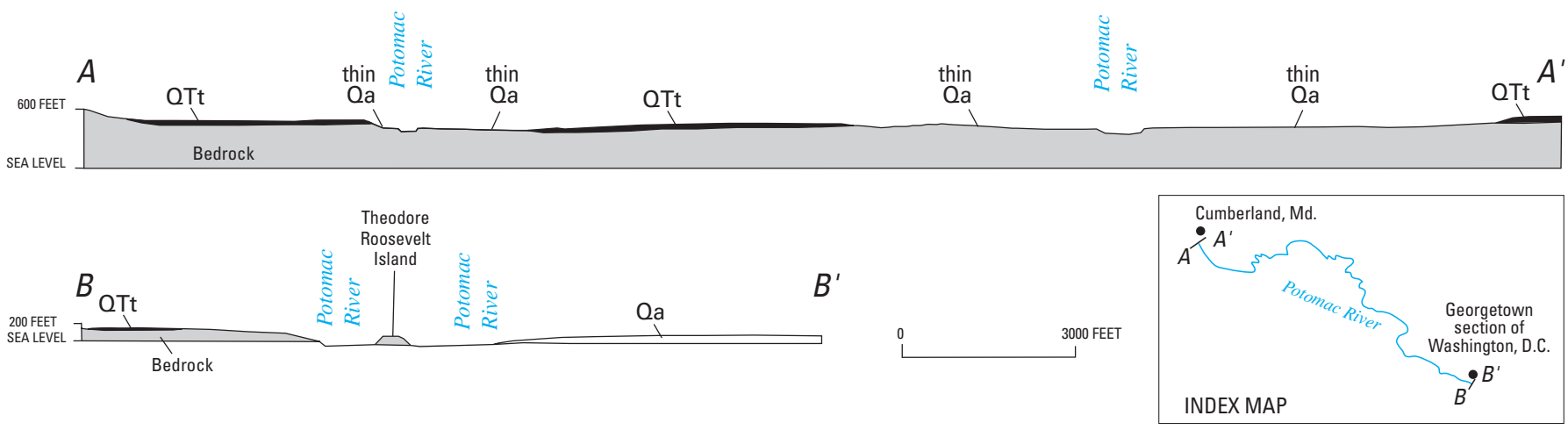

Figure 6. Schematic cross sections of the Potomac River valley at Cumberland, Md. $\left(A-A^{\prime}\right)$, and the Georgetown section of Washington, D.C. $\left(B-B^{\prime}\right)$, showing the change in terrace morphology, topographic elevation, and surficial deposits along its course. Evidence that the Potomac River migrated across the valley is best preserved

is no evidence that the river migrated laterally across a broad region; rather, it has cut downward, mainly using its early course.

The distribution, thickness, and height above the present river level of terraces and sediments deposited on the flood plain varies from province to province and from rock type to rock type (fig. 6). Elevations of terraces along the river show that the slope angles of the ancient and modern river valley are similar; this in turn suggests that the terraces formed as the result of either eustatic sea-level drop or uplift (Zen, 1997a,b). The Pliocene (5.3 Ma) fluvial deposits at Tysons Corner, Va., occur over $330 \mathrm{ft}$ above the Potomac River (470 to $500 \mathrm{ft}$ elevation), and are about 5 mi away, south of Great Falls. Mt. Sterling, near Sterling, Va., is at about $270 \mathrm{ft}$ elevation and is located about $3 \mathrm{mi}$ south of the Potomac River in the Culpeper basin. By analogy, some of the high terraces along the Potomac River could be as old as Miocene or Pliocene. In the absence of supportive data, the landforms and deposits probably formed during late Tertiary to Quaternary time, when a wetter climate, sparse vegetation, and frozen ground caused increased precipitation to run into the ancestral river, enhancing downcutting and erosion (Zen, 1997a,b).

\section{River Morphology}

The morphology of the Potomac River changes as it drops about $610 \mathrm{ft}$ in elevation as it flows more than $190 \mathrm{mi}$ from the western part of the Valley and Ridge province to the Coastal Plain in the District of Columbia (figs. 5 and 6). From the tidal part of the Potomac near Theodore Roosevelt Memorial Bridge to the Culpeper basin at Seneca Falls, the Potomac River has cut a gorge into bedrock. From Great Falls west to Seneca Falls, the gorge has numerous islands and a considerable amount of alluvium is preserved. Numerous flat-topped islands are located around Great Falls Tavern along the C\&O Canal in Maryland and near Great Falls Park, Va. The islands are bedrock strath terraces (remnants of bedrock in valley floors) that formed when the Potomac River cut across the ancient valley floor and incised channels into it. The riverbed at Cumberland, Md.; Paw Paw Bends (river meanders near Paw Paw, W. Va.); Williamsport, Md.; and near Seneca, Md., where terrace gravels are preserved overlying shale bedrock. The modern flood plain is the most extensive at Cumberland and Seneca. QTt, Tertiary to Holocene terrace deposits; Qa, Holocene alluvium.

is rock with channels and depressions as much as $80 \mathrm{ft}$ deep (Reed, 1981). Some alluvium was deposited on the bedrock terraces and radiocarbon dates on organic matter suggest that they have been vegetated for more than 10,000 years (Reed, 1981). At Great Falls, the Potomac River drops $70 \mathrm{ft}$ from Olmstead Island, which is a strath terrace at $140 \mathrm{ft}$ elevation. The Potomac River then drops another $70 \mathrm{ft}$ to sea level.

From Seneca Falls to Point of Rocks, Md., the Potomac River drops about $300 \mathrm{ft}$ in elevation; the channel is about $5 \mathrm{ft}$ deep and flows on bedrock with scattered cobbles and boulders in the riverbed. The deepest part of the channel (the thalweg) is between the northern shore and the islands in the center of the river. The modern flood plain is broad. Bedrock is exposed in tributaries, which suggests that the alluvium is 2 to $20 \mathrm{ft}$ thick at most. Terraces also are broad and can be as much as $270 \mathrm{ft}$ above and as far as $3 \mathrm{mi}$ away from the present river.

From Point of Rocks, Md., to Harpers Ferry, W. Va., the Potomac River flows across resistant bedrock ledges of the Blue Ridge province. There are islands and flood plains consisting of alluvium, but the few preserved terraces are located along the north shore and slope to the flood plain. The river drops about $40 \mathrm{ft}$, from 250 to $210 \mathrm{ft}$ elevation.

From Harpers Ferry west to McCoys Ferry, Md., the Potomac River drops about $130 \mathrm{ft}$ in elevation. Entrenched meanders cut into a plateau with near-vertical bluffs of carbonate rock of the Great Valley section. The largest meander occurs in the shale of the Martinsburg Formation at Williamsport, Md., where extensive gravel terraces are preserved as much as $220 \mathrm{ft}$ above the river. Along this section, there are no falls and there is a lack of coarse alluvium because the river cuts into soft shale.

The section of the river with the most abandoned incised meanders, entrenched meanders, and broadest terraces adjacent to the modern flood plain of the Potomac River is from McCoys Ferry west to Cumberland, Md., in the Valley and Ridge province. Along this section, the river is about $5 \mathrm{ft}$ deep and flows over bedrock with large amounts of coarse alluvium in the riverbed. The river drops about $230 \mathrm{ft}$, from 610 to 380 $\mathrm{ft}$ elevation, in this region. 


\section{Alluvial Terraces}

On the geologic maps (plates 2 to 20), terraces that were mapped at different elevation levels are shown as one group because the four distinct terrace elevation levels are difficult to correlate. Terrace formation can be understood by study of the modern river system. The channel bottom of the Potomac River is a nearly flat surface where the bedrock has been eroded by running water. The bedrock surface has local irregularities-such as ridges, swales, and potholes (figs. 7 and 8 ) — that formed by differential erosion of various rock types. A veneer of boulders, cobbles, gravel, sand, and some silt was deposited on the channel bottom. In areas of low hydraulic energy (slack water), there are thick deposits of fine material, whereas only a little coarse material remains on the riverbed where the current is torrential. Fish weirs constructed in the 18th century (Guzy, 1999) or perhaps earlier by Native Americans (fig. 9) near Shepherdstown, W. Va.; Sandy Hook and Brunswick, Md.; and near the Monocacy River in Maryland indicate that the riverbed is shallow and that erosion of and deposition in the bed did not affect their construction.

The river migrated over time across the alluvial plain and cut down into the bedrock in response to changing climatic or tectonic conditions. As a new channel was cut into bedrock, the elevated former riverbed was exposed to weathering and became vegetated. Subsequent erosion left an irregular patchwork of terraces that represents stages in the river's history.

One of the more common types of terraces of the Potomac River is an inclined surface created as the river migrated from a higher to a lower elevation along a continuous slope. Allu- vial material commonly is not preserved on these slopes. Good examples may be seen along the South Branch of the Potomac River, the Cacapon River, Little Cacapon River; and on the meanders of the Potomac River north of Paw Paw, W. Va., and east of Four Locks, Md. in the Great Valley section.

In general, alluvial terraces and deposits of mainly quartz gravel, cobbles, and boulders are best developed and preserved on areas underlain by siltstone and shale bedrock (fig. 10A). This relationship holds true in the Great Valley and Culpeper basin sections. Large alluvial boulders may have been transported by ice rafting or by interference from tree roots (fig. 10B). The most extensive deposits are found upstream of ridges capped by resistant sandstone in the Valley and Ridge province. Their presence suggests that the former river may have been impounded by the water gaps through the ridges. Such examples can be seen around Cumberland, Md., just west of the Patterson Creek anticlinorium (MM 175). In this area, broad terraces underlie the town, Mexico Farm Airport, and Death Valley (fig. 5).

\section{Abandoned Entrenched Meanders}

Abandoned entrenched meanders of the ancestral Potomac River demonstrate how the river locally migrated into its present position. An outstanding example of a former riverbed can be seen near Paw Paw, W. Va., where West Virginia Route 51 follows Purslane Run. The distribution of strath terraces and material deposited on them provide the chronologic development of the landscape in this area (Braun, 1976; Fitzpatrick, 1987); the

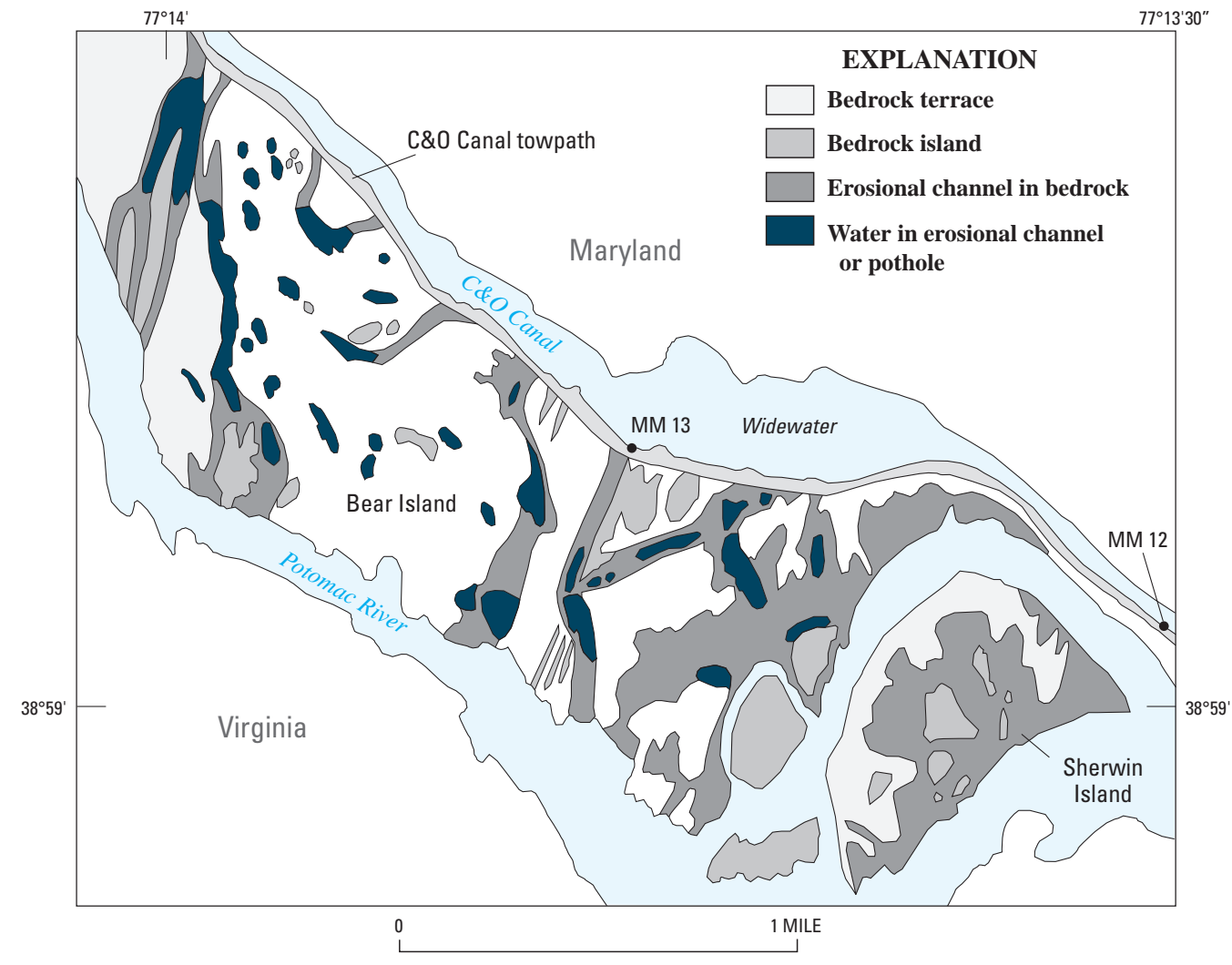

Figure 7. Sketch map showing large water-filled potholes and channels on the eastern half of Bear Island near MM 13 and Widewater. Interpreted from 5 -ft-contour topographic map compiled by the National Park Service (NPS, unpub. data). 


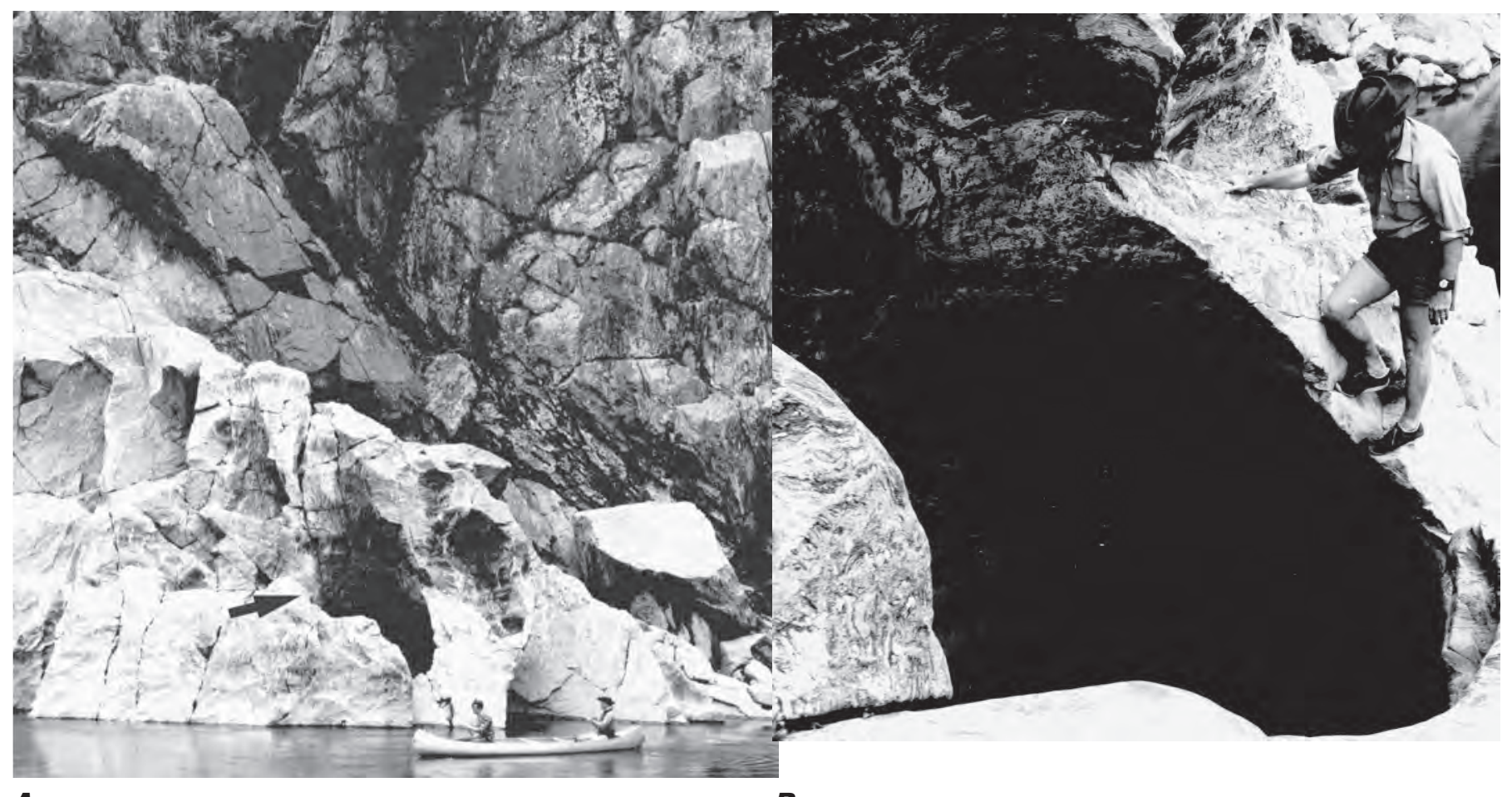

\section{A}

B

Figure 8. Potholes in migmatite of the Neoproterozoic and (or) Lower Cambrian Mather Gorge Formation along the bluff of Mather Gorge in Virginia, opposite MM 13 and Bear Island. A, View from across river channel; 16-ft-long canoe for scale; arrow points to area shown in $B$. B, Close-up view of pothole from part $A$. Photographs by David F. Usher (U.S. Geological Survey).

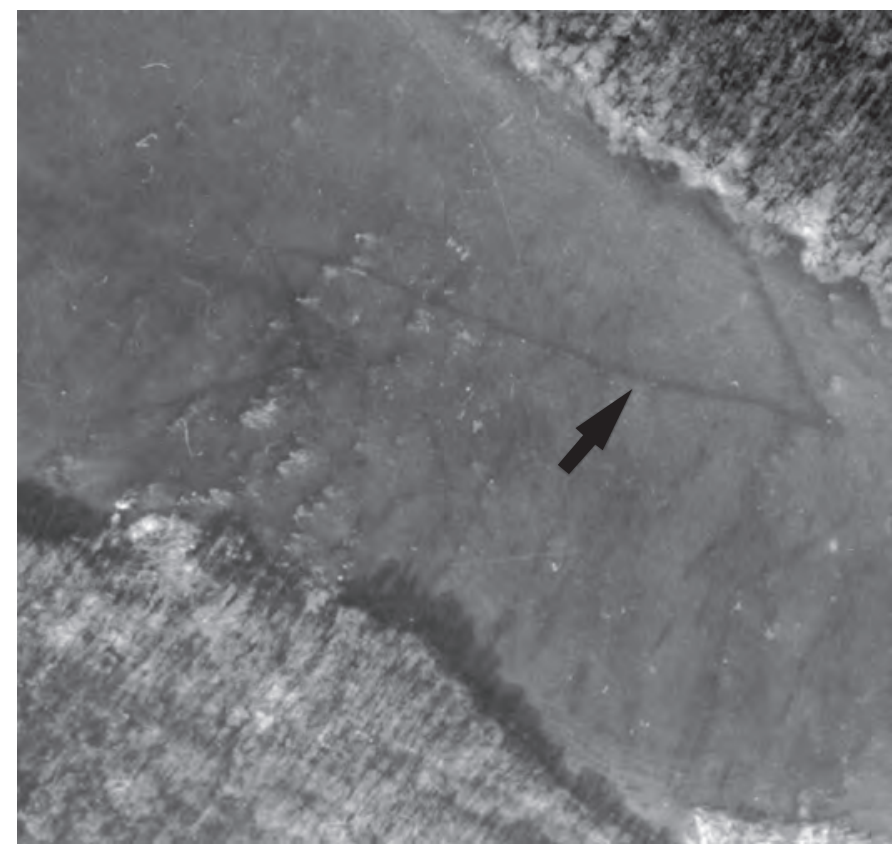

Figure 9. Aerial photograph showing fish weirs constructed by Native Americans; arrow points to a weir segment. The weirs are constructed from alluvial boulders piled about $3 \mathrm{ft}$ high on the bed of the Potomac River. meander at Reckley Flat and Purslane Run was abandoned when the ancestral Potomac River eroded into the ancestral valley of the Little Cacapon River (fig. 11A). The meander at Paw Paw was abandoned as the meander neck was narrowed and eroded (fig. 11B). In addition, the canal at Four Locks (MM 109) occupies an abandoned fluvial channel that bypassed a meander loop. To the east, there is an "island" within an abandoned river meander adjacent to Conococheague Creek at Williamsport (MM 100).

A well-developed, abandoned channel may be seen at Widewater (MM 13), which is a large body of water incorporated within the C\&O Canal east of Great Falls. In Great Falls Park, Va., the Potomac River flowed around an island locally known as Glade Hill (fig. 12). The boulder deposit on the crest of the hill indicates that the river previously flowed at that higher level (fig. 13) (Reed and others, 1980; Zen, 1997a; Southworth and others, 2000).

\section{Recent Flood-Plain Alluvium}

The areal distribution of the modern flood plain (0a) was determined by mapping the debris deposited by the floods of January and September 1996. The flood plain of the Potomac River is relatively broad (fig. 5) upstream from constrictions such as (1) west of the Patterson Creek anticlinorium at Spring 


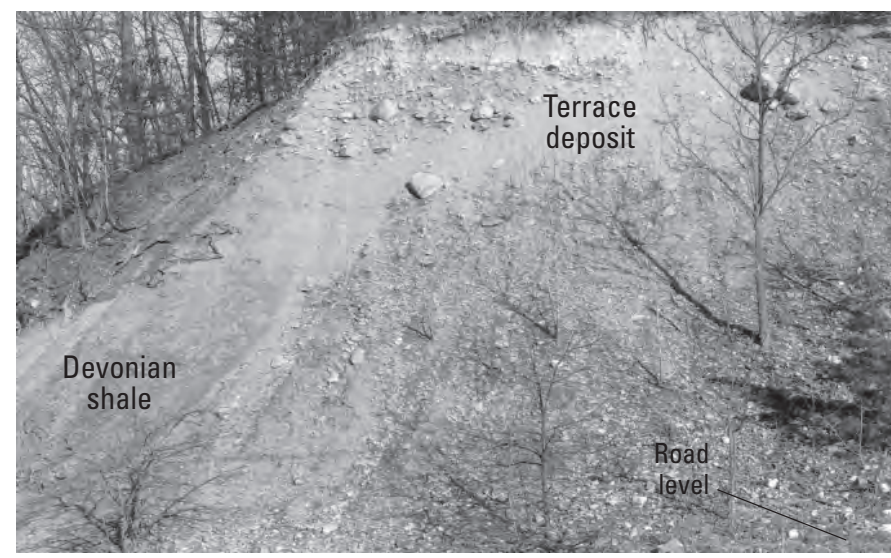

$\boldsymbol{A}$

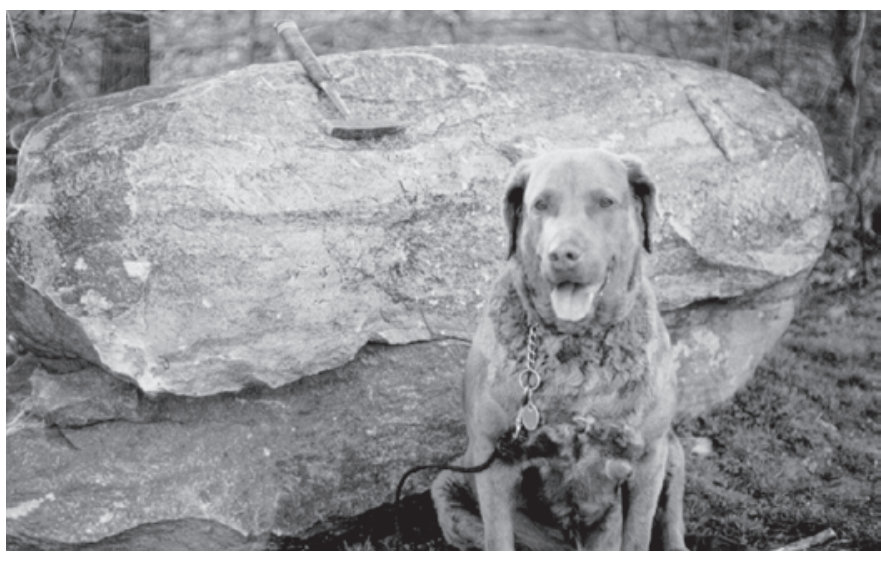

$\boldsymbol{B}$

Figure 10. Remnants of Quaternary alluvial terraces. A, Alluvial terrace deposit of the Potomac River in the Valley and Ridge province near Cumberland, Md., near MM 180. The large samdstone boulders are about $3 \mathrm{ft}$ across. $B$, A large quartzite boulder of quartzite (possibly from the Lower Cambrian Weverton Formation of the Blue Ridge province) that was deposited on a terrace about $65 \mathrm{ft}$ above and 1 mi away from the Potomac River near Sterling, Va.

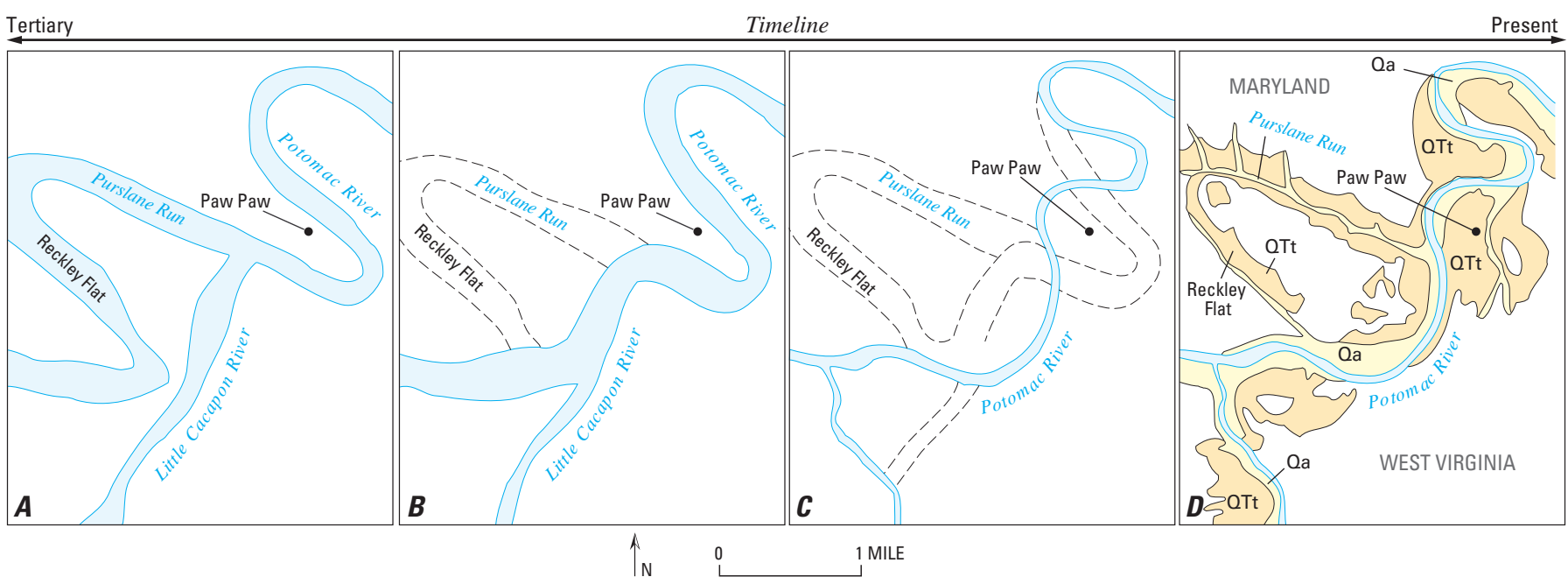

Figure 11. Sketch maps illustrating the evolution of the abandoned incised meanders of the Potomac and Little Cacapon Rivers near Paw Paw, W. Va. (centered on MM 157), a process that occurred probably within the past 1 million years. $A-C$, Planimetric sketches. $D$, Generalized surficial geologic map. Map-unit abbreviations are as follows: QTt, Tertiary to Holocene terrace deposits; Qa, Holocene alluvium.

Gap near Cumberland, Md.; (2) west of Broadtop Mountain at Oldtown, Md.; (3) west of North Mountain at McCoys Ferry, Md.; (4) where the river meanders $90^{\circ}$ to the south across rocks of the Martinsburg Formation at Williamsport, Md.; (5) where the river crosses rocks of the Culpeper basin west of Seneca Falls; (6) upstream of where the river turns south $90^{\circ}$ near Swains Lock, Md. (MM 16.5); and (7) at the Fall Line, where the Potomac River meets the Coastal Plain.

The thickness and size of the alluvial material also varies. Along the shores and islands, as much as $20 \mathrm{ft}$ of silt overlies several feet of gravel (fig. 14); drill holes on the flood plain north of Whites Ferry, Md. (MM 35), show depths of 21 and 22 ft (Froelich, 1975). Radiocarbon dates indicate that this material probably was deposited about 10,000 years ago as the climate warmed at the end of continental glaciation (Reed, 1981; Froelich and others, 1992). Modern floods, such as those during 1996, tend to scour existing deposits and then redeposit the material elsewhere. During such floods, the surface of the towpath was locally scoured and sometimes breached through to the canal. Thick deposits of silt and mud in the canal have been accumulating since the canal was drained in 1928. Along the river, coarse gravel and cobbles tend to be deposited in areas where there is high-energy flow. Fine silt and sand tends to be deposited in areas of low energy flow. 


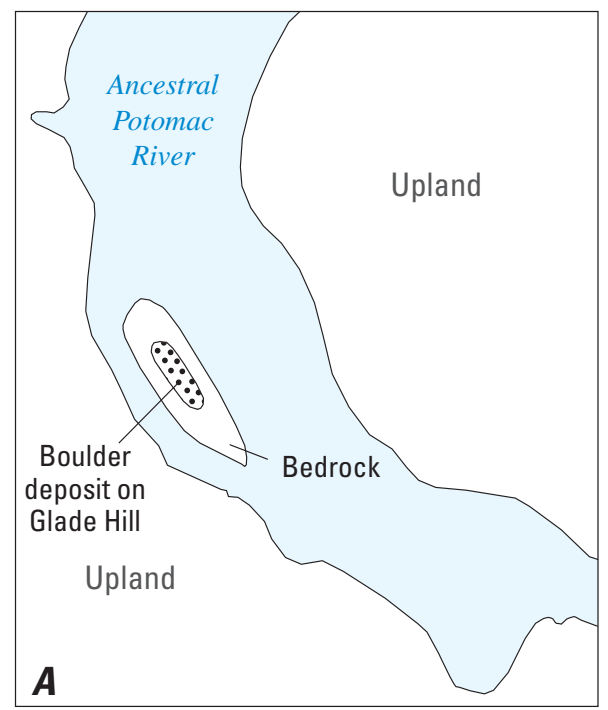

$\uparrow_{N}$

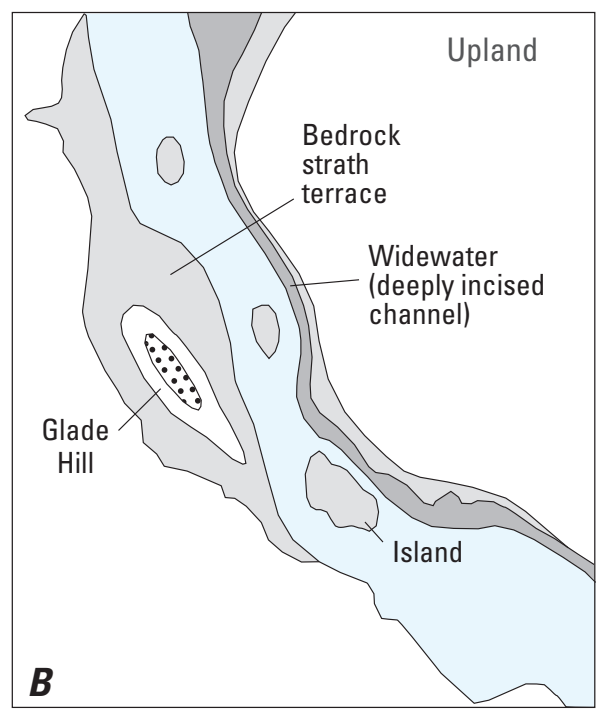

1 MILE
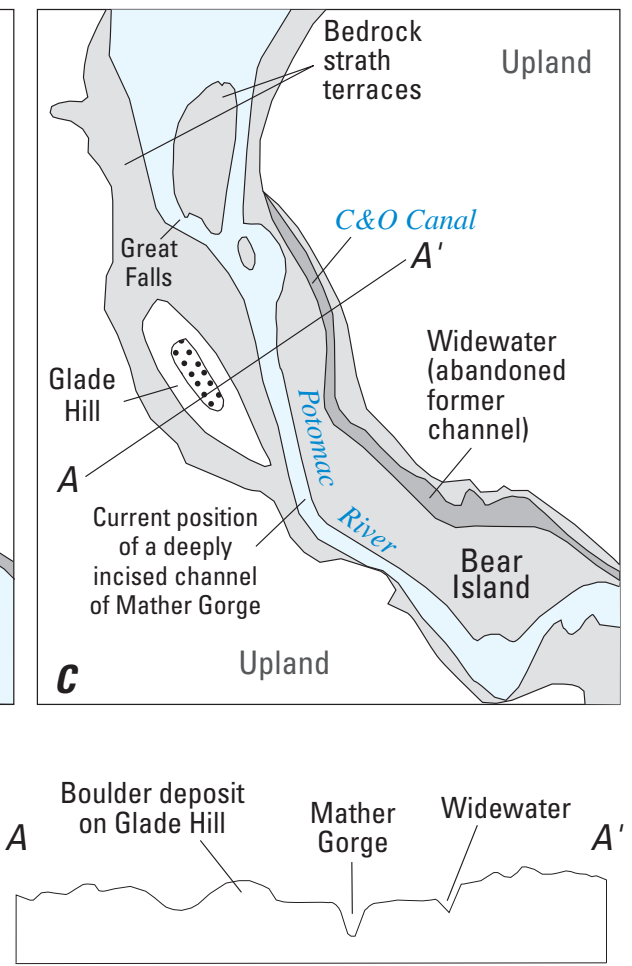

D

Figure 12. Schematic maps of the Great Falls of the Potomac River showing the evolution of the abandoned channel of Widewater and of Glade Hill. $A$, The area as it may have looked before the Pleistocene. The ancestral Potomac River was wide and Glade Hill was merely a boulder-covered island in the channel. $B$, Narrower ancestral Potomac River, the deeply incised channel where Widewater would eventually be located, and the beginnings of the bedrock strath terraces. $C$, Present-day features. The Potomac River channel is currently incised into Mather Gorge and Widewater is separated from the Potomac River by a terrace (modified from Reed and others, 1980); the canal enginers incorporated Widewater into the canal construction. $D$, Schematic cross section shown in $C$.

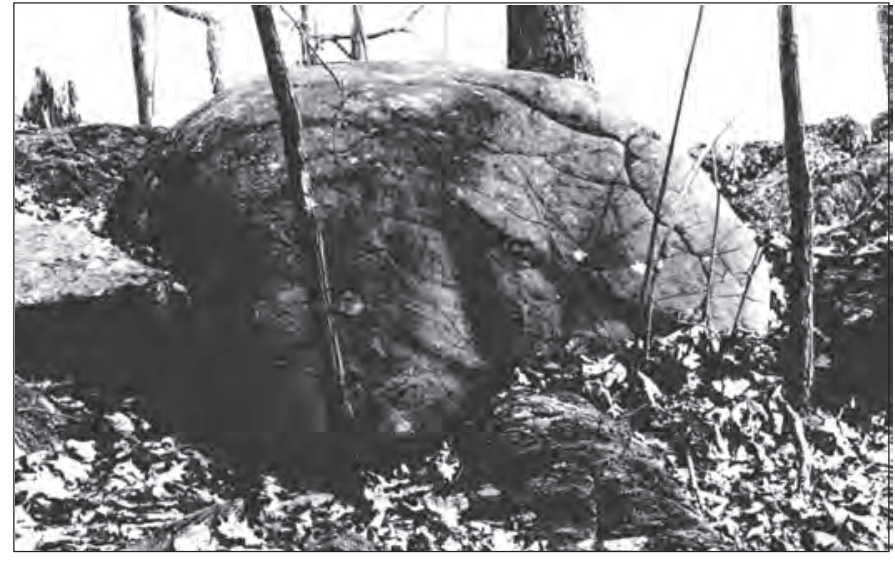

Figure 13. Rounded boulder of diabase ( $5 \mathrm{ft}$ in diameter) deposited by the Potomac River on terrace at south end of Glade Hill, approximately $135 \mathrm{ft}$ above the present river level (south of MM 14 in Virginia). Photograph by David F. Usher (U.S. Geological Survey).

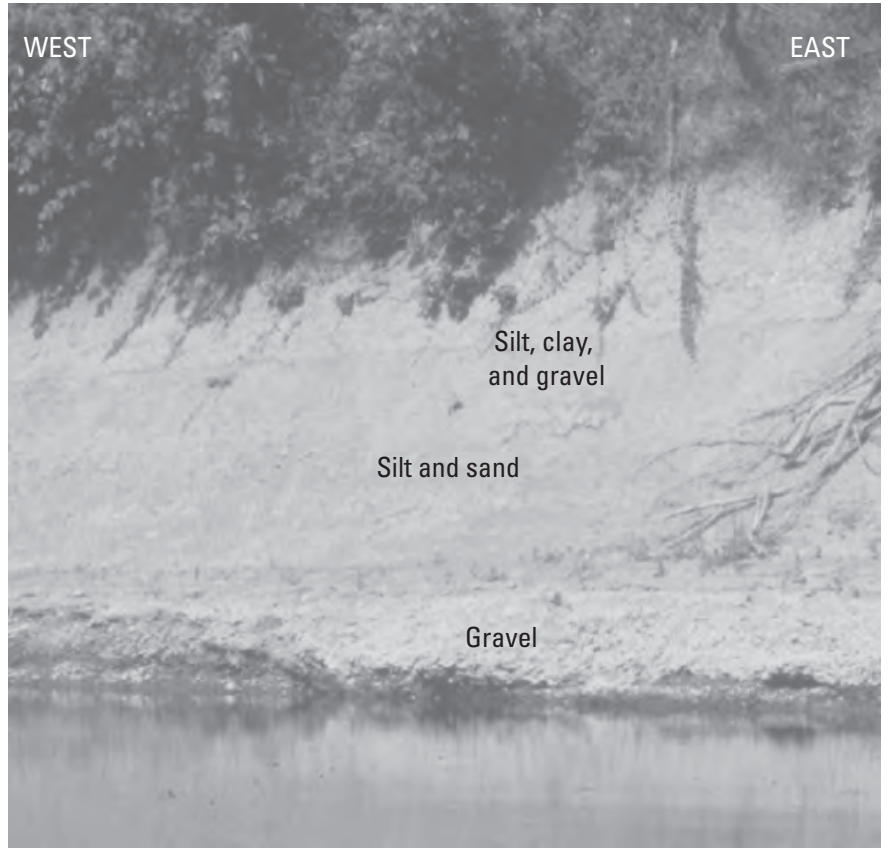

Figure 14. Recent alluvium along the Monocacy River, near its confluence with the Potomac River near MM 42, consists of gravel, sand, and silt as much as $20 \mathrm{ft}$ thick. 


\section{Colluvium}

Colluvium is abundant on all slopes adjacent to ridges that are underlain by sandstone, quartzite, and other resistant rocks. The slopes have thin to thick veneers of colluvial boulders and blocks that have been transported by gravity or by freezing and thawing. Large rock streams and block fields locally are shown on the geologic map, but none are found near the canal. Near Rosslyn, Va., and the Georgetown section of Washington, D.C., gravel derived from the Cretaceous and Tertiary deposits of the Coastal Plain have been transported down slope as colluvium.

On the west limb of the Patterson Creek anticlinorium, east of Cumberland, Md. (MM 180), are fan-shaped deposits of coarse sandstone colluvial boulders that are intermixed with alluvial deposits. Extensive alluvial fans along Mill Run, northwest of Oldtown, Md. (MM 167), are composed of fine colluvial sandstone cobbles that were eroded from Warrior Mountain. Similar deposits and landforms are found from Licking Creek to Fort Frederick in Maryland.

\section{Karst Landforms}

Karst landforms (sinkholes and caves) occur in areas underlain by limestone, dolomite, and marble in the Great Valley section of the Valley and Ridge province, and in the Frederick Valley, Culpeper basin, and Westminster terrane in the western Piedmont province (fig. 15). In the Great Valley, sinkholes are developed throughout most of the carbonate rock formations, but are mostly concentrated in the Elbrook, Conococheague, and Stonehenge Limestones, Rockdale Run Formation, and Chambersburg Limestone. There are caves along the canal and some have emergent springs (fig. 16). The Great Valley also has travertine and tufa deposits. Karst landforms are rare in the Blue Ridge province because marble occurs as small bodies.

Kanawha Spring, which is in the Piedmont province east of Point of Rocks, Md., flows from limestone of the Frederick Formation, which underlies the flood plain. Limestone cobbles within the conglomerate of the Leesburg Member of the Bull Run Formation southeast of Point of Rocks dissolved to form hummocky topography with abundant sinkholes and springs; travertine and tufa deposits also may be seen here. These features evolved as springs and streams that were supersaturated with calcite discharged and flowed over rough channels where the calcite was deposited and built up over time (White, 1988). In addition, marble and limestone of the Westminster terrane (exposed along Monocacy River north of Indian Flats) underlie linear valleys and contain abundant sinkholes to the north.

\section{Fossils Along the C\&O Canal}

\section{Introduction}

The rocks that are exposed along the $\mathrm{C} \& \mathrm{O}$ Canal contain a variety of preserved remains, traces, tracks, or imprints of ancient plants and animals. Although the Triassic and Jurassic rocks of the Culpeper basin in the western Piedmont province contain dinosaur footprints that are as old as $210 \mathrm{Ma}$, many of the rocks farther to the west in the Valley and Ridge province contain fossils that are much older, ranging in age from 530 to $340 \mathrm{Ma}$. Along the $\mathrm{C} \& \mathrm{O}$ Canal, the most common types of fossils are shells of creatures that inhabited the ancient seas that covered this region hundreds of millions of years ago. Less commonly, remains of animals and plants that lived on land are preserved in some of the younger exposed rocks.

For an animal or plant to become a fossil, several things must occur. First, the animal or plant must inhabit an environ-

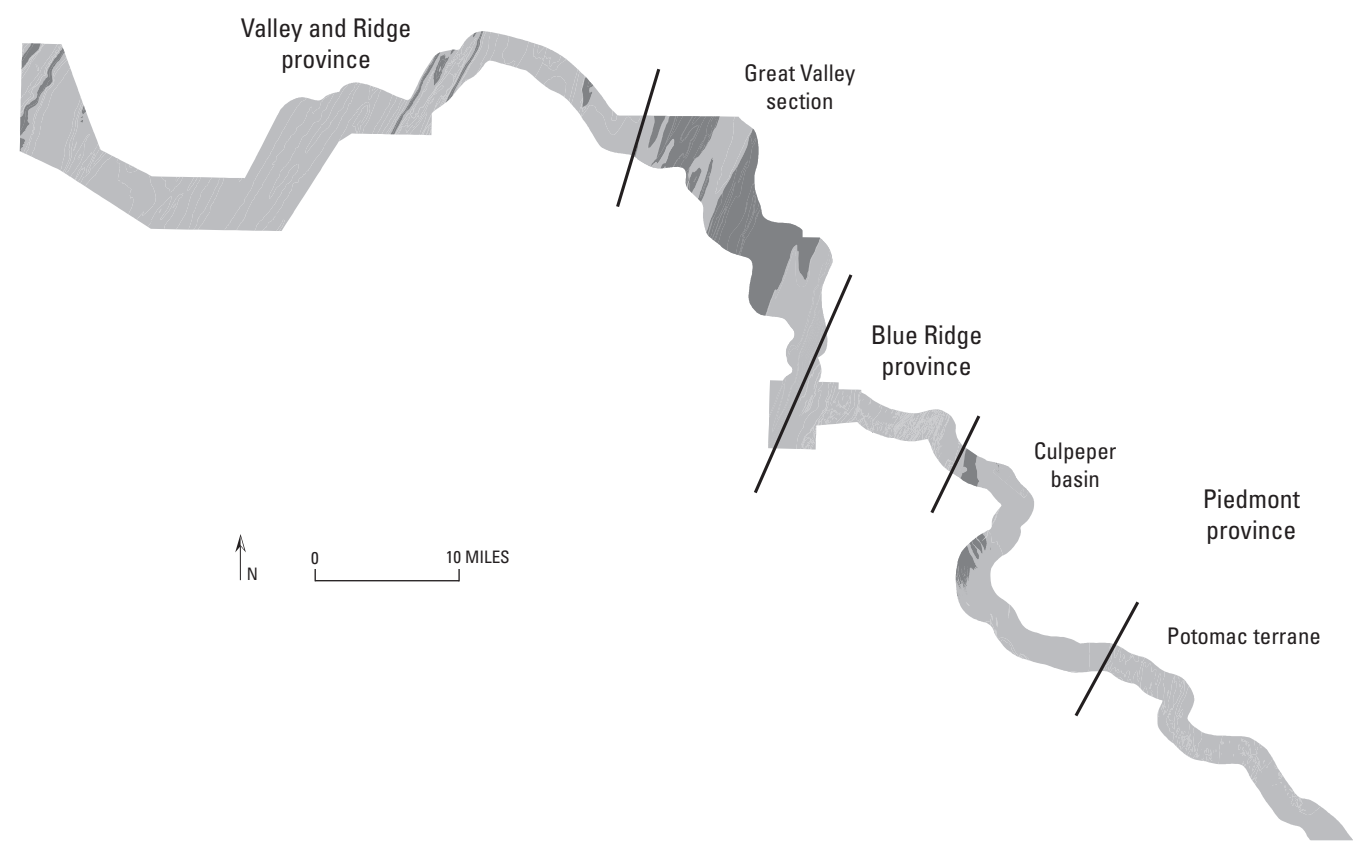

Figure 15. Schematic map showing the distribution of carbonate rocks (dark gray) and noncarbonate rocks (light gray) along the C\&O Canal and Potomac River corridor. Carbonate rocks are susceptible to the development of karst landforms. Many caves and sinkholes are known to exist in the carbonate rocks along the canal. 

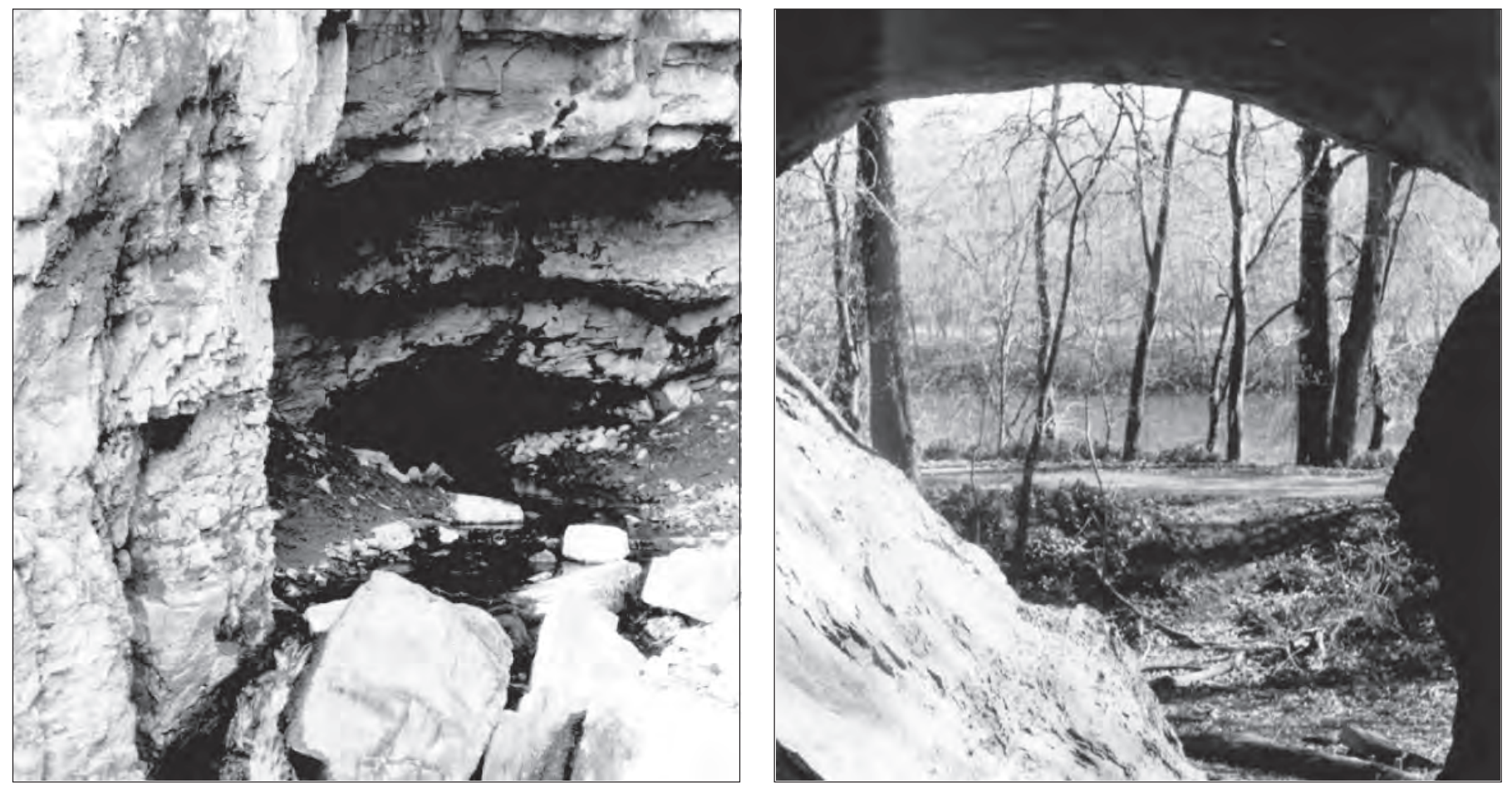

\section{$\boldsymbol{A}$}

B

Figure 16. The cave at Dam 4 near MM 83.5. The cave and emergent spring are in the Conococheague Limestone. $A$, View looking into the cave. $B$, View looking out of the cave.

ment that is conducive to preservation. As a general rule, organicrich, dark-gray, fine-grained rocks (such as shale and limestone) preserve fossils better than light-colored, coarse-grained rocks (such as sandstone and conglomerate). A second prerequisite for fossilization is rapid burial. Some of the best-preserved fossils are of animals and plants that were buried alive by storms and landslides, or that fell into sinkholes or tar pits. Once entombed in sediment, the animal, plant, or imprint must remain undisturbed while the sediment becomes lithified into rock; this process commonly takes place over millions of years.

\section{Piedmont Province}

Fossiliferous rocks are present in the Frederick Valley and Culpeper basin in the western Piedmont. No fossils are known within the rocks of the Westminster and Potomac terranes to the east; either these rocks were deposited prior to the development of shelly organisms, or extreme deformation and metamorphism destroyed any fossils that were present.

Fossils are present, but uncommon, in Frederick Valley rocks. The Upper Cambrian Frederick Formation and Upper Cambrian and Lower Ordovician Grove Formation were deposited on the continental slope and edge, respectively, of a continental shelf. Well-preserved fossils in the limestone are mainly parts of trilobites (fig. 17); however, because these rocks were deposited in deep water, the abundance of fossils is low.
The Frederick and Grove Formations both contain conodonts, which are microscopic $(0.1$ to $1.0 \mathrm{~mm})$ fossils that are thought to be the teeth of an extinct group of marine animals closely related to early vertebrates (fig. 17). Conodonts consist of phosphatic material much like human teeth.

In the Culpeper basin in Virginia and Maryland, the red sandstone and shale exposed from Seneca west to the Monocacy River contain abundant fossils (Kranz, 1989). The Upper Triassic Poolesville Member of the Manassas Sandstone in the eastern part of the basin in Fairfax County, Va., has yielded footprints of crocodiles and a small bird-like animal (Weems and Kimmel, 1993). Sandstone and siltstone of the Upper Triassic Balls Bluff Member of the Bull Run Formation near Dulles International Airport in Virginia have yielded bones and teeth of a crocodile-like parasuchian (phytosaur) (Weems, 1979) and a large coelacanth fish (Weems and Kimmel, 1993). Shale beds that are interlayered with the Balls Bluff Siltstone to the south were deposited in a lake and preserve the remains of arthropods and fish, as well as probable lizard footprints (Gore, 1988). Rocks exposed to the south in the Culpeper quarry have yielded parasuchian (phytosaur) teeth and footprints of a medium-size carnivorous dinosaur (K ayentapus minor) (fig. 18), two small carnivorous dinosaurs, a primitive sauropod dinosaur, a small ornithischian dinosaur, a prosauropod dinosaur, and a large armadillo-like aetosaur (Weems, 1987, 1992).

Lower Jurassic strata that overlie the Balls Bluff Member to the south in Virginia also contain fossils. In Fauquier County, Va., siltstone of the Midland Formation contains abun- 

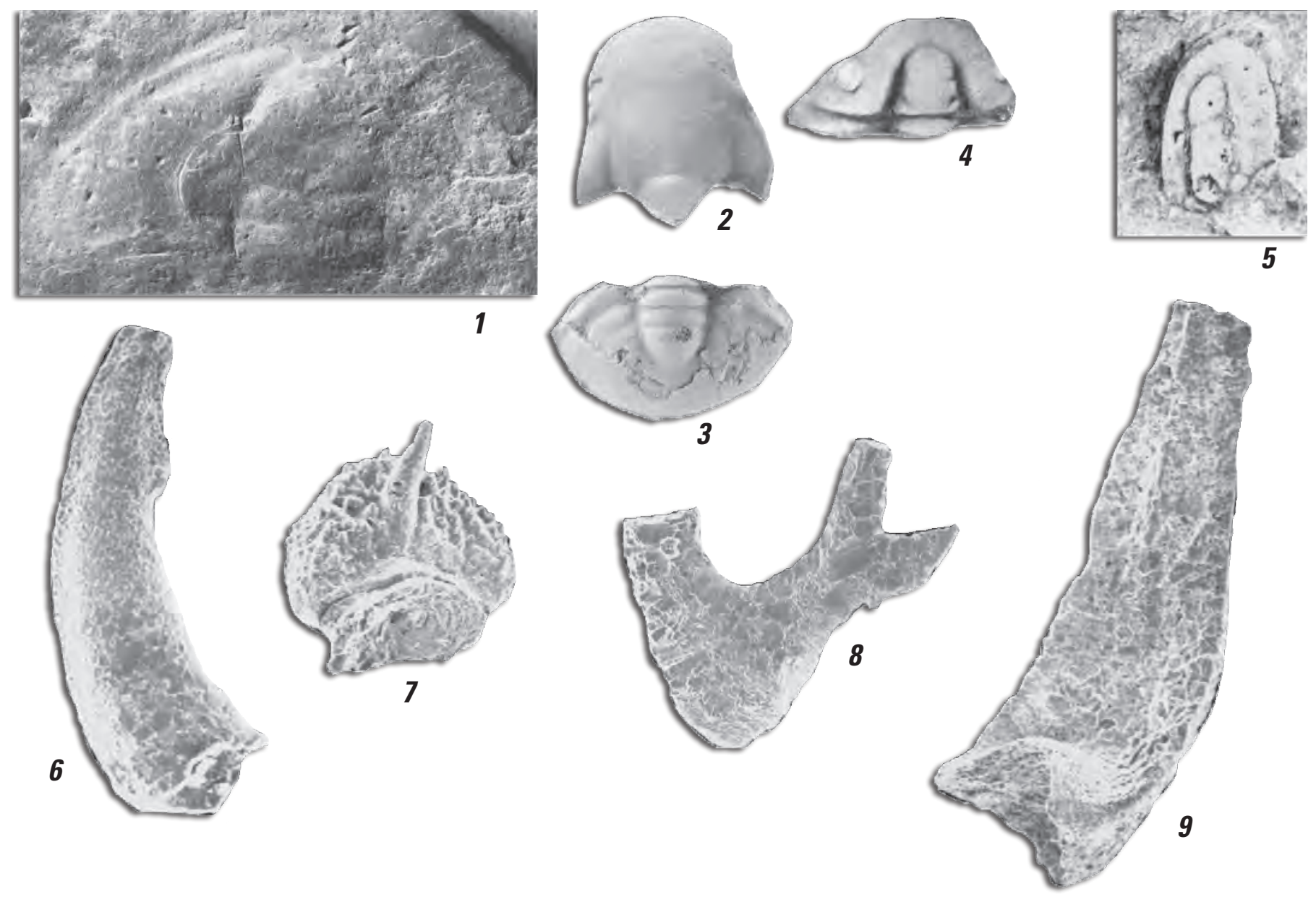

Figure 17. Fossils from rocks of the Frederick Valley section, western Piedmont province. Fossils are catalogued and reposited in the Carnegie Museum (CM) in Pittsburgh, Pa., or in the U.S. National Museum (USNM) in Washington, D.C. Fossils 1 through 5 are trilobites and 6 through 9 are conodonts. 1, Olenellus sp., Middle and Lower Cambrian Araby Formation (CM 53211). 2, Plethopeltis armatus (Billings), Upper Cambrian Grove Formation (CM 35116). 3, Rasettia capax (Billings), Upper Cambrian Grove Formation (CM 35110). 4, Westonaspis laevifrons Rassetti, Upper

dant fish remains (Olsen and others, 1982). Shale of the Turkey Run Formation has yielded footprints of a small carnivorous dinosaur, large prosauropod dinosaurs, and a crocodile (Weems, 1992, 1993). Siltstones and shales represent sediments of ephemeral lakes and riverbanks where some reptiles and dinosaurs typically lived. Rocks in the Culpeper basin also contain plant impressions, pollen, and spores.

\section{Blue Ridge Province}

Rocks of the Blue Ridge province contain few known fossils. Most shelly fossils did not appear until about $560 \mathrm{Ma}$. The Neoproterozoic Catoctin Formation was dated at about
Cambrian Frederick Formation (CM 35122). 5, Acmarachis, lower part of the Upper Cambrian Frederick Formation (CM 53212). 6 , Proconodontus muelleri Miller, Upper Cambrian Grove Formation (USNM 488831). 7, Clavohamulus hintzei Miller, Upper Cambrian Grove Formation (USNM 488826). 8, Cordylodus intermedius Furnish, Lower Ordovician Grove Formation (USNM 521104). 9, Rossodus manitouensis, Lower Ordovician Grove Formation (USNM 488819).

$565 \mathrm{Ma}$ (Badger and Sinha, 1988), but preserved fossils have not been recognized either in this formation, which represents ancient lava flows, or in the overlying quartzites of the Lower Cambrian Weverton Formation.

The interval of time during which the rocks of the Weverton Formation and overlying rocks of the Harpers and Antietam Formations were deposited represents a major biologic evolutionary episode. Although no fossil shells have been recovered from rocks of either the Weverton or Harpers Formations, some of the oldest trilobites have been found within the Antietam Formation. In places, metasiltstone of the Harpers Formation contains abundant burrows of ancient soft-bodied animals. The most common burrow trace, Skolithos linearis, is oriented perpendicular to the stratification, which 


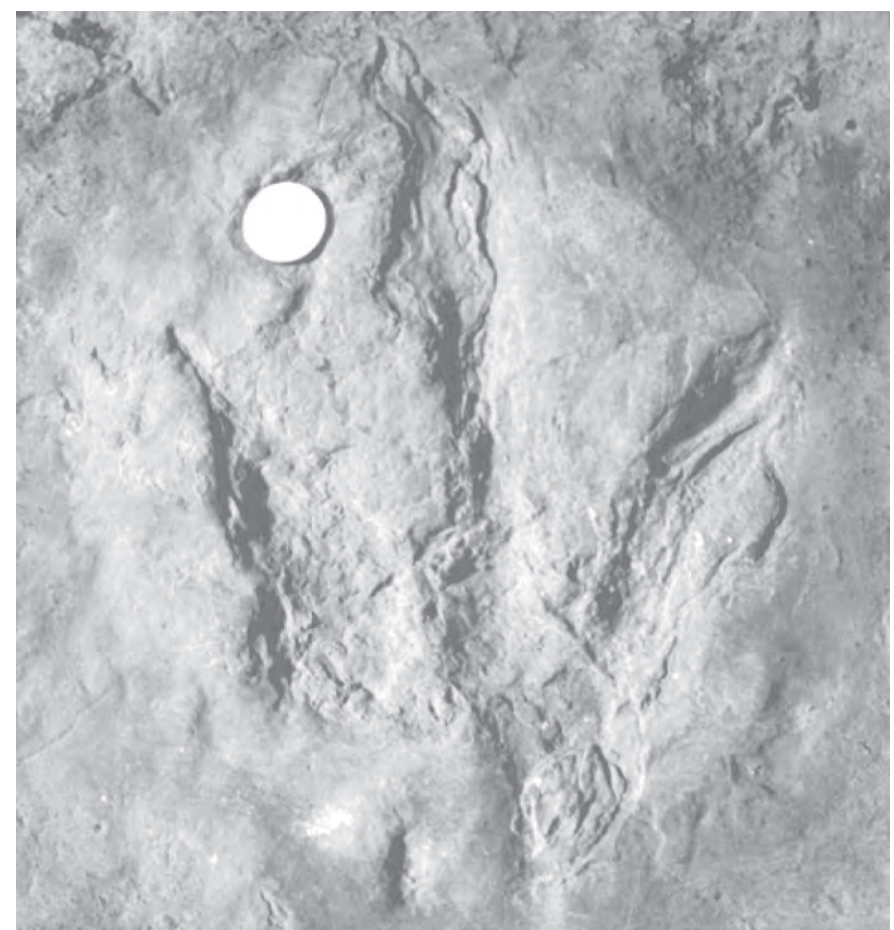

Figure 18. Dinosaur tracks in the Upper Triassic Balls Bluff Siltstone exposed in the Culpeper Stone Co. quarry near Culpeper, Va., are of three-toed Kayentapus minor, a carnivorous dinosaur. Quarter for scale. Although no dinosaur footprints are found in the vicinity of the C\&O Canal, the rocks are similar to those near Culpeper.

suggests that the burrows represent sites where the animal once lived.

\section{Valley and Ridge Province}

From the Great Valley section westward through the rest of the Valley and Ridge province, the rocks generally become younger, which is reflected by the abundance and diversity of fossils (fig. 19, 20, and 21). For instance, fossils are extremely rare in rocks of the Lower Cambrian Tomstown and Waynesboro Formations at the eastern margin of the Great Valley because not many types of shelly animals lived during this period of time. Progressing farther to the west, younger rocks are encountered and the fossils are more abundant and diverse. This general trend continues through the Ordovician and into the Silurian and Devonian.

\section{Cambrian Fossils}

The oldest rocks of the Valley and Ridge province are Cambrian and are restricted to the Great Valley section. Deformation associated with the formation of the Blue Ridge-South Mountain anticlinorium destroyed most of the fossils. As a result, the best Cambrian fossils have been recovered from the Elbrook and Conococheague Limestones on the western side of the Great Valley (fig. 20).

The most common types of Cambrian fossils are trilobites and stromatolites (algal colonies). Many of the trilobite species found in the Conococheague Limestone also are found in the Frederick Formation of the Frederick Valley in the western Piedmont province. The similar trilobite remains in both formations indicate that these two different geologic units are equivalent in time (that is, they are correlative). Even though trilobites are the main biostratigraphic tools for correlating Cambrian rocks, conodonts appear in the Late Cambrian and supplant the trilobite as the most useful fossil for correlation.

\section{Ordovician Fossils}

Lower Ordovician rocks contain fossils that are very similar to those found in the Upper Cambrian rocks (fig. 20), but younger Ordovician rocks contain fewer trilobites and more snails, brachiopods, and cephalopods. For instance, the Lower Ordovician Stonehenge Limestone contains mainly trilobites and conodonts. The transition to other fossil types is evident in the overlying Lower and Middle Ordovician Rockdale Run

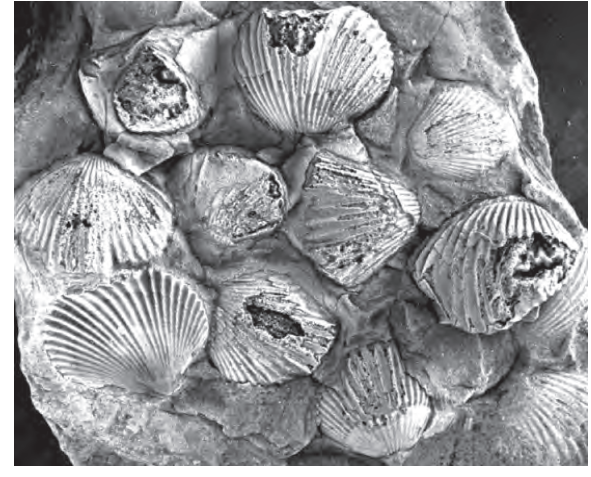

A

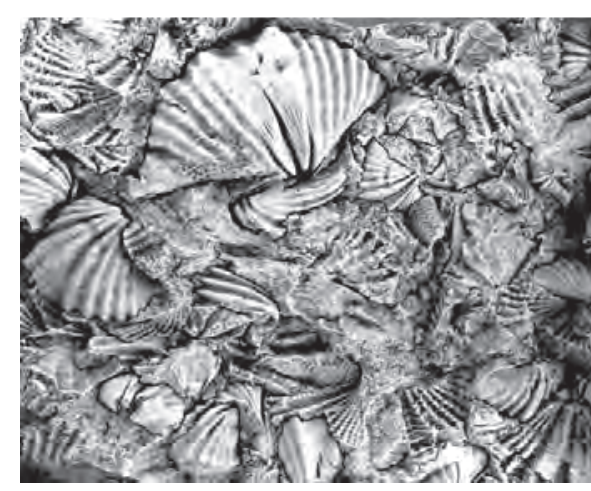

B

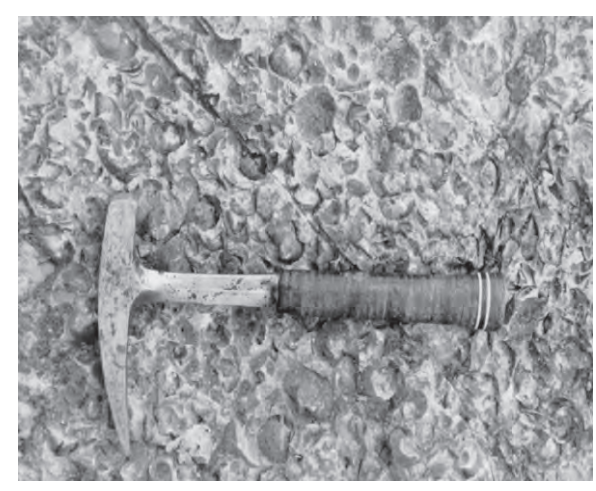

C

Figure 19. Brachiopods in Silurian and Devonian rocks. A, Brachiopod shell fragments from the Middle to Upper Silurian McKenzie Formation. $B$, Internal molds of brachiopods in the Upper Devonian Foreknobs Formation. $C$, Internal molds of brachiopods in the Lower Devonian Oriskany Sandstone. 


\begin{tabular}{|c|c|c|}
\hline \multicolumn{2}{|c|}{ SERIES } & FORMATION \\
\hline$\stackrel{\mathscr{N}}{\sum}$ & 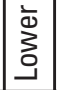 & Rockwell Fm. \\
\hline \multirow{9}{*}{ 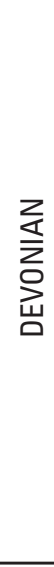 } & \multirow{2}{*}{$\begin{array}{l}\frac{1}{0} \\
\frac{0}{2}\end{array}$} & Hampshire Fm. \\
\hline & & $\begin{array}{c}\text { Greenland Gap } \\
\text { Group }\end{array}$ \\
\hline & \multirow{3}{*}{$\frac{0}{\overline{\frac{D}{0}}}$} & Mahantango Fm. \\
\hline & & Marcellus Sh. \\
\hline & & Needmore Sh. \\
\hline & \multirow{4}{*}{ ב⿱亠凶禸 } & Oriskany Ss. \\
\hline & & Shriver Fm. \\
\hline & & New Creek Ls. \\
\hline & & Keyser Ls. \\
\hline \multirow{5}{*}{ 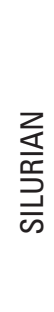 } & \multirow{3}{*}{ 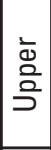 } & $\begin{array}{c}\text { Wills Creek and } \\
\text { Tonoloway Fms., undiv. }\end{array}$ \\
\hline & & Bloomsburg Fm. \\
\hline & & McKenzie Ls. \\
\hline & \multirow{2}{*}{ 㐫 } & Rose Hill Fm. \\
\hline & & Tuscarora Ss. \\
\hline \multirow{7}{*}{ 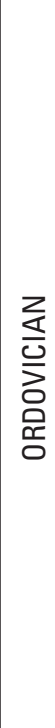 } & \multirow{5}{*}{$\frac{0}{\bar{D}}$} & Juniata Fm. \\
\hline & & $\begin{array}{l}\text { Martinsburg } \\
\text { Formation }\end{array}$ \\
\hline & & Chambersburg Fm. \\
\hline & & St. Paul Group \\
\hline & & $\begin{array}{c}\text { Pinesburg Station } \\
\text { Dolomite } \\
\end{array}$ \\
\hline & \multirow{2}{*}{ 高 } & $\begin{array}{l}\text { Rockdale Run } \\
\text { Formation }\end{array}$ \\
\hline & & Stonehenge Ls. \\
\hline \multirow{5}{*}{ 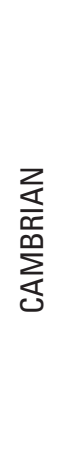 } & \begin{tabular}{|l|}
$\frac{1}{2}$ \\
$\frac{2}{2}$ \\
$口$
\end{tabular} & $\begin{array}{l}\text { Conococheague } \\
\text { Formation }\end{array}$ \\
\hline & $\frac{\text { 음 }}{\text { 을 }}$ & Elbrook Formation \\
\hline & \multirow{3}{*}{ 产 } & Waynesboro Fm. \\
\hline & & Tomstown Fm. \\
\hline & & Antietam Ss. \\
\hline
\end{tabular}
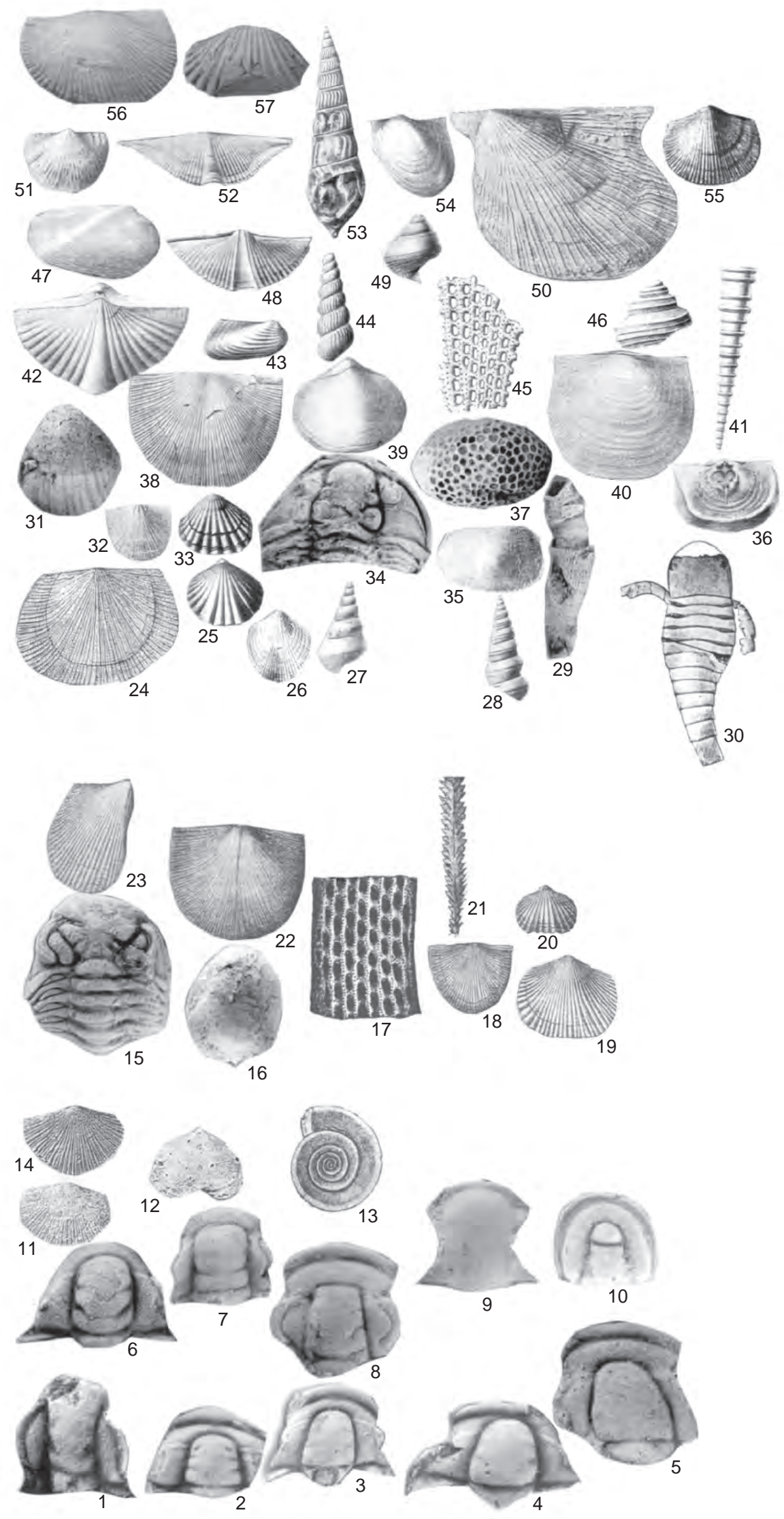
Figure 20 (facing page). Key index fossils present in the rocks found along the C\&O Canal in the Valley and Ridge province. Some of the individual specimens illustrated here are from other regions in the Appalachians, and have been noted as such, but all of these species have been recovered from formations in the immediate vicinity of the C\&O Canal or from formations correlative with those along the canal. Abbreviations are as follows: Miss., Mississippian; L., Lower; Dol., Dolomite; Fm., Formation; Ls., Limestone; Sh., Shale; Ss., Sandstone.

1. Glossopleura sp., Middle Cambrian, Elbrook Formation, X5.

2. Elrathina sp., Middle Cambrian, Elbrook Formation, X4.

3. Modocia sp., Upper Cambrian, Elbrook Formation, X4.

4. Genevievella sp., Upper Cambrian, Elbrook Formation, X5.

5. Crepicephalus sp., Upper Cambrian, Elbrook Formation, X5.

6. Ptychaspis sp., Upper Cambrian, Conococheague Limestone, $\mathrm{X} 4$.

7. Calvinella sp., Upper Cambrian, Conococheague Limestone, X4.

8. Pseudosaratogia sp., Upper Cambrian, Conococheague Limestone, $\mathrm{X} 3$.

9. Bellefontia sp., Lower Ordovician, Stonehenge Limestone, X4.

10. Homagnostus sp., Lower Ordovician, Stonehenge Limestone, X7.

11. Finkelburgia stonehengensis Sando, Lower Ordovician, Rockdale Run Formation (from Sando, 1957, pl. 12, fig. 26), X2.

12. Diaphelasma pennsylvanicum Ulrich and Cooper, Lower Ordovician, Rockdale Run Formation (from Sando, 1957 pl. 15, fig. 1), X2.

13. Ophileta sp., Lower Ordovician, Rockdale Run Formation (from Bassler, 1919, pl. 33, fig. 1.), X?.

14. Diparelasma marylandicum Sando, Lower Ordovician, Rockdale Run Formation (from Sando, 1957, pl. 13, fig. 15), X2.

15. Calliops callicephala (Hall), Middle Ordovician, Chambersburg Limestone, $\mathrm{X} 4$.

16. Echinospherites sp., Middle Ordovician, Chambersburg Limestone, $\mathrm{X} 2$.

17. Rhinidictya sp., Middle Ordovician, Chambersburg Limestone (from Bassler, 1919, pl. 44, fig. 11), X18.

18. Strophomena hallie (Miller), Middle Ordovician, Chambersburg Limestone (from Bassler, 1919, pl. 54, fig. 8), X2.

19. Hebertella chaziensis Ruedemann, Middle Ordovician, Chambersburg Limestone (from Bassler, 1919, pl. 38, fig. 5), X2.

20. Orthorhyncula, Middle Ordovician, Maysville Group, Cincinnati, Ohio (from Bassler, 1919, pl. 57, fig. 10), X10.

21. Diplograptus, Middle Ordovician, Normanskill Shale, New York (from Bassler, 1919, pl. 53, fig. 10), X3.

22. Rafinesquina alternata (Emmons), Upper Ordovician, Maysvile Formation, Cincinnati, Ohio (from Bassler, 1919, pl. 57, fig. 18), X2.

23. Byssonychia praecursa Ulrich, Upper Ordovician, Lorraine Shale, New York (from Bassler, 1919, pl. 57, fig. 28).

24. Schuchertella tenuis Hall, Silurian, Rochester Shale (from Swartz and others, 1923, pl. 18, fig. 8), X10.

25. Uncnulus obtusiplicata (Hall), Silurian, McKenzie Formation (from Swartz and others, 1923, pl. 21, fig. 8), X1.

26. Atrypa reticularis (Linne), Silurian, Rochester Shale (from Swartz and others, 1923, pl. 21, fig. 8), X1.

27. Hormatoma hopkinsi Prouty, Silurian, McKenzie Formation (from Swartz and others, 1923, pl. 29, fig. 23), X2.

28, Hormatoma rowei Swartz, Silurian, Tonoloway Limestone (from Swartz and others, 1923, pl. 29, fig. 12), X2

29. Cyathophyllum sp., Silurian, Keyser Limestone, X2.
30. Dolichopterus cumberlandensis Swartz, Silurian, Wills Creek Formation (from Swartz and others, 1923, pl. 47, fig. 1), X1.

31. Gypidula sp., Silurian, Keyser Formation, X2.

32. Stropheodonta varistriata (Conrad), Silurian, Tonoloway Limestone (from Swartz and others, 1923, pl. 22, fig. 19), X2

33. Camarotoechia tonolowayensis Swartz, Silurian, Tonoloway Limestone (from Swartz and others, 1923, pl. 22, fig. 19), X2

34. Calymene sp., Silurian, Keyser Limestone, $\mathrm{X} 3$.

35. Leperditia scalaris Swartz, Silurian, Keyser Limestone, X3.

36. Leptaena rhomboidalis (Wilckens), Lower Devonian, Helderberg Formation (Swartz and others, 1913, pl. 16, fig. 16), X2.

37. Favosites sp., Silurian, Keyser Limestone, X4.

38. Schuchertella woolworthana (Hall), Lower Devonian, New Scotland Limestone (from Swartz and others, 1913, pl. 51, fig. 7), X2.

39. Meristella arcuata (Hall), Devonian, New Scotland Formation (from Swartz and others, 1913, pl. 74, fig. 5), X?

40. Stropheodonta becki (Hall), Lower Devonian, New Scotland Limestone (from Swartz and others, 1913, pl. 57, fig. 12), X3

41. Tentaculites aculus Hall, Lower Devonian, Helderberg Formation (from Swartz and others, 1913, pl. 86, fig. 7), X4.

42. Spirifer intermedus Hall, Lower Devonian, Oriskany Sandstone (from Swartz and others, 1913, pl. 69, fig. 18), X?

43. Cypricardinia indenta (Conrad), Middle Devonian, Hamilton Formation (from Swartz and others, 1913b, pl. 34, fig. 6), X2.

44. Loxonema hamiltoniae Hall, Middle Devonian, Hamilton Formation (from Swartz and others, 1913b, pl. 36, fig. 16), X1.25.

45. Polypora compacta (Hall), Lower Devonian, New Scotland Formation (from Swartz and others, 1913, pl. 51, fig. 11), X2.

46. Cyclonema liratum Prosser, Middle Devonian, Hamilton Formation (from Swartz and others, 1913b, pl. 36, fig. 8), X1.5.

47. Palaeoneilo fecunda Hall, Middle Devonian, Hamilton Formation (from Swartz and others, 1913b, pl. 36, fig. 19), X1.25.

48. Mucrospirifer mucronatus (Conrad), Middle Devonian, Hamilton Formation (from Swartz and others, 1913b, pl. 41, fig. 12), X2.

49. Cyclonema concinnum Hall, Upper Devonian, Foreknobs Formation (from Swartz and others, 1913b, pl. 67, fig. 27), X?

50. Pterinea chemungensis (Conrad), Upper Devonian, Foreknobs Formation (from Swartz and others, 1913b, pl. 61, fig. 22), X1.

51. Productella lachryma (Conrad), Upper Devonian, Foreknobs Formation (from Swartz and others, 1913b, pl. 50, fig. 22), X?.

52. Mucrospirifer mucronatus (Conrad), Upper Devonian, Foreknobs Formation (from Swartz and others, 1913b, pl. 68, fig. 2), X1.

53. Loxonema terebrum Hall, Upper Devonian, Foreknobs Formation (from Swartz and others, 1913b, pl. 69, fig. 3), X2.

54. Leptodesma medon Hall, Upper Devonian, Foreknobs Formation (from Swartz and others, 1913b, pl. 63, fig. 15), X?.

55. Dalmanella sp., Upper Devonian, Foreknobs Formation (from Swartz and others, 1913b, pl. 52, fig. 6), X3.

56. Rugosochonetes sp., Lower Mississippian, Riddlesburg Shale Member of Purslane Formation (from Brezinski, 1988, pl. 1, fig. 1), Carnegie Museum 35565, X3.

57. Macropotamorhyncus sp., Lower Mississippian, Riddlesburg Shale Member of the Purslane Formation (from Brezinski, 1988, pl. 1, fig. 3), Carnegie Museum 35569, X2. 


\begin{tabular}{|c|c|c|}
\hline \multicolumn{2}{|c|}{ SERIES } & FORMATION \\
\hline$\frac{\mathscr{N}}{\Sigma}$ & 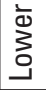 & Rockwell Fm. \\
\hline \multirow{9}{*}{ 竞 } & \multirow{2}{*}{$\begin{array}{l}\frac{\bar{a}}{2} \\
\stackrel{2}{\frac{2}{2}}\end{array}$} & Hampshire Fm. \\
\hline & & $\begin{array}{l}\text { Greenland Gap } \\
\text { Group }\end{array}$ \\
\hline & \multirow{3}{*}{$\frac{\text { o }}{\frac{0}{0}}$} & Mahantango Fm. \\
\hline & & Marcellus Sh. \\
\hline & & Needmore Sh. \\
\hline & \multirow{4}{*}{$\sum_{0}^{\bar{\jmath}}$} & Oriskany Ss. \\
\hline & & Shriver Fm. \\
\hline & & New Creek Ls. \\
\hline & & Keyser Ls. \\
\hline \multirow{5}{*}{ 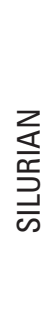 } & \multirow{3}{*}{$\begin{array}{l}\frac{\bar{\alpha}}{2} \\
\frac{2}{2}\end{array}$} & $\begin{array}{c}\text { Wills Creek and } \\
\text { Tonoloway Fms., undiv. }\end{array}$ \\
\hline & & Bloomsburg Fm. \\
\hline & & McKenzie Ls. \\
\hline & \multirow{2}{*}{ 产 } & Rose Hill Fm. \\
\hline & & Tuscarora Ss. \\
\hline \multirow{7}{*}{ 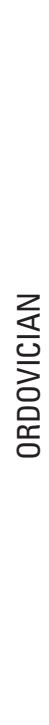 } & \multirow{5}{*}{$\frac{0}{\overline{\frac{0}{0}}}$} & Juniata Fm. \\
\hline & & $\begin{array}{l}\text { Martinsburg } \\
\text { Formation }\end{array}$ \\
\hline & & Chambersburg Fm. \\
\hline & & St. Paul Group \\
\hline & & $\begin{array}{c}\text { Pinesburg Station } \\
\text { Dolomite }\end{array}$ \\
\hline & \multirow{2}{*}{ ऐo } & $\begin{array}{l}\text { Rockdale Run } \\
\text { Formation }\end{array}$ \\
\hline & & Stonehenge Ls. \\
\hline \multirow{5}{*}{ 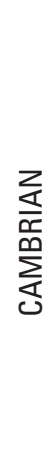 } & ळ & $\begin{array}{c}\text { Conococheague } \\
\text { Formation }\end{array}$ \\
\hline & $\frac{0}{\overline{\frac{D}{0}}}$ & Elbrook Formation \\
\hline & \multirow{3}{*}{ ฏั } & Waynesboro Fm. \\
\hline & & Tomstown Fm. \\
\hline & & Antietam Ss. \\
\hline
\end{tabular}
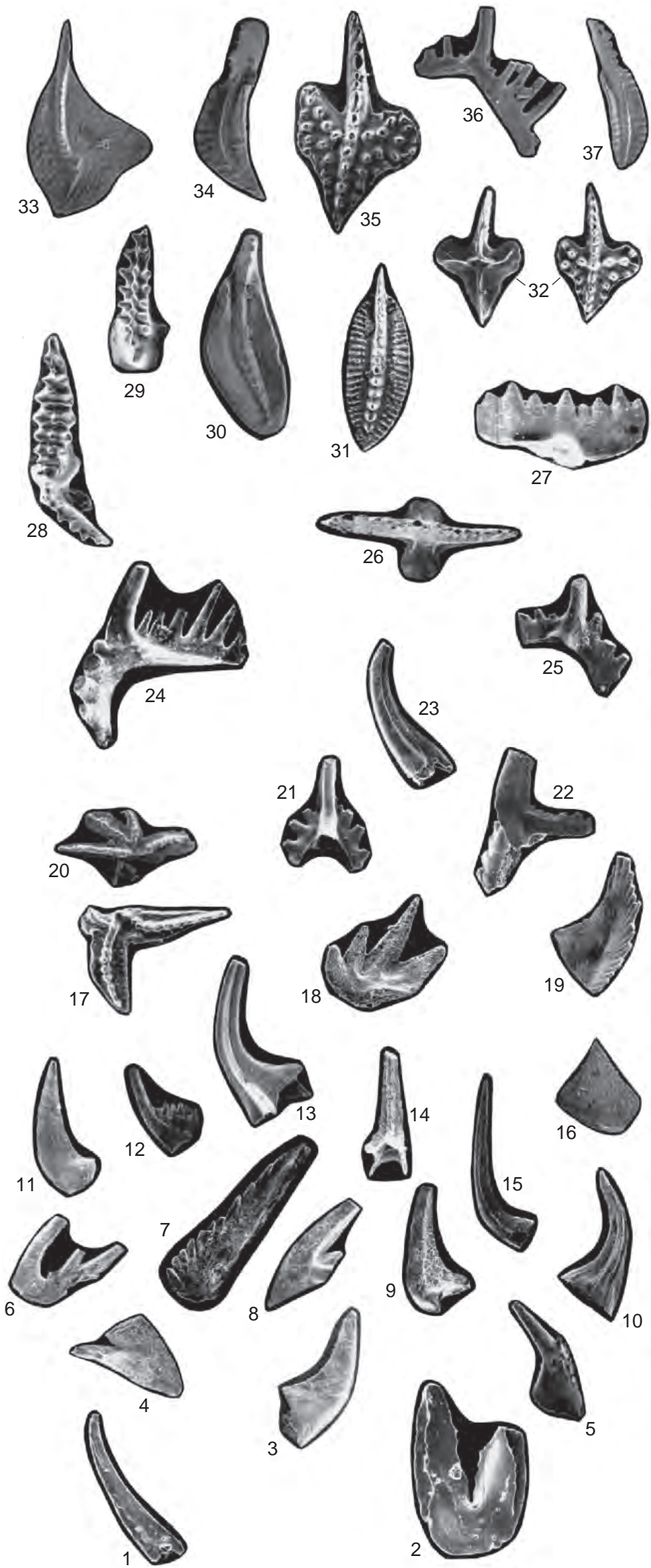
Figure 21 (facing page). Key guide conodonts to the strata of the Valley and Ridge province. Some of the individual specimens illustrated here are from other regions in the Appalachians and are noted as such, but all of these species have been recovered from formations in the immediate vicinity of the C\&O Canal or from formations correlative with those along the canal. Abbreviations are as follows: Miss., Mississippian; L., Lower; Dol., Dolomite; Fm., Formation; Ls., Limestone; Sh., Shale; Ss., Sandstone.

\section{Phakelodus elongatus (An), Upper Cambrian, Nolichucky Shale, eastern} Tennessee, X55 (USNM 521105).

2. Westergaardodina matsushitai Nogami, Upper Cambrian, Nolichucky Shale, eastern Tennessee, X40 (USNM 521106).

3. Proconodontus serratus Miller, Upper Cambrian, Lime Kiln Member of the Frederick Formation, quarry at Lime Kiln, Md., X30 (USNM 521107).

4. Cambrooistodus minutus (Miller), Upper Cambrian, Lime Kiln Member of the Frederick Formation, quarry at Lime Kiln, Md., X55 (USNM 521108).

5. Hirsutodontus simplex (Druce and Jones), Upper Cambrian, Grove Formation, Stup Farm section of Taylor and others (1996), Frederick, Md., X35 (USNM 521109).

6. Cordylodus angulatus Pander, Lower Ordovician, Stonehenge Limestone (from Brezinski and others, 1999, fig. 3-T), X25 (USNM 507012).

7. Loxodus bransoni Furnish, Lower Ordovician, basal foot of Rockdale Run Formation (from Brezinski and others, 1999, fig. 3-V), X40 (USNM 507014).

8. Rossodus manitouensis Repetski and Ethington, oistodontiform element, Lower Ordovician, top foot of Stonehenge Limestone (from Brezinski and others, 1999, fig. 3-W), X25 (USNM 507015).

9. Rossodus manitouensis Repetski and Ethington, coniform element, Lower Ordovician, basal foot of Rockdale Run Formation (from Brezinski and others, 1999, fig. 3-X), X40 (USNM 507016).

10. Scolopodus sulcatus Furnish, Lower Ordovician, one foot above base of Rockdale Run Formation (from Brezinski and others, 1999, fig. 3-Y), X25 (USNM 507017).

11. Eucharodus toomeyi (Ethington and Clark), Lower Ordovician, Rockdale Run Formation, C\&0 Canal section (from Brezinski and others, 1999, fig. 3-0), X20 (USNM 507007).

12. Oepikodus communis (Ethington and Clark), Lower Ordovician, Rockdale Run Formation, C\&O Canal section (from Brezinski and others, 1999, fig. 3-M), X35 (USNM 507005).

13. Pteracontiodus cf. Pt. gracilis Ethington and Clark, Middle Ordovician, upper part of Rockdale Run Formation, C\&O Canal section (from Brezinski and others, 1999, fig. 3-E), X40 (USNM 506997).

14. Tropodus comptus (Branson and Mehl), Lower Ordovician, Rockdale Run Formation, C\&0 Canal section (from Brezinski and others, 1999, fig. 3-P), X20 (USNM 507008).

15. Colaptoconus quadraplicatus (Branson and Mehl), Lower Ordovician, Rockdale Run Formation, C\&O Canal section (from Brezinski and others, 1999, fig. 3-R), X35 (USNM 507010).

16. Histiodella altifrons Harris, Middle Ordovician, uppermost one foot of Rockdale Run Formation, C\&O Canal section (from Brezinski and others, 1999, fig. 3-F), X55 (USNM 506998).

17. Cahabagnathus friendsvillensis (Bergström), Middle Ordovician, $39 \mathrm{~m}$ above base of St. Paul near Worleytown, Franklin Co., Pa., USGS fossil locality 9306-CO, X25 (USNM 521110).

18. Leptochirognathus quadratus Branson and Mehl, Middle Ordovician, $48 \mathrm{ft}$ below top of Pinesburg Station Dolomite near Marion, Franklin Co., Pa. (from Brezinski and others, 1999, fig. 3-C), X30 (USNM 506995).

19. Appalachignathus delicatulus Bergström and others, Middle Ordovician, Lincolnshire Limestone, Tumbling Run section, Shenandoah Co., Va., X40 (USNM 521111).
20. Amorphognathus tvaerensis Bergström, Upper Ordovician, Nealmont Formation, Tyrone, Pa., X5 (USNM 521112).

21. Plectodina n. sp., Middle Ordovician, $260 \mathrm{ft}$ below top of Rockdale Run Formation, C\&O Canal section, X30 (USNM 507002).

22. Phragmodus undatus Branson and Mehl, Upper Ordovician, Jacksonburg Limestone, Northampton Co., Pa., X30 (USNM 521113).

23. Panderodus gracilis (Branson and Mehl), Upper Ordovician, Jacksonburg Limestone, Northampton Co., Pa., X5 (USNM 521114).

24. Oulodus sp., Upper Silurian, Tonoloway Limestone, $34 \mathrm{ft}$ above base, Giles Co., Va., USGS fossil locality 11569-SD of K. Denkler and A.G. Harris, X25 (USNM 521115).

25. Oulodus elegans (Walliser), Upper Silurian, upper part of the Keyser Limestone, Lambert Gap, W. Va. (from Denkler and Harris, 1988, pl. 1, fig. U), X40 (USNM 418600).

26. Ozarkodina remscheidensis eosteinhornensis (Walliser), Silurian, lower limestone member of the Keyser Limestone, Lambert Gap, W. Va., USGS fossil locality 10700-SD of K. Denkler and A.G. Harris, X30 (USNM 521116).

27. Ozarkodina remscheidensis remscheidensis (Zeigler), Tonoloway Limestone, $39.5 \mathrm{ft}$ above base, Giles Co., Va., USGS fossil locality 11572-SD of K. Denkler and A.G. Harris, X35 (USNM 521117).

28. Icriodus claudiae Klapper, Lower Devonian, Licking Creek Limestone, Frederick Co., Va. (from Harris and others, 1994), USGS fossil locality 12151-SD, X20 (USNM 521118)

29. Icriodus difficilis Ziegler and Klapper, Upper Devonian, Harrell Shale, Mineral Co., W. Va. (from Weary and Harris, 1994), USGS fossil locality 12137-SD, X30 (USNM 521119).

30. Polygnathus alatus Huddle, Upper Devonian, Harrell Shale, Mineral Co., W. Va. (from Weary and Harris, 1994), USGS fossil locality 12137-SD, X25 (USNM 521120).

31. Mesognathus dengleri (Bischoff and Ziegler), Upper Devonian, Harrell Shale, Grant Co., W. Va. (from Weary and Harris, 1994), USGS fossil locality 12137-SD, X20, (USNM 521123).

32, 35. Ancyrodella alata Glenister and Klapper, lower and upper views of immature specimen (fig. 32) and upper view of mature specimen (fig. 35), Upper Devonian, Harrell Shale, Allegany Co., Md. (from Weary and Harris, 1994), USGS fossil locality 12293-SD, pl. 2, figs. 11, 12, X20 (fig. 32) and X25 (fig. 35), (USNM 481789 and 521124, respectively).

34. Polygnathus linguiformis linguiformis Hinde, Upper Devonian, Scherr Formation, Greenland Gap Group, Randolph Co., W. Va., X20 (USNM 521121).

37. Polygnathus sp., Upper Devonian, Scherr Formation, Greenland Gap Group, Randolph Co., W. Va., X25 (USNM 521122).

33. Palmatolepis sp., Upper Devonian, Scherr Formation, Greenland Gap Group, Randolph Co., W. Va., X30, (USNM 521125).

36. Delotaxis sp., Upper Devonian, Scherr Formation, Greenland Gap Group, Randolph Co., W. Va., X20, (USNM 521126). 
Formation that contains many snails and only a few trilobites. The change is most obvious in the diverse fauna present in the E chinosphaerites beds of the Middle Ordovician Chambersburg Limestone. These beds, which were named for an echinoderm E chinosphaerites, contain abundant brachiopods, bryozoans, and only a few trilobites. The changes observable in the macrofossils are further illustrated by rapid changes in conodonts through the Ordovician, as illustrated in figure 21.

The diverse numbers of organisms that had inhabited the clear waters during limestone deposition were replaced by a group of organisms that could live in the muddy sea bottoms that existed during deposition of the Martinsburg Formation in the Middle and Late Ordovician. These include snails and clams; brachiopods and bryozoans are absent. To exist on the muddy sea floor, animals had to be able to filter out clay and silt.

\section{Silurian Fossils}

The Silurian was a time of great diversity in brachiopods; many Silurian units contain abundant brachiopod remains. The units that best exemplify species diversity are the Middle Silurian Rose Hill Formation, Middle and Upper Silurian McKenzie Formation, and Upper Silurian and Lower Devonian Keyser Limestone, all of which were deposited in very shallow marine waters. Some of the thin beds of limestone within the McKenzie Formation are made up completely of brachiopod or snail shells (see figure 19). This highly fossiliferous limestone can be seen along the abandoned Western Maryland railroad bed near MM 133. The limestone is interbedded with units such as the Upper Silurian Bloomsburg and Wills Creek Formations, which were deposited mostly above high tide and, as a result, contain almost no fossil remains. The exception is the large ostracode Leperditia that is found in the Wills Creek Formation. The Upper Silurian Tonoloway Limestone is known to contain the rare remains of extinct arthropods known as eurypterids. These arthropods lived in shallow marine water and looked like scorpions, so they are commonly called sea scorpions. Eurypterids flourished in the Late Silurian.

The Keyser Limestone was deposited during the latest Silurian and earliest Devonian. This unit contains a diverse fossil assemblage of brachiopods, bryozoans, corals, trilobites, and stromatoporoids (sponge-like colonial animals). During the Late Silurian, stromatoporoids formed small reefs similar to the modern coral reefs off the coast of Florida. Although no fossil reefs have been identified along the $\mathrm{C} \& \mathrm{O}$ Canal, Brezinski (1996b) described a reef north of it near the village of Flintstone, Md. Small stromatoporoids can be found along the abandoned Western Maryland railroad grade at Dam 6.

\section{Devonian and Mississippian Fossils}

Perhaps the most fossiliferous Lower Devonian formation along the $\mathrm{C} \& \mathrm{O}$ Canal is the Oriskany Sandstone. This white sandstone contains abundant molds of brachiopod shells.
Because this sandstone is so porous, water dissolved the shell material from these fossil fragments, leaving molds where the shells once were (fig. 19C). Many of the younger Devonian shales (Needmore, Marcellus, and Brallier Shales) as well as sandstones of the Mahantango and Foreknobs Formations, contain abundant clams, snails, brachiopods, and cephalopods, most of which are preserved as molds (fig. 19). Conodonts are common, but trilobites are uncommon in these Devonian rocks.

Mississippian rocks occur at only one location along the C\&O Canal. Near the Sideling Hill Creek Aqueduct, sandstone within the Lower Mississippian Riddlesburg Shale Member, a marine unit of the Upper Devonian and Lower Mississippian Rockwell Formation, is exposed. This earliest Mississippian sandstone was deposited as beach sand and as such contains no fossils. However, the black shale that is present immediately above this sandstone represents mud deposited in a nearshore lagoon and it contains a few brachiopods. Conodonts have been found in some of the rare carbonate horizons in this shale unit.

\section{Engineering Geology}

\section{Introduction}

To fully understand the engineering achievement of the C\&O Canal, walk along the shore of the Potomac River in Virginia or West Virginia and envision what would be necessary in order to transport 120 tons of cargo in a 92 -ft-long boat in a waterway that parallels the river. A 6-ft-deep canal that was 40 to $60 \mathrm{ft}$ wide at the top had to be excavated. Small tributaries of the river had to be crossed, using culverts to carry the tributaries beneath the canal. Large tributaries required aqueducts to carry the boats over the water (fig. 22; table 1). Where bedrock bluffs adjoined the river, breaking rock with sledgehammers, drilling with special bits, and blasting with black powder were required to excavate a canal. Parallel to the canal and adjacent to the river, an elevated towpath needed to be constructed. Dams were required at strategic locations to divert river water into the canal. Locks needed to be constructed at specific locations to lift and lower the boats as the canal changed in elevation along its length. Lock keepers needed lock houses to live in because the canal would operate 24 hours a day. Necessary construction materials needed to be brought in, such as dimension stone for locks, lock houses, culverts, and aqueducts; stone rubble for towpath fill; clay to line the canal; cement for mortar; iron and manganese for the production of iron for lock fittings; and lumber for lock gates and forms.

The 184.5-mi-long canal and towpath eventually required an infrastructure of over 74 lift locks and lock houses, 11 aqueducts, more than 182 culverts and waste weirs, 7 dams, and 1 tunnel through bedrock. As a result, building stone was in great demand for the project. The facing of all locks, aqueducts, and culverts required cut or hammer-dressed stone. Sandstone and limestone were highly desired because the rocks could be easily split along bedding 
surfaces, providing two smooth sides for a typical block. The locations of locks, aqueducts, dams, and the known quarry sites for building stone are shown on figure 22 (1828 to 1850). During construction, the dimension stone and cement were transported to the canal by river barge, wagon, and rail. Subsequent repairs to these structures have used stone, brick, and concrete in modern time.

Construction of the canal, towpath, and other structures between the Georgetown section of Washington, D.C., and Cumberland, Md., took 22 years. Discussions and illustrations of the engineering and construction of the canal are provided in the Chesapeake and Ohio Canal Official National Park Handbook (National Park Service, 1991, p. 32-37) and in Davies (1971, 1999).

\section{Canal Excavation and Towpath}

The dimensions of the canal are $6 \mathrm{ft}$ deep, $48 \mathrm{ft}$ wide at the base, and $60 \mathrm{ft}$ wide at the surface; upriver of Harpers Ferry, the dimensions are slightly smaller. The canal was excavated mostly by pick and shovel in unconsolidated Quaternary alluvial gravel, sand, silt, and clay. These materials were dug out and then placed on the riverside to form the towpath. Flood scour in 1996 revealed that the towpath locally is a stone crib of vertical blocks filled with soil and capped with gravel. Stone embankments and berms were constructed locally along the river, adjacent to the towpath (fig. 23), and sometimes even on the far side of the canal to keep floodwaters out; examples may be seen at the McKee-Besher Wildlife Management Area west of Seneca, Md., and at Big Pool. The canal prism was lined with impervious clay to hold water (fig. 24). The source of the clay is not known. Karst in limestone must have caused local water loss because today there are caves exposed in the dry canal.

Excavating the C\&O Canal could not be accomplished in the same exact manner as the 363-mi-long Erie Canal in New York, which was under construction from 1817 to 1825 and is located almost entirely in thick unconsolidated glacial till, outwash, and alluvium. About $34 \mathrm{mi}$ of the C\&O Canal and towpath had to be drilled and blasted through bedrock using sledgehammers, star-bit drill rods, and black powder (fig. 25A). Many of the drillholes may still be seen along the bluffs and in the canal bed. Men roped themselves to trees or hung over cliffs and used sledgehammers to pound steel rods (fig. 25B) held by other trustworthy men. Bedrock excavated for the adjacent railroad and canal berm was used as fill to create the towpath (fig. 25C).

A 3,118-ft-long tunnel (fig. 26) was excavated through folded siltstone and shale of the Upper Devonian Brallier Shale north of Paw Paw, W. Va., from 1836 to 1841 and from 1847 to 1850 . The tunnel was the alternative to constructing a canal along $6 \mathrm{mi}$ of river meanders bordered by bedrock cliffs. As many as 44 men excavated 10 to $12 \mathrm{ft}$ of tunnel each week using hand drills, picks, sledge hammers, and black powder. There were two vertical shafts for access so that the tunnel could be excavated from six positions. Debris hauled up the shafts was dumped in spoil piles above the north portal.

\section{Locks and Lock Stone}

The water in the canal did not flow unimpeded from Cumberland to Georgetown, like the water flows down the Potomac River; instead, water in the canal was impounded at a constant level and released 74 times as a boat made its trip. There were 74 locks that raised westbound boats and lowered eastbound boats an average of $8 \mathrm{ft}$ to accommodate the change in elevation of $605 \mathrm{ft}$ along the length of the canal. The locks are 100-ft-long, 15-ft-wide chambers made of stone on timber foundations with watertight wooden gates at both ends.

There also were 12 river feeder locks and guard locks that regulated the flow of water from the Potomac River into the canal. Several of these river locks, such as at Goose Creek, Va.; Shenandoah River in Harpers Ferry, W. Va.; and Shepherdstown, W. Va., were requested by the Virginia Legislature in 1833 to provide a means to transport Virginia products to market. The Goose Creek and Little River Navigation provided access from the canal to as far west as Middleburg, Va. (Trout, 1991). The Shenandoah River lock at Harpers Ferry was built by the Patowmack Company for access as well. Skirting canals associated with the Patowmack Canal remain on the Virginia shore opposite Seneca and Weverton, Md. River locks also were used to take boats into the Potomac River where bluffs prevented construction of a canal, such as at Big Slackwater.

The dominant building material required for the $\mathrm{C} \& \mathrm{O}$ Canal was dimension stone. Sandstone of the Lower Cretaceous Potomac Formation (informally called "Aquia Sandstone") was quarried from Aquia Creek in Stafford County, Va., and transported by barge over $35 \mathrm{mi}$ up the Potomac River for use in Locks 1 to 7 (fig. 27). Sandstone of the Upper Triassic Poolesville Member of the Manassas Sandstone (informally called "Seneca Red Sandstone") was quarried mostly at Seneca, Md., (fig. 28) with smaller amounts quarried north of MM 46 east of Point of Rocks, Md. This sandstone was used in Locks 7 to 13, 15 to 24 (fig. 29), 25 to 30, 33, and 34. Ordovician Ellicott City Granodiorite from the Patapsco River valley in eastern Maryland was used in Locks 14, 28 (fig. 30) to 30, 32, and 33. Lower Cambrian(?) Sugarloaf Mountain Quartzite quarried from the southern base of Sugarloaf Mountain was used in Lock 28.

Locks 31 and 33 used a combination of local Lower Cambrian stones that included quartzite of the Weverton Formation (fig. 31), limestone, metasiltstone of the Harpers Formation, as well as Upper Triassic Manassas Sandstone. In the Great Valley section, locally quarried limestone (fig. 32) was used extensively from Lock 32 to Lock 53, as well as in Locks 56 and 57. Locks 53 to 57 used sandstone and limestone that were excavated along the canal. Locks 58 to 67 used Devonian sandstone and shale that also were locally excavated along the canal. Some of these locks were lined with wood 


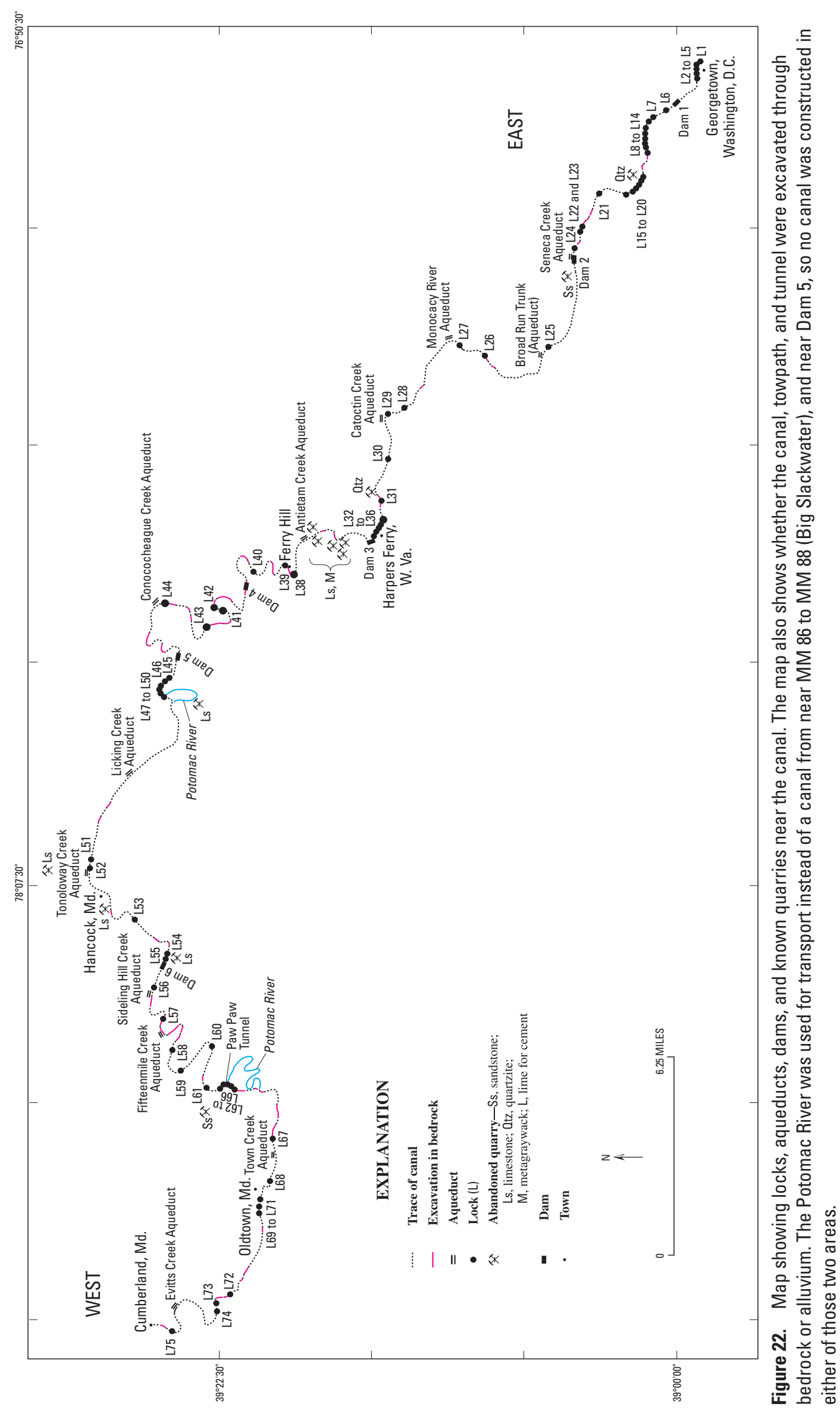


Table 1. Dimension stone used for the C\&O Canal locks and aqueducts and the source geologic unit.

[See figure 22 for locations of locks and aqueducts. Names in parentheses are informal names]

\begin{tabular}{lll}
\hline \multicolumn{1}{c}{ Lock number or aqueduct name } & Dimension stone \\
\hline $1-7$ & Sandstone & Potomac Group (Aquia Sandstone) \\
$7-13,15-27,28-30,33-34$ & Sandstone & Poolesville Member of Manassas Sandstone (Seneca Red Sandstone) \\
$14,28-30,32-33$ & Granodiorite & Ellicott City Granodiorite \\
28 & Quartzite & Sugarloaf Mountain Quartzite \\
$31,33,53-67$ & Mixture & Local stones quarried nearby \\
$32-53,56-57$ & Limestone & Variable. Limestone unit usually quarried nearby \\
$68,70-71$ & Sandstone & Oriskany Sandstone \\
Seneca Creek & Sandstone & Poolesville Member of Manassas Sandstone (Seneca Red Sandstone) \\
Sideling Hill Creek, Town Creek & Sandstone & Variable. Sandstone unit usually quarried nearby \\
Catoctin Creek & Granodiorite & Ellicott City Granodiorite \\
Monocacy River & Quartzite & Sugarloaf Mountain Quartzite \\
Antietam Creek, Conococheague Creek, Licking & Limestone & Variable. Limestone unit usually quarried nearby \\
\multicolumn{1}{c}{ Creek, Tonoloway Creek, Sideling Hill Creek, } & & \\
Fifteen Mile Creek, Town Creek, and Evitts Creek & & \\
\hline
\end{tabular}

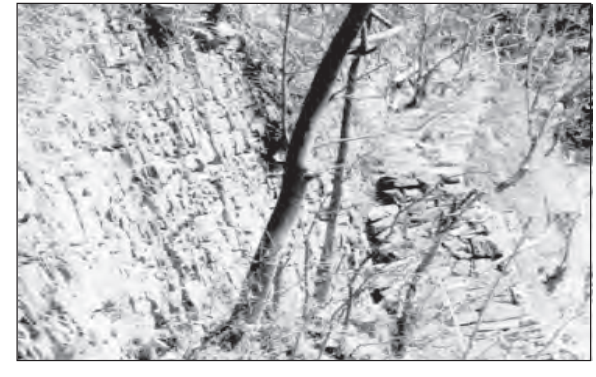

$\boldsymbol{A}$

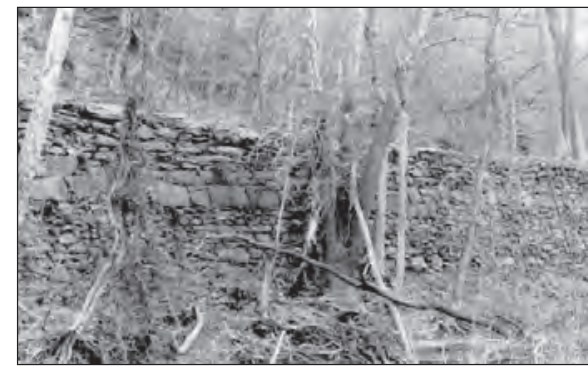

B

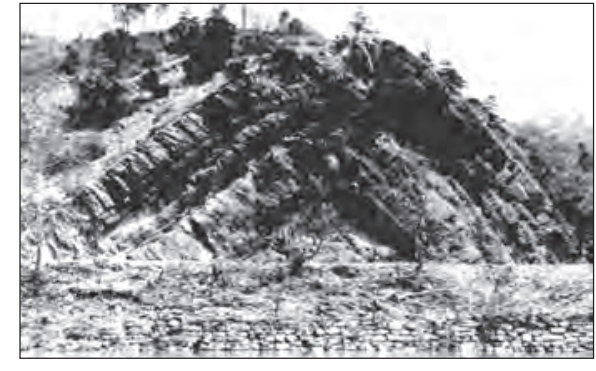

C

Figure 23. Stone berms constructed to prevent erosion between the towpath and the Potomac River. A, Mary's Wall (MM 14). Towpath is above the wall. $B$, Near Blockhouse Point (MM 21). C, At Devil's Eyebrow, west of Hancock (MM 127.5). Historical photograph by Charles D. Walcott (U.S. Geological Survey, 1897).

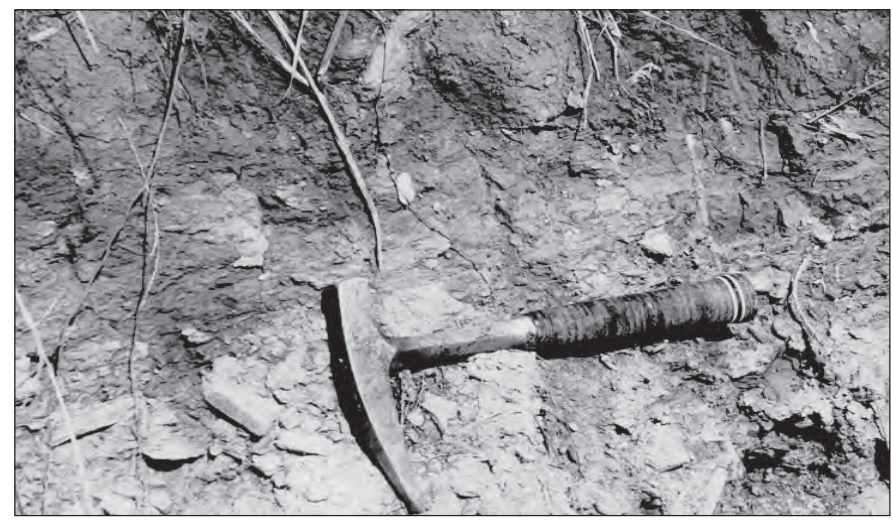

Figure 24. An example of modern erosion in the canal near Lock 34 (west of MM 62) that has exposed the clay liner (above the rock hammer) that was placed above rubble fill (below the rock hammer) to hold water. This clay was probably taken from the residuum that developed on the carbonate rocks of the Tomstown Formation near Fort Duncan to the immediate west. planks (fig. 33) to help seal water that leaked from between the masonry stones. Sandstone of the Lower Devonian Oriskany Sandstone was used in Locks 68, 70, and 71 because it had been excavated to build the canal.

\section{Cement}

More than 500,000 barrels of cement were used to bond the stone in the locks and aqueducts. From 1828 to 1837 , cement plants were built along or near the Potomac River at Tuscarora, Md.; Shepherdstown, W. Va.; Hooks Mill and Roundtop Hill near Hancock, Md.; Leopards Mill near Dam 6; and at Cumberland, Md. (Hahn and Kemp, 1994). Beginning in 1837, limestone from the Upper Silurian Wills Creek Formation was quarried or mined and used for cement by the Round Top Cement Company, located west of Hancock along the C\&O Canal (fig. 34). This company provided cement not only for the canal masonry, but also for the construction of the 


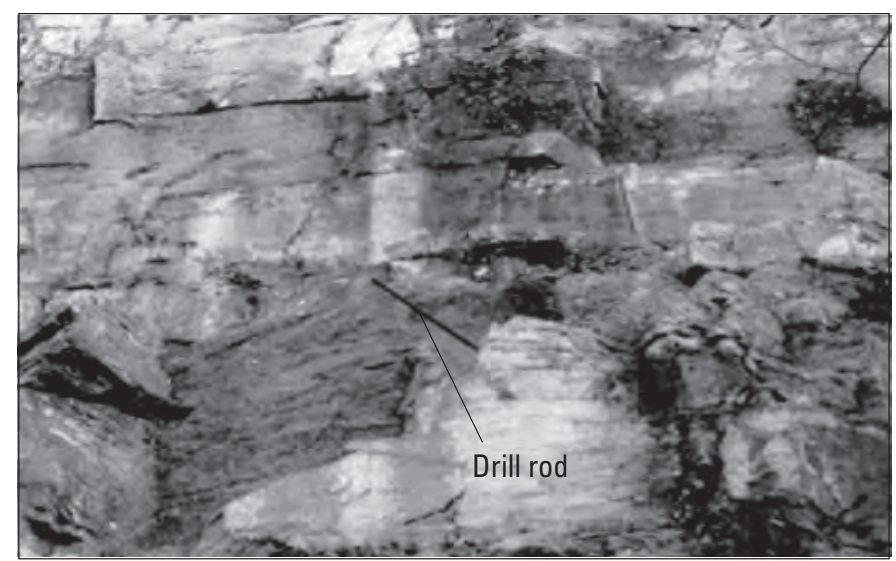

A

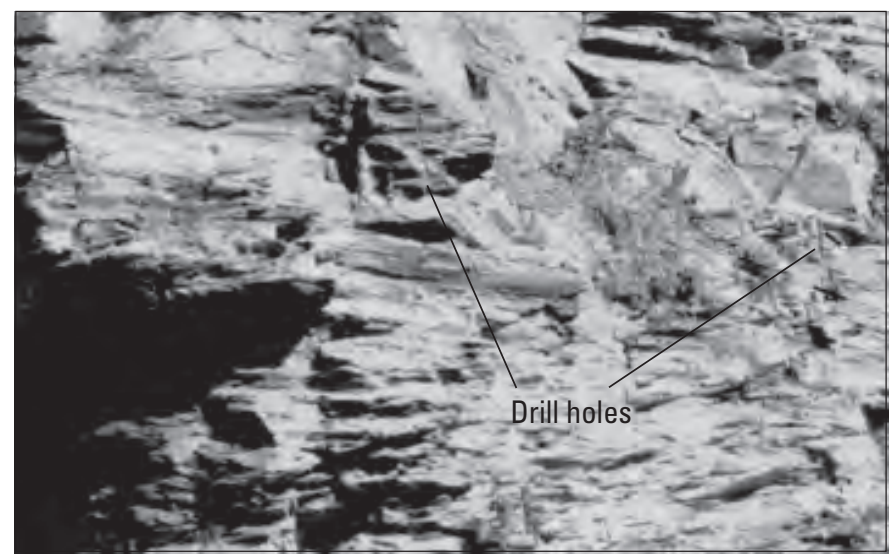

B

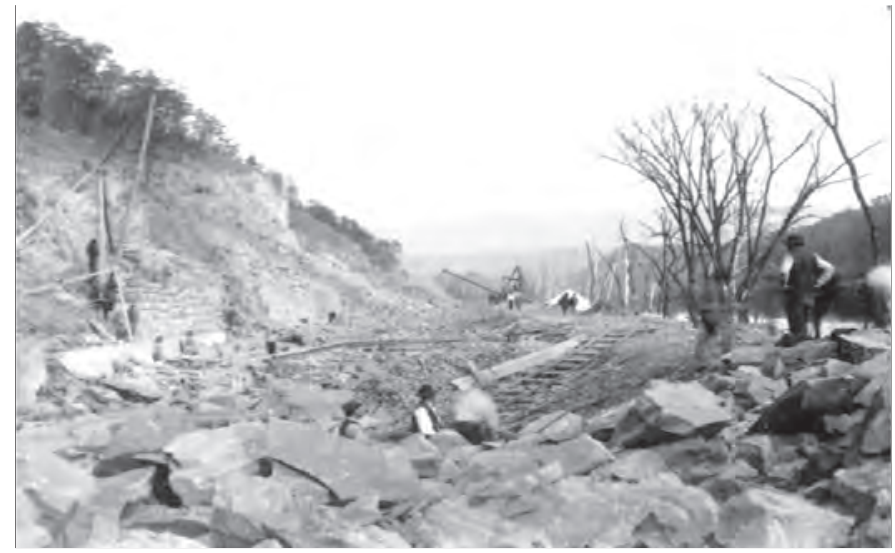

c

Figure 25. Evidence of excavated bedrock. $A$, Drill holes and drill rod (indicated by arrow) stuck in a limestone cliff about $50 \mathrm{ft}$ above Big Slackwater (MM 87.5). B, Drill holes in metagraywacke over $50 \mathrm{ft}$ above the canal at Blockhouse Point (MM 21). C, Historical photograph (around 1904-1906) showing that bedrock excavated for the Western Maryland Railroad (on the left) was used to fill the towpath of the C\&O Canal east of Oldtown, Md., near MM 164. Photograph courtesy of the National Park Service.

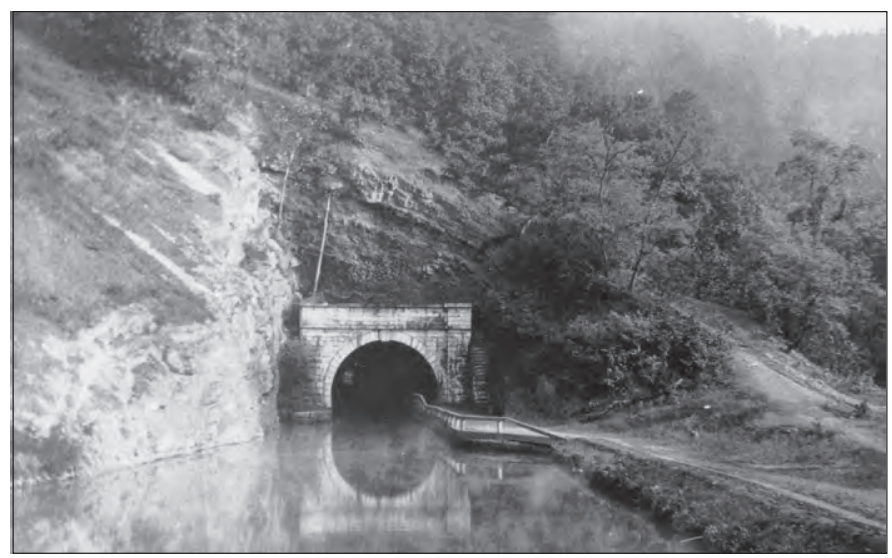

A

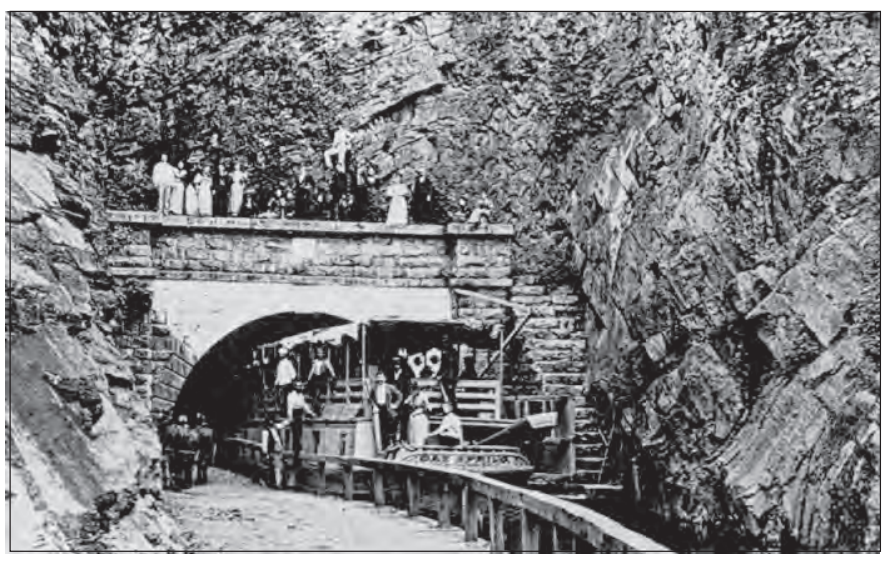

B

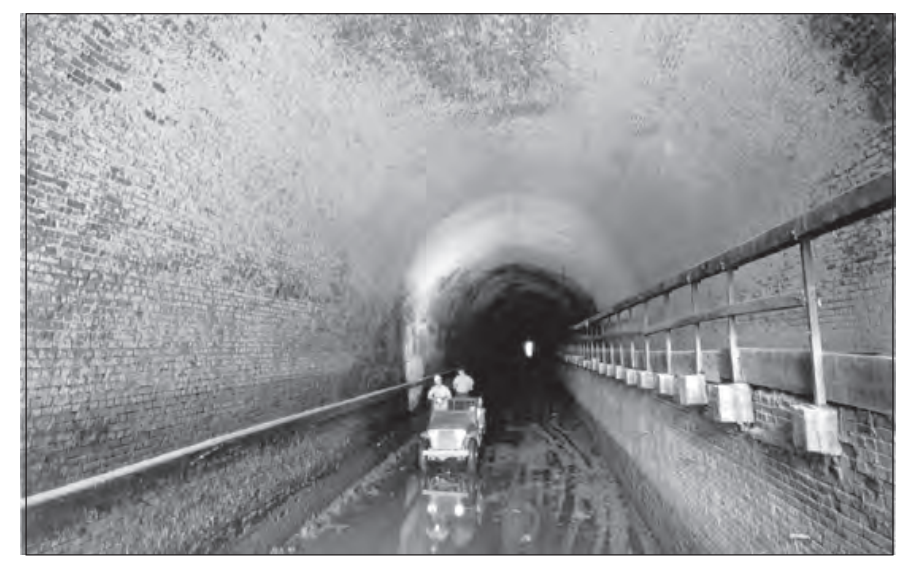

C

Figure 26. Historical photographs of Paw Paw Tunnel, near MM 155. A, View of the south portal, looking north (1904). Photograph courtesy of National Park Service (NPS). $B$, View of the north portal, looking south (around 1900). The tunnel penetrates the southeast limb of an anticline of shale and thin sandstone of Upper Devonian Brallier Shale. The anticline's crest is exposed above the upper-right stonework of the north portal. Photograph courtesy of NPS. C, Brick lining of the 3,118-ft-long tunnel. Photograph courtesy of NPS. 


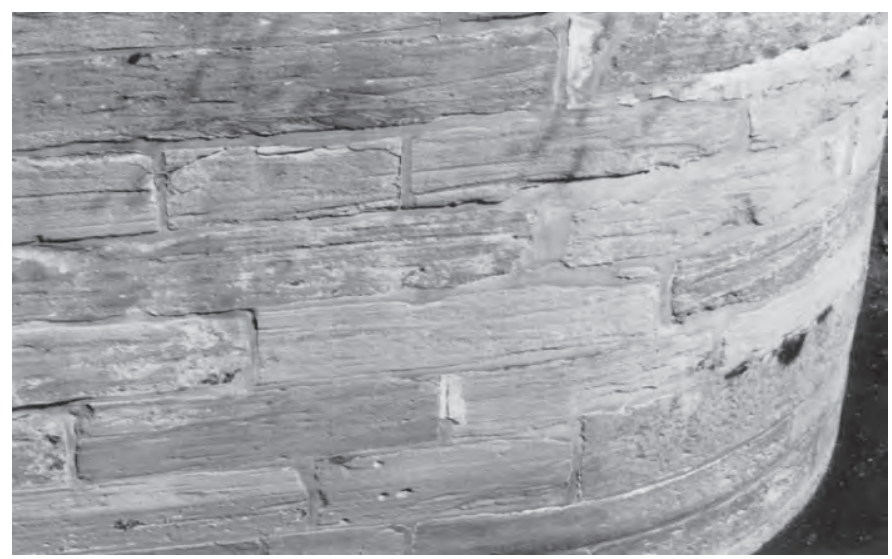

$\boldsymbol{A}$

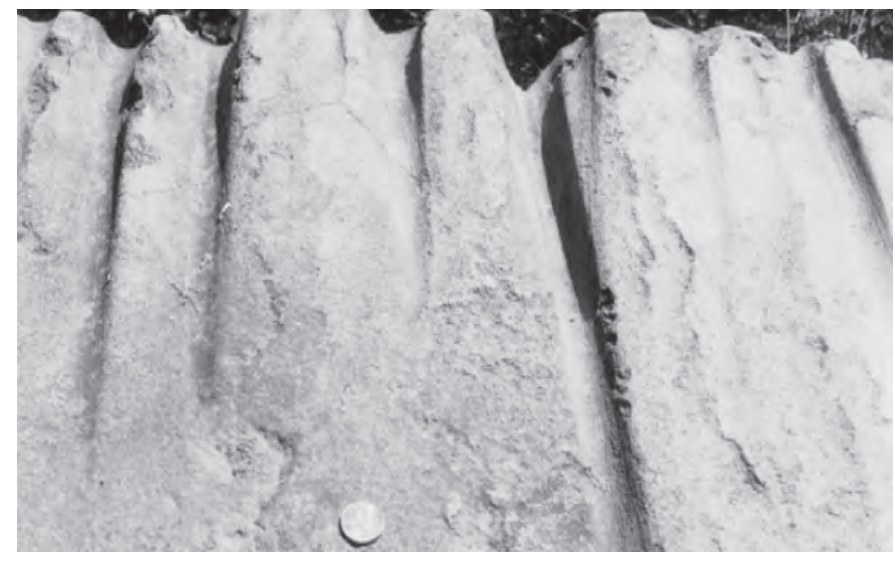

C

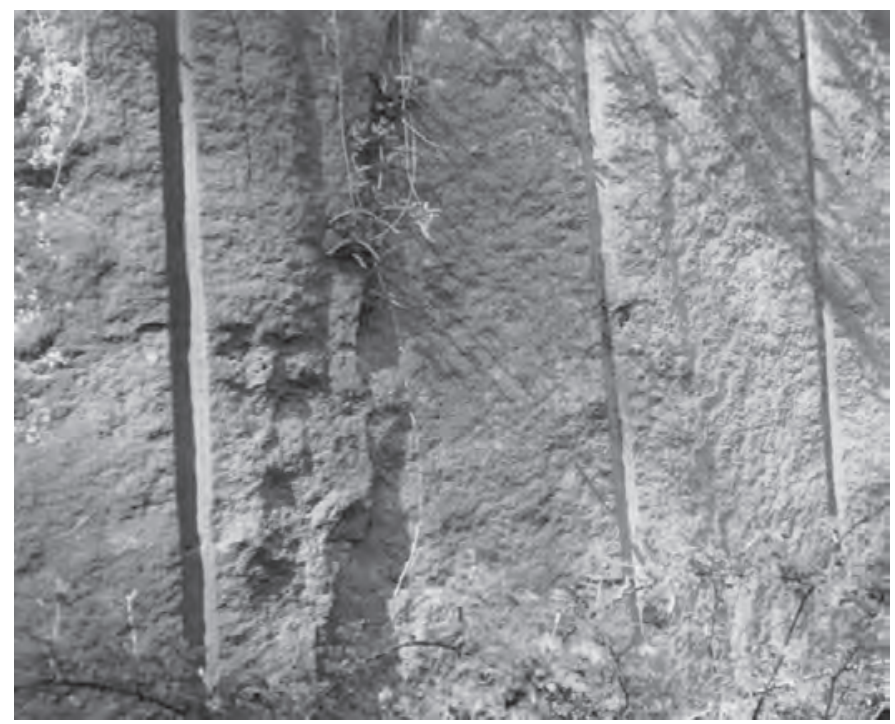

A

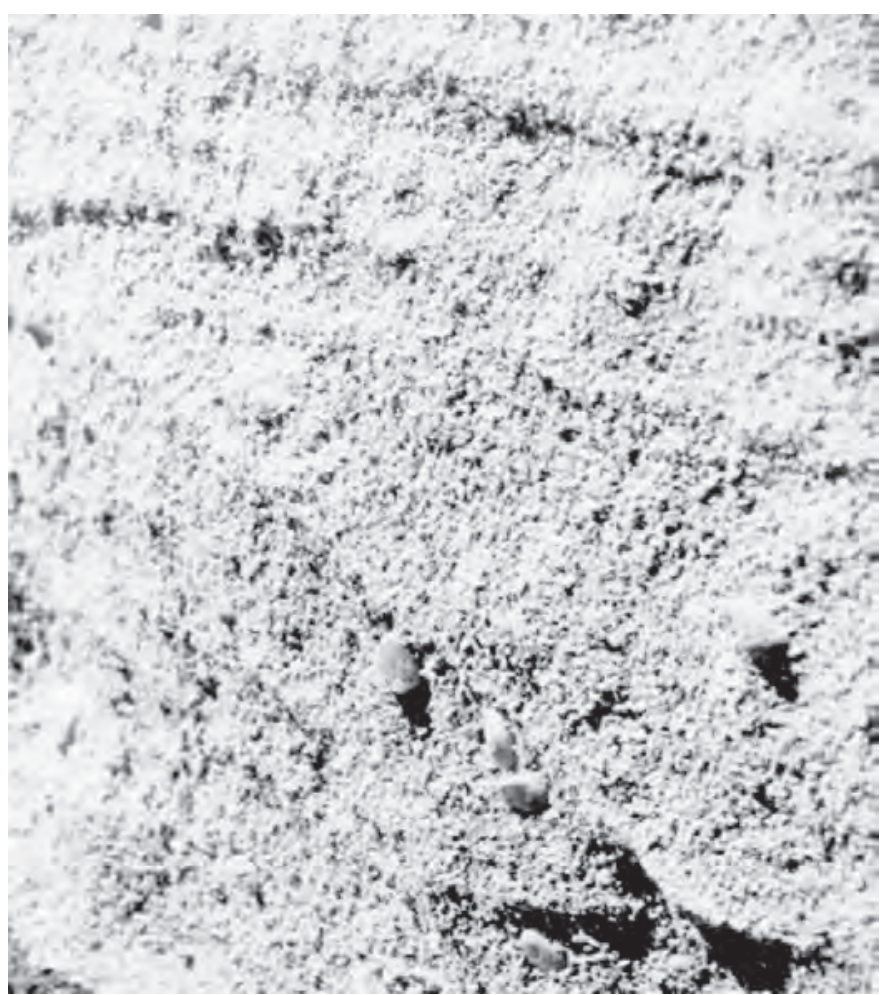

B

Figure 27. Examples of Lower Cretaceous Potomac Formation (informally called "Aquia Sandstone"). $A$, Cut blocks of Potomac Formation used in construction of Lock 6 . $B$, Closeup of $A$ showing crossbedding and rounded quartz clasts. $C$, Grooves in the friable Potomac Formation made by the rope that mules used to pull canal boats (penny for scale).

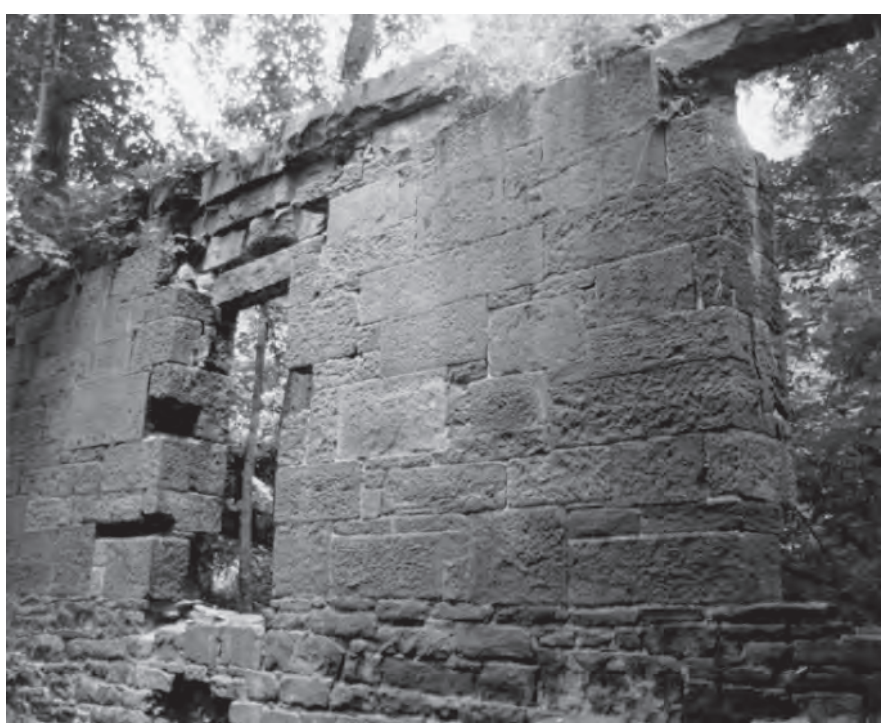

B

Figure 28. Upper Triassic Poolesville Member of the Manassas Sandstone (informally called "Seneca Red Sandstone") was drilled and quarried for dimension stone along the bluffs west of Seneca, Md. A, View of quarry wall showing three vertical drill holes visible in the quarry face. $B$, Dressed blocks (showing hammer and chisel marks) in the ruins of the Seneca Stone Cutting Mill, located $300 \mathrm{ft}$ north of MM 23. 


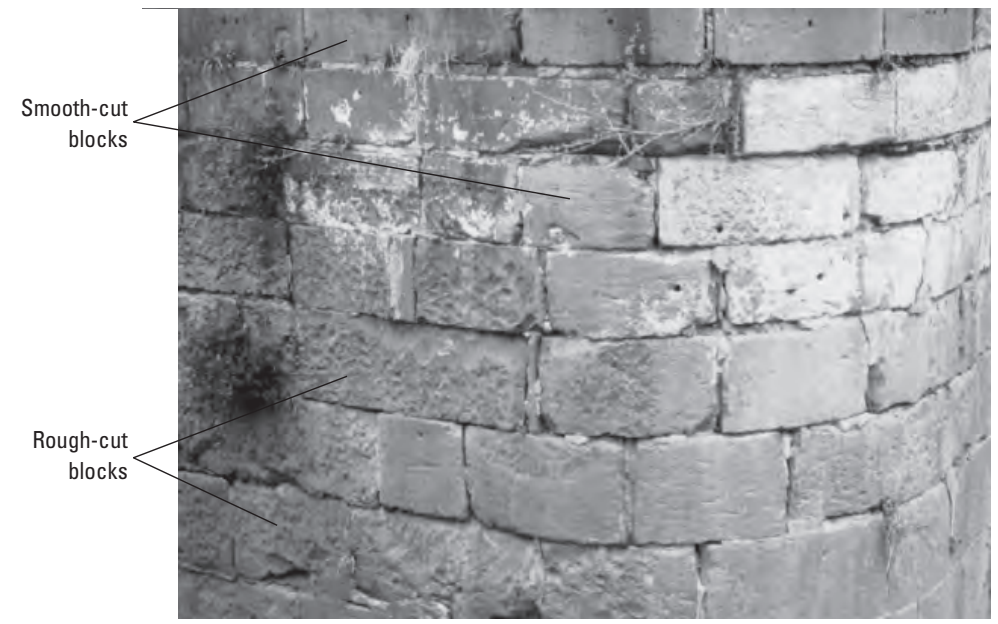

$\boldsymbol{A}$

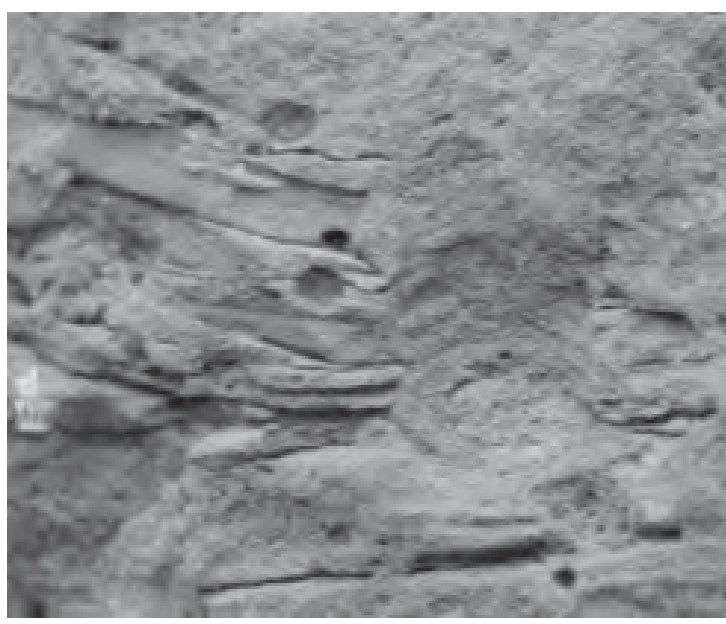

$\boldsymbol{B}$

Figure 29. East end of Lock 24 (Rileys Lock at MM 23). A, Smooth-cut (wire saw) and rough-cut (hammer dressed) blocks of Upper Triassic Poolesville Member of Manassas Sandstone (informally called "Seneca Red Sandstone"). B, Closeup of rough-cut block showing beds of finer grained siltstone interbedded with sandstone.

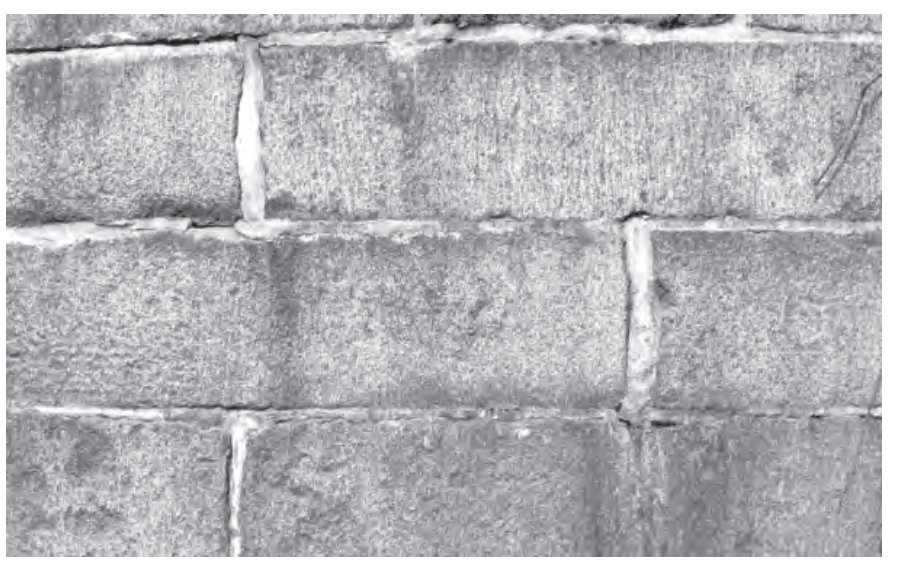

$\boldsymbol{A}$

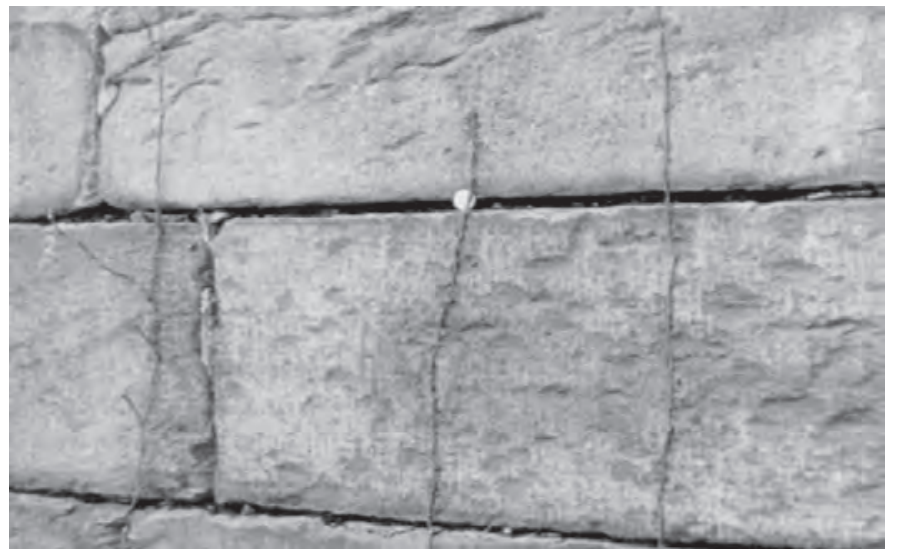

$\boldsymbol{A}$

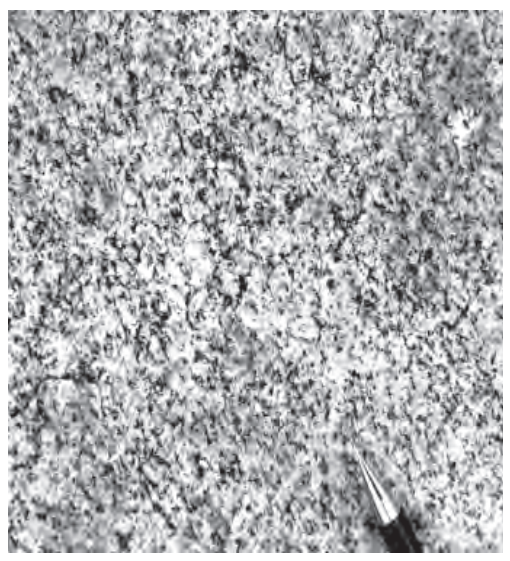

B
Figure 30. Nonfoliated Ordovician Ellicott City Granodiorite. A, Blocks of the granodiorite were used in the construction of Lock 28, near MM 49. $B$, Closeup of $A$ showing a crystalline texture exhibited by amphibole (dark) and feldspar (light) crystals.

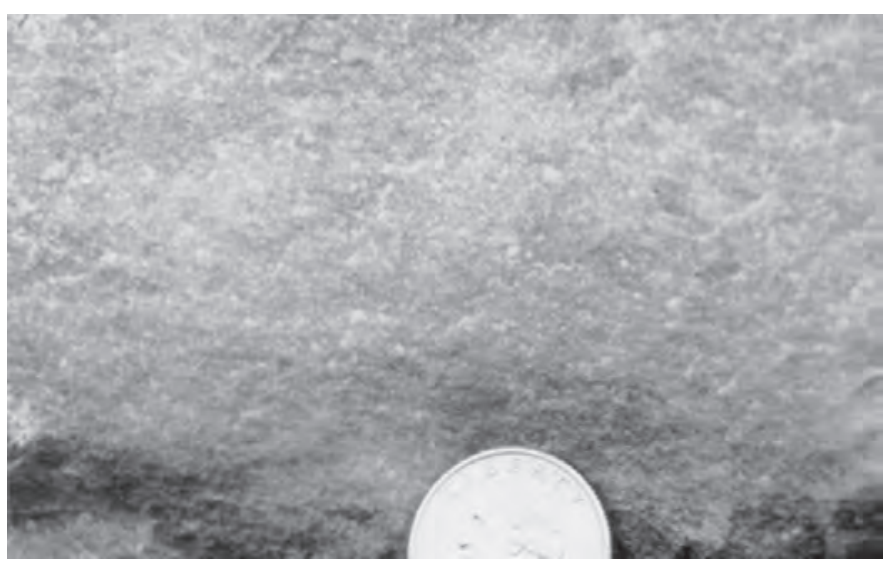

B

Figure 31. Quartzite of the Lower Cambrian Weverton Formation. A, Blocks of the quartzite were used to construct Lock 31 at MM 58. $B$, Closeup of $A$ showing the vitreous orthoquartzite variety of the Weverton Formation; elsewhere, the Weverton is a granular quartzite. 


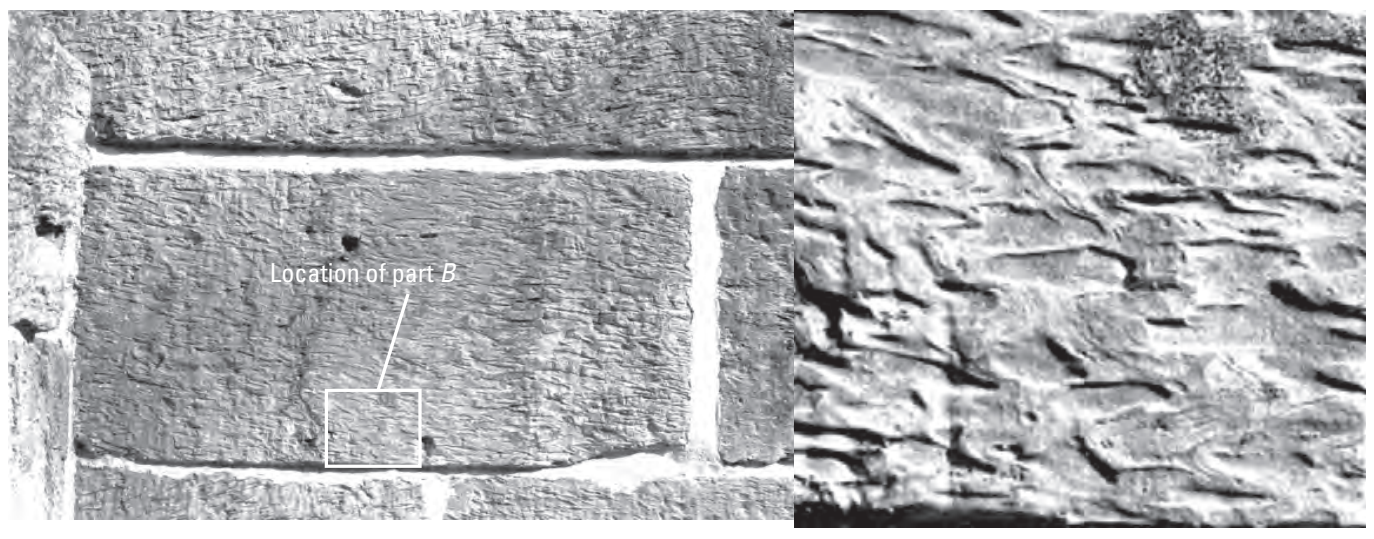

$\boldsymbol{A}$

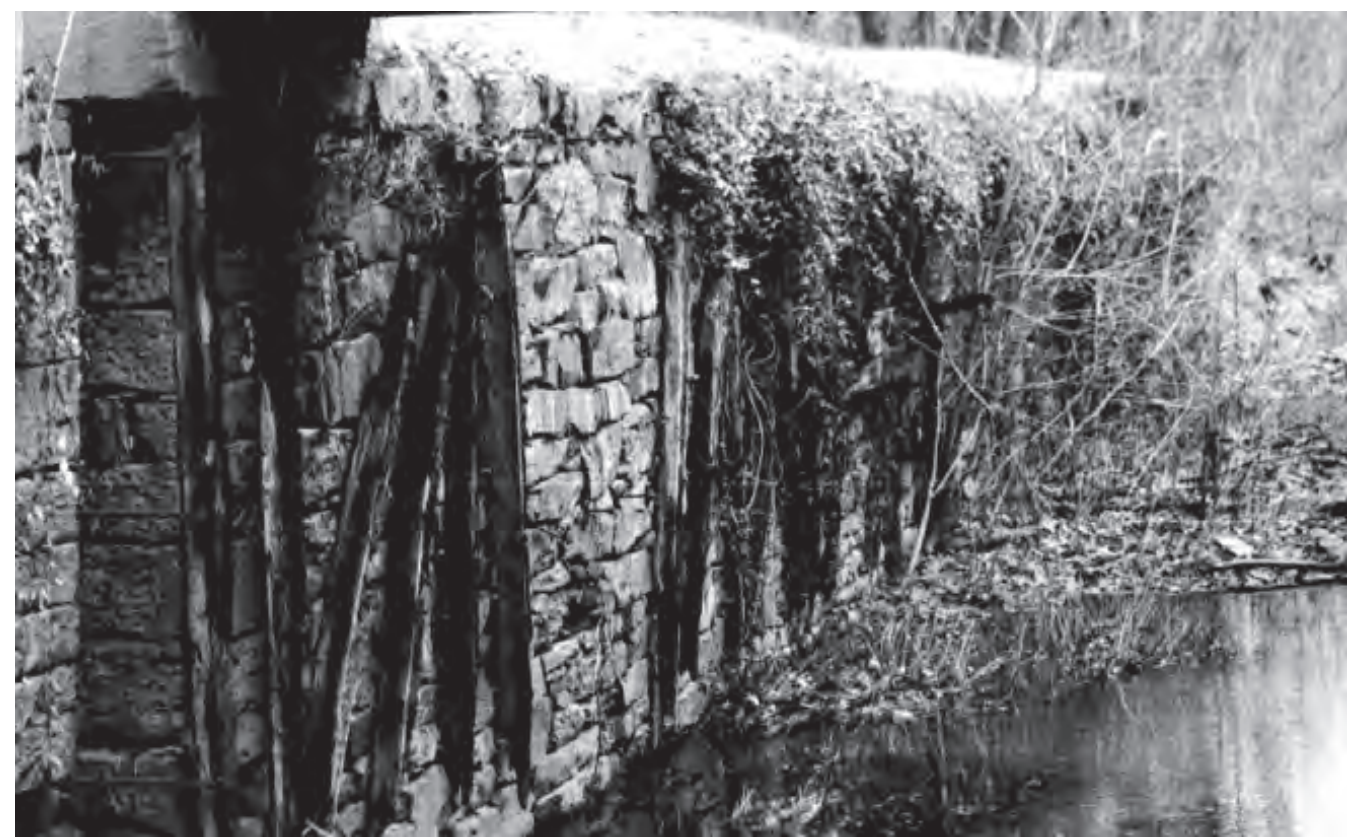

Figure 32. Limestone of the Lower Cambrian Bolivar Heights Member of the Tomstown Formation. $A$, Blocks of limestone were used in the construction of Lock 37 (Mountain Lock) just south of MM 67. $B$, Closeup of $A$ showing beds (vertical) and burrows accentuated by cleavage (horizontal). Elsewhere in the Valley and Ridge province, the Bolivar Heights is a thin-bedded, laminated limestone and was a popular choice for dimension stone.

Figure 33. Lock 60 at $\mathrm{MM}$ 149.5, which was constructed from locally quarried, roughcut sandstone of the Upper Devonian Foreknobs Formation. Wood planks lined the walls to help prevent water from leaking out of the canal through the stone blocks. Photograph courtesy of the National Park Service.
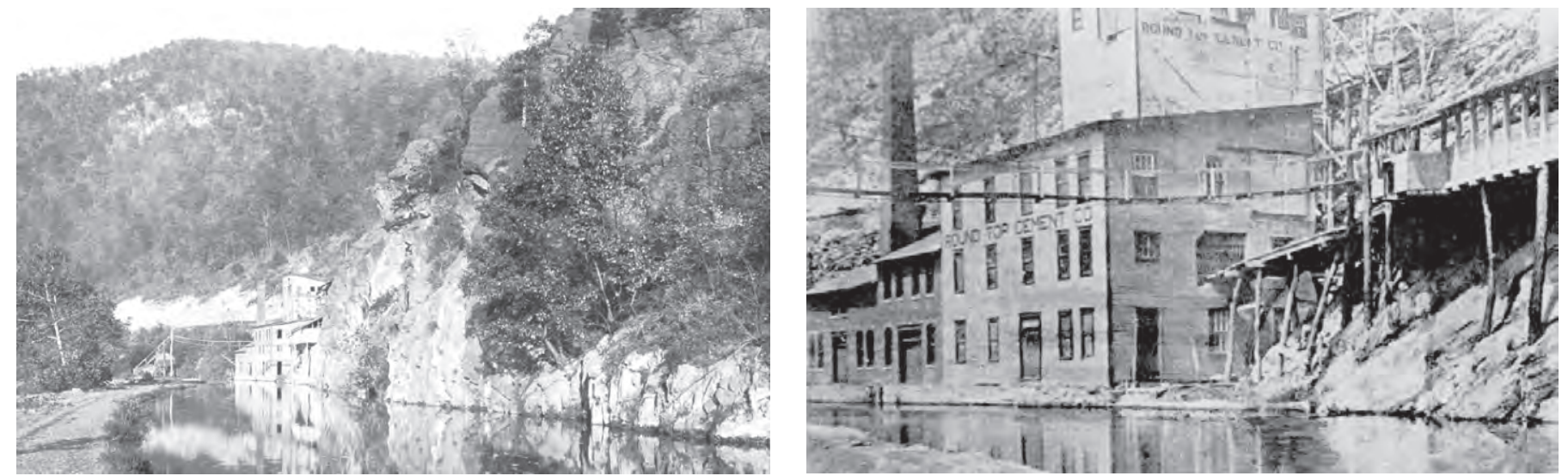

Figure 34. Round Top Cement Company, west of Hancock, Md., where limestone was quarried, mined, and processed. A, Historical photograph (not dated) provides view of the plant and its surroundings from downstream along the canal. $B$, Historical photograph (1907) showing the plant buildings. Both photographs courtesy of National Park Service. 
Washington Monument in Washington, D.C., and the Cabin John Bridge, which carries MacArthur Boulevard over the Cabin John Parkway in Montgomery County, Maryland.

\section{Aqueducts, Culverts, and Waste Weirs}

With the exception of the Broad Run Trunk (Aqueduct) that was made of wood planks, the other 10 aqueducts were impressive structures made of stone that did not leak. The Alexandria Aqueduct carried boats over the Potomac River to the Alexandria wharf in Virginia. The Seneca Creek Aqueduct (fig. 35) was constructed from Upper Triassic Manassas Sandstone that was quarried to the immediate west. The Monocacy River Aqueduct (fig. 36) used quartzite of the Lower Cambrian(?) Sugarloaf Mountain Quartzite. This granular white rock was quarried at the base of Sugarloaf Mountain near the FrederickMontgomery County line and hauled to the site by horse-drawn

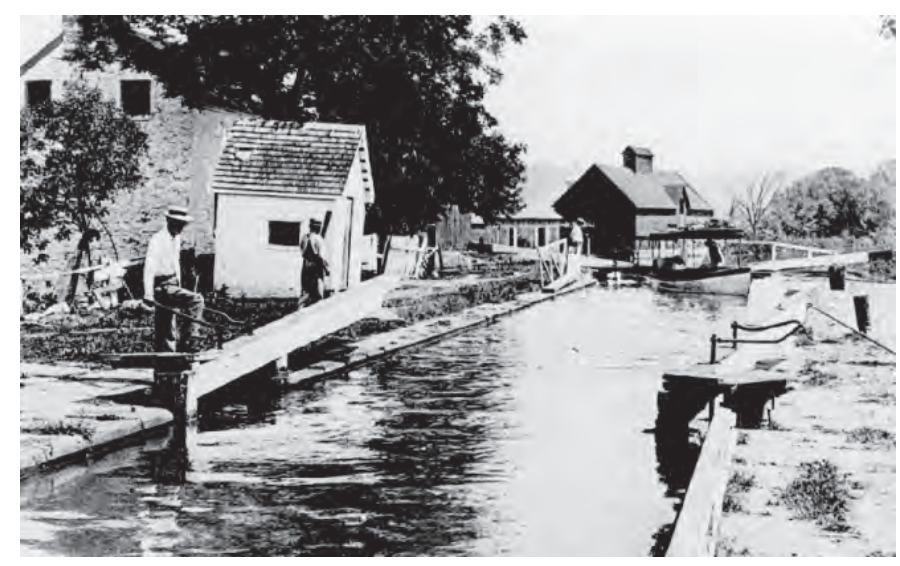

\section{$\boldsymbol{A}$}

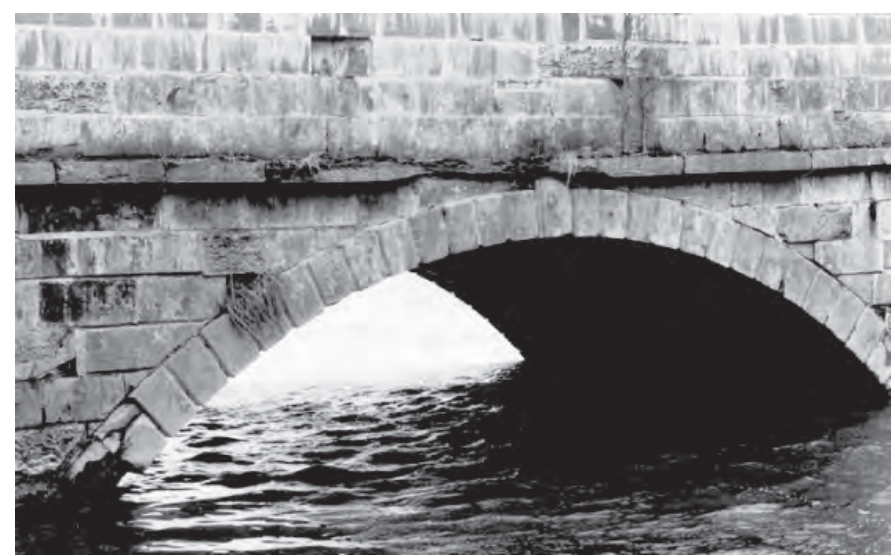

\section{$B$}

Figure 35. Seneca Creek Aqueduct, just east of MM 23. $A$, Historical photograph (undated) showing view of water-filled aqueduct. Photograph courtesy of the National Park Service. B, The aqueduct is constructed of smooth-cut Upper Triassic Manassas Sandstone. wagon and light rail. The Catoctin Creek Aqueduct, now in ruins, used Ordovician Ellicott City Granodiorite from the Patapsco River valley (in northern Maryland) and Manassas Sandstone from the Seneca Quarry. Parts or all of the aqueducts at Antietam Creek, Conococheague Creek, Licking Creek, Tonoloway Creek, Sideling Hill Creek, Fifteenmile Creek, Town Creek, and Evitts Creek were constructed of limestone quarried nearby. The aqueducts at Sideling Hill Creek and Town Creek also used locally quarried sandstone.

More than 200 culverts mostly were constructed from local stone, lined with brick, and dressed with cut stone. The culverts carried water from Potomac River tributaries beneath

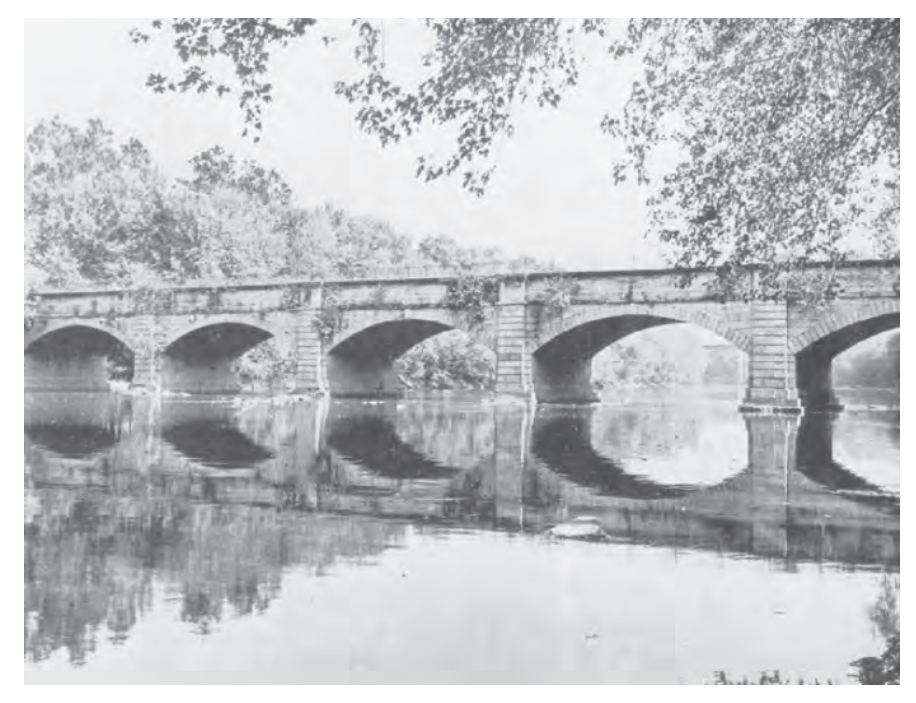

A

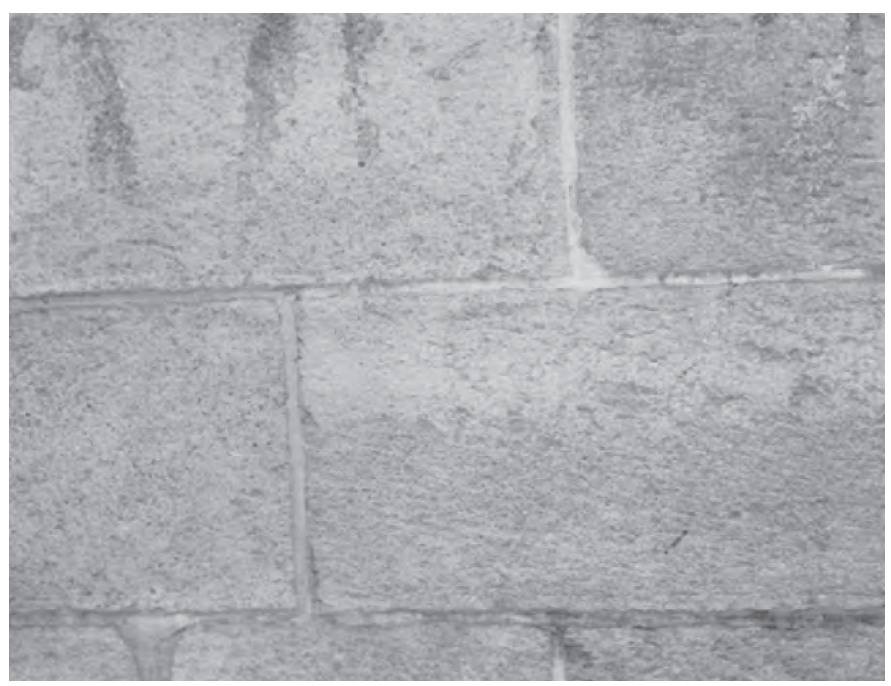

$\boldsymbol{B}$

Figure 36. The Monocacy River Aqueduct at MM 42. A, Historical photograph (undated) looking upstream at the Monocacy River. Photograph courtesy of the National Park Service. $B$, The aqueduct is constructed from smooth-cut blocks of Early Cambrian(?) Sugarloaf Mountain Quartzite. 
the canal and towpath. Waste weirs were ditches and flumes lined with stone that were used to control the water level in the canal by diverting excess water around the locks.

\section{Dams}

Dams were constructed near the top of natural steep gradients in the river in order to raise the level of water to feed the canal. The seven dams have foundations that rest on bedrock and all of the dams were constructed where resistant bedrock (metagraywacke and sandstone) crops out as ledges to create shallow falls.

Dam 1 was built in the 1750s at Little Falls in the eastern Piedmont. Dam 2 was built in 1828 at Seneca Falls, which is located on metagraywacke of the Mather Gorge Formation, at the eastern margin of the Culpeper basin in the eastern Piedmont. Both are rubble dams constructed of blocks and boulders of local rock. Dam 3 (built in 1879 near Harpers Ferry), which is located on sandstone of the Antietam Formation, was a crib timber dam (fig. 37) that later was replaced with masonry. Dam 4 (built between 1832 and 1834), Dam 5 (built between 1833 and 1835), and Dam 6 (built in 1839 east of Woodmont, Md., on the Oriskany Sandstone) (fig. 38) were timber-framed dams that were filled with stone and covered with wooden planks. Dam 8 at Cumberland was a masonry dam that was removed in 1958 for flood control. Dam 7 was planned for near Paw Paw, W. Va., but was not constructed for unknown reasons.

\section{Control of Geology on Engineering}

Several engineering features are worth mentioning here because they illustrate the challenge posed by the geology in the construction of the C\&O Canal.

(1) From near MM 2 in Georgetown to Great Falls Tavern (MM 14), the canal and towpath were built on an incised chan- nel on a bedrock strath terrace of the Potomac River. From near Cropley (MM 12) to MM 14, the canal used an abandoned channel of the Potomac River known as Widewater (fig. 39). This channel was cut into the bedrock terrace by the river, which later abandoned this course and migrated south to its present course. Because the channel was wider than the locks, timber abutments were used to fill the gaps. Channels from Widewater to the present river have wooden dams to keep floodwaters away from the towpath and canal. The towpath was constructed along a rocky stretch of ground adjoining Widewater.

(2) At four locations, bedrock bluffs prevented construction of a canal and towpath. From MM 85.5 to MM 88.8 south of Hagerstown, Md., the north shore of the Potomac River is lined with high bluffs of Stonehenge Limestone and has no flood plain. This problem was solved, at Dam 4 and Big Slackwater, by having boats enter the Potomac River at Guard Lock 4 and rejoin the canal 4 mi upriver at Lock 41. The towpath along this stretch is a narrow bench that was drilled and blasted into the limestone bluff (fig. 40A). In order to avoid river bluffs beyond MM 154, the canal and towpath were constructed in a ravine that is a tributary to the Potomac River. This section then leads to the 3,118-ft-long tunnel through shale and siltstone near Paw Paw, W. Va. The canal and towpath use the valley of Mill Run near Oldtown, Md., to bypass bedrock cliffs; here, both the canal and towpath were excavated through shale (fig. 40B).

(3) Four Locks (MM 108.5) routed the canal through an abandoned channel that probably once was a tributary of the Potomac River; the rerouting was necessary in order to cut off the 7-mi-long "neck."

(4) Big Pool (MM 113 to MM 114) and Little Pool (MM 120) are lakes that were created by building dikes, levees, and berms on a broad low-lying flood plain, and then filling the resulting structure with water diverted from the canal and river. The towpath was located on a higher ridge or intervening island; therefore, a canal prism did not have to be excavated and constructed.

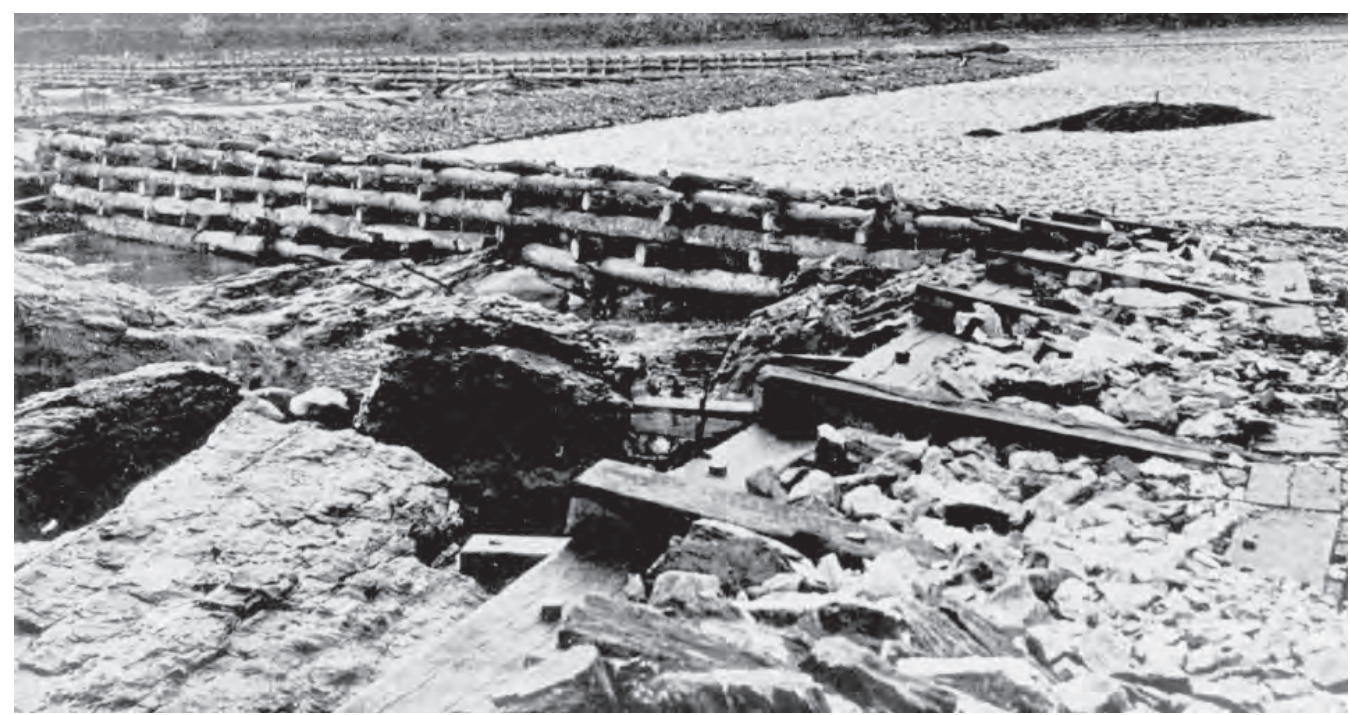

Figure 37. Historical photograph (1936) of Dam 3, which was a timber crib filled with stone located north of Harpers Ferry, W. Va., near MM 62.5. View is to the south. Photograph courtesy of the National Park Service. 


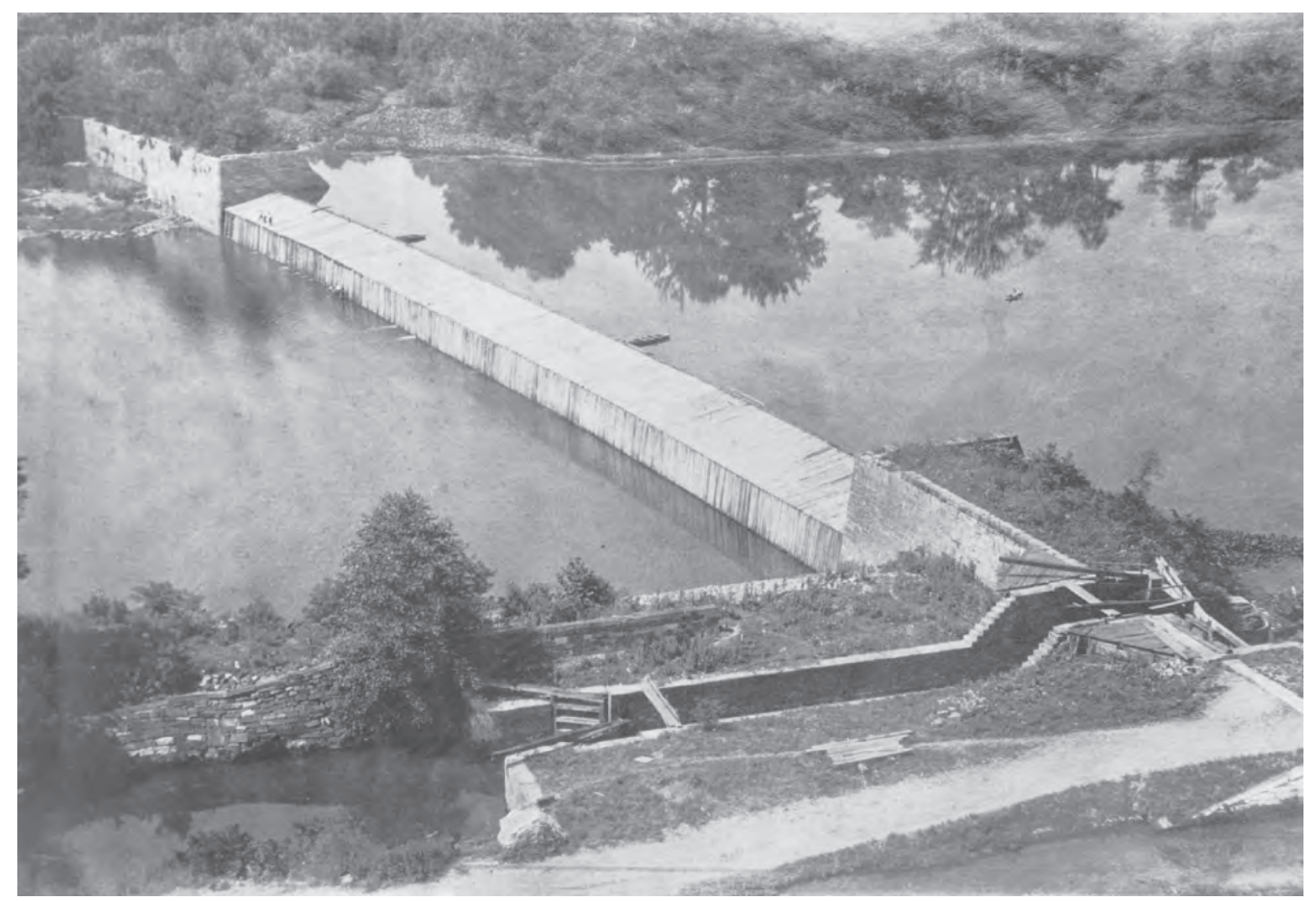

$\boldsymbol{A}$

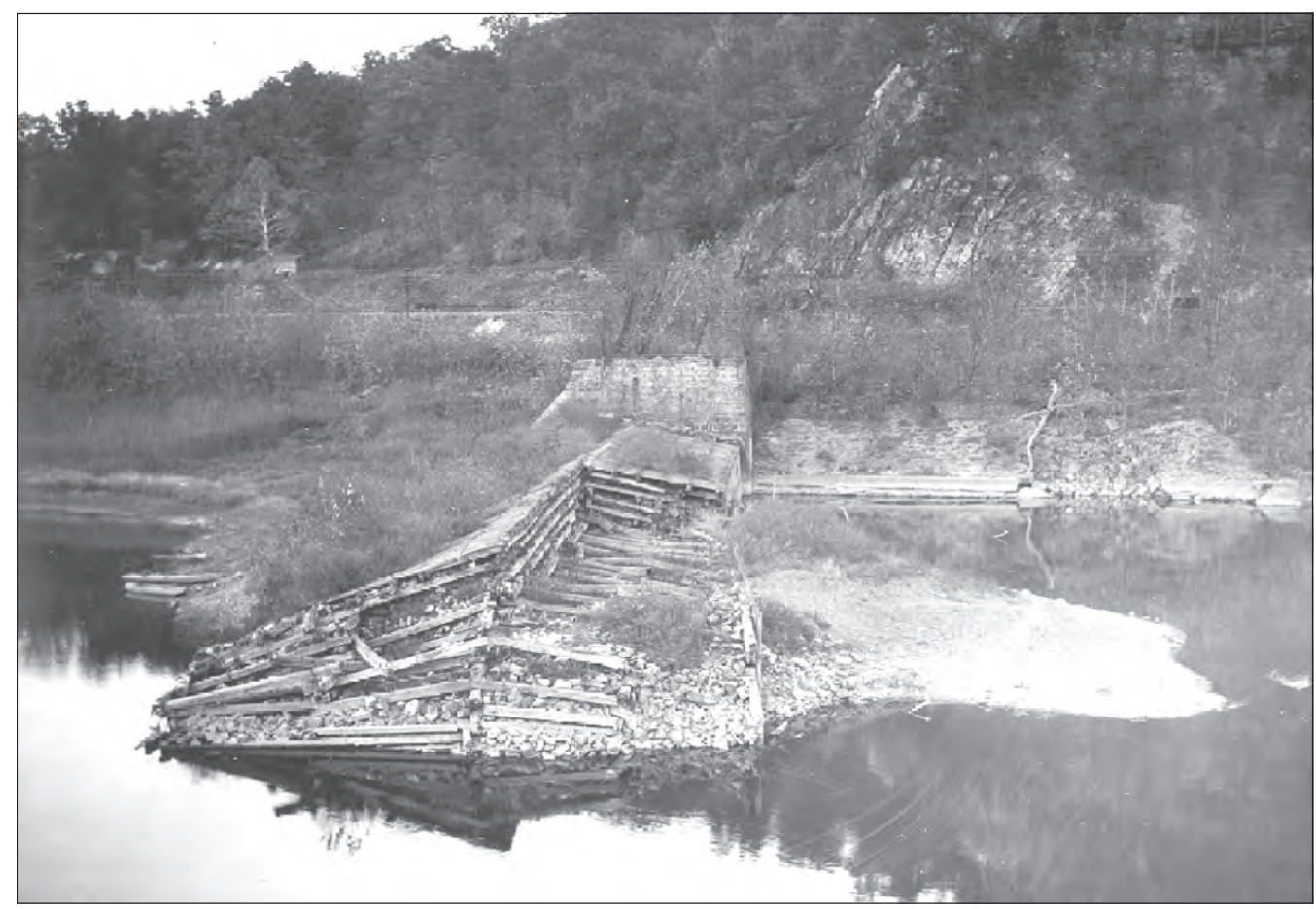

Figure 38. Dam 6, which was located north of Great Cacapon, W. Va., near MM 134. A, Historical photograph (around 1900), looking south, of the woodplanked, stone-filled crib of Dam 6. B, Historical photograph (1938), looking north, of Dam 6 after being breached in the 1936 flood. In the upper-right background are west-dipping beds of Lower Devonian Oriskany Sandstone that provided rubble for the fill. Both photographs are courtesy of the National Park Service. 

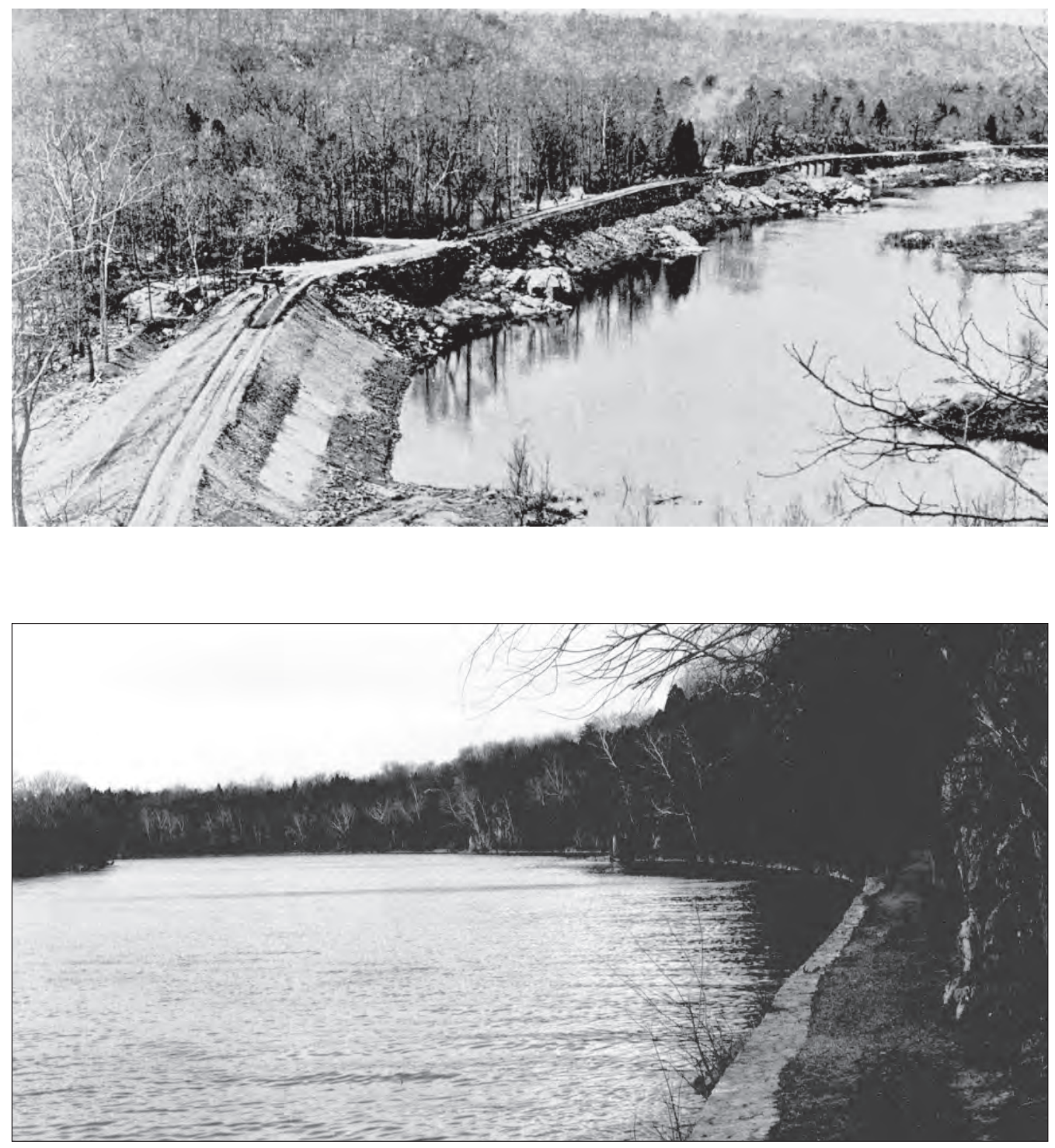

A

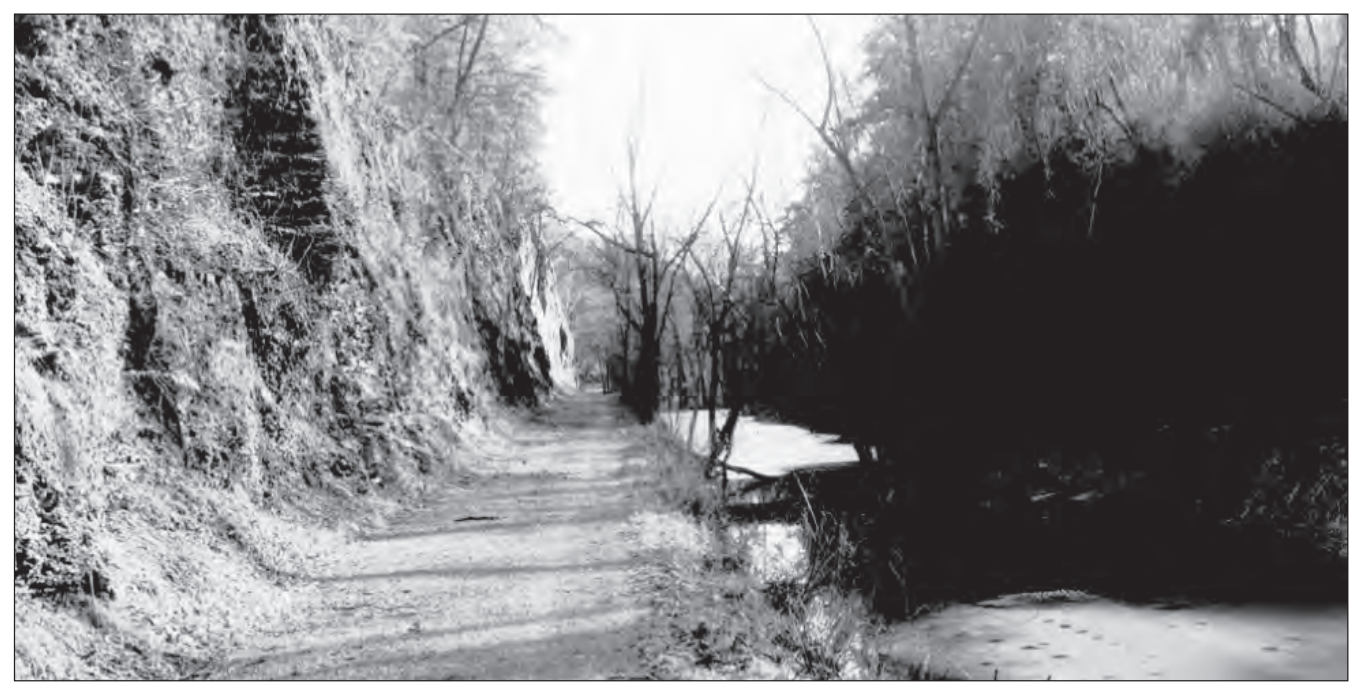

B
Figure 39. Historical photograph (1940) showing reconstruction of the towpath and canal at Widewater. The canal occupied an abandoned channel of the river. Photograph courtesy of National Park Service
Figure 40. Excavation of the canal through bedrock. $A$, View of the towpath adjacent to the Potomac River at Big Slackwater (MM 87.5), where canal boats used the river. Limestone cliffs adjacent to the river prevented construction of the canal. $B$, West of Oldtown, Md. (MM 168), both the towpath and canal were excavated through thin-bedded fissile shale of the Devonian Mahantango Formation. 


\section{Geologic Guide}

For the following Geologic Guide, please refer to plates 2 through 20 for detailed geologic maps of the entire $\mathrm{C} \& \mathrm{O}$ Canal and the Potomac River corridor. An index to plates 2 through 20 is found on plate 1. Map-unit symbols shown in this guide correspond to those used on plates 2 through 20 .

\section{Piedmont Province-Potomac Terrane}

\section{Georgetown Section of Washington, D.C., to Seneca, Md. (MM 0 to MM 23)}

\section{Access Points}

Georgetown section of Washington, D.C., south of M Street, N.W.

Clara Barton Memorial Parkway

Carderock

MacArthur Boulevard

Great Falls Tavern Visitor Center

Swains Lock, off River Road

Watts Branch Park

Pennyfield Lock, off River Road

Violettes Lock, off River Road

Rileys Lock, off River Road

\section{Introduction}

The Potomac River has cut a beautiful gorge through the complexly deformed crystalline metamorphic rocks of the Potomac terrane (fig. 41). These rocks formed when sediments and extrusive volcanic material were deposited in Neoproterozoic and Early Cambrian time (about $550 \mathrm{Ma}$ ); the rocks subsequently were transported and deformed along thrust faults. Debris shed from the thrust sheets mixed with unconsolidated sediments to form a tectonic mélange (mixture of rocks). A modern analog would be the rock debris that calves off of the front of an advancing glacier.

Along the Potomac River, Drake (1989) mapped the Mather Gorge-Sykesville tectonic motif, which is a geologic structure that formed when rocks of the older Mather Gorge Formation overrode the younger Sykesville Formation along the Plummers Island thrust fault. The Neoproterozoic and (or) Lower Cambrian Mather Gorge Formation consists of quartzrich schist and metagraywacke ( $€ Z m g)$ that has been sheared locally to form phyllonite (€Zmp). These rocks originally formed as turbidites deposited in a submarine fan (Drake and Morgan, 1981). The complexly deformed and polymetamorphosed Mather Gorge Formation locally contains migmatite
( $€ \mathrm{Zmm})$, which is rock that was partially melted due to heat and pressure. The Mather Gorge Formation also contains mappable bodies of ultramafic rock (such as serpentinite, talc, actinolite schist mapped as €Zu), and amphibolite (€Za) that were derived from oceanic crust. The Lower Cambrian Sykesville Formation ( $€$ s) is a mélange that consists of quartz- and feldspar-rich sedimentary rock that contains fragments and blocks of phyllonite derived from the Mather Gorge Formation. The Sykesville Formation also contains exotic blocks and cobbles of granitoids, schist, and vein quartz that were incorporated into the giant submarine-slide deposit (Drake and Morgan, 1981).

The Lower Cambrian Laurel Formation ( $€$, shown only on plate 1) of the Loch Raven-Laurel tectonic motif is exposed only at the ramp of Theodore Roosevelt Bridge in Washington, D.C. The Laurel Formation resembles the Sykesville Formation, but differs in that it contains more numerous and a wider variety of clasts.

East of the Plummers Island thrust fault, near the American Legion Bridge, four groups of igneous plutonic rocks intrude the Sykesville Formation. They are, from oldest to youngest based on isotopic dating (Aleinikoff and others, 2002), the Ordovician(?) Bear Island Granodiorite (Ob), and Early to Middle Ordovician Dalecarlia Intrusive Suite (Odm, Odt), Georgetown Intrusive Suite (Ogh, Ogb, Ogg, Ogu), and Kensington Tonalite (Ok).

Regional metamorphism of the Mather Gorge Formation occurred at $490 \mathrm{Ma}$ (Becker and others, 1993), which was before the Taconian orogeny. Metamorphic mineral assemblages in rocks of the Potomac terrane range from chlorite grade in the west to sillimanite grade in the east. Rocks of the Sykesville Formation are at biotite \pm garnet grade and rocks of the Laurel Formation are at biotite \pm garnet grade with local overgrowths of staurolite. The deformation of these rocks started in Cambrian time during eastward subduction (Drake, 1989). The rocks in the composite thrust sheets were then thrust onto the continental slope and rise deposits of the Westminster terrane during subduction related to the Ordovician Taconian orogeny (fig. 4).

The spectacular scenery of the Potomac Gorge is a result of the fairly recent incision by the Potomac River. Several different levels of strath terraces are cut into the bedrock. They are mostly confined to the north shore of the Potomac River, but some may be seen on the islands. These terraces are nearly flat benches of bedrock with abundant potholes (see figures 8 and 9) and channels (Zen, 1997a). Upland areas, such as Carderock and the Palisades, are built upon such terraces. Upstream of Great Falls, the river valley has a wide alluvial flood plain, except for the area around Blockhouse Point, which forms a promontory into the river.

Lower Cretaceous sand and gravel of the Potomac Formation ( $\mathrm{Kp}$ ) occur as erosional patches in Arlington, Va., and Washington, D.C. Marine clay, silt, and sand of the lower and middle Miocene Calvert Formation overlie the Potomac Formation. Elsewhere, gravel, sand, silt, and clay deposits range in age from late Miocene to late Pliocene. These older deposits are more weathered than the latest Tertiary(?) to late Pleistocene alluvial terrace deposits (OTt) that occur at similar elevations. 


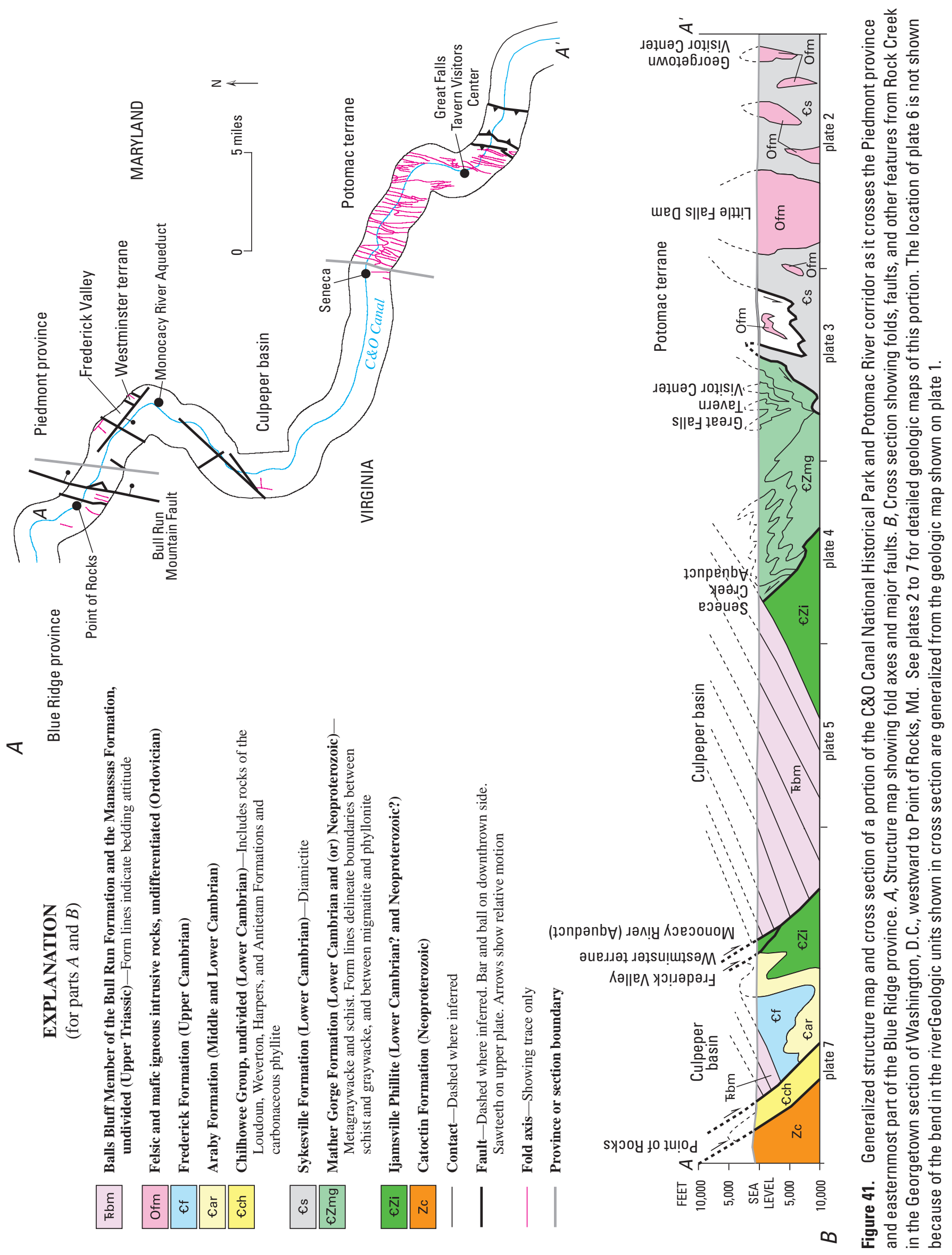




\section{Georgetown to Glen Echo Park Area (MM 0 to MM 7)}

The east end of the C\&O Canal is at sea level at Tidewater Lock (Lock 1), which is located at the confluence of Rock Creek and the Potomac River (fig. 41 and plate 2) in the Georgetown section of Washington, D.C. Rock Creek was used as the canal for about $0.38 \mathrm{mi}$, beyond which the canal was excavated in bedrock. Near Lock 1 is a National Historical Marker attached to a block of the Lower Cambrian Sykesville Formation that shows rock fragments in a fine-grained matrix (fig. 42). Theodore Roosevelt Island and bluffs in Washington, D.C., and Arlington County, Va., are underlain by similar bedrock. Rocks of the Sykesville Formation ( $€ s$ ) first crop out in the canal bed at the National Park Service's (NPS) Georgetown Visitor Center. Westward to near Three Sisters Islands are igneous rocks of the Early to Middle Ordovician Georgetown Intrusive Suite, which are mostly biotite-hornblende tonalite (Ogh), with some gabbro (Ogg) and biotite tonalite (Ogb) (fig. 43). Outcrops show drill holes from the canal excavation; locally, the canal berm was excavated in bedrock.

The remains of the Alexandria Aqueduct, which carried boats across the Potomac River to Alexandria, Va., may be

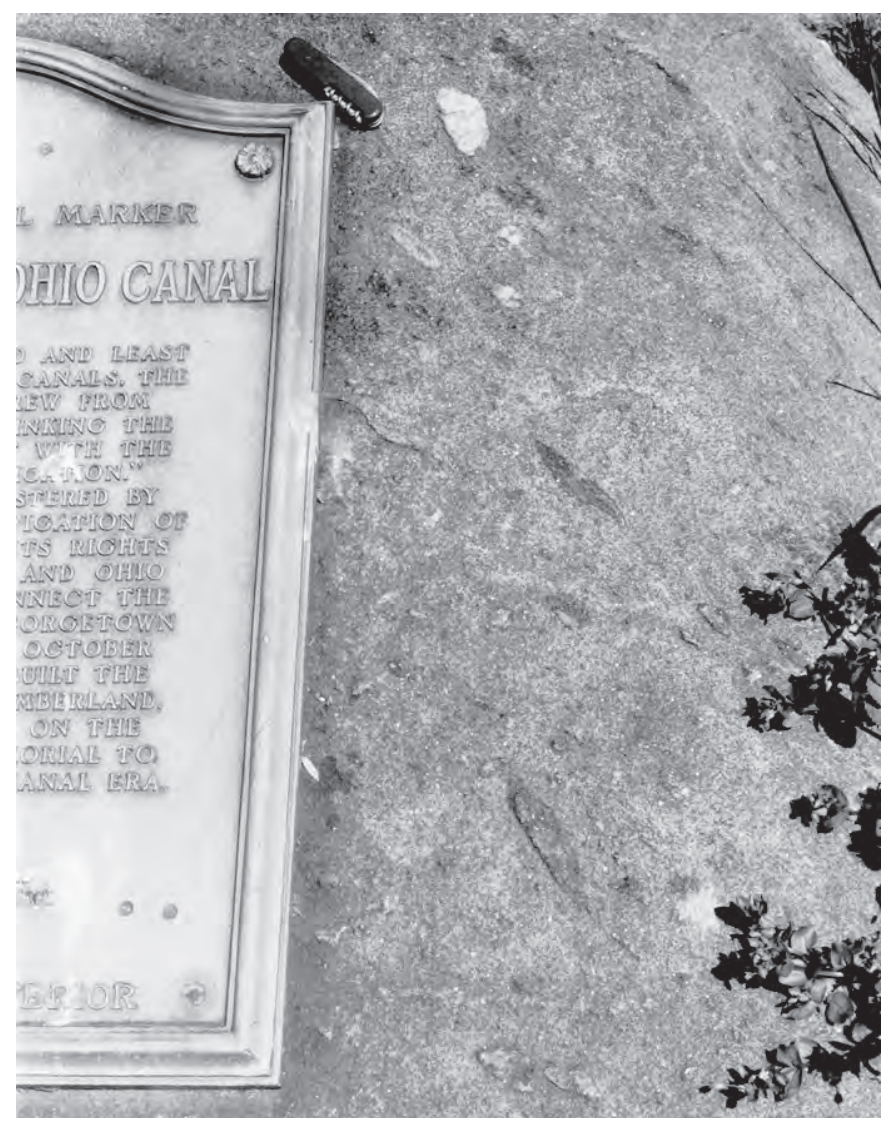

Figure 42. Part of a National Historical Marker where the C\&0 Canal enters Rock Creek. Dark and light olistoliths (rock fragments) occur in metagraywacke of the Lower Cambrian Sykesville Formation to which the marker is bolted. seen under Key Bridge. The lock stones consist of quartz fragments in a sandy matrix that are typical of the Sykesville Formation. Near MM 1.7, the canal is partially excavated into a bedrock terrace and the towpath is elevated; here the Capital Crescent Trail (a hike-and-bike trail) descends onto a younger lower terrace. Beginning about here are large bedrock terraces above and north of the canal that extend to near Widewater.

From MM 2 to MM 5, the canal traverses rocks of the Sykesville Formation, which contains rare blocks of gabbro and amphibolite. The canal bed along this stretch locally was excavated in bedrock, but many cobbles of quartz derived from the Cretaceous and Pleistocene upland and terrace deposits litter the canal bottom (fig. 44A). Some of these cobbles are crossbedded sandstone (fig. 44B) that probably was transported by the Potomac River from the Valley and Ridge province west of Harpers Ferry (MM 110).

Little Falls Dam at MM 5.8 is the first of the eight original dams that provided water to the canal. At about MM 6.5, good outcrops of light-colored monzogranite of the Early to Middle Ordovician Dalecarlia Intrusive Suite (Odm) may be seen along the canal.

\section{Glen Echo Park Area to Swains Lock (MM 7 to MM 16.6)}

From MM 7 to almost MM 10, the canal crosses rocks of the Lower Cambrian Sykesville Formation ( $€ s)$ that locally were intruded by rocks of the Early to Middle Ordovician Georgetown and Dalecarlia Intrusive Suites (plate 3). From MM 7.5 west to Interstate Route I-495, these rocks had to be drilled and blasted to create the canal. Between MM 9.5 and MM 10 is a major rock boundary within the Potomac terrane (see figure 41). Metasedimentary rocks of the older Neoproterozoic and (or) Lower Cambrian Mather Gorge Formation were transported westward over rocks of the younger Sykesville Formation along the Plummers Island thrust fault. From here west to Violettes Lock (except for an area near MM 11.5) are metagraywacke and schist of the Mather Gorge Formation (€Zmg) that originated as turbidite deposits in deep marine water. Phyllonite (€Zmp), which was produced by shearing along the faults, and migmatite $(€ Z \mathrm{~mm})$, which was produced by partially melting rock, also occur in this interval. Some of the best outcrops of the Mather Gorge Formation in this region are along this section of the Potomac River on Bear Island; to see them, take the Billy Goat Trail that begins near the east end of Widewater. Relatively undeformed rocks of the Sykesville Formation (fig. 45) become very sheared near the Plummers Island thrust fault (fig. 46). On bedrock islands in the Potomac River, the rocks are so sheared that the two formations cannot be readily distinguished. From about MM 9 to MM 11, the canal was excavated into the margin of a broad bedrock terrace above the Potomac River (at Carderock) and its berm is lined with rock.

Building stone from the Sykesville Formation was quarried at the Potomac Granite Mill in the early 1900s near MM 11.7; the abandoned pits are immediately north of the canal. This 

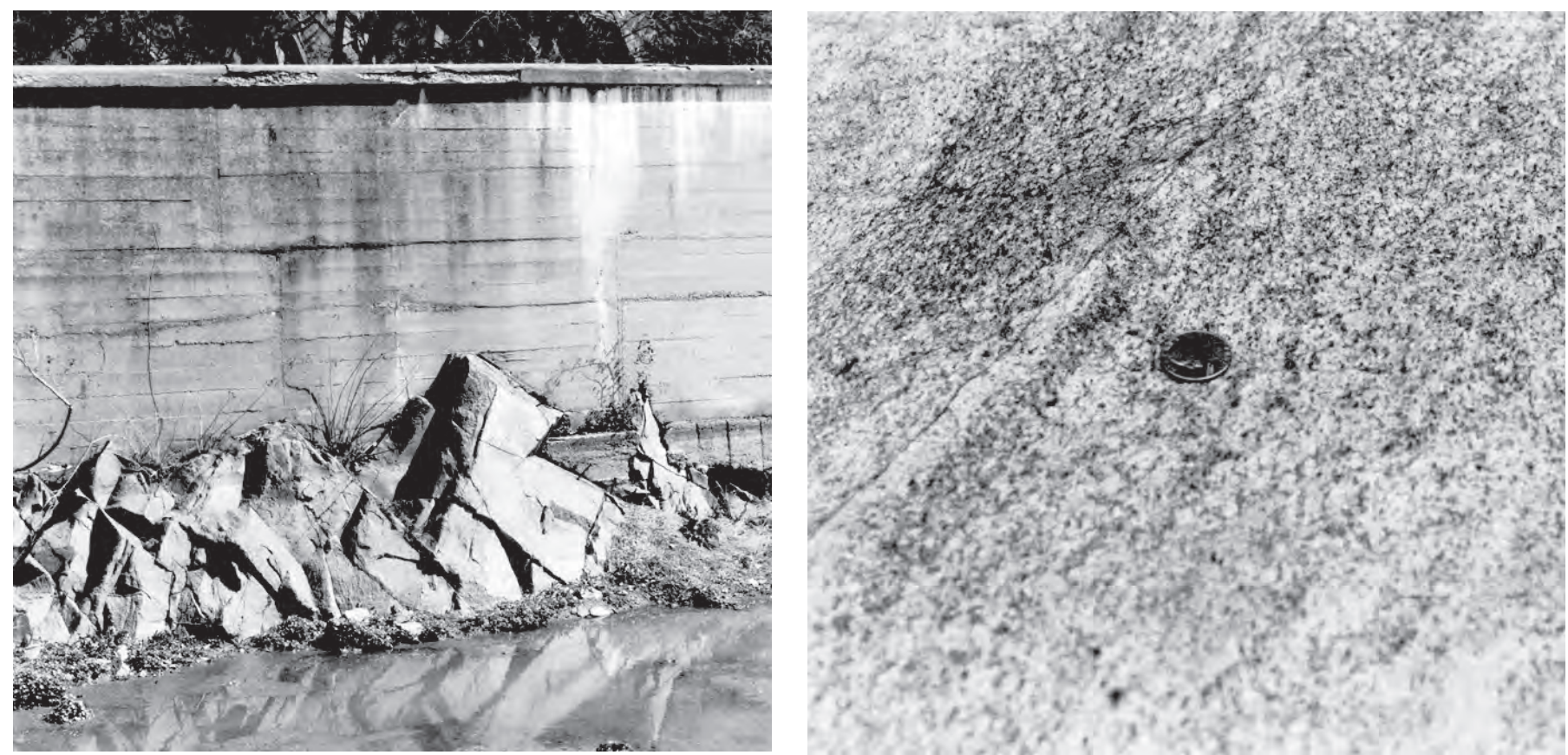

$\boldsymbol{A}$

$\boldsymbol{B}$
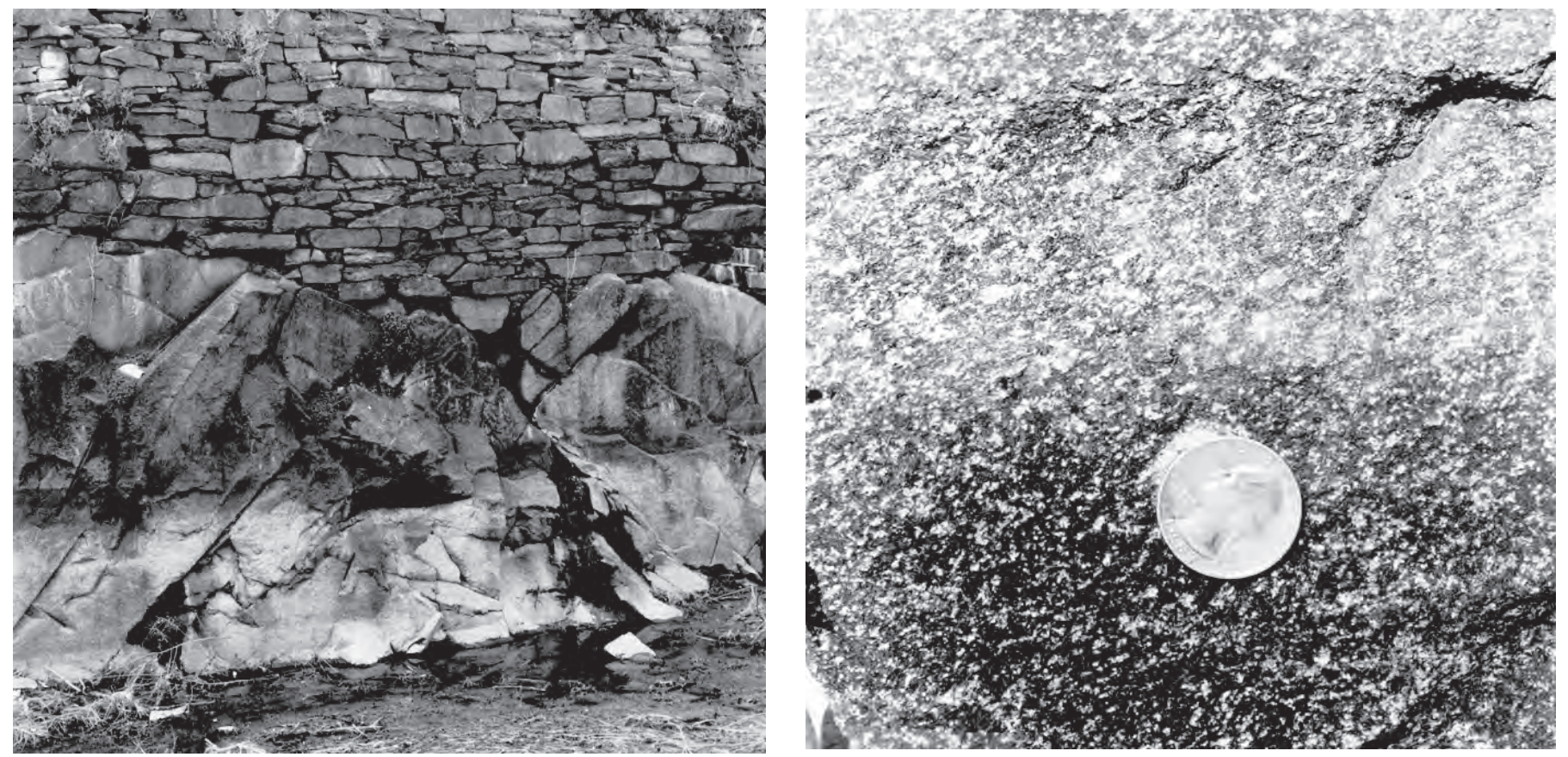

C

D

Figure 43. Igneous rocks of the Early to Middle Ordovician Georgetown Intrusive Suite near Key Bridge in Washington, D.C. The canal was excavated through these rocks, which include leucocratic and melanocratic varieties. $A$, Leucocratic (light-colored) granitoid. $B$, Closeup of $A$ showing quartz and plagioclase crystals. Quarter for scale. $C$, Melanocratic (dark-colored) gabbro. $D$, Closeup of $C$ showing the crystalline texture of amphibole and plagioclase crystals. Quarter for scale. 


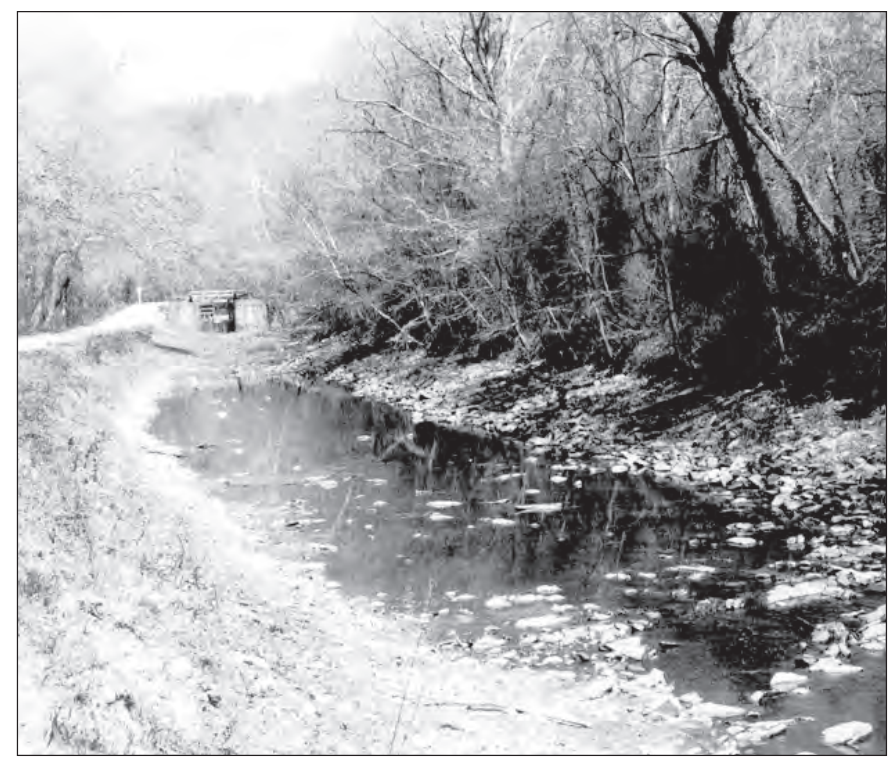

$\boldsymbol{A}$

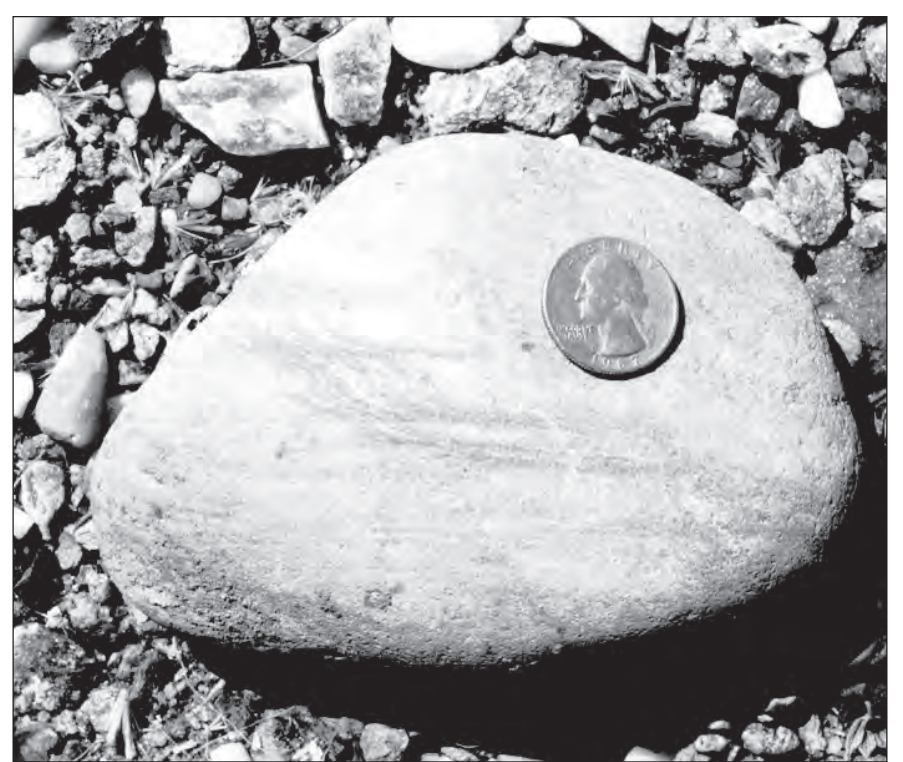

B

Figure 44. Sandstone cobbles along canal. $A$, View of alluvial sandstone cobbles that litter the canal; cobbles were derived from terrace deposits near MM 5.5. $B$, Example of a cobble with crossbedded laminations. Cobbles probably were derived originally from early Paleozoic sandstone found west of Harpers Ferry, W. Va.; were carried by the Potomac River to this site; were next deposited as part of the terrace deposits; and, finally, were deposited in the canal by erosion of the terrace. Quarter for scale.

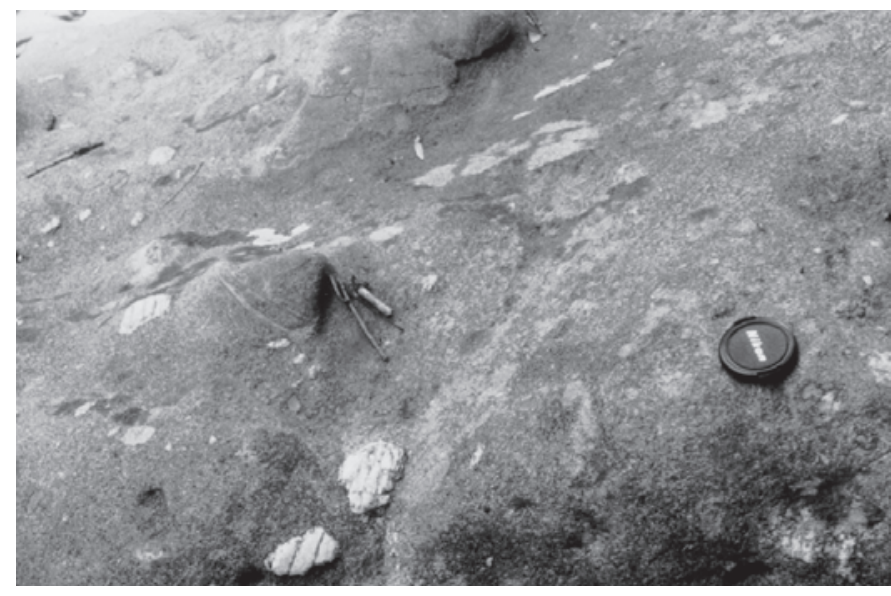

Figure 45. Undeformed sedimentary mélange of the Lower Cambrian Sykesville Formation at MM 9.8 contains olistoliths (clasts) of older rocks derived from the Neoproterozoic and (or) Lower Cambrian Mather Gorge Formation. Lens cap for scale.

rock, which is a sedimentary mélange with large rock clasts, was long thought by geologists to be a granite that contained abundant xenoliths. The rocks of the Sykesville Formation, last seen just west of Interstate Route I-495, are exposed here again. The structurally overlying rocks of the Mather Gorge Formation have been eroded to expose the rocks beneath the Plummers Island thrust fault in a tectonic window (Drake and Froelich, 1997). As with the Plummers Island thrust fault near MM 9.5, the fault that frames the tectonic window here is a penetrative shear zone in the rocks on either side of the fault.

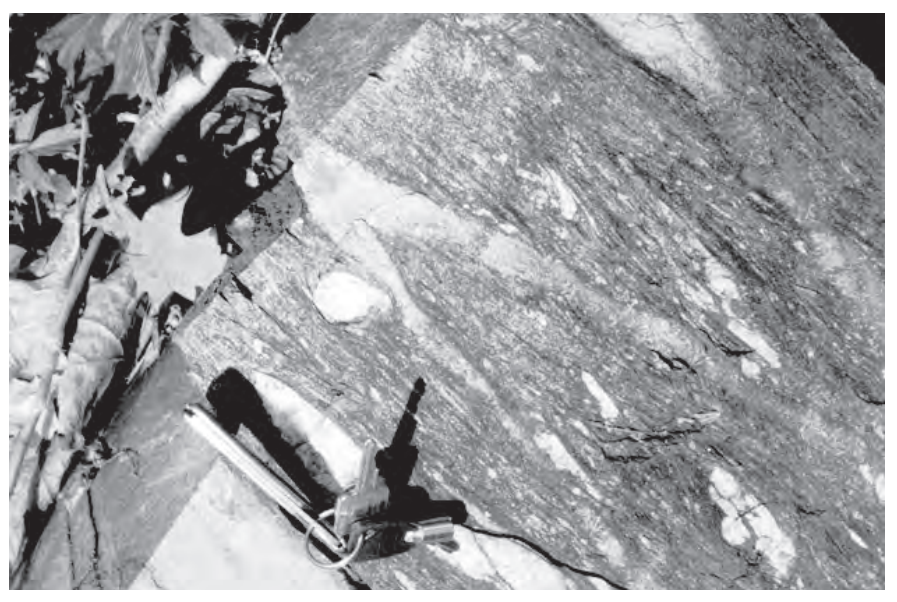

Figure 46. Sheared mélange of the Lower Cambrian Sykesville Formation near MM 11.5. Note elongated fragments of quartzite and quartz in a matrix of quartz and feldspar above a bed of white quartzite. Knife and keys for scale.

To the west of the parking area opposite Old Anglers Inn is Widewater (MM 13), which is a section of the canal that uses an abandoned channel of the Potomac River (figs. 12 and 47). The towpath locally had to be constructed above the channel (see figure 39), but elsewhere it was excavated in the bedrock terrace. Bedrock is well exposed in this region (Reed and others, 1980). Folded vein quartz and phyllonite of the Mather Gorge Formation ( $€ Z m p)$ show that deformation predates the intrusion of the Ordovician(?) Bear Island Granodiorite (Ob) (fig. 48). Upright antiforms consisting of isoclinal folds in meta- 

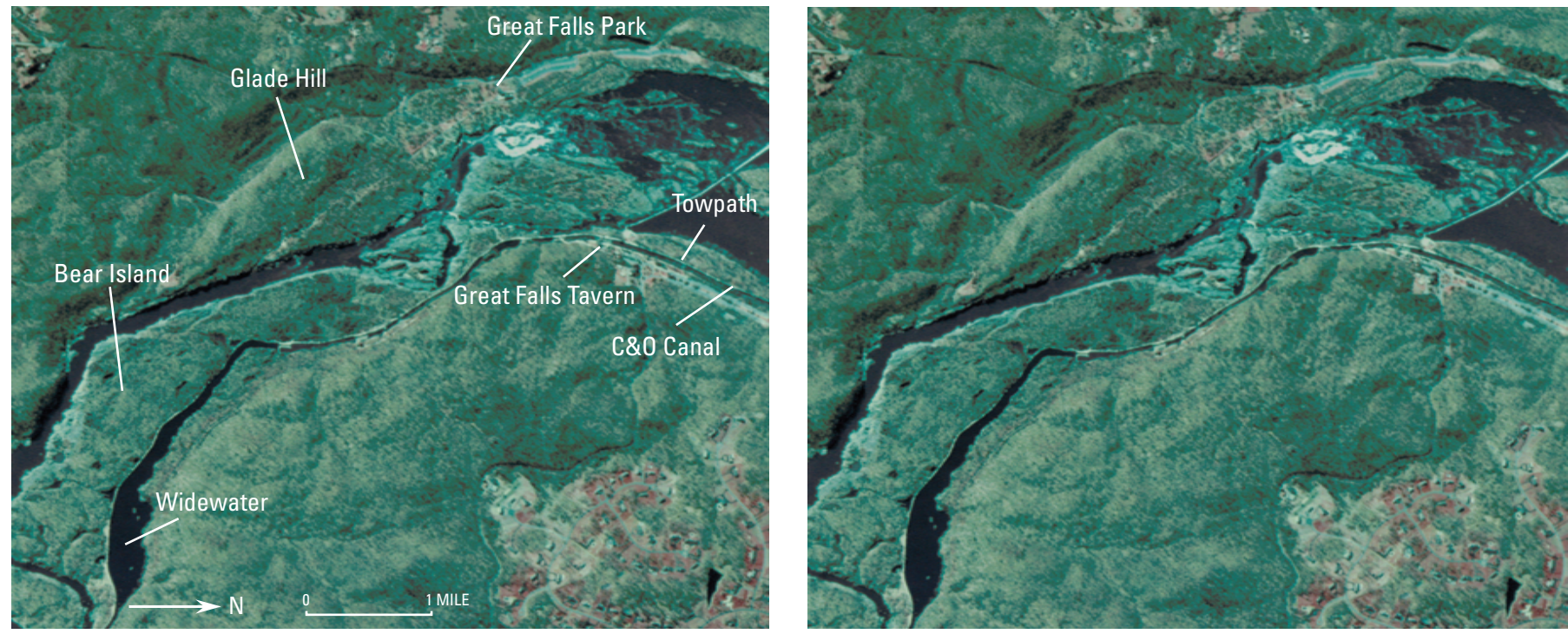

$\boldsymbol{A}$

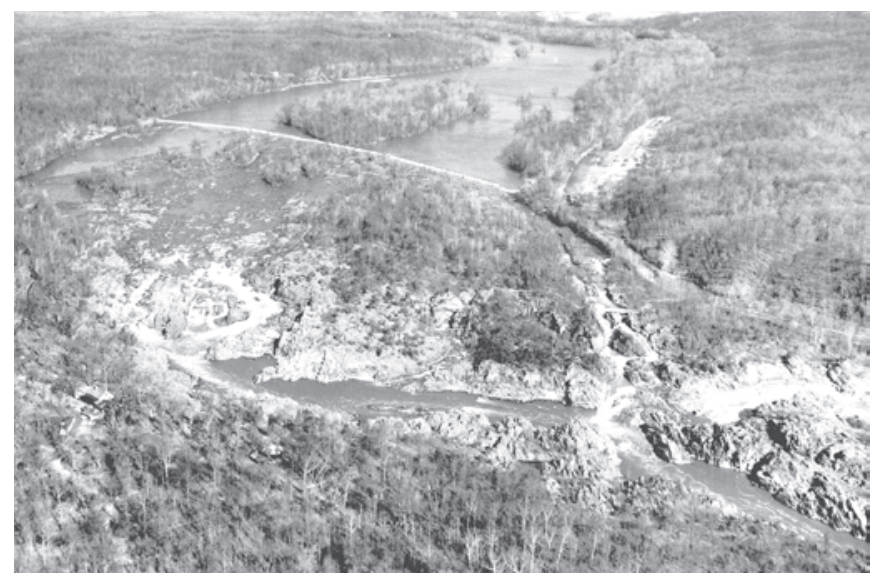

B

Figure 47. The Great Falls of the Potomac River. $A$, Stereoscopic pair of aerial photographs with some features labeled. $B$, Oblique aerial photograph (looking north). Photograph by Abbie Rowe (1959), courtesy of the National Park Service.
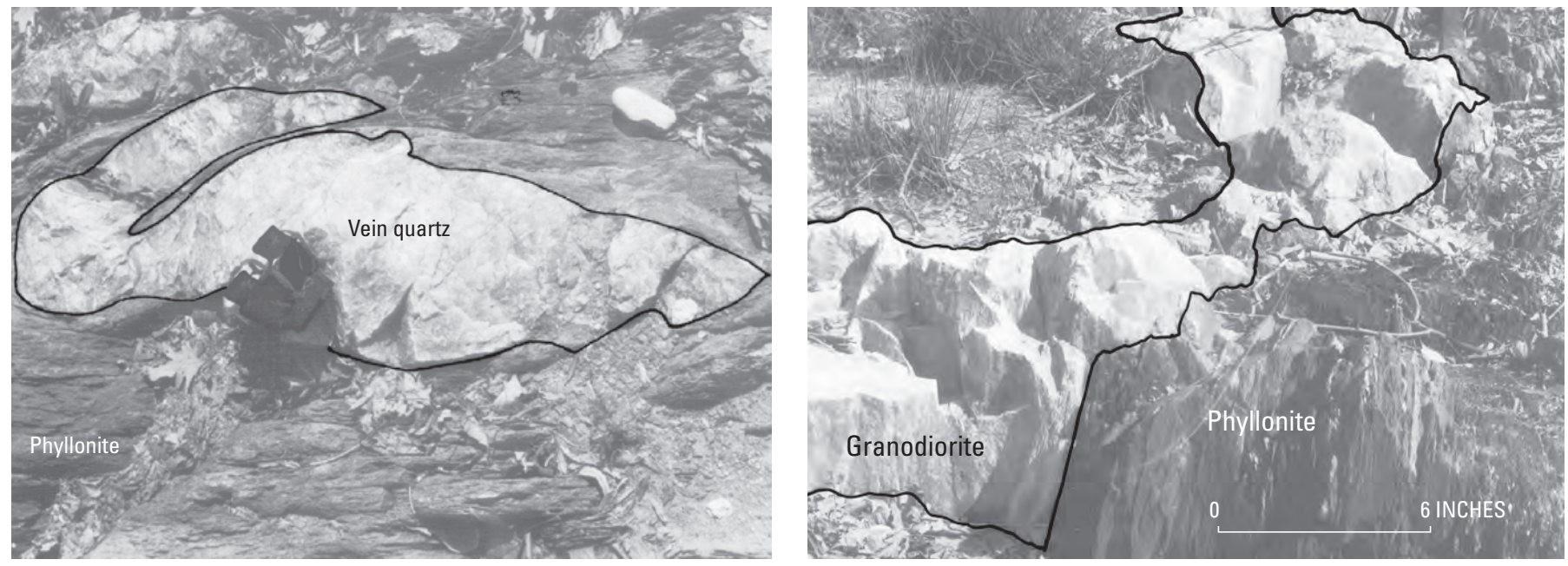

A

B

Figure 48. Phyllonite of the Neoproterozoic and (or) Lower Cambrian Mather Gorge Formation near MM 12.5. A, Phyllonite and folded vein quartz (white body outlined by black line). Binoculars for scale. B, Intrusion of undeformed Ordovician(?) Bear Island Granodiorite (Ob) (white body outlined by black line) into phyllonite . 
graywacke are seen opposite the concrete structure at the overflow of Widewater. Dismembered folds of migmatitic metagraywacke of the Mather Gorge Formation ( $€ Z m g)$ are exposed on both sides of Widewater (fig. 49). Bodies of dark amphibolite (€Za) and light-colored Bear Island Granodiorite and pegmatite contrast with the gray migmatite (€Zmm) (fig. 50). The amphibolite is dark due to hornblende crystals (fig. 51).

Vein quartz intruded the migmatite near Lock 15 (fig. 52). Between the canal and MacArthur Boulevard to the north, gold was discovered in similar vein quartz in 1861 and was mined sporadically until 1951 (fig. 53). Trenches and pits from this gold mining activity remain today (Reed and Reed, 1970).

Near MM 13.8 is "Mary's Wall" (fig. 33A) where a rock berm was required to keep water in the canal and floodwater of the Potomac River out of the canal. An elevated bedrock terrace formed across the islands and the opposite shore; the alluvial boulders deposited at the crest of a feature locally known as Glade Hill (figs. 13 and 14) in Great Falls Park, Va., are evidence of this terrace. On Bear Island and along Mather Gorge are some of the largest potholes formed by the ancient Potomac River (see figures 8 and 9). Rare Devonian lamprophyre dikes (DI) composed of fine-grained biotite, quartz, and plagioclase are exposed in the bluff of Mather Gorge (fig. 54). The dikes intruded schist of the Mather Gorge Formation (€Zms) along a prominent set of fractures that have remained open for $360 \mathrm{~m}$.y. in spite of intervening tectonic activity.

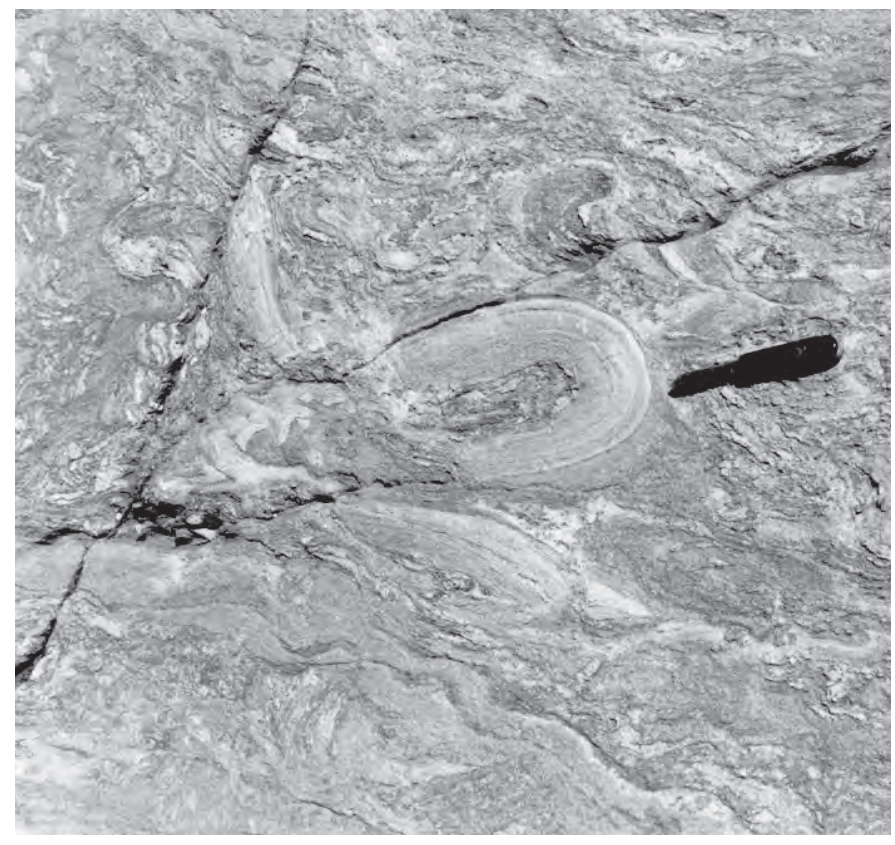

The complex deformation that occurred before the Ordovician Taconian orogeny may be seen in many outcrops on Bear Island. The outcrops exhibit isoclinal folds of metagraywacke and schist that were refolded as upright antiforms and then intruded by Ordovician pegmatite and granodiorite (Drake, 1989) (fig. 55). From the approach to Great Falls Tavern and westward to MM 16, the canal was excavated in alluvium deposited on a bedrock terrace.

\section{Swains Lock to Seneca (MM 16.6 to MM 22.8)}

From Swains Lock to Violettes Lock (plate 4), bluffs consisting of metagraywacke and schist of the Neoproterozoic and (or) Lower Cambrian Mather Gorge Formation (€Zmg) were drilled and blasted to construct the canal. The best areas in which to see this feat of labor are near MM 19 and at Blockhouse Point (MM 21), where bedded metagraywacke shows near-vertical drill holes (see figure 25B). The rocks along this section of the canal are complexly folded at all scales. Isoclinal folds of metagraywacke and schist are seen on the bluffs (fig. 56). Near Lock 23, the Upper Triassic rocks of the Culpeper basin unconformably overlie schist and metagraywacke of the Mather Gorge Formation. This contact represents an interval of more than 320 m.y. of geologic time.

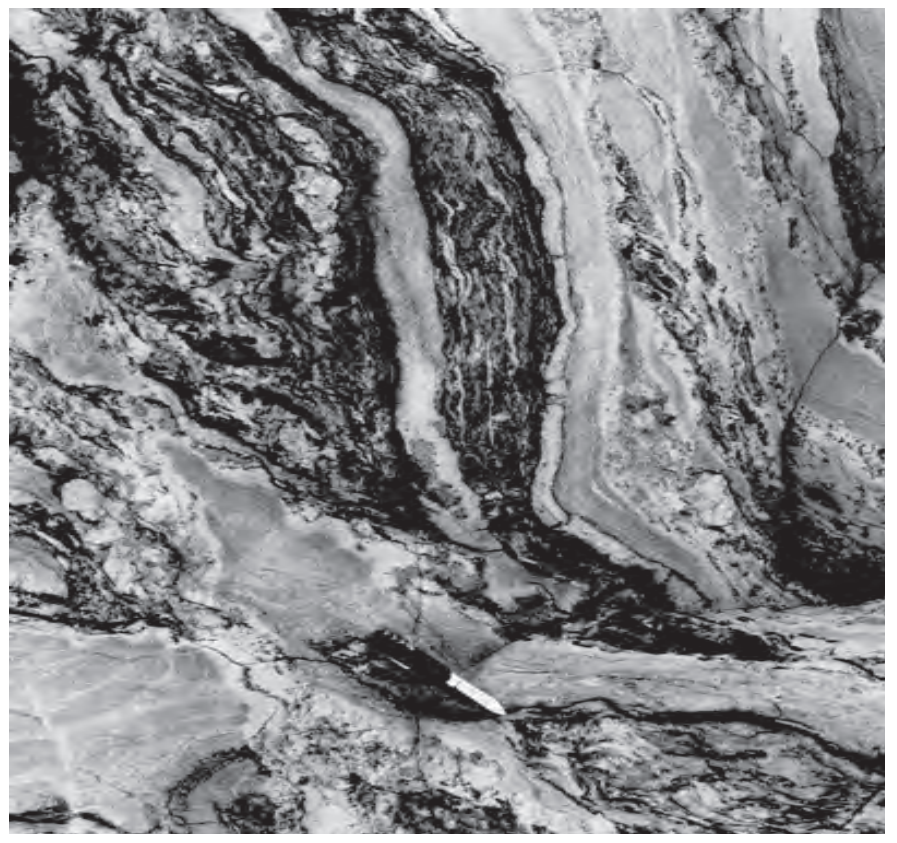

B

Figure 49. Migmatite of the Neoproterozoic and (or) Lower Cambrian Mather Gorge Formation. $A$, Rootless, ductile folds. $B$, Thin layers of metagraywacke. Pocket knives for scale. 


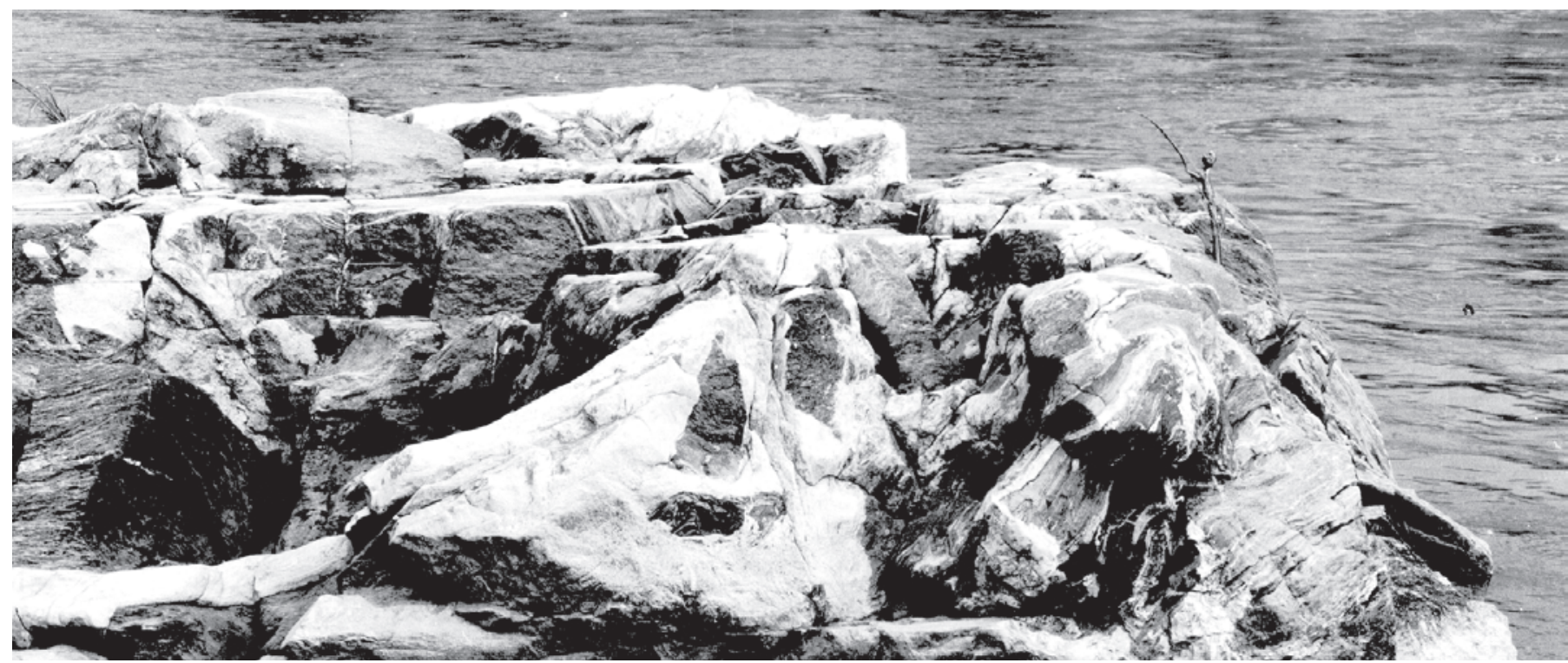

\section{A}

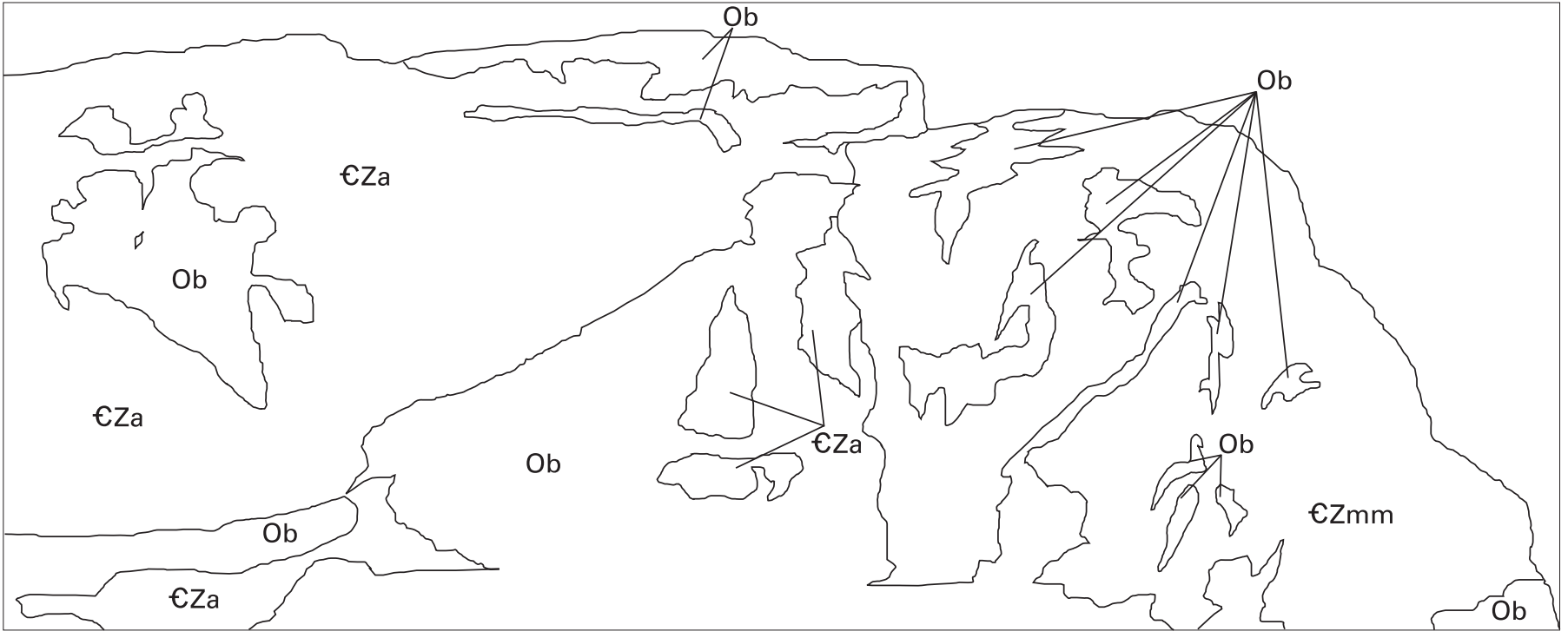

$\boldsymbol{B}$

Figure 50. Migmatite of the Neoproterozoic and (or) Lower Cambrian Mather Gorge Formation. A, Outcrop containing blocks of darkcolored amphibolite intruded by light-colored Ordovician(?) Bear Island Granodiorite on an island in Mather Gorge along the Potomac River south of MM 13. Photograph by David B. Usher (U.S. Geological Survey). B, Sketch of $A$ with rock units labeled as follows: $€ Z m m$, migmatite of the Mather Gorge Formation; $€ Z$ a, amphibolite blocks within Mather Gorge Formation; Ob, Bear Island Granodiorite. 


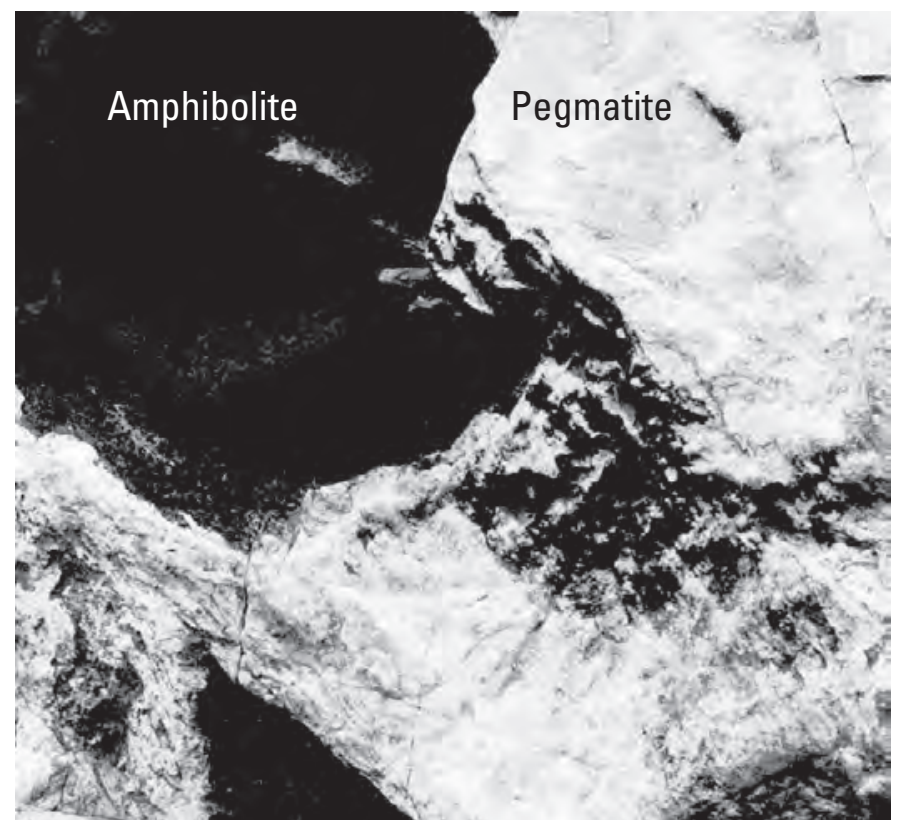

A

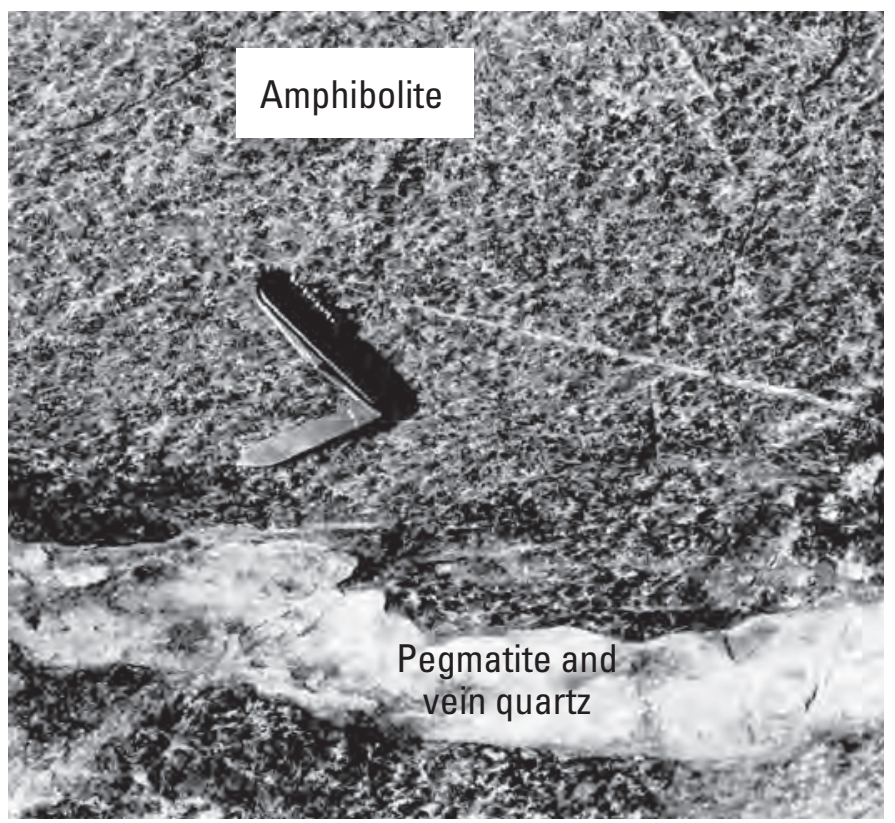

B

Figure 51. Dark amphibolite within the Neoproterozoic and (or) Lower Cambrian Mather Gorge Formation intruded by white pegmatite of the Ordovician(?) Bear Island Granodiorite. A, Outcrop north of MM 13. B, Same outcrop as $A$ shows amphibolite, which consists of crystals of hornblende (dark) and plagioclase feldspar (light); the light-colored veins of pegmatite from the Bear Island Granodiorite and quartz intrude the amphibolite. Pocket knife for scale.

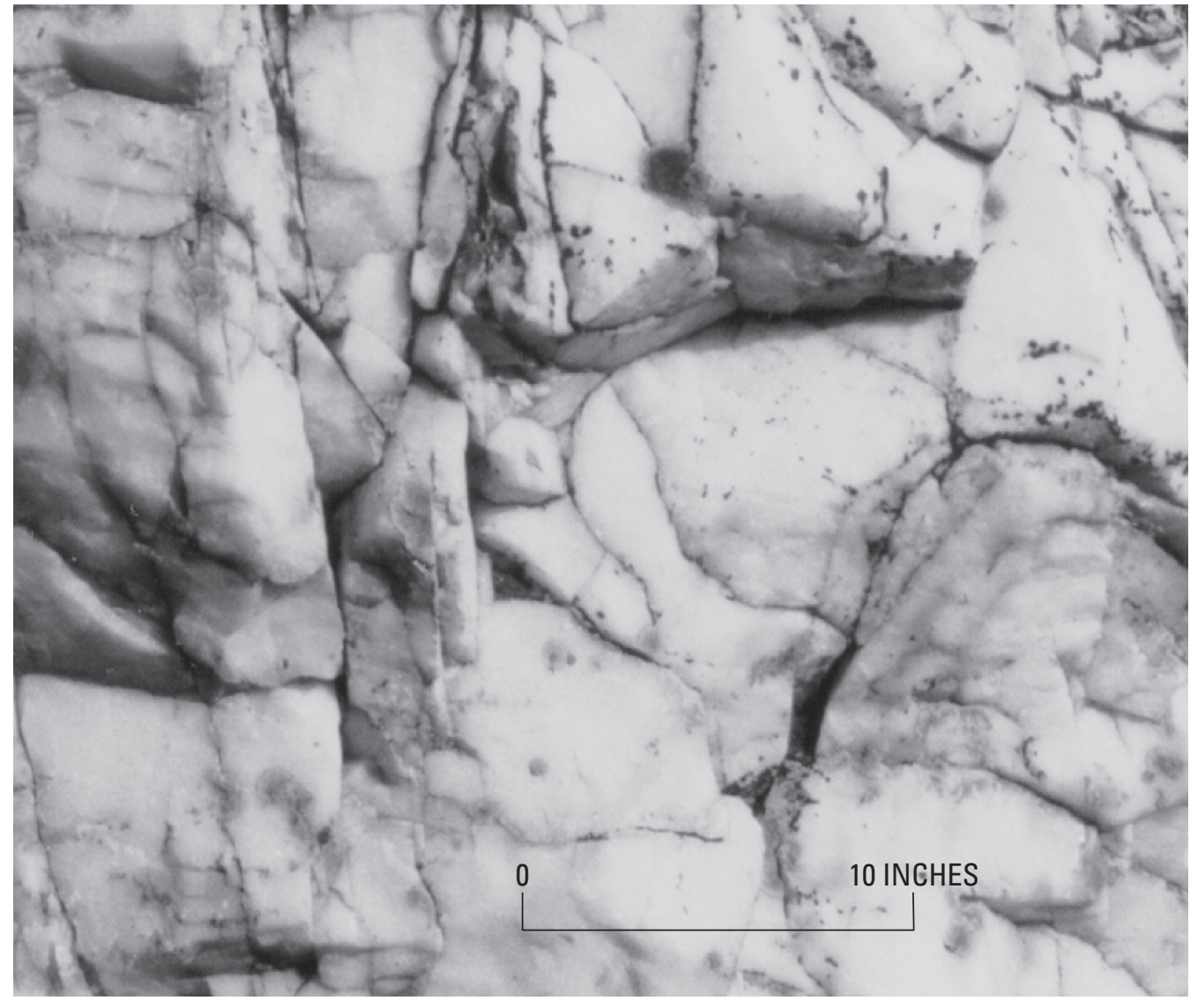

Figure 52. Milky white, fractured vein quartz intruding metagraywacke of the Neoproterozoic and (or) Lower Cambrian Mather Gorge Formation near Widewater near MM 13.5. Similar quartz contained gold veins and was mined to the immediate north. 


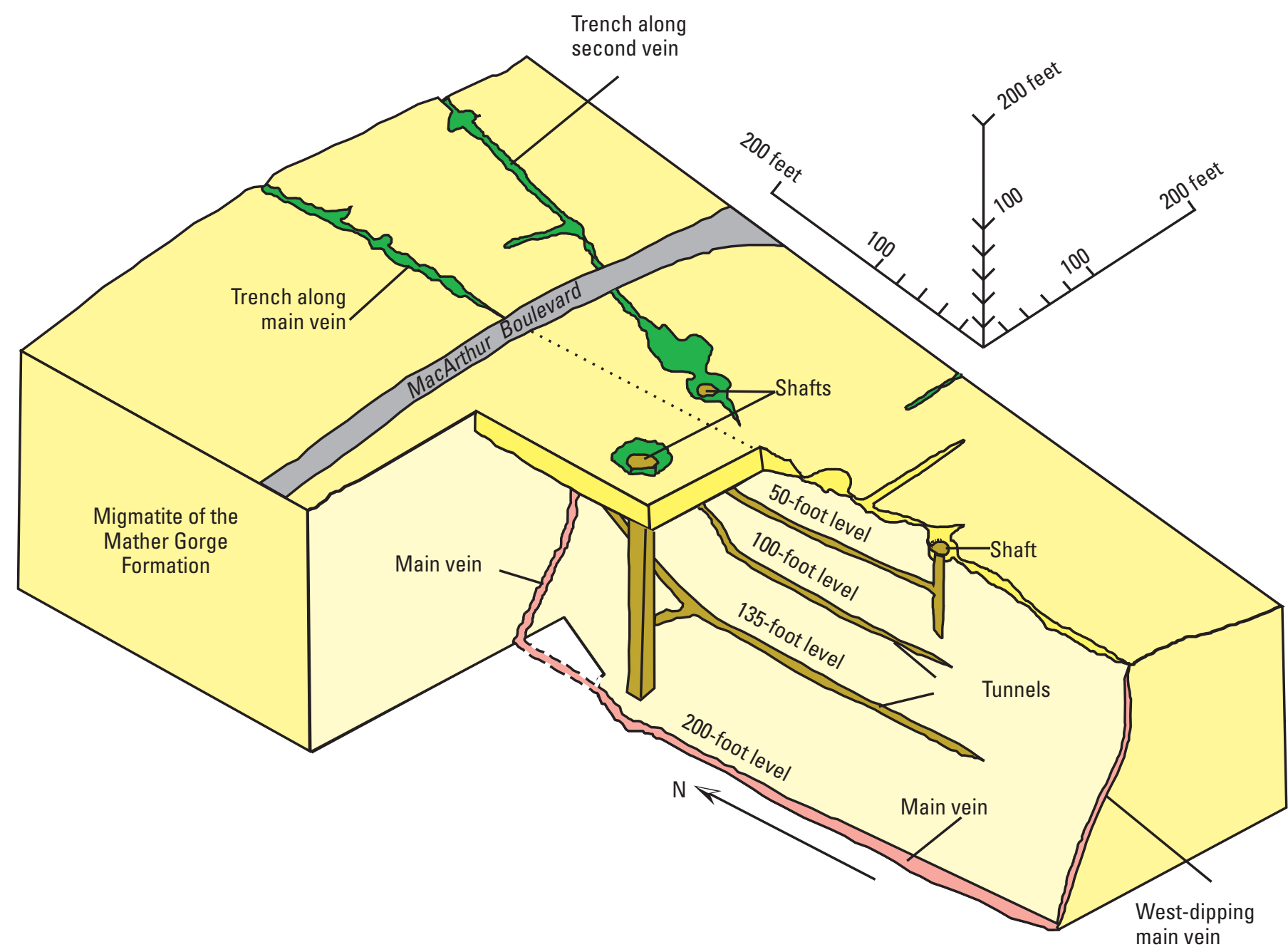

$\boldsymbol{A}$

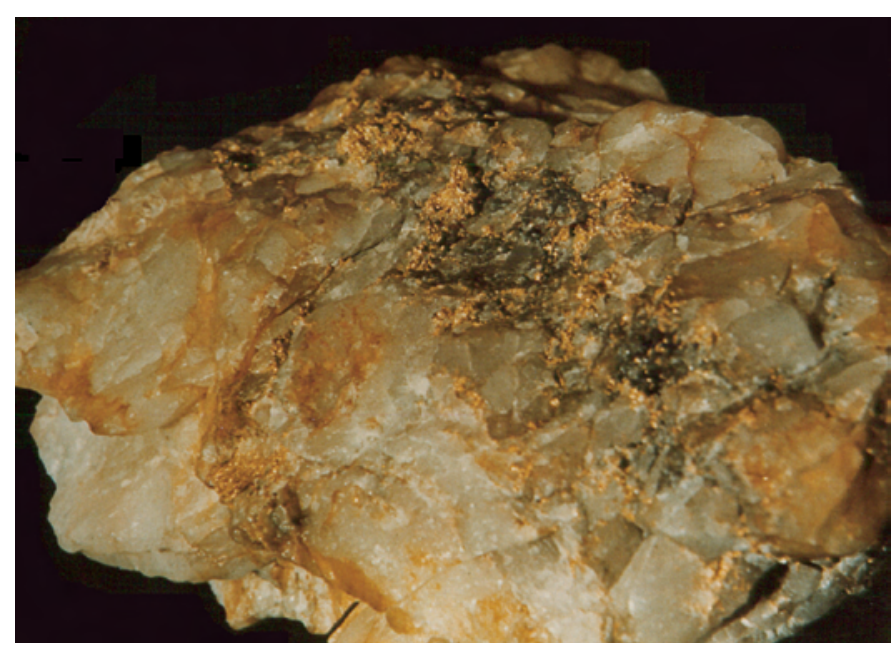

B
Figure 53. Underground gold mine north of Great Falls Tavern. $A$, Block diagram based on illustration from Reed and Reed (1970). $B$, Gold in a vein of quartz that measured $3 \mathrm{~cm}$ across. Photograph courtesy of National Park Service. 


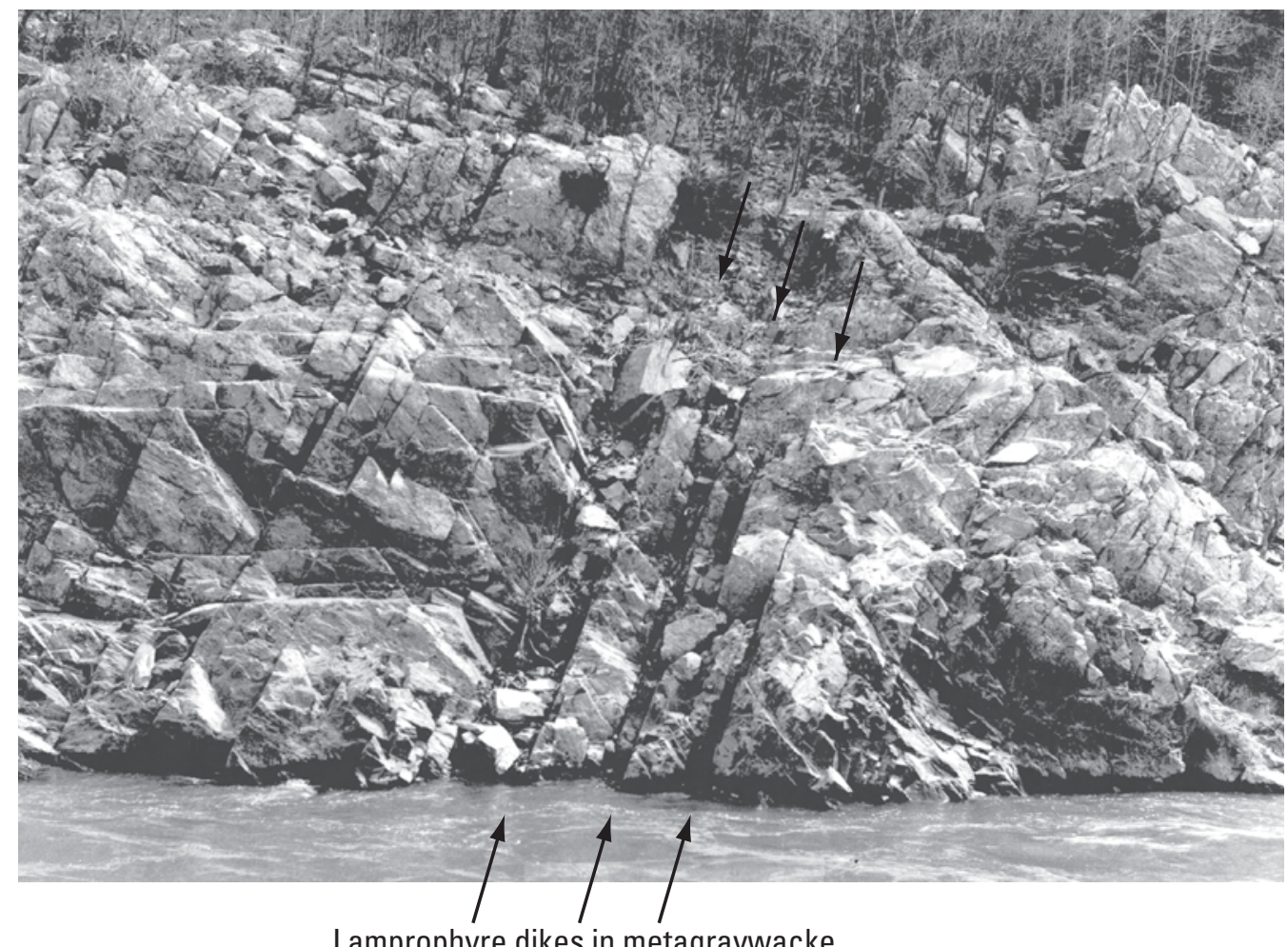

Lamprophyre dikes in metagraywacke
Figure 54. Late Devonian lamprophyre dikes intruding metagraywacke of the Neoproterozoic and (or) Lower Cambrian Mather Gorge Formation along a prominent fracture system (parallel to arrows) on Bear Island south of Lock 16 at MM 13.8 (Reed and others, 1980). Photograph by David F. Usher (U.S. Geological Survey).

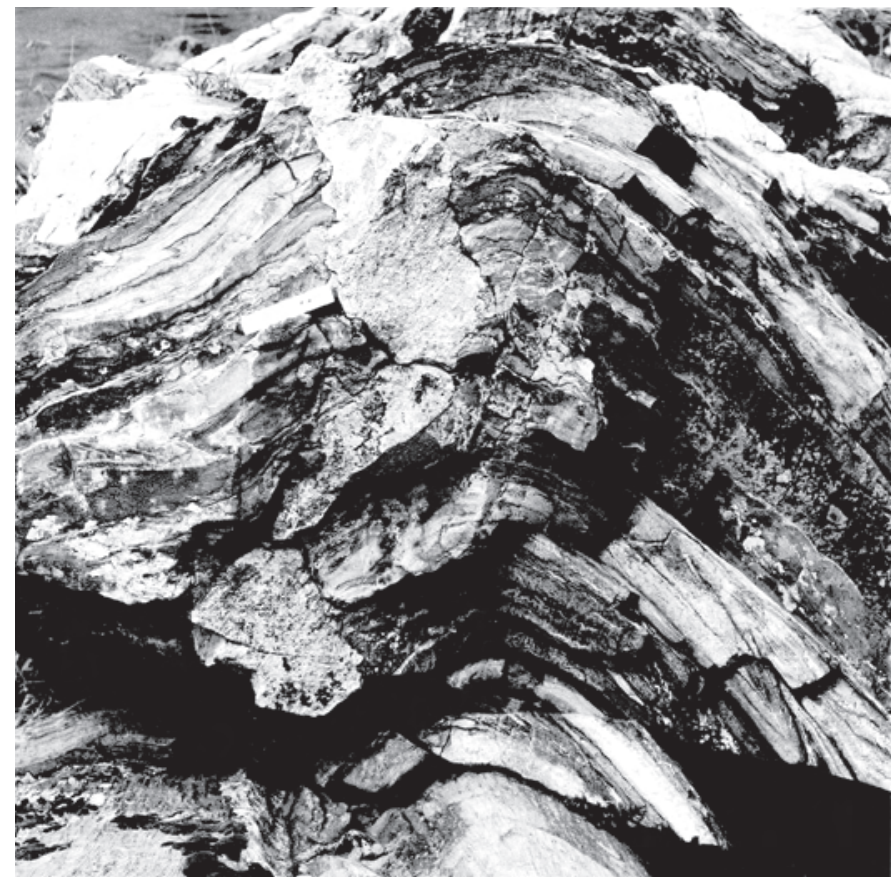

\section{A}

Figure 55. Folding in metagraywacke and schist of the Neoproterozoic and (or) Lower Cambrian Mather Gorge Formation (south of MM 12.5 in Virginia). A, Outcrop revealing the following events: recumbent folding $\left(F_{1}\right)$, upright folding $\left(F_{2}\right)$, and then intrusion by 0 rdovician(?) Bear Island Granodiorite (Ob) which also includes pegmatite (Reed and others, 1980; Drake, 1989). Ruler for scale, left of center. Photograph by David F. Usher (U.S. Geological Survey). B, Sketch of $A$ with features labeled as follows: Ob, Bear Island Granodiorite; $\mathrm{F}_{1}$, first-generation recumbent fold; $F_{2}$, second-generation upright fold.

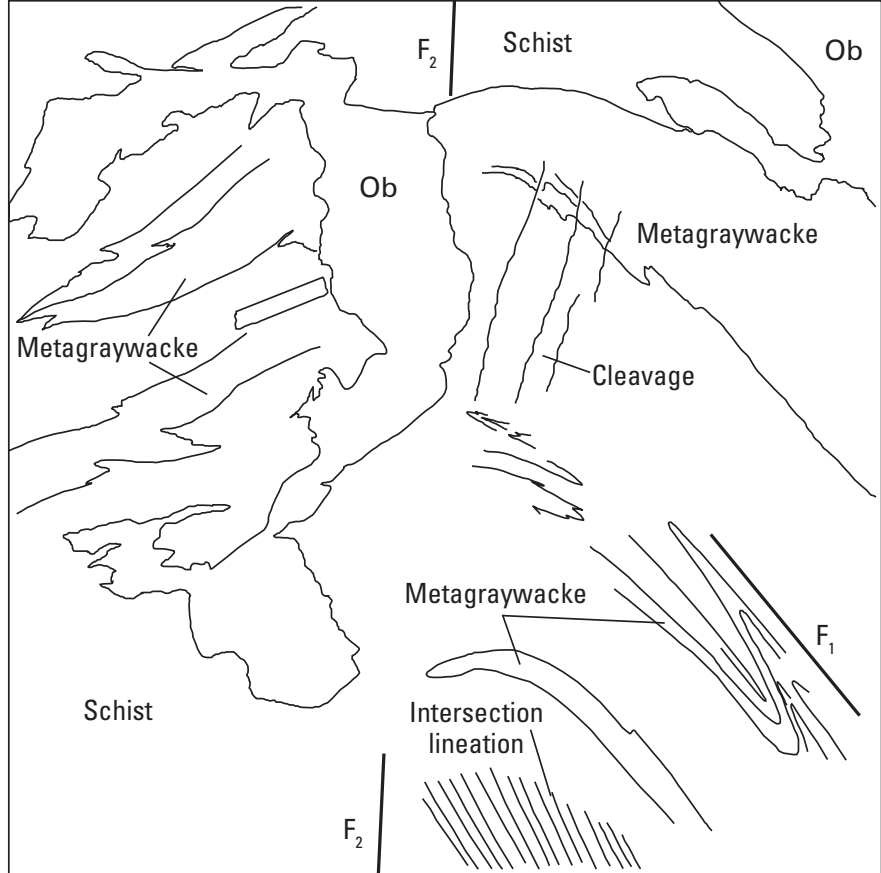

B 


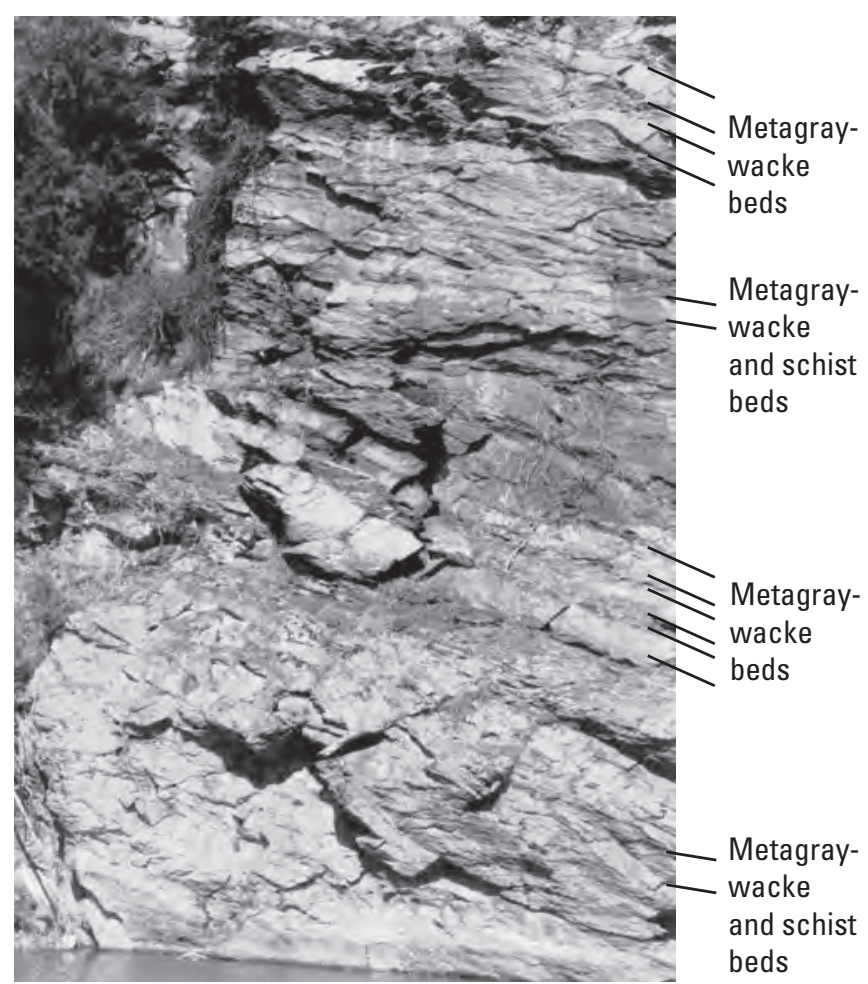

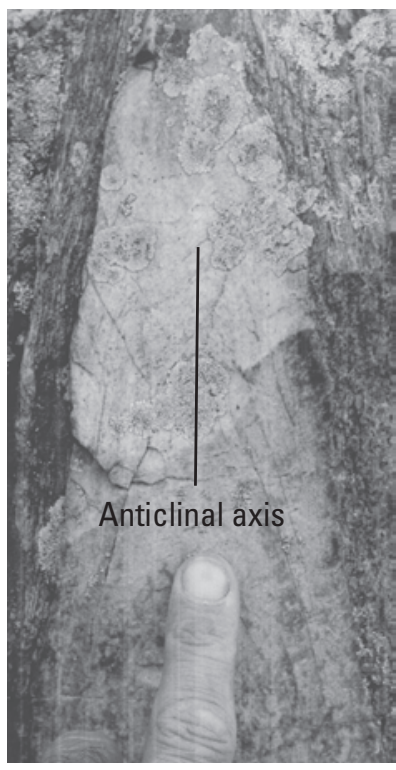

B

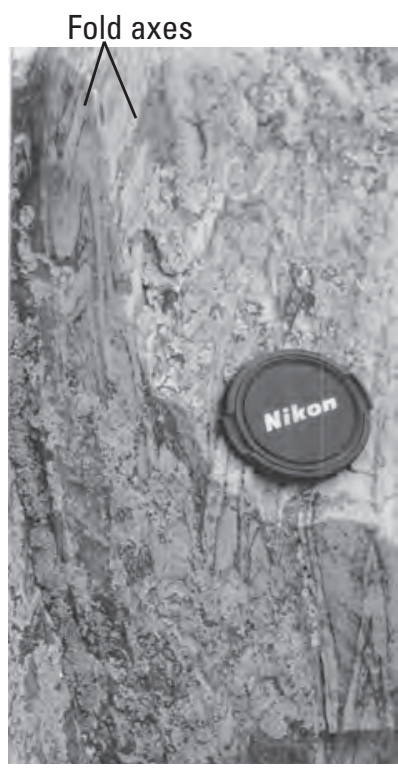

C

\section{$\boldsymbol{A}$}

Figure 56. Folded metagraywacke of the Neoproterozoic and (or) Lower Cambrian Mather Gorge Formation, which is common from Great Falls Tavern to Blockhouse Point. A, Bluffs at MM 19. B, Isoclinal folds of quartzite at Blockhouse Point (MM 21). C, Same location as $B$, showing isoclinal upright folds. Lens cap for scale.

\section{Piedmont Province-Culpeper Basin, Westminster Terrane, and Frederick Valley}

\section{Seneca, Md., to Point of Rocks, Md. (MM 22.8 to MM 48.2)}

\section{Access Points}

Seneca, Md.

McKee-Besher Wildlife Management Area, Md.

Edwards Ferry, Md.

Whites Ferry, Md.

Dickerson Regional Park, Md.

Monocacy River Aqueduct, Md.

Nolands Ferry, Md.

Point of Rocks, Md.

\section{Introduction}

From MM 22.8 to MM 48.2, the area of the C\&O Canal National Historical Park encompasses three sections of the Piedmont province - the Culpeper basin, the Westminster terrane, and the Frederick Valley. The towpath actually traverses only the Culpeper basin and Frederick Valley, but other parts of the park are located in the Westminster terrane. A discussion of all three sections, from east to west, follows.

Culpeper basin.-At the end of the late Paleozoic, a continental collision (the Alleghanian orogeny) formed the Appalachian Mountains. Some 10 m.y. later during the Mesozoic, extensional tectonics created rift basins on the continent, which eventually caused the Atlantic Ocean to open. These rift basins extended along the eastern edge of the Appalachian orogen from Florida to Newfoundland, Canada. One of these basins, the Culpeper basin, extends from central Virginia near Culpeper, to Frederick, Md. The Culpeper basin once was continuous with the Gettysburg basin to the north of Frederick, but the connecting rocks have since been eroded. 
The Culpeper basin is a half graben filled with strata that dip westward into a border fault at the base of Catoctin Mountain. Faulting occurred during and after sediment deposition in the basin. Much later, the Potomac River followed a southeasterly course from Nolands Ferry (MM 44.5) to the mouth of the Monocacy River (MM 42.2) along such a fault.

The Upper Triassic rocks in this part of the Culpeper basin (fig. 41 and plates 4 through 7) consist of a basal conglomerate overlain by and interbedded with sandstone and siltstone that were deposited by rivers and lakes. There are two basal conglomerate units. The western part of the basin contains a variegated limestone conglomerate of the Tuscarora Creek Member of the Manassas Sandstone ( $\mathrm{kcmt}$ ). The limestone clasts within the conglomerate locally were derived from the Upper Cambrian Frederick Formation and the Upper Cambrian and Lower Ordovician Grove Formation. The basal conglomerate along the north and east margin of the basin is the Reston Member of the Manassas Sandstone ( $\mathrm{kcmr}$ ). This conglomerate is composed of locally derived quartz and schist of the Potomac and Westminster terranes. Overlying the Reston Member basal conglomerate is red sandstone of the Poolesville Member of the Manassas Sandstone ( $\mathrm{cmp}$ ) (informally known as the "Seneca Red Sandstone"). This unit was quarried at Seneca and was one of the most widely used building stones along the C\&O Canal; it also was used to build the original Smithsonian Institution building, popularly known as "the castle" in Washington, D.C. The grain size of the sandstone becomes finer upward in the section to become the Balls Bluff Member of the Bull Run Formation (Kcbb) (Weems and Olsen, 1997). Interbedded with the Balls Bluff Member from near Whites Ferry, Md., to east of Furnace Mountain in Loudoun County, Va., is a variegated limestone conglomerate, the Leesburg Member of the Bull Run Formation ( $\mathrm{kcbl}$ ), which is similar to the Tuscarora Creek Member of the Manassas Sandstone. Historical maps show quarries in the Leesburg Member near Whites Ferry (Frye and Jefferson, 1775) and east of Point of Rocks, Md. (Keith, 1894; Scheel, 1995). These conglomeratic rocks are interpreted to be ancient debris-flow deposits on a large alluvial fan that extended eastward from a highland near presentday Catoctin Mountain (Smoot, 1989). Therefore, the limestone conglomerate of the Tuscarora Creek Member and the Leesburg Member may be continuous in the subsurface. A significant amount of Cambrian limestone must have been exposed on and west of Catoctin Mountain in order to supply the abundant limestone clasts for these units (Lindholm and others, 1979).

Near-vertical planar dikes and thick subhorizontal sills of Early Jurassic diabase (Jd) intrude these Late Triassic sedimentary rocks. Outcrops are scarce and the dike rocks commonly occur only as a float of brown and gray cobbles and boulders. Locally, the sedimentary rocks are altered by contact metamorphism that occurred when the molten diabase was intruded.

Within the Culpeper basin are some of the most extensive alluvial-terrace deposits of the Potomac River. About 2 mi east of MM 37 and about 1 mi west of MM 41 in Loudoun County, Va., these deposits lie at 288 and $240 \mathrm{ft}$, respectively, above the Potomac River. Auger holes near Martinsburg, W. Va., reveal deposits that are more than $40 \mathrm{ft}$ thick; relief on the terrace in Loudoun County suggests a thickness of over $100 \mathrm{ft}$ (Southworth, 1998).

The eastern margin of the Culpeper basin coincides with the location of Dam 2 (MM 22.1), which was built where the shallow, broad bed of the Potomac River crosses the resistant metasedimentary rocks of the Mather Gorge Formation at Seneca Falls (plate 4). The remains of a rubble dam, which was constructed by placing local boulders on the bedrock ledges in the riverbed, may be seen at Dam 2. On the Virginia shore at Dam 2, a skirting canal that was variably called the "Seneca Bypass," "Seneca cut," "Seneca break," or "Washington cut," was used by George Washington's Patowmack Company before construction of the C\&O Canal (Garrett and Garrett, 1987).

Westminster ter rane.-Phyllite, metalimestone, and metabasalt of unknown age occur north of the confluence of the Potomac and Monocacy Rivers (plate 7). These rocks are assigned, respectively, to the Neoproterozoic(?) and Lower Cambrian(?) Ijamsville Phyllite (€Zi), Silver Run Limestone, and Sams Creek Formation, and they were transported here along the Martic thrust fault. These rocks are interpreted to be deepwater deposits of the Iapetus Ocean that were thrust westward onto metasiltstone of the Lower and Middle Cambrian Araby Formation ( $€$ ar) of the Frederick Valley. The Araby Formation and overlying Upper Cambrian Frederick Formation were deposited on the continental shelf and subsequently were folded into the Frederick Valley synclinorium (Southworth, 1996, 1998). The highly folded phyllite (fig. 57) and metalimestone (fig. 58) of the Ijamsville Phyllite are best exposed along the bluff of the Monocacy River immediately north of the canal near MM 42.5, but there are rare outcrops within the flood plain at Indian Flats. These rocks are truncated to the east along a Mesozoic normal fault that juxtaposes Upper Triassic sandstone (Poolesville Member of the Manassas Sandstone) against them. The terrace deposits at the north margin of Indian Flats flood plain contain blocks of quartzite as much as $10 \mathrm{ft}$ long that were transported by the Potomac River during flood stages.

Frederick Valley.-Early to Late Cambrian metasedimentary rocks are juxtaposed against older rocks of the east limb of the Blue Ridge-South Mountain anticlinorium along a Mesozoic normal fault that runs $22 \mathrm{mi}$ from Furnace Mountain, Va., to Catoctin Furnace, Md. (plate 6). These rocks constitute the Frederick Valley synclinorium that is interpreted to have formed along with the Blue Ridge-South Mountain anticlinorium during late Paleozoic deformation of the Alleghanian orogeny. The oldest rocks are quartz-rich metasiltstone of the Lower and Middle Cambrian Araby Formation ( $€$ ar), which was deposited in a basin (Reinhardt, 1974). The type locality is to the north near the Monocacy River at Araby Station. Overlying these rocks is limestone of the Upper Cambrian Frederick Formation ( $€ f, € f a, € f r)$, which marks the beginning of the development of the passive continental margin during Cambrian and Ordovician time. Mesozoic normal faults along the Potomac River cause the bedrock in Virginia to be quite different from that in Maryland.

East of Catoctin Mountain in Virginia and Maryland are Cambrian rocks of the Antietam, Tomstown, and Frederick 
Formations that underlie the Furnace Mountain area. The ironand manganese-rich arkosic sandstone of the Lower Cambrian Antietam Formation ( $€_{c a}$ ) was mined in the 1800s for manganese. With the exception of the dark-gray, graphitic phyllite exposed in excavations, this sequence of rocks is the same as the sequence exposed on the westernmost limb of the Blue Ridge-South Mountain anticlinorium west of Harpers Ferry, W. Va.

Highly cleaved, tan and gray metasiltstone of the Lower and Middle Cambrian Araby Formation ( $€$ ar) is exposed in the railroad cut opposite the broad flood plain from MM 42.6 to MM 44 (fig. 59). Gray limestone of the Upper Cambrian Frederick Formation occurs in several varieties: thin-bedded limestone (€f) is exposed along New Design Road and along Tuscarora Creek near Nolands Ferry (fig. 60A), limestone conglomeratic breccia ( $€ f r)$ is exposed near the Monocacy River (fig. 60B), and thin, folded argillaceous limestone interbedded with shale (€fa) is exposed in Virginia (fig. 60C). Similar limestone was used to build the water treatment facility along the towpath near MM 44.5. North of Nolands Ferry, the limestone is overlain by patches of limestone conglomerate of the Upper Triassic Tuscarora Creek Member of the Manassas Sandstone ( $\mathrm{kcmt}$ ) as well as by coarse Quaternary alluvium. Of note is the conical hill covered with rounded cobbles of quartzite and sandstone north of the intersection of Maryland Route 28 and New Design Road (fig. 61). The conical shape of

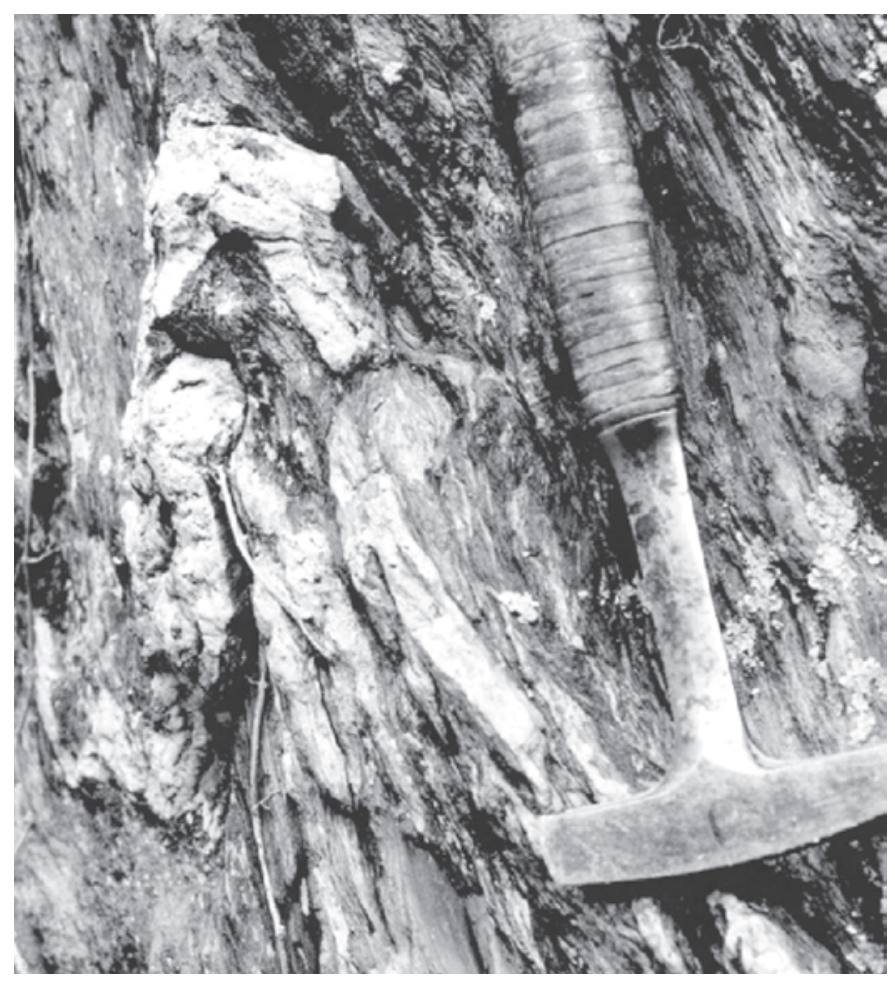

Figure 57. Sheared phyllite (to the right of the hammer) and folded white vein quartz (to the left of the hammer) of the Neoproterozoic(?) and Lower Cambrian(?) ljamsville Phyllite that lies above the Martic thrust fault along the Monocacy River, north of Indian Flats campsite (MM 42.5). the hill and the cobble deposit resulted when coarse alluvium filled a sinkhole in limestone. The resistant quartz cobbles in the alluvium protected the otherwise soluble limestone below. As erosion progressed, the limestone elsewhere dissolved, except for the protected depression. This process resulted in a topographic inversion; that is, the depression became a hill.

\section{Seneca to Edwards Ferry (MM 22.8 to MM 30.8)}

The nature of the Potomac River changes dramatically here (fig. 62). To the west of Seneca Creek, the river valley is broad with many elevated terraces, but to the east, the Potomac has cut a gorge with abundant outcrops forming the falls and islands.

The Upper Triassic basal conglomerate of the Reston Member of the Manassas Sandstone ( $\mathrm{kcmr}$ ) is poorly exposed north of River Road and contains cobbles of vein quartz and schist (derived from the underlying Neoproterozoic and (or) Lower Cambrian Mather Gorge Formation) in a matrix of arkosic sandstone (fig. 63). Near MM 23, the Seneca Creek Aqueduct (fig. 35), lock keeper's house, and Seneca Stone Cutting Mill (fig. 28) are constructed from the red sandstone of the Upper Triassic Poolesville Member of the Manassas Sandstone ( $\mathrm{kcmp}$ ) (informally known as "Seneca Red Sandstone"). This rock was quarried extensively on the Potomac River bluffs west of the aqueduct. The quarries opened in 1774 and operated until 1898 (Davies, 1999). The large water impoundment between the towpath and bluffs was constructed as a holding basin for the barges that transported the stone. Along the bluffs from here to MM 24 are abandoned sandstone quarries, at least one of which also contained copper deposits.

Near MM 24, siltstone is more dominant than sandstone, so the rocks are assigned to the Upper Triassic Balls Bluff

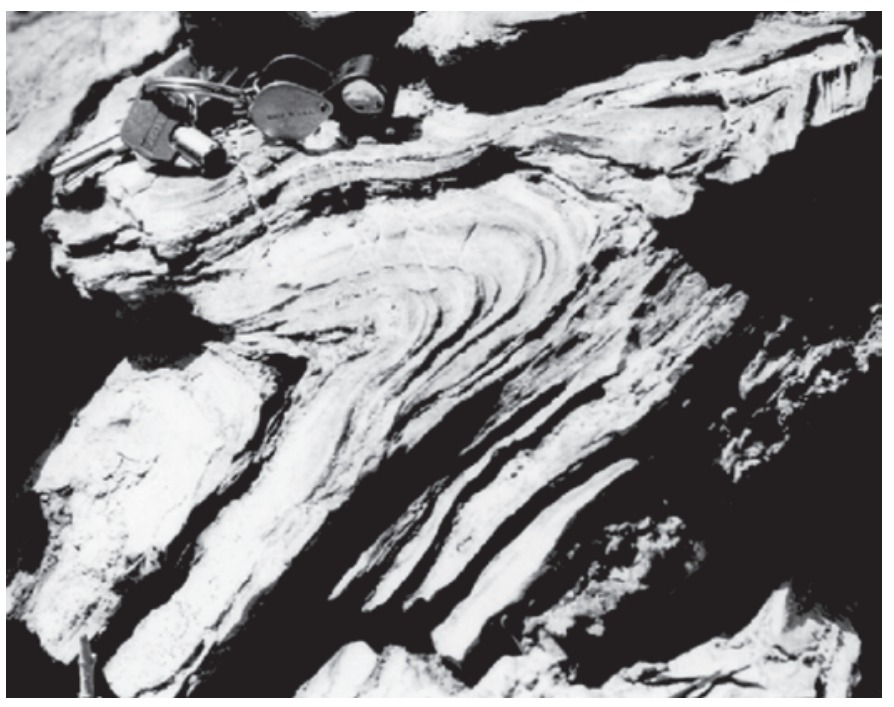

Figure 58. Tightly folded, thin-bedded limestone within the ljamsville Phyllite along the Monocacy River. Hand lens for scale. 


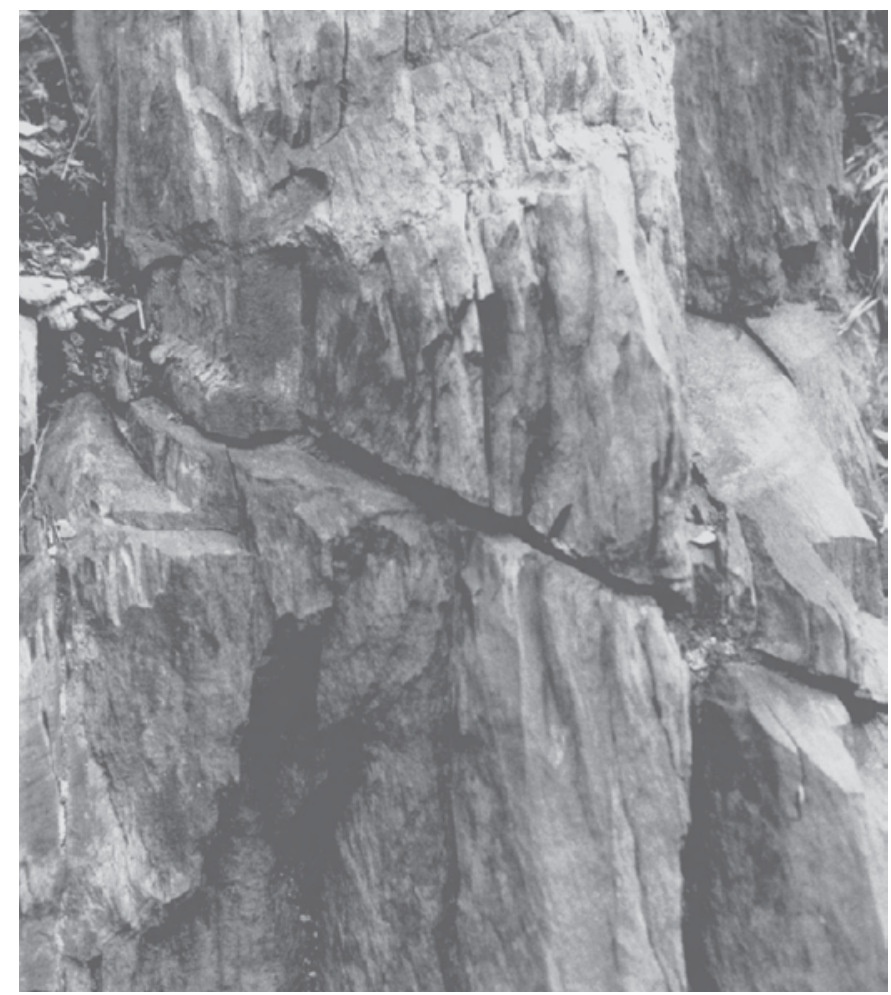

Figure 59. Metasiltstone of the Lower and Middle Cambrian Araby Formation showing foliation with near-vertical cleavage along the CSXT railroad north of MM 43. View is about 1 foot across.

Member of the Bull Run Formation ( $\mathrm{kcbb})$. Finer grained siltstone is rather poorly exposed along the canal but can be seen at the member's type locality in the bluffs of Balls Bluff National Cemetery in Virginia, across the river from MM 34.

From MM 24 to MM 30, the canal and towpath cross the broad flood plain within the McKee-Besher Wildlife Management Area. The lowland required berms to be built above the canal to keep out floodwater and overbank deposits of silt.

Near the Chisel Branch campsite, west of MM 30, is the only siltstone exposed until almost MM 38. At Chisel Branch, the rock had to be drilled and blasted to construct the canal. Just to the west, the Goose Creek River Lock (Lock 25) connected the C\&O Canal with the Goose Creek and Little River Navigation (Trout, 1991), a canal that was used to transport goods as far away as Middleburg, Va.

\section{Edwards Ferry to Monocacy Aqueduct (MM 30.8 to MM 42.2)}

Near MM 32 are the remains of the Broad Run Trunk (Aqueduct), the only aqueduct along the canal constructed from wood. To the west beyond MM 32.5, the canal and towpath cross the flood plain. Scattered on the flood plain are large blocks of quartzite that were transported by the Potomac River during floods. At Whites Ferry (MM 35.5) are the remains of a large bridge, constructed from red sandstone, that carried ferry users across the canal to the river. From near MM 38 to west of the Marble Quarry campsite (plate 6), graded beds of limestone conglomerate (Upper Triassic Leesburg Member of the Bull Run Formation, Kcbl) (fig. 64) are interbedded with siltstone and sandstone. These conglomerates are ancient distal debris flows that brought carbonate clasts derived from north and west of Catoctin Mountain into a basin of muddy silt. An Early Jurassic diabase dike (Jd) intrudes the conglomeratic rock. Also present within the Leesburg Member are limestone clasts derived from the Frederick Formation. These clasts were metamorphosed into white marble that was quarried for agricultural lime. Native Americans lived on the islands and along the shore of this section of the Potomac River; some of their most well preserved fish weirs (fig. 10) are found here (Scheel, 1995; Guzy, 2000).

From near MM 41 north to the Monocacy River good outcrops of siltstone interbedded with sandstone of the Poolesville Member of the Manassas Sandstone (plate 7) may be seen. These outcrops exhibit drill holes and the remnants of small quarries (fig. 64). The Monocacy River Aqueduct (fig. 36) was constructed from white Lower Cambrian(?) Sugarloaf Mountain Quartzite quarried from the southern part of Sugarloaf Mountain in Frederick County, Md., and transported here by horse and wagon and by light rail.

\section{Monocacy Aqueduct to Point of Rocks (MM 42.2 to $\mathrm{MM}$ 48.2)}

From MM 42 to near MM 47.5, the canal and towpath cross a broad flood-plain deposit on Triassic rocks that are, in part, downfaulted against older rocks of the Piedmont to the north (plate 7). Limestone conglomerate of the Upper Triassic Tuscarora Creek Member of the Manassas Sandstone ( $\mathrm{kcmt}$ ) crops out on the flood plain of Indian Flats and looks identical to conglomerate of the Upper Triassic Leesburg Member of the Bull Run Formation ( $\mathrm{kcbl}$ ) that occurs near MM 47. The Leesburg Member, which was informally called "Potomac marble" or "Calico rock" was quarried here for the columns of Statuary Hall in the U.S. Capitol building in Washington, D.C. (fig. 65B). Indian Flats was undoubtedly the site of a major village of Native Americans. Upstream of MM 43, a complex fish weir may be seen in the Potomac River (fig. 9).

From about MM 47.5 to MM 48.2, the area is underlain by limestone of the Lower Cambrian Tomstown Formation (€t) (fig. 66A), which is exposed only in the Virginia portion of the map. Extensive alluvial and colluvial deposits (fig. 66B) mantle the bedrock so that only water-well records and drill core (Hoy and Schumaker, 1956) reveal its presence in Maryland. Kanawha Spring (also known as "Big Spring") discharges from the limestone near MM 47.5. Stratigraphically beneath the Tomstown Formation is a dark, carbonaceous, and graphitic phyllite unit that produces a distinctive ashy soil where exposed in excavations (fig. 67A). Similar black shales are found locally within the limestone of the Upper Cambrian Frederick Formation (Southworth and Brezinski, 2003). 

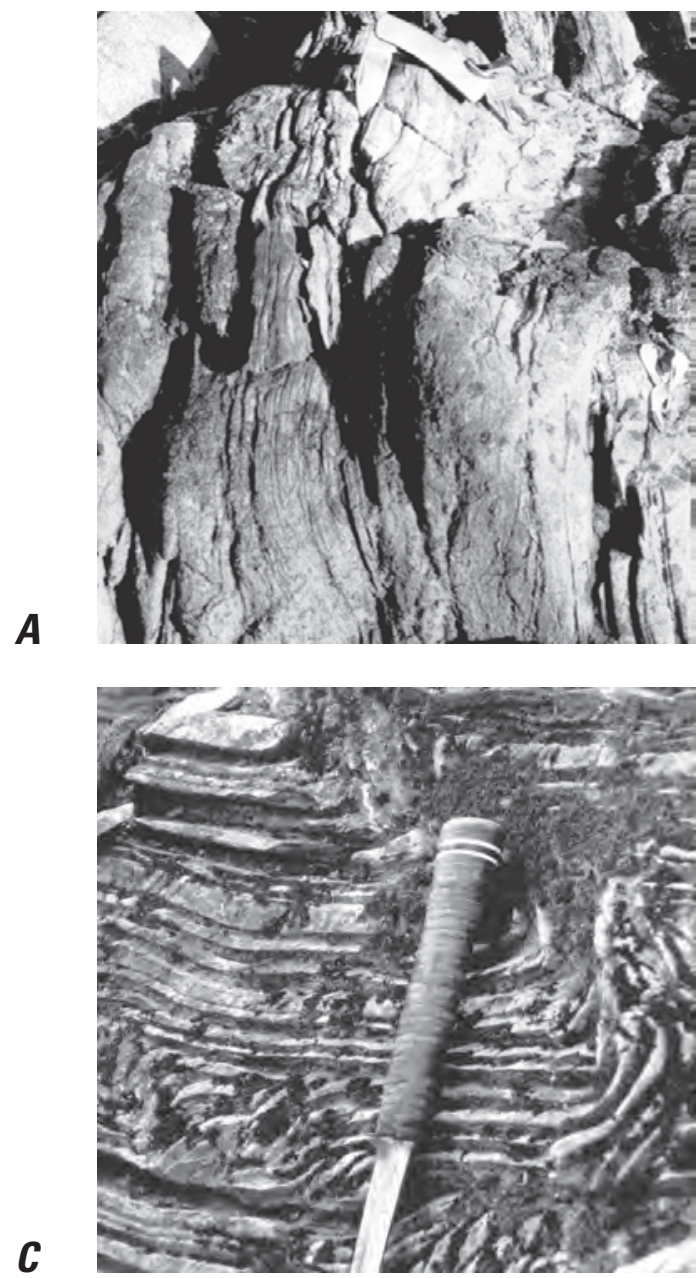

B

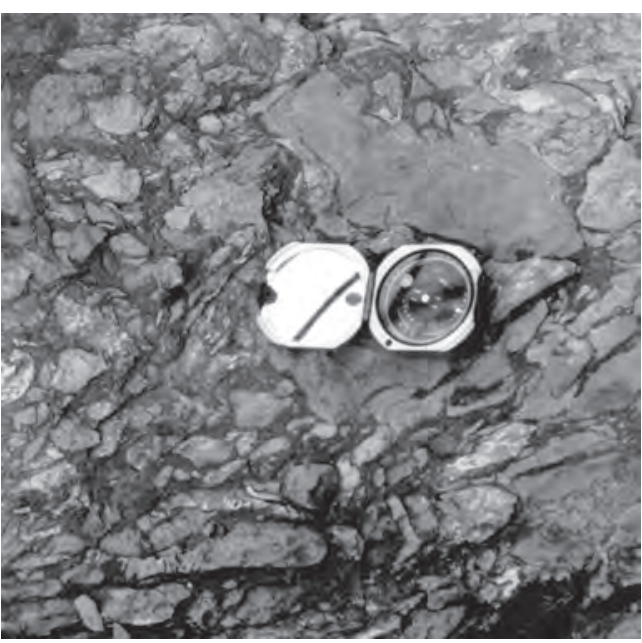

Figure 60. Examples of the varieties of limestone in the Upper Cambrian Frederick Formation. $A$, Thin-bedded limestone is exposed in Tuscarora Creek north of Nolands Ferry. Pocket knife for scale, top center. $B$, Platy limestone conglomerate breccia near the Monocacy River, about 2 mi north of the map area. Brunton compass for scale. $C$, Folded, thin limestone beds interbedded with shale south of the Potomac River in Virginia, opposite MM 47.5 .

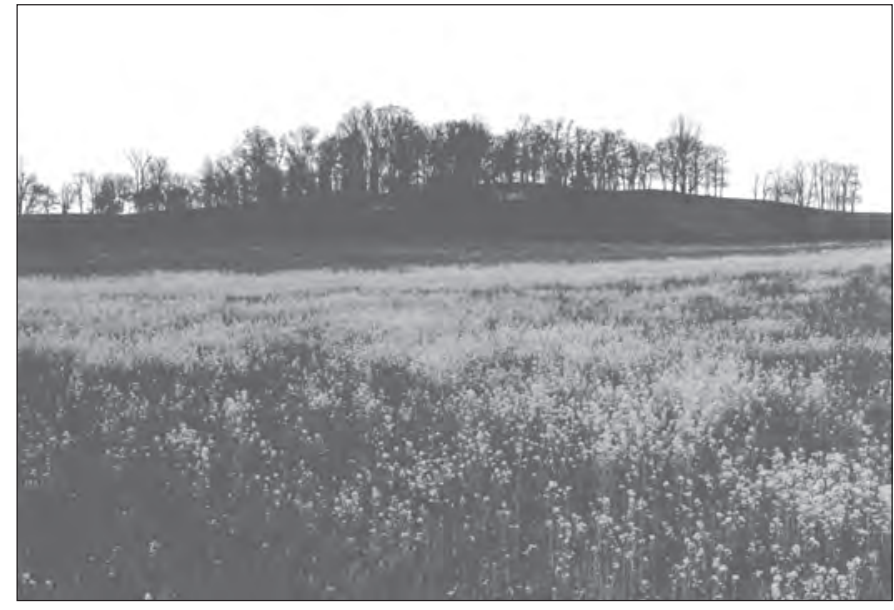

$\boldsymbol{A}$

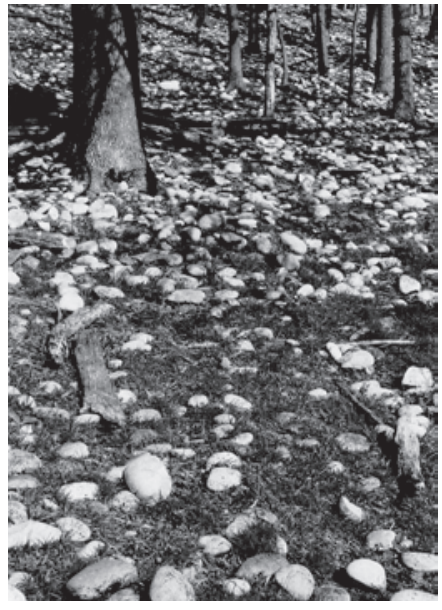

B
Figure 61. Conical hill north of Nolands Ferry and Maryland Route 28 representing topographic inversion. $A$, Broad view of the hill showing its conical form. $B$, Closeup view of the slopes of the conical hill showing the cobbles of sandstone and quartzite that were deposited in a sinkhole in limestone. The surrounding limestone has since been eroded while the resistant sandstone and quartzite gravel remained and armor the hill. 

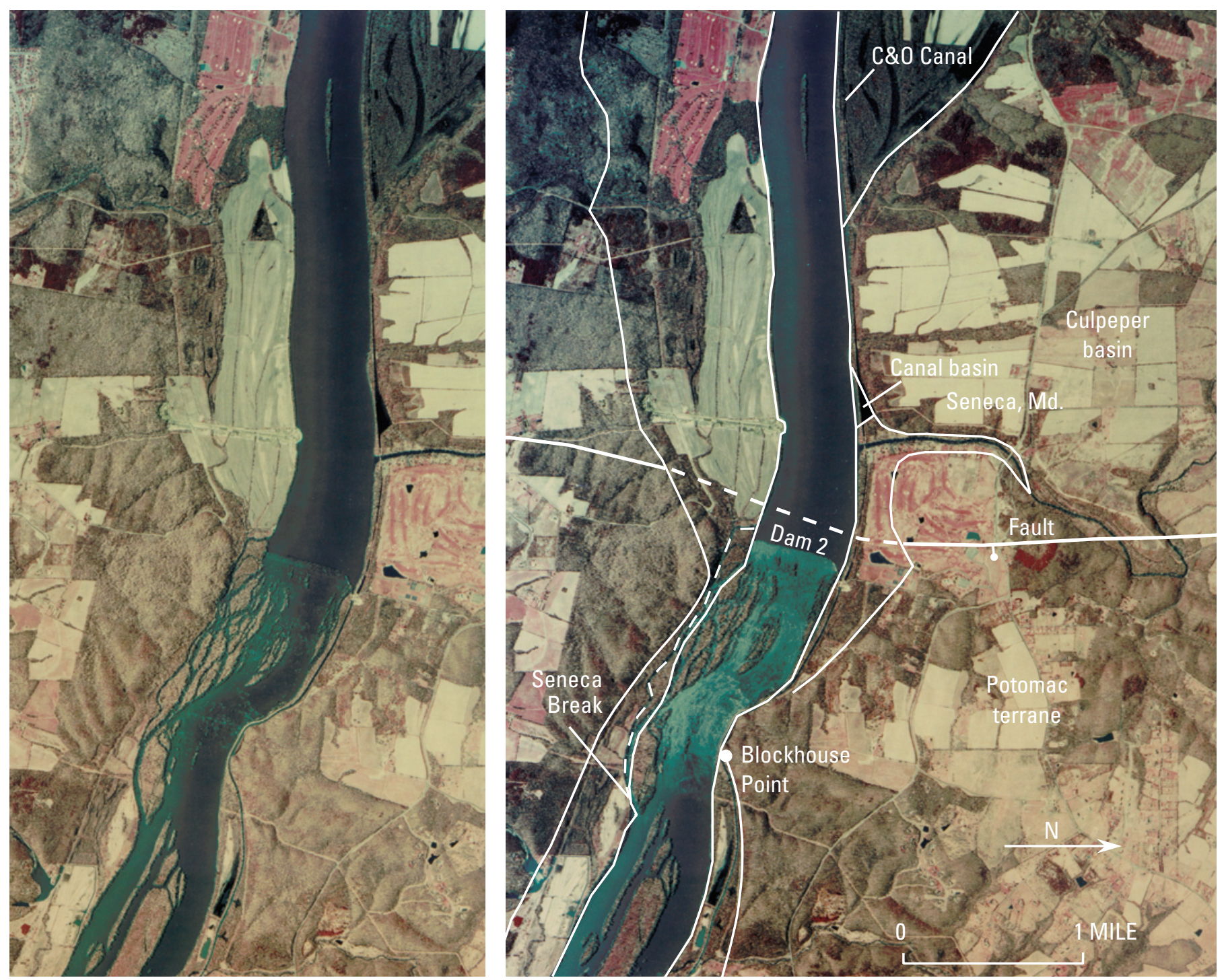

Figure 62. Stereoscopic pair of aerial photographs showing the change in the morphology of the Potomac River valley in the Piedmont province across the boundary (shown by the solid line) between the Culpeper basin (west) and Potomac terrane (east). Note that the Potomac terrane is dissected and the Culpeper basin has a broader flood plain. The tonal change in the river is Seneca Falls and the rubble remains of Dam 2. Seneca Break was a skirting canal constructed around Seneca Falls by George Washington's Patowmack Company; canal towpath indicated by dashed white line.

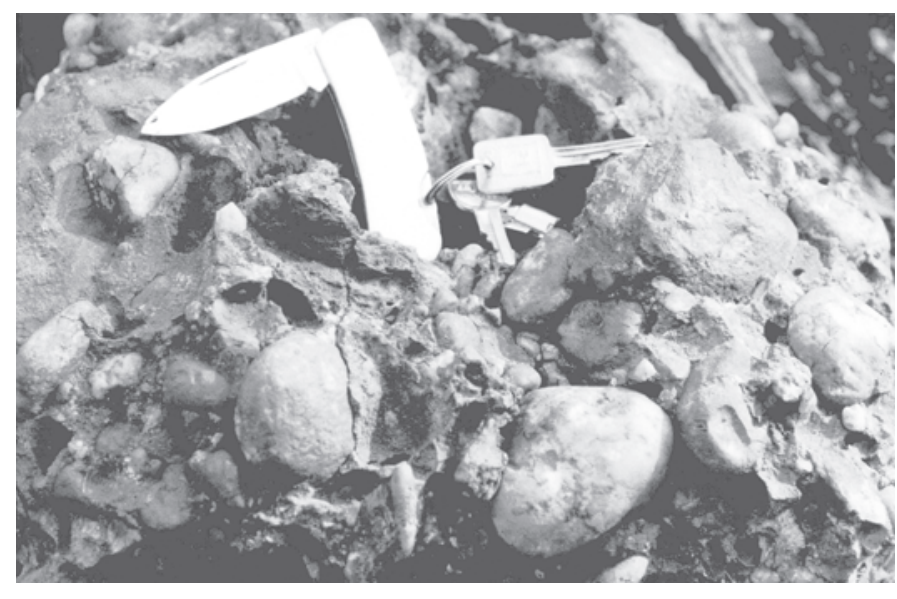

Figure 63. Conglomerate of the Upper Triassic Reston Member of the Manassas Sandstone that forms the base of the Culpeper basin. The conglomerate includes rounded cobbles of vein quartz and metamorphic rocks. Knife and keys for scale. 

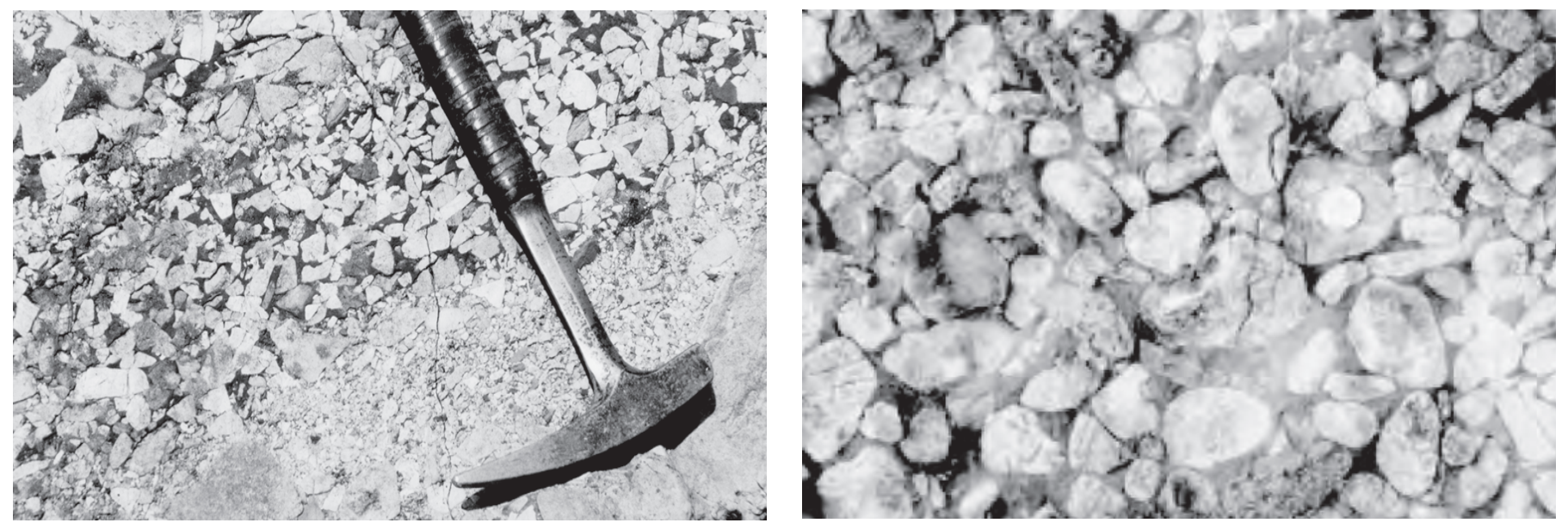

A

B

Figure 64. Limestone conglomerate interbedded with red siltstone of the Upper Triassic Leesburg Member of the Balls Bluff Siltstone. $A$, Outcrop of Leesburg Member in bluffs opposite Marble Quarry campsite. Hammer's head lies on an Early Jurassic diabase dike that intruded the conglomerate and locally metamorphosed the limestone clasts to marble. $B$, Conglomerate of the Leesburg Member, which was excavated to create the floor of the canal. Quarter for scale.

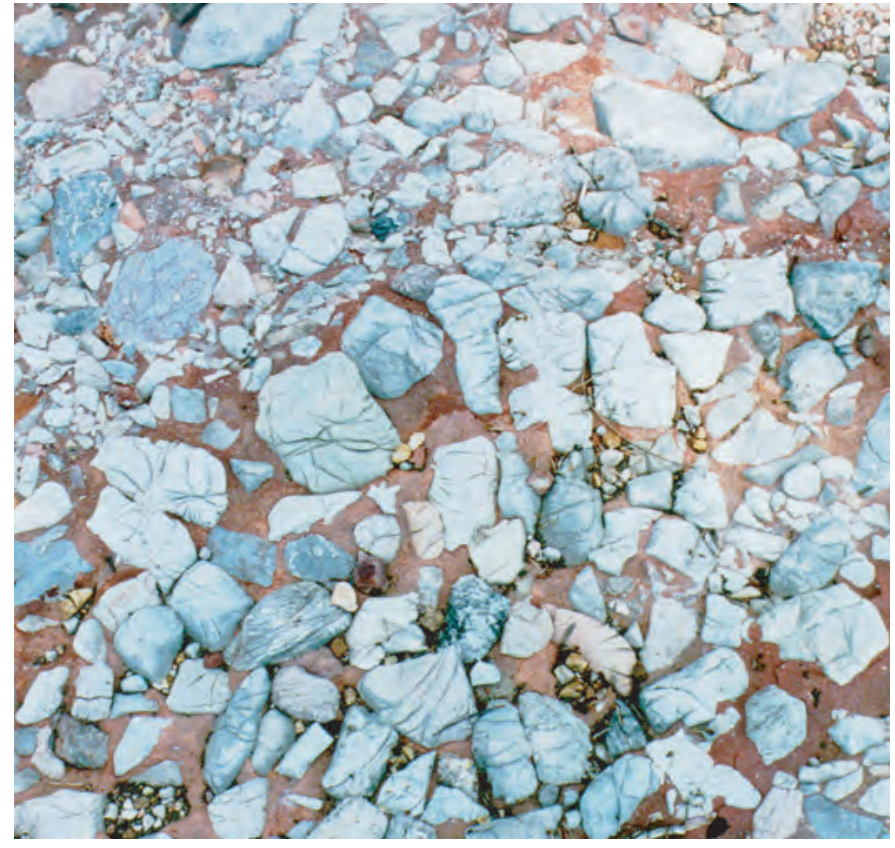

$\boldsymbol{A}$

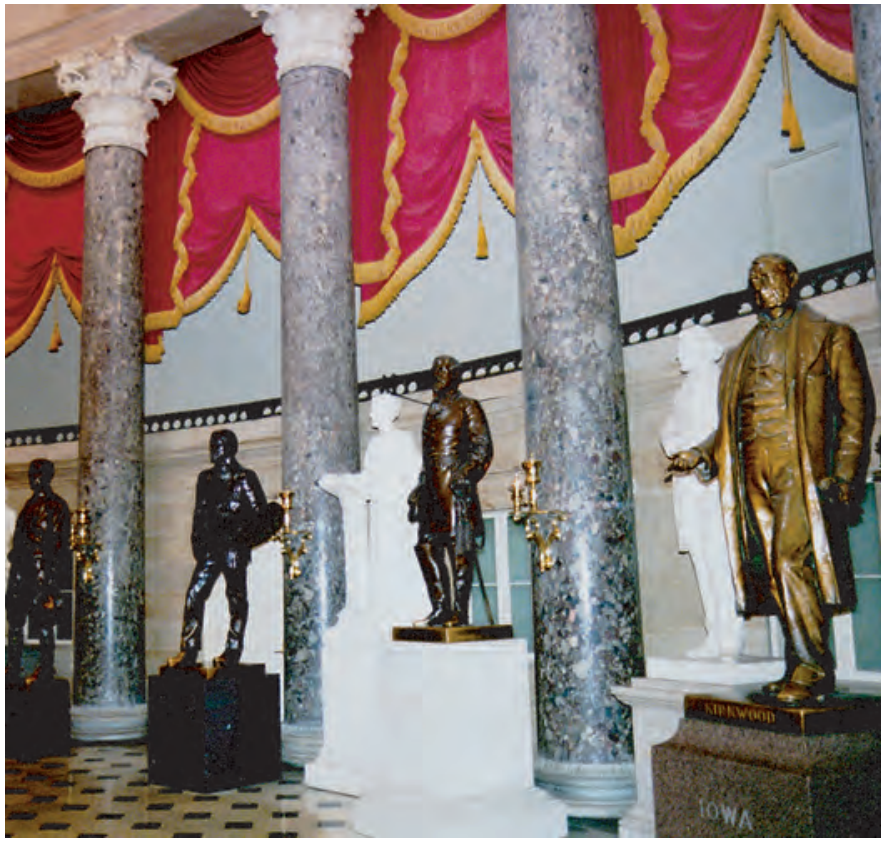

$\boldsymbol{B}$

Figure 65. Limestone conglomerate of the Upper Triassic Leesburg Member of the Bull Run Formation. A, Conglomerate near MM 47. The canal was excavated through this unit, and it was quarried to the immediate east. $B$, Ornamental columns of Statuary Hall in the U.S. Capitol Building formed from the Leesburg Member. Photograph courtesy of the National Park Service. 
The graphitic phyllites were deposited over metasandstone of the Lower Cambrian Antietam Formation ( $€_{c a}$ ). These dirty metasandstones (fig. 67B) are exposed in excavations along Furnace Mountain in Virginia. They are not composed of clean quartz such as the metasandstone of the Antietam Formation

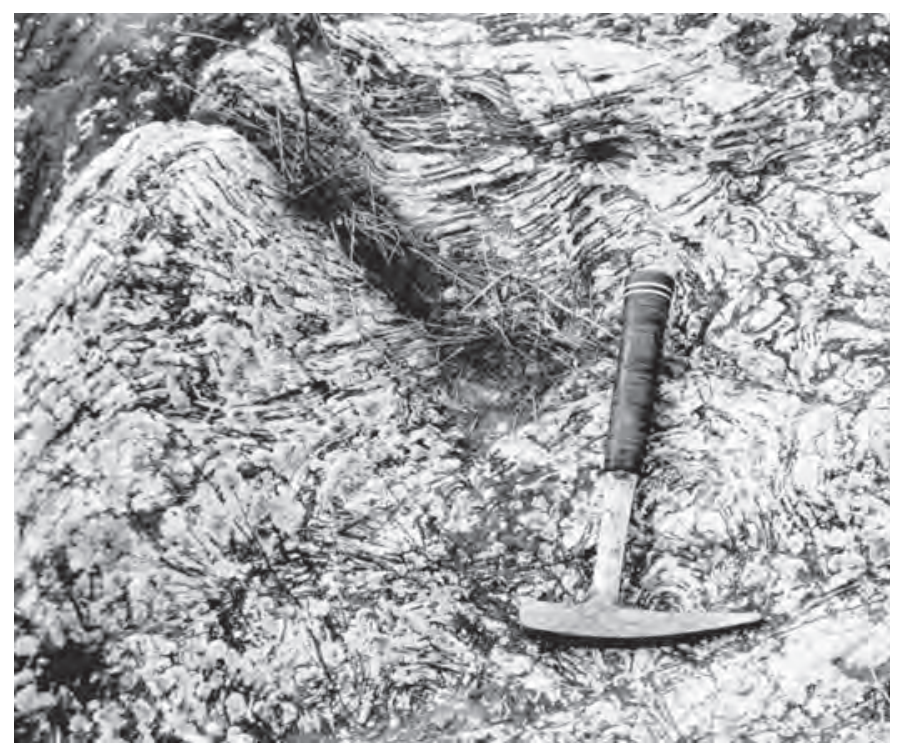

\section{$\boldsymbol{A}$}

found west of Harpers Ferry, W. Va., but are more similar to the rocks of the Araby Formation. The facies change within the Antietam Formation across the Blue Ridge province probably reflects a depositional change from a shallow-marine to a deep-water-slope environment.

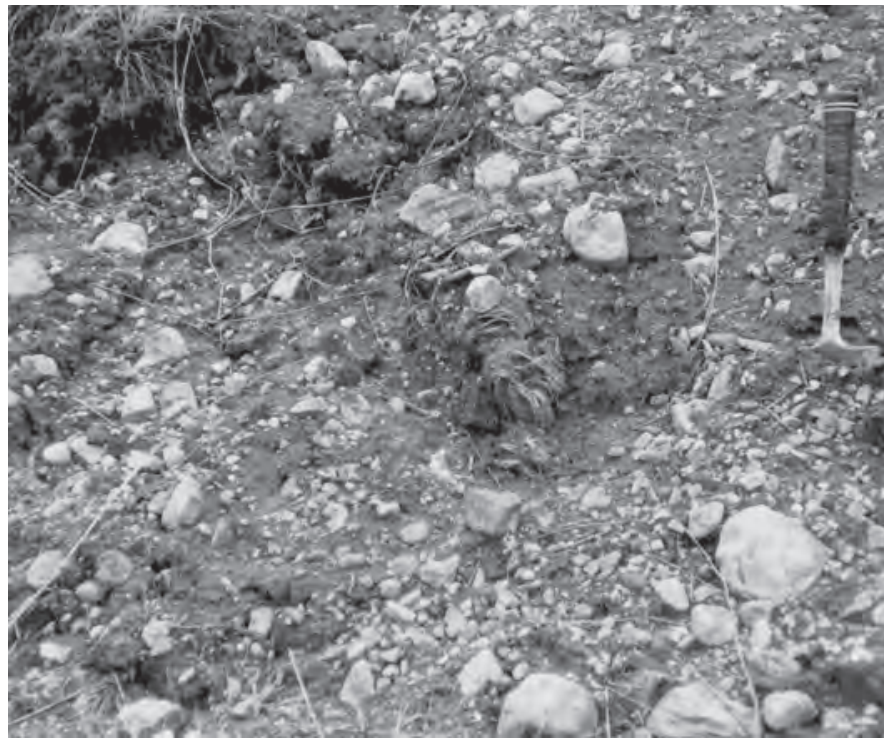

B

Figure 66. Lower Cambrian Tomstown Formation. A, Folded beds of limestone and marble of the Tomstown Formation, which only crops out south of the Potomac River in Loudoun County, Va. B, Colluvium of sandstone and vein quartz covering Tomstown Formation in Maryland. The Tomstown is known in Maryland only from water-well records and drill cores.

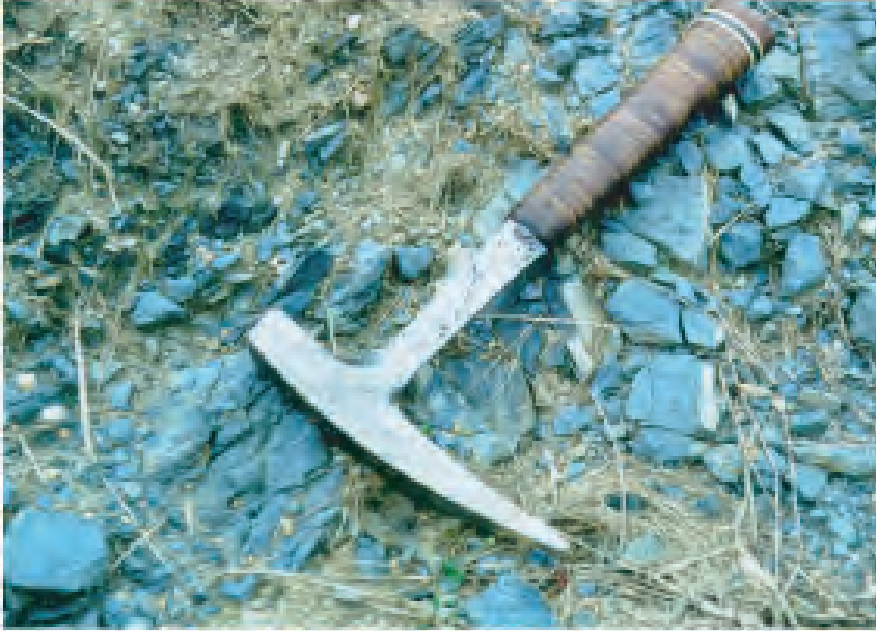

$\boldsymbol{A}$

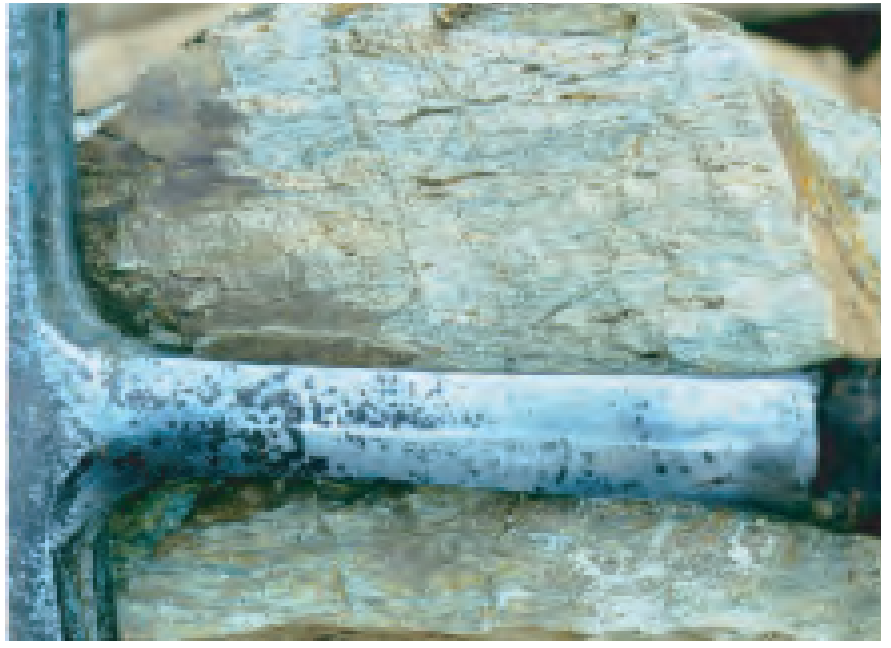

B

Figure 67. Lower Cambrian rocks of the Blue Ridge province. These two rock units are not exposed along the canal and river, but are within the map area along U.S. Route 15 in Loudoun County, Va. A, Dark-gray to black, carbonaceous phyllite unit which forms ashy soil. $B$, Arkosic metasandstone of the Antietam Formation, which was quarried for manganese in the 1700s along Furnace Mountain just south of the river. In Pennsylvania, this unit contains trilobites and is the oldest fossil-bearing rock known in this region. 


\section{Blue Ridge Province}

\section{Point of Rocks, Md., to Fort Duncan (MM 48.2 to MM 63)}

\section{Access Points}

\author{
Point of Rocks, Md. \\ Lander, Md. \\ Brunswick, Md. \\ Weverton, Md. \\ Sandy Hook, Md. \\ Harpers Ferry, W. Va. \\ Pleasantville, Md.
}

\section{Introduction}

Some of the oldest rocks in the Appalachian Mountains are exposed in the Blue Ridge province. The main structure is a large overturned fold known as the Blue Ridge-South Mountain anticlinorium. This anticlinorium is defined by one eastern and two western flanks that underlie Catoctin Mountain, South Mountain-Short Hill Mountain, and Blue RidgeElk Ridge, respectively (fig. 68); the latter two pairs of mountains are continuous mountain ridges breached by the Potomac River. The rocks were metamorphosed, folded, faulted, and transported westward during the late Paleozoic Alleghanian orogeny, which was the result of continental collision of North America with Africa.

The rocks underlying Catoctin Mountain on the east limb of the anticlinorium consist of resistant metabasalt of the Neoproterozoic Catoctin Formation (Zcm) and quartzite of the Lower Cambrian Weverton Formation $(€ \mathrm{cw})$. Likewise, the same rocks underlie South Mountain-Short Hill Mountain and Blue Ridge-Elk Ridge to the west, but the strata there are more folded and are overturned. Blue Ridge-Elk Ridge is almost a replica of South Mountain-Short Hill Mountain because a regional fault duplicates the strata and resultant ridges. The core of this anticlinorium contains $1.1 \mathrm{Ga}$ granitic rocks that were metamorphosed and deformed during the Mesoproterozoic Grenville orogeny (Burton and Southworth 1996; Southworth and others, 2006). These unnamed granitic rocks are gneissic, well layered, and include the following varieties: biotite granite gneiss (Ybg), leucocratic metagranite $(\mathrm{Yg})$, garnetiferous leucocratic metagranite (Ygt), and hornblende monzonite gneiss (Yhg). The $1.1 \mathrm{Ga}$ age of these rocks was determined by using uranium-lead (U-Pb) dating techniques on zircon crystals that formed when the intrusive granite crystallized (Aleinikoff and others, 2000).

The first strata deposited over the granitic basement rocks were fluvial deposits that were later lithified and metamorphosed to form quartzite, metasandstone, schist (Zss); phyllite (Zs), and rare marble (Zsm) of the Neoproterozoic Swift Run
Formation. The type locality of these rocks is Swift Run Gap in the Shenandoah National Park to the southwest. The Catoctin Formation, which overlies the Swift Run Formation, is composed of metabasalt (metamorphosed basalt) (Zcm), lightcolored metarhyolite, and some metasedimentary phyllite (Zcs) and marble similar to that found within the underlying Swift Run Formation. The formation is named after Catoctin Mountain in Maryland. The age of the volcanic rocks ranges from $571 \mathrm{Ma}$ (from a rhyolite dike exposed along the Potomac River opposite MM 52.5) to $565 \mathrm{Ma}$ (from metabasalt in the Shenandoah National Park area) (Badger and Sinha, 1988; Aleinikoff and others, 1995).

Many metadiabase dikes (Zmd) intruded the granitic rocks within the core of the anticlinorium. These dikes represent fissures that fed basaltic lava through the granite to the surface where it was extruded as lava flows. The lava flows on top of the clastic sediments that would later become rocks of the Swift Run Formation. The fissures and volcanic activity were the result of continental rifting of the land mass referred to as Laurentia. The rifting in turn resulted in the formation of the ancient Iapetus Ocean between approximately 600 and $545 \mathrm{Ma}$.

Fossil soil, volcanic tuff, silt, and gravel were lithified to collectively make up the rocks of the overlying Lower Cambrian Loudoun Formation ( $€$ clc, $€$ clp). These rocks represent a dramatic change in the depositional environment from a volcanic landscape to one dominated by rivers and deltas.

Fluvial sand and gravel shed from the continent eastward to its shore were lithified to form light and dark quartzite of the Lower Cambrian Weverton Formation ( $€ \mathrm{cw})$, whose type locality is Weverton Cliffs, north of Lock 31. Silty rocks within the quartzite increase stratigraphically upward to form the Lower Cambrian Harpers Formation ( $€$ ch, $\epsilon_{\text {chq), }}$ whose type locality is along the Shenandoah River in Harpers Ferry National Historical Park in West Virginia, south of MM 61. These dark, fine-grained rocks that form the bold cliffs along the Potomac River at Harpers Ferry probably are deltaic deposits (Southworth and Brezinski, 1996a). The siltstones of the Harpers are interbedded with thin beds of sandstone near the top of the formation. Where the sandstone rocks become dominant, the rocks are assigned to the Lower Cambrian Antietam Formation ( $€ \mathrm{ca})$, which is named after Antietam Creek to the north where there are typical exposures. The tan metasandstone of the Antietam contains the trace fossil Skolithos linearis. In rocks of the Antietam Formation in Pennsylvania, the Olenellus trilobite is the oldest shelly fossil recognized in all of the rocks of the Blue Ridge province. Collectively, the Loudoun, Weverton, Harpers, and Antietam Formations are part of the geographically more extensive Chilhowee Group, which is named after Chilhowee Mountain in Tennessee. The Olenellus trilobite is the basis for the Early Cambrian age designation (Stose and Stose, 1944).

The western boundary of the Blue Ridge province generally is considered to be the contact between the Antietam Formation and the overlying limestone of the Lower Cam- 


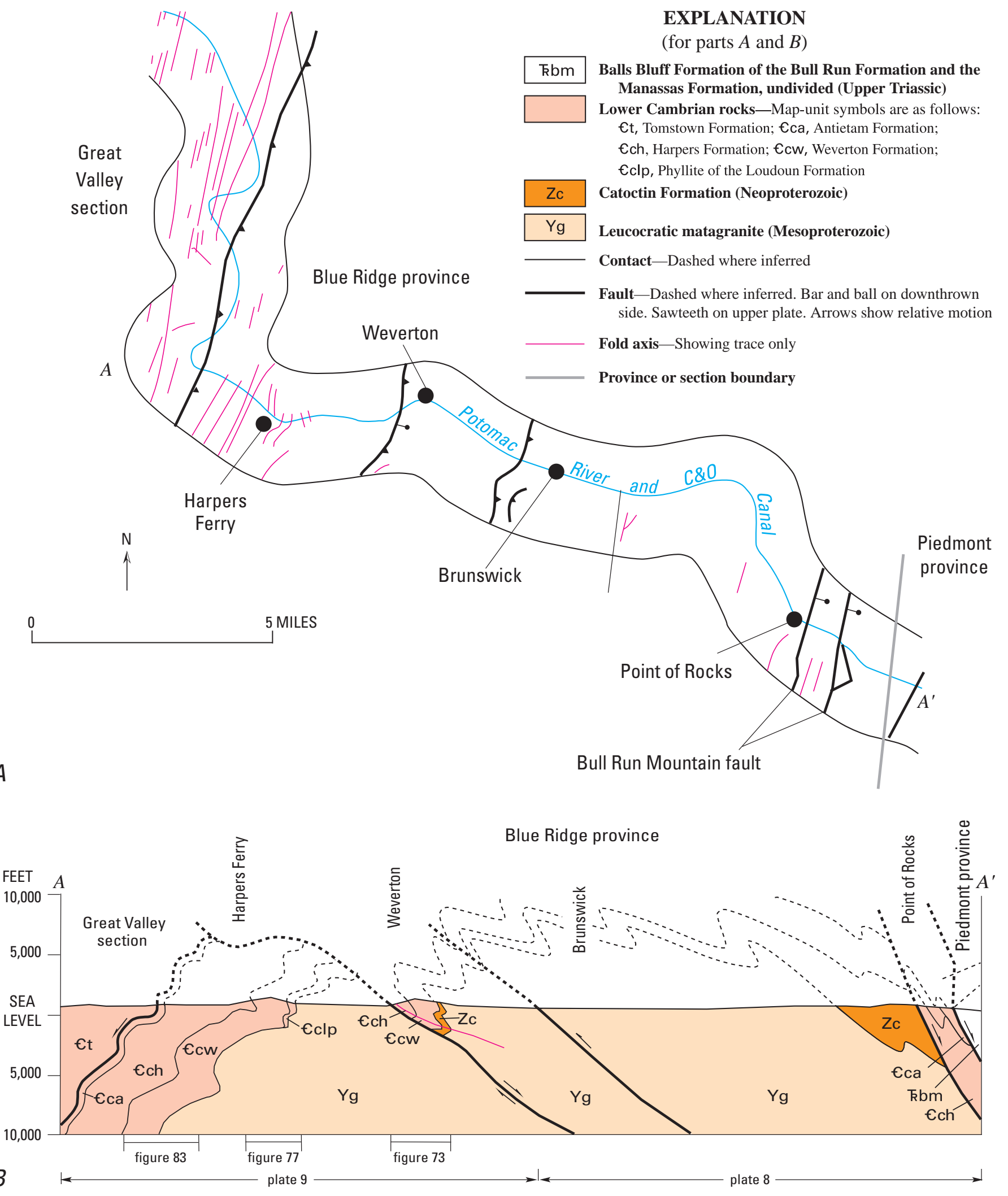

Figure 68. Generalized structure map and cross section of a portion of the C\&O Canal National Historical Park and Potomac River corridor as it crosses the westernmost part of the Piedmont province, the Blue Ridge province, and the easternmost part of the Great Valley section of the Valley and Ridge province. $A$, Structure map showing fold axes and major faults. $B$, Cross section showing folds and faults from Point of Rocks, Md., westward to just past Harpers Ferry, W. Va. See plates 8 and 9 for detailed geologic maps of this portion. Geologic units shown in cross section are generalized from the geologic map shown on plate 1. 
brian Tomstown Formation $(€ t)$ of the Great Valley section. The eastern boundary of the province is the foot of the slope of Catoctin Mountain, west of the border fault of the Culpeper basin. The complex geologic history of the region is illustrated in figure 4.

\section{Point of Rocks to Brunswick (MM 48.2 to MM 55)}

Point of Rocks is a steep bluff of Neoproterozoic Catoctin Formation metabasalt $(\mathrm{Zcm})$ that was exposed when the Potomac River cut a water gap through Catoctin Mountain (plates 7 and 8, fig. 69A). The Potomac River and flood plain widen as the less resistant rocks of the Piedmont are crossed (fig. 70). The steep bluff, which gives Point of Rocks its name, left little room for both a canal and railroad, so a tunnel was excavated through the metabasalt for the railroad. Just east of the bridge, folded rocks of the Lower Cambrian Harpers Formation ( $€$ ch) were juxtaposed against the Catoctin Formation along a normal fault at about $200 \mathrm{Ma}$. Metabasalt crops out in the middle of the Potomac River and is the dominant rock exposed from Point of Rocks to Lander (MM 51). At the railway tunnel (MM 48.4), both metabasalt with gas vesicles (fig. 69B) and intrusive vein quartz were folded and broken by faults (fig. 69C).

The linear creek that drains into the Potomac River immediately east of Lander flows along the contact between metabasalt of the Catoctin Formation and Mesoproterozoic granite gneiss $(\mathrm{Yg})$. Locally, the metabasalt contains small pods of marble (fig. 71). From here west to Brunswick and beyond to Weverton, the bedrock is a granite gneiss $(\mathrm{Yg})$ intruded by metadiabase dikes (Zmd) (fig. 72). These poorly exposed rocks can be seen just east of Catoctin Creek in the railroad cut at MM 51.5.

Quaternary cobbles and boulders of sandstone and quartzite that litter the embankment here were deposited by the Potomac River in one of its now-abandoned meanders. The Catoctin Creek Aqueduct (at about MM 51.6) collapsed in 1973 when floodwaters scoured its supports. The remains of the aqueduct, which was constructed from Ordovician Ellicott City Granodiorite, are present beneath the footbridge. From Catoctin Creek to Brunswick is a large rail yard that takes advantage of the broad low terrace of the flood plain of the Potomac River.

\section{Brunswick to Fort Duncan (MM 55 to MM 62.5)}

From Brunswick to Knoxville (at about MM 57) and beyond to Weverton (at about MM 58), the canal and towpath are constructed on a broad low terrace of the Potomac River (plate 9). Rocks of the Lower Cambrian Weverton Formation ( $\left.€_{\mathrm{cw}}\right)$ are located at Weverton Cliffs, which is at the southern end of South Mountain, east of MM 58, where the Potomac River cut through the western limb of the Blue Ridge-South Mountain anticlinorium. This ridge is underlain by folded and

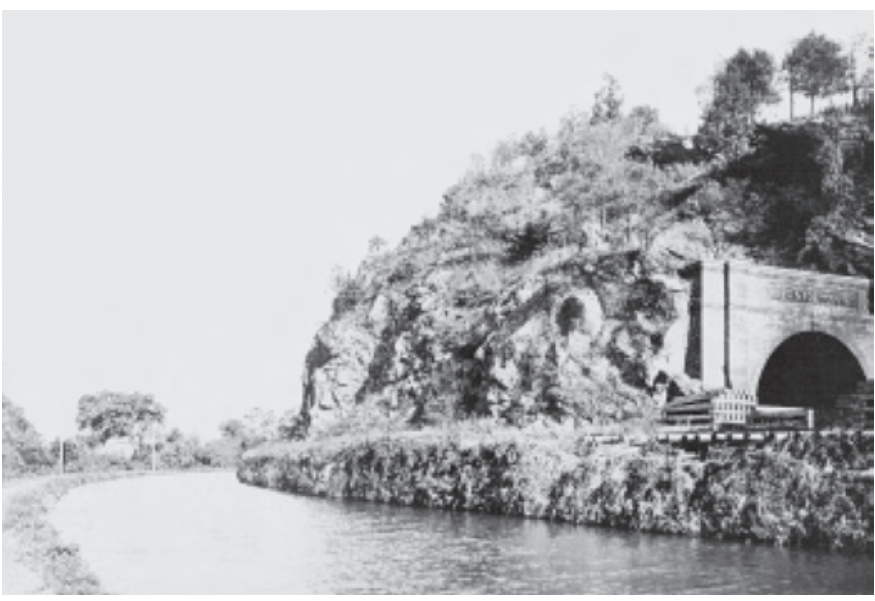

$\boldsymbol{A}$

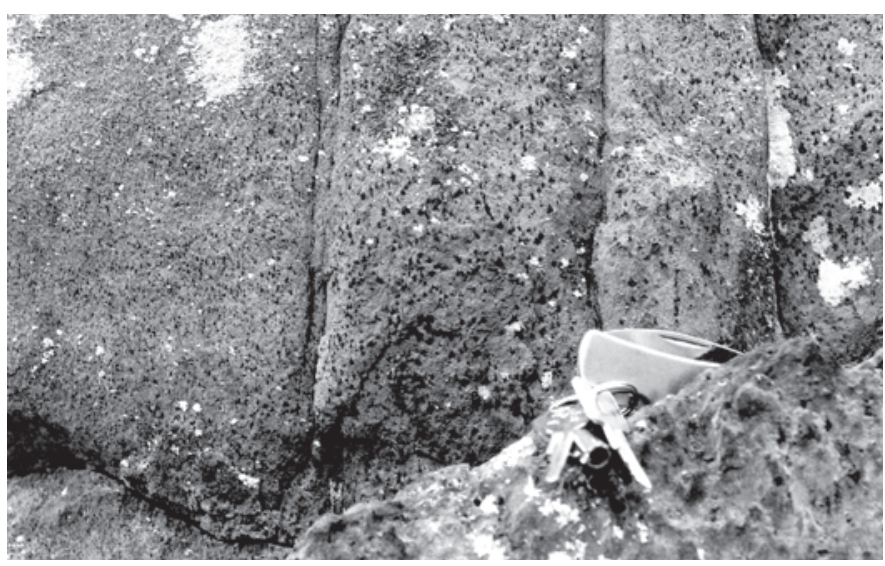

B

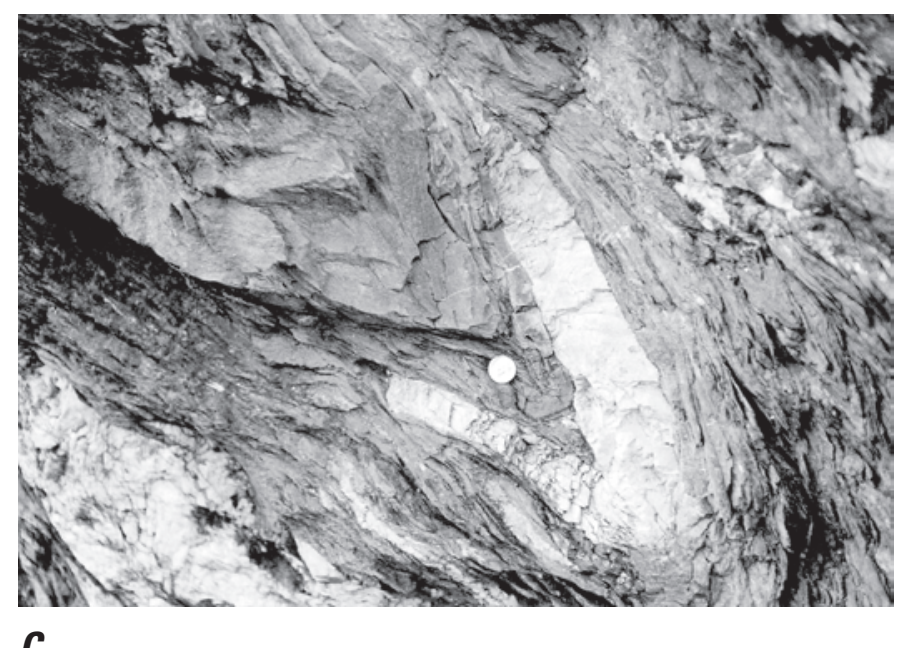

C

Figure 69. Neoproterozoic Catoctin Formation. $A$, Historical photograph (around 1920) of Point of Rocks, Md., showing cliffs of the Catoctin Formation that form the north side of the water gap of Catoctin Mountain. Note railroad tunnel entrance on right side of photograph. Photograph by Consolidated Coal Co.; courtesy of National Park Service. The Catoctin contains a variety of rocks as illustrated in $B$ and $C$. $B$, Vesicular metabasalt. $C$, Schist and phyllite containing folded vein quartz. The vein quartz intruded the Catoctin sometime before the late Paleozoic Alleghanian orogeny. 

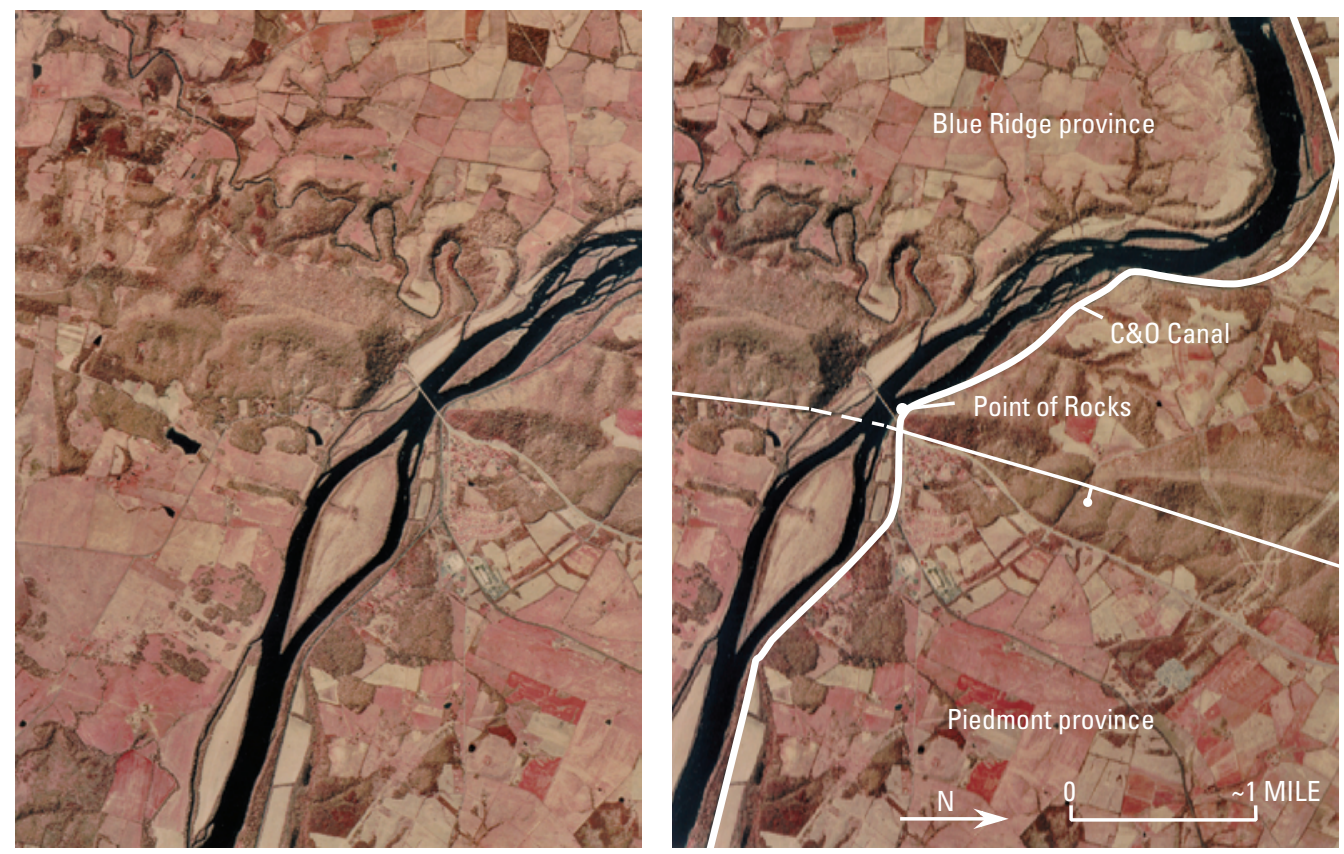

Figure 70. Stereoscopic pair of aerial photographs and sketch centered on Point of Rocks, Md., which is on the north side of the water gap in Catoctin Mountain. A fault separates the Blue Ridge and Piedmont provinces; bar and ball are on downthrown block.

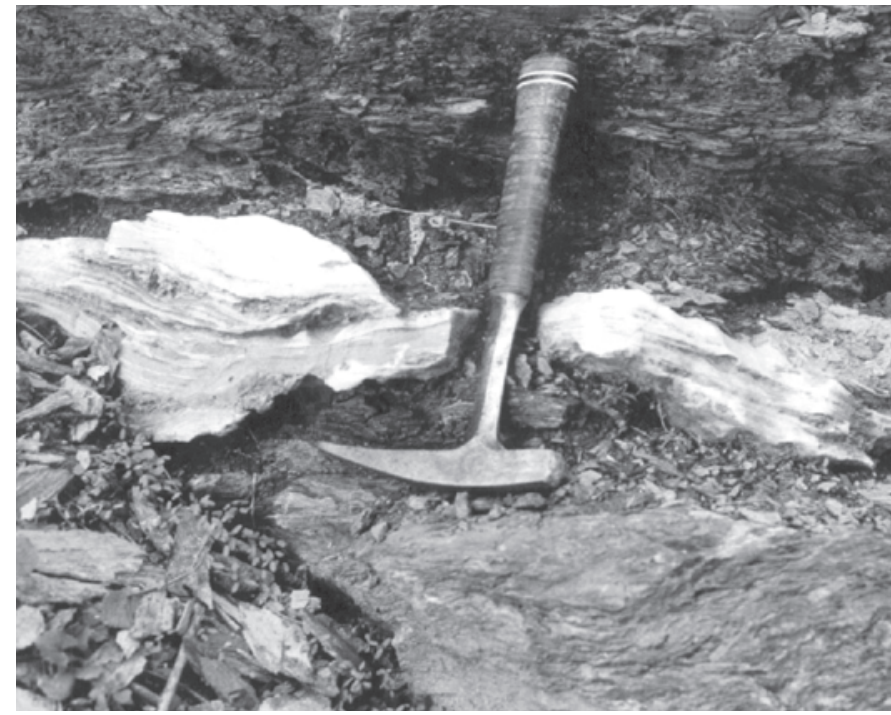

Figure 71. Pods of marble in the Neoproterozoic Swift Run Formation found along the creek northeast of Lander, Md., and east of Short Hill Mountain to the west. The pods probably resulted from deposits of shallow-water limestone.

faulted quartzite and metasiltstone of the Weverton Formation and the rocks are mostly overturned to the west (fig. 73) (Southworth and Brezinski, 1996b). Coarse pebble conglomerate of the Lower Cambrian Loudoun Formation (€clc) (fig. 74) is found at the base of the Weverton Formation north of the Potomac River, but north of MM 57.5, only phyllite (€clp) is exposed. The clasts in the conglomerate consist mostly of quartz, but red jasper and metabasalt also are present and probably were derived from erosion of the underlying Neoproterozoic Catoctin Formation.

The stone remains of Weverton Mills (MM 57.8), which was constructed in 1834 for manufacturing, may be seen along

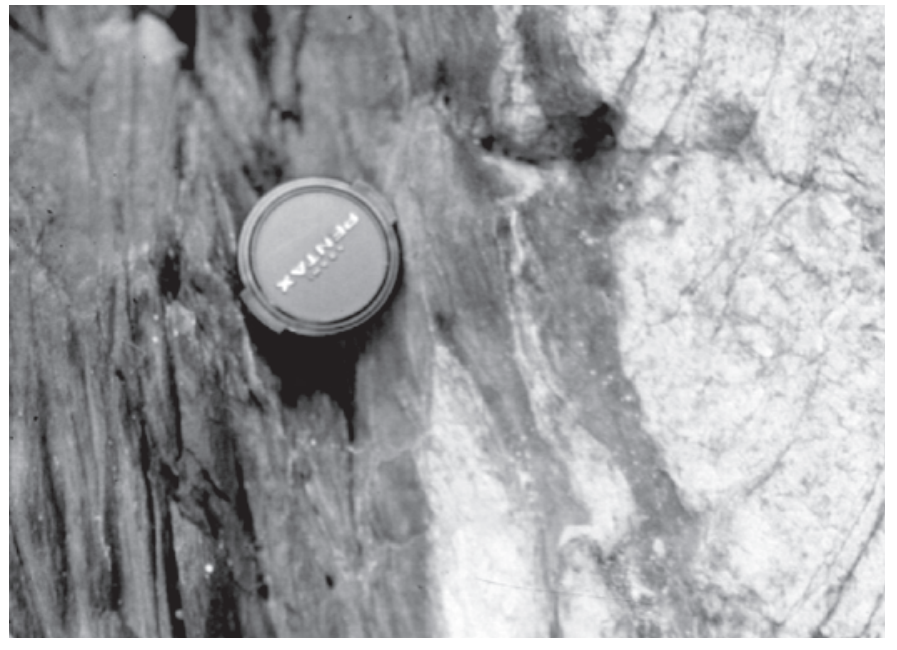

Figure 72. Basement rocks of the Blue Ridge province. The core of the anticlinorium in this area consists of Mesoproterozoic light granitic gneiss intruded by numerous dark metadiabase dikes that probably fed the basalt flows of the Neoproterozoic Catoctin Formation. Camera lens for scale. Photograph by William C. Burton (U.S. Geological Survey).

the Potomac River (lower left part of figure 73A). The bedrock ledge in the river and the mill ruins consist of quartzite. The sandy flood plain from here to Knoxville was the location of a "hobo jungle" during the Great Depression.

Just west of Lock 31, the poorly exposed trace of the Short Hill-South Mountain fault duplicates the stratigraphic sequence of the west limb of the Blue Ridge-South Mountain anticlinorium by placing phyllitic metasiltstone of the Harpers Formation ( $€ \mathrm{ch}$ ) over garnetiferous leucocratic granite (Yg) to the west. Drill core from a spot immediately north of the canal indicates that the fault is an early Paleozoic normal fault that was folded and reactivated as a thrust fault in the late 


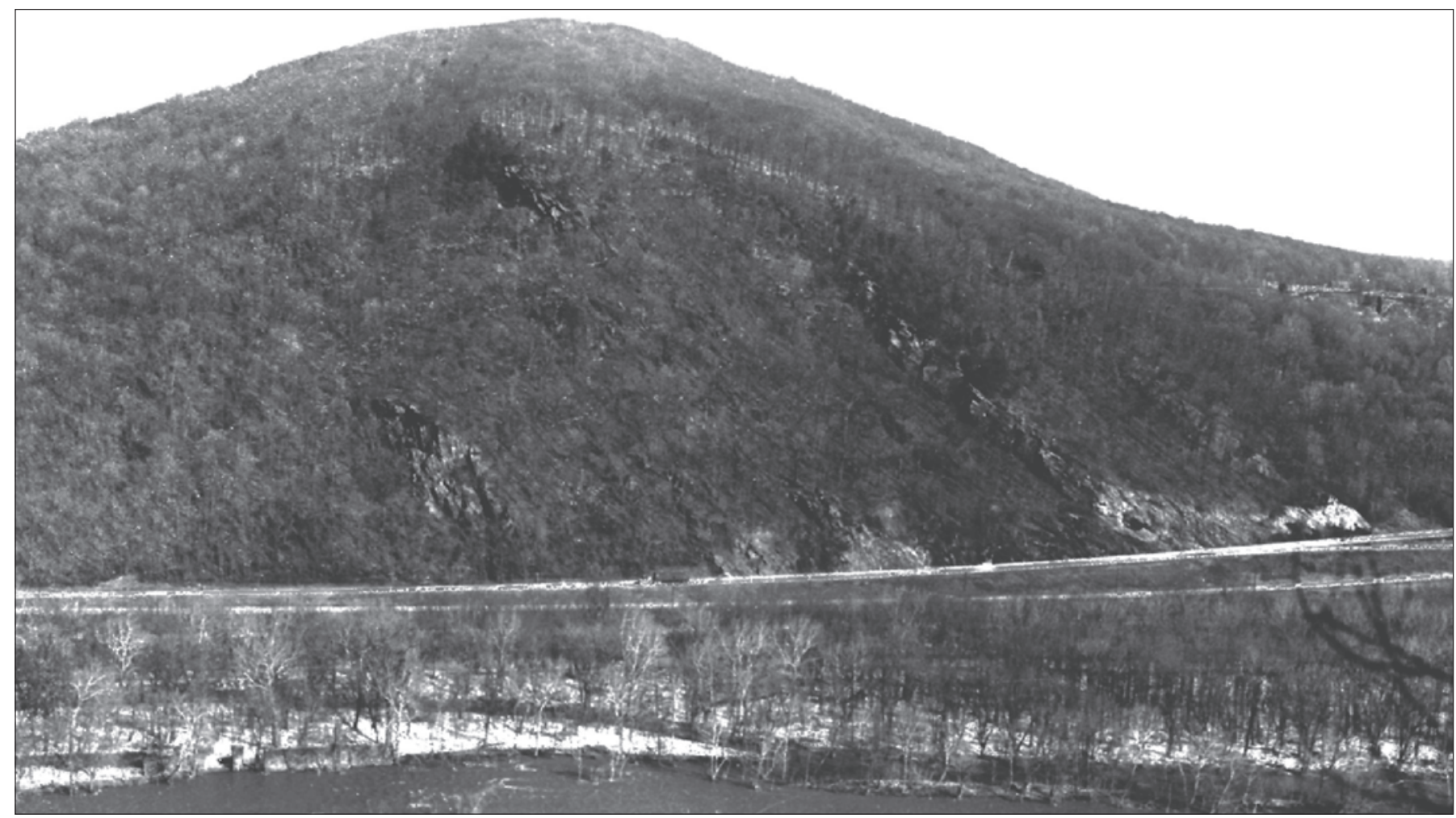

$\boldsymbol{A}$

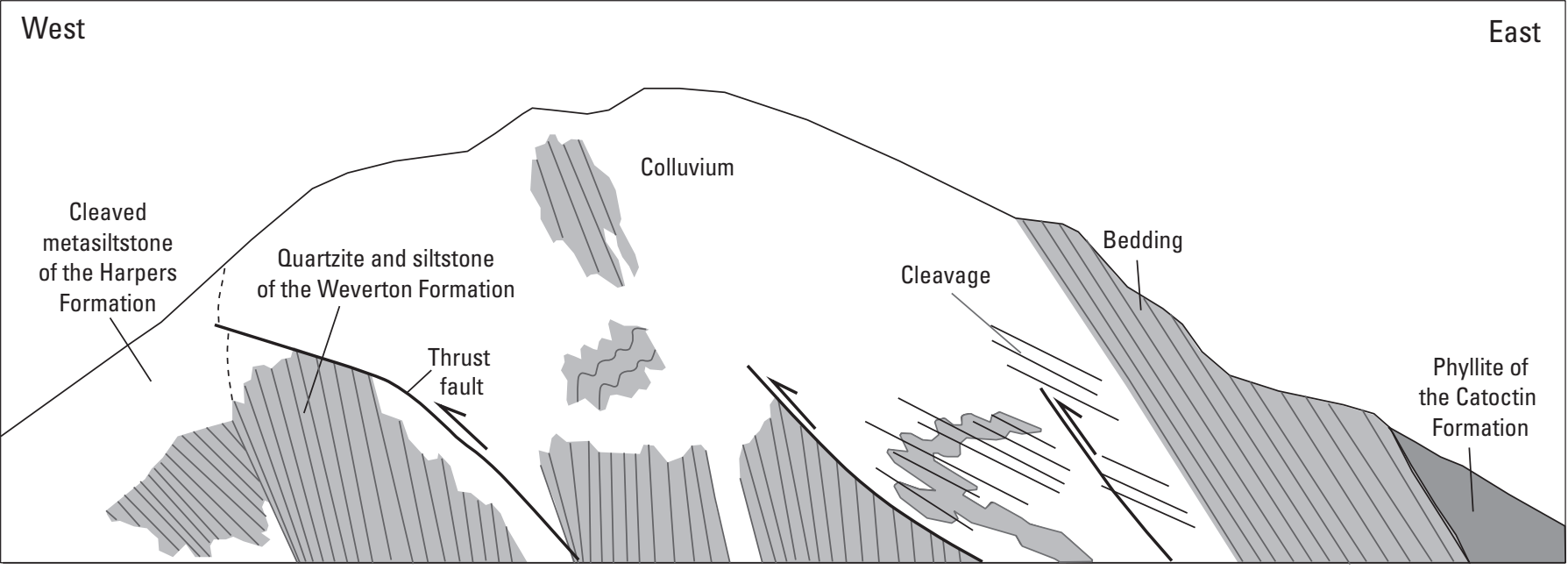

\section{B}

Figure 73. Weverton Cliffs at the southern end of South Mountain in Maryland. $A$, White rocks are outcrops of quartzite beds of the Lower Cambrian Weverton Formation. In the left foreground of the photograph are the stone ruins of the Weverton mills. $B$, Sketch of Weverton Cliffs showing geologic units and other features.

Paleozoic (Southworth and Brezinski, 1996a,b). This fault is unique to the region in that there is no other evidence of a normal fault and extensional event between the Neoproterozoic (760-542 Ma) and Jurassic (about 220-200 Ma) Periods.

From MM 58 westward to Harpers Ferry, W. Va. (MM 60.5 ), the rock sequence that is crossed from Lander to Weverton (granitic gneiss intruded by metadiabase dikes, overlain by metabasalt, quartzite, and metasiltstone) is repeated. Outcrops of gneiss and intrusive metadiabase dikes are covered with soot along the adjacent railroad tracks to the north, but the Mesoproterozoic ( $1 \mathrm{Ga}$ ) folded, light-colored, garnetiferous granite (Ygt) can be seen in fresh exposures nearby (fig. 75). The rust-colored massive body of rock exposed near MM 59 is a Jurassic diabase dike (Jd) that intruded the older rocks when North America was rifting apart to create the Atlantic Ocean; a pyroxene crystal in the diabase here was dated at $200 \mathrm{Ma}$ 


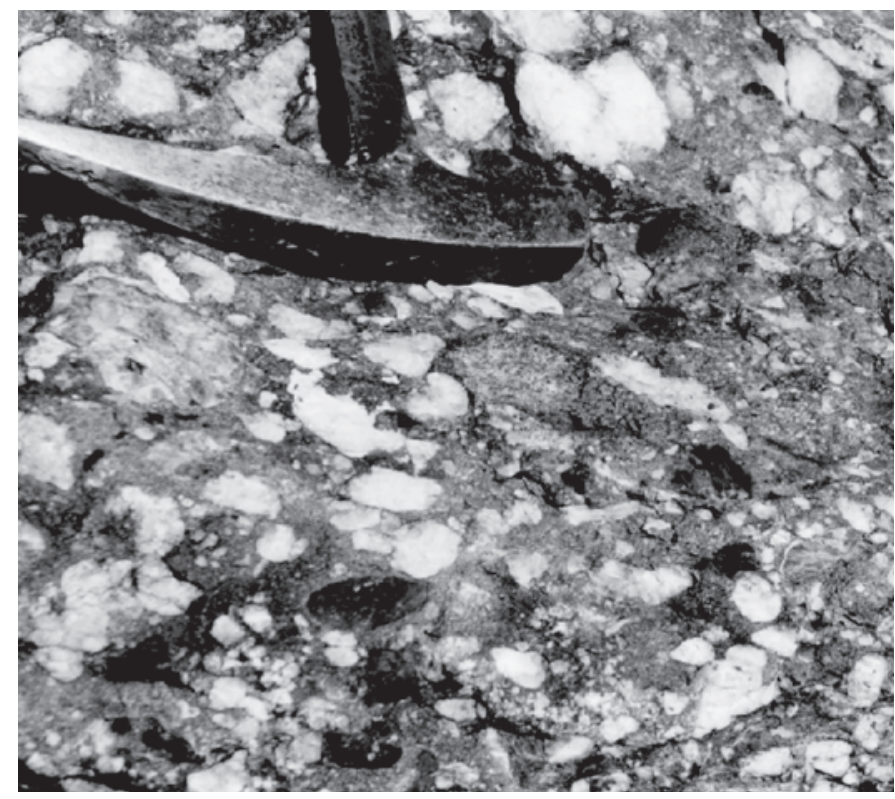

Figure 74. Polymictic conglomerate of the Lower Cambrian Loudoun Formation north of the Potomac River on the east flank of South Mountain. This unit was deposited locally stratigraphically above phyllite and metabasalt of the Neoproterozoic Catoctin Formation. The conglomerate may represent alluvial-fan and channel deposits that preceded the deposition of the quartz-rich sediments of the Lower Cambrian Weverton Formation. using the technique of analyzing the ratio of argon isotopes (Kunk and others, 1992).

The flat uplands above the bluffs in Maryland and Virginia resemble river terraces, but no such deposits have been found. Chips of Ordovician Ellicott City Granodiorite along the towpath near Lock 32 (about MM 60.5) suggest that some of the dimension stone was transported here from Ellicott City, $\mathrm{Md}$., as rough blocks that were dressed at the site.

The Harpers Ferry area is a spectacular water gap, described by Thomas Jefferson as "worth the voyage across the Atlantic" (Jefferson, 1982). A stereoscopic pair of aerial photographs (fig. 76) shows the three-dimensional perspective of the gorge created where the Potomac and Shenandoah Rivers converge to cross the Great Valley section into the Blue Ridge province (fig. 76). Maryland Heights and Blue RidgeElk Ridge are composed of erosion-resistant, hard quartzite and metagraywacke of the Weverton Formation. Exposures of folded and faulted rocks and coarse colluvium may be seen in the blufs above the river (figs. 77 to 80). Figure 81 shows the westernmost, southward-plunging, overturned anticline exposed during low-water conditions in the Potomac River (see figure 76). The crossbedded quartzite provides good examples of the overturned, folded strata (fig. 82). Much of the canal across this section was excavated in this quartzite. According to local folklore, workers built fires on the quartzite bedrock and then quenched them with cold water hauled from the river; this process shattered the quartzite. A tunnel was required to accommodate both the canal and the $\mathrm{B} \& \mathrm{O}$ Railroad. The west portal to the tunnel (MM 60.5) is along the near-vertical contact between the Weverton Formation and the

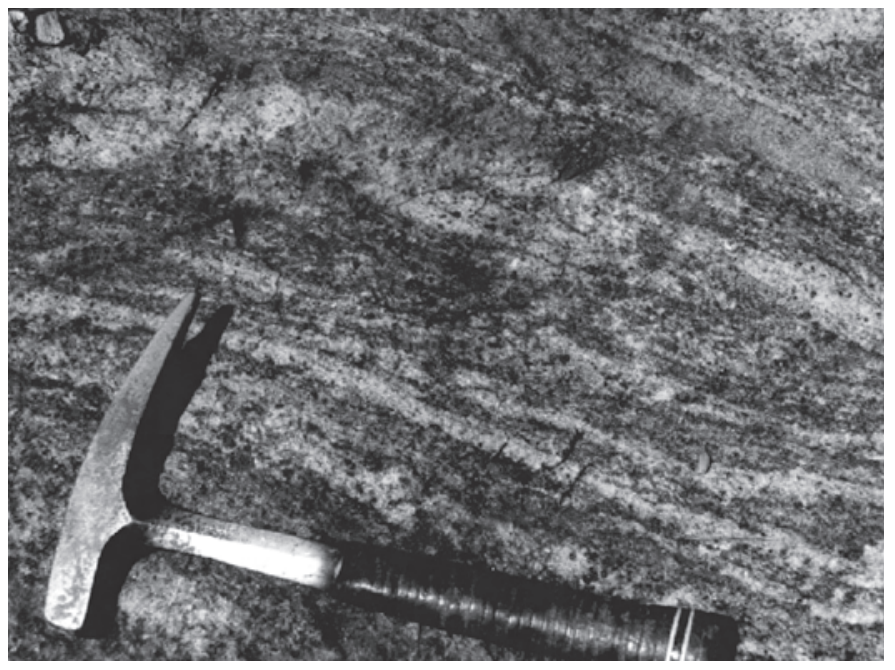

$\boldsymbol{B}$

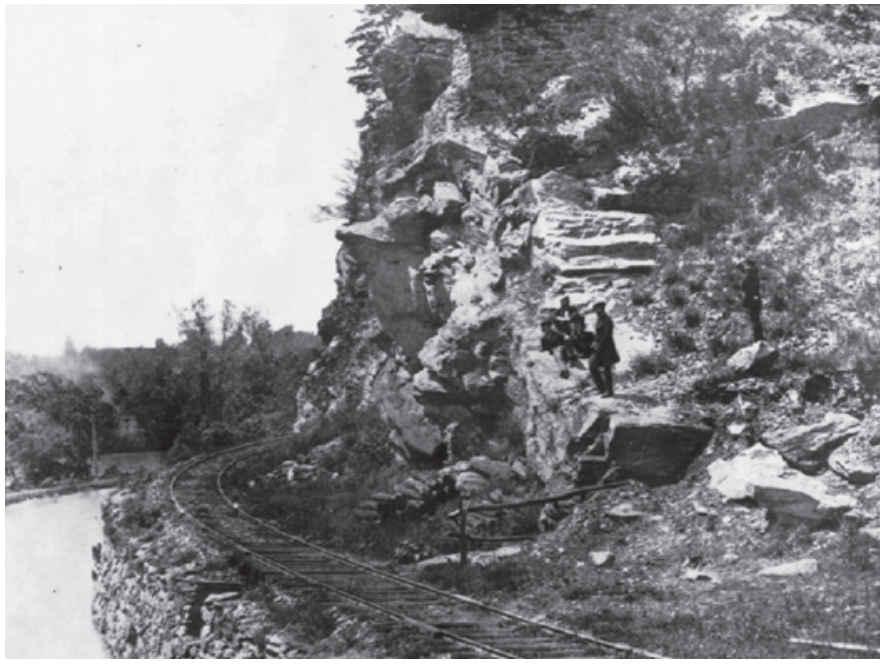

Figure 75. Mesoproterozoic rocks between Weverton, Md., and Harpers Ferry, W. Va. A, Historical photograph (date unknown) showing bluffs of Mesoproterozoic granitic gneiss along the B\&O railroad and C\&O Canal west of Weverton. These rocks are now covered with soot. Photograph courtesy of the National Park Service. $B$, Fresh exposure of garnetiferous leucocratic granite in the roadcut of southbound U.S. Route 340, north of Potomac River. Uranium-lead dating of zircon crystals (Aleinikoff and others, 2000) shows that this granite formed over 1 billion years ago and was then metamorphosed and folded during the Grenville orogeny. Shiny graphite and almandine garnet in this rock suggest that an older suite of metasedimentary rocks melted to form the granite. 

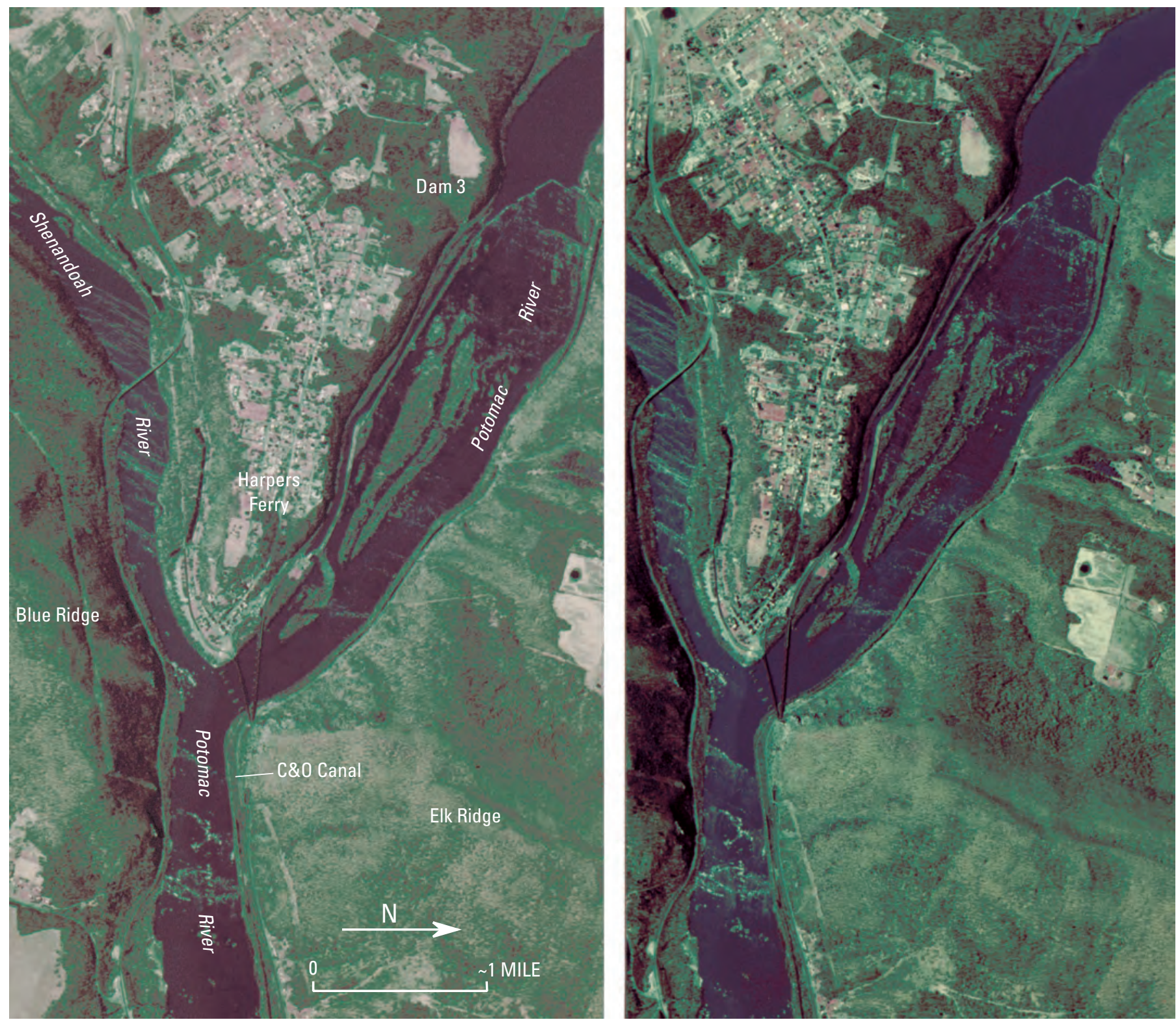

Figure 76. Stereoscopic pair of aerial photographs and sketch centered on Harpers Ferry, W. Va., showing the Potomac River gorge and water gap.

stratigraphically overlying Lower Cambrian Harpers Formation $\left(€_{c h}\right)$.

The point of land at the confluence of the Potomac and Shenandoah Rivers was subjected to extensive erosion during the numerous floods that affected the area. Historical photographs (Hahn, 1995) show many structures of the canal at this location that no longer exist because they were destroyed by flooding.

From Harpers Ferry westward to Lock 35 (MM 62.2), the rocks consist of highly cleaved and folded metasiltstone of the Harpers Formation (fig. 83). The canal along this stretch was excavated locally in the metasiltstone and drill holes can still be seen in the outcrops that served as canal berms (fig. 84A). Slabby, consolidated colluvium was used to build walls around the outcrops. A good example of bedding and cleavage may be seen in an outcrop of Harpers Formation along the berm of the canal near MM 61 (fig. 84B). Locally, the cleavage is folded by later folding or faulting, such as seen above the canal near MM 61.1 (fig. 85).

Lumpy, swirly patterns may be seen in blocks of limestone from the Lower Cambrian Tomstown Formation in Locks 34 to 36 . These features are bioturbation structures that formed when marine organisms mixed the sediments while they were still soft and unconsolidated. The few blocks of white Keedysville marble (informal name) in Locks 34 to 36 are from the Bolivar Heights Member at the base of the Tomstown Formation. The Keedsyville marble originally was a limestone that became detached from the underlying Lower Cambrian Antietam Formation and recrystallized as it moved along a regional fault (Brezinski and others, 1996). All of the 
West

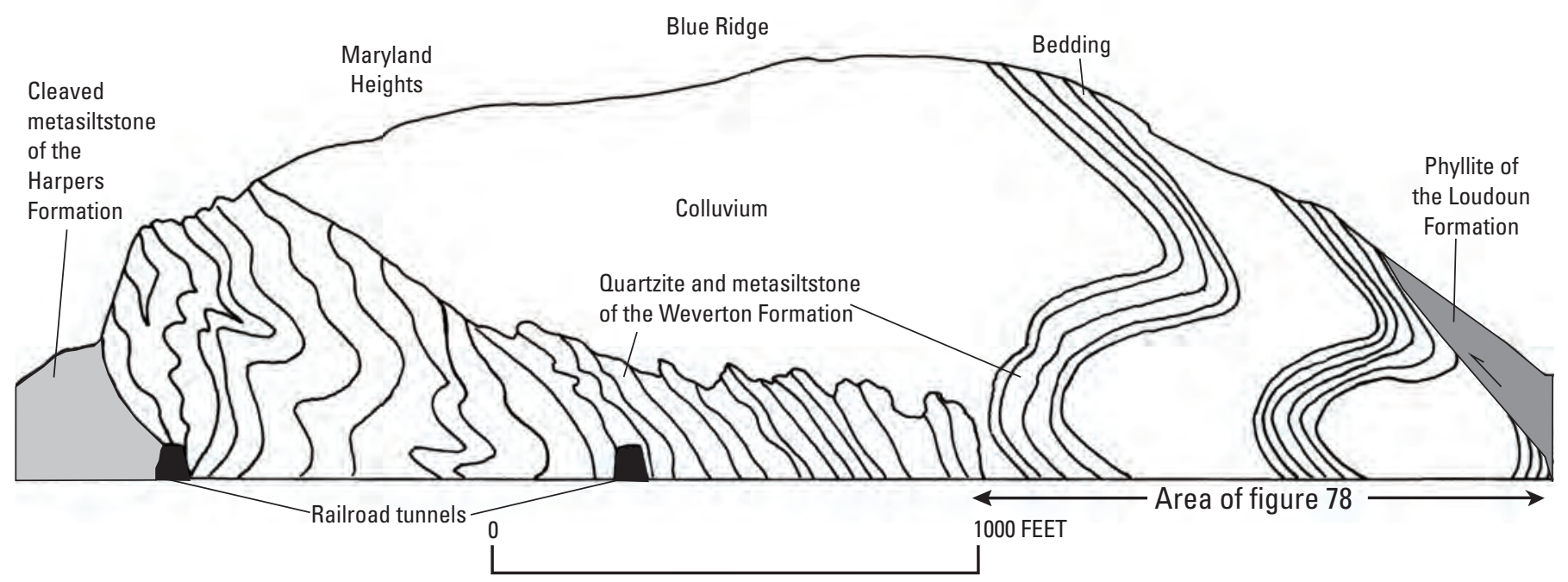

Figure 77. Sketch of the bluffs of Elk Ridge north of the C\&O Canal showing folded quartzite beds within the Lower Cambrian Weverton Formation that comprise the overturned west limb of the Blue Ridge-South Mountain anticlinorium. The two large folds on the east side in the Buzzard Knob Member are shown in figure 78.

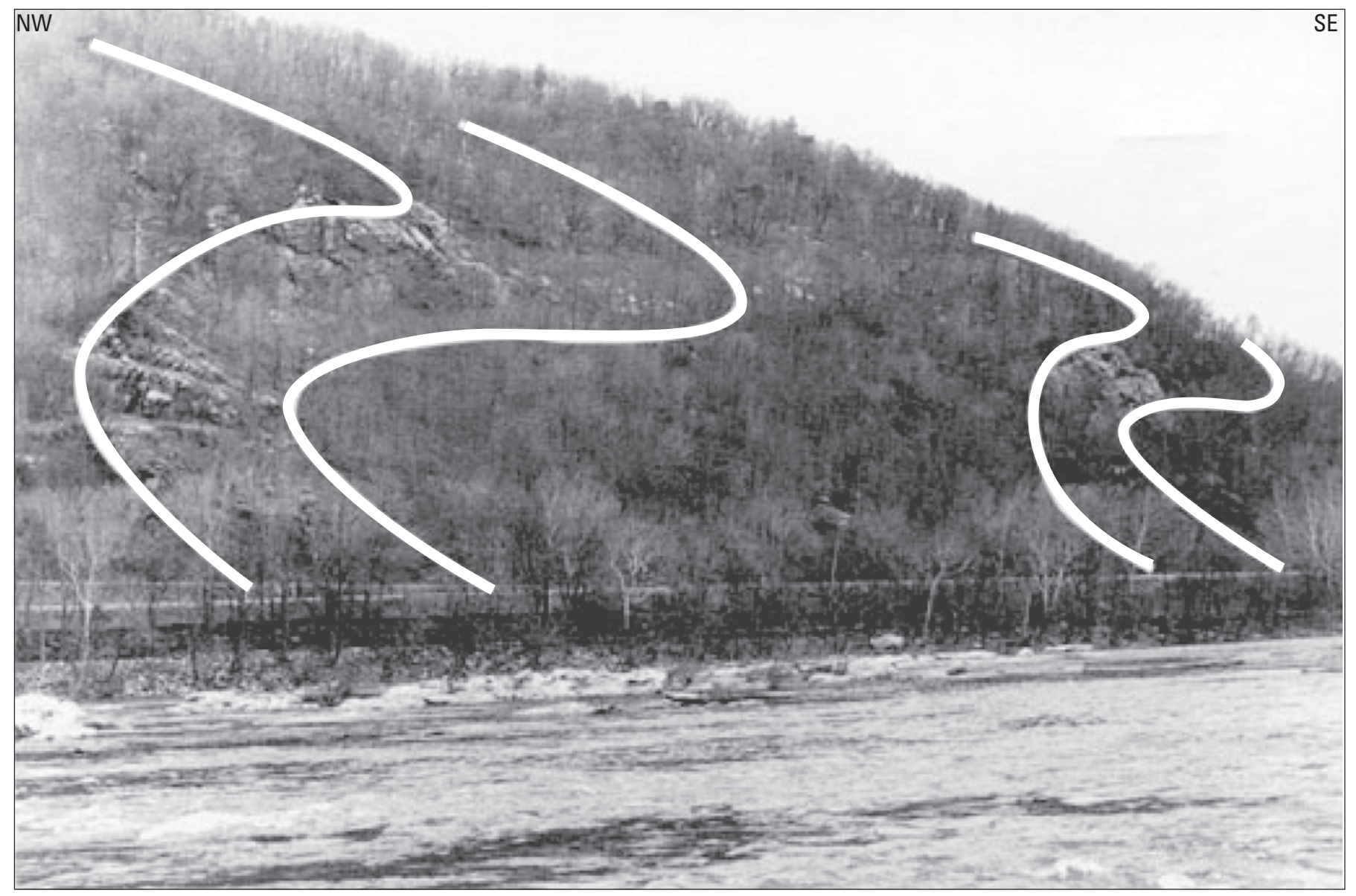

Figure 78. View of eastern end of Elk Ridge showing overturned pairs of anticlines and synclines (traces shown by white lines) in quartzite of the Lower Cambrian Buzzard Knob Member of the Weverton Formation. 


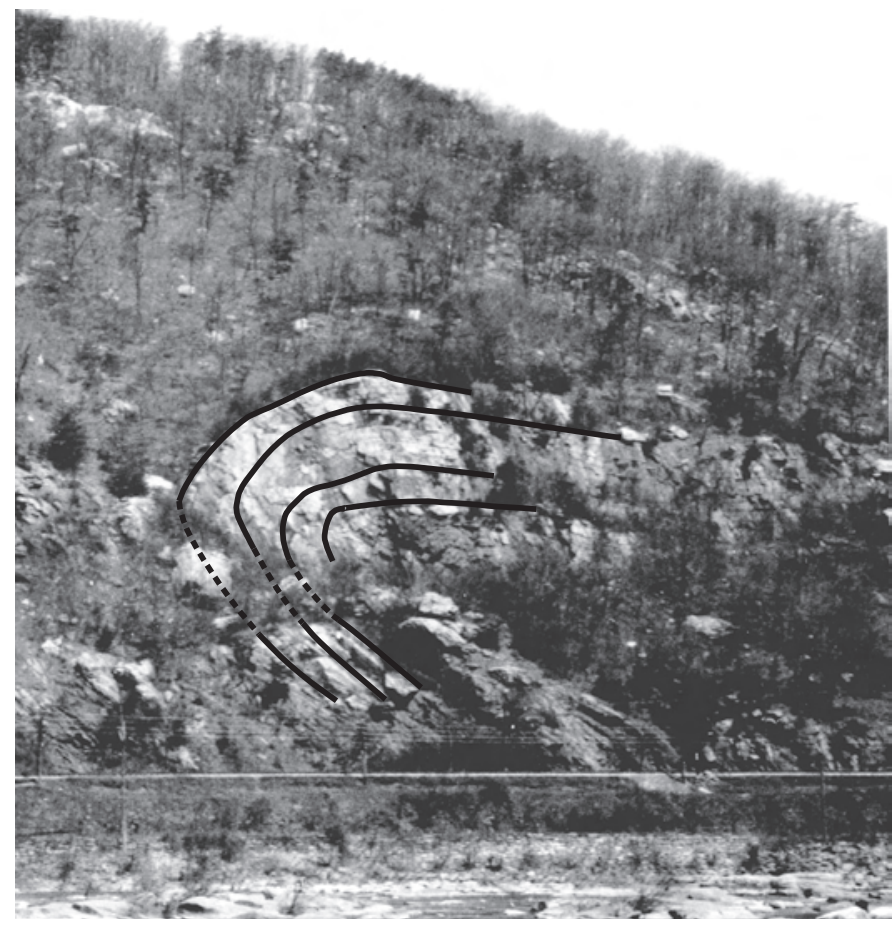

Figure 79. Historical photograph (around 1912) of the westernmost overturned anticline of quartzite in the Lower Cambrian Buzzard Knob Member of the Weverton Formation as shown in figure 78. Photograph by George W. Stose (U.S. Geological Survey).

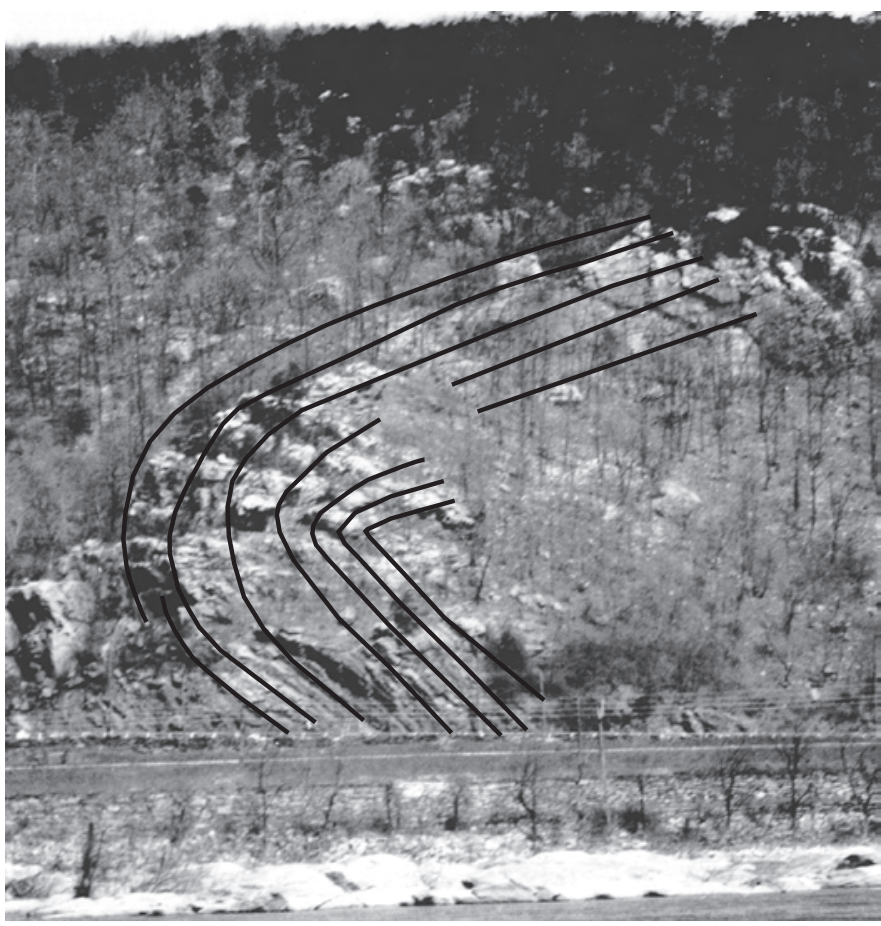

Figure 80. Historical photograph (around 1912) showing the easternmost overturned anticline in quartzite of the Lower Cambrian Buzzard Knob Member of the Weverton Formation as shown in figure 78. Photograph by George W. Stose (U.S. Geological Survey).

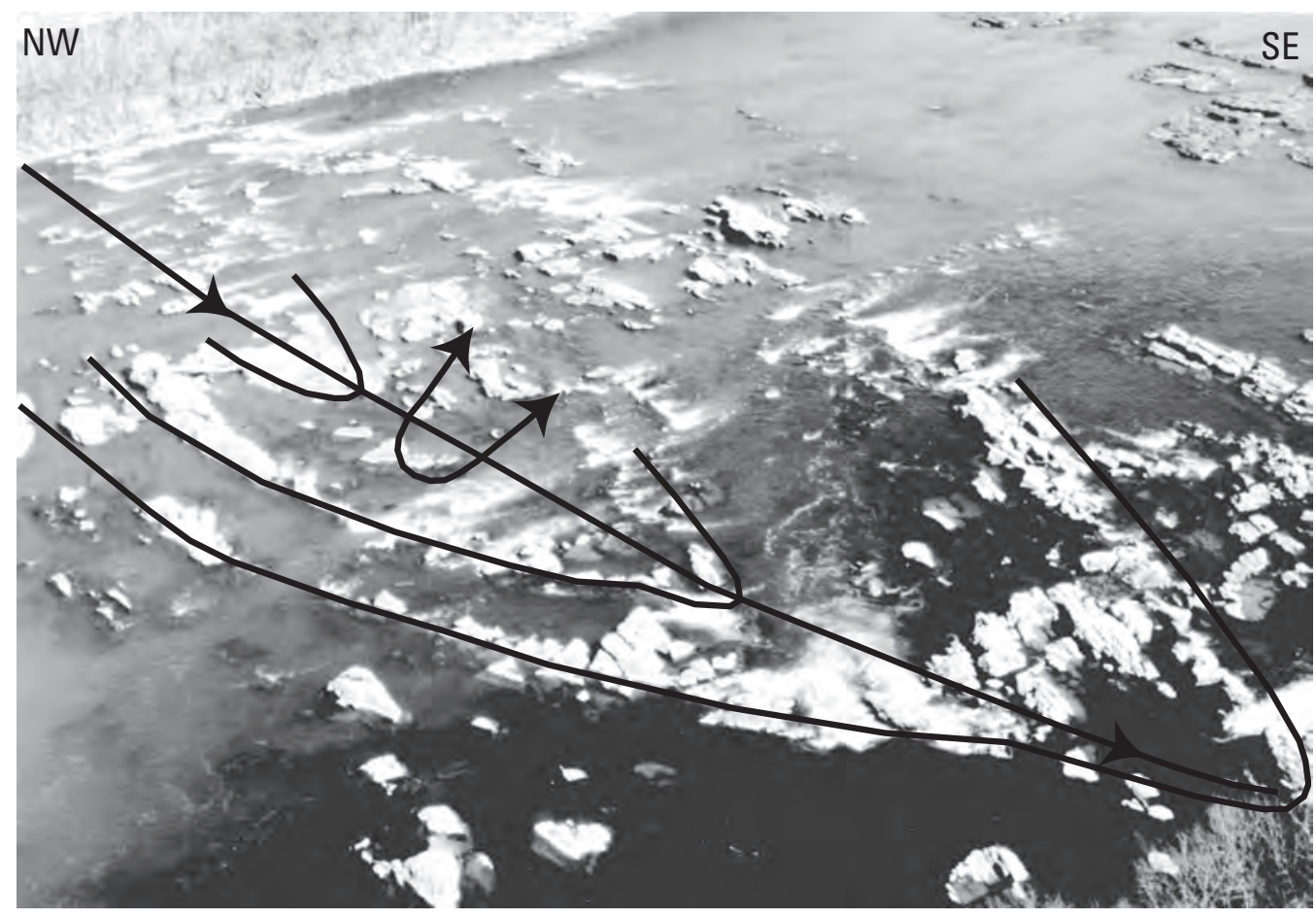

Figure 81. View of the westernmost overturned anticline shown in figure 80 . The anticline plunges southward toward the Potomac River and can be seen in the river bed during low-water conditions from Loudoun Heights, Va., as well as from the air (fig. 76). 

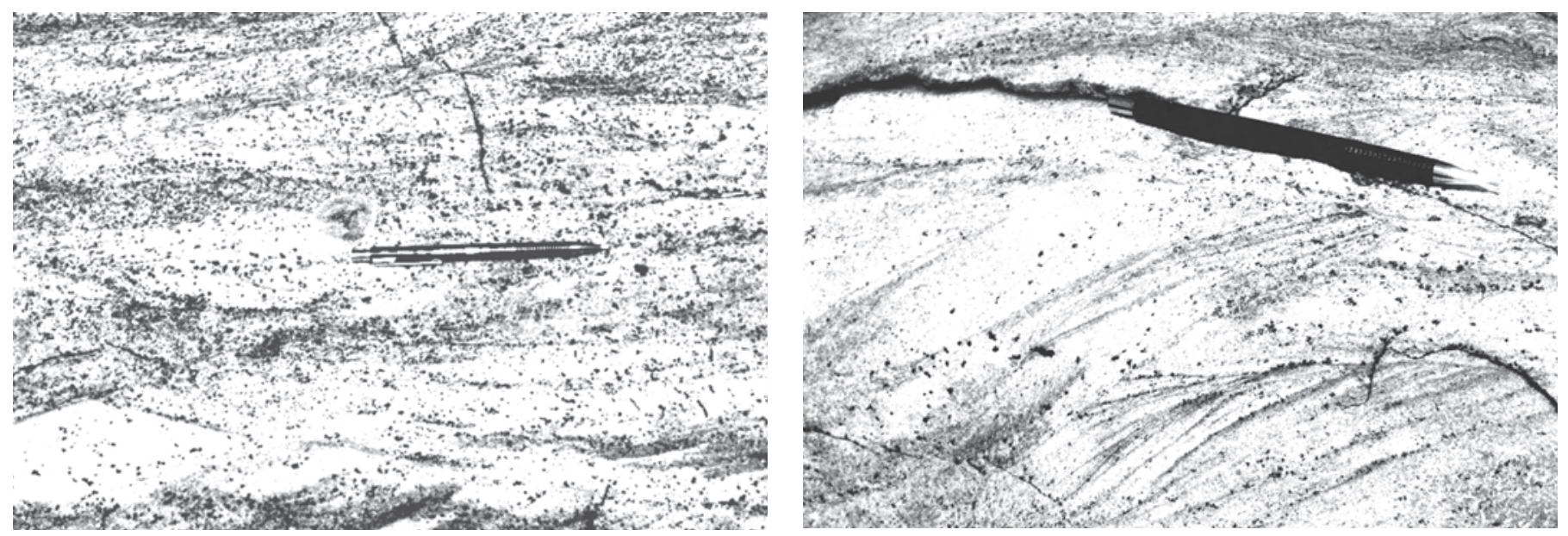

Figure 82. Crossbedding in quartzite of the Lower Cambrian Weverton Formation at Maryland Heights. Crossbeds are defined by layers of dark heavy minerals in light quartz sand. The truncation of the beds is used to determine whether the rocks are upright or overturned. $A$, Upright beds. $B, O$ verturned beds. Mechanical pencil for scale in both photographs.

WEST
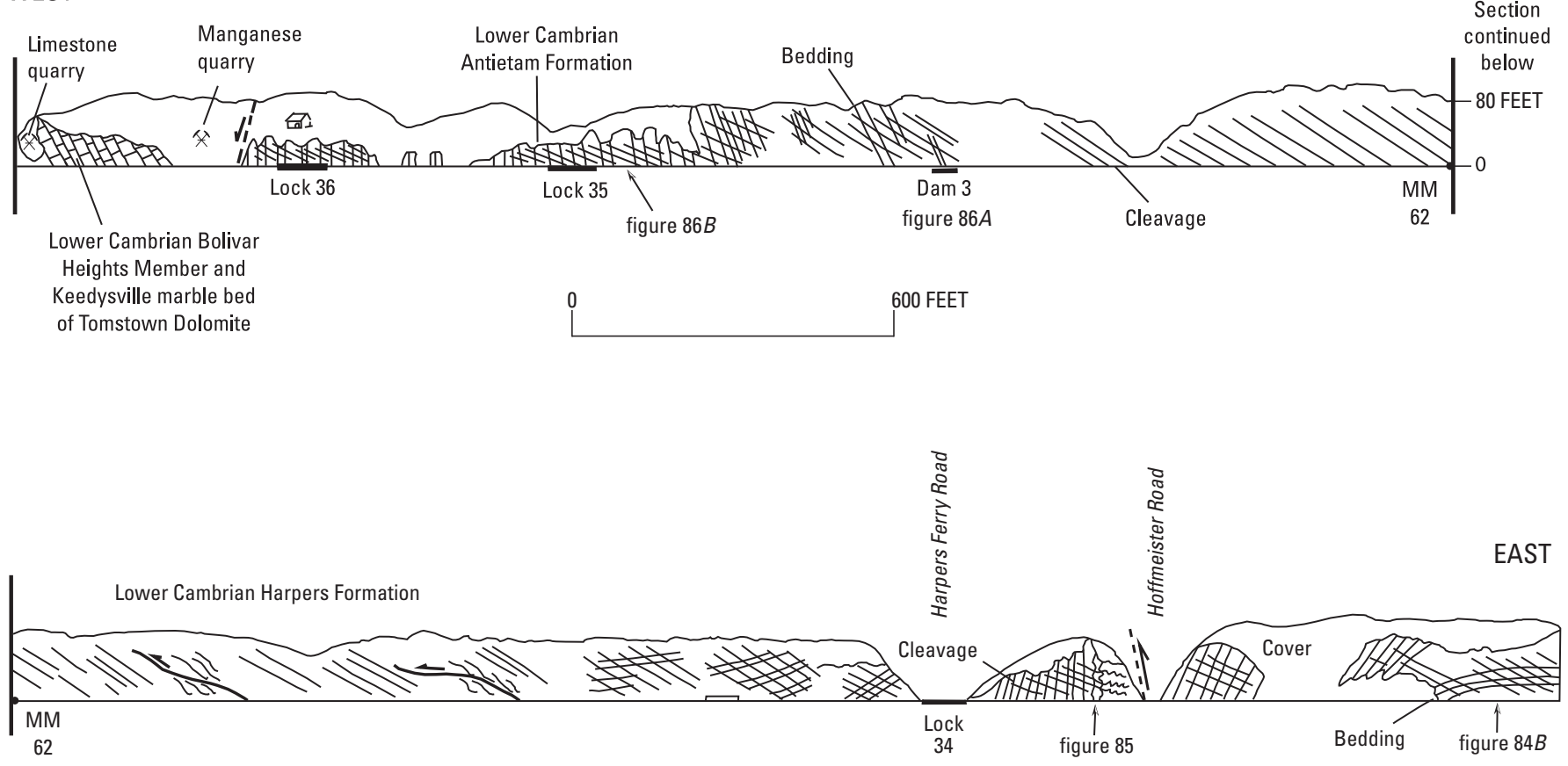

Figure 83. Geologic sketch of the bluffs from about MM 61 to the Great Valley west of Lock 36 (MM 62.5). Rocks of the Lower Cambrian Harpers Formation show penetrative cleavage, folds that are defined by bedding, and folded cleavage by deformation near thrust faults. The rocks of the Lower Cambrian Antietam and Tomstown Formations are oriented either vertically or steeply dipping (overturned) to the southeast. 

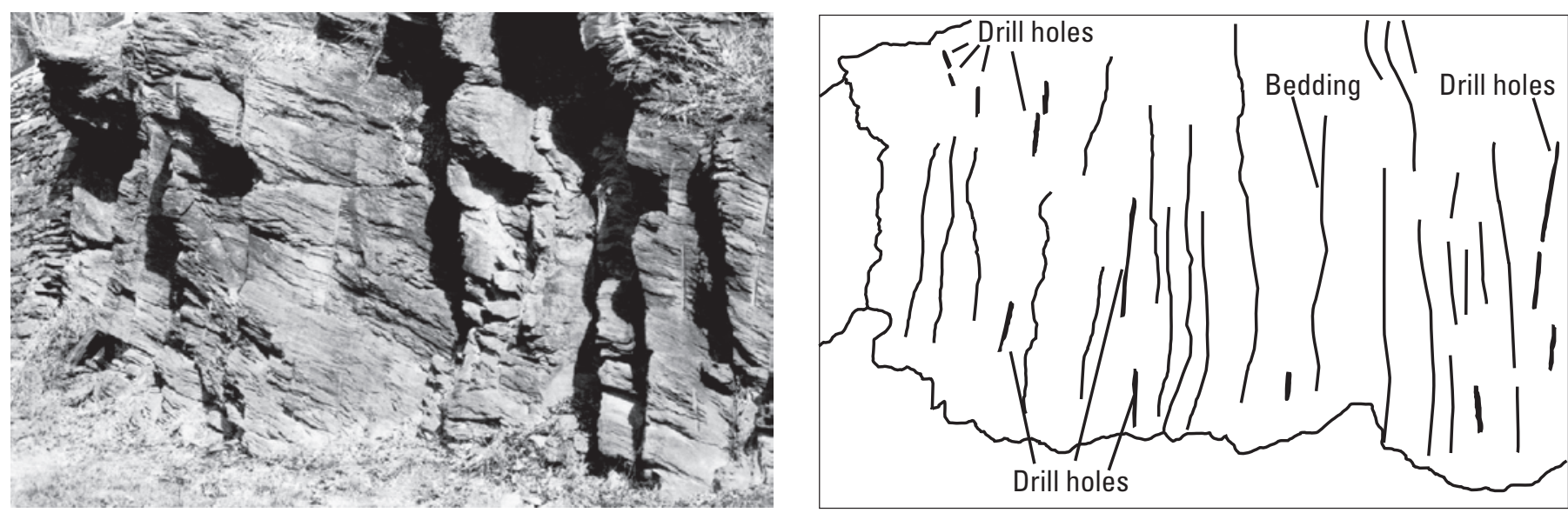

$\boldsymbol{A}$
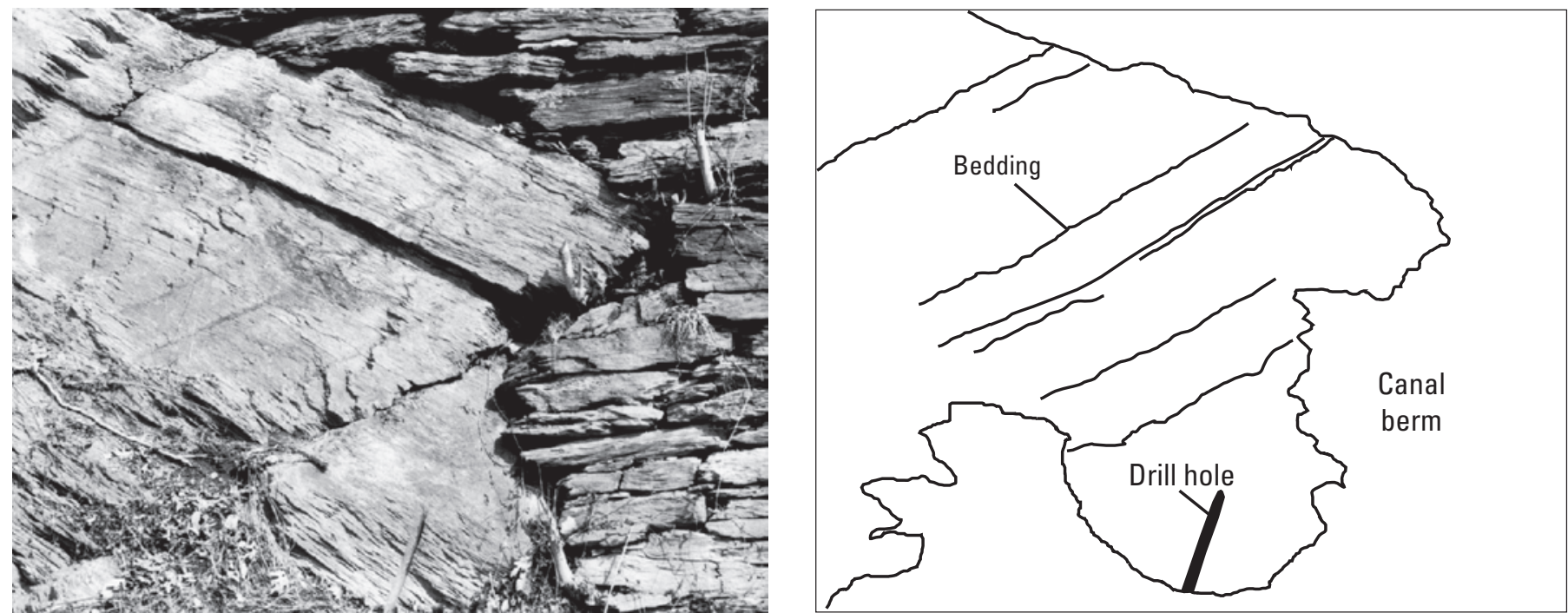

\section{$\boldsymbol{B}$}

Figure 84. Folded and cleaved metasiltstone of the Lower Cambrian Harpers Formation, which was drilled and blasted to excavate the canal near MM 61. A, Pervasive slaty cleavage dips at a low angle to the southeast, but bedding and drill-hole scars are nearly vertical. $B$, In another outcrop near $A$, bedding dips to the northwest. The rightmost one-third of the photograph shows slabs of Harpers Formation stacked to construct the berm of the canal.

overlying rocks of the Great Valley section were transported westward along this fault surface for some unknown distance. The fault was active early in the tectonic history of the region because it has been folded with the anticlinorium and is overturned and dips to the east.

From Lock 35 (MM 62.3) to Dam 3, stone berms were constructed to elevate the canal and towpath above the flood plain. Good exposures of cleaved metasiltstone interbedded with metasandstone at the transitional contact of the Harp- ers and stratigraphically overlying Antietam Formation (€ca) (fig. 86) may be seen near the remains of Dam 3 and behind Lock 35. The dark lines with raised centers that are perpendicular to bedding in metasandstone of the Antietam Formation are the remains of the trace fossil Skolithos linearis. On top of the hill of the meander bend above Lock 36 is the strategic location of Fort Duncan, which was built by Union forces in 1862 to defend Harpers Ferry. The foundation of the fort's ramparts is still preserved. 


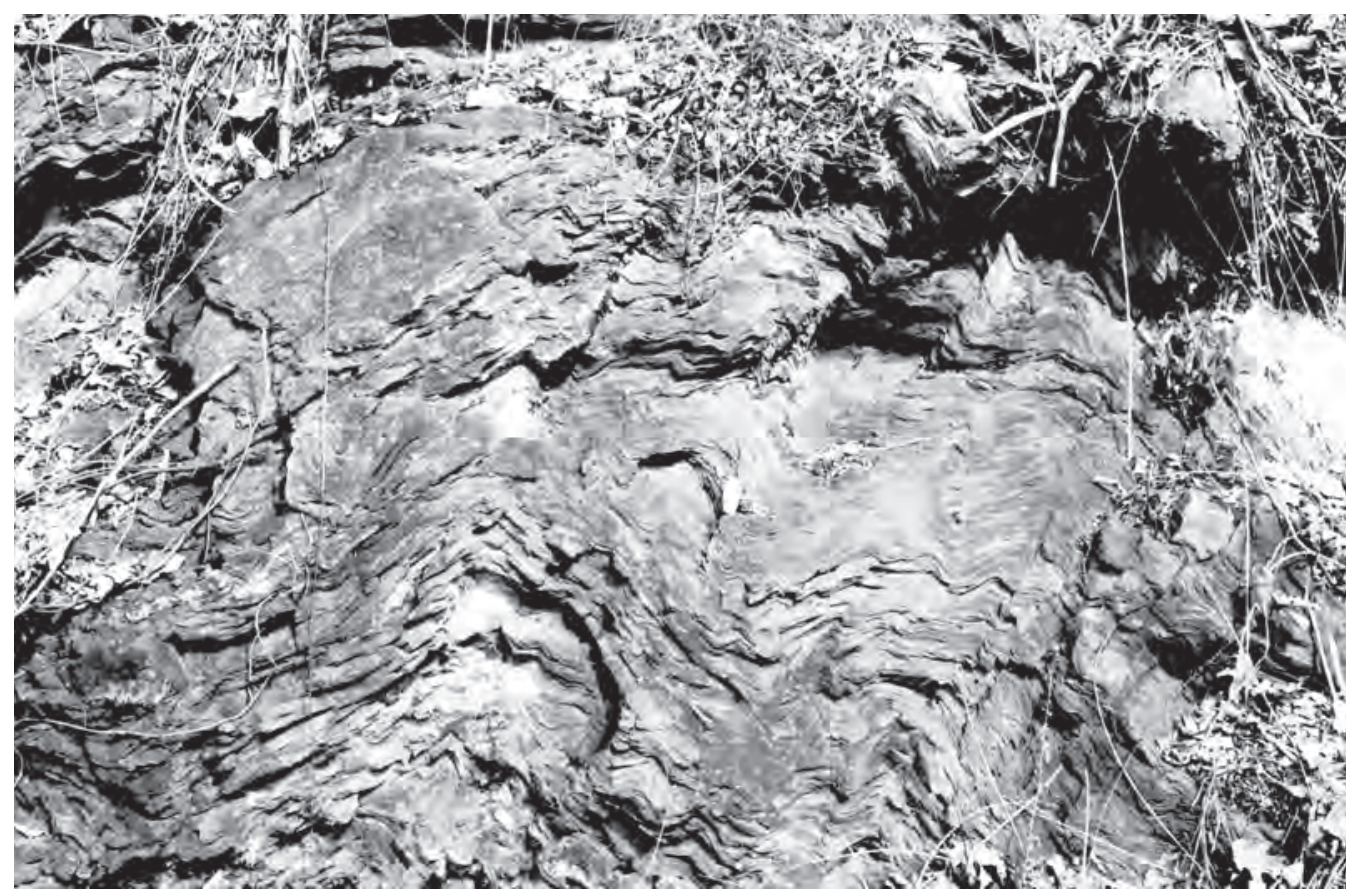

Figure 85. Cleavage (nearly horizontal) in metasiltstone of the Lower Cambrian Harpers Formation folded as the result of motion along a thrust fault. Spaced crenulation cleavage dips to the northwest, parallel to the late fold axes. Outcrop is west of Hoffmeister Road, immediately north of the canal near MM 61.5. Pocket knife in center for scale.
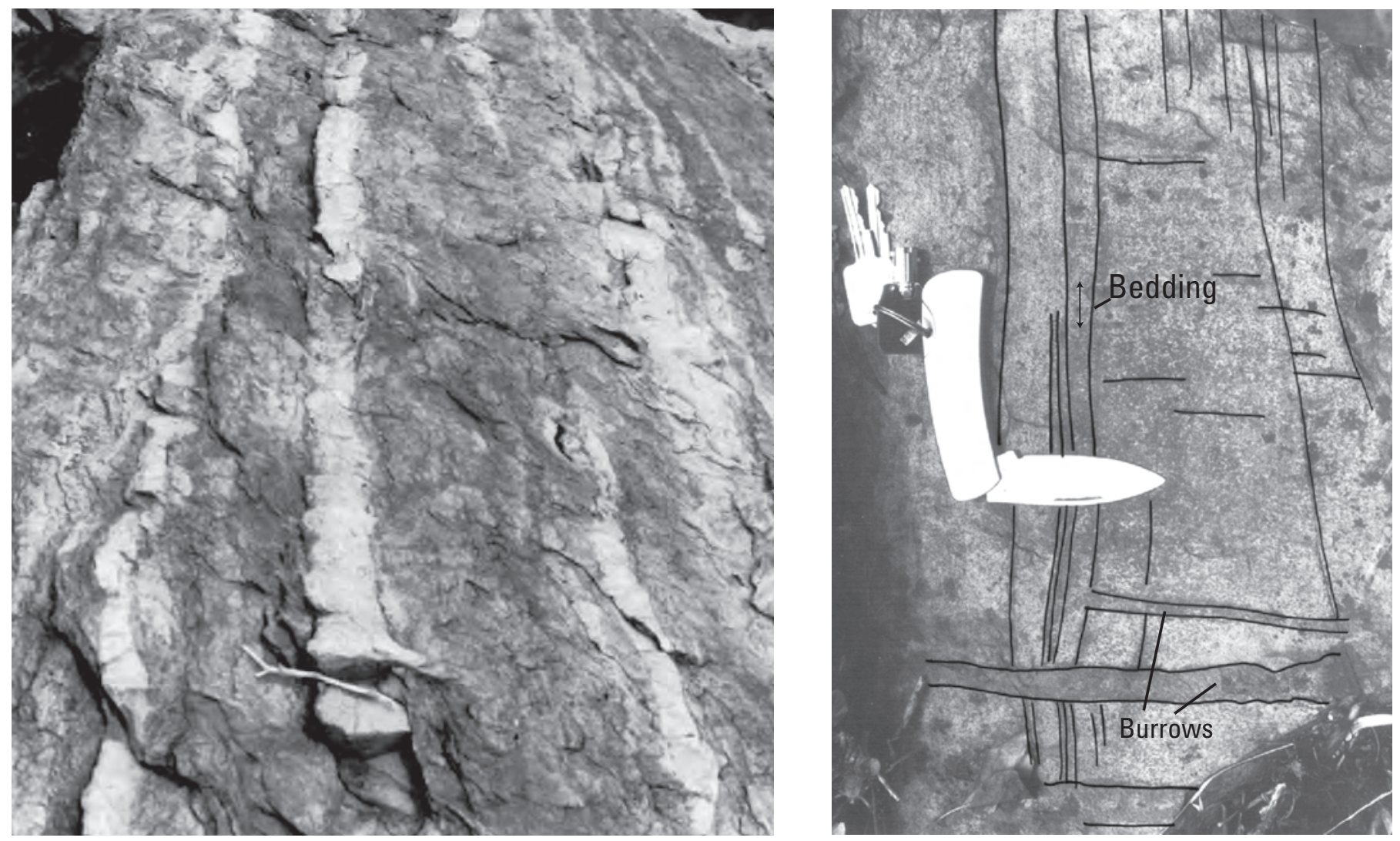

Figure 86. Outcrops of Lower Cambrian Harpers and Antietam Formations. A, Outcrop showing the transition from metasiltstone of the Harpers Formation upward into metasandstone of the Antietam Formation between Dam 3 and Lock 35, just west of MM 62. Here, 2- to 3-inch-thick beds of clean metasandstone are interbedded with darker metasiltstone. B, Outcrop of Antietam Formation showing dark lines (perpendicular to the laminated bedding) which indicate the presence of the trace fossil Skolithos linearis (tubular worm burrows in sand that were filled in with finer grained silt in shallow water). 


\section{Valley and Ridge Province-Great Valley Section}

\section{Fort Duncan to McCoys Ferry (MM 62.5 to MM 110)}

\section{Access Points}

Pleasantville (Harpers Ferry and Hoffmeister Roads)

Dargan Bend

Lock 37

Antietam

Lock 38

Snyders Landing

Taylors Landing

Dam 4

Charles Mill Road

Falling Waters Road

Williamsport

Dam 5

Two Locks

Four Locks

McCoys Ferry

\section{Introduction}

The Great Valley section (locally called the Shenandoah Valley in Virginia, Hagerstown Valley in Maryland, or Cumberland Valley in Pennsylvania) of the Valley and Ridge section is the broad area of low relief between the mountainous regions of the Blue Ridge province to the east and the remainder of the Valley and Ridge province (west of the North Mountain thrust fault) to the west (fig. 87 and plate 10). Because the Great Valley is underlain primarily by limestone and dolomite, caves and sinkholes are abundant (see fig. 15).

Structurally, the Great Valley is a large syncline called the Massanutten synclinorium, named after Massanutten Mountain in the core or center of the fold where the youngest rocks are found. The youngest rocks along the C\&O Canal in this province belong to the Middle and Upper Ordovician Martinsburg Formation (Om), which consists primarily of shale with lesser amounts of sandstone. The eastern flank of the Massanutten synclinorium generally dips southeastward rather than westward toward the center of the syncline; the overturned fold is a limb of the Blue Ridge-South Mountain anticlinorium. Westward across the Great Valley, the rocks become less intensely folded and faulted.

The western edge of the Great Valley is marked by the North Mountain fault, which places Cambrian and Ordovician carbonate rocks over younger shale and sandstone of the remainder of the Valley and Ridge province. The rocks of the Great Valley section, Blue Ridge province, and Piedmont province have been transported tens of miles westward along this fault.

\section{Fort Duncan to Antietam Creek (MM 62.5 to MM 69)}

The bedrock along the meander bends of the Potomac River is the Lower Cambrian Tomstown Formation $(€ t)$ (plate 10). Between MM 63 and MM 63.5, the outcrop of dark-gray dolomite is the type section of the Fort Duncan Member ( $€ t f)$ of the Tomstown. Some of the limestone near MM 63.4 is assigned to the Bolivar Heights Member ( $€$ tbh) of the Tomstown Formation. The type section of the Bolivar Heights Member is along the CSXT railroad tracks about 3 mi to the south in West Virginia. The red "terra rosa" soil exposed here characterizes the residuum that developed from the weathered carbonate rock.

Between MM 63.5 and 65.2, shale and thin sandstone of the Lower Cambrian Harpers Formation ( $€ \mathrm{ch})$ are exposed. By strict geologic definition, the Harpers actually is part of the Blue Ridge province; therefore, along this stretch, the boundary between the Blue Ridge province and Great Valley section is crossed twice. The lime kiln at MM 65.2 burned high-calcium limestone from the Bolivar Heights Member, which was quarried from 1876 to 1910 just to the west (fig. 88). A sinkhole filled with colluvium consisting of sandstone blocks of the Lower Cambrian Antietam Formation in a red-brown mud and clay matrix is located near the northeastern part of the quarry. Blocks of the sandstone and fragments of the limestone contain dark, nodular manganese that was discovered here during excavation of the canal and then was quarried and used to make steel (Hahn, 1985). The locations of additional small quarries to the north were all confined to the Bolivar Heights Member because the overlying Fort Duncan Member was not suitable for the needs of the lime kiln operators.

Near MM 66, riprap fill for the towpath 6 contains blocks of yellow jasper (a variety of quartz) that is usually found near the contact between the Antietam and Tomstown Formations. The jasper was prized by Native Americans for making tools.

The Bolivar Heights Member was quarried in order to construct Lock 37 (Mountain Lock) to the north. The weathered surface of the cut stone has a notable zigzag pattern (see figure 32). These structures resulted when the small dolomitized burrows within individual beds of limestone were folded and aligned along penetrative cleavage. Outcrops near MM 67.5 show a similar relationship of bedding, cleavage, and the distorted burrows (fig. 89).

The collapse breccia and calcium-carbonate-rich tufa deposits of the Fort Duncan Member are exposed on the bluff near MM 68 (fig. 90). Just west of MM 68, within the upper part of the Bolivar Heights Member, is a tight fold where bedding is obscured by cleavage. This cleavage is well developed within the limestone of the Bolivar Heights Member (see figures 32 and 89), but is absent within the dolomite of the overlying Fort Duncan Member. A little farther to the west are 
Valley and

Ridge province

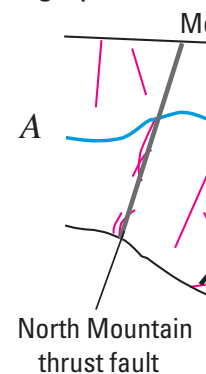

McCoys Ferry, Md.
Great Valley section of the

Valley and Ridge province

EXPLANATION

(for parts $A$ and $B$ )

Devonian rocks, undivided

Silurian rocks, undivided

Ordovician rocks, undivided-Form lines indicate trend of formational contacts

O€c Conococheague Limestone (Lower Ordovician to Upper Cambrian)

o€ Ordovician and Cambrian rocks, undivided

$€$ Cambrian rocks, undivided-Form lines indicate trend of formational contact

€cah Antietam and Harpers Formations, undivided (Lower Cambrian)

$€ c w$ Weverton Formation (Lower Cambrian)

DE Devonian to Cambrian rocks, undivided

$€ Z I c$ Loudoun and Catoctin Formations, undivided (Lower Cambrian and Neoproterozoic)

Contact-Dashed where inferred

Fault-Dashed where inferred. Arrows show relative motion

Fold axis - Showing trace only

Province or section boundary

0

5 MILES

$A$

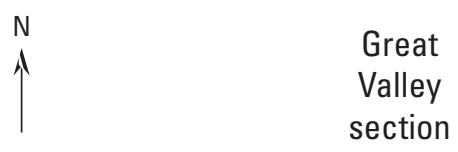

W. Va.
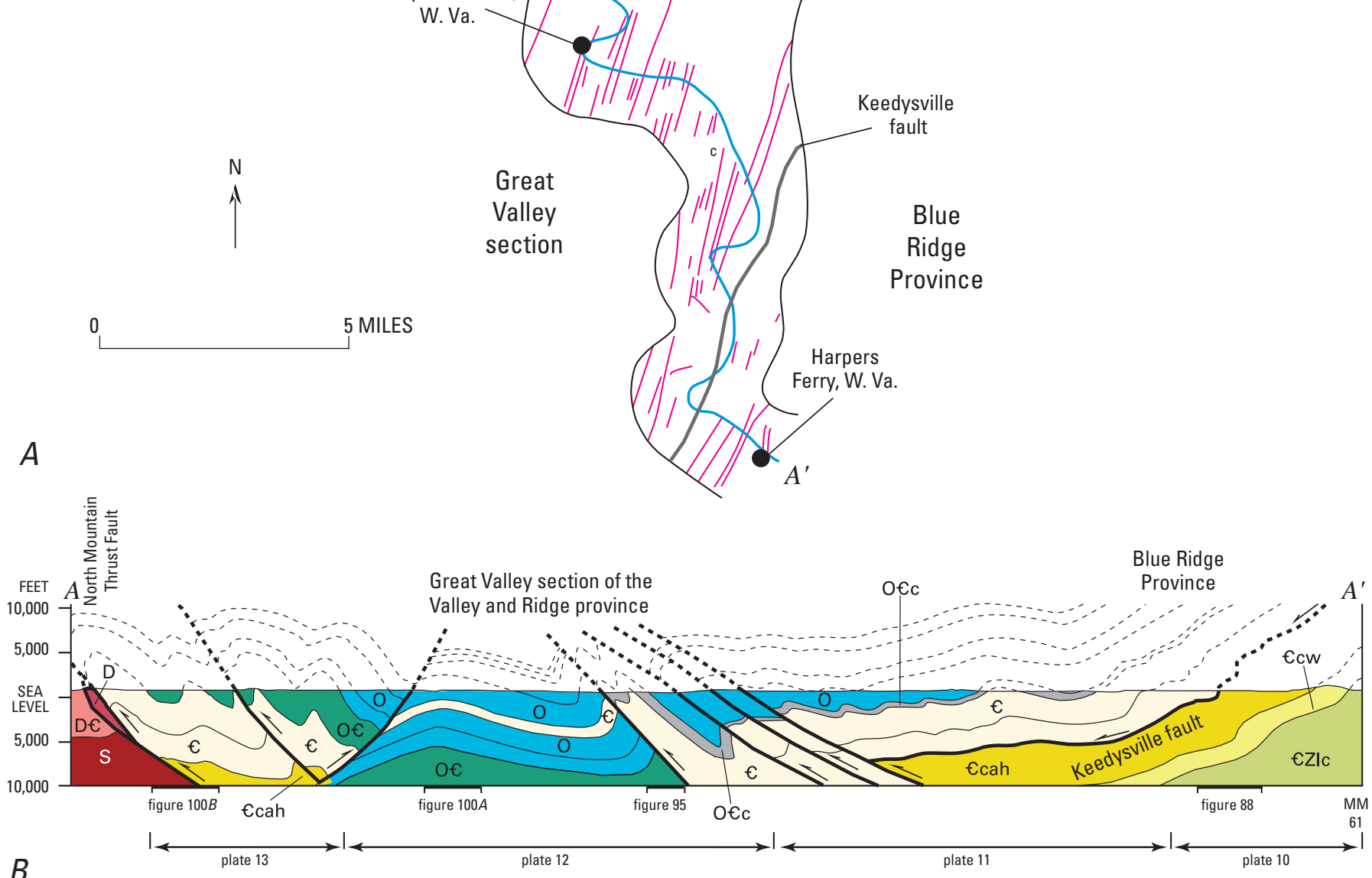

Figure 87. Generalized structure map and cross section of a portion of the C\&O Canal National Historical Park and Potomac River corridor as it crosses the western part of the Blue Ridge province and the Great Valley section of the Valley and Ridge province. $A$, Structure map showing fold axes and major faults. $B$, Cross section showing folds, faults, and other features from west of Harpers Ferry, W. Va., westward to the North Mountain fault. See plates 10 to 13 for detailed geologic maps of this portion. Geologic units shown in cross section are generalized from the geologic map shown on plate 1. 


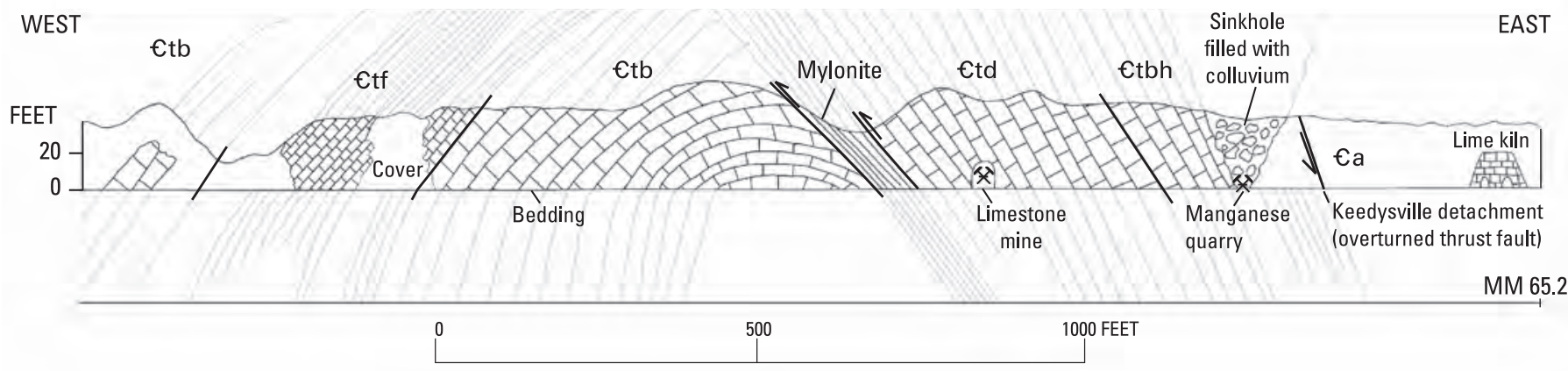

Figure 88. Geologic sketch from about MM 65.2 westward, across the overturned thrust fault contact (Keedysville detachment) of metasandstone of the Antietam Formation $\left(\epsilon_{a}\right)$ with limestone of the Bolivar Heights Member of the Tomstown Formation ( $\epsilon_{\text {tbh }}$ ), and another thrust fault cutting an upright anticline of the Bolivar Heights, Fort Duncan ( $\left.\epsilon_{t f}\right)$ and Benevola $\left(\epsilon_{t b}\right)$ Members of the Tomstown Formation. Both thrust faults are marked by mylonite, marble, and cleavage. The lime kiln near MM 65.2 was for cooking locally mined limestone in order to make cement and fertilizer. Manganese discovered during excavation of the canal was also mined near the overturned contact, near the sinkhole that is filled with colluvium.
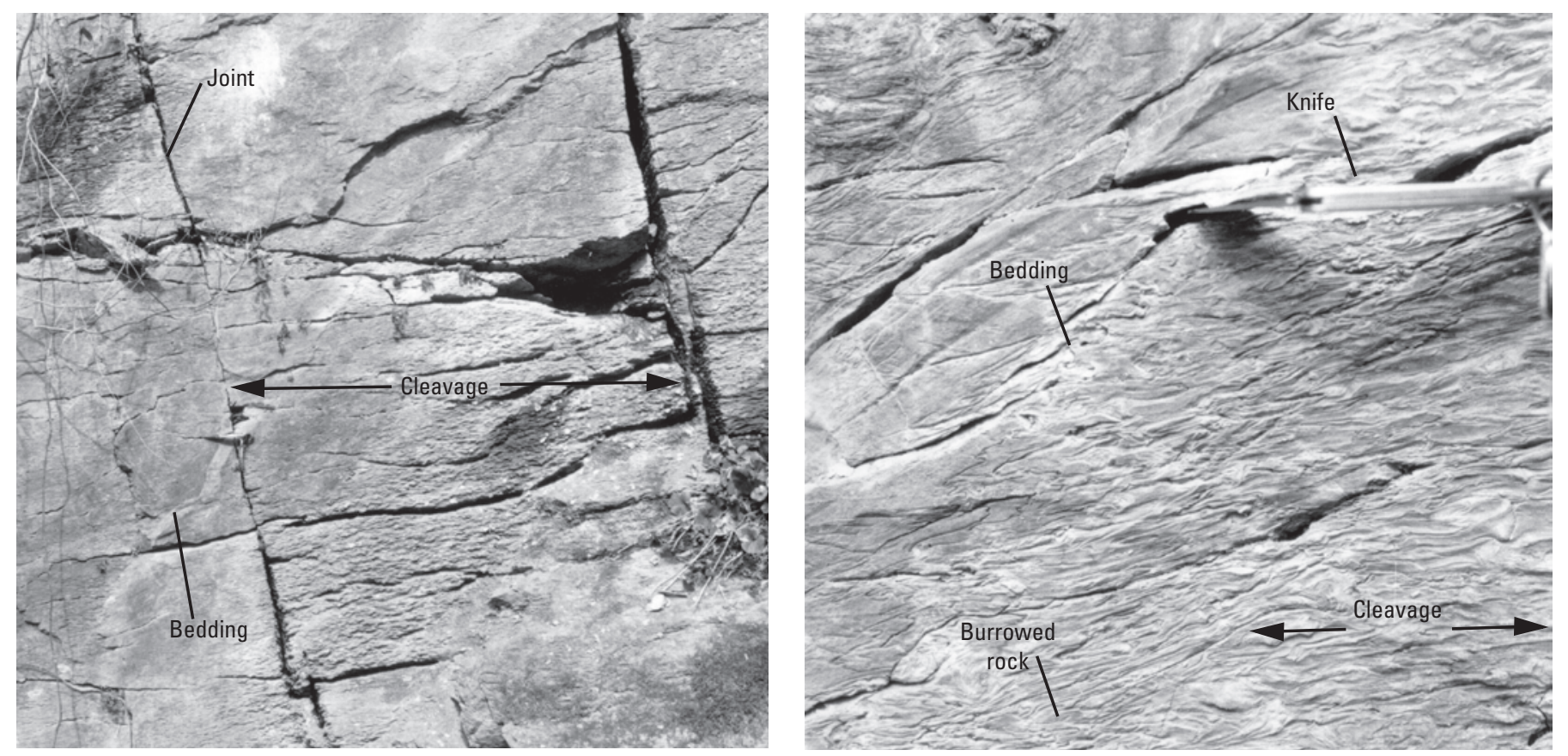

$\boldsymbol{A}$

B

Figure 89. Limestone of the Lower Cambrian Bolivar Heights Member of the Tomstown Formation near MM 68. A, Outcrop shows pervasive cleavage dipping at a low angle and beds dipping steeply to the northwest. $B$, Closeup of $A$ showing that fossil burrows (originally oriented perpendicular to beds) are disrupted and realigned by pervasive, nearly horizontal cleavage. Three-inch-long knife for scale.

(1) outcrops of massive, light-gray dolomite of the Benevola Member ( $€$ tb) of the Tomstown; and (2) the type section of the medium-bedded dolomite and limestone of the Dargan Member (€td) (Brezinski, 1992), which is the uppermost member of the Tomstown.

From MM 68.2 northwestward, the flood plain widens and is covered with alluvium, thus hiding the Lower Cambrian Waynesboro Formation (fig. 91) that underlies this section. The Waynesboro Formation is made up of three mem- bers (in ascending order): (1) the Red Run Member (€war), which consists of interbedded tan sandstone and dolomite; (2) the Cavetown Member ( $€$ wak), which is composed mainly of limestone and dolomite; and (3) the Chewsville Member ( $€$ wac), which consists of interbedded red shale, sandstone and tan dolomite (Brezinski, 1992). Near MM 69, the canal crosses the contact of the Waynesboro Formation with the overlying Middle and Upper Cambrian Elbrook Limestone $(€ \mathrm{e})$, which also is not exposed. 

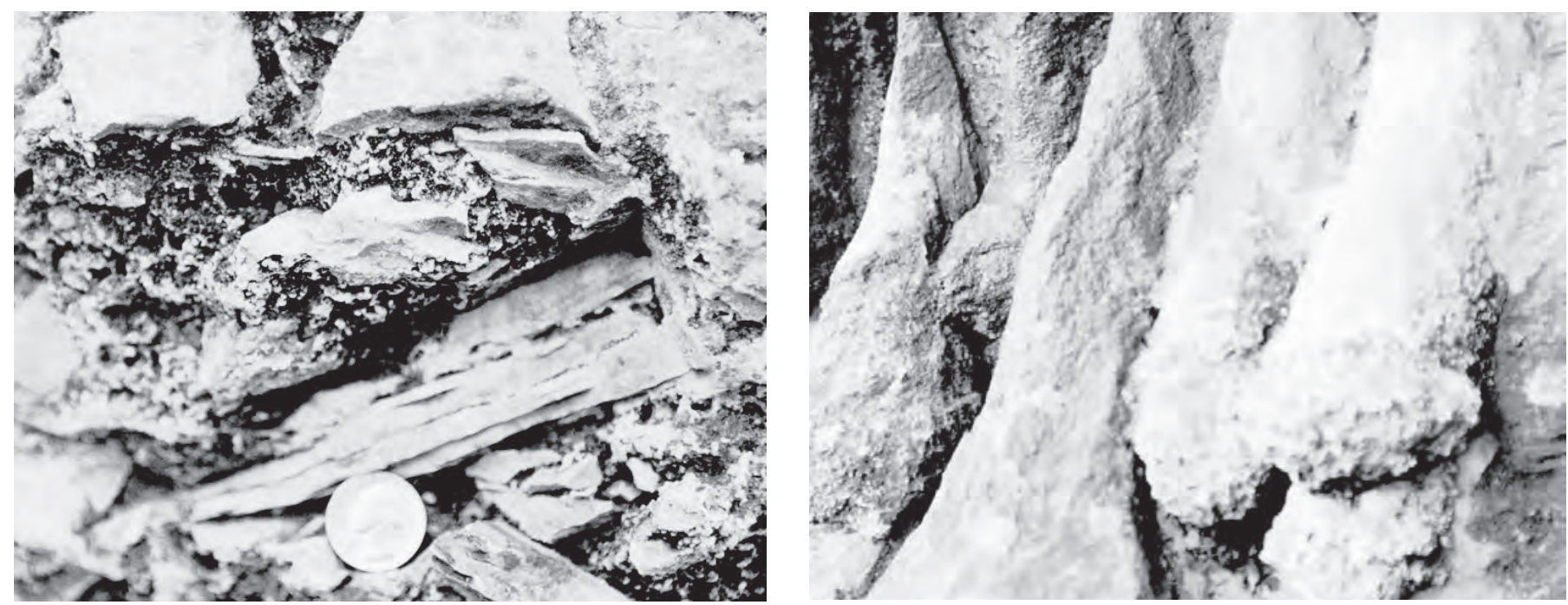

$\boldsymbol{A}$

B

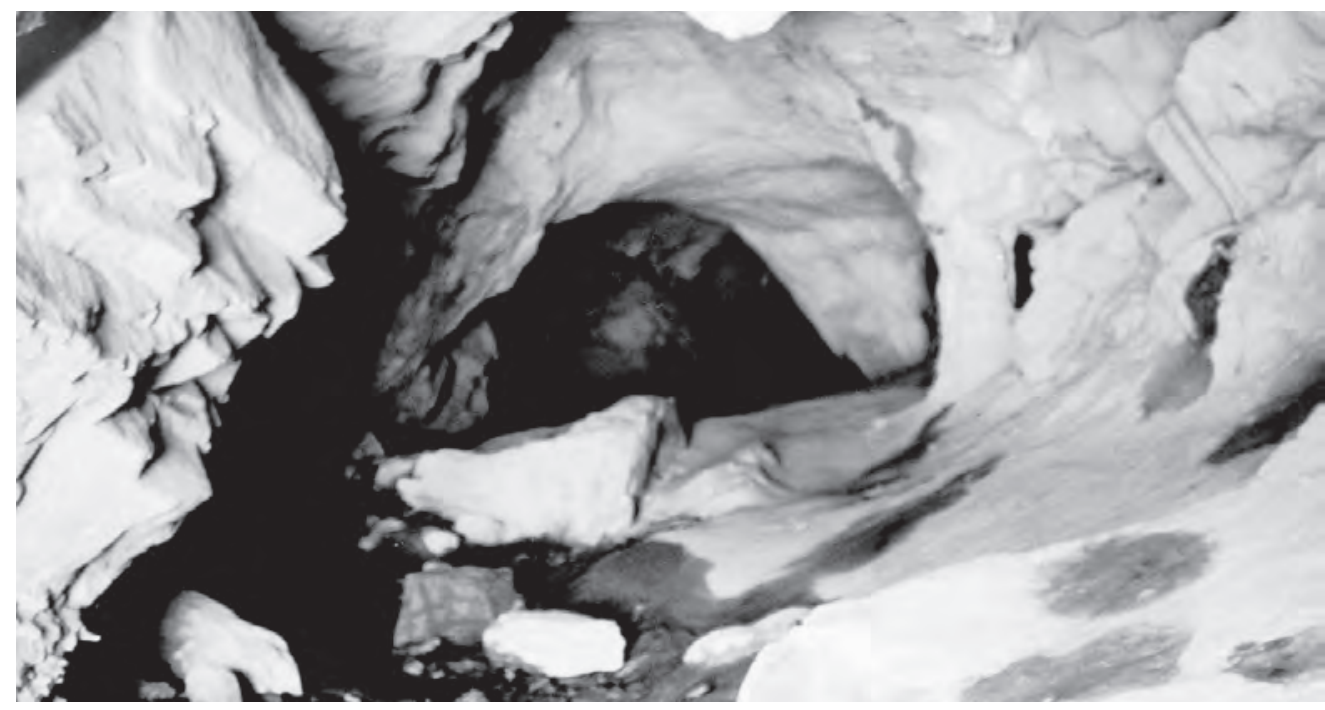

Figure 90. Examples of karst features in the Fort Duncan Member of the Tomstown Formation near MM 68. A, Collapse breccia of limestone cemented by calcium carbonate. $B$, Tufa deposits. $C$, One of many small caves in the bluffs of the Great Valley.

\section{C}

\section{Antietam Creek to Big Slackwater (MM 69 to MM 85.5)}

The Antietam Creek Aqueduct was built in 1834 of limestone and dolomite (Cavetown Member of the Lower Cambrian Waynesboro Formation) that was quarried about $0.75 \mathrm{mi}$ to the southeast (Davies, 1989). The rock is very finely laminated and was deposited on an intertidal mudflat at about 530 Ma. Each lamination represents a single tidal cycle or storm event. Blocks along the top of the aqueduct have fossil mud cracks that also formed in a tidal-flat environment.

From the aqueduct to MM 73, opposite Shepherdstown, W. Va., the Potomac River flood plain is wide and alluvium obscures the interbedded thin limestone and shaly tan dolomite of the Elbrook Limestone (€e) (Brezinski, 1996a) (plate 11). Abundant algal stromatolites are common in the Elbrook; on the West Virginia side of the Potomac River, opposite MM 71.5 , good exposures of stromatolites may be seen along the road that runs near the river. There are also abundant sinkholes and caves developed in the Elbrook Limestone in this region.

To the north and south of the Potomac River, rounded Quaternary gravel, cobbles, and boulders of sandstone and conglomerate cover the hills. These are river-channel deposits left by the Potomac River as it cut down to the modern channel. Kilns and abandoned limestone quarries were located on both sides of the river near MM 71.5. The Botelers and Reynolds Cement Mill (fig. 92) operated from 1828 to 1834 in West Virginia, and the Potomac Cement Company operated in Maryland from 1888 to 1903 (Davies, 1999).

From MM 72 to MM 85, nearly all of the bedrock is the Upper Cambrian and Lower Ordovician Conococheague Limestone $\left(\mathrm{O} €_{\mathrm{c}}\right)$. These rocks are characterized by ribbonlike, thin layers of gray limestone ( 0.25 to 1.0 inches thick) interbedded with layers of tan dolomite or dolomitic limestone. Bedrock is exposed along steep bluffs that show abundant drill holes and small caves. Shenandoah River Lock, near 


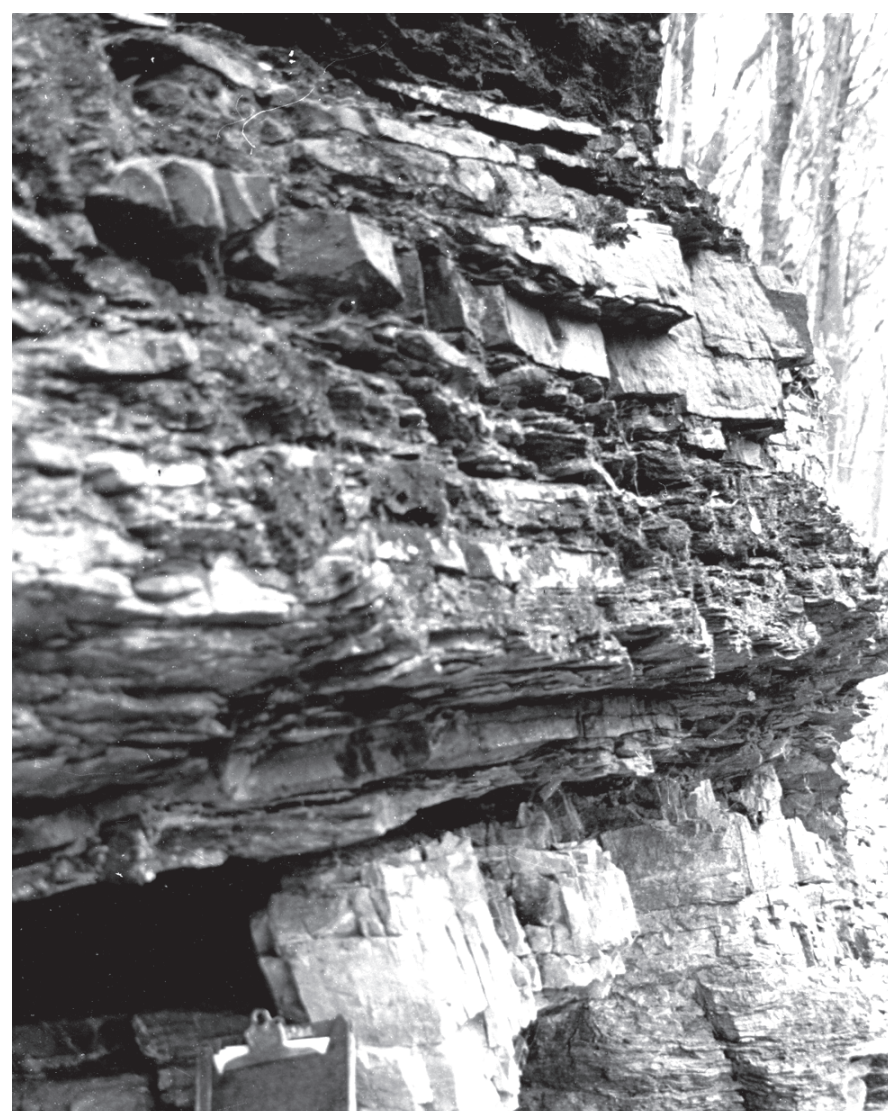

A

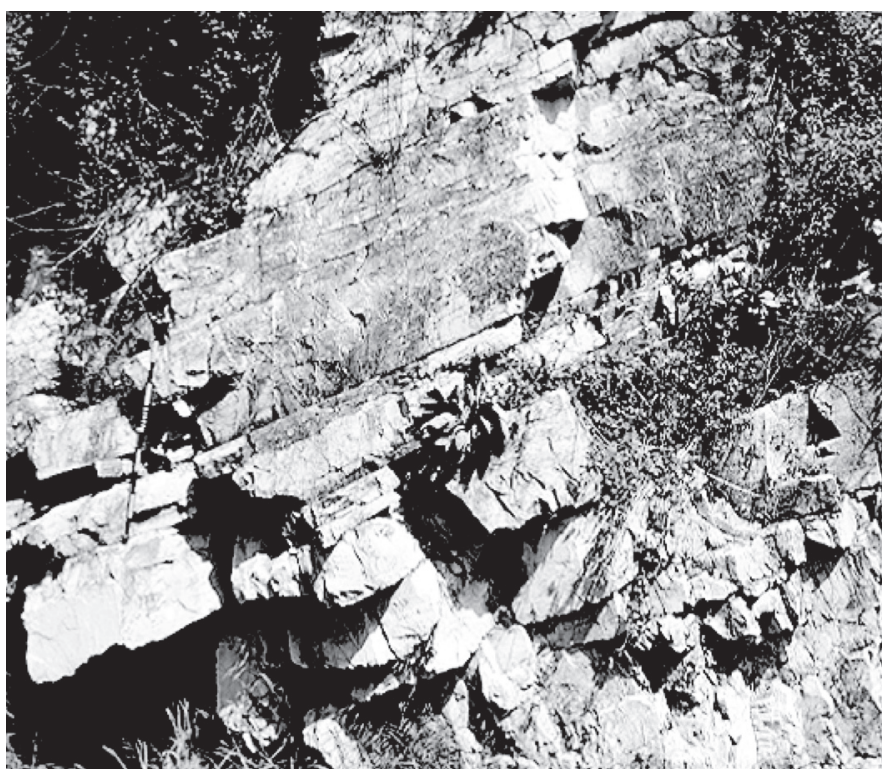

\section{B}

Figure 91. Outcrops of Lower and Middle Cambrian Waynesboro Formation in the vicinity of the C\&O Canal. $A$, Shale, sandstone, and dolomite of the Chewsville Member northeast of MM 69. Clipboard for scale. $B$, Limestone and dolomite of the Cavetown Member in an outcrop on the Virginia side of the Potomac River opposite MM 69.5. Jacobs staff (1 meter or about $3 \mathrm{ft}$ long) for scale. Along the canal, the Waynesboro is covered with alluvium.

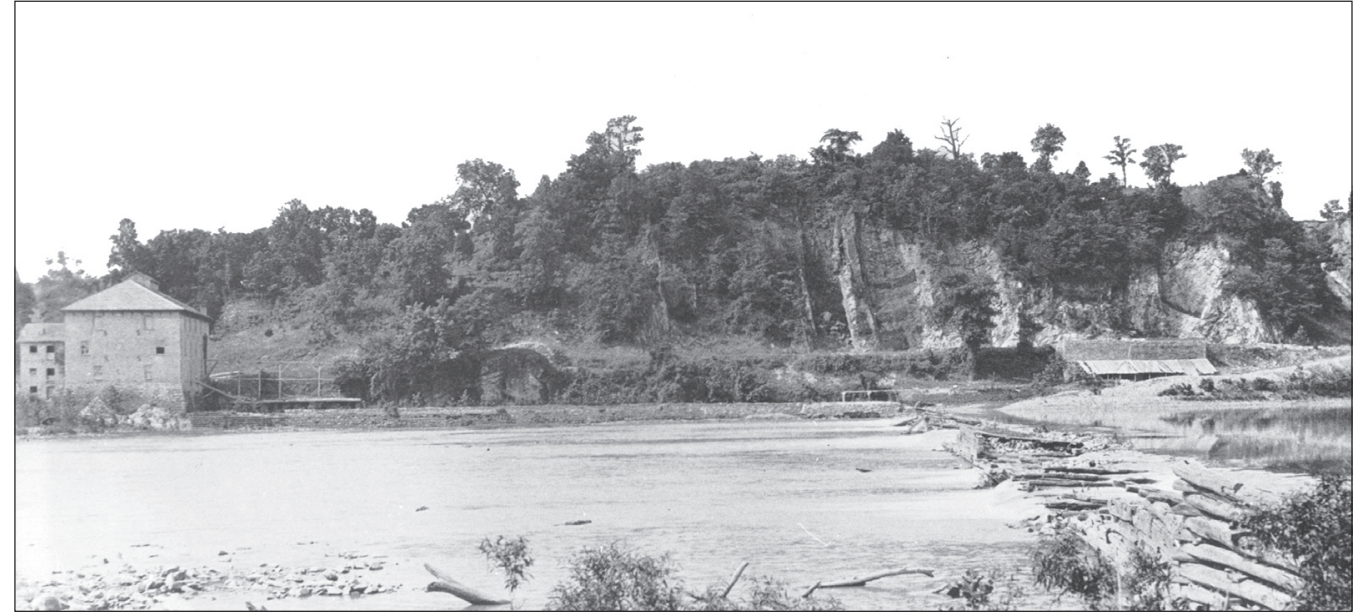

MM 72.6, provided access to Shepherdstown in the same manner as the Goose Creek and Alexandria Locks by linking the C\&O Canal to commerce centers to the east.

On top of the bluffs seen east of MM 73 are large blocks and cobbles of round sandstone and quartzite that were deposited by the ancestral Potomac River during the Pleistocene. The meander bends of the current river have extensive exposures on the north (upstream) side where erosion is most severe. In these areas, the berms to the towpath are often lined with stone for protection. The south sides of the meanders have a gentler slope and the terrace deposits are better preserved.
Figure 92. Historical photograph (about 1895) showing Botelers and Reynolds Cement Mill's quarries in near-vertical limestone (in West Virginia opposite MM 71.6) and Botelers and Reynolds Dam (on right) for mill race for the cement mill (left background). Before the Round Top Cement Company plant was built, this plant supplied the cement for the canal masonry. Photograph courtesy of National Park Service.

Near MM 75.7, a large overhang in the Conococheague Limestone (known as Killiansburg Cave) served as a Civil War shelter (fig. 93). Flowstone, or travertine, may be seen in the cave. Several more caves may be found between here and MM 76.2 (Davies, 1999). Tufa deposits may be seen in the tributaries of the Potomac River near Snyders Landing (MM 76.6). On the shore in West Virginia, opposite MM 81, the land that is enclosed by a large meander loop is known as Terrapin Neck. This is the location of the National Conservation Training Center of the U.S. Fish and Wildlife Service. West of MM 83, the Potomac River cuts across the strike of the Conoco- 
cheague Limestone. Between MM 83 and Dam 4, the Conococheague is tightly folded.

At MM 83.3, the cave (locally known as Bergen's Cave) at Dam 4 discharges spring water at canal level (fig. 16). In the bluffs at Dam 4, the near-flat-lying uppermost part of the Conococheague Limestone shows drill holes and a stuck drill rod (see fig. 25A).

\section{Big Slackwater to Williamsport (MM 85.5 to MM 99.5)}

Because bluffs prevented the construction of a canal, the canal boats entered the Potomac River (fig. 94) at MM 85.5. This stretch is known as the Big Slackwater because the water moved slowly enough to allow the canal boats to use the river. Limestone and dolomite of the Upper Cambrian and Lower Ordovician Conococheague Limestone $\left(\mathrm{O} \epsilon_{\mathrm{c}}\right)$ and Lower Ordo- vician Stonehenge Limestone (Obs) along this section are well exposed (plate 12 and fig. 95). Between Guard Lock 4 (MM 85.5) and McMahons Mill (MM 88), flooding severely eroded the canal towpath on the river bank. Numerous small caves may be found between MM 86.8 to MM 92 (Davies, 1999).

West of McMahons Mill (built in 1778) at the end of Charles Mill Road, is a 400-ft interval of medium-bedded limestone of the Stonehenge Limestone followed by a 120$\mathrm{ft}$-wide interval of the Stoufferstown Member of the Stonehenge (Obss). The rocks are characterized by paper-thin, parallel, calcite and clay laminations (fig. 96), which resulted from mylonitic foliation due to faulting.

Westward to Lock 41 (near MM 88.8), the bedrock consists of the Lower and Middle Ordovician Rockdale Run Formation (Obrr) (fig. 95), which is characterizied by gray limestone interbedded with tan to brown dolomite. These lithologies are repeated in vertical succession from ribbony to sandy limestone to tan, laminated dolomite. Although the relative thickness
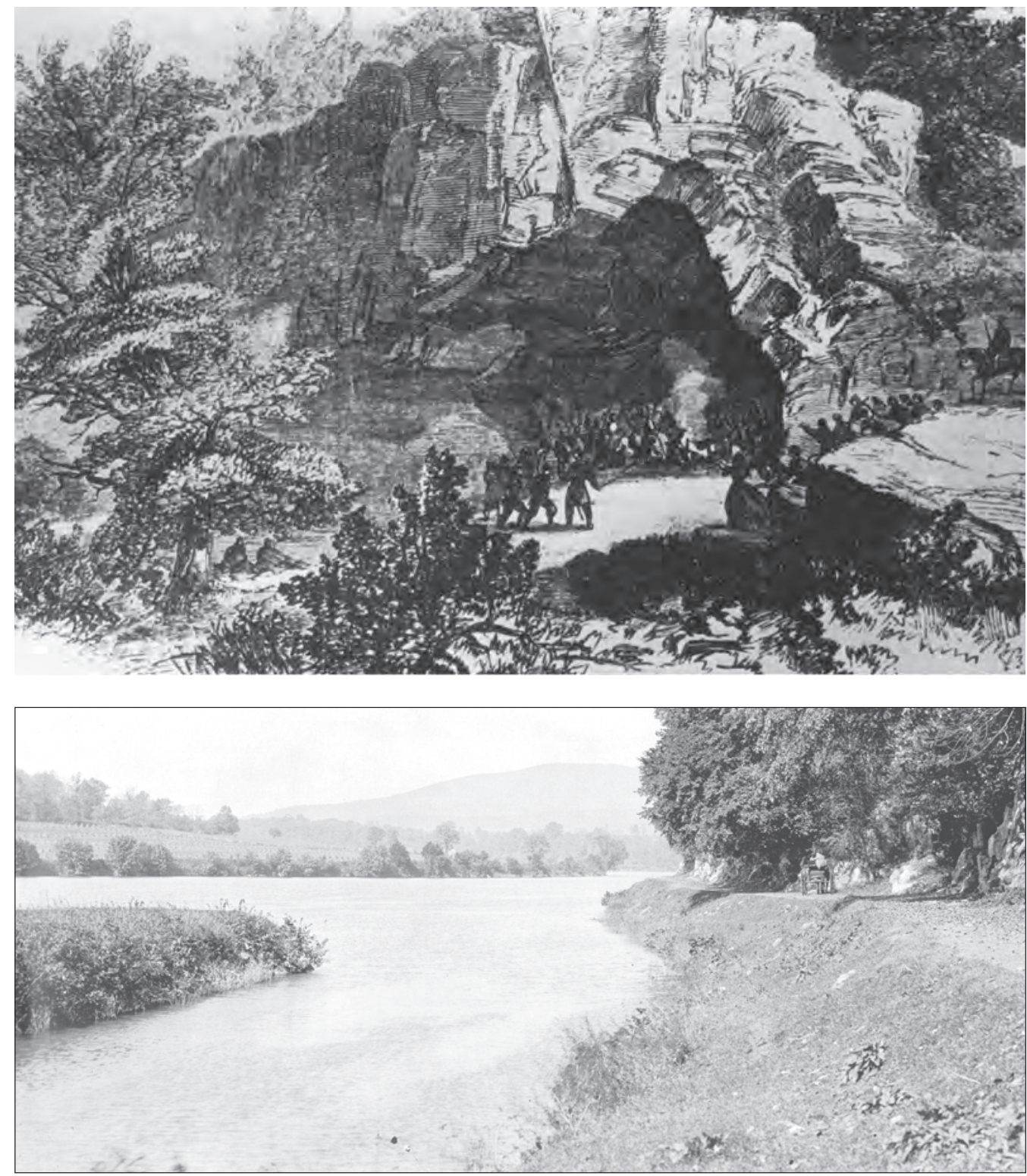

Figure 93. Historical sketch (about 1867) of soldiers and citizens in and around Killiansburg cave near MM 75.7. The sketch suggests that the cave is situated in the hinge of an anticline of the Upper Cambrian and Lower Ordovician Conococheague Limestone, but it is actually developed in the formation's east-dipping beds. From Hahn (1985); used with permission.

Figure 94. Historical photograph (date unknown) showing location north of Dam 4 where canal boats entered the Potomac River because limestone cliffs prevented construction of a canal (as with Big Slackwater to the west). Photograph courtesy of National Park Service. 
of the individual limestone or dolomite beds varies through the succession, the sequence of limestone to dolomite is repeated through the formation. The lithologic cycles reflect a change in depositional environments from shallow subtidal (limestone) to supratidal (dolomite). The cycles seen within these rocks indicates that, during the time of deposition, sea level rose and fell with considerable frequency and thus produced produce the repeated sequence of lithologies. The original depositional features (such as chert, burrows, crossbedding, graded beds, and ripple marks (fig. 97)) may be seen within the limestones; mud cracks are found within the dolomites.

Upstream of the Opequon Junction campsite and MM 91 are exposures of folded rocks of the Stonehenge Limestone and Rockdale Run Formation. These rocks contain abundant small caves (such as what is locally known as Dellinger's Cave at MM 92.14) and dissolution features (Davies, 1999). This is the midway point of the 184.5-mi-long canal. To the west, the rock is Middle Ordovician Chambersburg Limestone (Oc). A thrust fault places the rocks of the Rockdale Run Formation above the younger rocks of the Chambersburg Limestone near MM 92. A stream valley overlies the fault between the two units. Springs and tufa deposits are common in this area.
The Chambersburg is the youngest carbonate rock of the Great Valley section and perhaps the most fossiliferous. The rocks contain abundant brachiopods, bryozoans, trilobites, and, near its base, abundant remains of the echinoderm E chinosphaerites (fig. 20, item 16).

The Chambersburg grades into shale of the overlying Middle and Upper Ordovician Martinsburg Formation (Om) west of MM 92.5. The Martinsburg consists of gray to brown shale in its lower part and interbedded sandstone and shale in its upper part. This shaly interval marks the end of the depositional epoch that spans Early Cambrian to late Middle Ordovician time when only carbonate rocks were deposited. The environment on the shelf of the continent was similar to that east of Florida today. This stable environment resulted in the deposition of a carbonate rock sequence that is nearly 2 mi thick over a period of approximately 100 m.y. Shale of the Martinsburg marked the beginning of clastic-dominated (sandstone-siltstone-shale) deposition that continued through most of the middle and late Paleozoic over a period of about 200 m.y. The initiation of the shale deposition also represents the beginning of a tectonic event known as the Taconian orogeny, which occurred near the end of the Ordovician Period.

During this period, a mountainous highland formed in the east-

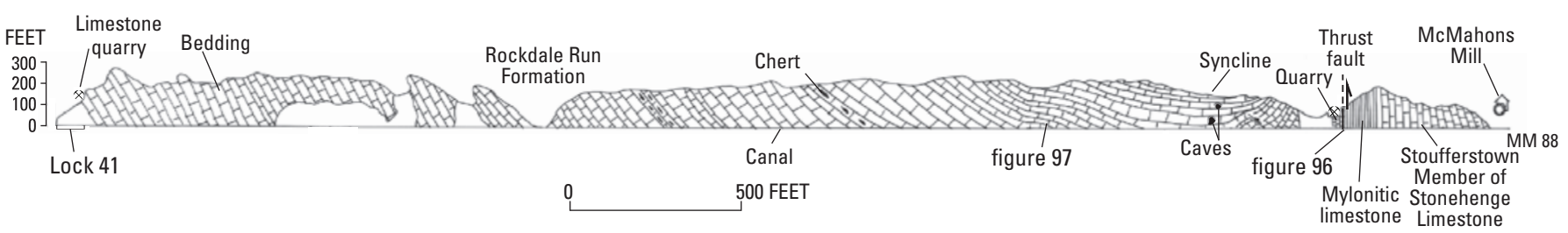

Figure 95. Geologic sketch from McMahons Mill near MM 88 westward to Lock 41 depicting Ordovician rocks of the older Stoufferstown Member of the Stonehenge Limestone thrust above limestone of the younger Rockdale Run Formation. The rocks are folded into a syncline beneath the fault. There are several limestone quarries and caves in the bluffs, some of which are shown in this sketch.

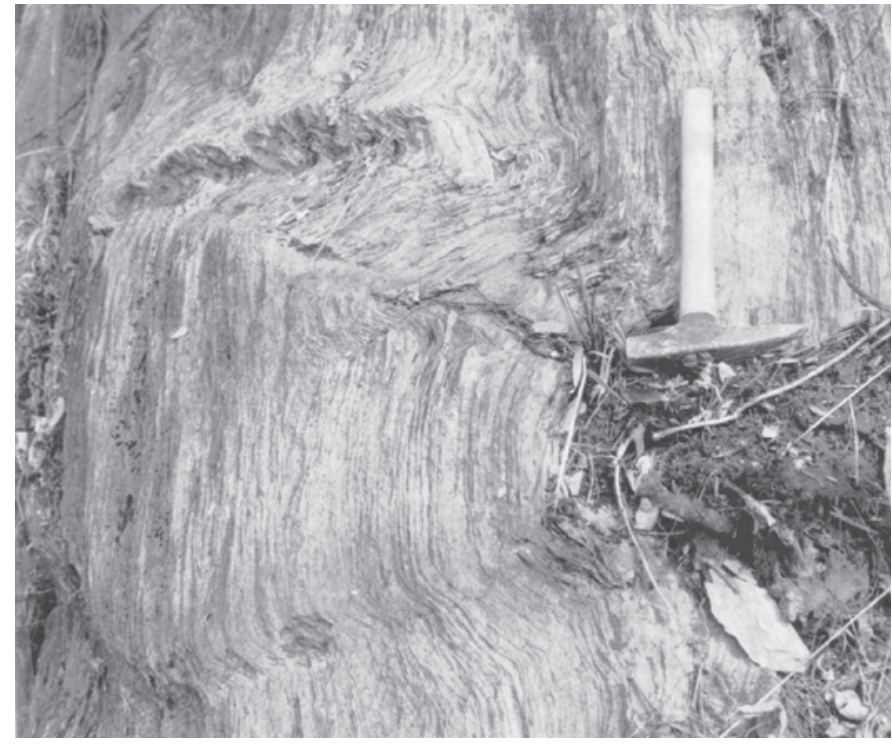

Figure 96. Mylonitic limestone within the Lower Ordovician Stoufferstown Member of the Stonehenge Limestone, immediately west of MM 88 and McMahons Mill. The mylonitic foliation was produced as the rocks were thrust westward above rocks of the Lower and Middle Ordovician Rockdale Run Formation. The mylonitic foliation is defined by clay seams and recrystallized limestone (parallel to the rock hammer handle). The mylonitic foliation is kinked by later folds. 


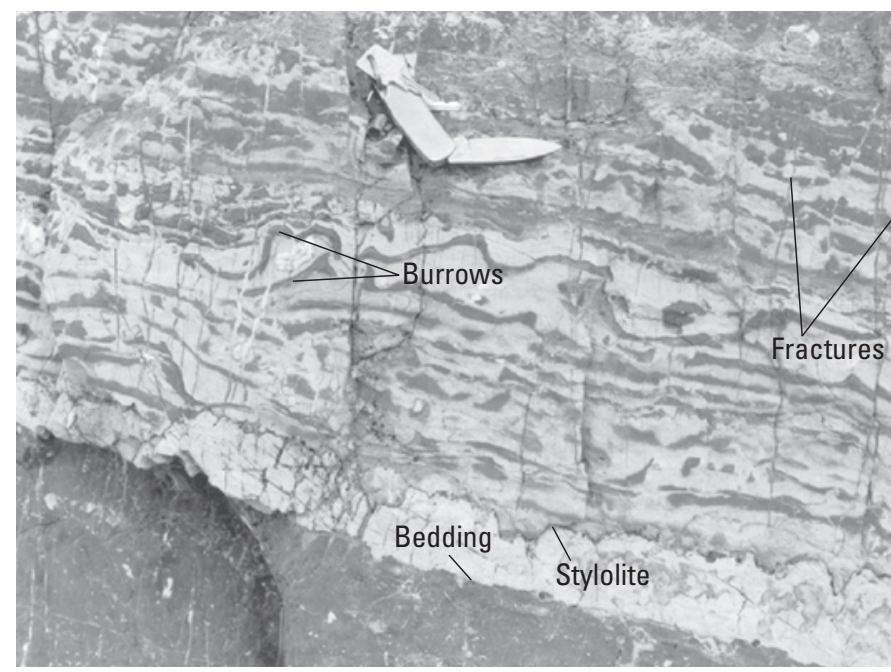

\section{$\boldsymbol{A}$}

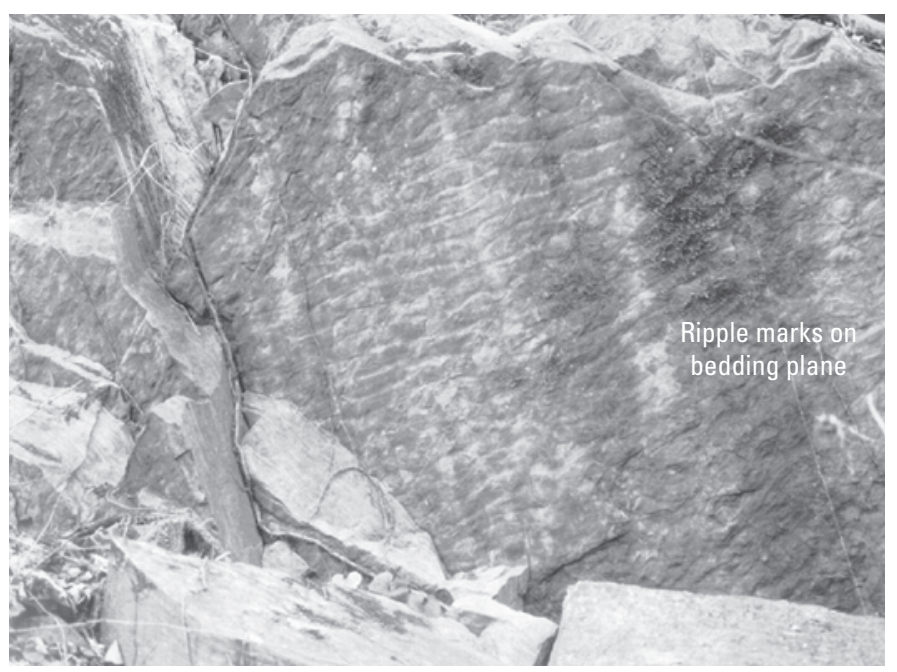

$\boldsymbol{B}$

Figure 97. Depositional features in the Lower and Middle Ordovician Rockdale Run Formation. $A$, Dark chert and limestone along the bluffs near MM 88.5. Note the stylolites (irregular, bedding-parallel seams of concentrated insoluble material formed by compaction; shown by arrow) that are parallel to beds. $B$, Ripple marks (3-inch spacing) on bedding plane in shaly limestone exposed on the bluff near MM 88.5. The ripple marks indicate that the rocks were deposited in a shallow tidal-water environment.

ern Piedmont of Maryland that was the source of the sand and clay in the Martinsburg Formation.

The contact between the Chambersburg Limestone and Martinsburg Formation may be seen in a small shale quarry east of MM 96. Scarce fossil remains of the trilobite Cryptolithus and fragments of graptolites occur here. These animals favored habitation within the deepwater environments where shale was deposited. The Martinsburg Formation is the youngest and only noncarbonate rock in the northern Shenandoah Valley and it forms the core of the Massanutten synclinorium. Because of the meandering nature of the Potomac River, the canal crosses the axial region (or center) of the Massanutten synclinorium three times (near MM 93.5, MM 96, and at about MM 100). A dramatic change in both physiography and land use (from agriculture to pasture and woodland) occurs in the area underlain by Martinsburg Formation because of the contrast in materials that result from weathering.

Good exposures of shale in the lower part of the Martinsburg Formation may be seen from MM 95 to MM 96.5. At the footbridge, dolomite of the Rockdale Run Formation (Obrr) is thrust-faulted above shale of the younger Martinsburg Formation, and rocks of the Middle Ordovician St. Paul Group and Chambersburg Limestone are missing.

At MM 97.1 are remnants of the piers for the old railroad trestle which were made of Triassic red sandstone similar to the Upper Triassic Manassas Sandstone quarried at Seneca, Md. These rocks most likely were quarried from the Gettysburg basin near Emmittsburg, Pa., and were transported here by railroad.

The Stonehenge Limestone (Obs) is exposed from MM 97 to MM 99 near Williamsport (plate 13). Immediately east of the powerplant (MM 99), shale of the Martinsburg Formation is exposed beneath the same fault encountered near Lock 43 and the footbridge near MM 96.5. This regional fault can be traced northward into Pennsylvania and southward into West Virginia. The steel drawbridge immediately north of the power plant allowed coal trains to cross the canal to supply the plant.

A feature locally known as the Cushwa basin at the National Park Service's C\&O Canal Visitor Center at Williamsport was a transfer station for canal cargo, which was principally coal from west of Cumberland (fig. 98). Like the basins at Seneca and Cumberland, this basin was a large holding area where canal boats and barges loaded or unloaded cargo. High (1997) provides a photograph of a canal boat that crashed through the Conococheague Creek Aqueduct at Williamsport in 1920.

\section{Williamsport to McCoys Ferry (MM 99.5 to MM 110)}

Over the next two miles, the wide flood plain of the Potomac River overlies the Middle and Upper Ordovician Martinsburg Formation (plate 13). Incompetent, dark-gray, silty shale of the unnamed lower member of the Martinsburg Formation $(\mathrm{Om})$ that was folded and faulted more easily than the adjacent competent carbonate rocks may be seen along the CSXT railroad tracks to the north. Approximately 2,000 $\mathrm{ft}$ of shale grades upward into more sandy beds that mark the base of the unnamed upper member. The upper member of the Martinsburg Formation consists of gray, silty shale interbedded with gray to brown, fine- to medium-grained sandstone. The sandstone beds typically are less than $1 \mathrm{ft}$ thick (fig. 99A) in the lower part of the member and gradually increase in thickness to more than $20 \mathrm{ft}$ near the top. The thinner beds exhibit basal scours and lineations (fig. 99B) that are typical of distal deposits resulting from high energy 
caused by deepwater turbidity currents (McBride, 1962). The thicker sandstones higher in the member were deposited in shallower water, closer to the sand source, as the depositional basin was filling.

The last shale outcrop that marks the eastern limb of the Massanutten synclinorium may be seen near MM 102. From this point westward to McCoys Ferry (MM 110), the same sequence of bedrock formations occurs on the eastern flank of the fold. Rocks underlying the western limb of the synclinorium were not as severely deformed as those of the overturned eastern limb; therefore, sedimentary structures and fossils are better preserved in the western limb.

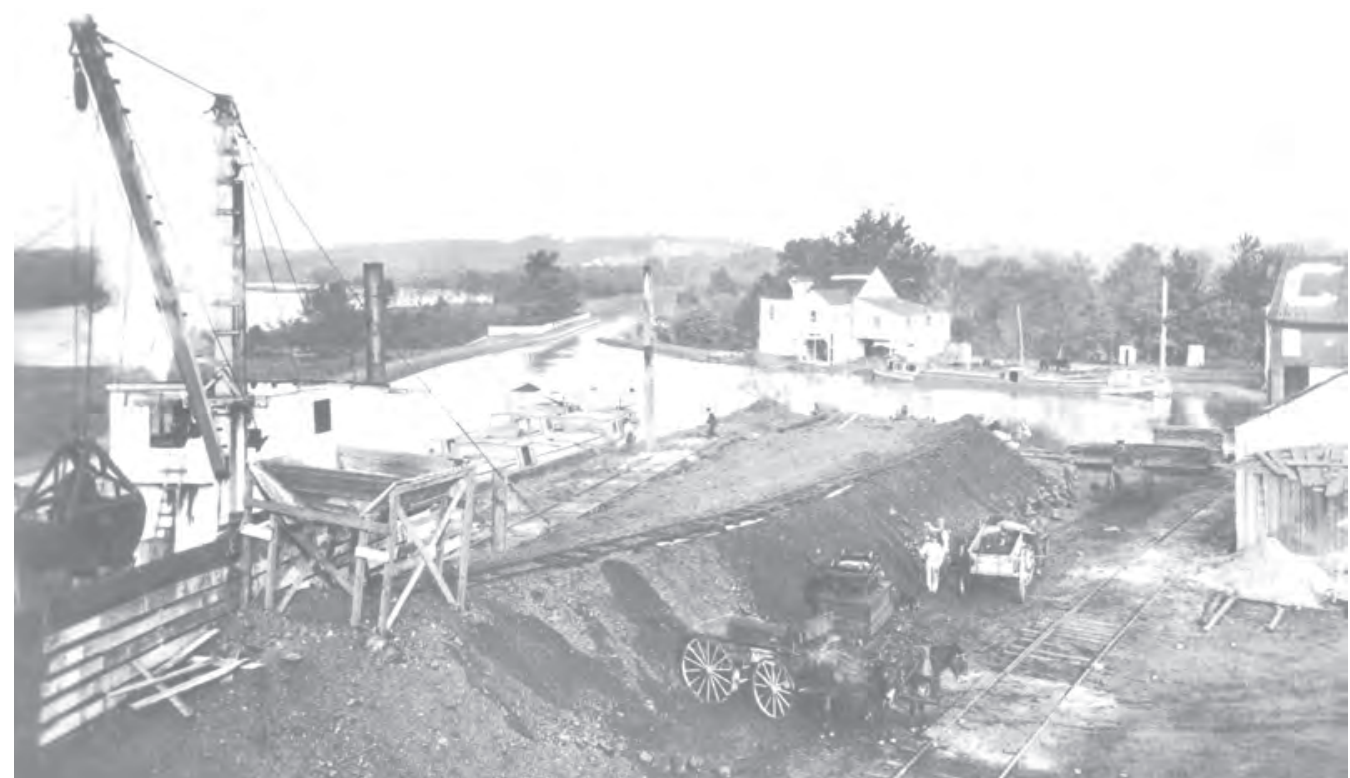

Figure 98. Historical photograph (about 1920) of Cushwa basin at Williamsport (MM 100) showing coal being loaded into horse-drawn wagons. The coal was transported down the canal from Cumberland. Photograph by Consolidated Coal Co.; courtesy of National Park Service).

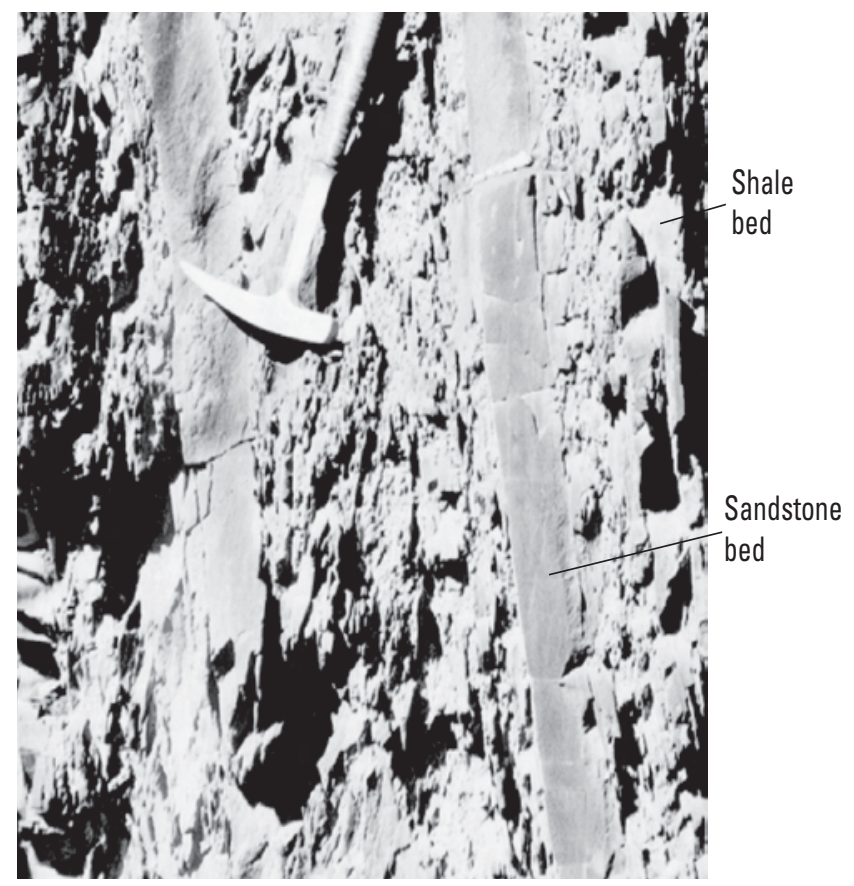

A

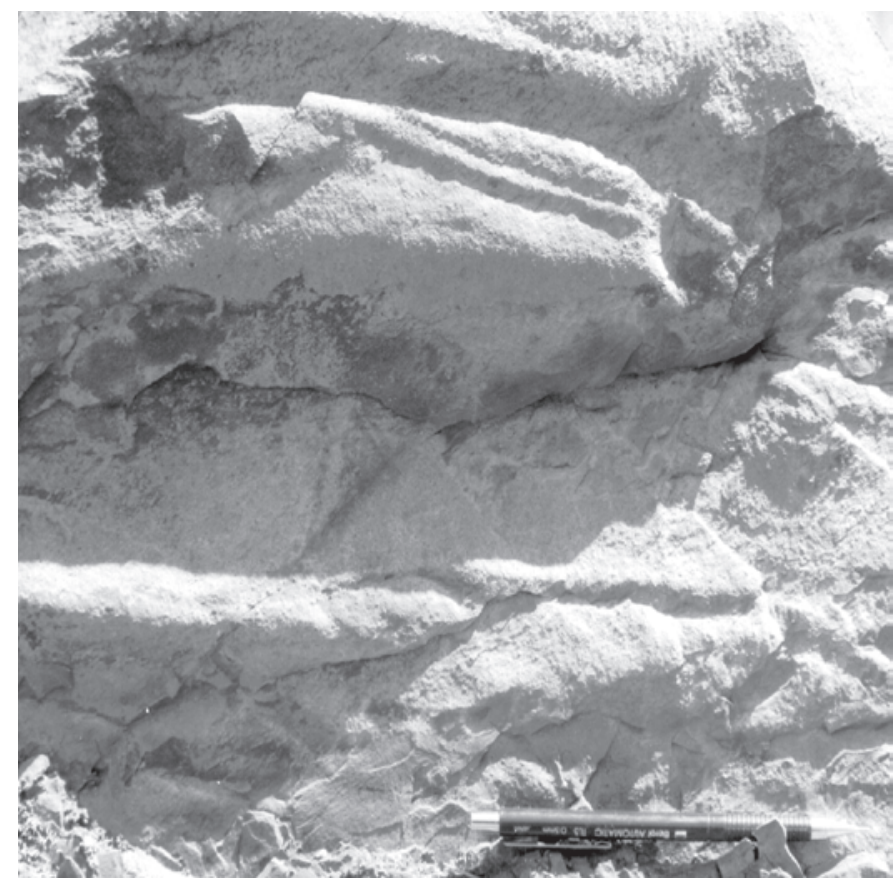

B

Figure 99. Upper part of Middle Ordovician Martinsburg Formation along the railroad north of MM 101. $A$, Thin-bedded sandstone and shale represent turbidites, which were deposited in a deepening basin at the onset of the Taconian orogeny during the Late Ordovician. They were the first clastic rocks deposited after almost 100 million years of carbonate deposition on the continental shelf. $B$, Flute casts at the base of a sandstone bed. These features formed where a trough, which formed as turbulent water scoured the surface, later filled with sand. The water flowed parallel to the direction of the mechanical pencil. 

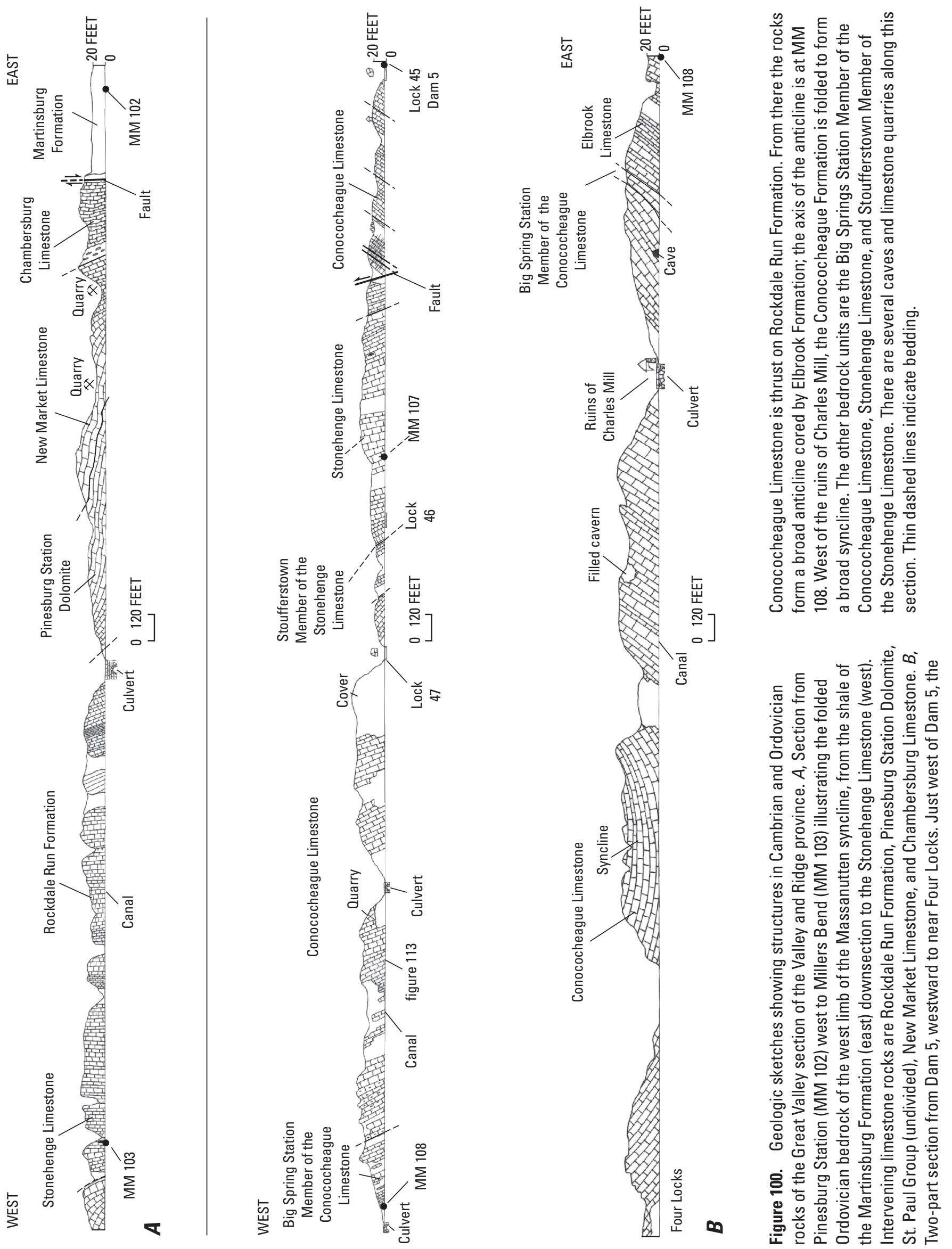

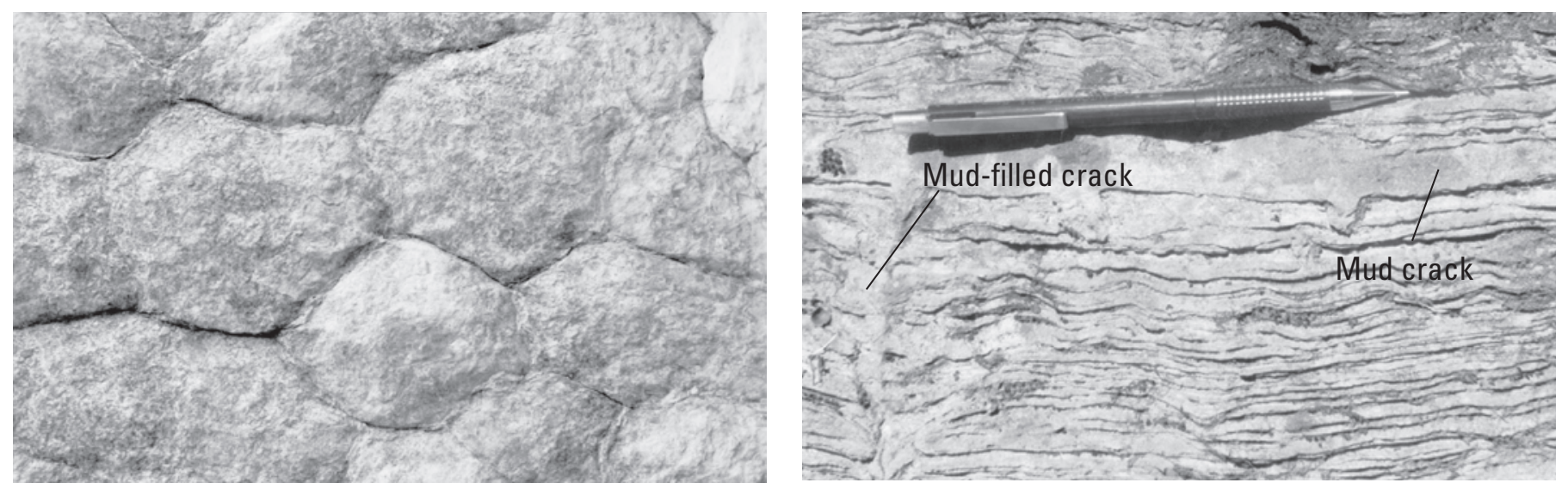

Figure 101. Mudcracks on Upper Cambrian and Lower Ordovician Conococheague Limestone at MM 107.8. A, Plan view of mudcracks developed on the top of the limestone. The polygonal shape (4 inches across) is very similar to present-day mudcracks that form in the silty deposits after the Potomac River floods. B, Cross section of laminated Conococheague Limestone with mudcracks.

Westward from MM 102 to MM 103.2, the section contains a nearly continuous bedrock exposure starting near the base of the Martinsburg Formation and descending stratigraphically (westward) to the top of the Lower Ordovician Stonehenge Limestone (Obs) (fig. 100). The Middle Ordovician Chambersburg Limestone (Oc), below the Martinsburg, here consists of medium- to dark-gray, wavy- to nodular-bedded, fossiliferous limestone that is shaly at its base near the eastern wall of the active quarry immediately to the north. To the west, the more gently dipping strata are part of the Middle Ordovician St. Paul Group (Osnr) rocks (Neuman, 1951), which are actively being quarried. The St. Paul Group, which consists of the Row Park and New Market Limestones mapped as an undivided unit, consists mainly of light-gray, thick-bedded limestone with thin interbeds of tan dolomite. An interval of gray, fractured dolomite of the Middle Ordovician Pinesburg Station Dolomite (Op) underlies the St. Paul Group and is exposed at the parking area at MM 103.2. Along the meander immediately to the south are scattered outcrops of folded rocks within the Conococheague and Stonehenge Limestones.

At Dam 5 and Lock 45 north of MM 107, the exposed rocks are the Upper Cambrian and Lower Ordovician Conococheague Limestone $\left(O €_{c}\right)$. Quaternary boulders and gravel litter a low river terrace. Approximately 1,000 ft west of Lock 45, the rocks are highly cleaved due to a southeast-dipping thrust fault that places the Conococheague Limestone over the Lower and Middle Ordovician Rockdale Run Formation (Obrr). Immediately to the west (MM 106.8) are the underlying rocks of the Lower Ordovician Stonehenge Limestone (Obs); a complete section (from top to bottom) of the Stonehenge is exposed from here to the area between Locks 46 and 47 (MM 107.2). From Lock 47 westward, the Conococheague Limestone is exposed relatively continuously until MM 108, where the upper strata of the underlying rocks of the Middle and Upper Cambrian Elbrook Limestone (€e) occur in an anticline. Laminated Con- ococheague Limestone with mud cracks is exposed near MM 107.8 (fig. 101). The Conococheague is exposed all the way to Four Locks (MM 108.5) in a broad syncline (fig. 100).

At Four Locks, canal boats were lifted to pass through the neck of a meander, thereby obviating about $4.5 \mathrm{mi}$ of canal construction. The elevated valley occupied by the canal and towpath is an abandoned Pleistocene channel of a former tributary to the Potomac River. Shaly and algal limestones with stromatolites (fig. 102) exposed near the North Mountain campsite characterize the Elbrook Limestone along the western limb of the Massanutten synclinorium (Brezinski, 1996a).

At MM 110 (plate 14) is an outcrop of very light gray to white quartzite of the Upper Ordovician and Lower Silurian Tuscarora Quartzite (SOt) (fig. 103). The Tuscarora Quartzite and the Elbrook Limestone are separated by the North Mountain thrust fault, which is perhaps the most regionally significant thrust fault in the central Appalachian region. This thrust fault transported all of the rocks between here and

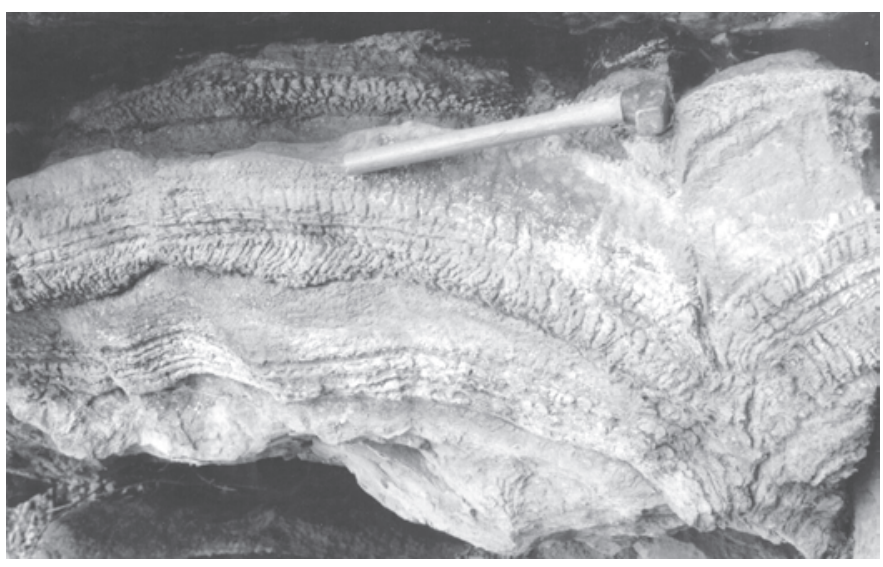

Figure 102. Stromatolites (fossilized algal remains) in the Middle and Upper Cambrian Elbrook Limestone east of McCoys Ferry, near MM 109.5. Knife for scale. 
Georgetown in Washington, D.C., westward over Silurian and Devonian rocks. For the next $74.5 \mathrm{mi}$ to the western terminus of the canal at Cumberland, the Potomac River transects the rest of the Valley and Ridge province.

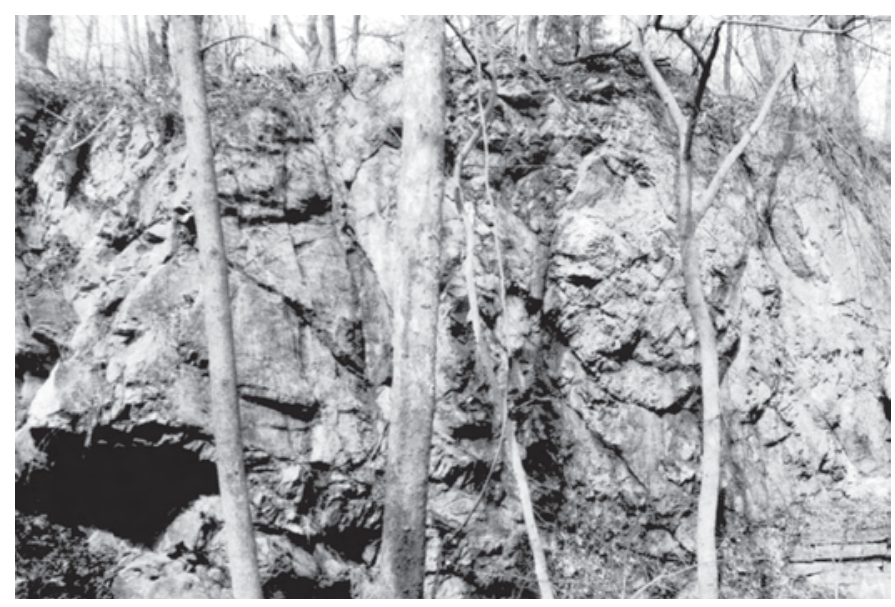

\section{$\boldsymbol{A}$}

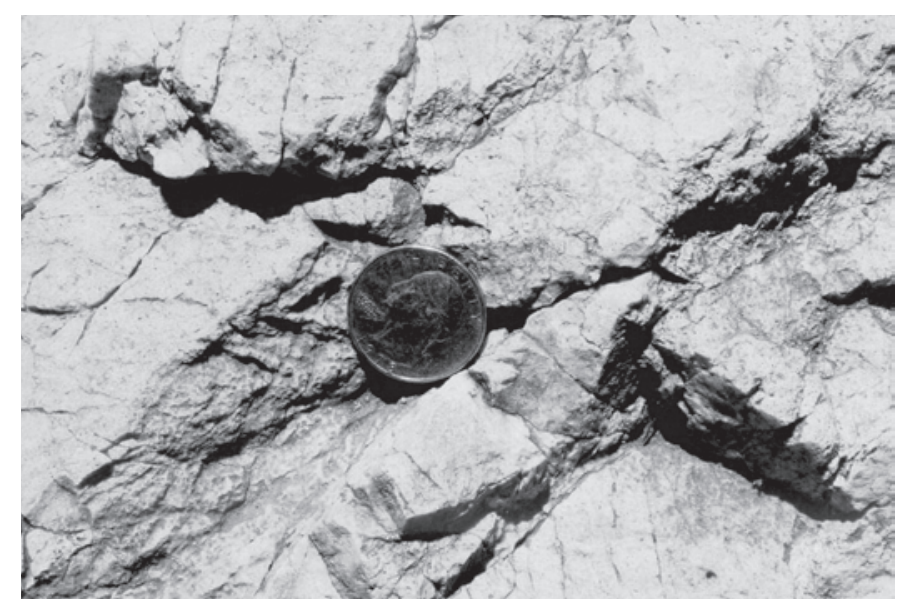

$B$

Figure 103. Upper Ordovician and Lower Silurian Tuscarora Quartzite. The Tuscarora is highly fractured along the North Mountain thrust fault. Rocks to the east were transported westward, structurally above the fractured and brecciated quartzite. To the south, this resistant quartzite underlies North Mountain. $A$, Tuscarora Quartzite at McCoys Ferry (MM 110). B, Fractured and brecciated Tuscarora Quartzite. Quarter for scale.

\section{Valley and Ridge Province-West of North Mountain Thrust Fault}

\section{McCoys Ferry to Cumberland, Md. (MM 110 to MM 184.5)}

\author{
Access Points \\ McCoys Ferry \\ Fort Frederick State Park \\ Big Pool \\ Little Pool \\ Hancock \\ Cohill \\ Woodmont \\ Pearre \\ Little Orleans \\ Green Ridge/Kasecamp Road \\ Twigg Hollow Road \\ Paw Paw Tunnel \\ Keifers \\ Town Creek \\ Oldtown \\ Spring Gap \\ North Branch \\ Wiley Ford \\ Cumberland
}

\section{Introduction}

The Valley and Ridge physiographic province west of the Great Valley section consists of Ordovician to Permian sandstone, siltstone, shale, and limestone that were folded into anticlinoria and synclinoria west of the North Mountain thrust fault during the late Paleozoic Alleghanian orogeny (fig. 104). Silurian, Devonian, and Mississippian rocks are exposed along the C\&O Canal; Ordovician rocks are exposed in the core of the Wills Mountain anticline west of Cumberland; and Pennsylvanian and Permian rocks are exposed in the Appalachian Plateaus farther to the west. The limbs of the anticlinoria are underlain by resistant Upper Ordovician and Lower Silurian Tuscarora Quartzite (SOt) and Lower Devonian Oriskany Sandstone (Do) that make up ridges. These rocks exhibit bedforms such as ripple marks, crossbeds, and worm burrows (Skolithos linearis) that indicate a beach environment that is similar to that found along the Atlantic Coast today. Most of the younger rocks are Devonian and consist of siltstone and shale that form mostly broad valleys with low ridges underlain by sandstone. The youngest rocks are the Upper Devonian and Lower Mississippian Rockwell Formation (MDr) and the Lower Mississippian Purslane Formation (Mp), both of which are preserved in the Sideling Hill syncline and are 

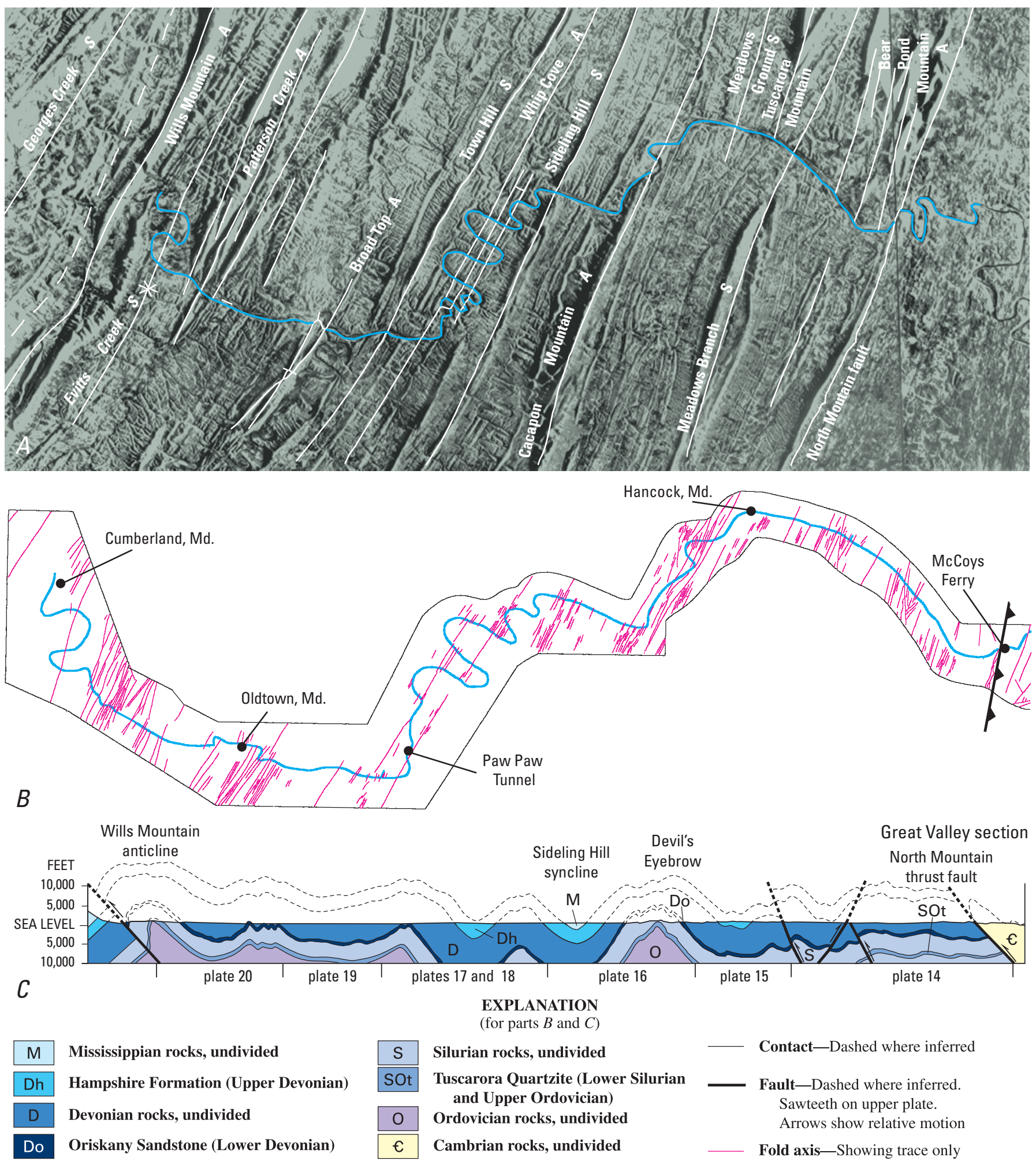

Figure 104. Side-looking airborne radar (SLAR) image, generalized structure map, and cross section of a portion of the C\&0 Canal National Historical Park and Potomac River corridor as it crosses the Valley and Ridge province, including the westernmost part of the Great Valley section. A, SLAR image illustrating the namesake physiography of the Valley and Ridge province. Erosion-resistant rocks on the limbs of anticlines and synclines underlie the hills, ridges, and mountains. Easily eroded shale and limestone are in the valleys. $B$, Structure map showing fold axes and major faults. $C$, Cross section showing folds and faults from the North Mountain fault westward to the Wills Mountain anticline and the edge of the Appalachian Plateaus province. See plates 14 to 20 for detailed geologic maps of this portion. Geologic units shown in cross section are generalized from the geologic map shown on plate 1. 
best exposed in the Interstate Route 68 roadcut at the State of Maryland's Sideling Hill Exhibit Center.

The oldest rocks along the C\&O Canal in the Valley and Ridge province are shale and sandstone of the Upper Ordovician Juniata Formation ( $\mathrm{Oj}$ ) which is exposed in the core of the Wills Mountain anticline in The Narrows, a water gap northwest of Cumberland. Silurian and Lower Devonian rocks are exposed on North Mountain in the footwall of the North Mountain thrust fault and in the following anticlinoria (from east to west): Cacapon Mountain anticlinorium (between Tonoloway Ridge and Warm Springs Ridge), Irons Mountain anticline of the Patterson Creek anticlinoria, and Wills Mountain anticline (fig. 104). The mostly Middle and Upper Devonian siltstone and shale units are exposed (east to west) in the Meadow Branch synclinorium, Sideling Hill syncline, Whip Cove anticlinorium, Town Hill syncline, and Evitts Creek syncline. Erosion of these rocks and their structures resulted in the classic valleys and ridges that give this physiographic province its name.

The oldest rocks exposed along the canal west of North Mountain are Silurian and range in age from about 443 to 418 Ma (Tucker and others, 1998). Shale and sandstone of the Middle Silurian Rose Hill Formation (Sr) are exposed along the canal at Leopards Mill. These rocks are overlain by (in ascending order) white Middle Silurian Keefer Sandstone (Sk), shaly limestone of the Middle and Upper Silurian McKenzie Formation $(\mathrm{Sm})$, and red shale and sandstone of the Upper Silurian Bloomsburg Formation (Sb). The clastic rocks are overlain by shale of the Upper Silurian Wills Creek Formation (Sw), Upper Silurian Tonoloway Limestone (StI), and Upper Silurian and Lower Devonian Keyser Limestone (DSk). The boundary between the Silurian and Devonian Periods is within the Keyser. These rocks record a shallow marine sea that transgressed over and submerged much of the Appalachian basin during the Late Silurian.

Devonian rocks range in age from about 418 to $362 \mathrm{Ma}$ (Tucker and others, 1998) and consist of the Lower Devonian Oriskany Sandstone (Do), Lower and Middle Devonian Needmore Shale and Middle Devonian Marcellus Shale (mapped undivided as Dmn), Middle Devonian Mahantango Formation (Dm), Upper Devonian Brallier Shale (Db), Upper Devonian Foreknobs Formation (Df), and Upper Devonian Hampshire Formation (Dh). The boundary between the Devonian and Mississippian periods is located within the Rockwell Formation (MDr), which is the youngest unit exposed along the canal in the Valley and Ridge province. Sideling Hill and Purslane Mountain are underlain by younger rocks (350 Ma) of the Lower Mississippian Purslane Formation (Mp).

The Oriskany Sandstone is interpreted as a beach sand deposited during the regression of the sea that deposited the underlying Keyser Limestone. Overlying the Oriskany Sandstone are shale, siltstone, and sandstone of the Needmore Shale, Marcellus Shale, and Mahantango Formation that were deposited as turbidites when another Early Devonian sea transgressed over the region. During the Late Devonian, regional regression of the sea led to the development of a broad swampy lowland with deltas and rivers. Some of these rivers carried debris from a rising highland to the east that may have resulted from the Acadian orogeny (a tectonic event). Fragments of metamorphic rocks and granitic gneiss that constitute a diamicton (a bouldery deposit) at the Devonian-Mississippian boundary may be derived from rocks of the Blue Ridge and Piedmont that were exposed as the result of this orogeny; the diamicton may be seen at the Sideling Hill roadcut along Interstate Route 68 to the north of the canal.

All of the Devonian shale, siltstone, and sandstone that was deposited above the Oriskany Sandstone is a rather monotonous section of rock. The turbidite deposits are not laterally extensive and there are abundant facies changes both along and across strike that make defining unit contacts difficult. The transitional nature of these units and the inconsistent definition and mapping of them is manifested in the varying interpretations published in the geologic literature.

The Ordovician to Mississippian rocks were folded and faulted during the late Paleozoic Alleghanian orogeny when the North American tectonic plate collided with the African tectonic plate. The resultant forces folded the rocks and transported them westward above thrust faults that are in the subsurface (figs. 4 and 104).

\section{McCoys Ferry to Licking Creek Aqueduct (MM 110 to MM 116)}

Along this section of the C\&O Canal, the Potomac River has eroded a broad flood plain with sloping terraces along the north shore that overlie mostly Devonian shales and siltstones (plate 14). Abundant sandstone colluvium mantles the ridge slopes. The combination of colluvium and alluvium on the lower slopes forms an extensive Quaternary deposit that conceals most of the bedrock. The canal along this section was excavated in alluvium.

Much of the towpath was raised to prevent repeated damage from floods. The large sandstone boulders that remain along the lower terrace near MM 111 are evidence of ancient floods in the region. Similar boulders deposited by the Potomac River litter the uplands as much as $140 \mathrm{ft}$ above the current river level. They were used as building stones for the construction of Fort Frederick in 1756, north of MM 112 (fig. 105).

Big Pool (MM 112.5 to MM 114), located in a formerly swampy area, is a feature unique to the $\mathrm{C} \& \mathrm{O}$ Canal. At this spot, engineers used the swamps of the broad flood plain to make the canal (fig. 106). Levees were constructed and water was impounded within the enclosed swampy lowland. Little Pool to the west is a similar feature. The swampy area near the campground at Fort Frederick is probably what the areas near Big Pool and Little Pool looked like prior to canal construction.

\section{Licking Creek Aqueduct to Round Top Cement Mill (MM 116 to MM 127.5)}

Fossilized mud cracks, similar to those shown in figure 101, occur on top of several limestone blocks used in con- 

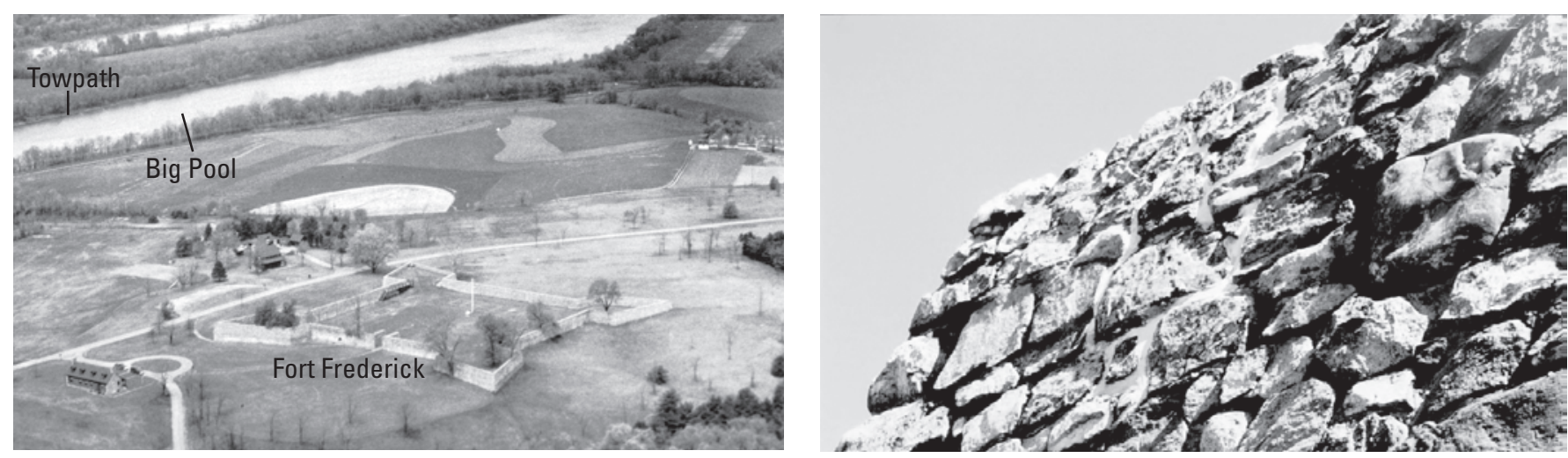

\section{A}

$B$

Figure 105. Fort Frederick and Big Pool at MM 112. A, Aerial view of Fort Frederick (north of MM 112), which was built in 1756. View looks to the southwest. Big Pool, the water body to the south, was a lowland that engineers used for the canal. Photograph by Abbie Rowe, 1955; courtesy of the National Park Service. $B$, Colluvial and alluvial sandstone boulders that were gathered from the fields for construction of the fort's walls.

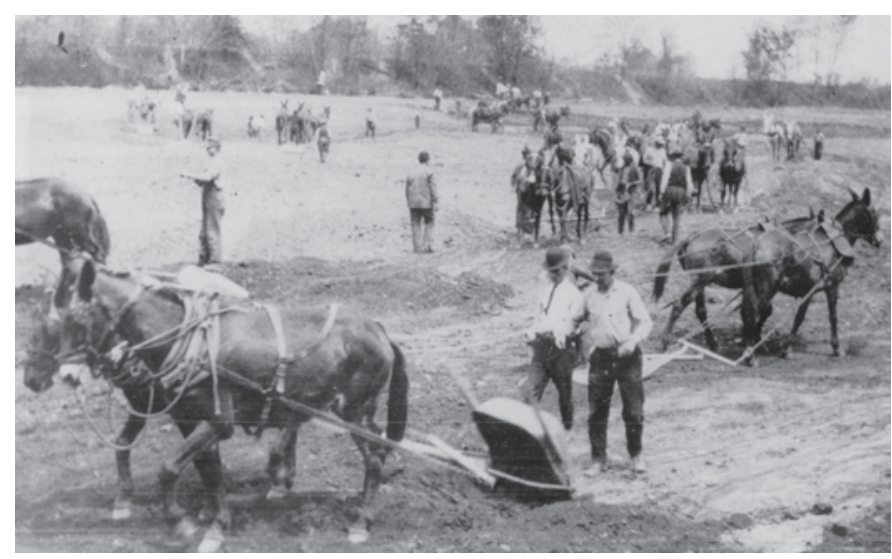

Figure 106. Historical photograph (date unknown, probably late 19th century) of workers and mules scraping the floor of Big Pool after it was drained to remove silt. Photograph courtesy of National Park Service.

structing the Licking Creek Aqueduct (near MM 116) (fig. 107A). Between the aqueduct and the overpass for Interstate Route 70, limestone and chert of the Upper Silurian and Lower Devonian Keyser Limestone (DSk) (fig. 107B) are thrust over shale of the Middle Devonian Mahantango Formation (Dm). The thrust fault is not exposed. From here to the Tonoloway Creek Aqueduct (plate 15) the canal was excavated in alluvium and the only rock that is exposed is the Upper Devonian Brallier Shale (Db) at MM 119 (fig. 108) and Foreknobs Formation (Df) at MM 120. Little Pool, a swampy lowland used for part of the canal channel, is located at MM 119 (see previous discussion).

Near MM 122, the towpath crosses the shale and siltstone of the Upper Devonian Foreknobs and Hampshire Formations (Dh) (fig. 109) in the Meadows Ground syncline. At the southeast abutment of the Tonoloway Creek Aqueduct (MM 123) is an outcrop of sandstone of the upper part of the Foreknobs Formation. This location is a good example of the geomor- phology of the flood plain. The modern flood plain was deposited on shallow bedrock of the Foreknobs Formation, which was leveled by the meandering Potomac River; the bedrock was later exposed by downcutting of Tonoloway Creek, a tributary of the Potomac. To the immediate north is the National Park Service's C\&O Canal Hancock Visitor Center. Hancock is situated on the east limb of the Cacapon Mountain anticlinorium (plate 15), a regional fold that extends for over $45 \mathrm{mi}$ from Virginia to Pennsylvania. The east limb of the Cacapon Mountain anticlinorium is Warm Springs Ridge, which is underlain by the Lower Devonian Oriskany Sandstone (Do). This pure quartz sandstone is quarried commercially in West Virginia for making glass. The Oriskany Sandstone also is a major subsurface reservoir for natural gas throughout the central Appalachians. Natural warm-water springs, such as Berkeley Springs to the south in West Virginia, are situated where radiogenically heated ground water rises within the sandstone and discharges at the surface. Dark, fissile shale of the Middle Devonian Needmore Shale (Dmn) and the Lower and Middle Devonian Marcellus Shale stratigraphically overlie the Oriskany. The uppermost part of the Marcellus contains limestone nodules (fig. 110).

The Potomac River eroded through and deposited alluvium over the Oriskany Sandstone and older rocks from Little Tonoloway Creek (MM 124.3) west to MM 127. White cliffs of Oriskany Sandstone, locally known as Lovers Leap, crop out southeast of MM 126 in West Virginia. North of the canal near MM 127 (west of White Rock campsite), the creek flows across broadly folded beds of white Middle Silurian Keefer Sandstone (Sk).

The remains of the Round Top Cement Company's mill (fig. 34), as well as good outcrops of folded and faulted rock, are located at about MM 127.5. As summarized by Glaser (1987), the studies of these folds, cleavages, and faults here and along the abandoned railroad cut above the canal by Cloos $(1951,1958,1964)$ and Geiser $(1970,1974)$ have advanced the understanding of the mechanisms of structural geology. The 


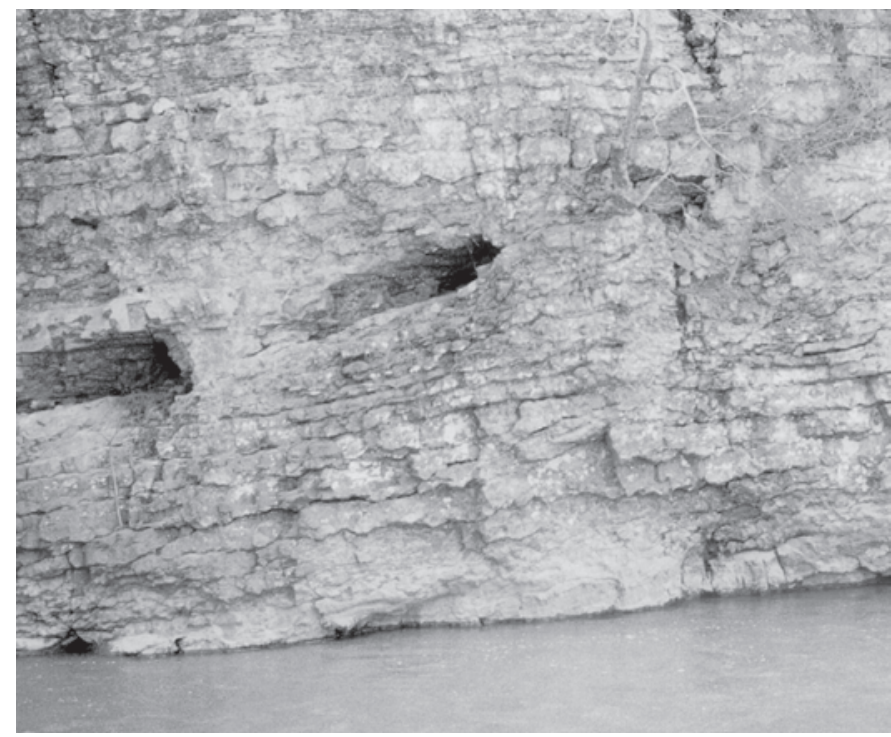

$\boldsymbol{A}$

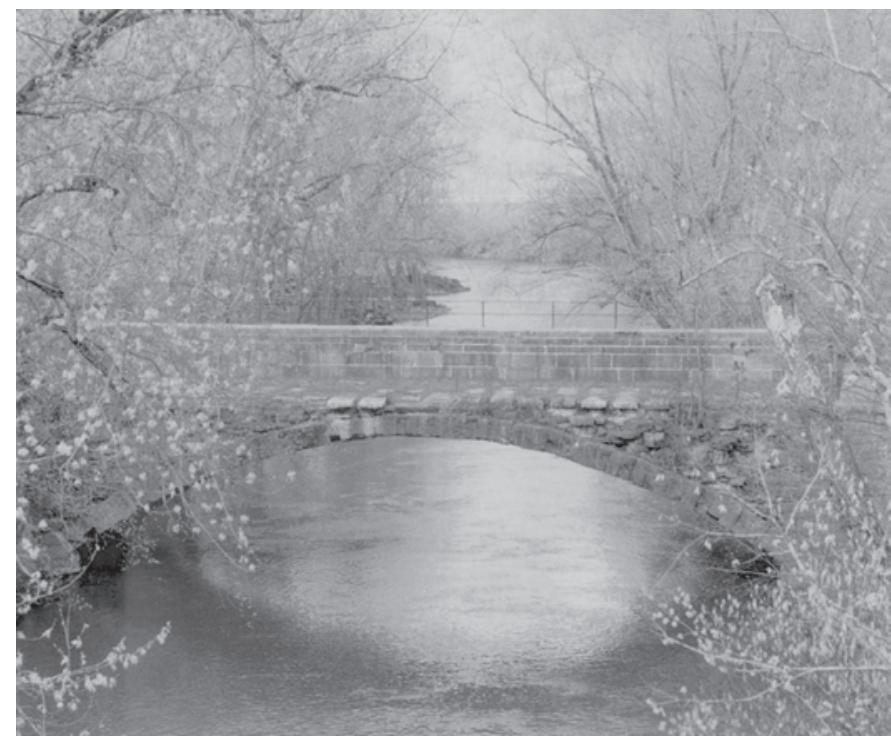

\section{B}

Figure 107. Upper Silurian and Lower Devonian Helderberg Limestone and Lower Devonian Shriver Chert. A, Helderberg Limestone and limestone within the Shriver Chert, exposed north of MM 116, are located above a blind thrust fault that places them over shale of the Middle Devonian Mahantango Formation (not shown). Note the two caverns (located in the Helderberg) on the left side and center of the photograph. $B$, Licking Creek Aqueduct at MM 116 was constructed from limestone blocks. Beneath the aqueduct and alluvium is the Mahantango Formation, which at this location also is located below the thrust fault.

anticline (locally called Devil's Eyebrow) (figs. 111, 112, and 113) and adjacent folds (fig. 113) are in red sandstone, siltstone, and shale of the Upper Silurian Bloomsburg Formation (Sb). Calcareous shale and limestone have weathered away to form a cavelike recessed area in the hinge of the Devil's Eye-

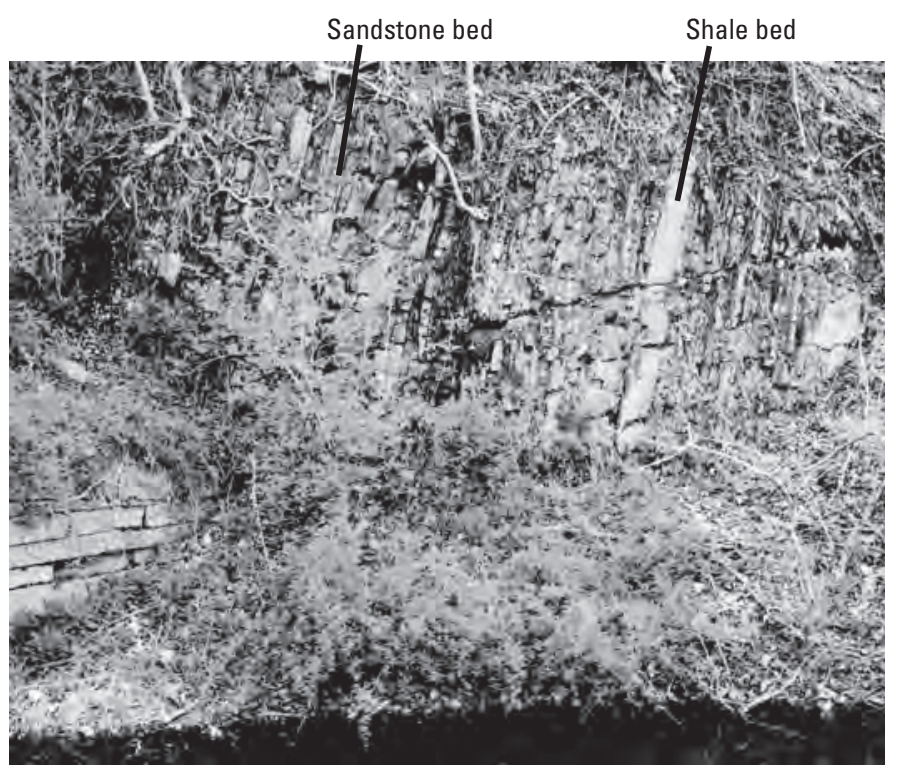

Figure 108. Thin-bedded sandstone and shale of the Upper Devonian Brallier Shale, east of the access trail to Little Pool (at about MM 120.2), resemble turbidites of the Middle and Upper Ordovician Martinsburg Formation near Williamsport (see figure 99). The stone berm of the canal is visible in the lower left of the photograph.

brow anticline (fig. 112). High-calcium limestone of the overlying Upper Silurian Wills Creek Formation (Sw) was mined (fig. 114) and processed for cement beginning in 1837.

\section{Round Top Cement Mill to Sideling Hill Aqueduct (MM 127.5 to about MM 137)}

From MM 127.5 to MM 133, the Potomac River meanders through complexly folded rocks in the core and along the northwest limb of the Cacapon Mountain anticlinorium (plate 16). The nearly flat-lying rocks excavated along the canal northeast of Leopards Mill are from the axial region (or crest) of the main anticline. The oldest rocks, Late Ordovician and Early Silurian Tuscarora Quartzite (SOt), are exposed opposite the river near Sir Johns Run in West Virginia. Outcrops of shale and sandstone of the Middle Silurian Rose Hill Formation (Sr) (fig. 115) and Keefer Sandstone (Sk) are located along the road and creek northwest of MM 130; elsewhere, Quaternary colluvium and alluvium cover the gentle slope and obscure bedrock. Near MM 131.8, shale of the Rose Hill Formation contains drill holes that resulted from excavation of the canal.

The Potomac River cuts across the strike of bedding from near MM 133 to the Sideling Hill syncline near MM 137 (fig. 116). Folded Silurian and Devonian rocks on the northwest limb of the Cacapon Mountain anticlinorium may be seen from MM 133 west to Dam 6 and Tonoloway Ridge (MM 134) (fig. 117). An anticline of tan Keefer Sandstone (Sk) is located near MM 133 (fig. 118A). Also present in this area are thrust faults that truncate sandstone beds (fig. 118B). 


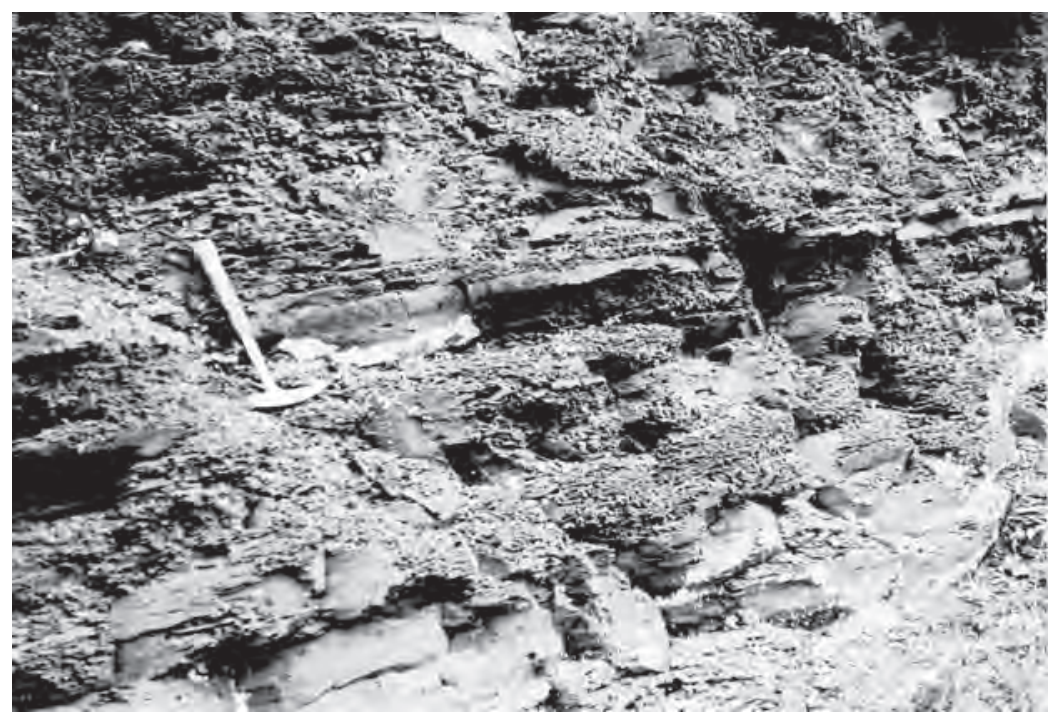

A

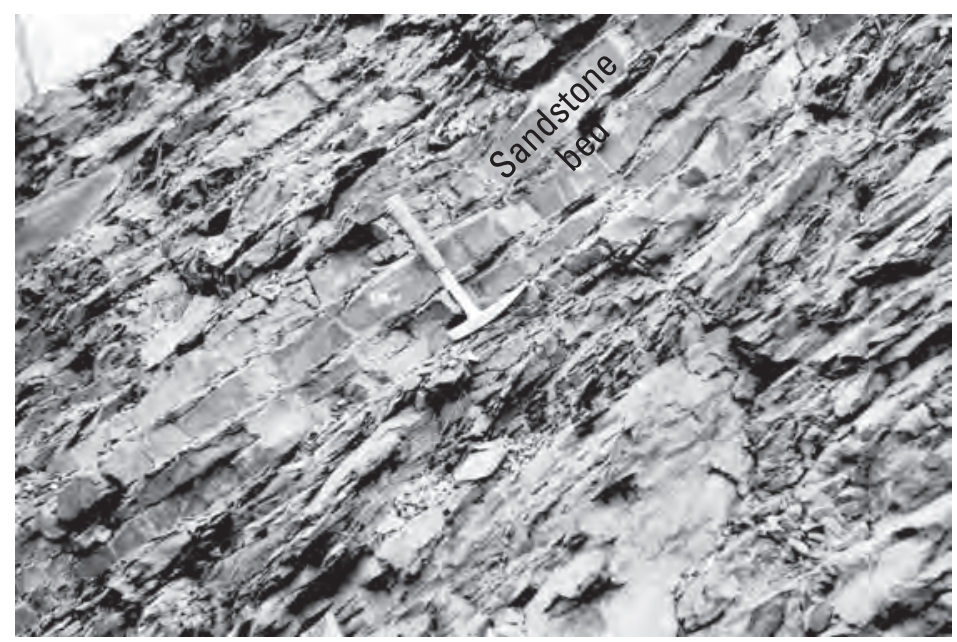

C

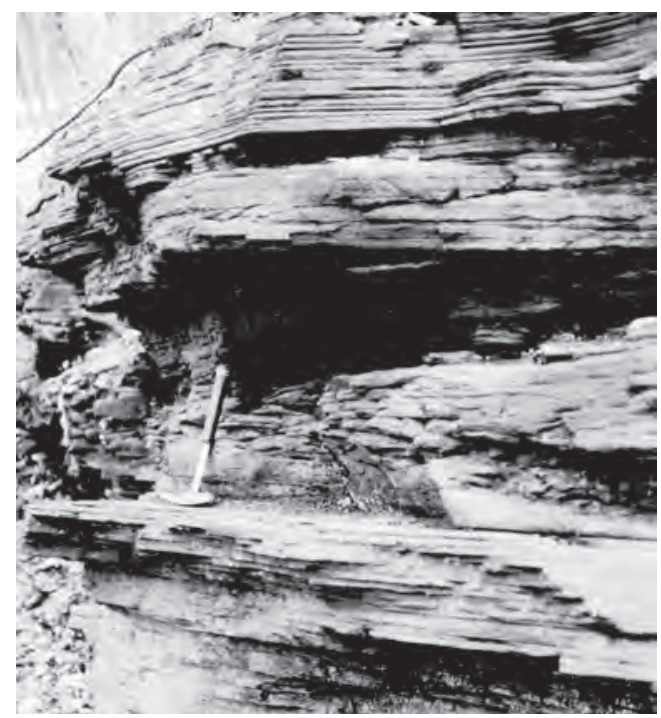

B

Figure 109. Upper Devonian Foreknobs Formation. $A$, Fissile, red shale interbedded with thin sandstone in the Upper Devonian Foreknobs Formation. $B$, Thin-bedded, red sandstone of the Foreknobs Formation. Both $A$ and $B$ are characteristic of the Foreknobs, which is best exposed south of the Potomac River on the limbs of the Meadows Ground syncline. The sandstone beds become more massive and thicker upsection into the Upper Devonian Hampshire Formation in the core of the syncline. $C$, Thick red shale of the Foreknobs Formation shown transitioning to thin-bedded sandstone and shale of the Upper Devonian Brallier Shale, which was last seen near MM 120.2 (see fig. 108).

Drill holes in the sandstone are oriented perpendicular to the beds. Tubelike lines of trace fossil Skolithos linearis also are present (fig. 118C). The intricately folded rocks along this section of the canal (fig. 119) are best exposed to the south along the Cacapon River at Fluted Rocks, W. Va. (fig. 120). Here, the folds are secondary to the larger fold that underlies Cacapon Mountain to the east where the white Tuscarora Quartzite is exposed. The folds in these fluted rocks show how contrasting rock types, such as sandstone and shale, respond differently to deformation. Differences in the geometry of the folds (Lessing, 1988) reflect this competency contrast. In the Potomac River near MM 133.5, Davies (1999) noted a fish weir constructed by Native Americans.

Resistant, cherty, fossiliferous limestone of the Upper Silurian and Lower Devonian Keyser Limestone (DSk) (fig. 121) and overlying Lower Devonian Oriskany Sandstone (Do) underlie Tonoloway Ridge west of MM 134. The Oriskany was quarried locally for silica-rich sand and dimension stone. Like Dam 3 at Harpers Ferry, feeder Dam 6 was built above resistant sandstone ledges and shallow waterfalls. Sandstone outcrops with fossil brachiopod molds (fig. 122) form the base to the dam abutment. The original dam was a timber crib filled with sandstone rubble and then covered with wooden planks, but only the rubble remains (fig. 38). Opposite Dam 6 are well-developed fluvial terraces of both the Potomac and Cacapon Rivers.

Stratigraphically above the Oriskany Sandstone are shale, siltstone, and sandstone turbidite deposits of the Lower and Middle Devonian Needmore Shale and Middle Devonian Marcellus Shale (Dmn) (fig. 123). Westward from MM 134, the siltstone and sandstone are folded (fig. 124) (Cloos, 1951). The axial region of the Sideling Hill syncline is crossed at the Sideling Hill Creek Aqueduct. This syncline is best exposed to the north along the Interstate Route 68 roadcut at the State of Maryland's Sideling Hill Exhibit Center (fig. 125). The east end of the aqueduct is made up of sandstone taken from the 


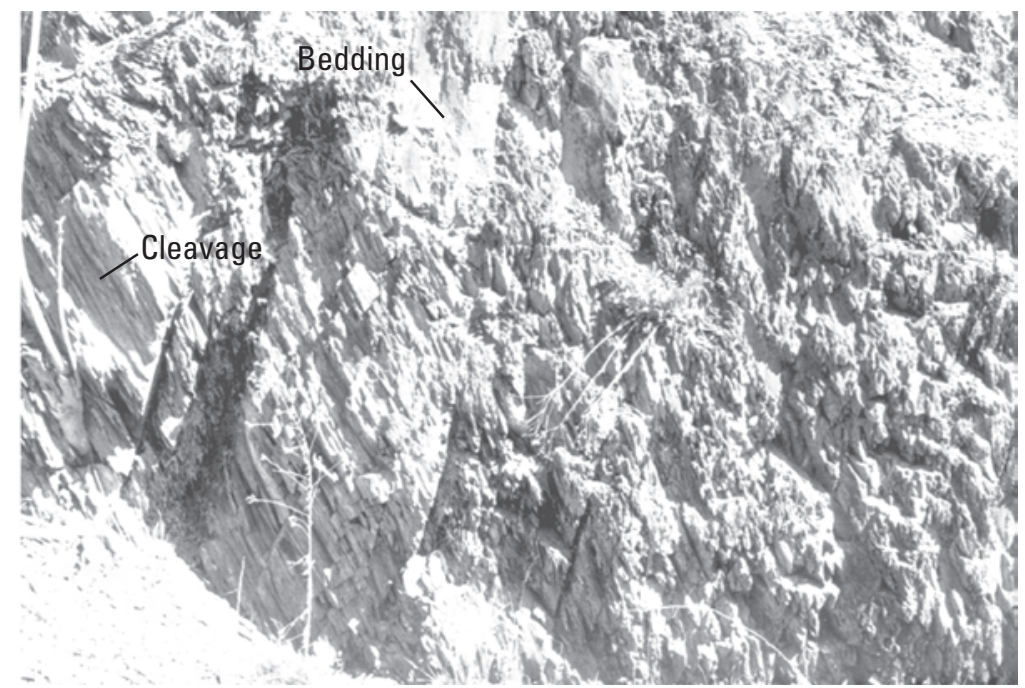

\section{$\boldsymbol{A}$}

Figure 110. Middle Devonian Marcellus Shale southeast of MM 125 in West Virginia. A, Fissile black shale dipping east on the limb of the Cacapon Mountain anticlinorium and displaying west-dipping cleavage. $B$, Local concretions of limestone in the Marcellus that were deposited above the Lower Devonian Oriskany Sandstone.

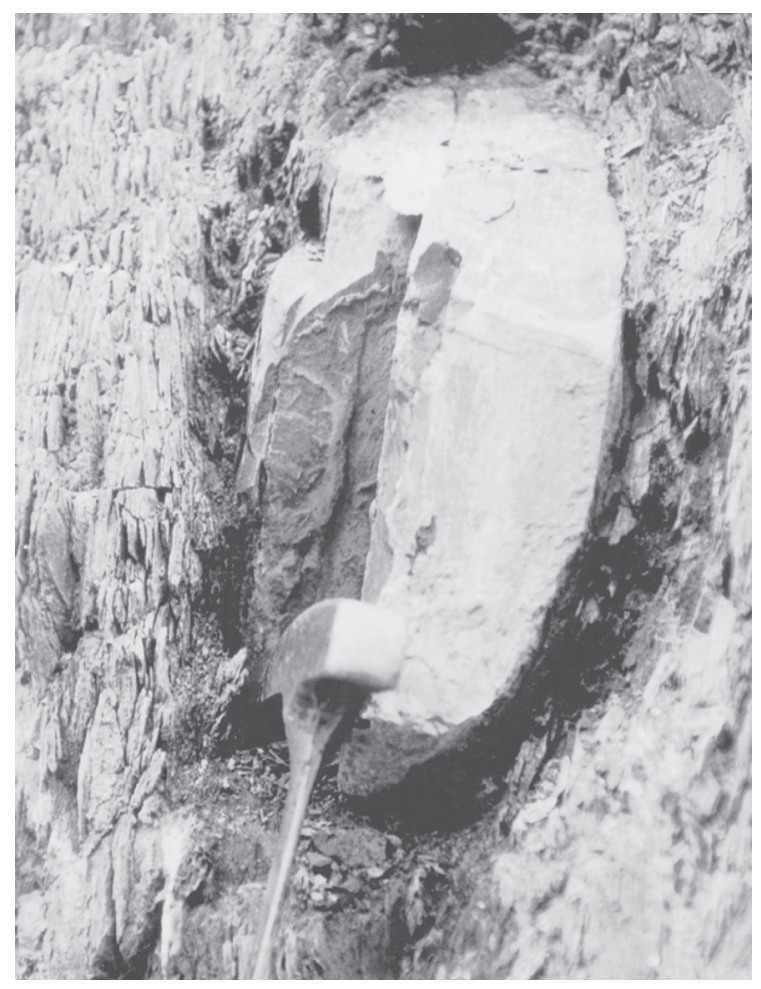

B

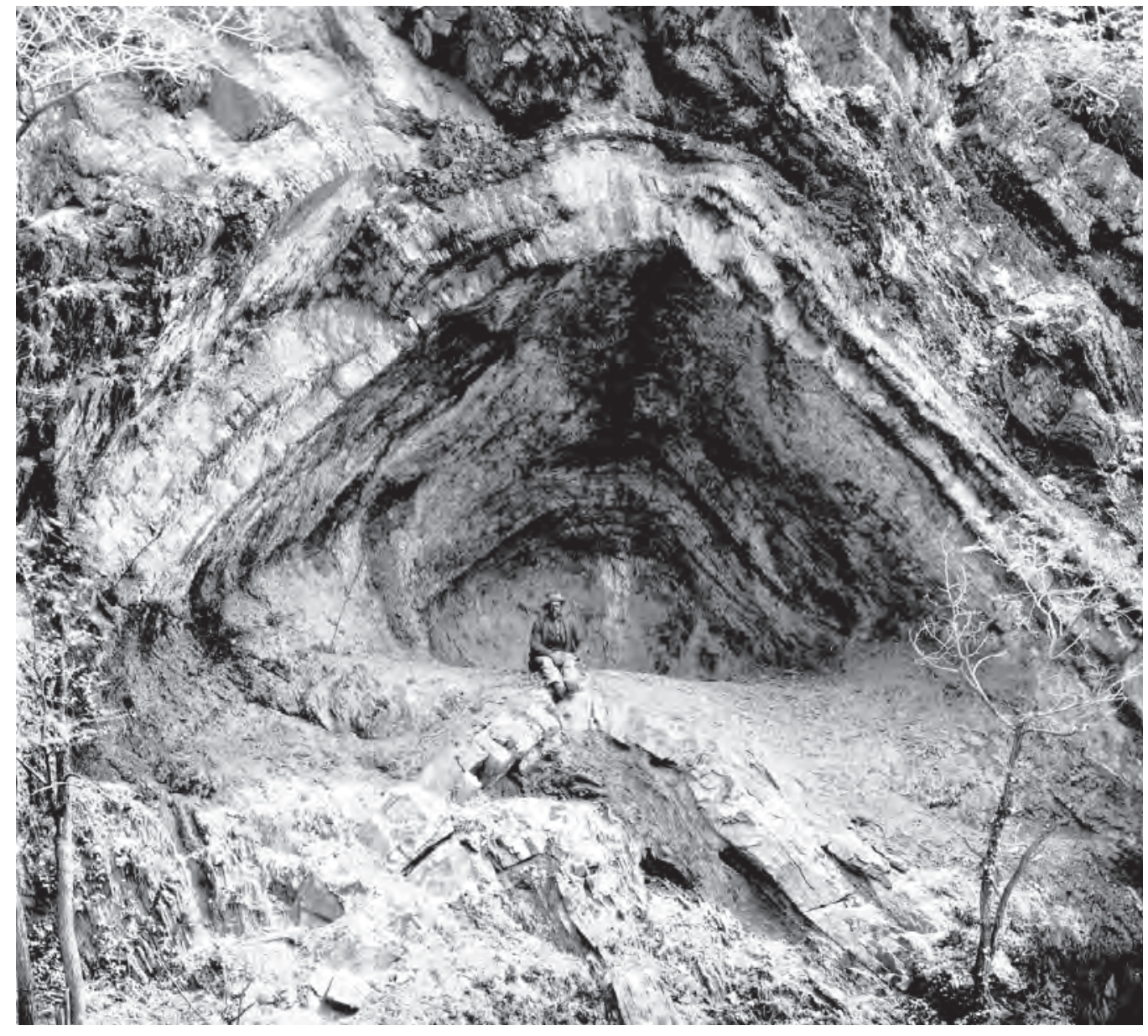

Figure 111. Historical photograph (1897) of the Devil's Eyebrow, an anticline in rocks of the Upper Silurian Bloomsburg Formation at MM 127. The shallow cave in the core of the anticline behind the seated man was formed from the weathering of limy shale and limestone. Photograph by Charles D. Walcott (U.S. Geological Survey). 


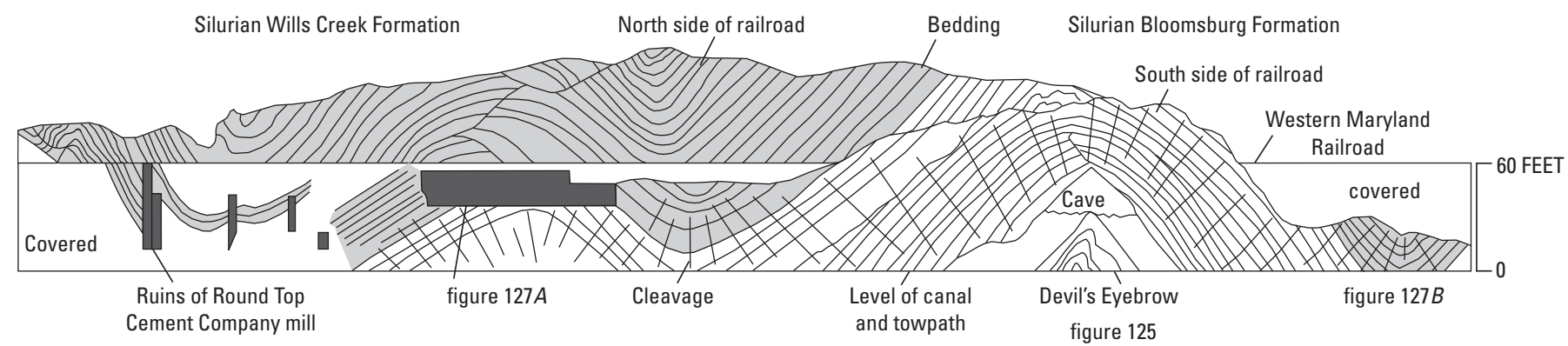
100 FEET

Figure 112. Sketch of the Devil's Eyebrow and ruins of Round Top Cement Company mill west of Hancock, Md. (modified from Davies, 1989).

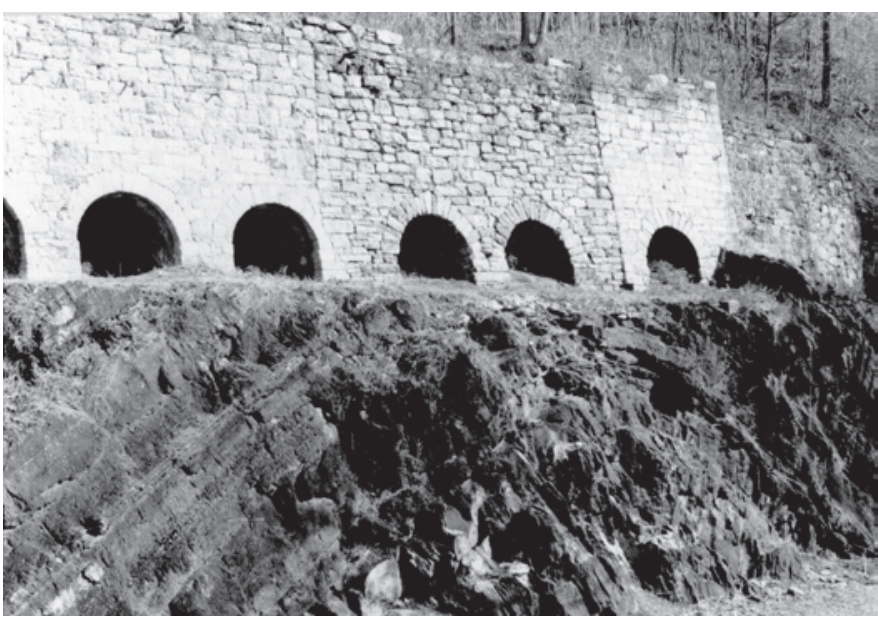

$\boldsymbol{A}$

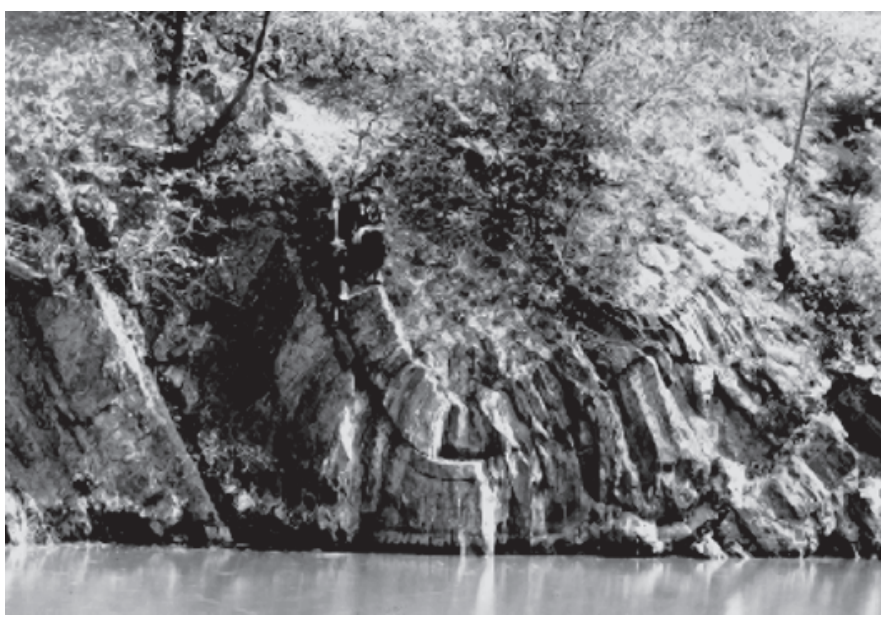

$\boldsymbol{B}$

Figure 113. Folds in Upper Silurian Bloomsburg and Wills Creek Formations. In both photographs, note that the cleavage is nearly perpendicular to the folded beds. A, Lime kilns of the Round Top Cement Company mill situated above an anticline of Bloomsburg Formation west of MM 127 and the Devil's Eyebrow, which is also composed of Bloomsburg. $B$, Historical photograph (1897) showing intervening syncline in Wills Creek Formation. Photograph by Charles D. Walcott (U.S. Geological Survey).

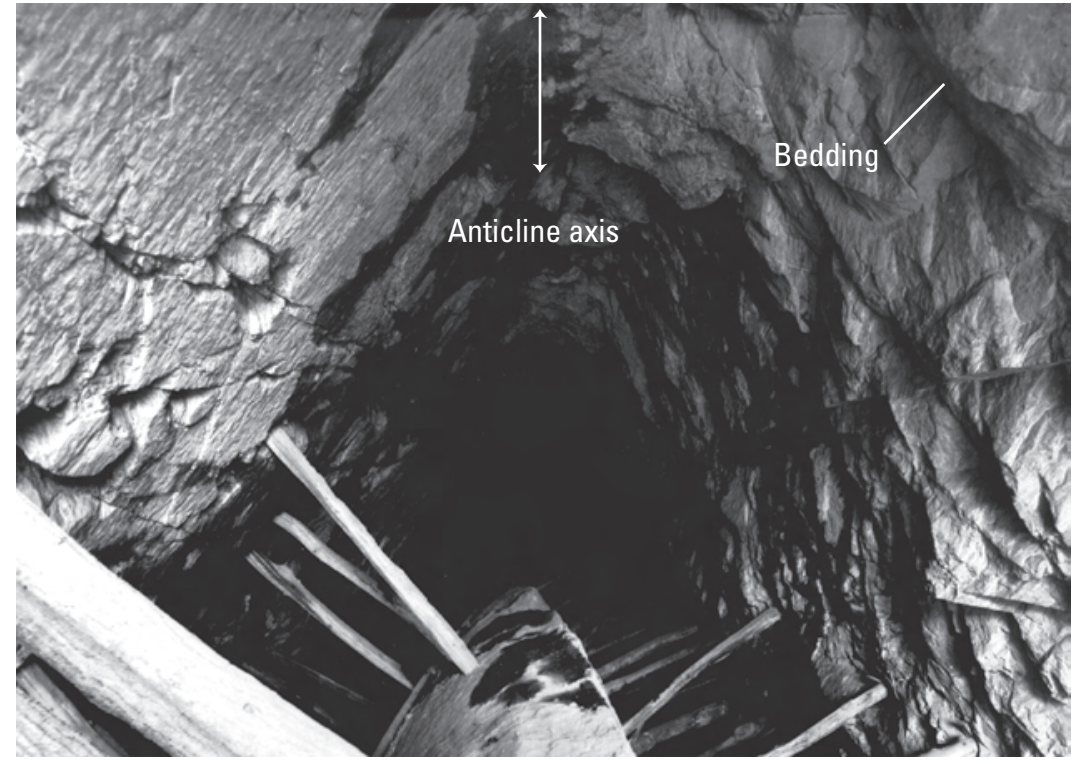

Figure 114. Historical photograph (1897) looking down the axis of an anticline. Limestone in the core of the fold was mined on the side of Round Top. Timber was used to support the rock during mining. Photograph by Charles D. Walcott (U.S. Geological Survey). 


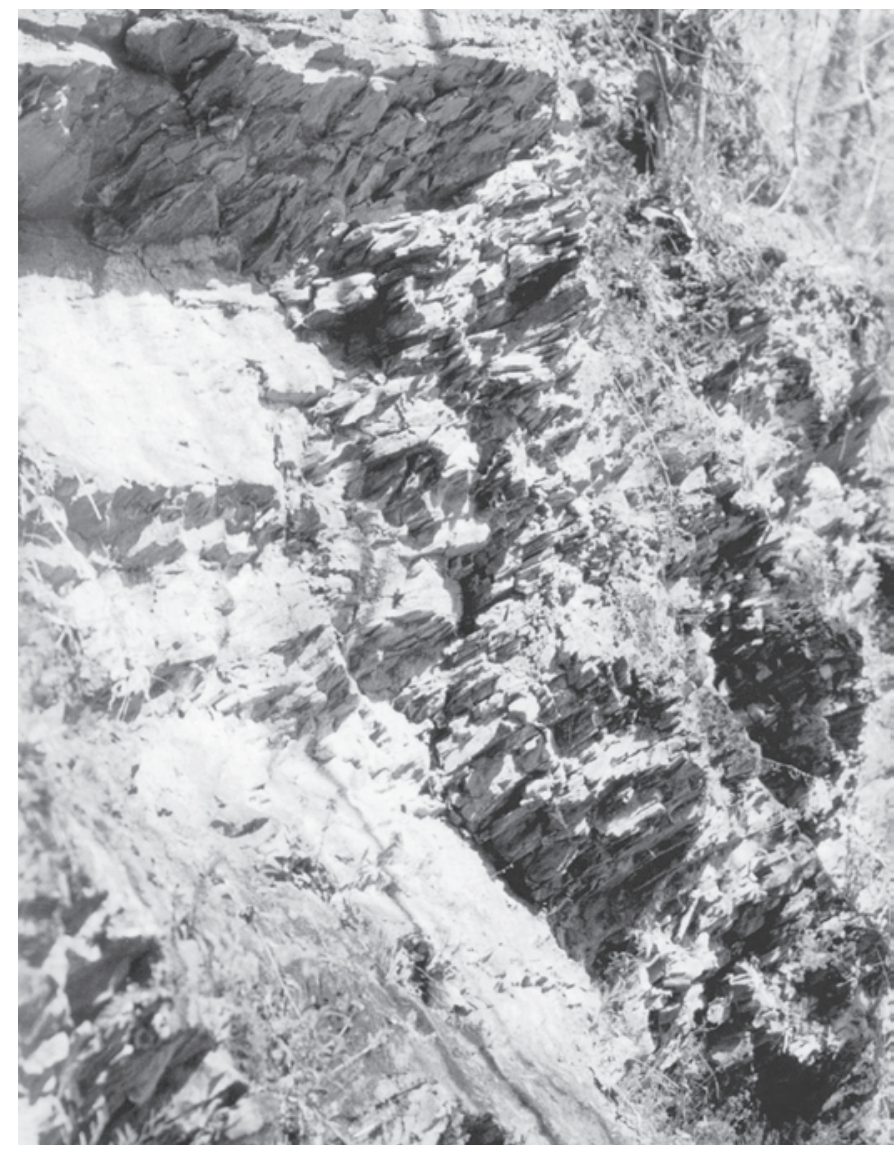

Figure 115. Shale of the Middle Silurian Rose Hill Formation, which was drilled and excavated near Leopards Mill (MM 130). These are some of the oldest rocks exposed along the C\&O Canal in the Valley and Ridge province. Note that bedding dips to the left and joints dip to the right.

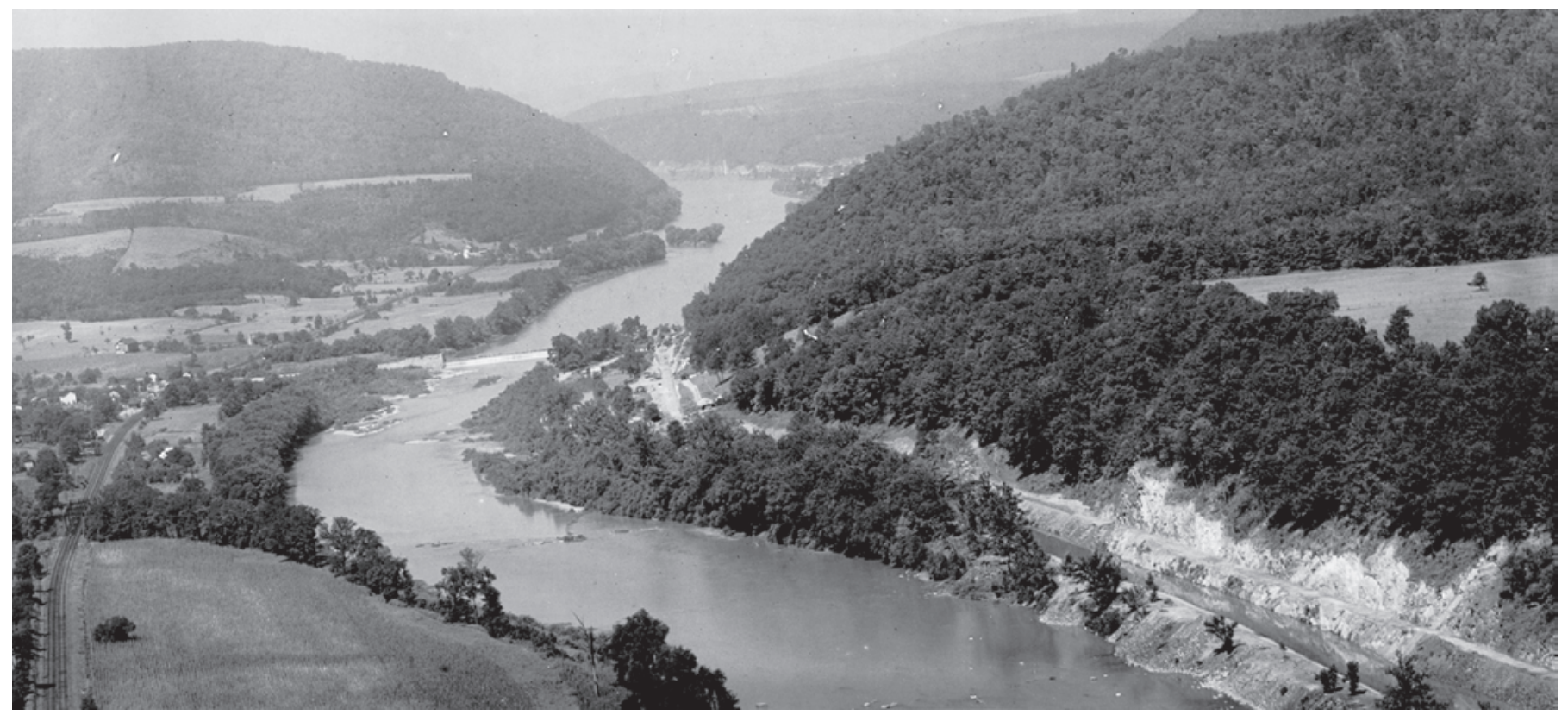

Figure 116. Historical photograph (date unknown) from the overlook on Cacapon Mountain in West Virginia, looking west toward the town of Great Cacapon, W. Va. (on left side of photograph). Note the fresh rock exposed along the canal and railroad excavations in the lower right (illustrated in figure 117). The nearly flat open pastures amid forests on the hills on either side of the Potomac River are terraces of the ancestral river deposited during early Quaternary or possibly Tertiary time. Similar terraces south of the Potomac River (to the left, beyond Great Cacapon), are younger in age and lower in elevation. Dam 6 and Lock 51 are located at the bend of the river at the end of Tonoloway Ridge, in the center of the photograph. Photograph courtesy of the National Park Service. 
West

A

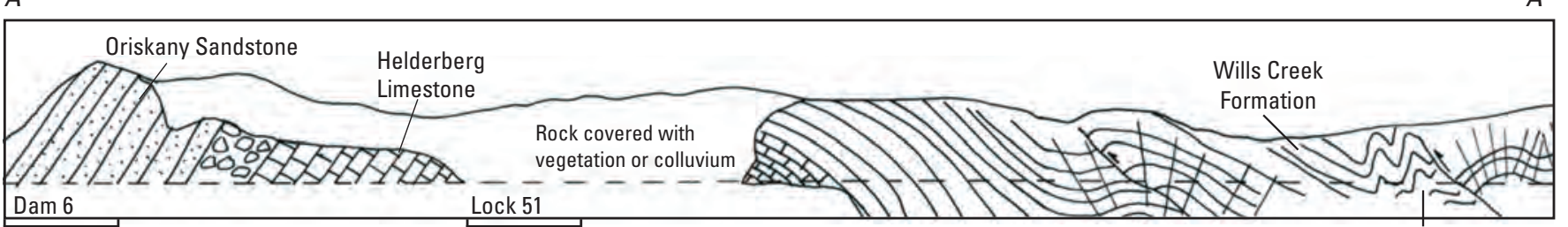

figure 119

A

East

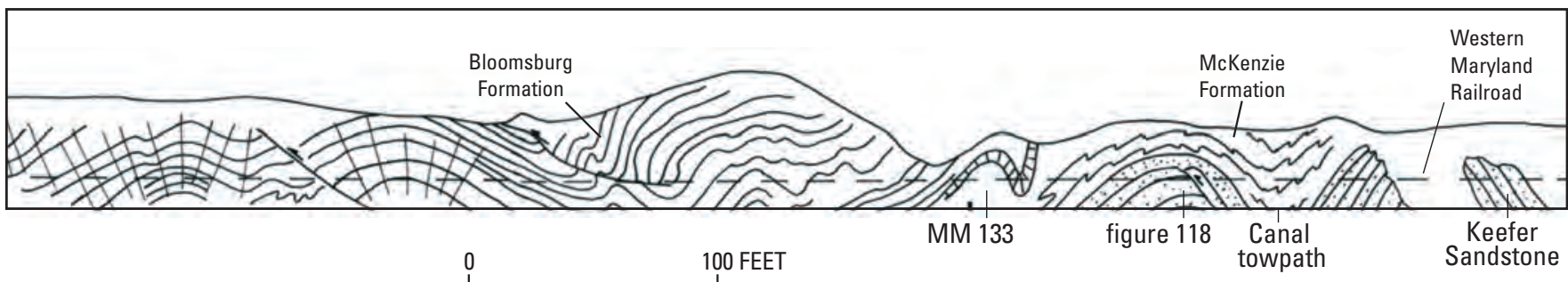

Figure 117. Geologic sketch of the bedrock along the section of the C\&O Canal from east of MM 133 west to Dam 6 and Tonoloway Ridge (see figure 116), showing the folded and faulted Silurian and Devonian rocks on the west limb of the Cacapon Mountain anticlinorium. Locations of figures 118 and 119 are shown.

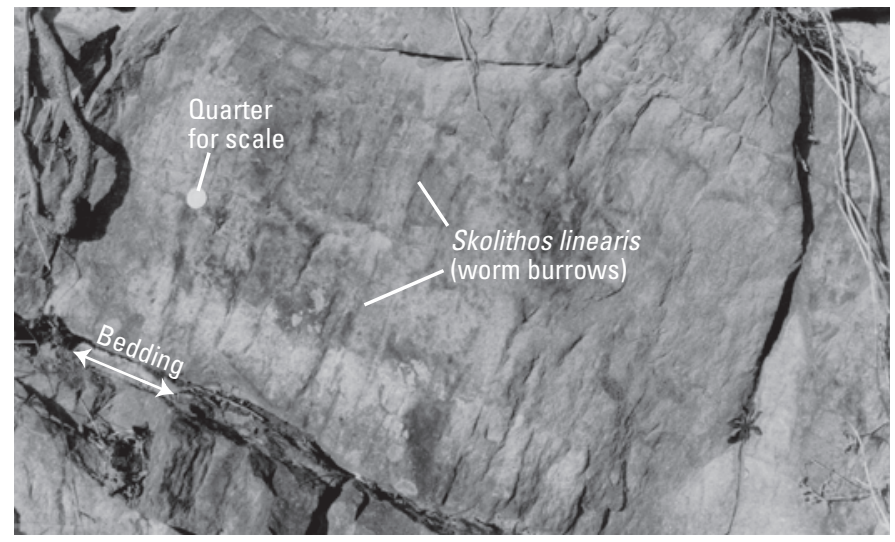

$\boldsymbol{A}$

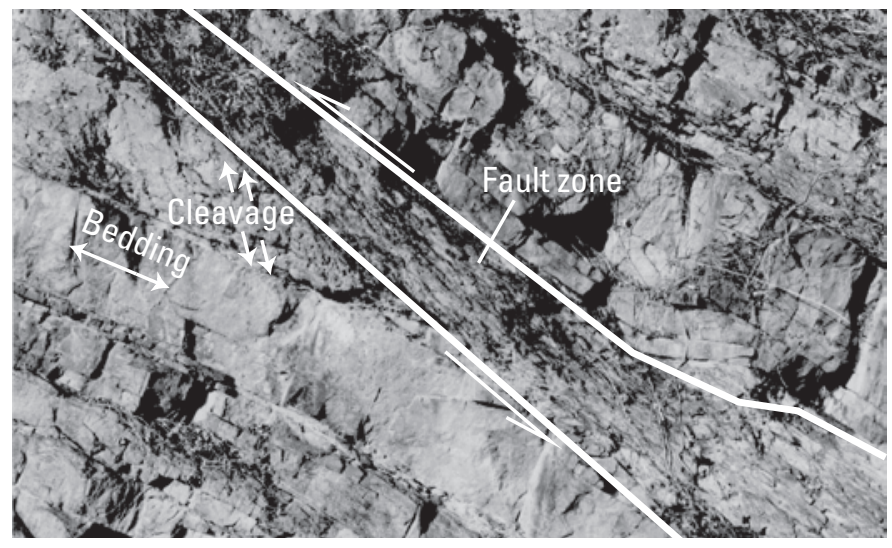

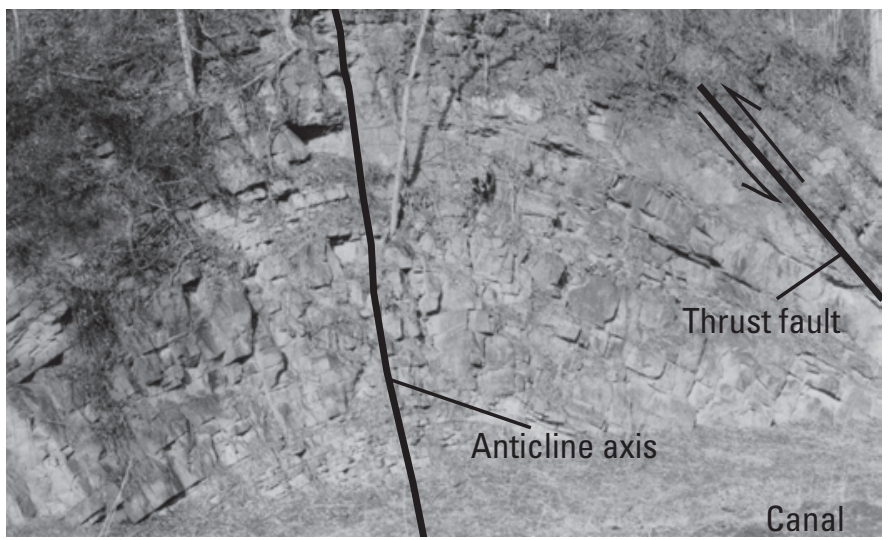

B

Figure 118. Middle Silurian Keefer Sandstone. A, An anticline of Keefer Sandstone exposed along the canal east of MM 133 (locations shown on figure 117). Compare the style of folding seen here with the chevron folds shown in figure 120 . The thrust fault on the eastern limb of the fold is shown in $B$. Outcrop is about $15 \mathrm{ft}$ high. $B$, Thrust fault, which formed during flexural-slip folding of the beds. Sandstone beds are fractured and truncated beneath the fault, which is in the more ductile and cleaved shale. $C$, Outcrop showing Skolithos linearis (trace fossil worm burrows) perpendicular to sandstone beds. Burrows are similar to those seen in the Lower Cambrian Antietam Formation near Harpers Ferry, W. Va. (fig. 86B). Quarter for scale. 


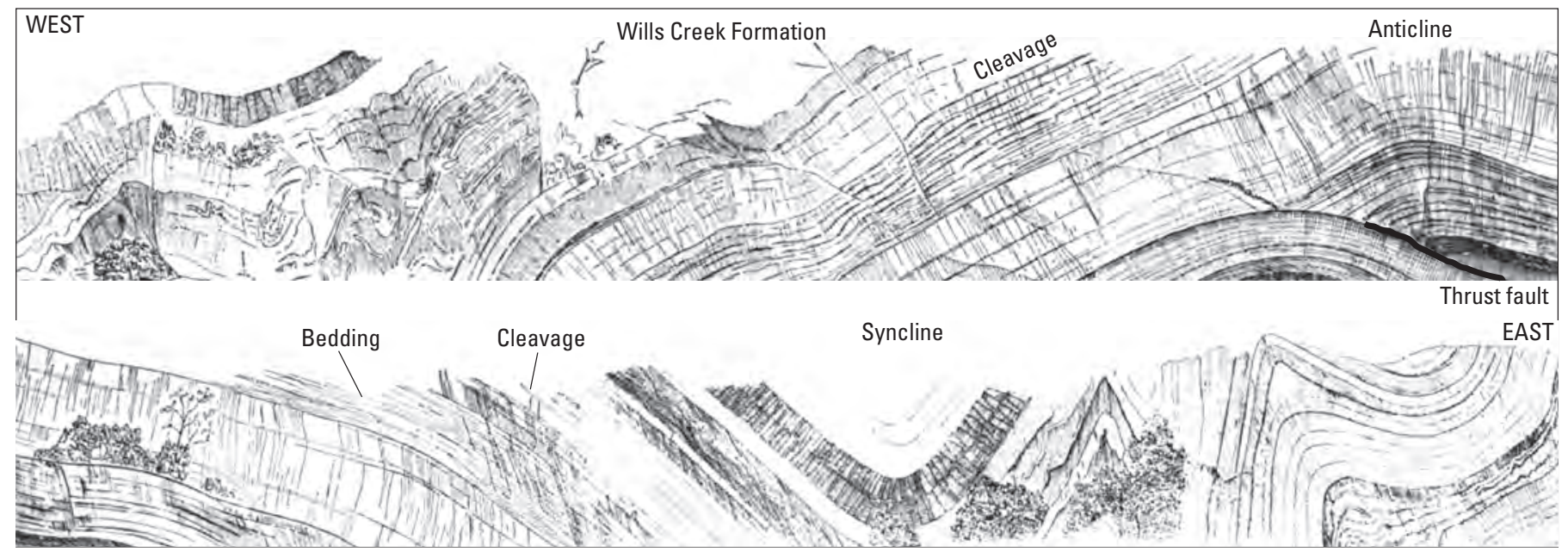

Figure 119. Geologic sketch (after Cloos, 1951) of folded and faulted rocks of the Upper Silurian Wills Creek Formation east of MM 134. Outcrop is about $15 \mathrm{ft}$ high.

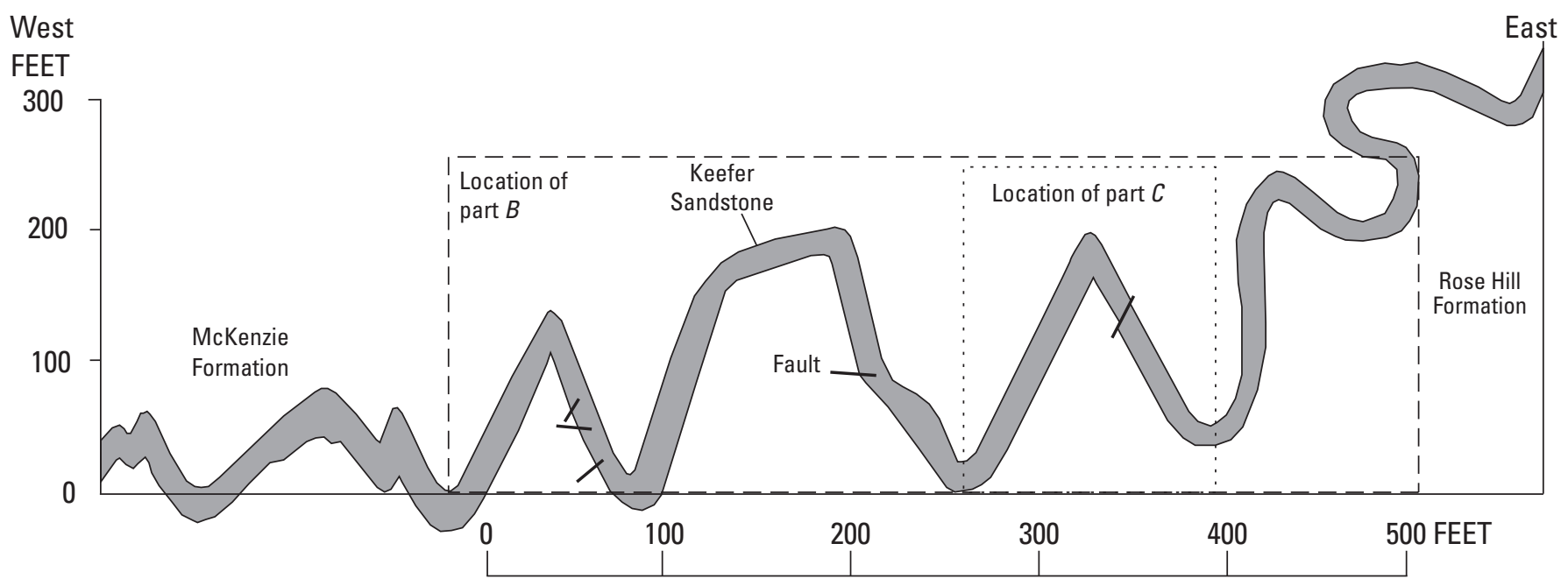

$\boldsymbol{A}$

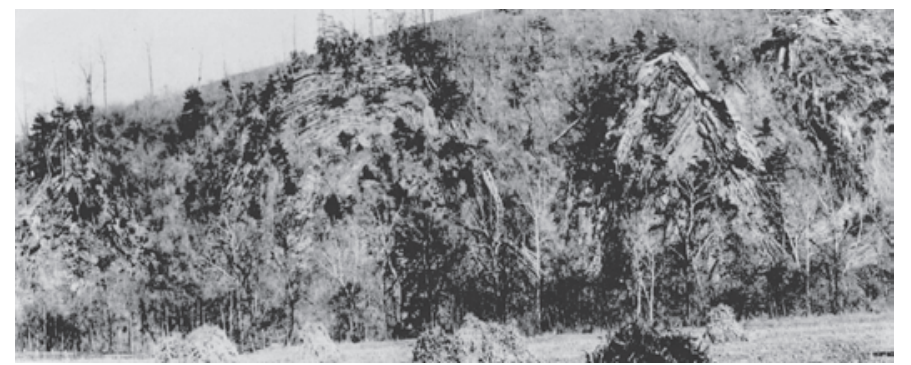

\section{$\boldsymbol{B}$}

Figure 120. Folded and faulted strata at Fluted Rocks, along the Cacapon River in West Virginia. A, Geologic sketch showing Silurian rocks of the Rose Hill Formation, Keefer Sandstone, and McKenzie Formation folded into anticlines and synclines (modified from Lessing, 1988). $B$ and $C$ are historical photographs (around 1910) showing intricately folded and faulted rocks. Photographs by George W. Stose (U.S. Geological Survey).

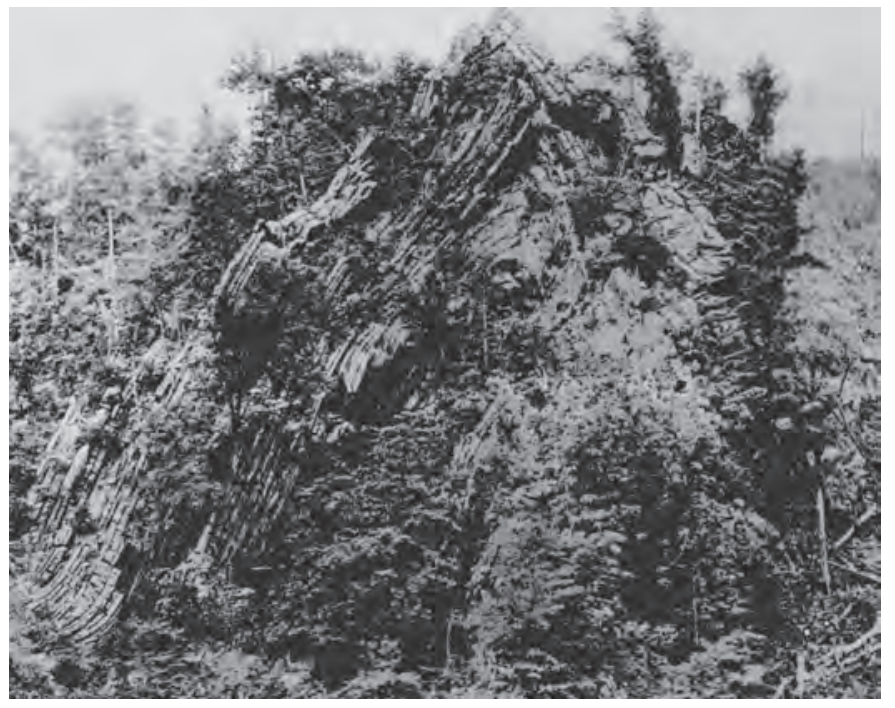




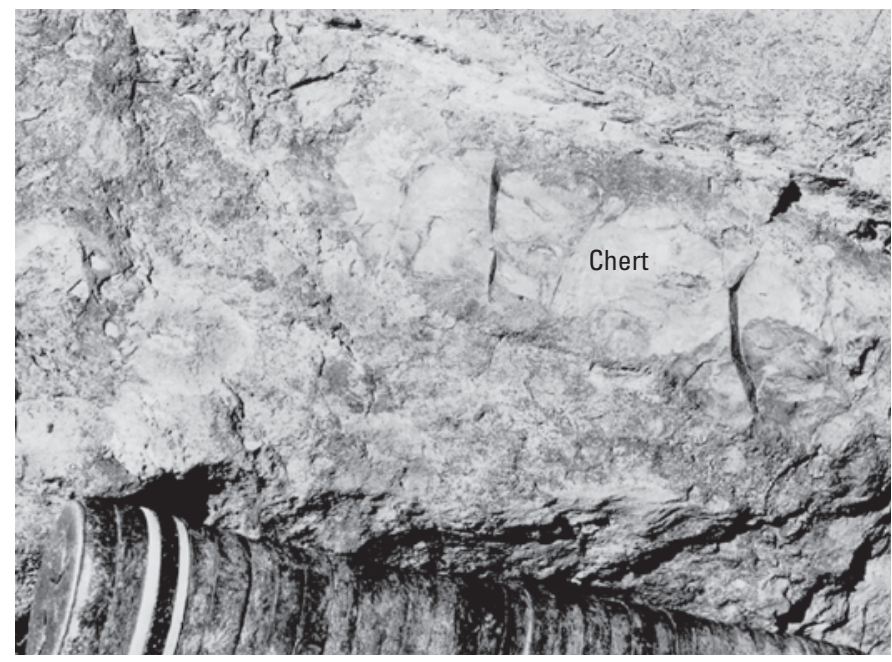

\section{A}

Figure 121. Upper Silurian and Lower Devonian Helderberg Limestone. $A$, Chert within the Helderberg Limestone. $B$, Anthozoans (coral fossils) are abundant in the Helderberg Limestone.

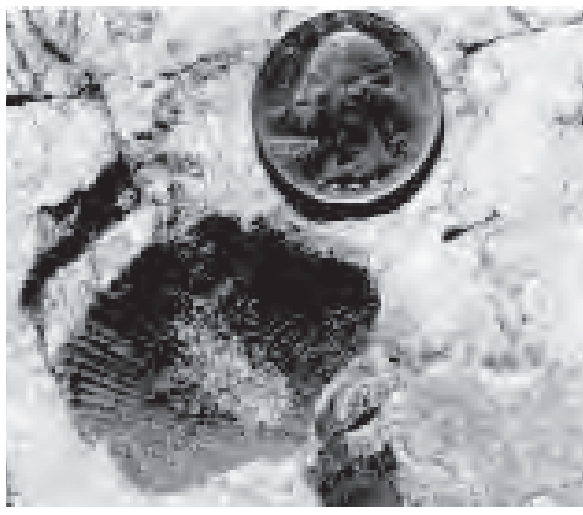

$\boldsymbol{A}$

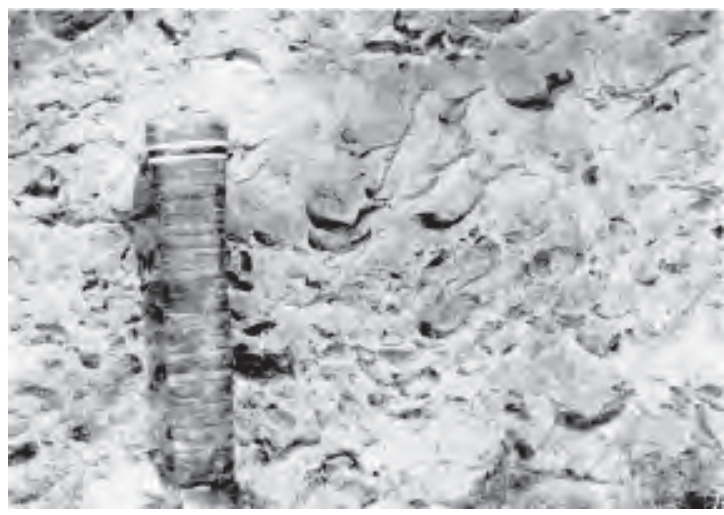

$\boldsymbol{B}$

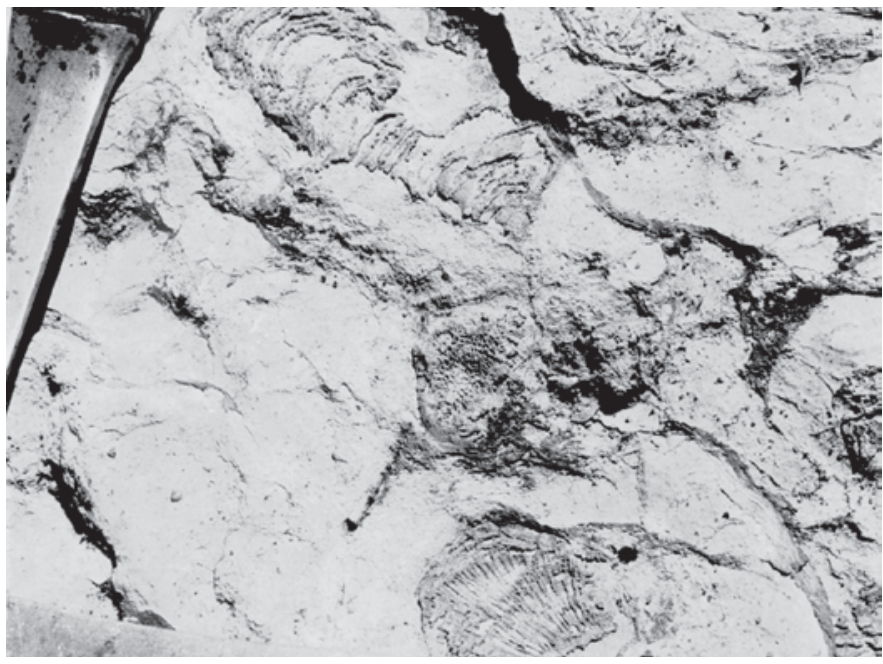

B
Figure 122. Brachiopods in Lower Devonian Oriskany Sandstone underlying Tonoloway Ridge at Dam 6. A, The Oriskany Sandstone contains abundant molds of Spiriferida shells, which were deposited on a sandy beach. Quarter for scale. $B$, Cross sections of brachiopod molds.

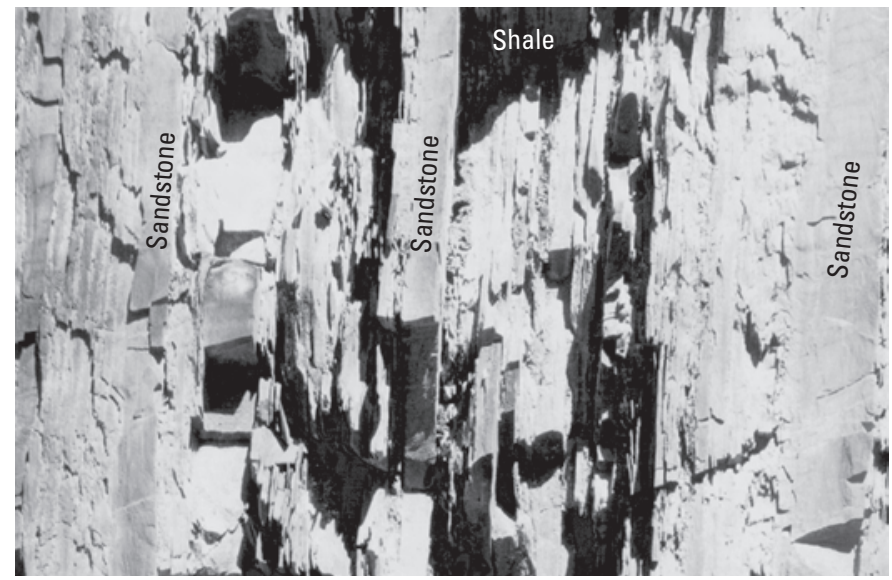

Figure 123. Outcrop of Lower and Middle Devonian Needmore Shale, which was the first shale unit deposited as part of the thick Devonian clastic sequence. The Needmore contains thin sandstone beds and is exposed above the Lower Devonian Oriskany Sandstone immediately west of Tonoloway Ridge near MM 134.2.

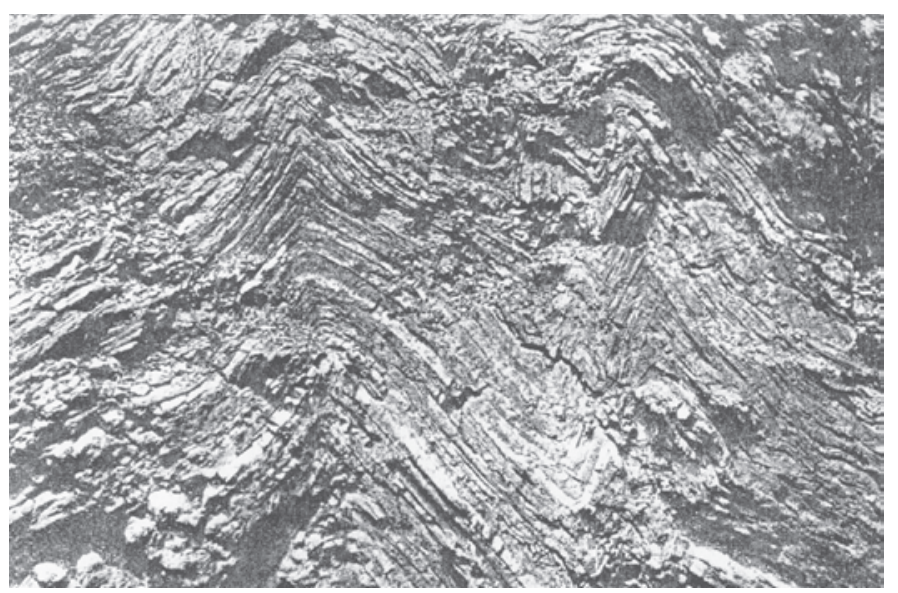

Figure 124. Historical photograph (undated) showing folded and faulted shale and sandstone of the Upper Devonian Brallier Shale exposed above the C\&O Canal along the railroad at MM 135 near the Woodmont station. Chevron folds are in sandstone beds about 3 in thick. Photograph by George W. Stose (U.S. Geological Survey). 
adjacent outcrop of the basal part of the Upper Devonian and Lower Mississippian Rockwell Formation (MDr) (fig. 126), which is the youngest unit seen along the canal west of Point of Rocks, Md. The best exposures of the Rockwell are along the abandoned railroad just north of the canal.

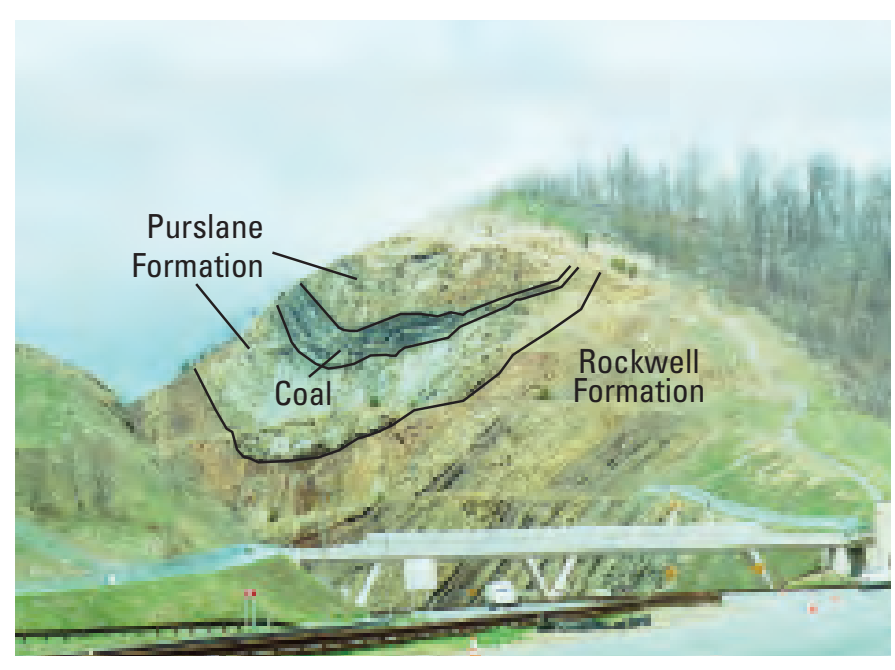

Figure 125. Mississippian rocks of the Sideling Hill syncline exposed in the Interstate Route 68 roadcut through Sideling Hill at the State of Maryland's Sideling Hill Exhibit Center. The black seams are the oldest beds of coal deposited in the region.

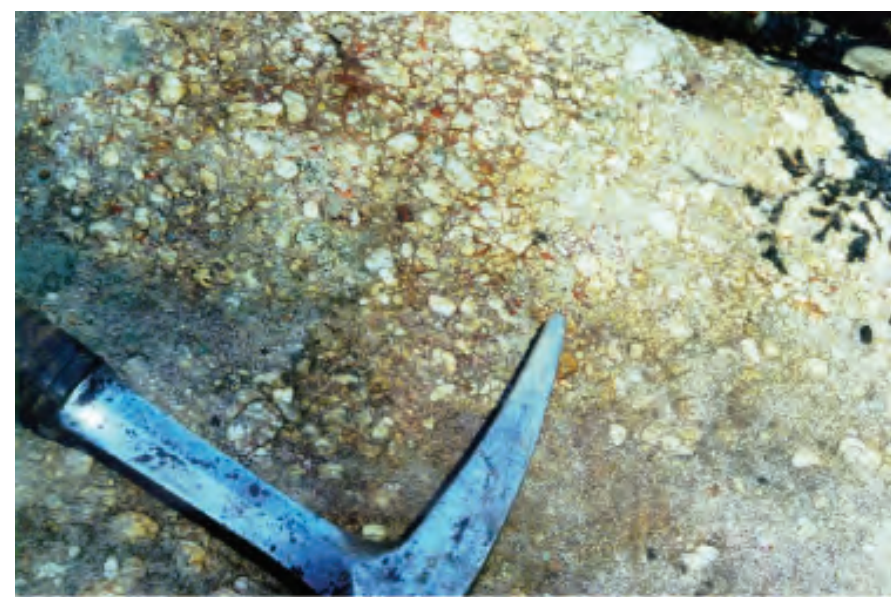

Figure 126. Sandstone in the Upper Devonian and Lower Mississippian Rockwell Formation exposed along the Sideling Hill Creek Aqueduct at MM 136.5. The sandstone consists of cemented vein-quartz gravel which may have been derived from rocks of the Piedmont province exposed and eroded by tectonic activity associated with the Acadian orogeny.

\section{Sideling Hill Aqueduct to Paw Paw Tunnel (MM 137 to MM 156)}

The Broadtop synclinorium (the largest fold structure of this region) occurs between the Cacapon Mountain anticlinorium (MM 133) and the Broadtop anticlinorium (MM 167 at Oldtown) (fig. 104). The Broadtop synclinorium consists of numerous secondary folds such as the Sideling Hill syncline, Whip Cove anticlinoria, and Town Hill syncline. The Potomac River meanders across the rocks of the Broadtop synclinorium to form the incised channels east of Paw Paw, W. Va. (fig. 104). A composite geologic sketch shows parts of the structure (fig. 127 and plate 17). From MM 137 to MM 138 are east-dipping rocks of the Upper Devonian Hampshire Formation (Dh) on the west limb of the Sideling Hill syncline. West of Indigo Neck campsite are the underlying rocks of the Upper Devonian Foreknobs Formation (Df). From about MM 140 west to the old railroad bridge are folded rocks of the Upper Devonian Brallier Shale (Db) that form an anticlinorium. Figure 127 also illustrates a tight anticline exposed west of MM 143. Like the Devil's Eyebrow anticline at the Round Top Cement Company mill (MM 127.5), the hinge of this anticline forms a "cave," which actually is an overhang. In this region, the shale bedrock and thin soil form a unique ecosystem known locally as the shale barrens. Plants such as cactus prefer the stratum and relatively dry climate. To the west, large folds of the Foreknobs and Brallier are exposed along the cliffs at MMs 145, 152 and 154.

Beyond Lock 62 (near MM 154.2) is the Paw Paw Tunnel, which is perhaps the most famous manmade structure associated with the C\&O Canal. The approach to the tunnel follows the route of a former tributary through three lift locks, two of which have fraction designations (Locks 631/3, 642/3, and 66). The tunnel was a solution to bypass the construction of a canal along bedrock cliffs on four meanders of the Potomac River. In order to retain the lock numbering system already in use to the west, fraction numbers were required for the additional locks. South of Lock 65 near MM 155, the canal was excavated at an oblique angle to folded shale and sandstone beds of the Brallier Shale. A cross section of the anticline is exposed at the north portal to the tunnel (fig. 26). The towpath cuts across the axis of the fold, but it mostly follows the northwest limb of the anticline and the beds dip toward it (fig. 128A). Steel rock bolts were installed by NPS to prevent bedrock landslides along bedding planes onto the towpath. On the opposite wall of the canal, the rocks dip into the slope. These rocks occasionally break along joints and fall into the canal. These slope failures suggest that the 12-year construction of the 3,118-ft-long tunnel was both a major accomplishment and hazardous. Exposed along the towpath are ancient mud cracks that are accentuated by cleavage that refracts through them (fig. 128B). The shale beds in the Brallier have fossil burrows and tracks (fig. 128C) made by Devonian organisms that crawled through the mud before it was lithified. Slickensides of vein quartz, which is parallel to the shale beds, formed as the beds flexed and slipped during folding (fig. 128D). 


Location of part $B$ (n)

\section{$\boldsymbol{A}$}

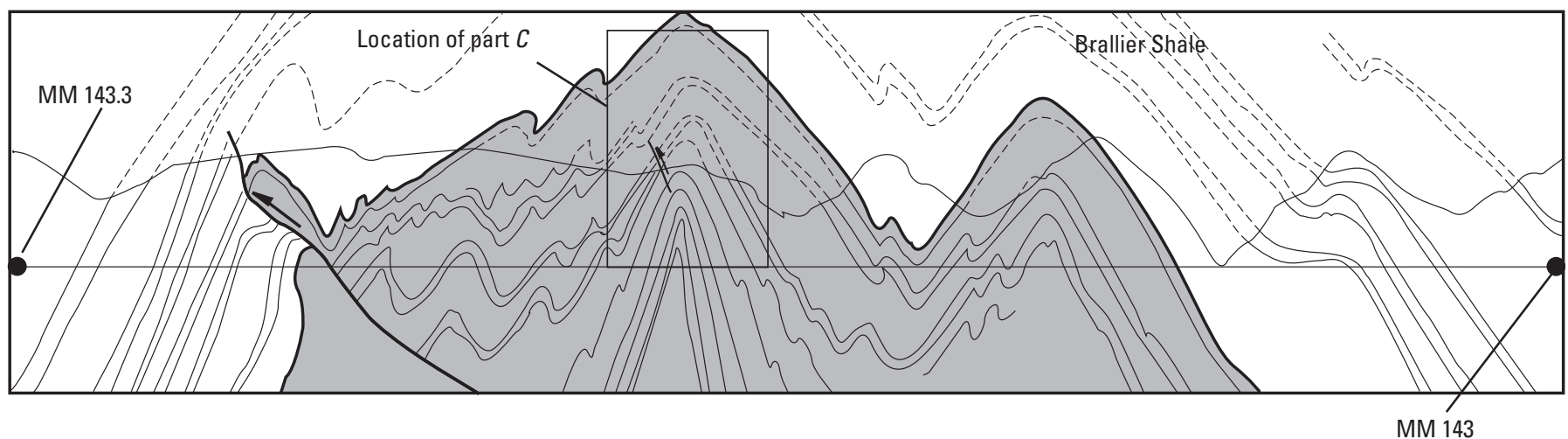

B

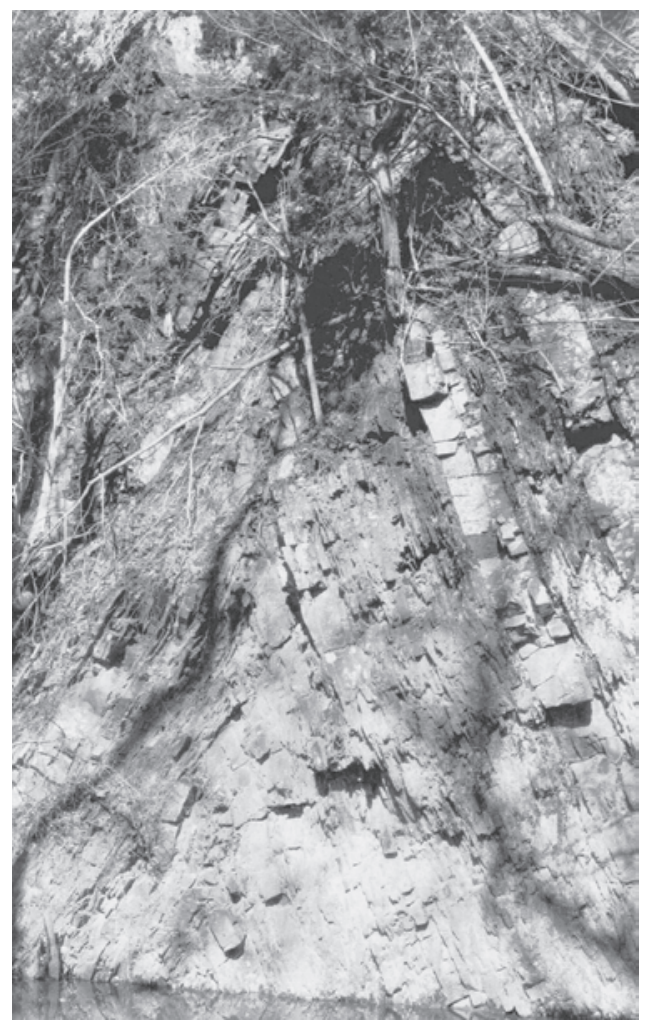

C

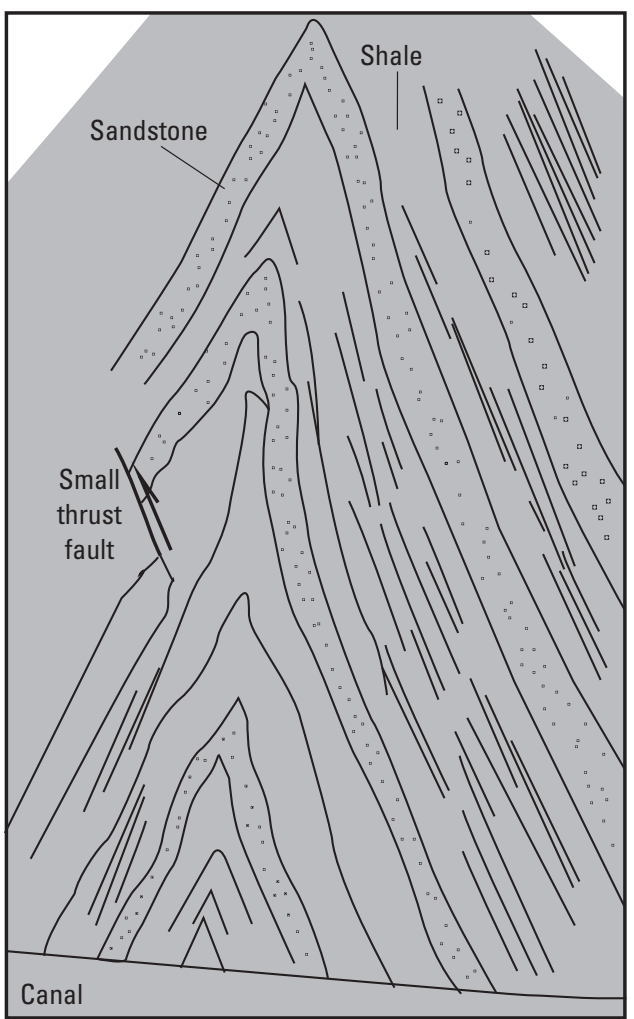

Figure 127. Structures in the Upper Devonian Brallier Shale. $A$, Composite geologic sketch from MM 137 west to MM 138, from Lock 57 west to the west portal of Indigo Tunnel, and from MM 143 west to the old railroad bridge (MM 143.5), illustrating the folded strata on the west limb of the Sideling Hill syncline. $B$, Detailed sketch of the anticlinorium of Brallier Shale centered on MM 143. See part $C$ for enlargement of center fold west of MM 143. $C$, Photograph and sketch of a tight, upright anticline in thin sandstone and shale of the Brallier Shale west of MM 143. 


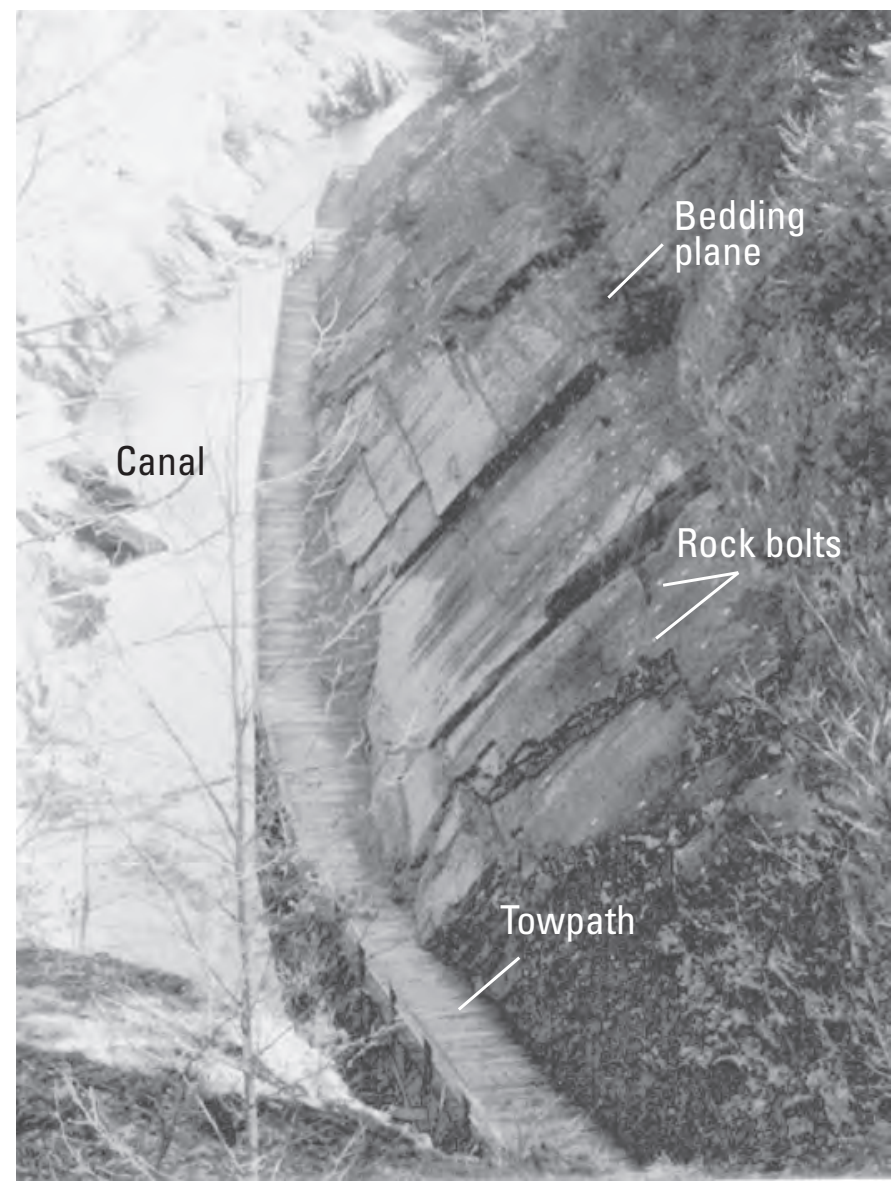

$\boldsymbol{A}$

Figure 128. Upper Devonian Brallier Shale near MM 155. A, West limb of an anticline, looking down from above the north portal of the Paw Paw Tunnel. The towpath and canal transect the anticline (see figure 26) so that bedrock of the west limb dips into the towpath and canal. The bedrock on the dip slope required bolts to prevent gravity slides along the bedding plane. $B$, Shale beds along the towpath north of the Paw Paw Tunnel with mudcracks accentuated by cleavage. Pen for scale. $C$, Burrows and trails made by organisms before the mud was lithified to rock. Pen for scale. $D$, Quartz slickensides along fault surfaces that are parallel to bedding. Pen for scale.
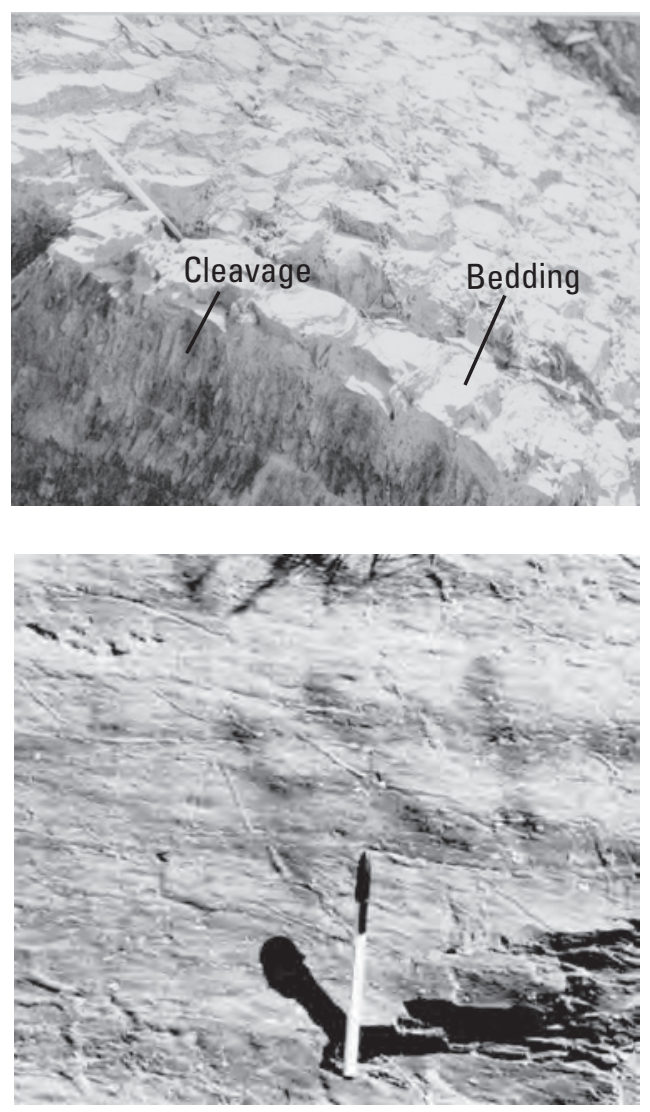

C

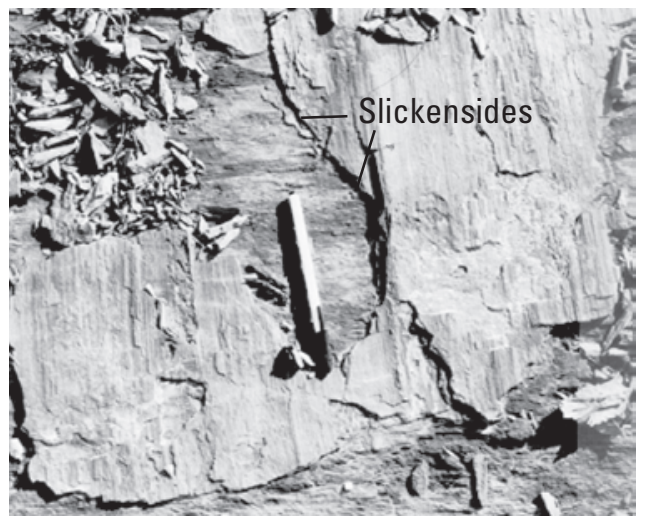

\section{Paw Paw Tunnel to Oldtown (MM 156 to MM 167)}

West of the exit of the Paw Paw Tunnel, the area is underlain by the same Devonian shale, siltstone, and sandstone sequence described between MM 135 and MM 156 (plate 18). Abandoned incised meanders and gravel deposits from the ancestral Potomac River and Little Cacapon River are found in the valley of Purslane Run (MM 157.3) and at Reckley Flat (around MM 159) (figs. 11 and 129) (see the previous discussion in the section on Abandoned Entrenched Meanders). Folds on the west-dipping east limb of the Town Hill syncline are seen at MM 159.5 before the axial region (center) is crossed at about MM 161. From here to Lock 68 (Crabtrees Lock at MM 164.7), the Devonian rocks dip east on the west limb of the Town Hill syncline.
The Potomac River branches into the South Branch Potomac River and the North Branch Potomac River west of MM 164.5. Like the Cacapon (MM 133.5) and Little Cacapon (MM 159) Rivers, there are well-developed incised meanders near the confluence of these major tributaries and the Potomac River. Near MM 161.5, the canal and towpath cross the axial region of the Town Hill syncline. The red, fissile shale and thin sandstone (fig. 130A), as well as crossbedded sandstone (fig. 130B) are rocks of the Upper Devonian Hampshire Formation (Dh). The Potomac River cut through an anticline of the Lower Devonian Oriskany Sandstone (Do) near MM 165 and parts of its northwest-dipping flank were drilled and blasted to create the canal (fig. 131). Note the pine trees and mountain laurel that prefer to grow on the thin 

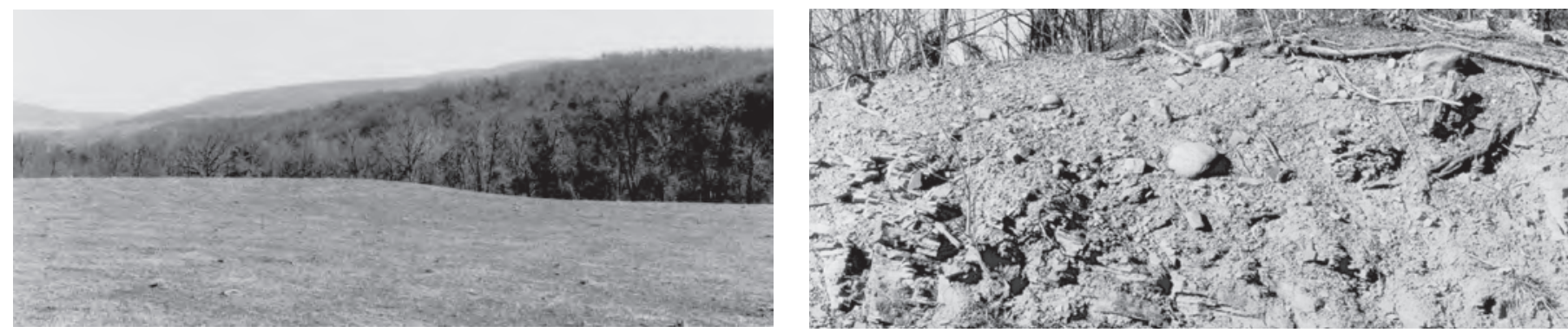

A

B

Figure 129. Reckley Flat, north of MM 160. $A$, Reckley Flat is a terrace, as shown by the broad, open landscape. $B$, Fluvial silt, sand, and gravel derived from sandstone above the shale bedrock that underlies Reckley Flat.
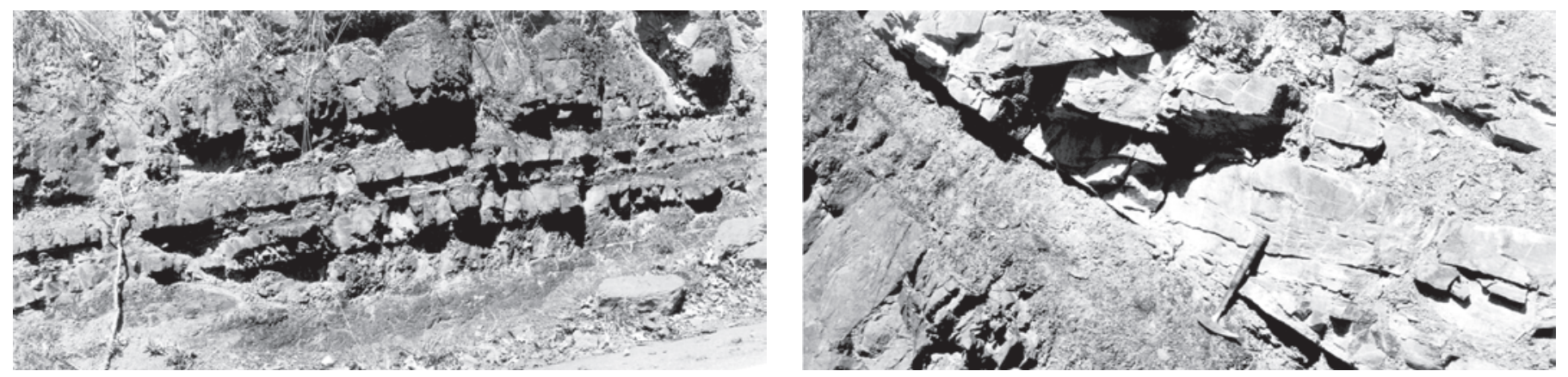

A

B

Figure 130. Devonian Hampshire Formation, exposed east of Town Creek on the limb of the Town Creek syncline, north of MM 161.5 along Maryland State Route 51. $A$, Red, fissile shale and thin sandstone beds. $B$, Thicker beds of crossbedded sandstone. Rocks shown in $A$ grade upward into the thicker beds shown in $B$.

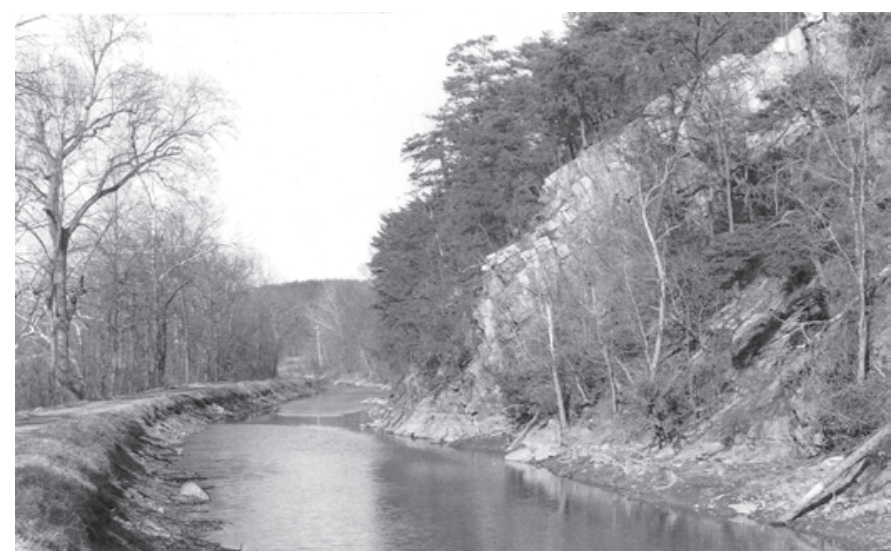

Figure 131. Lower Devonian Oriskany Sandstone on the west limb of the Broadtop anticline. The sandstone was excavated locally to construct the C\&O Canal and towpath east of Oldtown near MM 148. Pine trees and mountain laurel prefer the thin sandy soil that develops on the sandstone.

sandy soil. From about MM 165.5, the canal diverges from the Potomac River west to Oldtown, an early settlement and river crossing for the Great Warrior Path, which was a principal Native American east-west migration route over the mountains.

\section{Oldtown to Spring Gap (MM 167 to MM 173.5)}

West of Oldtown, the Potomac River cuts across the strike of Devonian rocks that form an unnamed syncline and rocks of the Patterson Creek anticlinorium (plate 19). The canal at Oldtown was excavated in shale of the Middle Devonian Mahantango Formation (Dm) in an abandoned valley of Mill Run because there are bluffs of shale along the Potomac River that prevented construction of a canal and towpath. North of MM 168 , both the canal and towpath were excavated through fissile Lower and Middle Devonian Needmore Shale and Middle Devonian Marcellus Shale (Dmn) in order to rejoin the bank of the Potomac River (fig. 40B; also see Engineering section). From here west to Spring Gap (MM 173.5), the area is characterized by shale barrens and a broad flood plain developed on an anticline and syncline. There are good outcrops of folded Upper Devonian Brallier Shale (Db) on the limb of the syncline near MM 172 (fig. 132). Near Spring Gap, the canal crosses anticlines (part of the Patterson Creek anticlinorium) underlain by resistant Lower Devonian Oriskany Sandstone (Do)

\section{Spring Gap to Cumberland (MM 173.5 to MM 184.5)}

Alluvial-terrace deposits left by the Potomac River, when it flowed almost $100 \mathrm{ft}$ higher in elevation than at present, may 


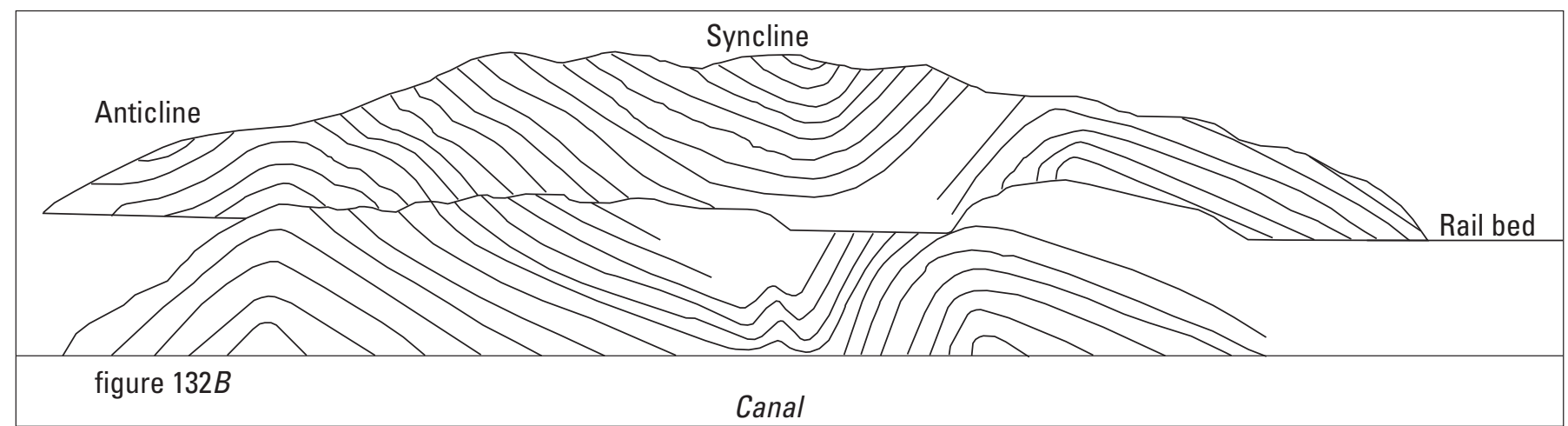

\section{$\boldsymbol{A}$}

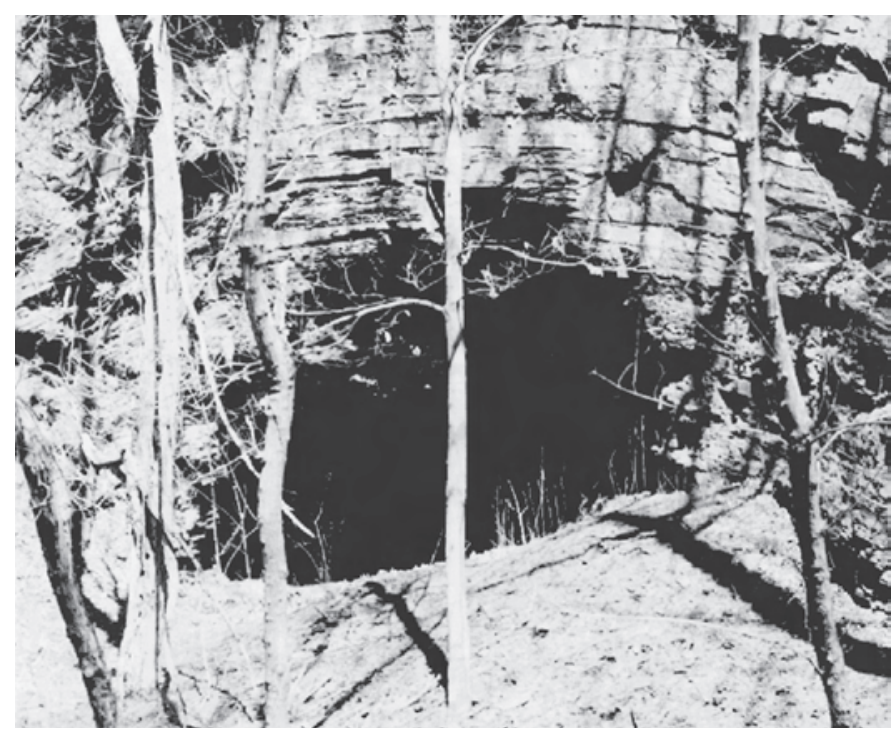

Figure 132. Upper Devonian Brallier Shale near MM 172. $A$, Geologic sketch showing folded Brallier Shale (after Davies, 1999). Distance between C\&O Canal and Western Maryland Railroad is about $20 \mathrm{ft}$. $B$, Recessed area of anticline illustrated on left side of $A$.

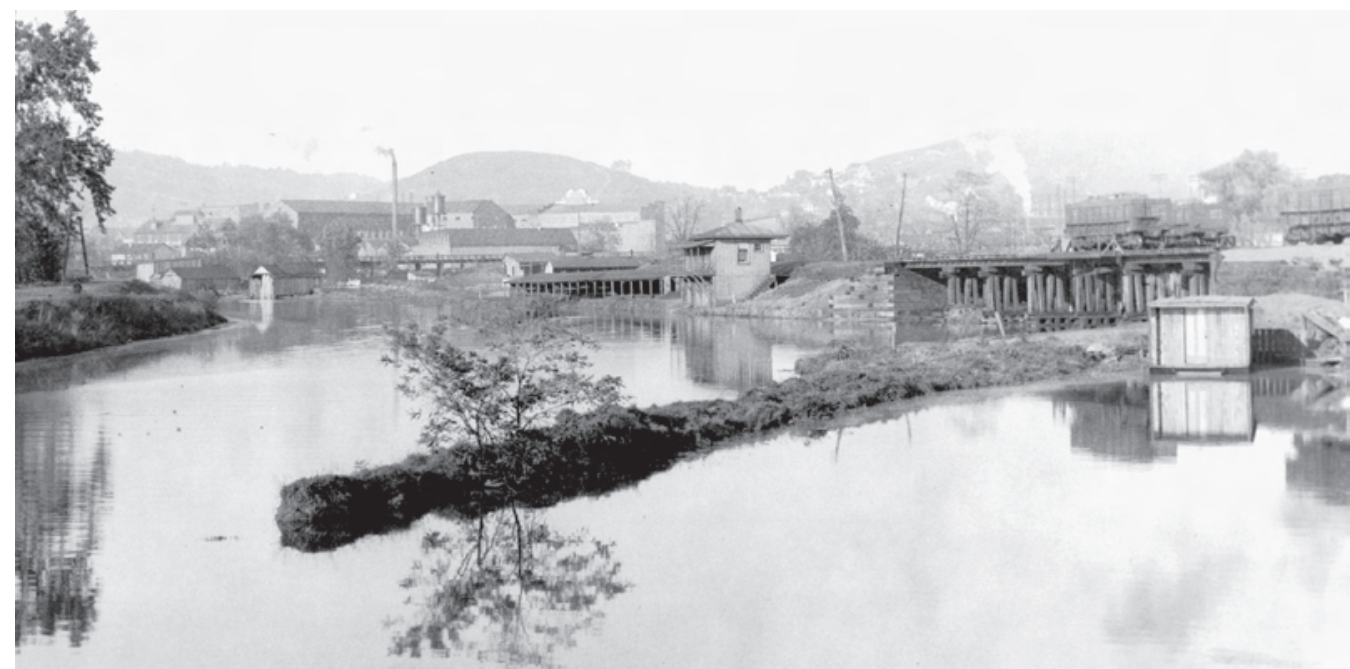

Figure 133. Historical photograph (around 1920) showing the C\&O Canal and wharf area at Cumberland where boats were loaded with coal for transport eastward. Photograph by Consolidated Coal Company, courtesy of National Park Service. 
be seen north of MM 174 (plate 20). The Lower Devonian Oriskany Sandstone (Do) is exposed again at MM 175. From the west flank of the westernmost anticline, the Potomac River meanders across the Upper Devonian Brallier Shale (Db) of the broad Evitts Creek-Bedford syncline.

For the next $3 \mathrm{mi}$, the canal crosses a large meander of the Potomac River now occupied by Mexico Farms, whose surface contains large, rounded sandstone boulders deposited by the river during the Pleistocene. To the south in West Virginia, above the Potomac River, is an elevated abandoned meander called Death Valley. To the north, the city of Cumberland and its municipal airport are built on similar elevated terraces. North of MM 180, hundreds of feet above the current river level, are excellent roadcuts that reveal Quaternary alluvial deposits on bedrock (see figure 10). From MM 181 to the National Park Service Cumberland Visitor Center, the canal follows a meander bend and the only bedrock units exposed are the Brallier Shale (Db) and the Middle and Lower Devonian Needmore and Marcellus Shales (Dmn) near MM 184.

Historical photographs are all that remain to show what this region looked like when the canal was in operation (fig. 133) because much of the canal's operating equipment has been removed and the canal has been filled in. Although this point represents the end of the east-to-west traverse, to many of its past travelers, Cumberland was an outpost on the western frontier where coal-filled canal boats began their journey eastward to supply the National capital region with heating fuel.

\section{Acknowledgments}

The authors gratefully acknowledge the work of many people that helped with this project: Douglas Faries, William Spinrad, and Marie Frias (National Park Service (NPS)-Chesapeake and Ohio Canal National Historical Park); Barbara Perdew (NPS-Great Falls Park); David Fox and William Hebb (NPS-Harpers Ferry National Historical Park); John Glaser (Maryland Geological Survey, retired); Robert E. Weems (U.S. Geological Survey (USGS)); Avery A. Drake, Jr., (USGS, Scientist Emeritus); E-an Zen (USGS, Scientist Emeritus); and Stanley Dickinson (USGS, Volunteer For Science). The authors thank Erin Caulfield, Peter Chirico, Carrie Fingeret, Angela Jacobini, Vicki Keegan, Kerry Lagueux, Remo Nardini, James Reddy, Phillip Reiss, and Christina Spiker for computer graphics and geographic information systems (GIS) work. Technical reviews by Arthur P. Schultz (USGS) and David B. Stewart (USGS, Scientist Emeritus) and editorial review by Elizabeth D. Koozmin (USGS) greatly improved the map and report. The late William E. Davies (USGS) is especially acknowledged for providing inspiration for this project.

\section{References Cited}

Aleinikoff, J.N., Burton, W.C., Lyttle, P.T., Nelson, A.E., and Southworth, C.S., 2000, U-Pb geochronology of zircon and monazite from Mesoproterozoic granitic gneisses of the northern Blue Ridge, Virginia and Maryland, USA: Precambrian Research, v. 99, no. 1-2, p. 113-146.

Aleinikoff, J.N., Horton, J.W., Jr., Drake, A.A., Jr., and Fanning, C.M., 2002, SHRIMP and conventional U-Pb ages of Ordovician granites and tonalites in the central Appalachian piedmont; implications for Paleozoic tectonic events: American Journal of Science, v. 302, p. 50-75.

Aleinikoff, J.N., Zartman, R.E., Walter, Marianne, Rankin, D.W., Lyttle, P.T., and Burton, W.C., 1995, U-Pb ages of metarhyolites of the Catoctin and Mount Rogers Formations, central and southern Appalachians; evidence for two pulses of Iapetan rifting: American Journal of Science, v. 295 , no. 4 , p. $428-454$.

Badger, R.L., and Sinha, A.K., 1988, Age and Sr isotopic signature of the Catoctin volcanic province; implications for subcrustal mantle evolution: Geology, v. 16, no. 8, p. 692-695.

Bassler, R.S., 1919, Cambrian and Ordovician: Baltimore, Md., Maryland Geological Survey Systematic Report, 424 p.

Becker, J.L., Kunk, M.J., Wintsch, R.P., and Drake, A.A., Jr., 1993, Evidence for pre-Taconic metamorphism in the Potomac terrane, Maryland and Virginia; hornblende and muscovite ${ }^{40} \mathrm{Ar} /{ }^{39} \mathrm{Ar}$ results [abs.]: Geological Society of America Abstracts with Programs, v. 25, no. 2, p. 5.

Boy Scouts of America, 1983, 184 miles of adventure; hiker's guide to the C\&O Canal: Washington, D.C., Boy Scouts of America, 48 p.

Braun, D.D., 1976, The relation of rock resistance to incised meander form in the Appalachian Valley and Ridge Province: Baltimore, Md., Johns Hopkins University, unpublished $\mathrm{Ph} . \mathrm{D}$. thesis, $246 \mathrm{p}$.

Brezinski, D.K., 1988, The Mississippian System in Maryland: Maryland Geological Survey Report of Investigations $52,75 \mathrm{p}$.

Brezinski, D.K., 1992, Lithostratigraphy of the western Blue Ridge cover rocks in Maryland: Maryland Geological Survey Report of Investigations 55, 69 p.

Brezinski, D.K., 1996a, Stratigraphy of the Elbrook Formation in Maryland and adjacent states, in Studies in Maryland geology: Maryland Geological Survey Special Publication 3, p. 165-185.

Brezinski, D.K., 1996b, Carbonate ramps and reefs, Guidebook for the Sixth North American Paleontological Convention: Maryland Geological Survey Fieldtrip Guidebook 6, 25 p. 
Brezinski, D.K., Anderson, T.H., and Campbell, P., 1996, Evidence for a regional detachment at the base of the Great Valley sequence in the central Appalachians: Maryland Geological Survey Special Publication 3, p. 223-230.

Brezinski, D.K., Repetski, J.E., and Taylor, J.F., 1999, Stratigraphic and paleontologic record of the Sauk III regression in the central Appalachians, in Santucci, V.L., and McClelland, Lindsay, eds., National Park Service, Paleontological Research, v. 4: National Park Service Geologic Resources Division Technical Report NPS/NRGRD/GRDTR-99/03, p. 32-41.

Brown, A.C., 1963, America's greatest eighteenth century engineering achievement: Virginia Cavalcade, v. 12, p. 40-47.

Burton, W.C., Froelich, A.J., Pomeroy, J.S., and Lee, K.Y., 1995, Geology of the Waterford quadrangle, Virginia and Maryland, and the Virginia part of the Point of Rocks quadrangle: U.S. Geological Survey Bulletin 2095, 30 p., scale $1: 24,000$.

Burton, W.C., and Southworth, Scott, 1996, Basement rocks of the Blue Ridge Province in Maryland, in Studies in Maryland geology: Maryland Geological Survey Special Publication 3, p. 187-203.

Clague, William, 1977, A collection of maps of the Chesapeake and Ohio Canal: Bethesda, Md., [privately published], 84 p.

Cloos, Ernst, 1951, The physical features of Washington County: Baltimore, Maryland Department of Geology, Mines, and Water Resources, 333 p.

Cloos, Ernst, 1958, Structural geology of South Mountain and Appalachians in Maryland, Guidebooks 4 and 5: Johns Hopkins University Studies in Geology 17, p. 1-76.

Cloos, Ernst, 1964, Wedging, bedding plane slips, and gravity tectonics in the Appalachians, in Tectonics of the southern Appalachians: Virginia Polytechnic Institute and State University, Department of Geological Sciences Memoir 1, p. 63-70.

Davies, W.E., 1971, Historical engineering geology of the Chesapeake and Ohio Canal [guidebook]: Washington, D.C., Geological Society of Washington, 10 p.

Davies, W.E., 1989, Highlights of the geology and engineering of the Chesapeake and Ohio Canal, in Hanshaw, P.M., ed., 28th International Geological Congress Guidebook T206: Washington, D.C., American Geophysical Union, 25 p.

Davies, W.E., 1999, The geology and engineering structures of the Chesapeake and Ohio Canal: Glen Echo, Md., C\&O Canal Association, $617 \mathrm{p}$.

Dean, S.L., Kulander, B.R., and Lessing, Peter, 1987, Geology of the Hedgesville, Keedysville, Martinsburg, Shepherdstown, and Williamsport quadrangles, Berkeley and Jefferson Counties, West Virginia: West Virginia Geological and Economic Survey Map WV-31, scale 1:24,000.
Dean, S.L., Lessing, Peter, and Kulander, B.R., 1995, Geology of the Hancock quadrangle, Morgan County, West Virginia: West Virginia Geological and Economic Survey Publication OF-9503, scale 1:24,000, $10 \mathrm{p}$.

Dean, S.L., Lessing, Peter, Kulander, B.R., and Langenderfer, E.A., 1995, Geology of the Cherry Run quadrangle, Morgan County, West Virginia: West Virginia Geological and Economic Survey Publication OF-9505, scale 1:24,000, 10 p.

Denkler, K.E., and Harris, A.G., 1988, Conodont-based determination of the Silurian-Devonian boundary in the Valley and Ridge province, northern and central Appalachians: U.S. Geological Survey Bulletin 1837, p. B1-B17.

De Witt, Wallace, Jr., and Colton, G.W., 1964, Bedrock geology of the Evitts Creek and Pattersons Creek quadrangles, Maryland, Pennsylvania, and West Virginia: U.S. Geological Survey Bulletin 1173, 90 p., scale 1:24,000.

Drake, A.A., Jr., 1989, Metamorphic rocks of the Potomac Terrane in the Potomac Valley of Virginia and Maryland, in Hanshaw, P.M., ed., 28th International Geological Congress Field Trip Guidebook T202: Washington, D.C., American Geophysical Union, 22 p.

Drake, A.A., Jr., and Froelich, A.J., 1997, Geologic map of the Falls Church quadrangle, Fairfax and Arlington Counties, and the city of Falls Church, Virginia, and Montgomery County, Maryland: U.S. Geological Survey Geologic Quadrangle Map GQ-1734, scale 1:24,000.

Drake, A.A., Jr., and Lee, K.Y., 1989, Geologic map of the Vienna quadrangle, Fairfax County, Virginia: U.S. Geological Survey Geologic Quadrangle Map GQ-1670, scale 1:24,000.

Drake, A.A., Jr., Lee, K.Y., and Southworth, Scott, 1999, Geologic map of the Seneca quadrangle, Montgomery County, Maryland, and Loudoun and Fairfax Counties, Virginia: U.S. Geological Survey Geologic Quadrangle Map GQ-1802, scale 1:24,000.

Drake, A.A., Jr., and Morgan, B.A., 1981, The Piney Branch Complex-A metamorphosed fragment of the central Appalachian ophiolite in northern Virginia: American Journal of Science, v. 281, no. 4, p. 484-508.

Drake, A.A., Jr., Sinha, A.K., Laird, Jo, and Guy, R.E., 1989, The Taconic orogen, in Hatcher, R.D., Jr., Thomas, W.V., and Viele, G.W., eds., The Appalachian-Ouachita orogen in the United States: Denver, Colo., Geological Society of America, The Geology of North America, v. F-2, p. 362-366.

Fitzpatrick, M.F., 1987, Active and abandoned incised meanders of the Potomac River, south of Little Orleans, Maryland, Geological Society of America Centennial Field Guide-Northeastern Section: Boulder, Colo., Geological Society of America, p. 1-4. 
Fleming, A.H., Drake, A.A., Jr., and McCartan, Lucy, 1994, Geologic map of the Washington West quadrangle, District of Columbia, Montgomery and Prince Georges Counties, Maryland, and Arlington and Fairfax Counties, Virginia: U.S. Geological Survey Geologic Quadrangle Map GQ-1748, scale 1:24,000.

Franz, Richard, and Slifer, Dennis, 1976, Caves of Maryland: Maryland Geological Survey Educational Series 3, 120 p.

Froelich, A.J., 1975, Thickness of overburden map of Montgomery County, Maryland. U.S. Geological Survey Miscellaneous Investigations Series Map I-920-B, scale 1:62,500.

Froelich, A.J., Hoffman, M.F., Taunton, S., and Phelan, D.J., 1974, Cleavage in some sedimentary rocks of the central Valley and Ridge Province, Maryland: Geological Society of America Bulletin, v. 85, no. 9, p. 1399-1412.

Froelich, A.J., Hoffman, M.F., Taunton, S., and Phelan, D.J., 1992, Preliminary results of coring surficial deposits in the Winchester 30 X 60 minute quadrangle, West Virginia and Virginia: U.S. Geological Survey Open-File Report 92-395, $46 \mathrm{p}$.

Frye, Joshua, and Jefferson, Peter, 1775, A map of the most inhabited part of Virginia: Richmond, Va., Virginia State Library.

Garrett, W.E., and Garrett, Kenneth, 1987, George Washington's Patowmack Canal: National Geographic, v. 171, no. 6, p. 716-753.

Geiser, P.A., 1970, Deformation of the Bloomsburg Formation in the Cacapon Mountains anticline, Hancock, Maryland: Baltimore, Md., Johns Hopkins University, unpublished Ph.D. thesis, $233 \mathrm{p}$.

Glaser, J.D., 1987, The Silurian section at Roundtop Hill near Hancock, Maryland, Geological Society of America Centennial Field Guide-Northeastern Section: Boulder, Colo., Geological Society of America, p. 5-8.

Glaser, J.D., 1994a, Geologic map of the Bellegrove quadrangle, Allegany and Washington Counties, Maryland: Baltimore, Md., Maryland Geological Survey, scale 1:24,000.

Glaser, J.D., 1994b, Geologic map of the Cresaptown quadrangle, Allegany County, Maryland: Baltimore, Md., Maryland Geological Survey, scale 1:24,000.

Glaser, J.D., 1994c, Geologic map of the Oldtown quadrangle, Maryland: Baltimore, Md., Maryland Geological Survey, scale $1: 24,000$.

Glaser, J.D., 1994d, Geologic map of the Paw Paw quadrangle, Allegany County, Maryland: Baltimore, Md., Maryland Geological Survey, scale 1:24,000.

Glaser, J.D., and Brezinski, D.K., 1994, Geologic map of the Cumberland quadrangle, Allegany County, Maryland: Baltimore, Md., Maryland Geological Survey, scale 1:24,000.
Gore, P.J.W., 1988, Late Triassic and Early Jurassic lacustrine sedimentation in the Culpeper basin, Virginia, in Manspeizer, Warren, ed., Triassic-Jurassic rifting; continental breakup and the origin of the Atlantic Ocean and passive margins: Developments in Geotectonics 22, pt. A, p. 369-400.

Guzy, Dan, 1999, Fish weirs in the upper Potomac River: Maryland Archeology, v. 35, no. 1, p. 1-24.

Hahn, T.F., 1985, The Chesapeake and Ohio Canal old picture album: Shepherdstown, W. Va., American Canal and Transportation Center, $103 \mathrm{p}$.

Hahn, T.F., 1995, Towpath guide to the Chesapeake \& Ohio Canal: Shepherdstown, W. Va., American Canal and Transportation Center, $226 \mathrm{p}$.

Hahn, T.F., and Kemp, E.L., 1994, Cement mills along the Potomac River: Institute for the History of Technology and Industrial Archaeology Monograph Series, v. 2, no. 1, $90 \mathrm{p}$.

Hall, A.J., 1991, L'Enfant's Washington: National Geographic, v. 180 , no. 2 , p. 122-134.

Harris, A.G., Stamm, N.R., Weary, D.J., Repetski, J.E., Stamm, R.G., and Parker, R.A., 1994, Conodont color alteration index (CAI) map and conodont-based age determinations for the Winchester 30' × 60' quadrangle, Virginia, West Virginia, and Maryland: U.S. Geological Survey Miscellaneous Field Studies Map MF-2239, 40 p., 1 sheet.

Hatcher, R.D., Jr., Thomas, W.A., and Viele, G.W., eds., 1989, The Appalachian-Ouachita orogen in the United States: Boulder, Colo., Geological Society of America, The Geology of North America, v. F-2, 767 p.

High, Mike, 1997, The C\&O Canal companion: Baltimore, Md., The Johns Hopkins University Press, 269 p.

Hoy, R.B., and Schumacher, R.L., 1956, Fault in Paleozoic rocks near Frederick, Maryland: Geological Society of America Bulletin, v. 67, no. 11, p. 1521-1528.

Jefferson, Thomas, 1982, Notes on the State of Virginia: New York, Norton Publishers, 315 p.

Keith, Arthur, 1894, Description of the Harpers Ferry quadrangle [Va.-Md.-W. Va.]: U.S. Geological Survey, Geologic Atlas, Folio 10, 5 p., 4 map sheets, scale 1:125,000.

Kranz, Peter, 1989, Dinosaurs in Maryland: Maryland Geological Survey Educational Series 6, 34 p.

Kulander, B.R., Dean, S.L., and Lessing, P., 1997, Geology of the Oldtown quadrangle, Hampshire County, West Virginia: West Virginia Geological and Economic Survey Open-File Report OF-9703, 6 p., scale 1:24,000. 
Kulander, B.R., Lessing, P., and Dean, S.L., 1997, Geology of the Paw Paw and Artemas quadrangles, Hampshire and Morgan Counties, West Virginia: West Virginia Geological and Economic Survey Open-File Report OF-9702, 6 p., scale 1:24,000.

Kunk, M.J., Froelich, A.J., and Gottfried, David, 1992, Timing of emplacement of diabase dikes and sheets in the Culpeper basin and vicinity, Virginia and Maryland; ${ }^{40} \mathrm{Ar} /{ }^{39} \mathrm{Ar}$ age spectrum results from hornblende and K-feldspar in granophyres [abs.]: Geological Society of America Abstracts with Programs, v. 24, no. 2, p. 125.

Landing, Ed, 1994, Precambrian-Cambrian boundary global stratotype ratified and a new perspective of Cambrian time: Geology, v. 22, no. 2, p. 179-182.

Lee, K.Y., 1979, Triassic-Jurassic geology of the northern part of the Culpeper basin, Virginia and Maryland: U.S. Geological Survey Open-File Report 79-1557, 29 p., 16 sheets, scale 1:24,000.

Lessing, Peter, 1988, Fluted rocks; a magnificent exposure to the forces of mother nature: Mountain State Geology, v. 1987, p. 20-28.

Lessing, P., Dean, S.L., Kulander, B.R., and Langenderfer, E.A., 1995, Geology of the Big Pool quadrangle, Berkeley and Morgan Counties, West Virginia: West Virginia Geological and Economic Survey Open-File Report OF-9502, 14 p., scale 1:24,000.

Lessing, P., Dean, S.L., and Kulander, B.R., 1997, Geology of the Great Cacapon and Bellegrove quadrangles, Morgan County, West Virginia: West Virginia Geological and Economic Survey Open-File Report OF-9701, 6 p., scale $1: 24,000$.

Lindholm, R.C., Hazlett, J.M., and Fagin, S.W., 1979, Petrology of Triassic-Jurassic conglomerates in the Culpeper basin, Virginia: Journal of Sedimentary Petrology, v. 49, no. 4, p. $1245-1262$.

McBride, E.F., 1962, Flysch and associated beds of the Martinsburg Formation (Ordovician), central Appalachians: Journal of Sedimentary Petrology, v. 32, no. 1, p. 39-91.

National Park Service, 1991, Chesapeake and Ohio Canal Official National Park Handbook 142: Washington, D.C., National Park Service, 111 p.

Neuman, R.B., 1951, St. Paul Group; a revision of the "Stones River" group of Maryland and adjacent states: Geological Society of America Bulletin, v. 62, no. 3, p. 267-324.

Nickelsen, R.P., 1956, Geology of the Blue Ridge near Harpers Ferry, West Virginia: Geological Society of America Bulletin, v. 67, no. 3, p. 239-269.
Olsen, P.E., McCune, A.R., and Thomson, K.S., 1982, Correlation of the early Mesozoic Newark Supergroup by vertebrates, principally fishes: American Journal of Science, v. 282 , no. 1 , p. $1-44$.

Reed, J.C., Jr., 1981, Disequilibrium profile of the Potomac River near Washington, D.C.; a result of lowered base level or Quaternary tectonics along the Fall Line?: Geology, v. 9, no. 10, p. $445-450$.

Reed, J.C., Jr., and Reed, J.C., 1970, Gold veins near Great Falls, Maryland: U.S. Geological Survey Bulletin 1286, 22 p.

Reed, J.C., Jr., Sigafoos, R.S., and Fisher, G.W., 1980, The river and the rocks-The geologic story of Great Falls and the Potomac River gorge: U.S. Geological Survey Bulletin $1471,75 \mathrm{p}$.

Reinhardt, Juergen, 1974, Cambrian off-shelf sedimentation, central Appalachians: Society of Economic Paleontologists and Mineralogists Special Publication 25, p. 83-112.

Sando, W.J., 1957, Beekmantown Group (Lower Ordovician) of Maryland: Geological Society of America Memoir 68, $161 \mathrm{p}$.

Scheel, E.M., 1995, The Potomac River from Brunswick to Van Deventer's Island and environs of Sugarloaf, Poolesville, Leesburg, Waterford, and The German Settlement: Waterford, Va., [privately published], scale about 1:42,000.

Schwartz, C.K., Prouty, W.F., Ulrich, E.O., and Bassler, R.S., 1923, Silurian: Baltimore, Md., Maryland Geological Survey, Systematic Report, 794 p.

Schwartz, C.K., Schuchert, C., Prosser, C.S., Poole, T., and Rowe, R.B., 1913a, Lower Devonian; plates: Baltimore, Md., Maryland Geological Survey, Systematic Report, 83 p.

Schwartz, C.K., Schuchert, C., Prosser, C.S., Poole, T., and Rowe, R.B., 1913b, Middle and Upper Devonian; plates: Baltimore, Md., Maryland Geological Survey, Systematic Report, $72 \mathrm{p}$.

Smoot, J.P., 1989, Fluvial and lacustrine facies of the early Mesozoic Culpeper basin, Virginia and Maryland, in Hanshaw, P.M., ed., 28th International Geological Congress Field Trip Guidebook T213: Washington, D.C., American Geophysical Union, 15 p.

Southworth, Scott, 1996, The Martic fault in Maryland and its tectonic setting in the central Appalachians, in Studies in Maryland geology: Maryland Geological Survey Special Publication 3, p. 205-221.

Southworth, Scott, 1998, Geologic map of the Poolesville quadrangle, Frederick and Montgomery Counties, Maryland, and Loudoun County, Virginia: U.S. Geological Survey Geologic Quadrangle Map GQ-1761, scale 1:24,000. 
Southworth, Scott, and Brezinski, D.K., 1996a, How the Blue Ridge anticlinorium in Virginia becomes the South Mountain anticlinorium in Maryland, in Studies in Maryland geology: Maryland Geological Survey Special Publication 3, p. 253-275.

Southworth, Scott, and Brezinski, D.K., 1996b, Geology of the Harpers Ferry quadrangle, Virginia, Maryland, and West Virginia: U.S. Geological Survey Bulletin 2123, 33 p., scale $1: 24,000$.

Southworth, Scott, and Brezinski, D.K., 2003, Geologic map of the Buckeystown quadrangle, Frederick and Montgomery Counties, Maryland, and Loudoun County, Virginia: U.S. Geological Survey Geologic Quadrangle Map GQ-1800, scale $1: 24,000$.

Southworth, Scott, Burton, W.C., Schindler, J.S., Froelich, A.J., Aleinikoff, J.N., and Drake, A.A., Jr., 2006, Geologic map of Loudoun County, Virginia: U.S. Geological Survey Geologic Investigations Map I-2533, scale 1:50,000.

Southworth, Scott, Fingeret, Carrie, and Weik, Thomas, 2000, Geologic map of the Potomac River gorge; Great Falls Park, Virginia, and part of the C\&O Canal National Historical Park, Maryland: U.S. Geological Survey Open-File Report 00-264, 1 CD-ROM, scale 1:10,000.

Stose, G.W., and Stose, A.J., 1944, The Chilhowee group and Ocoee series of the Southern Appalachians: American Journal of Science, v. 242, p. 367-416.

Taylor, J.F., Repetski, J.E., and Roebuck, C.A., 1996, Stratigraphic significance of trilobite and conodont faunas from the Cambrian-Ordovician shelfbreak facies in the Frederick Valley, Maryland, in Brezinski, D.K., and Reger, J.P., eds., Studies in Maryland geology: Maryland Geological Survey Special Publication 3, p. 141-164.

Tucker, R.D., Bradley, D.C., Ver Straeten, C.A., Harris, A.G., Ebert, J.R., and McCutcheon, S.R., 1998, New U-Pb zircon ages and the duration and division of Devonian time: Earth and Planetary Science Letters, v. 158, no. 3-4, p. $175-186$.

Trout, W.E., III, 1991, The Goose Creek Scenic River atlas: Lexington, Va., Virginia Canals and Navigations Society, 18 p.
Weary, D.J., and Harris, A.G., 1994, Early Frasnian (Late Devonian) conodonts from the Harrell Shale, western foreland fold-and-thrust belt, West Virginia, Maryland, and Pennsylvania Appalachians, U.S.A.: Courier Forschungsinstitut Senckenberg 168, p. 195-225.

Weems, R.E., 1979, A large parasuchian (phytosaur) from the Upper Triassic portion of the Culpeper basin of Virginia (USA): Proceedings of the Biological Society of Washington, v. 92, no. 4, p. 682-688.

Weems, R.E., 1987, A Late Triassic footprint fauna from the Culpeper basin, northern Virginia (USA): American Philosophical Society Transactions, v. 77, no. 1, p. 1-79.

Weems, R.E., 1992, A re-evaluation of the taxonomy of Newark Supergroup saurischian dinosaur tracks, using extensive statistical data from a recently exposed tracksite near Culpeper, Virginia, in Sweet, Palmer, ed., Proceedings, Twentysixth forum on the geology of industrial minerals: Virginia Division of Mineral Resources Publication 119, p. 113-127.

Weems, R.E., 1993, Stratigraphic distribution and bibliography of fossil fish, amphibians, and reptiles from Virginia: U.S. Geological Survey Open-File Report 93-222, 49 p.

Weems, R.E., and Kimmel, P.G., 1993, Upper Triassic reptile footprints and a coelacanth fish scale from the Culpeper basin, Virginia: Proceedings of the Biological Society of Washington, v. 106, no. 2, p. 390-401.

White, W.B., 1988, Geomorphology and hydrology of karst terrains: New York, Oxford University Press, 464 p.

Zen, E-an, 1997a, The seven-story river; geomorphology of the Potomac River channel between Blockhouse Point, Maryland, and Georgetown, District of Columbia, with emphasis on the gorge complex below Great Falls: U.S. Geological Survey Open-File Report 97-60, 142 p.

Zen, E-an, 1997b, Channel geometry and strath levels of the Potomac River between Great Falls, Maryland, and Hampshire, West Virginia: U.S. Geological Survey Open-File Report 97-480, 92 p. 

Appendix 1

$\longrightarrow$ 



\section{Appendix 1}

\section{Sources of Data-Geologic Maps of 7.5-Minute Quadrangles}

[Abbreviations are as follows: MGS, Maryland Geological Survey; USGS, U.S. Geological Survey; unpub., unpublished. See References Cited for complete reference citation.]

\section{Artemas}

Kulander and others (1997)

J.D. Glaser (MGS) and S. Southworth (USGS) (unpub. data, 19961997)

\section{Bellegrove}

Glaser (1994a)

Lessing and others (1997)

D.K. Brezinski (MGS) and S. Southworth (USGS) (unpub. data, 1996-1997)

\section{Big Pool}

Lessing and others (1995)

J.D. Glaser (MGS, unpub. data, 1996-1997)

D.K. Brezinski (MGS) and S. Southworth (USGS) (unpub. data, 1996-1997)

\section{Buckeystown}

Southworth and Brezinski (2003)

\section{Charles Town}

Nickelsen (1956)

D.K. Brezinski (MGS), R.C. Orndorff (USGS), and S. Southworth (USGS) (unpub. data, 1996-1997)

\section{Cherry Run}

Dean and others (1995)

J.D. Glaser (MGS, unpub. data, 1996-1997)

S. Southworth (USGS, unpub. data, 1996-1997)

\section{Cresaptown}

Glaser (1994b)

S. Southworth (USGS, unpub. data, 1996-1997)

\section{Cumberland}

Glaser and Brezinski (1994)

S. Southworth (USGS, unpub. data, 1996-1997)

\section{Evitts Creek}

DeWitt and Colton (1964)

S. Southworth (USGS, unpub. data, 1996-1997)

\section{Falls Church}

Drake and Froelich (1997)

S. Southworth (USGS, unpub. data, 1996-1997)

\section{Great Cacapon}

Lessing and others (1997)

S. Southworth (USGS, unpub. data, 1996-1997)

\section{Hancock}

Dean and others (1995)

J.D. Glaser (MGS, unpub. data, 1996-1997)

D.K. Brezinski (MGS), S. Dickinson (USGS volunteer), and S. Southworth (USGS) (unpub. data, 1996-1997)

\section{Harpers Ferry}

S. Southworth (USGS, unpub. data, 1996-1997)

\section{Hedgesville}

Dean and others (1987)

J.D. Glaser (MGS, unpub. data, 1996-1997)

D.K. Brezinski (MGS), R.C. Orndorff (USGS), and S. Southworth (USGS) (unpub. data, 1996-1997)

\section{Keedysville}

Dean and others (1987)

Brezinski (1992)

D.K. Brezinski (MGS) and S. Southworth (USGS) (unpub. data, 1996-1997)

\section{Leesburg}

Lee (1979)

S. Southworth (USGS, unpub. data, 1996-1997)

\section{Oldtown}

Glaser (1994c)

Kulander and others (1997)

Southworth and Brezinski (1996b)

\section{Patterson Creek}

DeWitt and Colton (1964)

S. Southworth (USGS, unpub. data, 1996-1997)

\section{Paw Paw}

Glaser (1994d)

Kulander and others (1997)

D.K. Brezinski (MGS), S. Dickinson (USGS volunteer), and S. Southworth (USGS) (unpub. data, 1996-1997) 


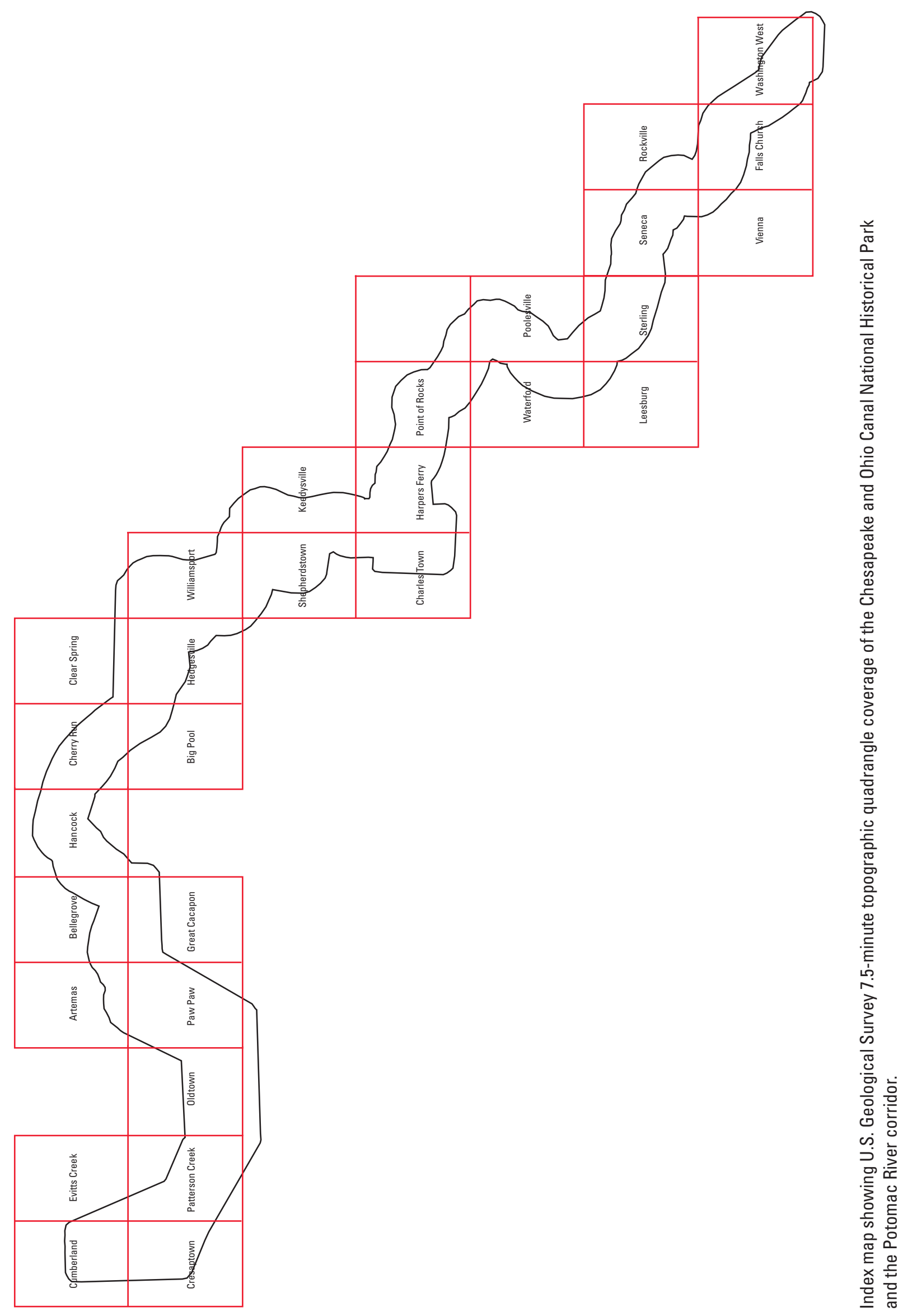




\section{Point of Rocks}

Burton and others (1995)

Burton and Southworth (1996)

D.K. Brezinski (MGS) and S. Southworth (USGS) (unpub. data, 1996-1997)

\section{Poolesville}

Southworth (1998)

\section{Rockville}

A.A. Drake, Jr. (USGS Scientist Emeritus, unpub. data, 1996-1997) S. Southworth (USGS, unpub. data, 1996-1997)

\section{Seneca}

Drake and others (1999)

S. Southworth (USGS, unpub. data, 1996-1997)

\section{Shepherdstown}

Dean and others (1987)

D.K. Brezinski (MGS), R.C. Orndorff (USGS), and S. Southworth (USGS) (unpub. data, 1996-1997)

\section{Sterling}

Lee (1979)

S. Southworth (USGS, unpub. data, 1996-1997)

\section{Vienna}

Drake and Lee (1989)

S. Southworth (USGS, unpub. data, 1996-1997)

\section{Washington West}

Fleming and others (1994)

S. Southworth (USGS, unpub. data, 1996-1997)

\section{Waterford}

Burton and others (1995)

S. Southworth (USGS, unpub. data, 1996-1997)

\section{Williamsport}

Dean and others (1987)

D.K. Brezinski (MGS), R.C. Orndorff (USGS), and S. Southworth (USGS) (unpub. data, 1996-1997) 



\section{Plates 2-20.}

Plates 2 through 20 are detailed geologic maps that roughly correspond to sections described in the Geologic Guide. An index to the plates is found on plate 1 (in pocket). Sources of data are listed by 7.5-minute quadrangle in Appendix 1. Each plate consists of a geologic map on the right-hand page, and a description of map units and explanation of symbols on the left-hand page.

The shaded-relief topography was derived from U.S. Geological Survey Digital Elevation Model (DEM) files. Selected hydrography was derived from U.S. Geological Survey Digital Line Graph (DLG) files. Selected roads were based on the U.S. Geological Survey's 1:100,000-scale planimetric maps of the Cumberland, Hagerstown, Winchester, Frederick, Washington West, and Washington East quadrangles. These maps are not intended for navigation.

Plates 2-20. Geologic map of the Chesapeake and Ohio Canal National Historical Park and Potomac River Corridor from:

2. Georgetown (MM 0) to near Glen Echo Park (about MM 7)

3. Near Glen Echo Park (about MM 7) to Swains Lock (MM 17)

4. Swains Lock (MM 17) to Seneca (MM 22.8)

5. Seneca (MM 22.8) to Edwards Ferry (MM 30)

6. Edwards Ferry (MM 30) to Monocacy River Aqueduct (MM 42.2)

7. Monocacy River Aqueduct (MM 42.2) to Point of Rocks (MM 48.2)

8. Point of Rocks (MM 48.2) to Brunswick (MM 55)

9. Brunswick (MM 55) to Fort Duncan (MM 62.5)

10. Fort Duncan (MM 62.5) to Antietam Creek (MM 69)

11. Antietam Creek (MM 69) to Big Slackwater (MM 85.5)

12. Big Slackwater (MM 85.5) to Williamsport (MM 99.5)

13. Williamsport (MM 99.5) to McCoys Ferry (MM 110)

14. McCoys Ferry (MM 110) to Licking Creek Aqueduct (MM 116)

15. Licking Creek Aqueduct (MM 116) to Round Top Cement Company mill (MM 127.5)

16. Round Top Cement Company mill (MM 127.5) to Little Orleans (MM 141)

17. Little Orleans (MM 141) to Paw Paw Tunnel (MM 156)

18. Paw Paw Tunnel (MM 156) to Oldtown (MM 167)

19. Oldtown (MM 167) to Spring Gap (MM 173.5)

20. Spring Gap (MM 173.5) to Cumberland (MM 184.5) 


\section{Plate 2.}

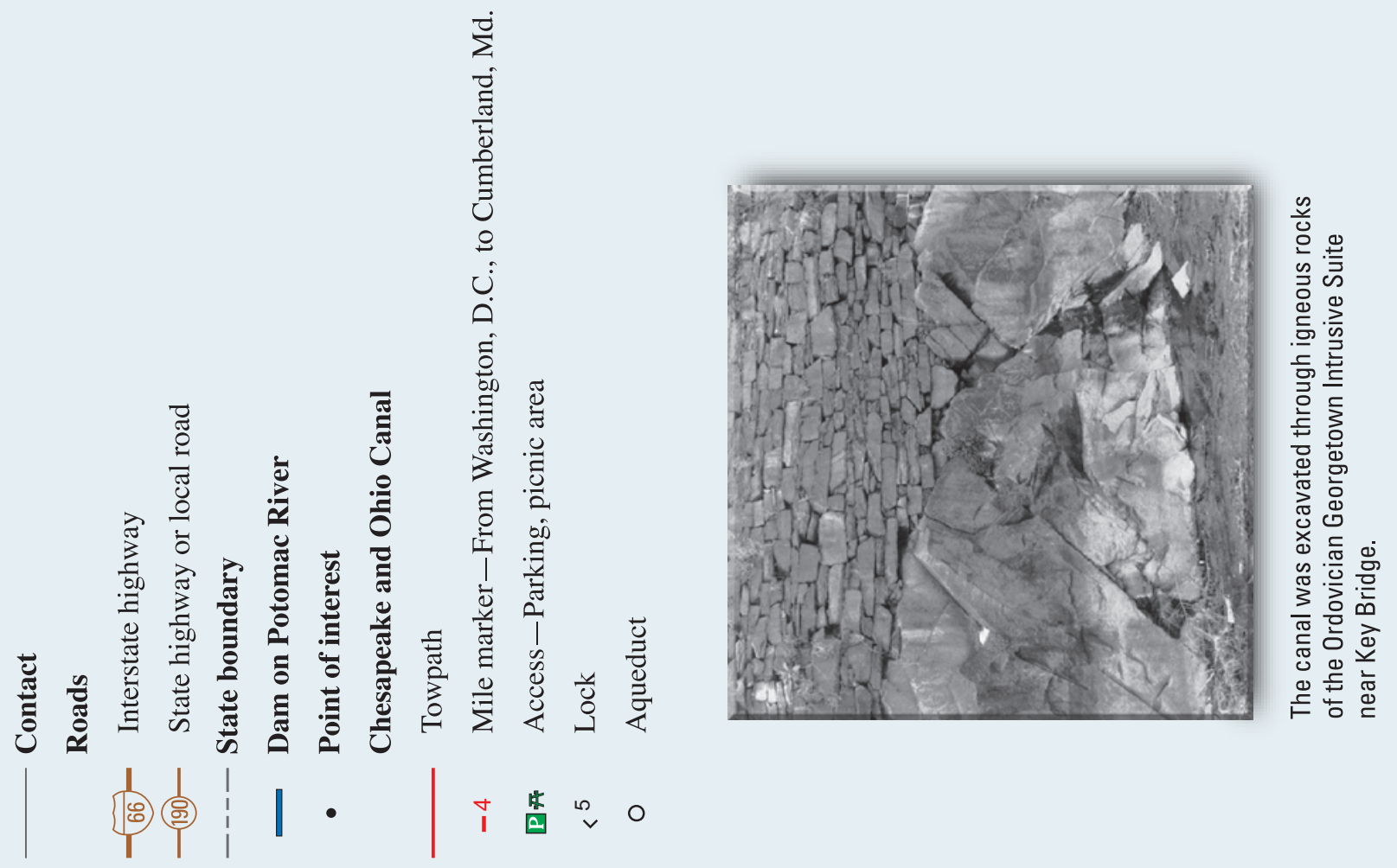

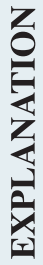

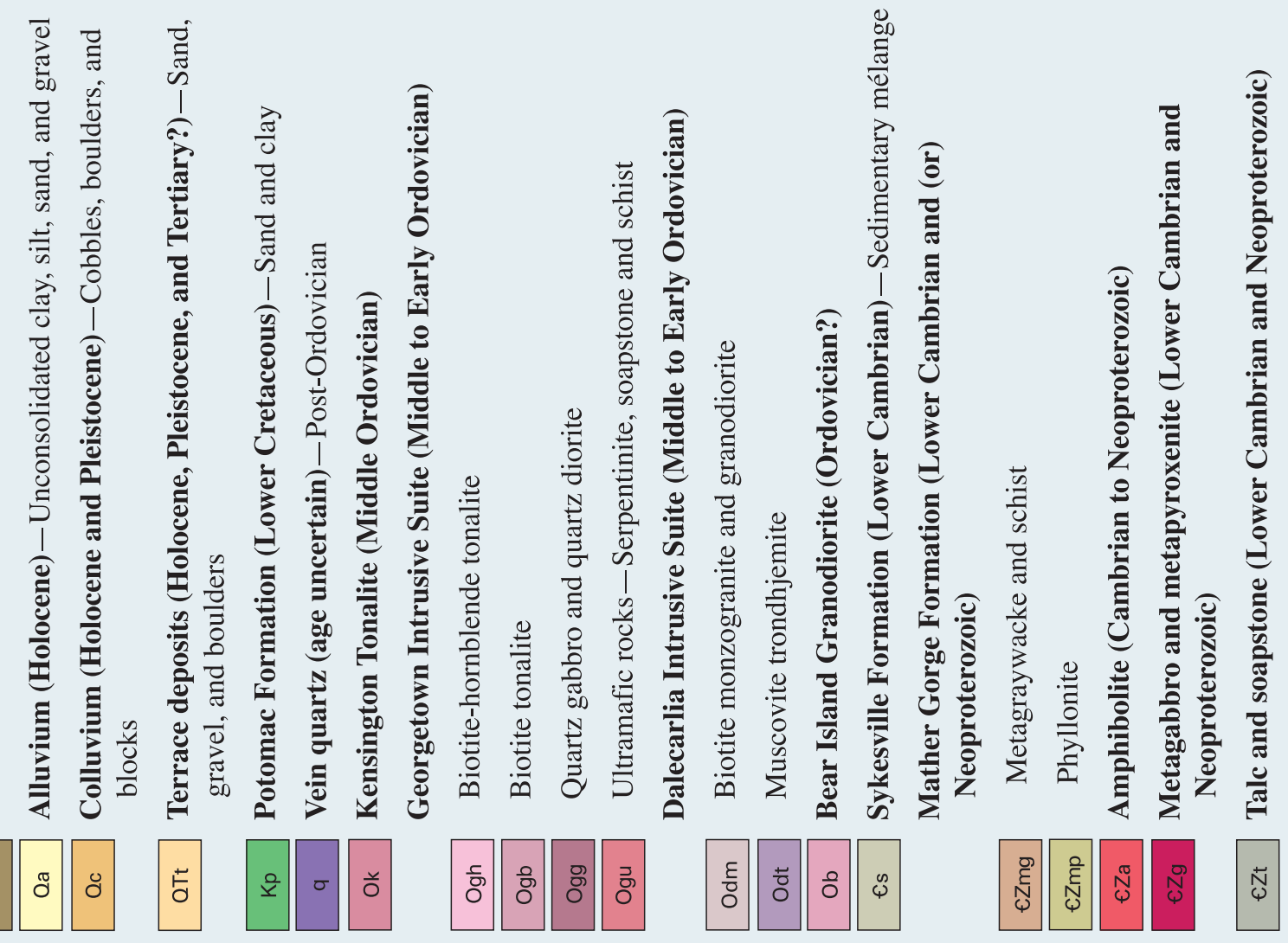




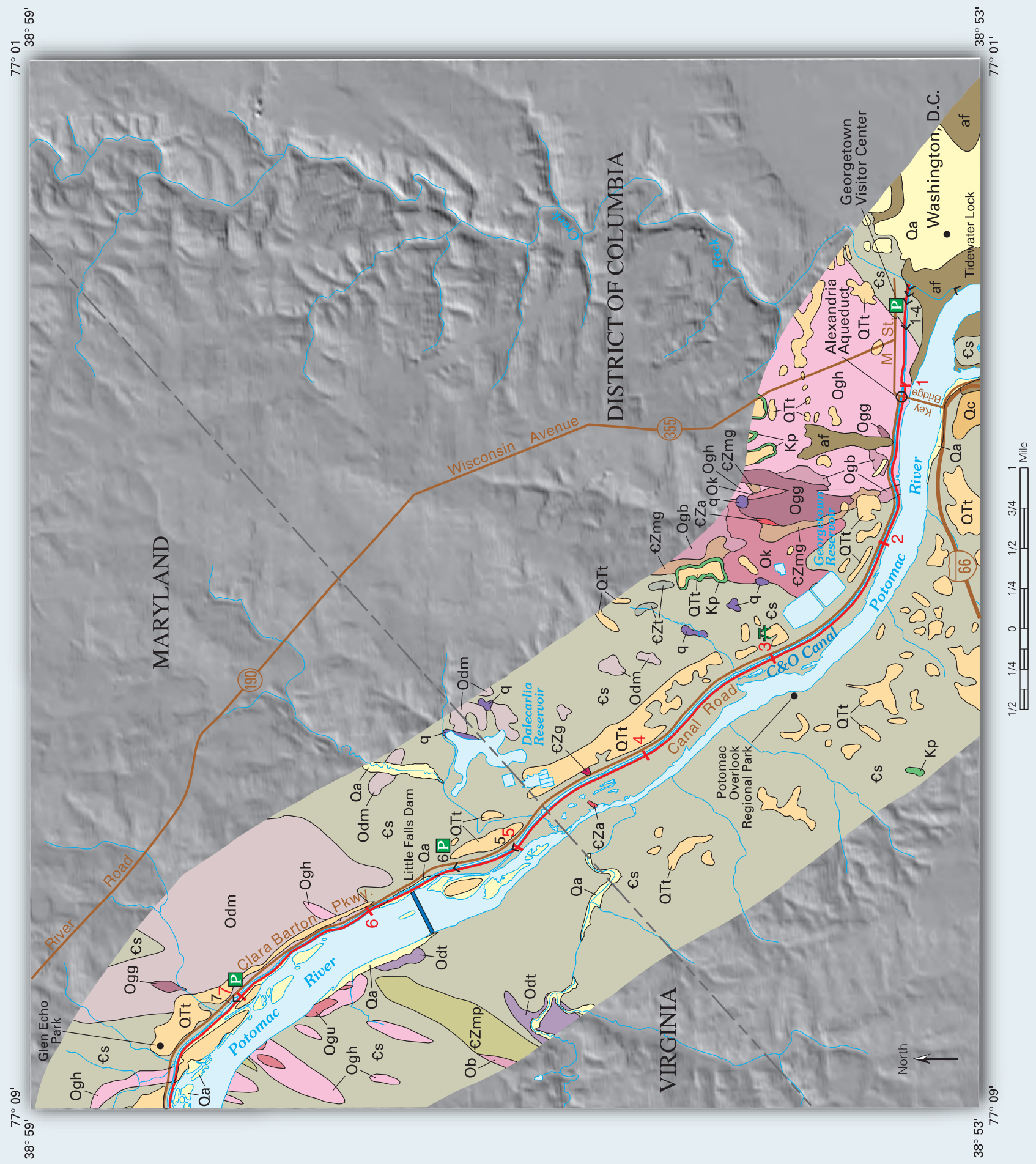




\section{Plate 3.}
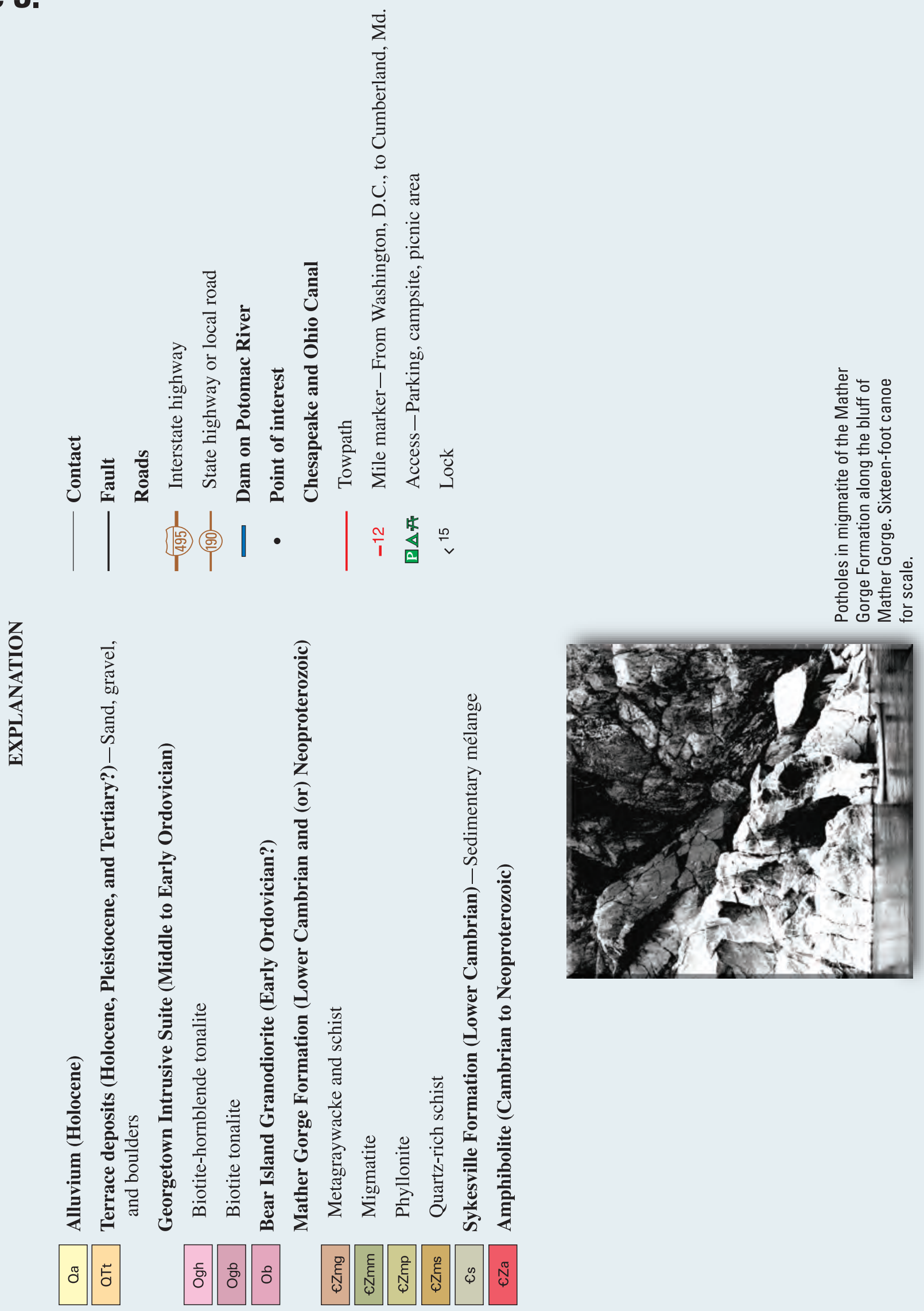


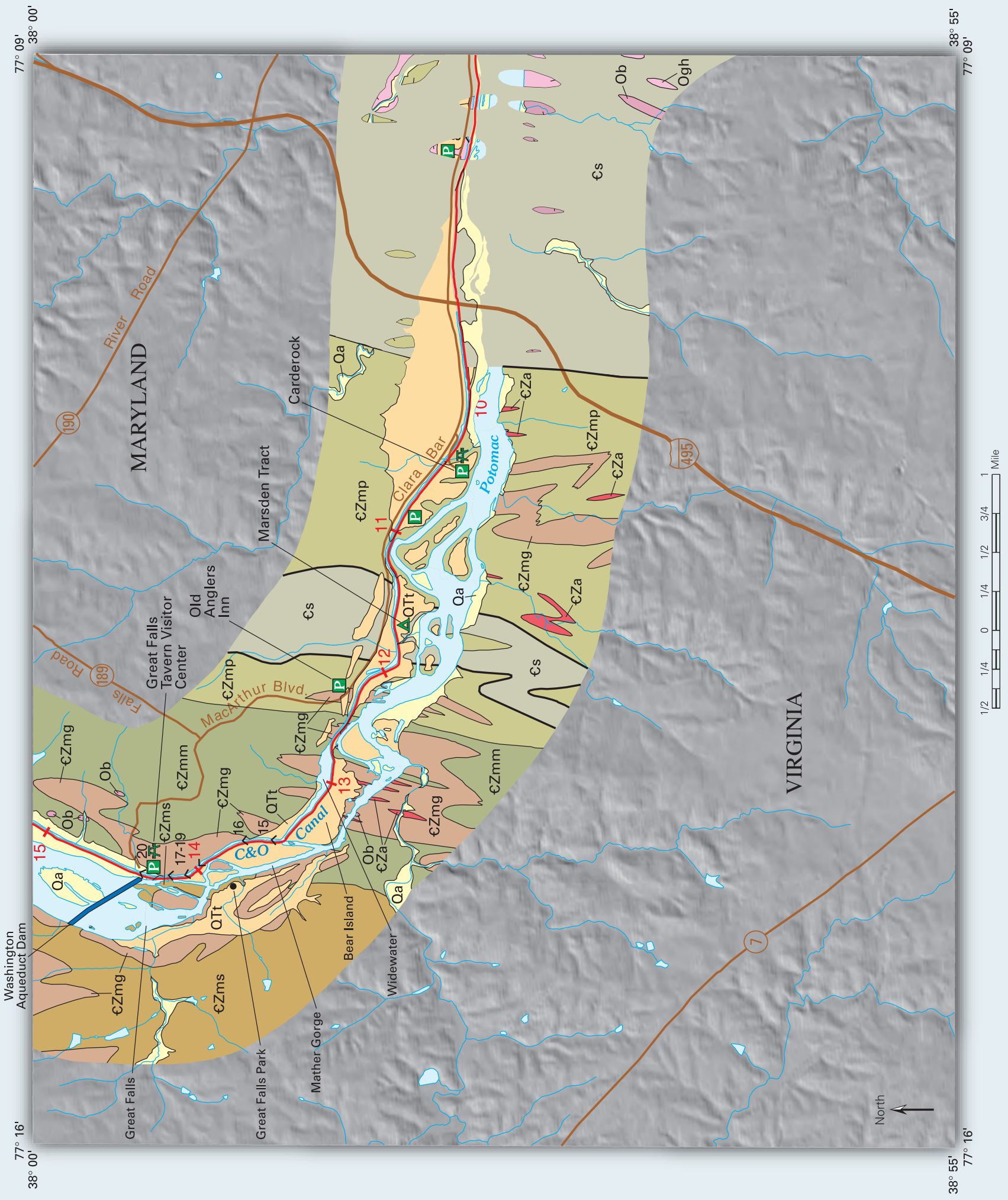




\section{Plate 4.}
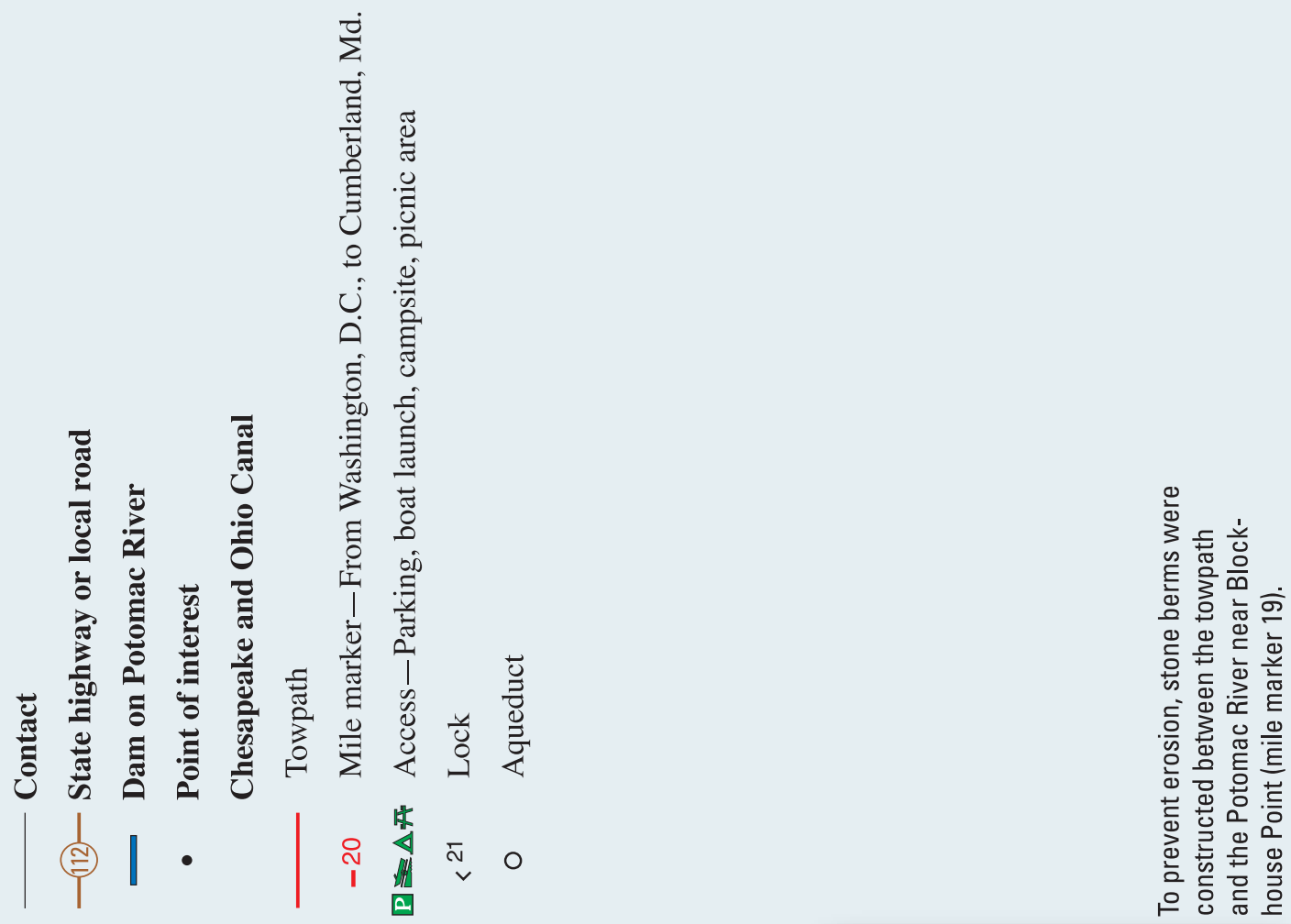

登
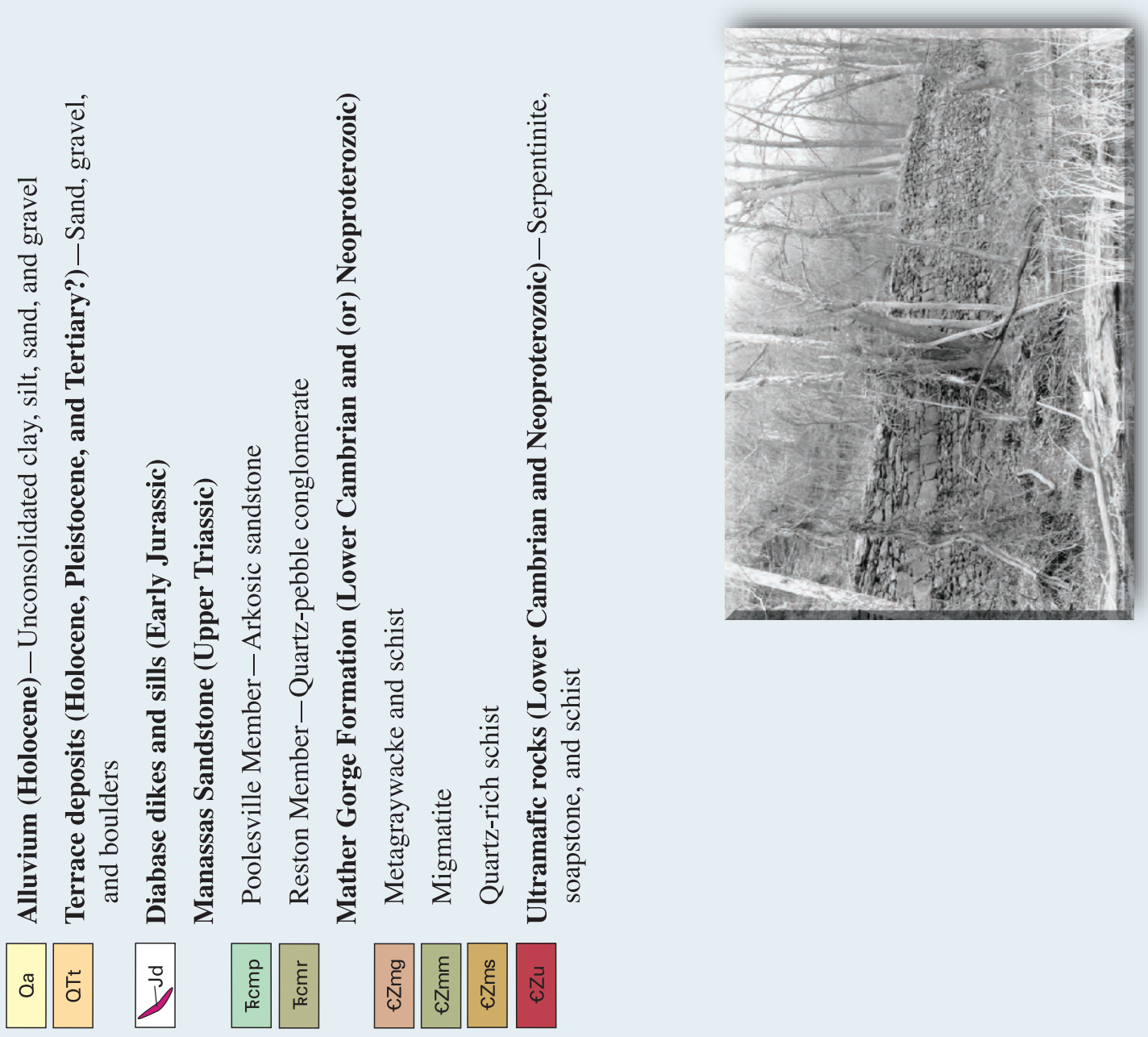


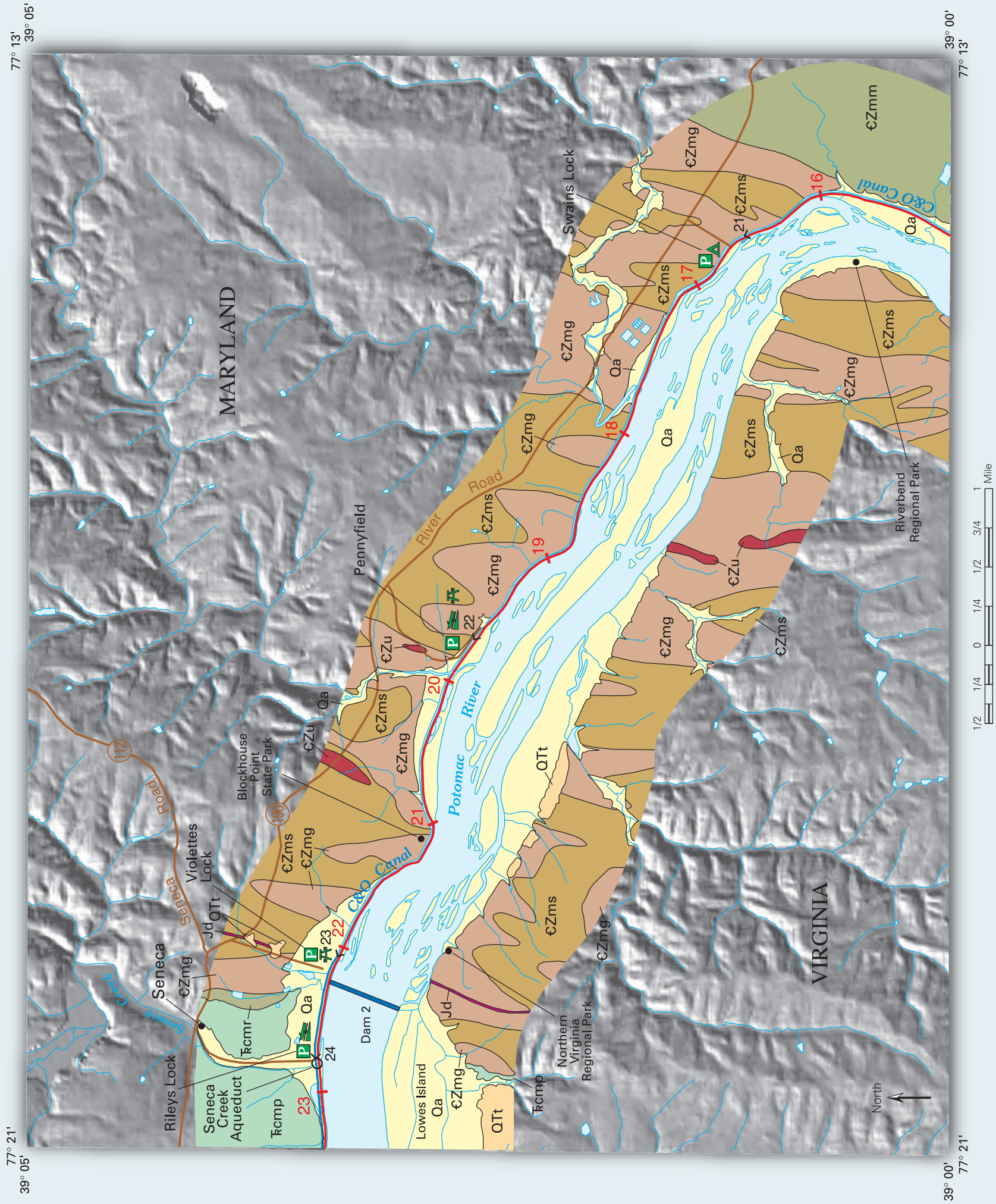




\section{Plate 5.}
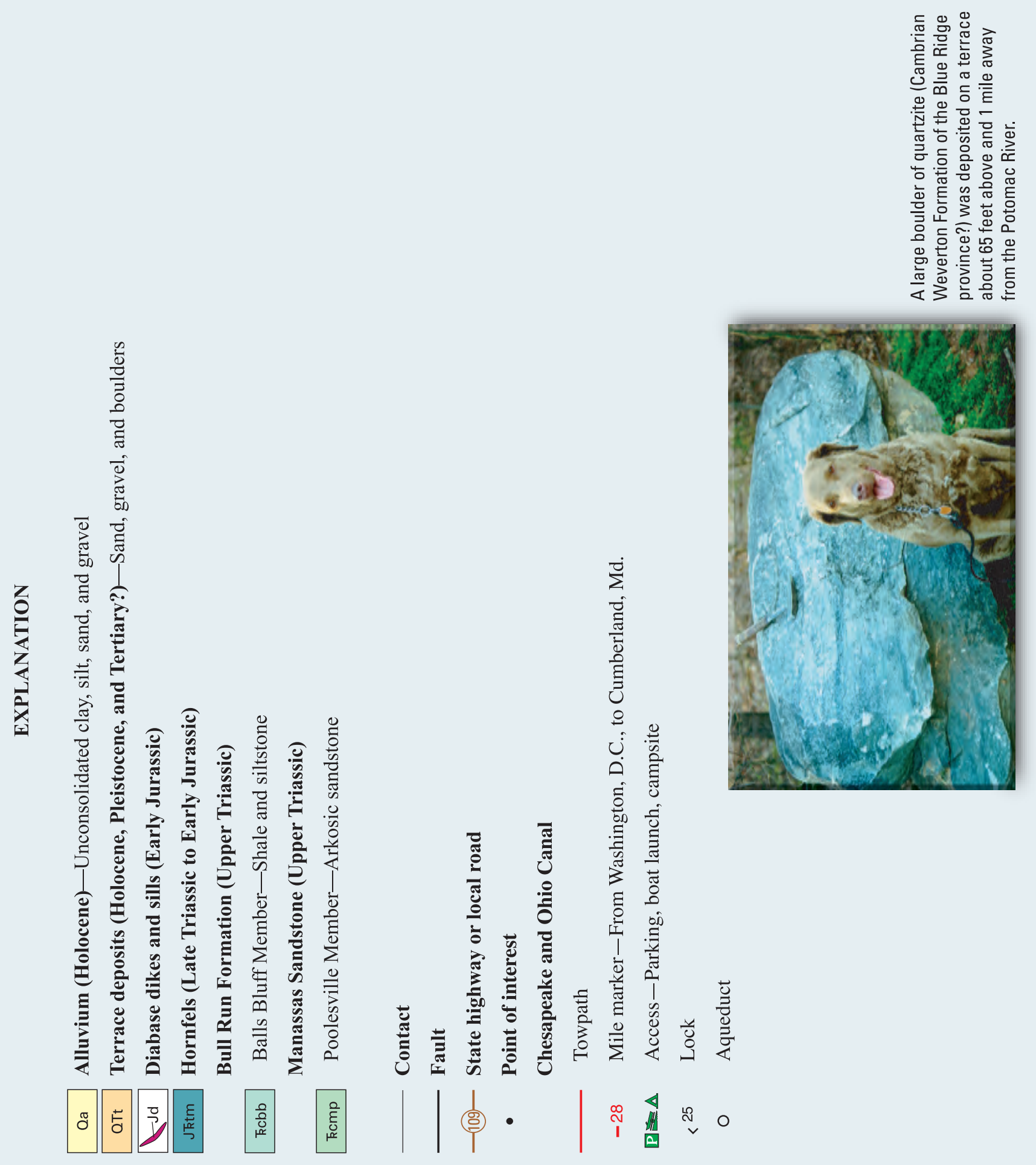


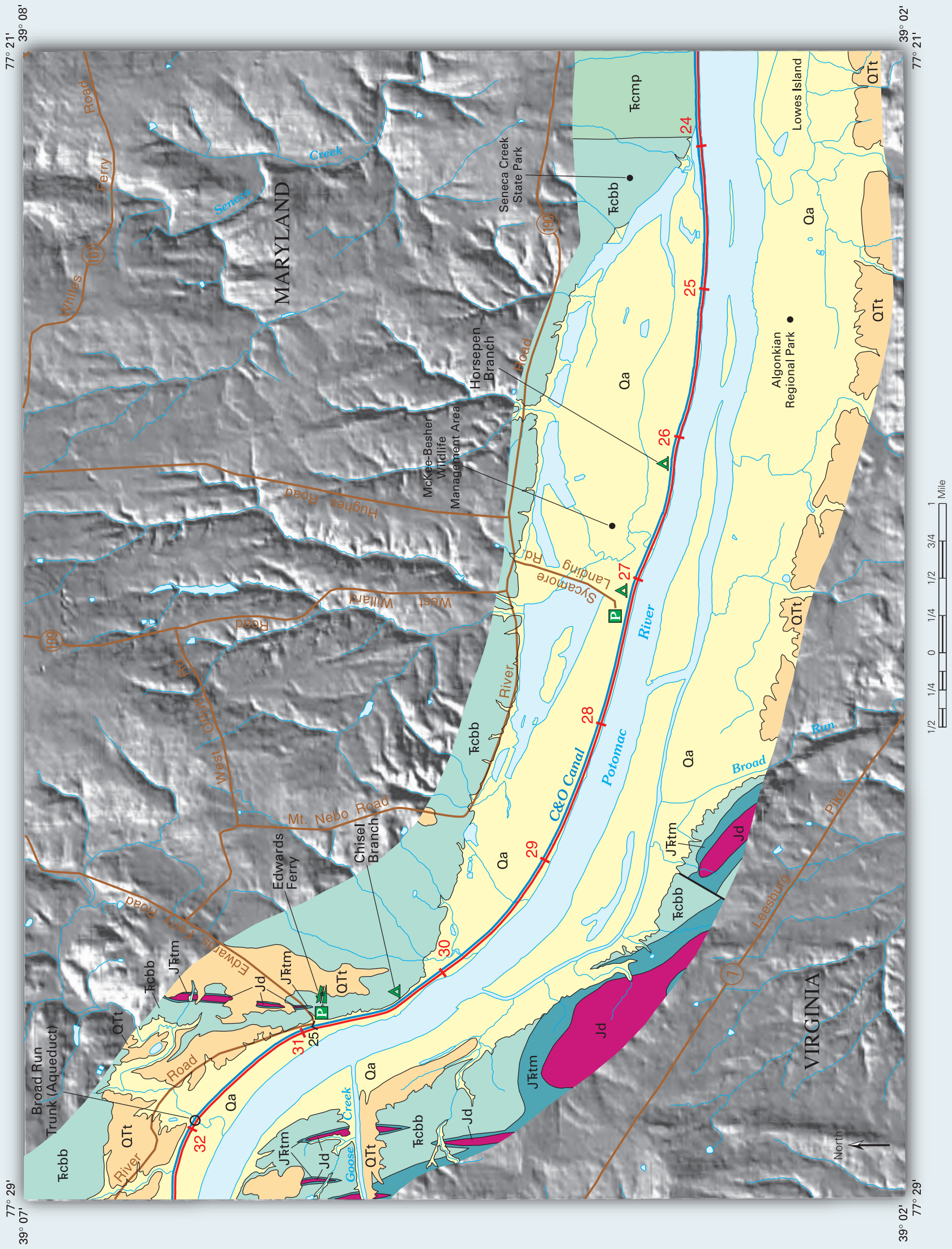




\section{Plate 6.}

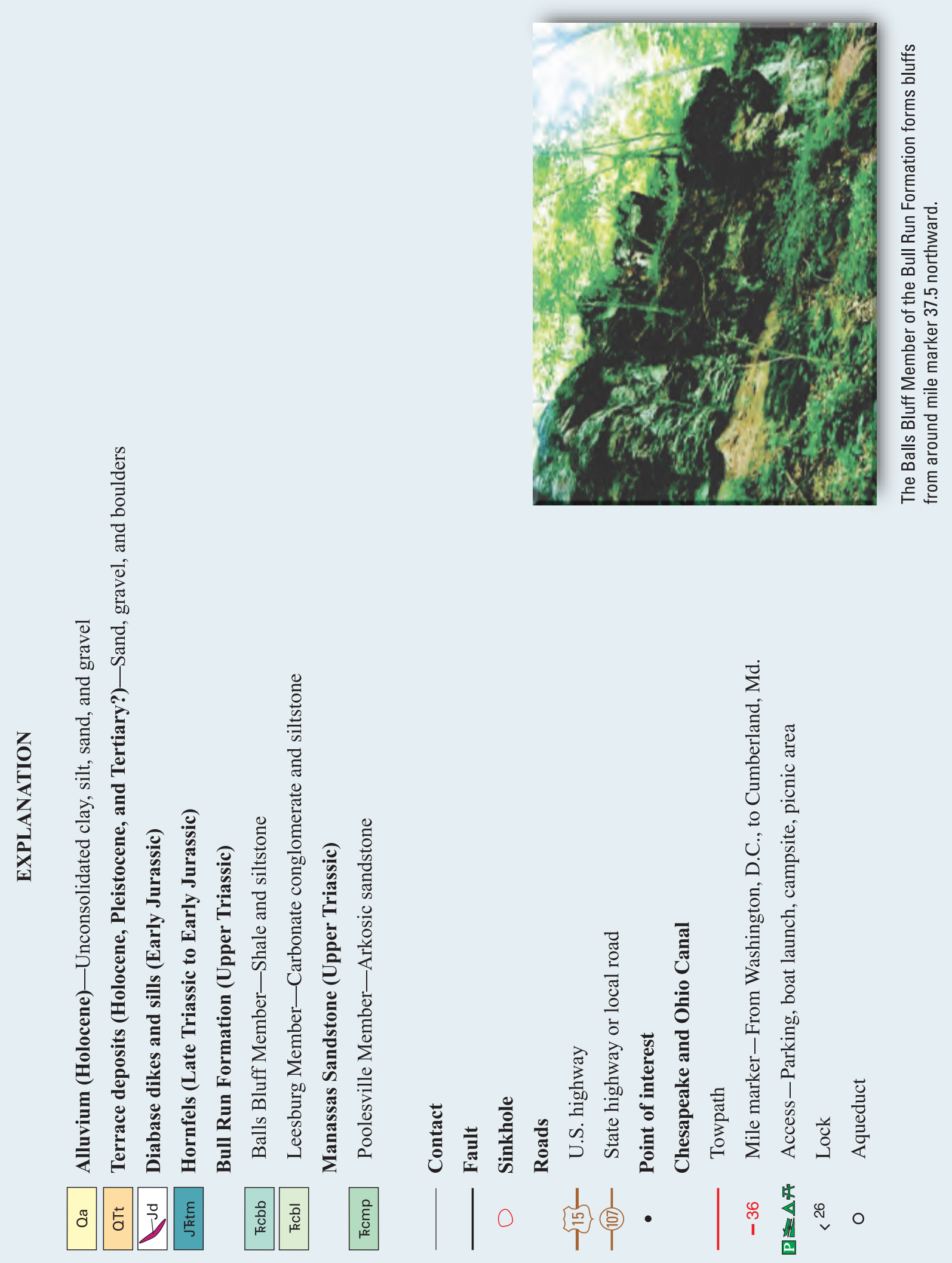




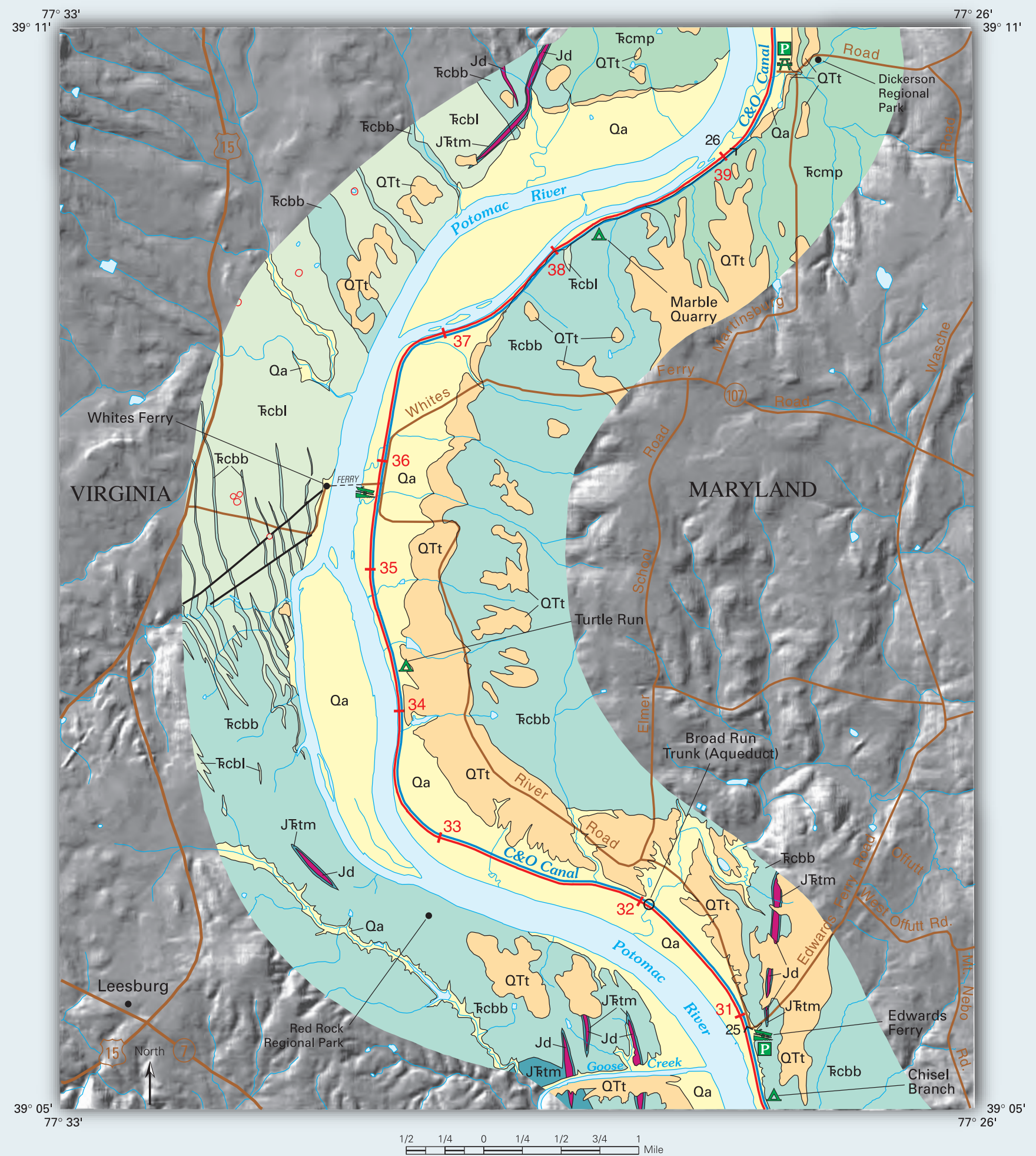




\section{Plate 7.}

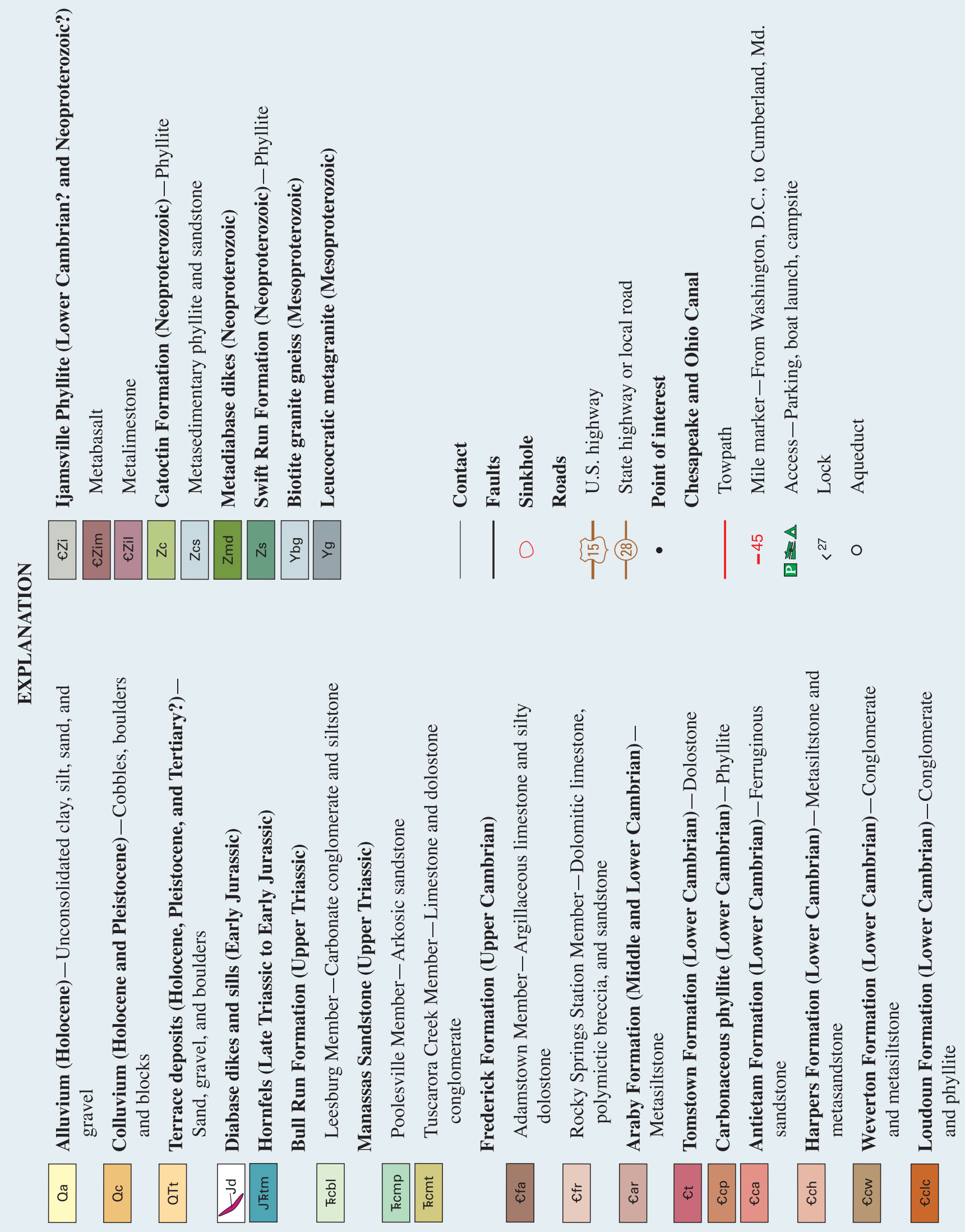




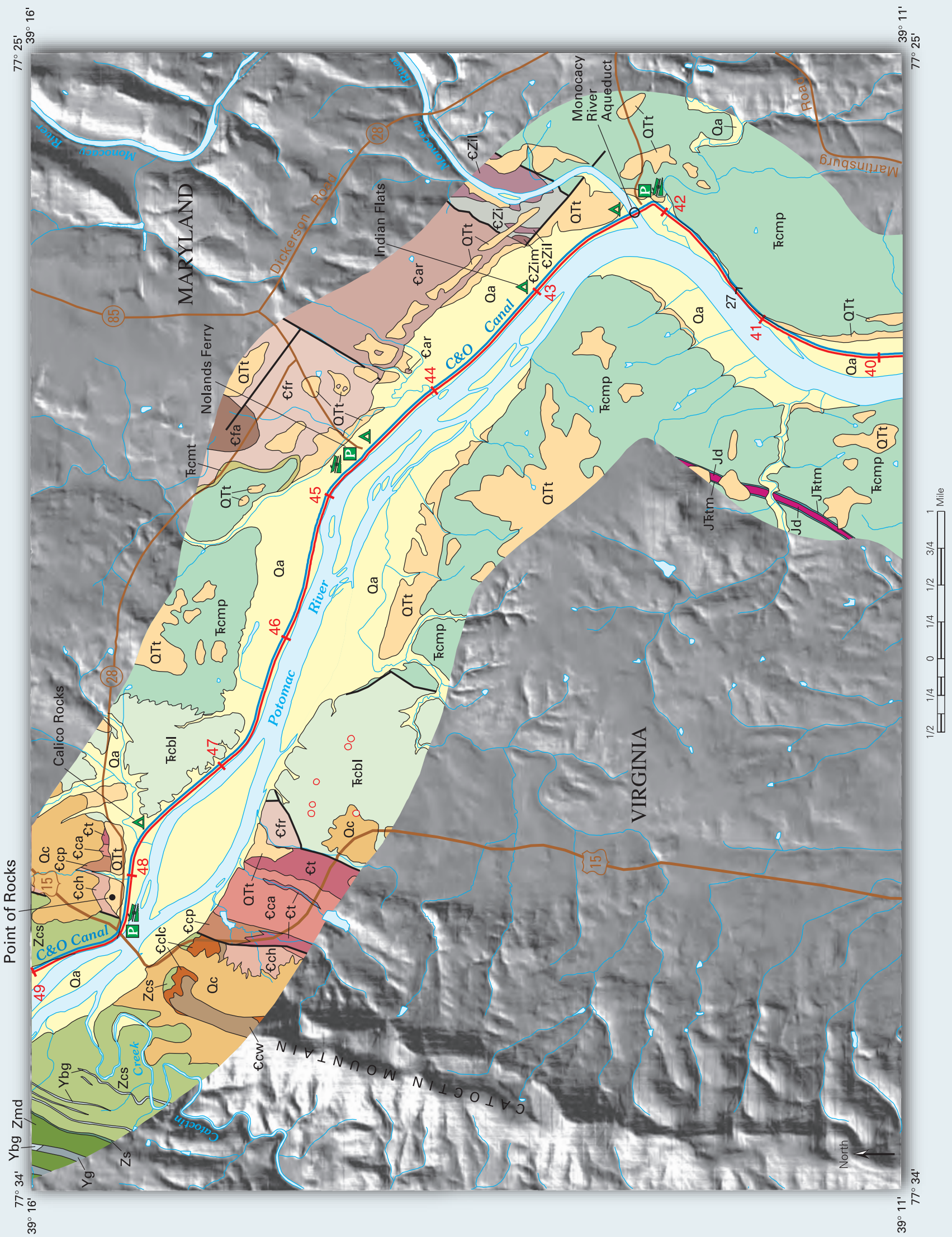




\section{Plate 8.}

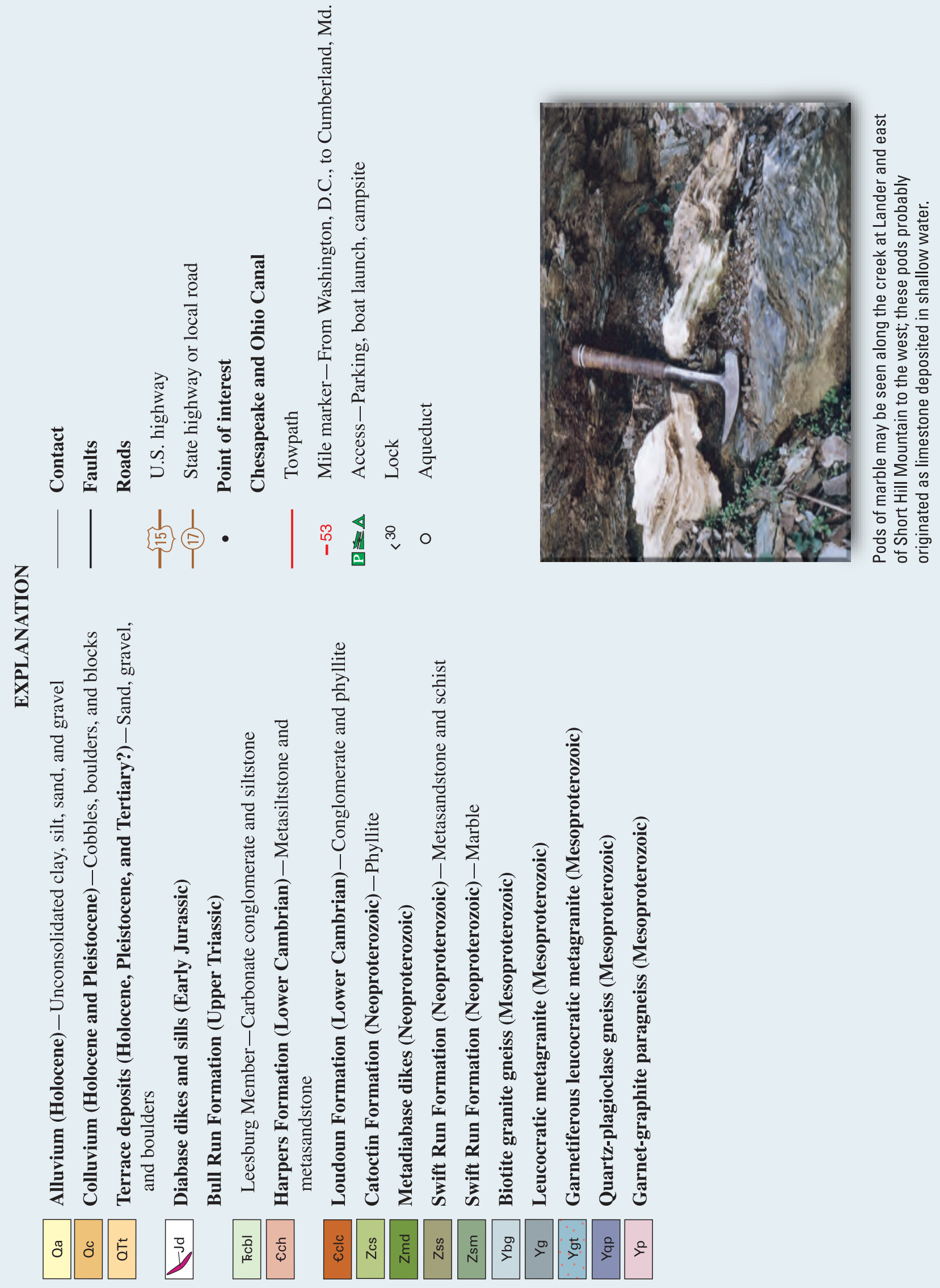




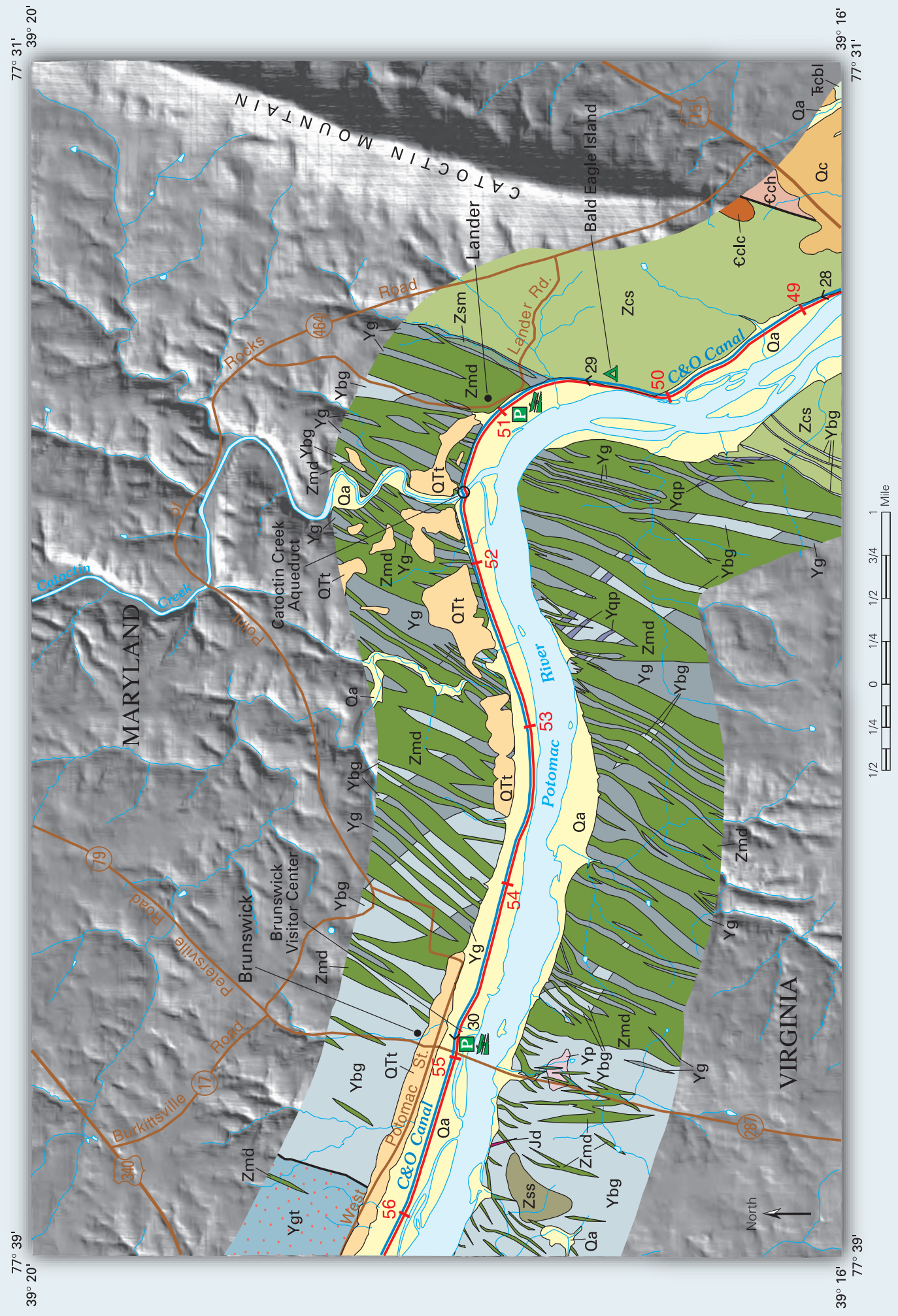




\section{Plate 9.}
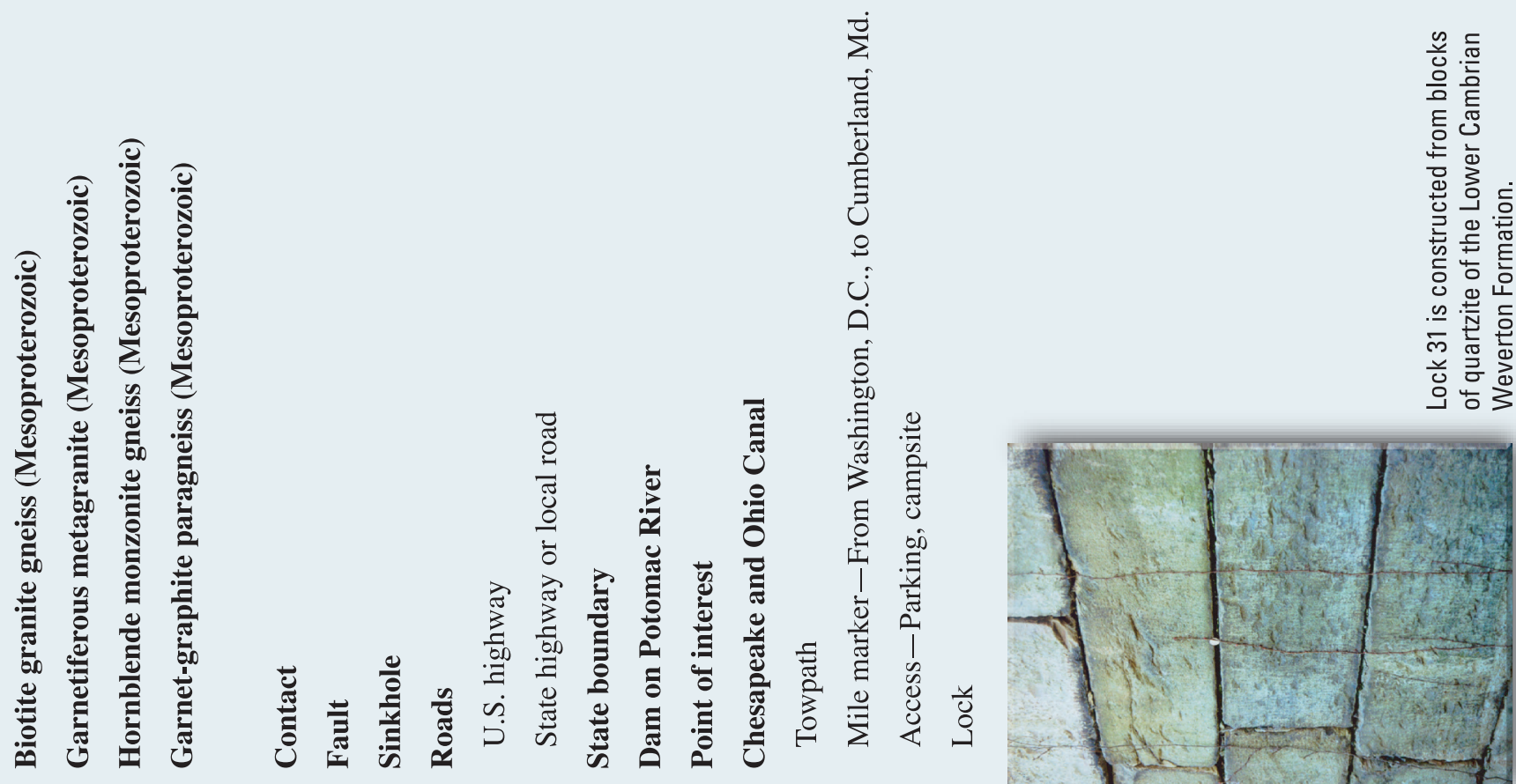

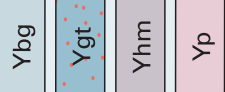

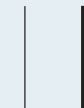

○通电

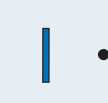

운

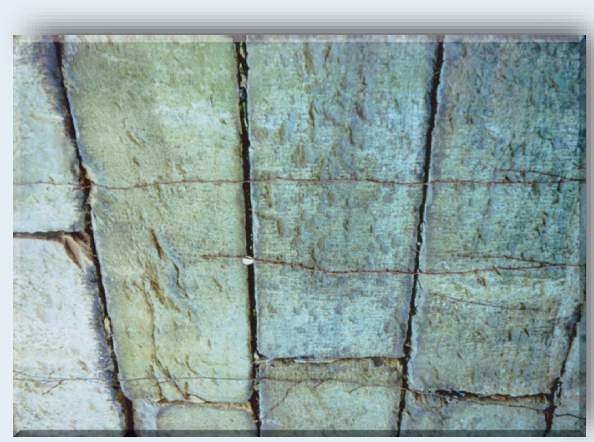

睧

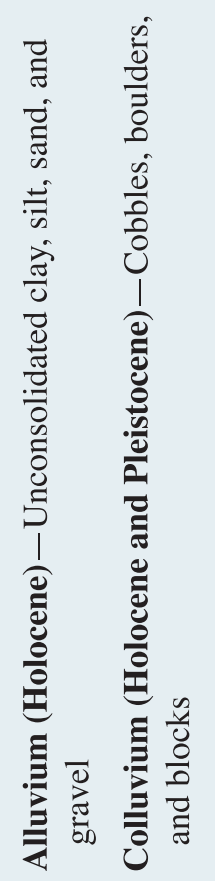

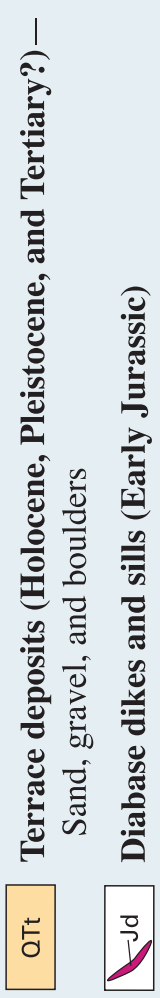

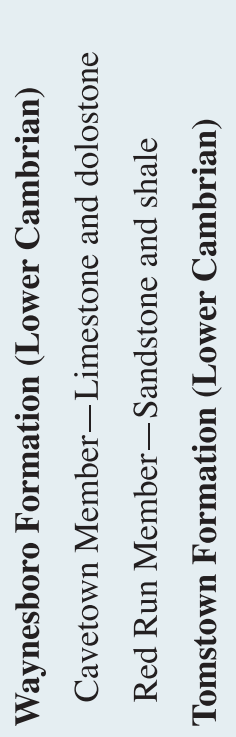

.
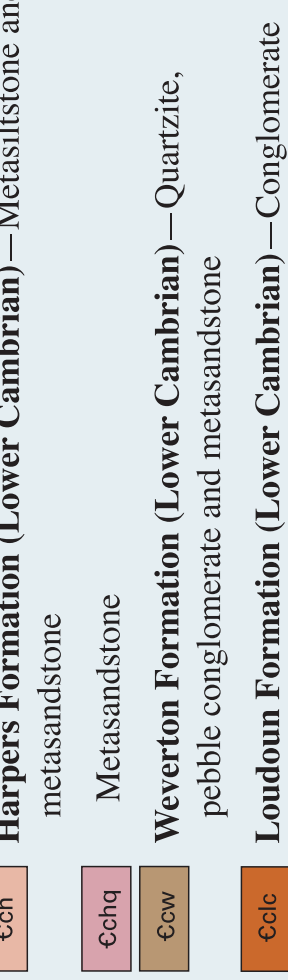

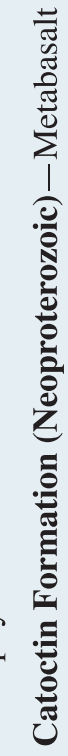

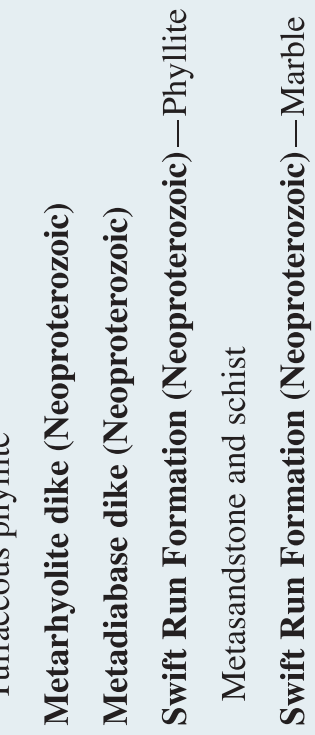




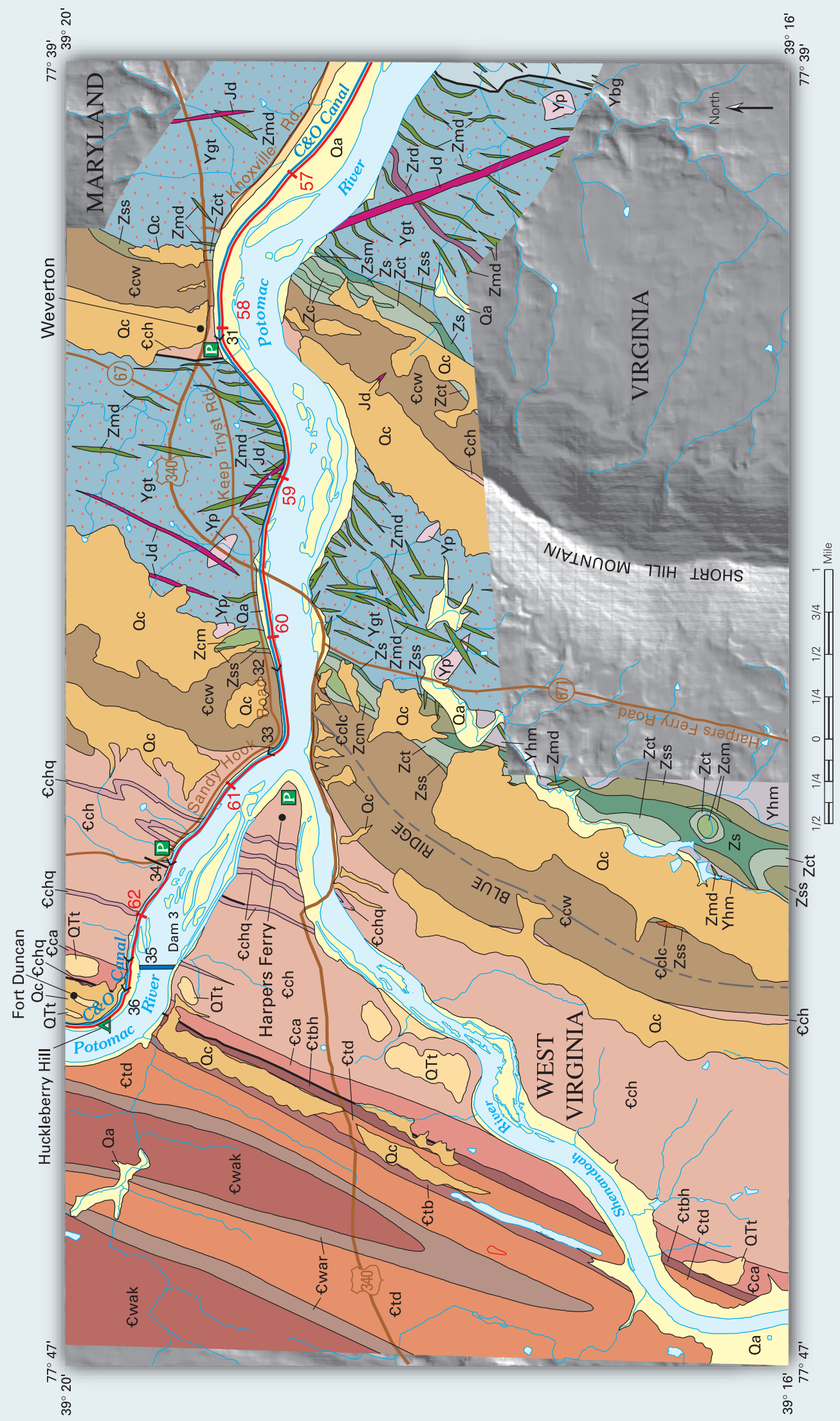




\section{Plate 10.}

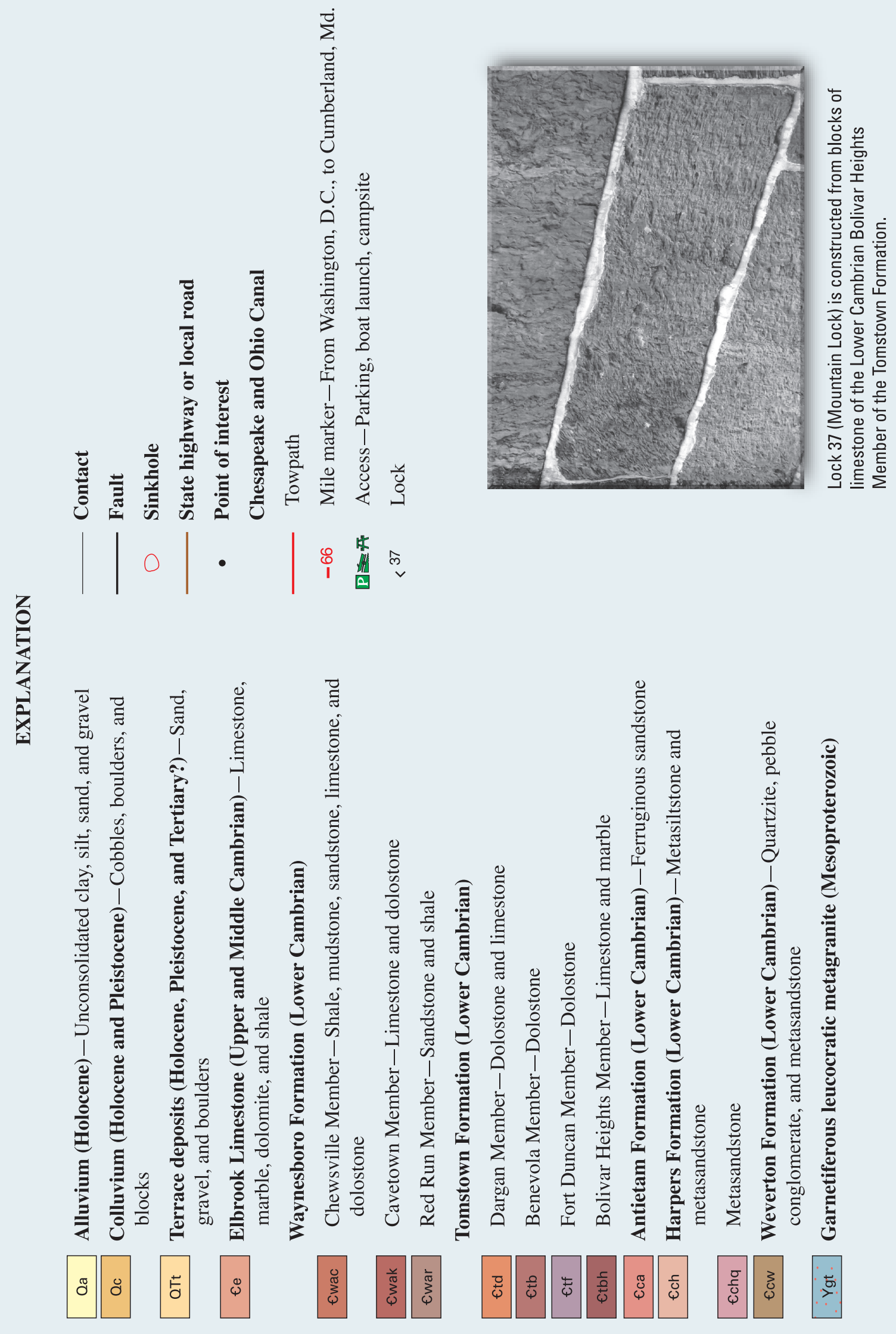




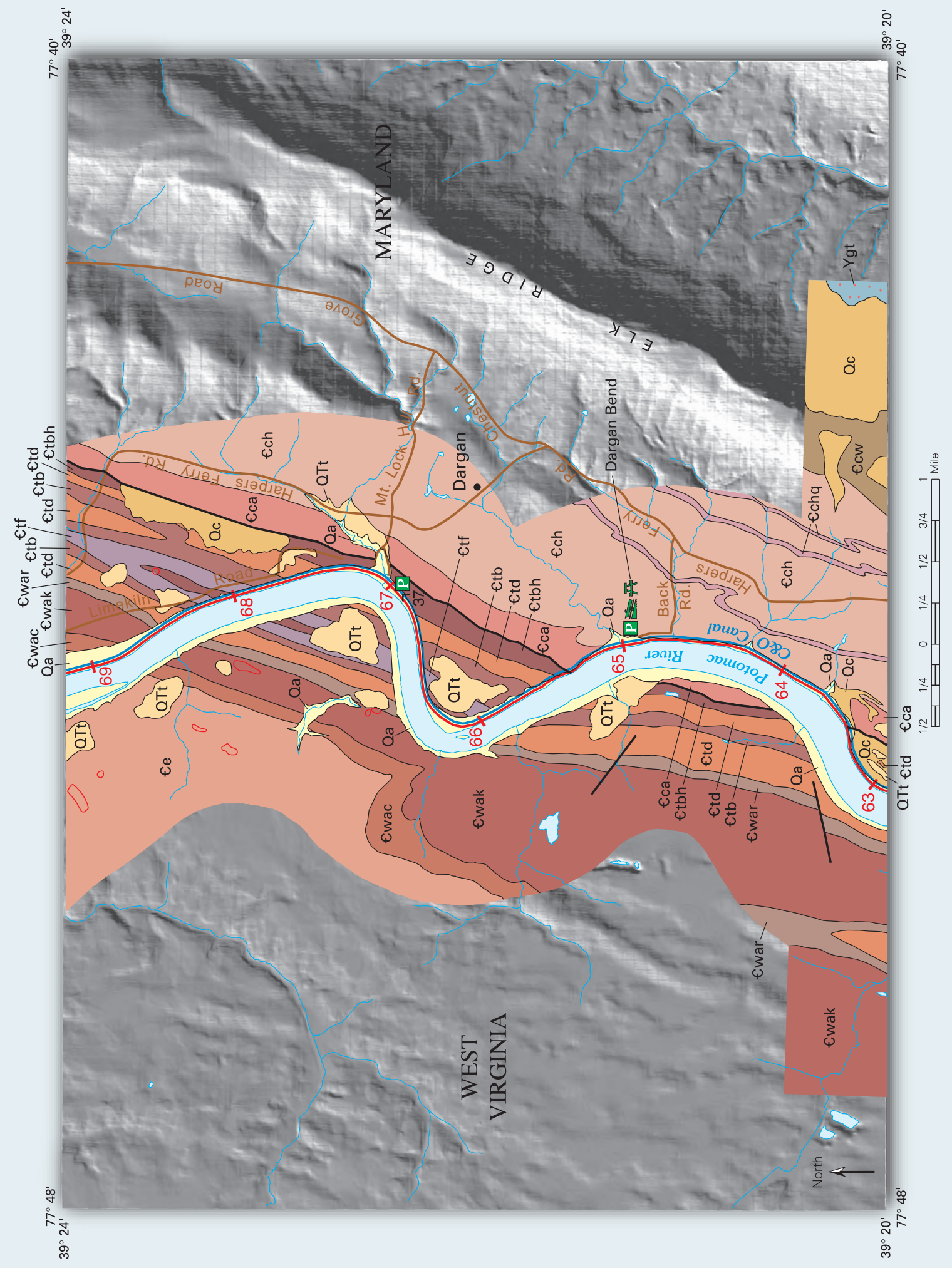




\section{Plate 11.}

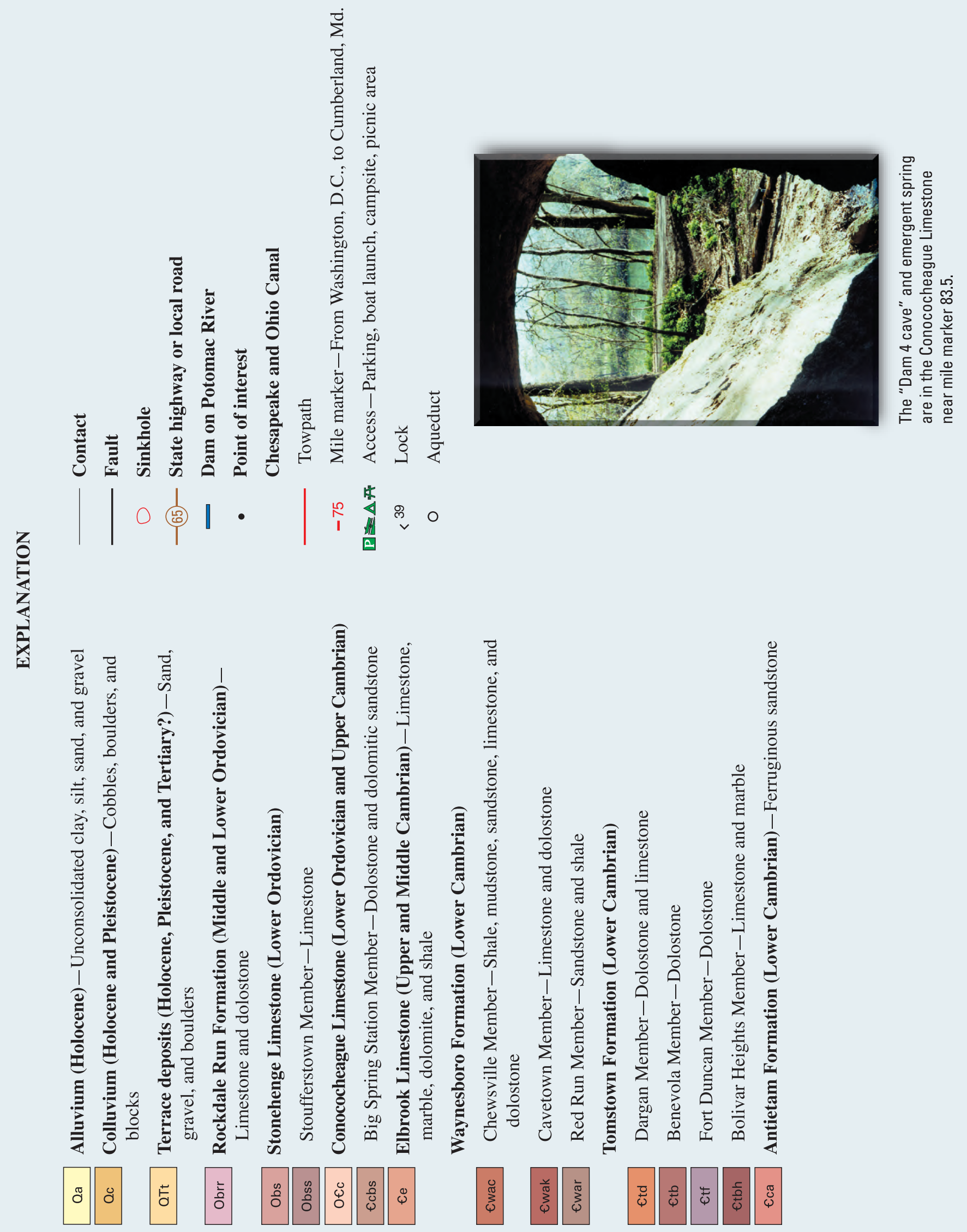




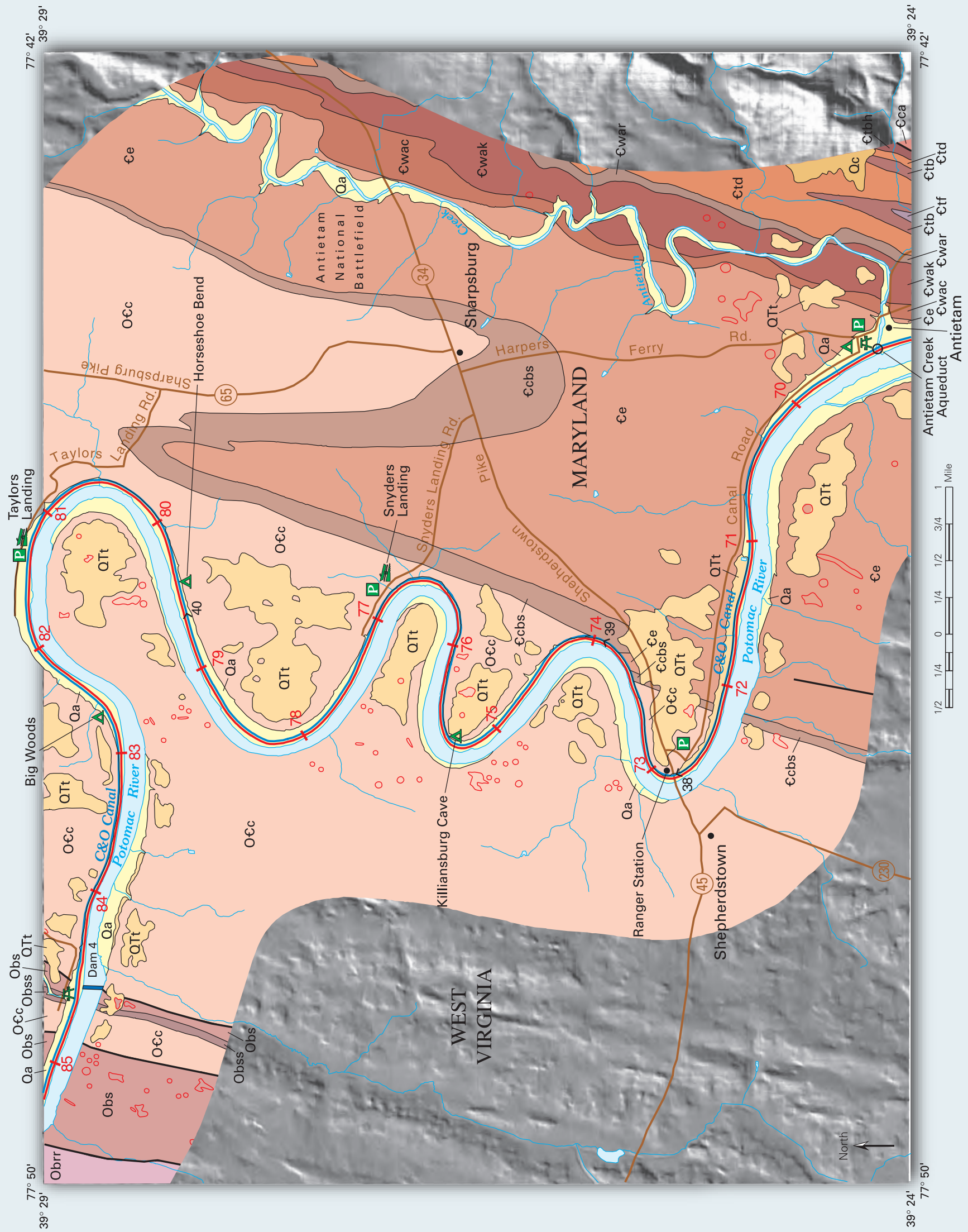




\section{Plate 12.}
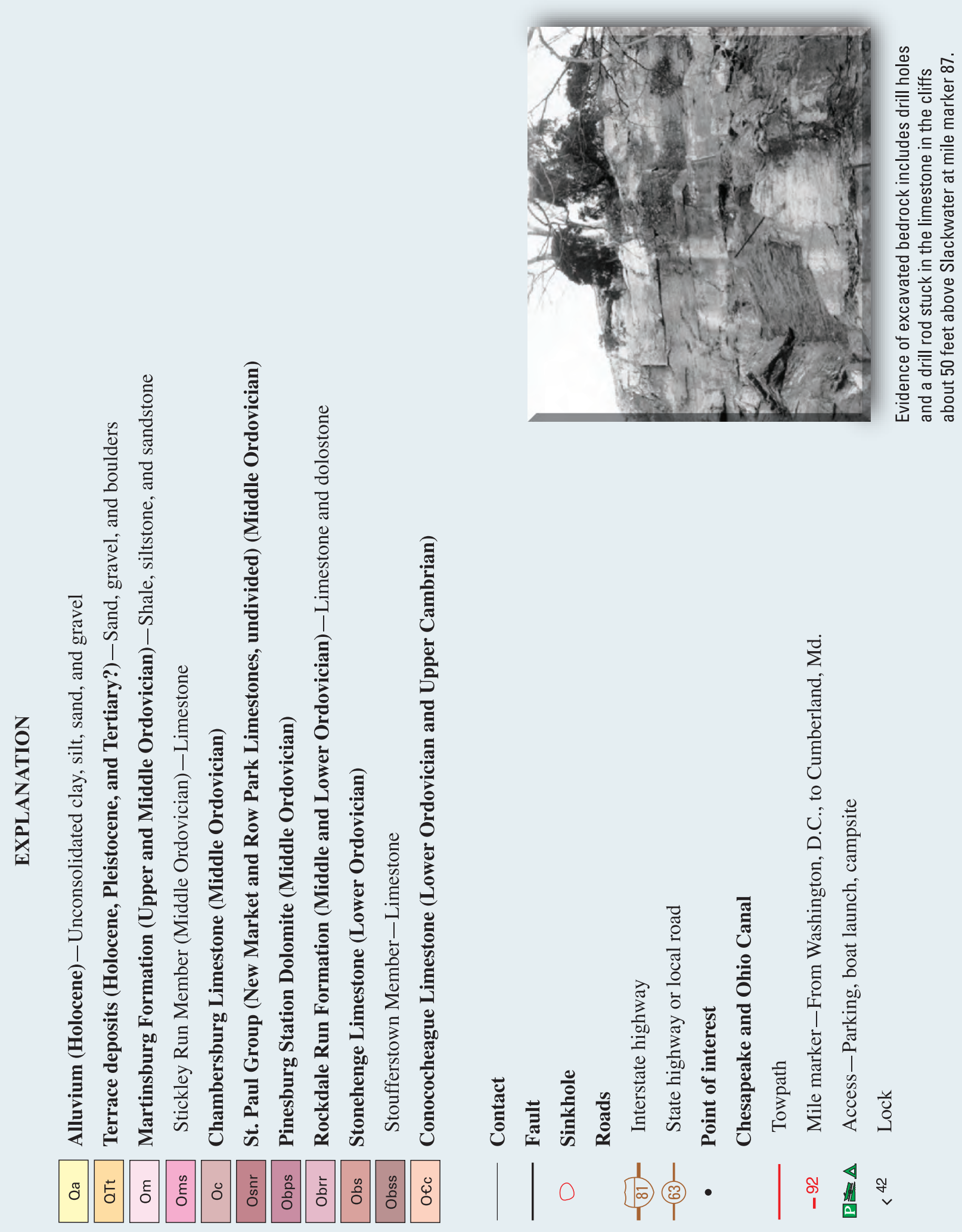


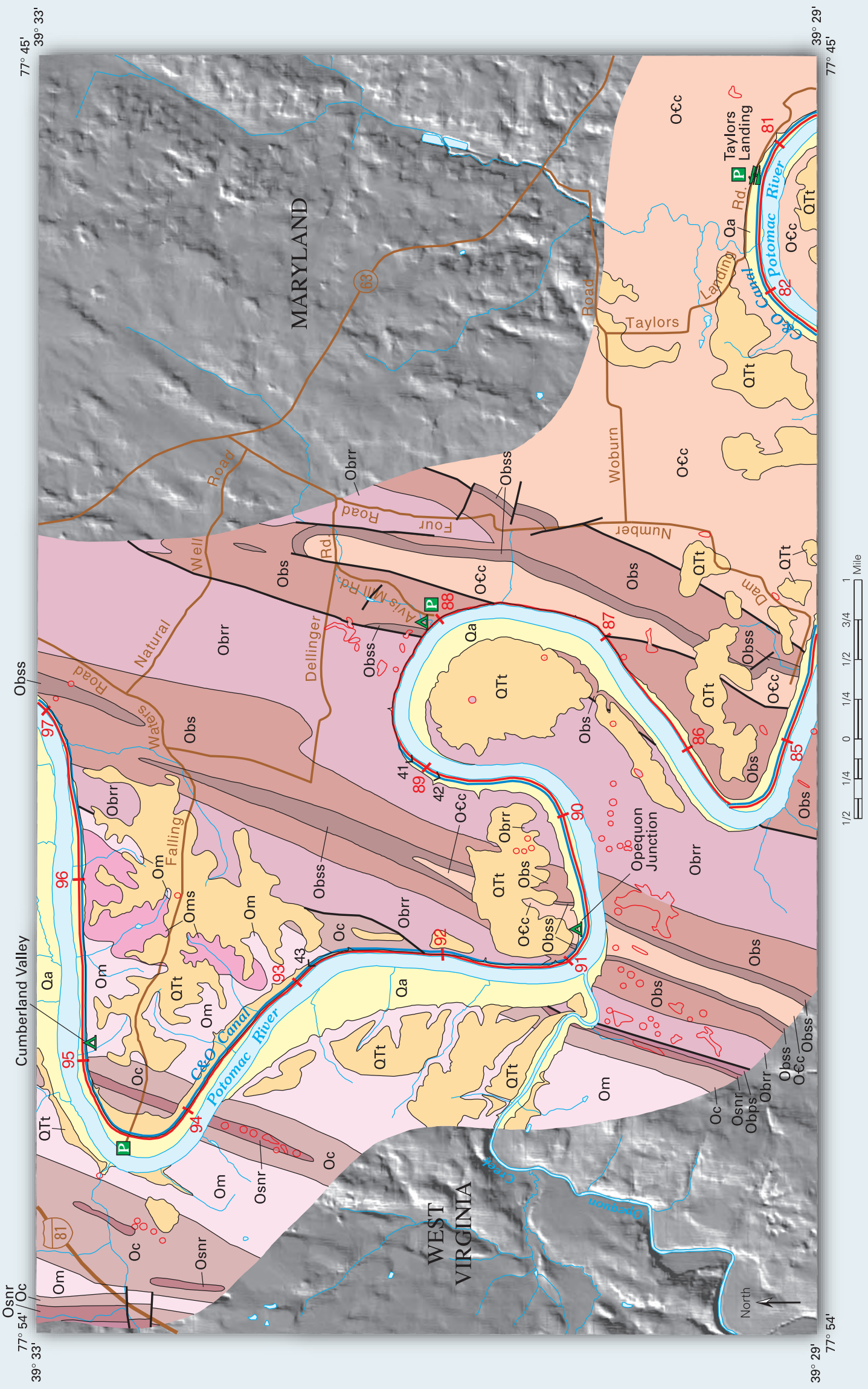




\section{Plate 13.}

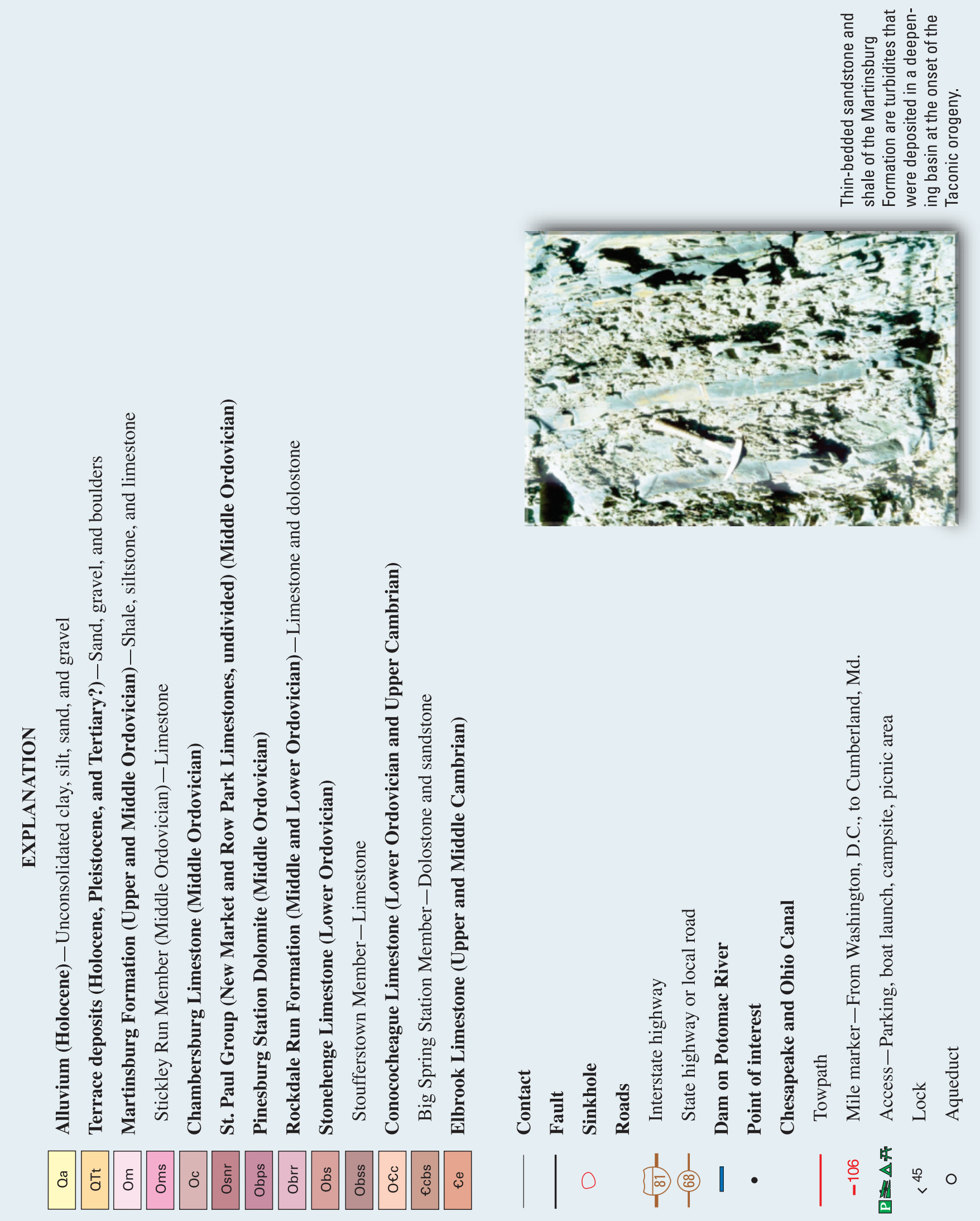




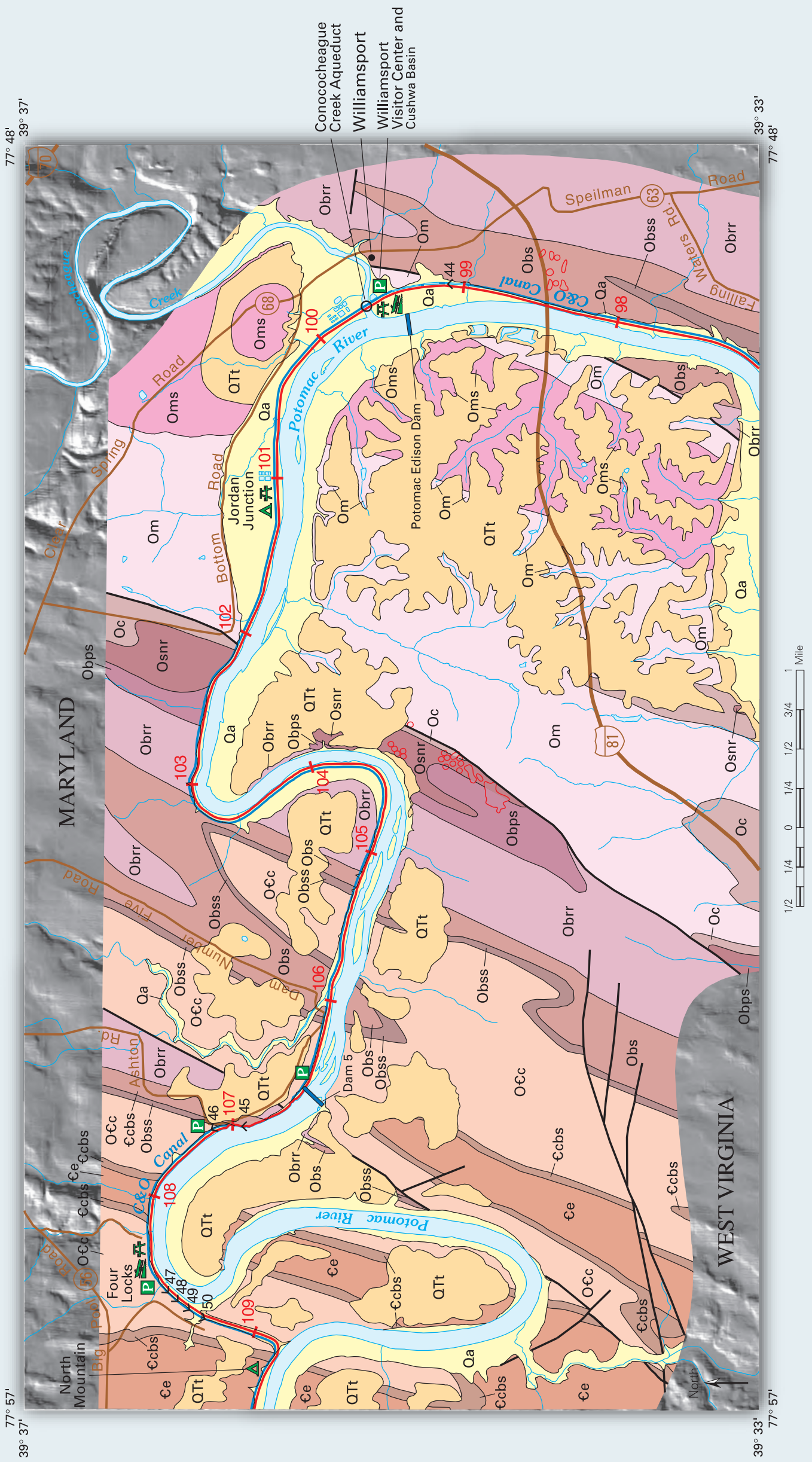




\section{Plate 14.}
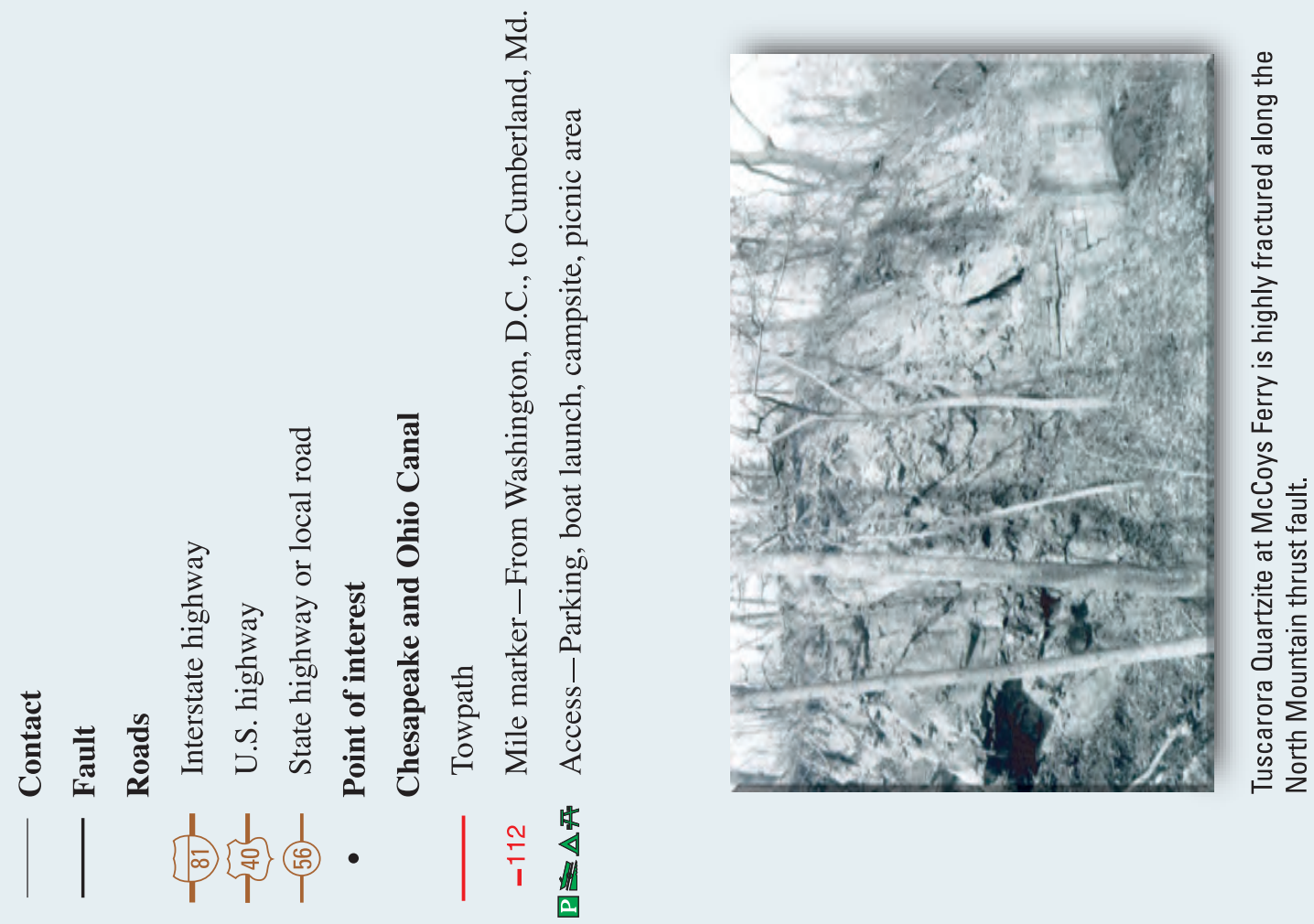

茨

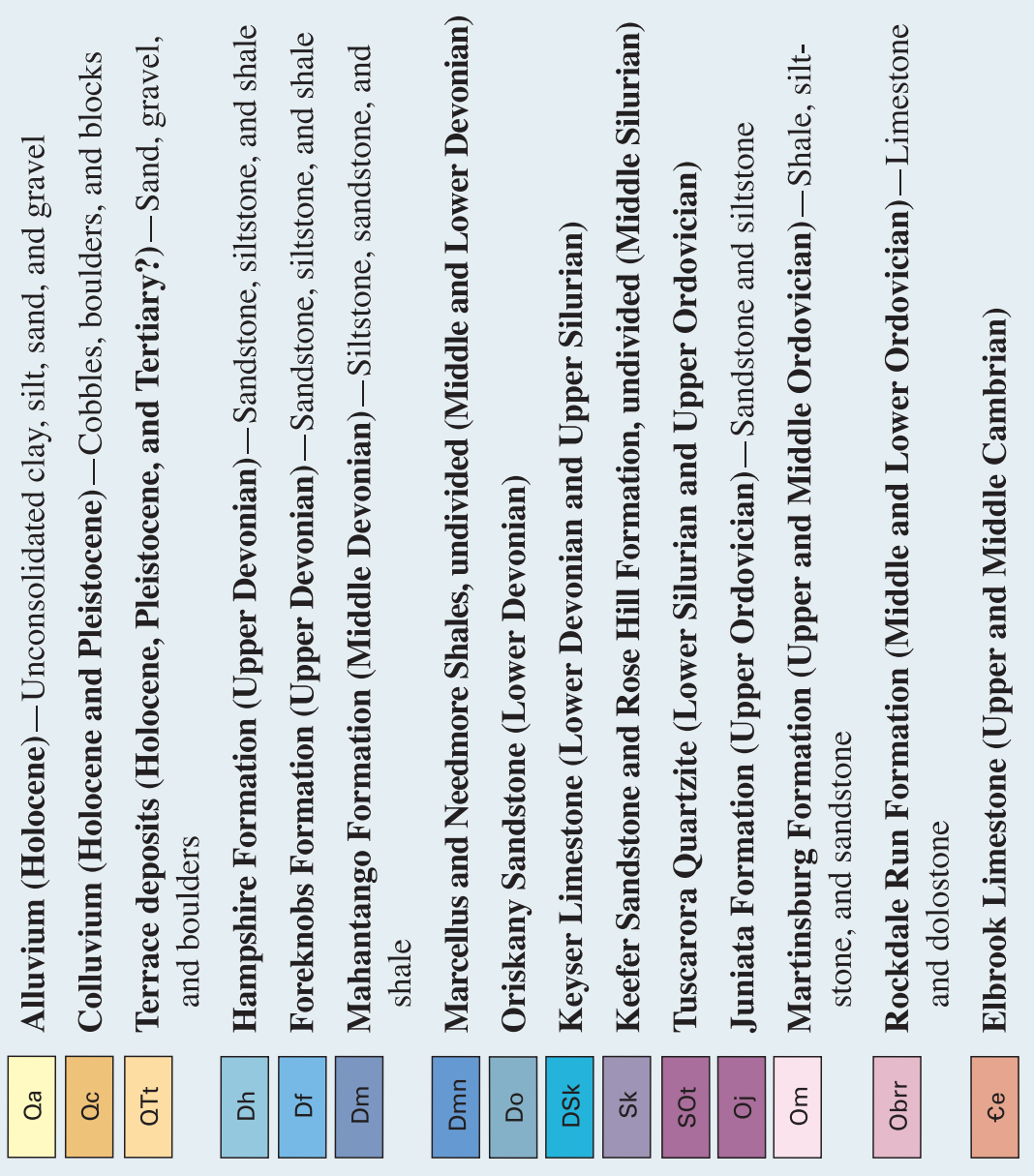




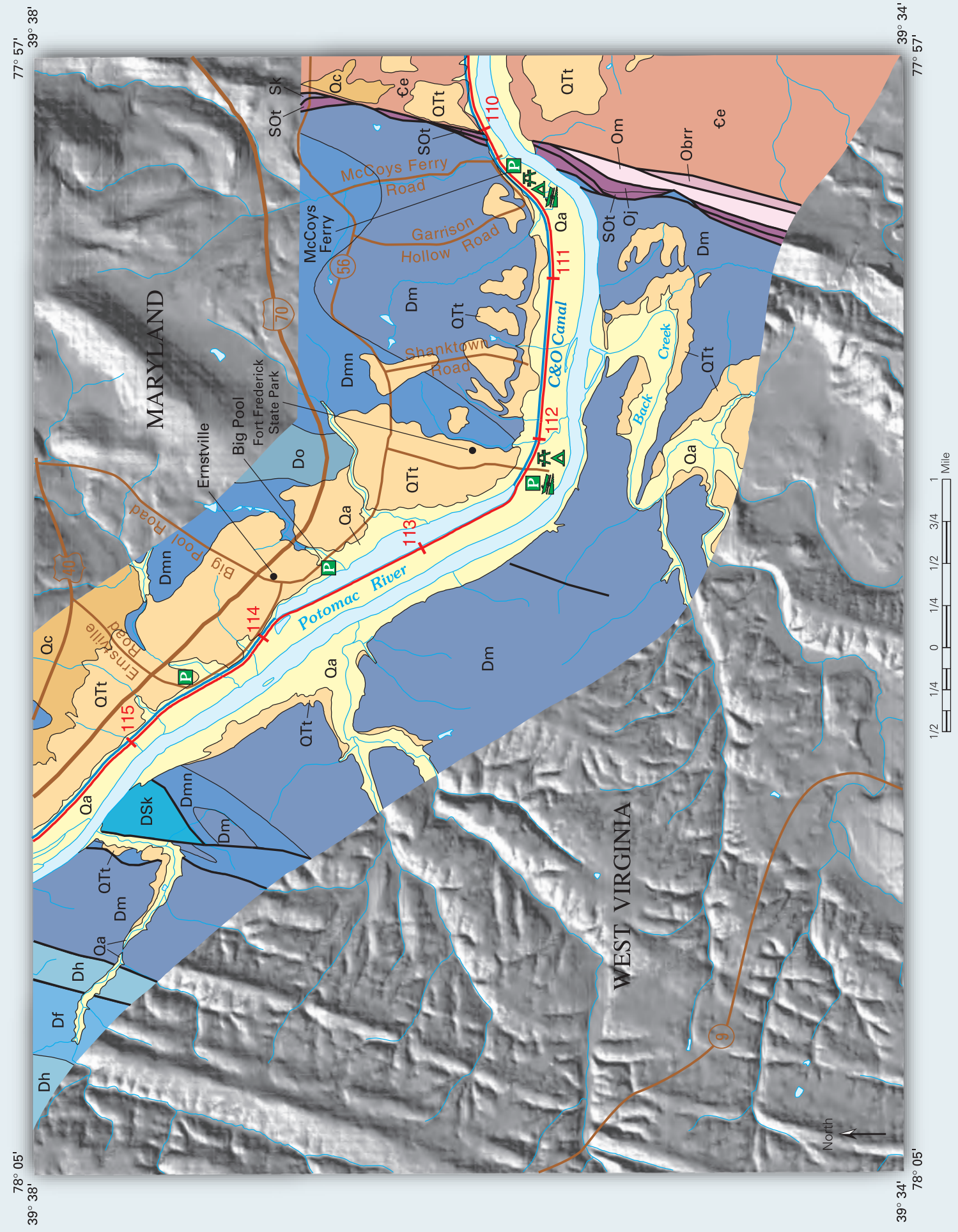




\section{Plate 15.}
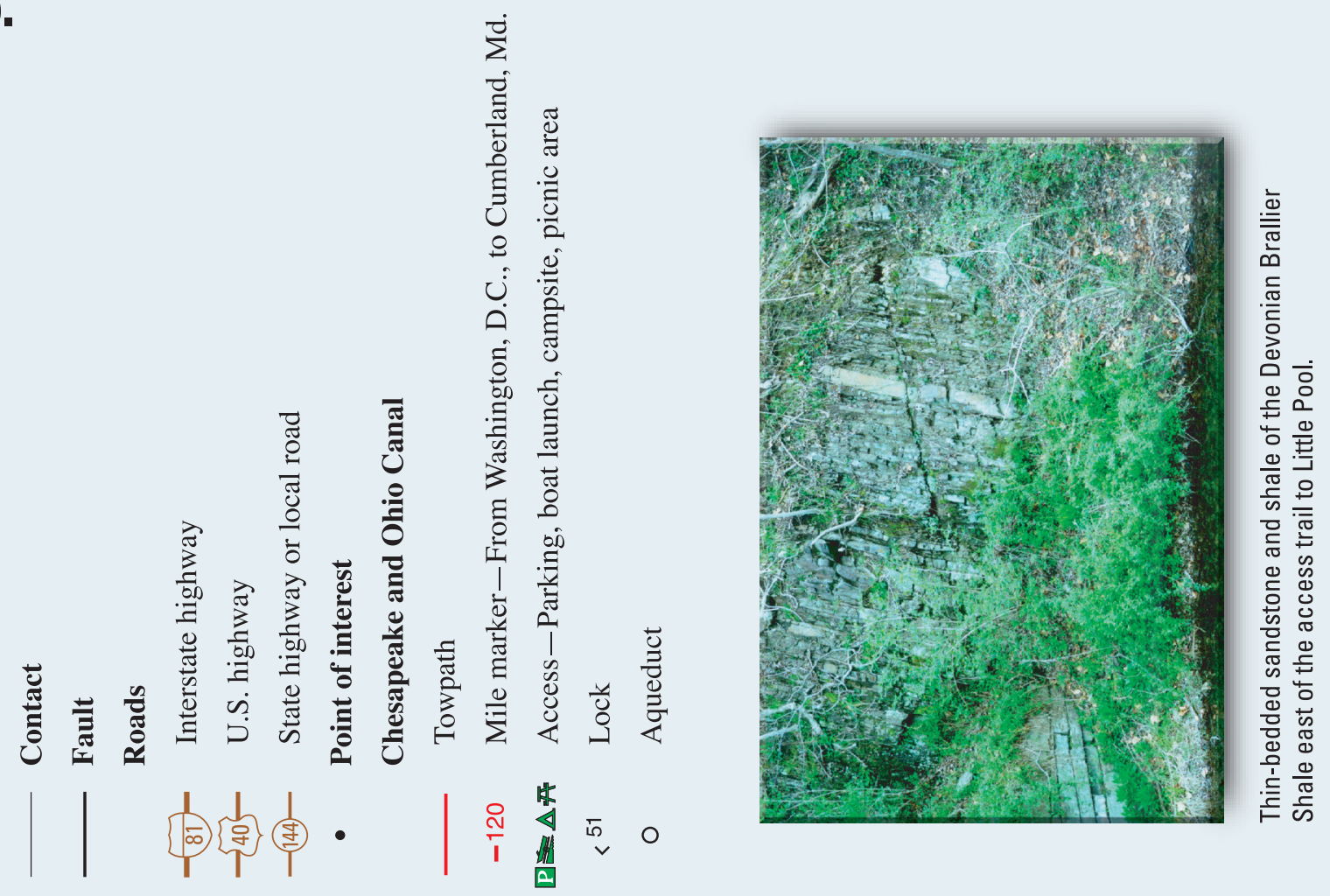

恣

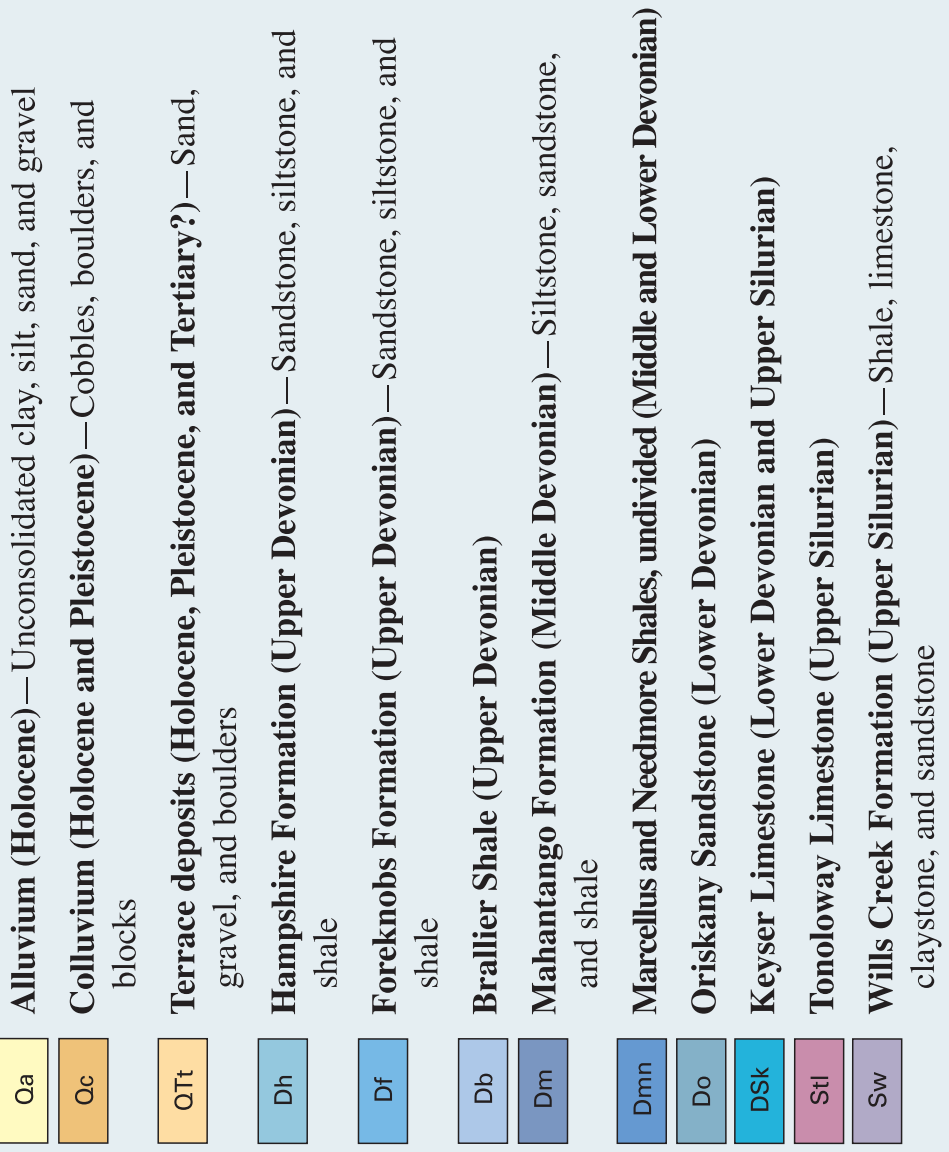




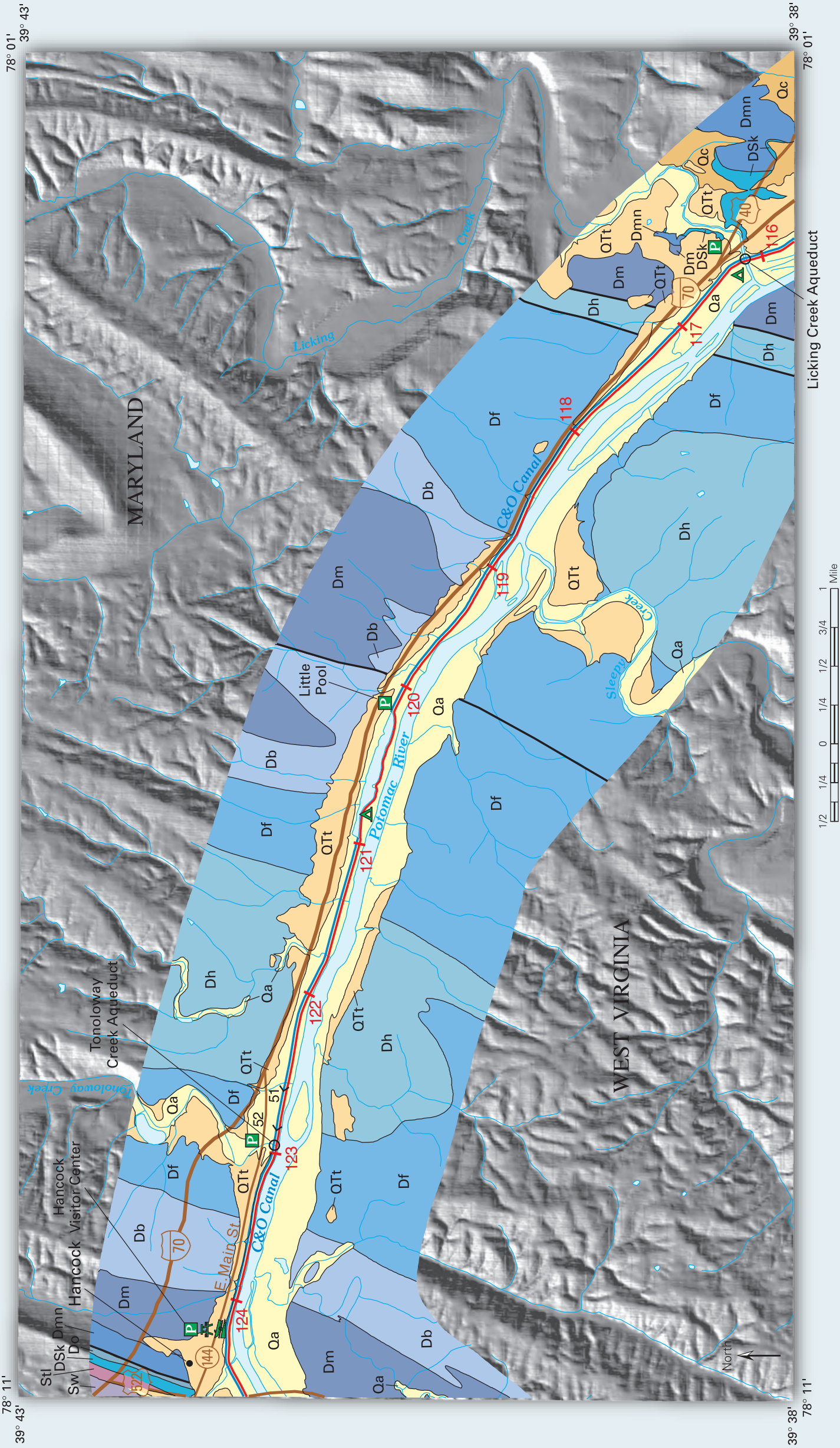




\section{Plate 16.}

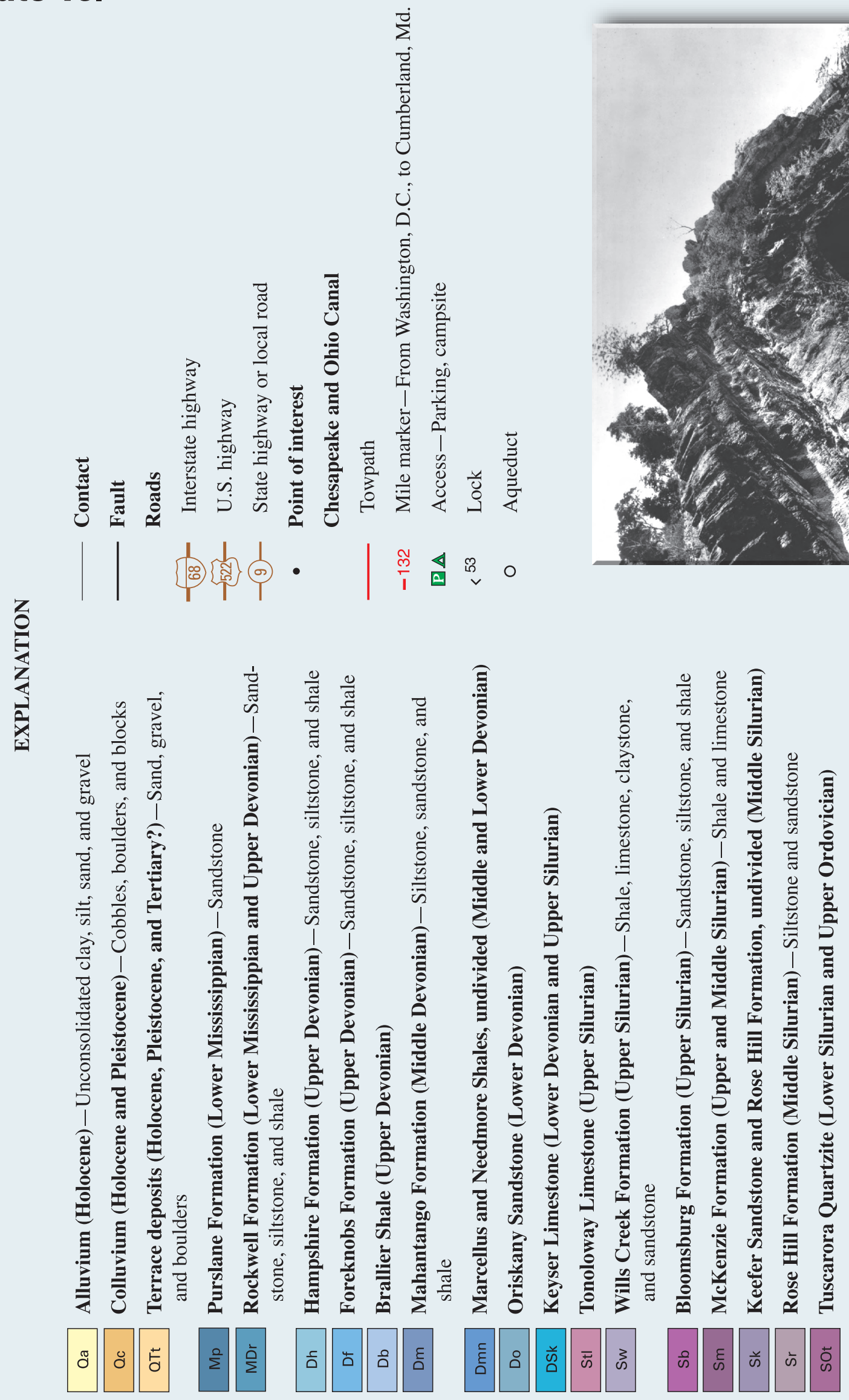




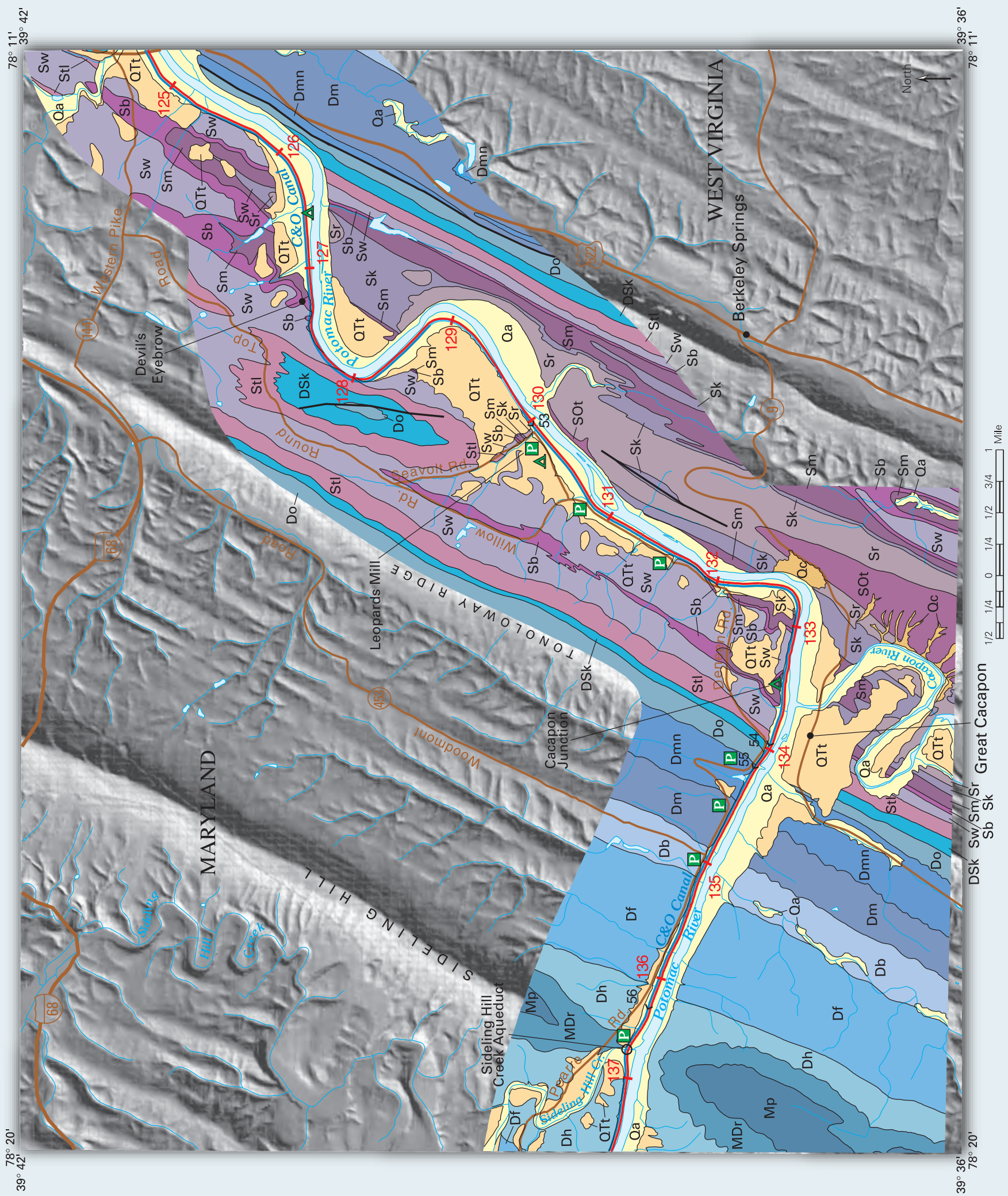




\section{Plate 17.}
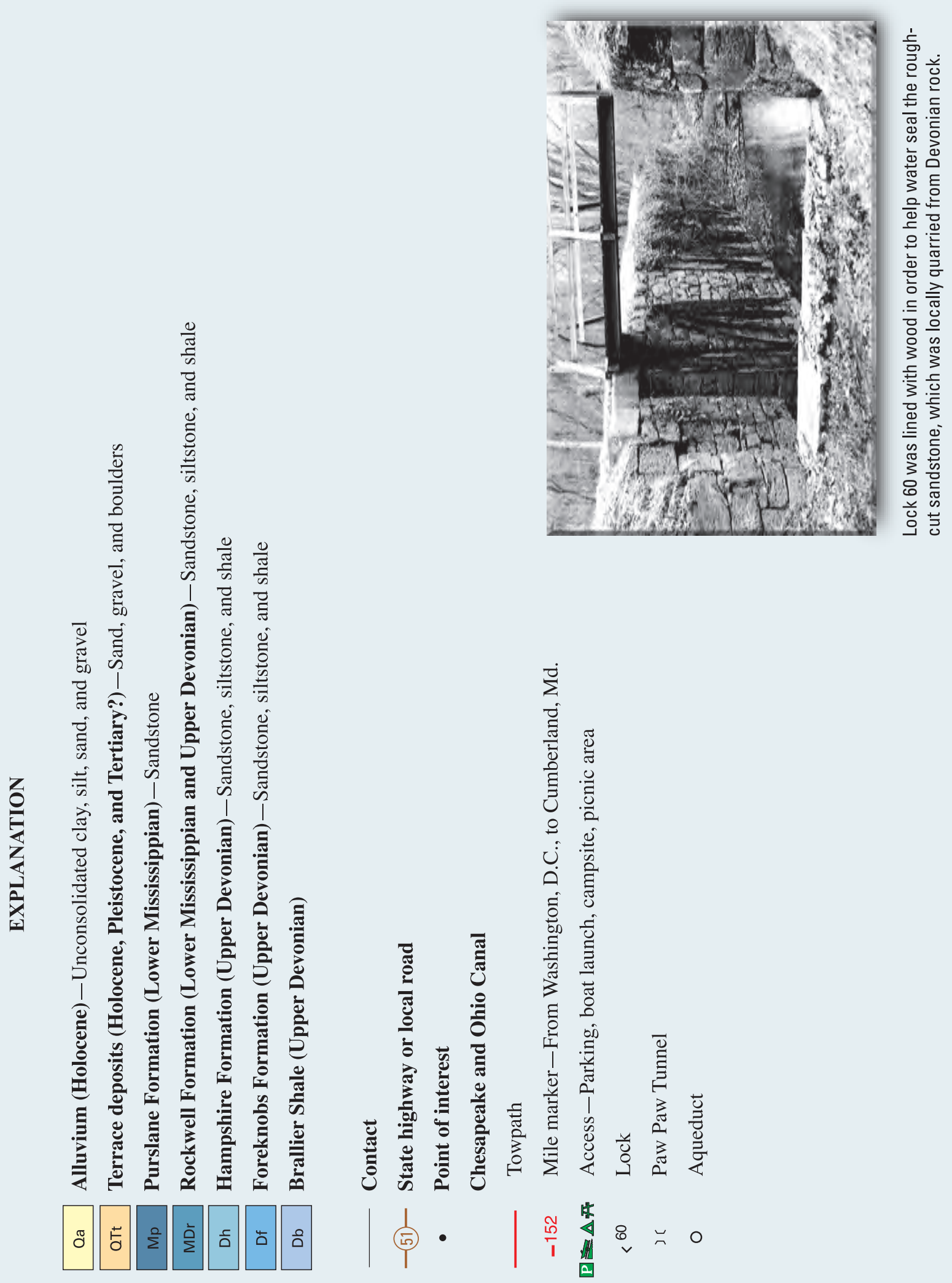


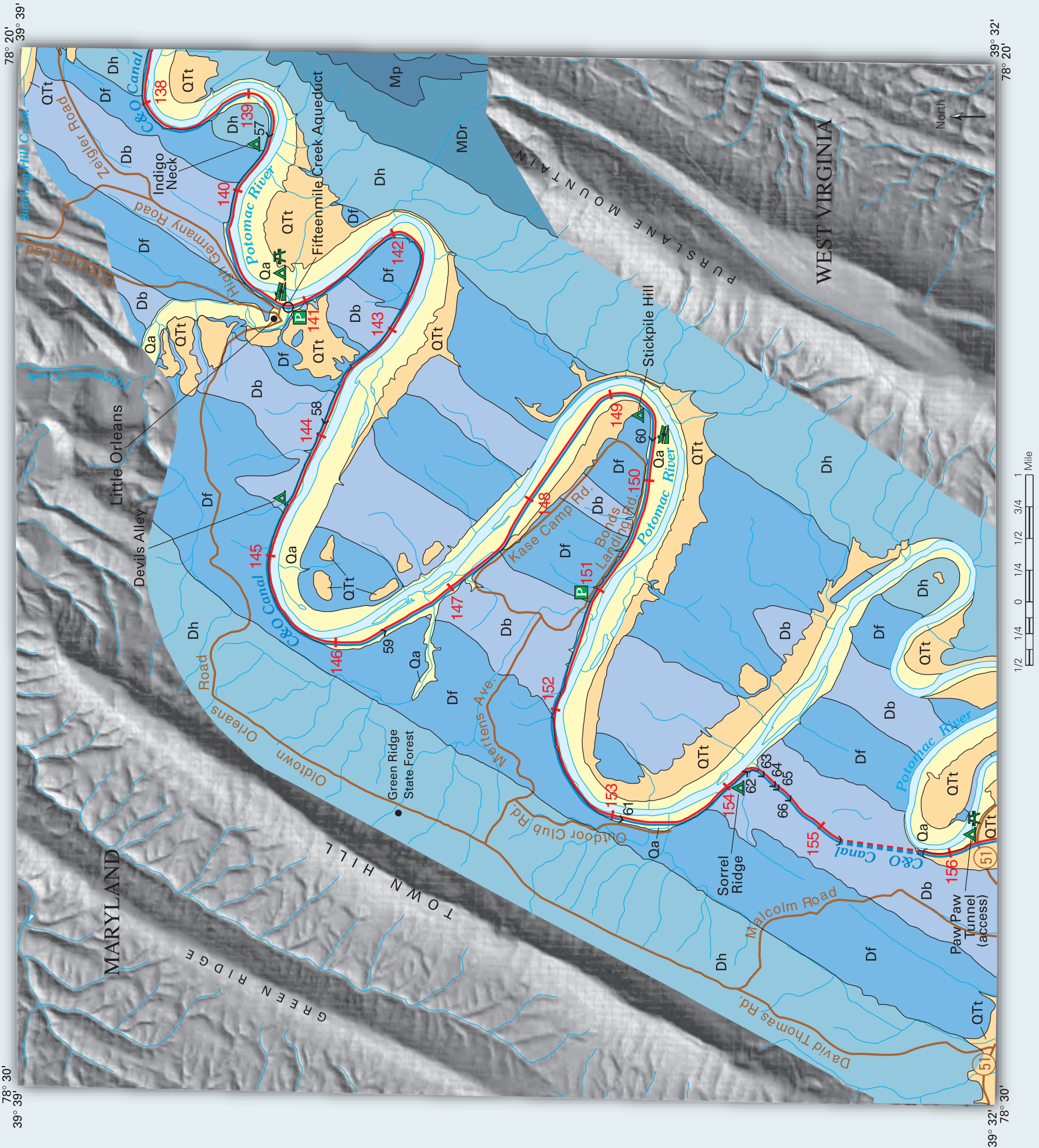




\section{Plate 18.}
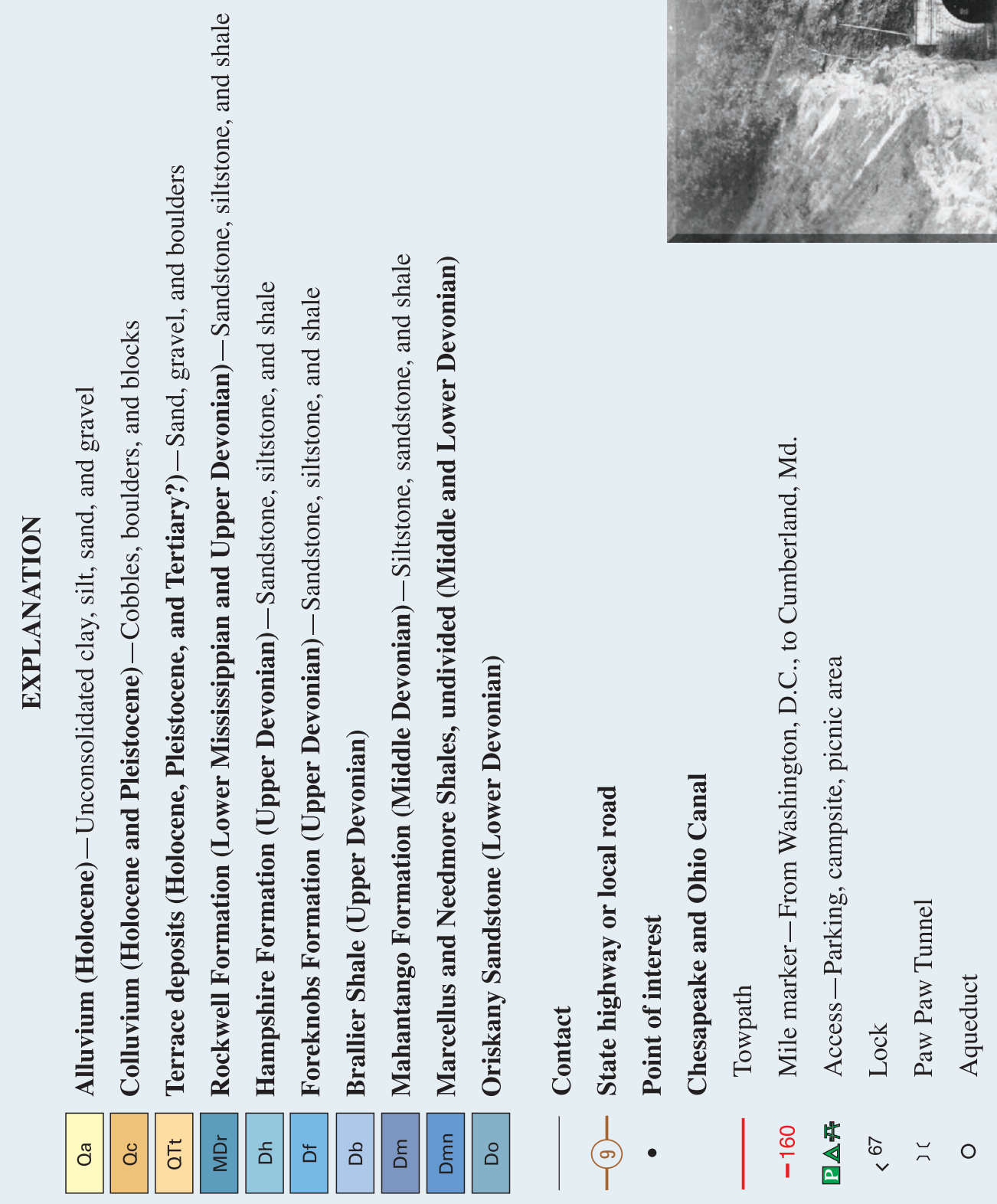


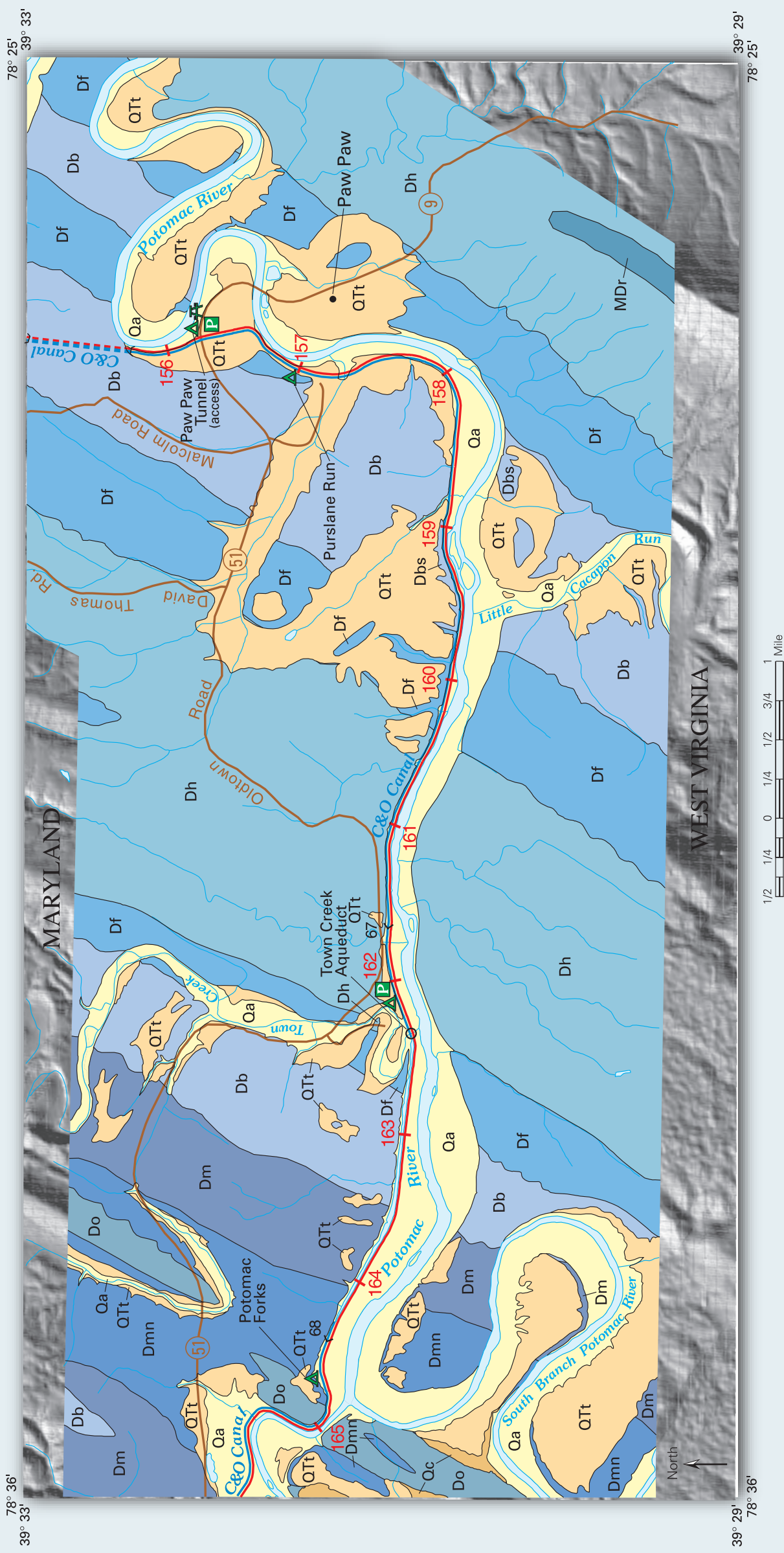




\section{Plate 19.}

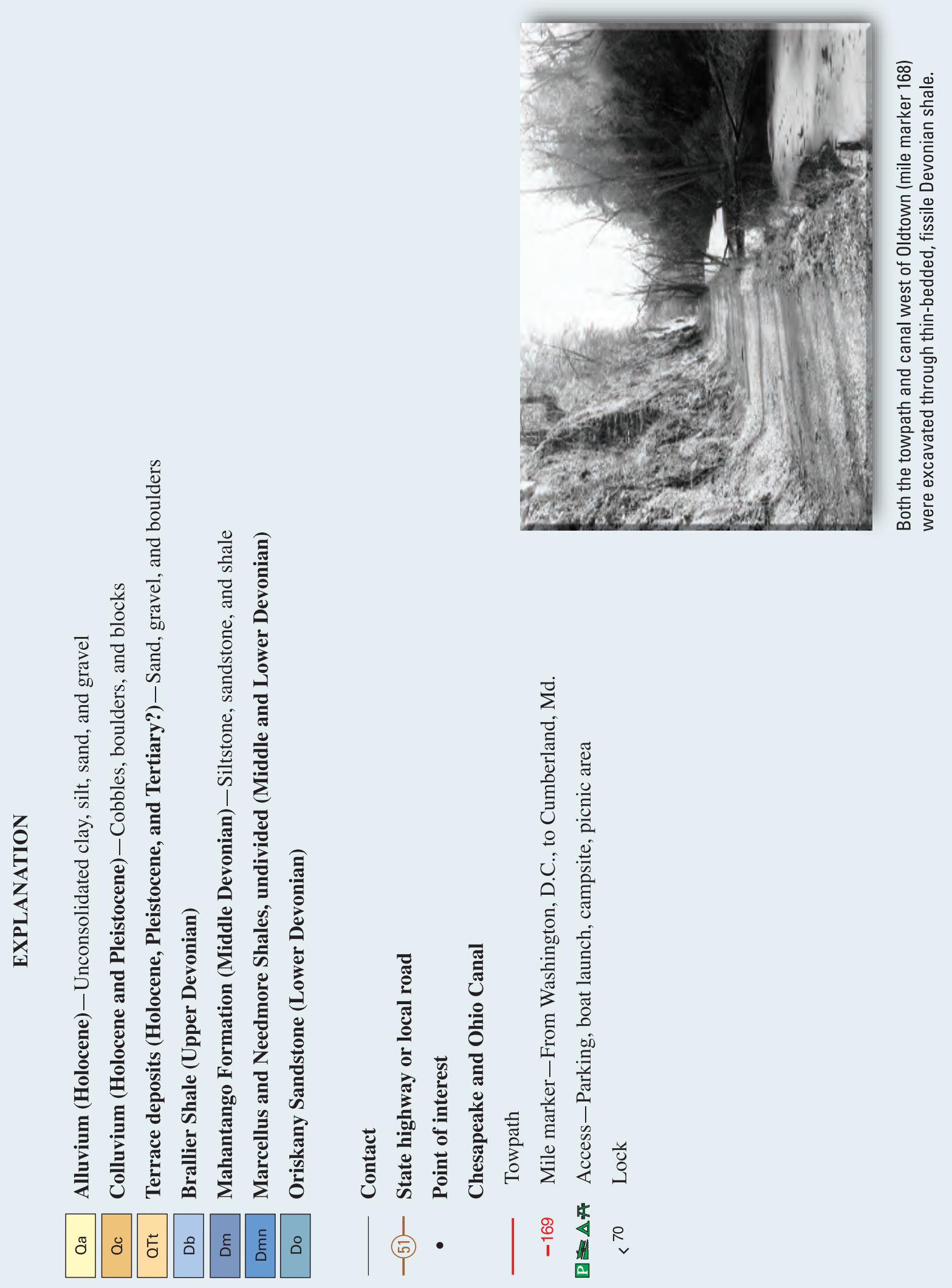




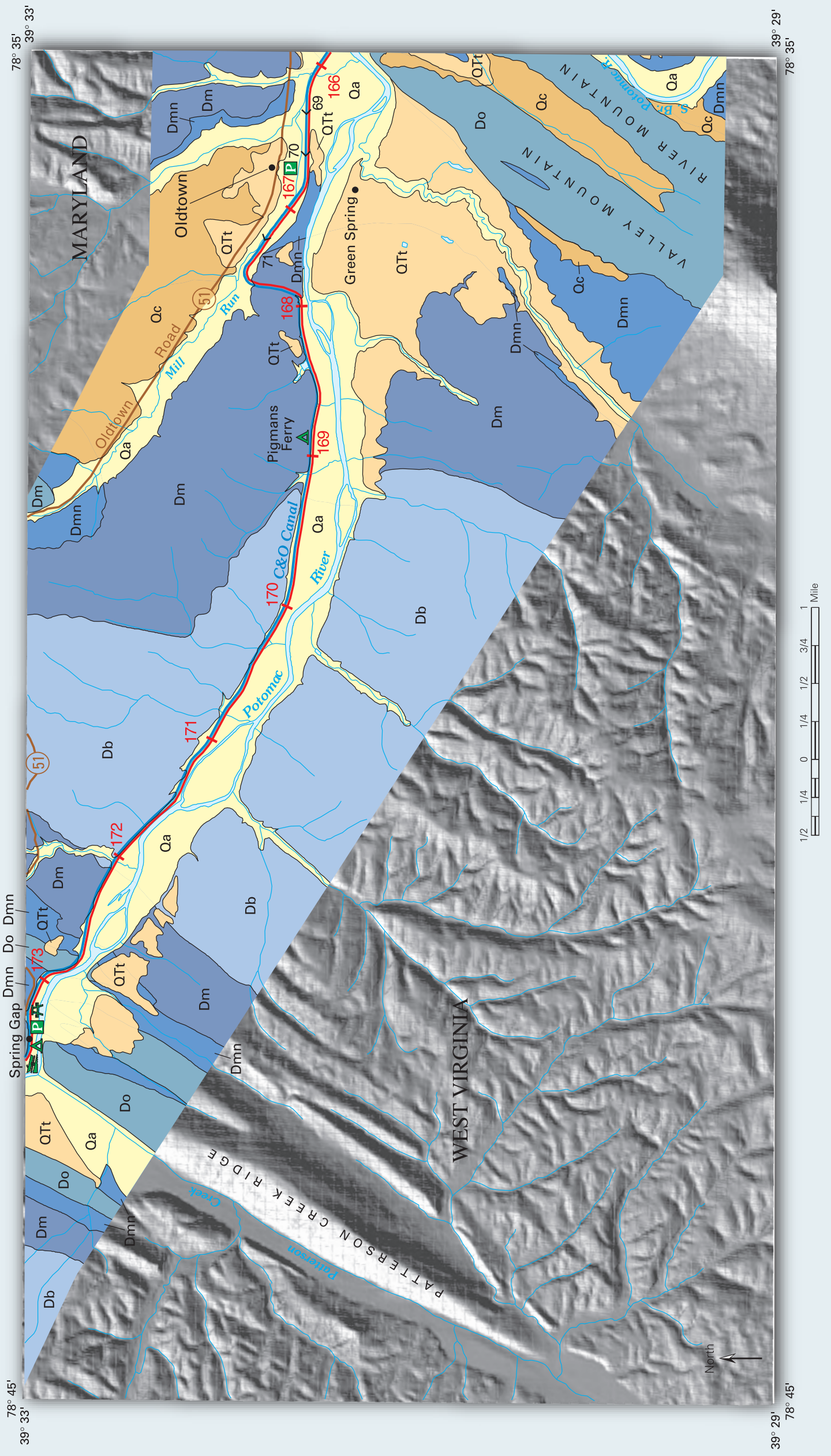




\section{Plate 20.}

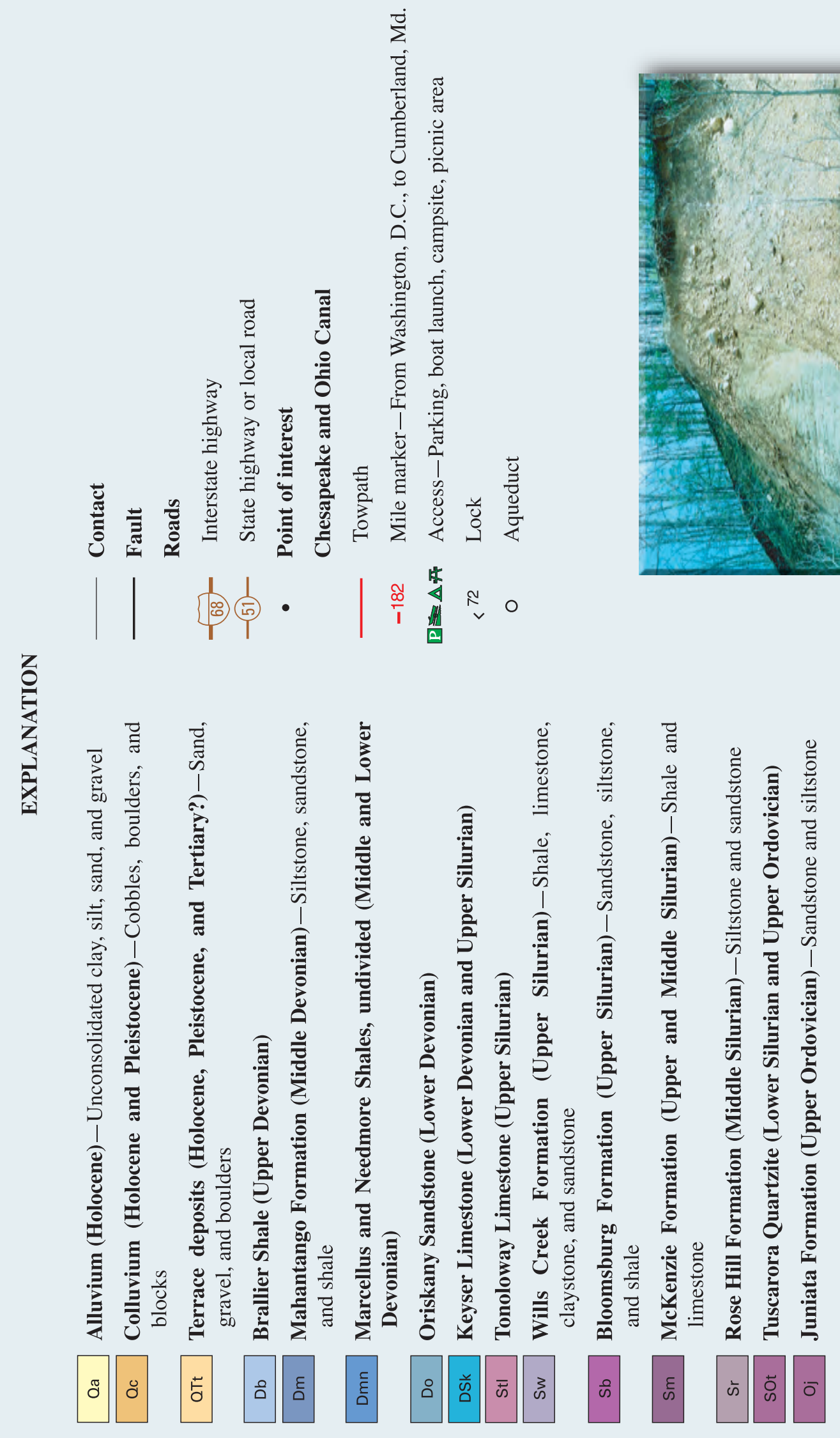




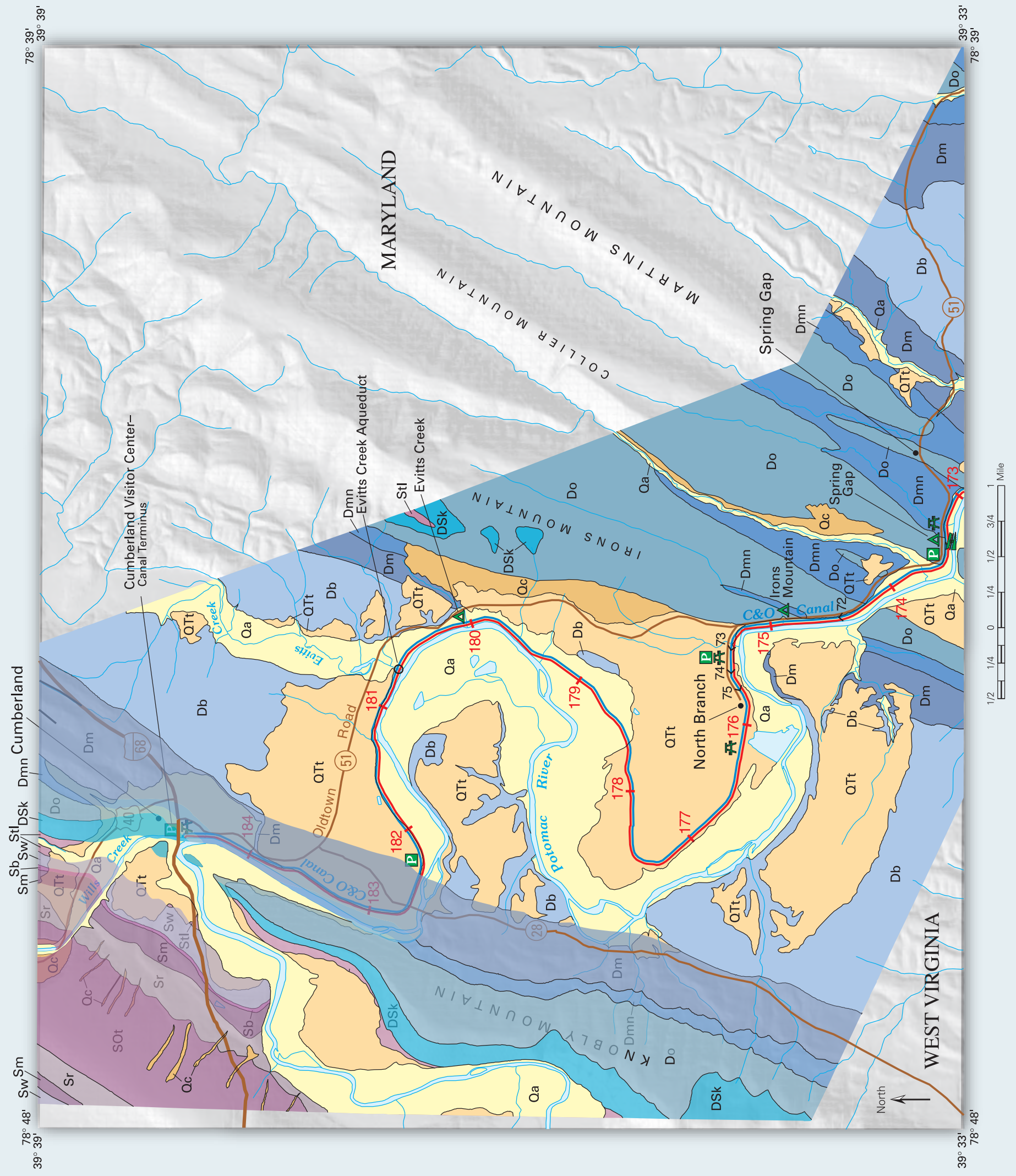


Manuscript approved for publication February 27, 2004.

Prepared by the Eastern Publications Group, Reston, VA.

Editing by Elizabeth D. Koozmin.

Photocomposition and design by Anna N. Glover.

Graphic art and cartography by Linda M. Masonic and Anna N. Glover. 
